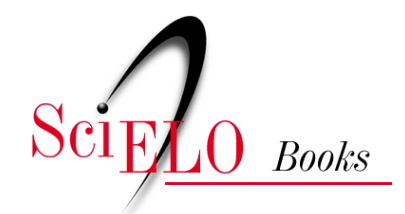

\title{
Revisitando o território fluminense, VI
}

\author{
Glaucio José Marafon \\ Miguel Angelo Ribeiro \\ (orgs.)
}

MARAFON, G.J., and RIBEIRO, M.A. orgs. Revisitando o território fluminense, VI [online]. Rio de Janeiro: EDUERJ, 2017, 366 p. ISBN: 978-85-7511-457-5. https://doi.org/10.7476/9788575114575.

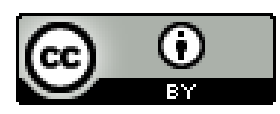

All the contents of this work, except where otherwise noted, is licensed under a Creative Commons Attribution 4.0 International license.

Todo o conteúdo deste trabalho, exceto quando houver ressalva, é publicado sob a licença Creative Commons Atribição $\underline{4.0}$.

Todo el contenido de esta obra, excepto donde se indique lo contrario, está bajo licencia de la licencia $\underline{\text { Creative Commons }}$ Reconocimento 4.0. 
Revisitando

OTerritório

Fluminense VI 


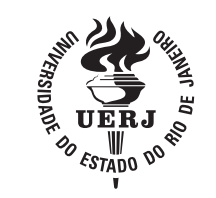

\title{
UNIVERSIDADE DO ESTADO DO RIO DE JANEIRO
}

\author{
Reitor
}

Ruy Garcia Marques

Vice-reitora

Maria Georgina Muniz Washington

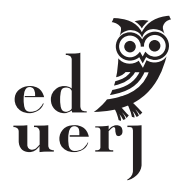

EDITORA DA UNIVERSIDADE DO
ESTADO DO RIO DE JANEIRO

\section{Conselho Editorial}

Bernardo Esteves

Erick Felinto

Glaucio Marafon (Presidente)

Jane Russo

Maria Aparecida Ferreira de Andrade Salgueiro

Italo Moriconi (membro honorário)

Ivo Barbieri (membro honorário)

Lucia Bastos (membro honorário) 


\section{Revisitando}

\section{OTerritório}

Fluminense VI

Glaucio José Marafon

Miguel Angelo Ribeiro

(Organização)

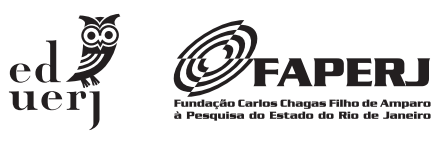

Rio de Janeiro 
Copyright (c) 2017, dos autores.

Todos os direitos desta edição reservados à Editora da Universidade do Estado do Rio de Janeiro. É proibida a duplicação ou reprodução deste volume, ou de parte do mesmo, em quaisquer meios, sem autorização expressa da editora.

\section{EdUERJ}

Editora da UNIVERSIDADE DO ESTADO DO RIO DE JANEIRO

Rua São Francisco Xavier, 524 - Maracanã

CEP 20550-013 - Rio de Janeiro - RJ - Brasil

Tel./Fax.: 55 (21) 2334-0720 / 2334-0721

www.eduerj.uerj.br

eduerj@uerj.br

Editor Executivo

Coordenadora Administrativa

Coordenadora Editorial

Assistente Editorial

Coordenadora de Produção

Supervisor de Revisão

Revisão

Capa

Diagramação

\author{
Glaucio Marafon \\ Elisete Cantuária \\ Silvia Nóbrega \\ Thiago Braz \\ Mauro Siqueira \\ Elmar Aquino \\ Shirley Lima \\ Fernanda Veneu \\ Mauro Siqueira \\ Emilio Biscardi \\ Thiago Netto
}

R454 Revisitando o território fluminense, VI / Glaucio José

Marafon, Miguel Angelo Ribeiro (organização). - Rio de

Janeiro : EdUERJ, 2017.

$370 \mathrm{p}$.

ISBN 978-85-7511-434-6

1. Geografia - Rio de Janeiro (Estado). I. Marafon, Glaucio

José. II. Ribeiro, Miguel Angelo.

CDU 908(815.3) 
"Seus sonhos só podem tornar-se realidade quando você mantém o compromisso de realização. Mas quem não se permite sonhar pode ficar estagnado. É tempo de deixar a imaginação fluir." Cláudia Lisboa O Globo, 07/03/2016 
Para Ruy Garcia Marques, pela sua contribuição à ciência fluminense. 


\section{Sumário}

Apresentação

1. Rio de Janeiro: trajetória institucional e especificidades do marco de poder.

Mauro Osorio, Henrique Rabelo Sá Rego e Maria Helena Versiani

2. Em busca de cidades mais justas por meio da tributação imobiliária: um olhar sobre as cidades fluminenses.

Angela M. S. Penalva Santos

3. O relevo do estado do Rio de Janeiro: cenário de beleza e fragilidade ambiental

Telma Mendes da Silva e Simone Lisboa dos Santos da Silva

4. Uma visão integrada dos impactos ambientais no estado do

Rio de Janeiro.

Tereza Coni Aguiar

5. Sustentabilidade da produção energética no Rio de Janeiro: as Pequenas

Centrais Hidrelétricas $(\mathrm{PCH})$ potencializando regionalmente o

território fluminense.

Augusto César Pinheiro da Silva, Davi Schulman Miguens e

Mônica Coelho Varejāo 
6. Transformações no espaço rural fluminense: o papel da agricultura familiar e das atividades turísticas.

Glaucio José Marafon

7. Os investimentos externos diretos da República Popular da

China no território fluminense no século XXI

Thiago Jeremias Baptista

8. Dinâmicas territoriais no estado do Rio de Janeiro: reflexôes em torno da região Noroeste Fluminense

Bruna Piraciaba e Linovaldo Lemos

9. O bairro de Santa Cruz, RJ: uma configuração socioespacial construída no decorrer do tempo

Vânia Regina Jorge da Silva

10. De povoado a município: transformações socioeconômicas em Nilópolis Enderson Alceu Alves Albuquerque

11. Situando Duque de Caxias no contexto metropolitano da baixada fluminense: de cidade-dormitório a cidade plena 209 Leandro Almeida da Silveira e Miguel Ângelo Campos Ribeiro

12. A flutuação turística na região das Baixadas Litorâneas (RJ): uma análise centrada nos municípios de Armação dos Búzios, Arraial do Cabo e Cabo Frio 259 Ulisses Fernandes

13. Porto do Açu, entre as forças de conservação e modernidade 275 Wedson Felipe Cabral Pacheco

14. Urbanismo imperial e planejamento dos barôes: a formação da cidade de Petrópolis (RJ) nas origens do processo urbanístico brasileiro 291 Ana Paula Silva de Araújo 
15. A espetacularização do lazer em Volta Redonda: os investimentos esportivos

Fábio Salgado Araújo

16. A importância da mobilidade populacional para a acumulação capitalista no setor petróleo e gás da Bacia de Campos, RJ.

Denise Cunha Tavares Terra e Joseane de Souza

17. A cartografia da ação social e a cidade de São Gonçalo, RJ: limites e possiblidades metodológicas para a contribuição do fazer geográfico

Catia Antonia da Silva 


\section{Apresentação}

$\mathrm{P}$ assados 13 anos desde a primeira publicação da coletânea intitulada Revisitando o Território Fluminense, organizada no âmbito do Núcleo de Geografia Fluminense (NEGEF) do Instituto de Geografia - UERJ, sob a coordenação do professor Glaucio José Marafon e com a colaboração do professor Miguel Angelo Ribeiro, apresentamos este novo volume, no qual convidamos pesquisadores doutores de outras instituiçōes e profissionais que acabaram de concluir suas pesquisas em níveis de mestrado e doutorado, com temáticas variadas, tendo como recorte espacial o estado do Rio de Janeiro.

O território fluminense abarca uma gama de singularidades que se imbricam, contemporaneamente, com os eventos em escalas nacional e global, o que proporciona reflexôes, análises e discussões de diferentes abordagens e propósitos.

No bojo de tais singularidades, os 16 artigos que compõem esta obra apresentam situações das mais diferentes ordens, desde aquelas vinculadas ao poder econômico e aos investimentos externos, até justiça por cidades mais habitáveis, produção energética, espaço rural fluminense associado à agricultura familiar e às suas relações com a atividade turística; além de questôes regionais, expansão da metrópole carioca em direção à Zona Oeste, com novos investimentos, cartografia da ação social, transformaçóes socioeconômicas de municípios localizados em diferentes regiōes de governo com implicação em suas sedes, importância da mobilidade turística, espetacularização do lazer e importância da mobilidade populacional em decorrência de novos projetos que visem ao desenvolvimento econômico do território fluminense.

Tais ordens não poderiam estar dissociadas daquelas vinculadas ao ambiente, em uma visão integrada dos aspectos econômicos e populacionais, bem como dos impactos ambientais, nos artigos apresentados por Mauro Osório et al., Angela Penalva Santos, Telma Mendes da Silva e Simone Lisboa dos Santos da Silva, Tereza Coni Aguiar, Augusto César Pinheiro da Silva et al., Glaucio José Marafon, Thiago Jeremias Baptista, Linovaldo Lemos, Vania Regina Jorge da Silva, Cátia Antônia da Silva, Enderson Alceu Alves Albuquerque, Leandro Almeida da Silveira e Miguel Angelo Ribeiro, Ulisses Fernandes, Ana Paula Silva de Araújo, Fábio Salgado Araújo, Denise Cunha Tavares Terra e Joseane de Souza e Wedson Felipe Cabral Pacheco.

Como é possível observar, as contribuições dos pesquisadores mencionados apresentam uma diversidade de temas que contemplam a realidade fluminense, servindo, portanto, para futuras pesquisas, além de oferecer subsídios para a sociedade e para os pesquisadores que se interessam e se preocupam com o território fluminense. 
Assim, gostaríamos de externar nossos sinceros agradecimentos aos autores que contribuíram para o engrandecimento desta obra e à Fundação Carlos Chagas Filho de Amparo à Pesquisa do Estado do Rio de Janeiro (Faperj), que concedeu os recursos financeiros necessários, contribuindo para a continuidade na publicação desta coletânea. Sem seu apoio, este livro não seria possível.

Rio de Janeiro, 18 de junho de 2016. 


\title{
Rio de Janeiro: trajetória institucional e especificidades do marco de poder ${ }^{1}$
}

\author{
Mauro Osorio ${ }^{2}$ \\ Henrique Rabelo Sá Rego ${ }^{3}$ \\ Maria Helena Versiani ${ }^{4}$
}

\section{Introdução}

\begin{abstract}
\ cidade do Rio de Janeiro, desde a sua fundação, consolidou-se institucionalmente como espaço de articulação nacional. De início, derivou seu dinamismo socioeconômico do fato de ser o principal porto e centro militar brasileiro e, em seguida, de ser a sede da família real portuguesa, capital do Brasil Imperial, capital da República e centro cultural, político e econômico do país - como lócus do poder federal, centro financeiro nacional e sede de empresas públicas e privadas atuantes no território brasileiro e até mesmo latino-americano.
\end{abstract}

Com essa trajetória singular, até o início do século XX a cidade apresentou o maior produto interno bruto (PIB) do país e constituiu seu maior parque industrial. Contudo, dados do Censo de 1919 mostram que, naquele ano, o PIB industrial do estado de São Paulo já superava o carioca, e era

\footnotetext{
${ }^{1}$ Registramos aqui nossos sinceros agradecimentos a Leonardo Amaral da Veiga, pelo cuidadoso trabalho de revisão deste artigo.

2 Professor associado da FND/UFRJ. Coordenador do Observatório de Estudos sobre o Rio de Janeiro, vinculado ao Programa de Pós-Graduação da FND/UFRJ e cadastrado nos Grupos de Pesquisa do CNPq. Presidente do Instituto de Estudos sobre o Rio de Janeiro (IERJ).E-mail: mauroosorio@uol.com.br.

3 Enomomista e integrante do grupo de pesquisa Observatório de Estudos sobre o Rio de Janeiro (UFRJ) e do IERJ. Mestrando em Planejamento Urbano e Regional no IPPUR/UFRJ. E-mail: henriquersr@hotmail.com.

${ }^{4}$ Historiadora vinculada ao Museu da República e integrante do grupo de pesquisa Observatório de Estudos sobre o Rio de Janeiro (UFRJ) e do IERJ. Doutora em História, Política e Bens Culturais pelo CPDOC/FGV. E-mail: m.versiani@globo.com.
} 
o estado paulista que liderava o processo de crescimento econômico brasileiro. Por outro lado, apesar de a economia da cidade do Rio de Janeiro apresentar, ao longo de todo o século XX, progressiva perda de posição relativa, em comparação a São Paulo, o dinamismo econômico carioca ainda se manteve próximo ao da média nacional entre 1920 e 1960. Isso porque, nesse período, a cidade ainda funcionava como sede do poder federal e também se constituía como o eixo de capitalidade do país, ${ }^{5}$ continuando a atrair e gerar investimentos. Carlos Lessa (2000, pp. 237-238) pontua essa questão:

As décadas de 1920 a 1960 foram de prosperidade e de acumulação de prestígio no Rio de Janeiro. A cidade desdobrou-se em novos comportamentos e dimensões. [...] O Rio urbanizou-se em sintonia com esses novos tempos. Cabe sublinhar que foi sendo secundarizado, em termos de produção industrial, em relação a São Paulo. Desde a Primeira Guerra Mundial, São Paulo lidera a produção industrial e, apesar de crescer, o Rio vê a distância relativa das respectivas bases industriais ser ampliada, para não lembrar a espantosa diferença no campo agrícola. Porém, o Rio - concentrando serviços sofisticados, com o núcleo de comando do sistema bancário, sediando os escritórios centrais da maioria das grandes empresas, sendo o portal dos visitantes nacionais e estrangeiros e sendo alimentado por contínuas e crescentes injeçóes de gasto público - parecia ter assinado um pacto com a eterna prosperidade.

Além disso, também o antigo estado do Rio de Janeiro - considerado por Lysia Bernardes (1964) uma região polarizada do ponto de vista econômico pela cidade do Rio - era cenário de importantes investimentos federais, com a instalação da Companhia Siderúrgica Nacional, da Fábrica Nacional de Motores, da Companhia Nacional de Álcalis e da Refinaria Duque de Caxias. Como lembra Carlos Lessa (2000, p. 346), as decisões locacionais para esses investimentos estiveram relacionadas com a proximidade da antiga capital federal e também com a existência de tendência dominante, dentro do governo central, a favor da realização de um contraponto, no país, ao predomínio econômico paulista. De fato, indicadores relativos ao PIB dos estados e regiōes do Brasil revelam que, nos anos 1950, o território que abrange a atual região fluminense apresentava um crescimento médio percentual de 6,6\% ao ano, bastante próximo ao da Região Sudeste, de 6,7\% ao ano, e ao do total do Brasil, de 7,1\% ao ano (Pacheco, 1998, p. 69).

Porém, a partir de 1960, com a transferência da capital federal para Brasília, a cidade do Rio de Janeiro sofre um processo de fratura em sua dinâmica institucional, o mesmo ocorrendo com a Velha Província, ${ }^{6}$ que deriva sua lógica econômica, pós-ciclo cafeeiro, do dinamismo existente na cidade do Rio de Janeiro e dos investimentos federais nela realizados até 1960.

\footnotetext{
5 Utilizamos aqui o conceito de capitalidade conforme proposto por Marly Silva da Motta (2001, p. 24), quando, a partir da formulação teórica de Giulio Argan - arquiteto, historiador da arte e prefeito comunista de Roma (1976-1979) -, define as cidades-capitais como "o lugar da política e da cultura, como núcleo da sociabilidade intelectual e da produção simbólica, representando, cada uma à sua maneira, o papel de foco da civilização, núcleo da modernidade, teatro do poder e lugar de memória”.

${ }^{6}$ Denominação costumeiramente dada ao antigo estado do Rio de Janeiro.
} 
A trajetória econômica, política e social da cidade e do estado do Rio de Janeiro, bem como seus impactos para a constituição do marco institucional e de poder dominante na região, são analisados neste artigo. Pretende-se também apontar os desafios para a superação, no século XXI, do processo de decadência econômica vivenciado na economia carioca e fluminense no período pós-1960.

\section{A transferência da capital federal: uma fratura na dinâmica institucional do Rio de Janeiro}

Utilizando a conceituação de economistas institucionalistas como Douglass North (1993), Geoffrey Hodgson (1997) e Thorstein Veblen (1934), que definem instituições como normas formais (leis e regulamentos) e informais (história, cultura, hábitos e rotinas), é possível afirmar que a cidade e o antigo estado do Rio de Janeiro, com a transferência da capital federal para Brasília em 21 de abril de 1960, sofreram uma ruptura em seu marco institucional.

Chegamos à mesma afirmação recorrendo à conceituação teórica de Paul Krugman (Krugman et al., 2002), quando esse autor busca analisar as diferenças marcantes entre os níveis de desenvolvimento das diversas regióes que compõem o mapa do mundo. Krugman aplica o conceito de linkages, proposto por Albert Hirschman (1958), e propõe que determinadas atividades econômicas podem gerar efeitos de encadeamento em certos territórios e, por conseguinte, rendimentos crescentes de escala. Além disso, incorpora o conceito de causação circular cumulativa, de Gunnar Myrdall (1968), para construir a ideia de que dada região, a partir de uma diferenciação inicial - como, por exemplo, a existência de um porto ou a ocorrência de algum fato histórico, ainda que fortuito -, pode vir a desenvolver novas diferenciações em relação às demais.

Tal processo envolveria tensão entre forças centrípetas (que gerariam dinamismo para a região em foco) e forças centrífugas (que poderiam estimular a migração de investimentos para outras regiōes). As forças centrípetas seriam, fundamentalmente, os efeitos de encadeamento que um investimento em determinada atividade geraria em outras; a formação de um mercado de trabalho com tal porte que permitisse que empregadores tivessem facilidade para encontrar trabalhadores - sobretudo trabalhadores com habilidades especializadas - e vice-versa; e o que o autor denomina de meras economias externas, ou seja, qualquer tipo de facilidade extra gerada pela concentração territorial.

Por sua vez, as forças centrífugas estariam relacionadas a questōes como: esgotamento de fatores produtivos, como, por exemplo, esgotamento de terras; aumento do custo dos aluguéis; a carência de infraestrutura; e qualquer forma de deseconomia externa, como poluição, violência etc. Dessa forma, dada região poderia apresentar um dinamismo econômico próximo ou superior ao de outras regiōes no cenário da economia de um país ou da economia mundial, e, a partir de certo momento, por efeito da preponderância das forças centrífugas vis-à-vis as forças centrípetas, poderia sofrer "bifurcação" ou reversão desse dinamismo econômico.

Nessa perspectiva, é possível afirmar que os territórios carioca e fluminense, por derivarem seu dinamismo econômico centralmente da história da capital e da capitalidade da cidade do Rio de Janeiro, sofreram, a partir dos anos 1960, um processo de erosão de sua importância e de seu dinamismo socioeconômico. O entendimento desse processo, contudo, não ocorreu de imediato pelos próprios 
cariocas e fluminenses, mas somente nos anos 1980, com a inversão do processo de crescimento da economia brasileira e a crise fiscal que então se instaurou, atingindo particularmente o estado do Rio de Janeiro, pelo peso que o gasto federal ainda tinha na região. Assim, até o final da década de 1970, viveu-se a doce ilusão de que a cidade do Rio de Janeiro teria assinado, nos dizeres de Carlos Lessa (2000, p. 238), "um pacto eterno com a prosperidade".

A demora na percepção do processo de crise em que o Rio de Janeiro imergiu a partir dos anos 1960 pode ser compreendida com base em um conjunto de fatores, a começar pela força da cultura de capitalidade no território carioca, construída a partir da histórica centralidade política, econômica e social do Rio de Janeiro no cenário nacional. Como sugere Douglass North (1993), determinada conformação institucional cria hábitos e rotinas arraigados, em que as questões de escolha se apresentam como algo regular, repetitivo e evidente, de tal modo que cerca de $90 \%$ de nossas ações em vida seriam realizadas de forma basicamente automática. É nessa perspectiva que se pode aferir que a cultura de capitalidade do Rio de Janeiro acabou por contribuir para que, nessa região, não ocorresse, de forma imediata, a percepção da quebra da dinâmica institucional a partir de um fator "exógeno" (a mudança da capital federal para Brasília, em 1960).

Com a mesma preocupação de observar as variáveis que impactam a dinâmica institucional de determinada regiāo, Geoffrey M. Hodgson (1997), a partir de pressupostos teóricos distintos e incorporando autores como Marx, Keynes e os institucionalistas americanos do final do século XIX e do início do XX - Veblen, Commons e Mitchell -,, chega a conclusões bastante próximas às construídas por North, conforme se pode deduzir da seguinte passagem:

[Veblen] observou que as instituiçôes têm uma qualidade de estabilidade e inércia e que tendem a manter e, portanto, a "transmitir" suas características importantes ao longo do tempo. As instituiçōes são consideradas frutos e reforçadores dos processos de pensamento rotinizados, sendo partilhadas por um conjunto de pessoas numa dada sociedade (Hodgson, 1997, p. 276).

Geoffrey Hodgson também afirma que o institucionalismo compreende os indivíduos a partir do modo como estão situados e envolvidos em seu mundo social. Dessa forma, suas funções e preferências não seriam dadas e fixas, mas sim socialmente construídas e reconstruídas, em um contínuo processo de adaptação e mudanças. Novamente citando Veblen, Hodgson (1997:10) escreve:

Uma linha de ação habitual constitui uma linha habitual de pensamento e dá o ponto de vista através do qual os fatos e eventos são apreendidos e reduzidos a um corpo de conhecimento. As instituições criam e reforçam os hábitos de ação e pensamento: a situação de hoje molda as instituições de amanhã, através de um processo coercivo e seletivo, através da ação sobre a visão habitual do homem das

\footnotetext{
7 Geoffrey Hodgson utiliza, como referência básica, os institucionalistas americanos citados. No entanto, em sua obra aparecem com centralidade os trabalhos de Veblen, quando este propõe que se troque, como paradigma econômico, a ideia do equilíbrio advinda da Física pela ideia da evolução, recorrendo-se à Biologia como metáfora.
} 
coisas e, dessa forma, alterando ou fortificando um ponto de vista de uma atitude mental trazida do passado. ${ }^{8}$

Ou seja, por um lado, conforme identificado por institucionalistas como Geoffrey Hodgson e Douglass North, determinadas culturas influenciam a conformação de certas formas de raciocínio e de percepção do mundo, podendo dificultar a compreensão imediata de uma mudança gerada a partir de um fator exógeno - no caso em exame, as consequências, para o Rio de Janeiro, da mudança da capital federal para Brasília, em 1960.

Por outro lado, o fato de a transferência da capital ter ocorrido de forma paulatina, acelerando-se somente a partir da década de 1970, no contexto do dinamismo apresentado pela economia brasileira no período 1968/1980, mascarou a lógica que se inaugurou com a mudança da capital, não se tendo a percepção de que, por exemplo, na década de 1970, o território que hoje abriga a cidade do Rio de Janeiro apresentava um crescimento industrial de apenas $173 \%$, contra um crescimento brasileiro em torno de 285\% e, em Minas Gerais, em torno de 342\% (Rosa e Osorio, 1995).

Para uma análise da demora na percepção das consequências da transferência da capital federal, em 1960, para o Rio de Janeiro, deve-se levar em conta também o modelo institucional adotado para o Distrito Federal quando da implantação da República no Brasil. Ao se organizar a capital federal, com o advento da República, buscou-se constituí-la de forma tecnocrática e conservadora, tomando como referência a cidade de Washington, ${ }^{9}$ capital dos Estados Unidos. Procurou-se, assim, restringir ao máximo o espaço da política local no Distrito Federal - opção institucional que, posteriormente, foi reiterada na Constituição de 1946 e na Lei Orgânica do Distrito Federal de 1948. Desse modo, ficou definido que o prefeito do Distrito Federal seria nomeado pelo presidente da República e que, ao contrário das demais localidades brasileiras, as leis votadas pelos vereadores da cidade do Rio de Janeiro/Distrito Federal que depois fossem vetadas pelo prefeito não retornariam à Câmara Municipal, mas seriam analisadas pelo Senado Federal.

O esforço de neutralizar a política local naquele território não era uma novidade da República. Desde 1834, quando ocorreu a separação institucional da capital da província fluminense com vistas à criação do município neutro, já se afirmava que a capital deveria constituir um espaço politicamente neutralizado, conforme assinalado por Carlos Lessa (2000, pp. 187-8):

\footnotetext{
Para a federação sonhada pela República, o Rio como município neutro era perfeito para a transmutação em Distrito Federal. Desde 1834, a cidade estava separada da província fluminense. A capital para a República deveria manter-se politicamente neutralizada. O prefeito, escolhido pelo presidente e submetido à aprovação pelo Senado, não é o chefe do Poder Executivo, independente de aprovação local. É um alto funcionário de confiança do presidente que pode demiti-lo ad nutum. [...] O Rio seria o "fórum asséptico", guardião e depositário do pacto oligárquico, o lugar de construção do marco zero da República e a moldura para dignificar a presidência.
}

\footnotetext{
8 Tradução livre de Alexandre Borges.

9 Sobre o assunto, ver Freire (2000) e Motta (2001).
} 
A forma como se organizou a institucionalidade local da cidade do Rio de Janeiro - ao lado de sua história de capitalidade - influenciou para que o debate e o jogo político local perdessem força na região, contribuindo, assim, para a conformação de um particular quadro de carência no tocante à reflexão local.

Desse modo, constituíram-se com força na cidade do Rio, conforme analisado por Marly Silva da Motta $(2000 ; 2001)$, duas lógicas políticas: a primeira, bastante focada nas questôes nacionais e radicalizada no que se refere à representação da cidade na Câmara Federal e no Senado - o que pode ser visto, por exemplo, no fato de disputarem o Senado, pelo Distrito Federal, em 1958, Afonso Arinos, prócer da UDN nacional e deputado por Minas Gerais, e Lutero Vargas, simbolizando o getulismo; ou no fato de, em 1962, haverem participado da disputa pela representação da Guanabara no Senado Juracy Magalhães, então governador da Bahia e liderança nacional da UDN, e Aurélio Viana, deputado federal por Alagoas e líder da esquerda nacionalista na Câmara dos Deputados.

A outra lógica, por sua vez, da política local, seria determinada pela ausência de eleições diretas locais para prefeito e pelo pouco poder dos vereadores eleitos para interferir na vida da cidade. Veja-se ainda que, no período de 1946 a 1960, as eleições para a representação federal na cidade do Rio de Janeiro/Distrito Federal realizaram-se centralmente em torno de poucos partidos e com forte participação de líderes políticos que simbolizavam o debate nacional, ao passo que o jogo político local ocorreu de forma fragmentária e clientelista, num quadro de forte pulverização das agremiações partidárias. Nos anos 1950, por exemplo, enquanto a representação federal do Rio limitava-se a quatro partidos com dois ou mais membros eleitos, a representação local fracionava-se em 11 partidos. Além disso, entre os quatro partidos que disputavam a representação federal, era grande a centralidade do PTB e da UDN, enquanto a representação do PSD carioca (maior partido do Congresso Nacional nos anos 1950, com posição mais centrista) limitava-se a um único parlamentar. Isso deixava em evidência o polarizado debate nacional reproduzido com particular força no Rio de Janeiro, nesse período, liderado, por um lado, por Getulio Vargas, Leonel Brizola e João Goulart, e, por outro, por Carlos Lacerda. Já a lógica política local, ao contrário da lógica política nacional, teria menos peso e importância na cidade do Rio de Janeiro, ocorrendo de forma marcadamente fragmentária. ${ }^{10}$

Assim, a forma como se organizou institucionalmente o Distrito Federal no território carioca também teve relação direta com o fato de, na segunda metade dos anos 1950, as reflexôes e proposições sobre os rumos e as estratégias para a cidade do Rio de Janeiro, após a transferência da capital, terem ocorrido de maneira bastante pobre e com muito pouca sensibilização social a partir de 1960, sem que se atentasse imediatamente para os impactos e as consequências desse processo para o Rio de Janeiro.

A esse respeito, cabe destacar que a transferência da capital para Brasília já estava definida na Constituição desde 1891, permanecendo durante anos como "letra morta". Isso fez com que a proposta lançada por Juscelino Kubitschek, durante sua campanha presidencial e quando assumiu o governo federal, tenha sido tratada com desdém por diversos setores da sociedade. Mesmo a UDN, partido de oposição, votou todas as leis propostas por JK que autorizavam a criação de Brasília. O objetivo era, pos-

\footnotetext{
${ }^{10}$ Sobre o assunto, ver Osorio (2005). Para uma discussão sobre o conceito de clientela, ver Diniz (1982).
} 


\section{Rio de Janeiro: trajetória institucional e especificidades do marco de poder}

teriormente, desmoralizar JK, afirmando que a UDN havia aprovado todas as solicitações do presidente para a construção de Brasília, mas que ele não cumprira a promessa de transferir a capital. ${ }^{11}$

A descrença quanto à efetivação da mudança da capital também conduziu a apenas um único debate público sobre os rumos do Rio de Janeiro após a transferência da capital para Brasília. Organizado pelo jornal Correio da Manhã, em 1958, esse debate compreendeu várias entrevistas com líderes comunitários e empresariais, intelectuais e políticos, em uma série denominada "O que será do Rio". ${ }^{12}$

Assim, na Belacap, ${ }^{13}$ em função de sua trajetória de cidade-capital e da forma como, historicamente, foi organizada do ponto de vista político-institucional, conforme assinalado por Arnaldo Niskier (1970, p. 15), a vivência dos problemas nacionais reduzia "a pálidos reflexos os problemas locais. Depois da mudança da capital para o Planalto, o povo carioca descobriu que só conhecia de si mesmo e de sua cidade a visão do turista apressado". Essa questão também é apontada no depoimento de Villas-Boas Corrêa ao CPDOC (Ferreira, 1998, p. 55), nos seguintes termos:

Acho que a bancada do Rio de Janeiro, como o Rio era Capital, se dissolvia muito, não tinha muita identidade. Até porque o prefeito do Rio era nomeado [...]. A grande verdade é a seguinte: cobria-se mal a política carioca, porque a política nacional, que era feita aqui no Rio de Janeiro, abafava a política local.

No mesmo sentido que na cidade do Rio de Janeiro, no antigo estado do Rio a presença da capital se fazia sentir, conforme mostra Marieta de Moraes Ferreira (1991), ao assinalar a dificuldade de interlocução entre as elites econômicas escravagistas da Velha Província e as elites políticas, de viés mais nacional, como Alberto Torres e Nilo Peçanha. Essa dificuldade de interlocução teria representado um obstáculo para a implantação de estratégias econômicas quando da decadência da cafeicultura na região, na segunda metade do século XIX.

A questão de as elites políticas do antigo estado do Rio apresentarem um marcante viés nacional apresentará continuidade, segundo nosso entendimento, até os anos 1950, o que se evidencia pela presença de personagens como Macedo Soares, Prado Kely, Raul Fernandes e Amaral Peixoto, que migrou da política carioca para a do antigo estado do Rio, a partir de seu relacionamento com Getulio Vargas, embora tenha mantido participação e influência na política carioca. ${ }^{14}$

A importância da articulação entre as elites políticas e econômicas de uma região para a alavancagem do processo de desenvolvimento econômico é ressaltada em Otávio Dulci (1999), quando o autor analisa essa relação como elemento-chave para a estratégia engendrada em Minas Gerais, a partir das décadas de 1940 e 1950, que gerou um articulado arcabouço institucional de fomento ao

\footnotetext{
${ }^{11}$ Sobre o assunto, ver depoimento de Luiz Alberto Bahia, anexo à tese de doutorado de Mauro Osorio (2004).

${ }^{12}$ A referida série também se encontra disponível no anexo da tese de doutorado de Mauro Osorio (2004).

${ }^{13}$ Como era então chamada a Guanabara, nos anos 1960, em oposição à Novacap (Brasília).

${ }^{14}$ Sobre o peso da participação de Amaral Peixoto nas negociações sobre a nova institucionalidade carioca, quando da transferência da capital para Brasília, ver, por exemplo, Motta (2000, p. 32).
} 
desenvolvimento daquele estado. ${ }^{15}$ Assim, a dificuldade de interlocução entre as elites econômicas e políticas na Velha Província certamente contribuiu para que a lógica econômica na região, no período pós-ciclo cafeeiro, viesse a depender de investimentos federais e da capital da República, tanto ou mais do que a própria cidade do Rio de Janeiro. Contribuiu também para que a transferência da capital para Brasília representasse, no antigo estado do Rio de Janeiro, da mesma forma que no território carioca, um marco na reversão de dinamismo. ${ }^{16}$

\section{Transferência da capital versus equívocos no fomento ao desenvolvimento regional}

Nos anos 1960, tendo em vista a conjunção de fatores enunciados, que abrangem a história de capital e de capitalidade da cidade do Rio de Janeiro, sua trajetória institucional, a radicalização vigente na política nacional e o fato de o processo de transferência da capital ter-se consolidado, de forma lenta e gradativa, ao longo dos anos 1960 e 1970, fez-se então hegemônica a percepção de que o Rio continuaria a ser a Belacap e a capital de fato. Isso levou, inclusive, a que os dois primeiros governos da Guanabara - Carlos Lacerda (1960-1966) e Negrão de Lima (1966-1971) - realizassem uma política de modernização urbana com base no entendimento de que tal política, per se, garantiria a centralidade do desenvolvimento carioca.

Do ponto de vista da formulação de uma política explícita de desenvolvimento econômico e expressando a falta de massa crítica sobre a realidade local -, desenvolveu-se, na Guanabara, nos governos Carlos Lacerda e Negrão de Lima, e com continuidade no governo Chagas Freitas (19711975), uma política de fomento focada na indústria, especialmente na organização de distritos industriais, conforme tese defendida pela representação patronal da indústria da Guanabara. Tal política realizou-se, fundamentalmente, com base em dados e pressupostos equivocados, sem que houvesse preocupação com o entendimento rigoroso e embasado sobre as potencialidades da região, resultando, ao final da década, em um rotundo fracasso.

A tese defendida pela representação patronal da indústria da Guanabara sugeria que, naquela região, da mesma forma que então ocorria na cidade de São Paulo e em outras metrópoles mundiais, estaria ocorrendo um derramamento do processo de industrialização, de seu núcleo central para a pe-

\footnotetext{
${ }^{15}$ Em Minas Gerais, visando fomentar o desenvolvimento regional e realizar pesquisas, criou-se um conjunto de instituições, incluindo: a Fundação João Pinheiro, voltada à realização de pesquisas sobre a realidade mineira; um programa de mestrado e, mais recentemente, de doutorado, denominado Cedeplar e vinculado à Universidade Federal de Minas Gerais; a Fundação INDI, órgão para a promoção econômica de Minas Gerais; e o Banco de Desenvolvimento Econômico de Minas Gerais (BDMG).

${ }^{16}$ Acreditamos que a Velha Província tenha sofrido com a transferência da capital de forma mais pesada do que a cidade do Rio de Janeiro, não só pela dependência econômica já apontada, mas também pela instabilidade político-institucional vivenciada naquela região entre 1960 e 1964, após a morte do governador Roberto da Silveira; pela posterior cassação do governador Badger da Silveira; e pelo fato de os governadores nomeados pelo governo militar haverem permanecido no cargo, em média, por apenas dois anos.
} 


\section{Rio de Janeiro: trajetória institucional e especificidades do marco de poder}

riferia - tendo em vista o crescimento do porte das indústrias, no auge da segunda Revolução Industrial -, sendo, portanto, de fundamental importância para a nascente cidade-estado da Guanabara a organização de uma política de oferta de terrenos e de infraestrutura que retivesse a indústria instalada dentro do território carioca.

Apresentou-se, como argumento, o fato de, nos anos 1940, 1950 e início dos 1960, a indústria do antigo estado do Rio de Janeiro haver crescido acima da média nacional. Porém, não se levou em consideração que, especificamente na Velha Província, isso não ocorria fundamentalmente pela transferência de plantas industriais privadas da cidade do Rio para o antigo estado do Rio de Janeiro, mas, sim, pela criação, naquela região, de empresas estatais, pelo governo federal. ${ }^{17}$

Outro pressuposto equivocado que instruiu as políticas implementadas pelos governos da Guanabara foi o de que Brasília não se consolidaria como capital e, por esse motivo, com a modernização da Belacap, o setor de serviços tenderia a se manter na Cidade Maravilhosa, não demandando políticas específicas de fomento. ${ }^{18}$ Tal pressuposto e o foco econômico dos três governos da Guanabara, entre 1960 e 1975, no setor industrial e em uma política de distritos industriais - inclusive constituindo-se, para tanto, no início do governo Lacerda, uma empresa de fomento denominada Companhia Progresso da Guanabara (Copeg) -, estavam em consonância com os interesses da representação industrial carioca (uma das poucas instituiçôes a se inserir, de forma organizada e com forte hegemonia, no rarefeito debate local), mas, de forma objetiva, não deram conta da problemática de reinserção estratégica dessa unidade federativa no cenário da economia brasileira.

De fato, a política focada em distritos industriais organizada para a Guanabara fracassou. No curso do governo Lacerda, só ocorreu a ocupação, por indústrias, de 1\% da área inicialmente prevista para o total dos distritos industriais, então criados na Avenida das Bandeiras e em Santa Cruz (Guanabara, 1970, p. 46). No governo Negrão de Lima, a política de distritos industriais também não alcançou resultado significativo, seja pela não ocupação do novo distrito por ele criado, a Fazenda Botafogo, seja porque o distrito industrial de Santa Cruz continuava praticamente desocupado.

Da mesma forma, essa política não apresentou, no período Chagas Freitas, resultados expressivos, embora, do ponto de vista da estratégia governamental, tenha ocorrido a amplificação de seu

\footnotetext{
${ }^{17}$ Sobre o assunto, ver Osorio (2005). Assinala-se que a carência de reflexão e de organização de dados no âmbito regional e a tradição do Rio de Janeiro de privilegiar o debate de temas nacionais e internacionais fazem com que, em diversos momentos, ao ser observada a existência de determinada tendência em outras regióes do planeta, e ao primeiro dado que aponte que, aparentemente, o mesmo estaria ocorrendo em nossa região, passemos a trabalhar com a mesma hipótese. Isso aconteceu quando da implantação da política de distritos industriais na Guanabara e, mais recentemente, com alguns autores apontando significativa interiorização da economia fluminense. No segundo caso, não se levou devidamente em conta que o crescimento do PIB no interior fluminense derivava centralmente da extração de petróleo em alto-mar, não tendo gerado uma significativa estrutura produtiva em terra, no interior do estado.

${ }^{18}$ Matérias publicadas no jornal $O$ Globo, logo após a mudança da capital para Brasília, mostram o carioca comemorando esse acontecimento. A comemoração baseava-se no fato de que, após muitos anos, finalmente o Rio poderia eleger seu governador e de que, pela hipótese da não consolidação de Brasília, a cidade se manteria como a "capital de fato".
} 
foco. Isso é o que mostra, por exemplo, o depoimento de José Augusto Assumpção Brito (apud Osorio, 2005, Conclusão), segundo o qual a consolidação dos investimentos de infraestrutura que permitiram que o Distrito Industrial de Santa Cruz viesse a funcionar de fato só ocorreria no final do governo Chagas Freitas. Além disso, de acordo com Assumpção Brito, a política de distritos industriais não teria grande importância no crescimento industrial carioca ocorrido nos anos 1970, que, segundo ele, teria derivado centralmente do milagre econômico. ${ }^{19}$ Por outro lado, a partir da análise dos documentos Economia Industrial do Novo Estado do Rio de Janeiro (Barros, 1975) e Tendências de crescimento da Guanabara (Ideg, 1974), é possível chegar à mesma conclusão. De acordo com Barros, por exemplo, em 1973 existiriam, para todo o bairro de Santa Cruz, apenas 15 indústrias, o que representava uma participação de $0,6 \%$ no total do número de estabelecimentos industriais existentes na cidade do Rio de Janeiro. Além disso, o autor analisa que o bairro de Jacarepaguá, onde Chagas Freitas estabeleceu um novo distrito industrial, possuiria, em 1973, apenas 1,83\% do total de estabelecimentos industriais da cidade (Barros, 1975, p. 156). Dessa forma, nenhum dos três governos da Guanabara conseguiu articular uma reversão do processo de "bifurcação" - utilizando a conceituação de Paul Krugman (2002) -, que, no território carioca, ocorreu em 1960.

Por sua vez, após a fusão da Guanabara com o antigo estado do Rio, em 1975, os governos persistiram em, por um lado, apresentar uma visão equivocada sobre quais deveriam ser as estratégias de desenvolvimento econômico para a região - no governo Faria Lima, por exemplo, a preocupação centrou-se no setor agrícola, apesar da diminuta participação desse setor no PIB carioca. Por outro lado, adotaram um foco pontual, sem estudos setoriais ou uma adequada estratégia e coordenação de políticas. $\mathrm{Ou}$, ainda, simplesmente dispensaram a formulação de quaisquer políticas de desenvolvimento econômico.

Para a análise da carência de uma adequada estratégia de desenvolvimento econômico para a cidade do Rio de Janeiro, e posteriormente, após a fusão, para o estado do Rio de Janeiro, é interessante citar a seguinte consideração de Raphael de Almeida Magalhães, vice-governador do primeiro governo da Guanabara e coordenador do Programa de Açōes Federais no Rio de Janeiro, durante os dois governos de Fernando Henrique Cardoso:

A criação do estado da Guanabara em si mesma não poderia dar conta das causas que determinaram a decadência da cidade. Teve, entretanto, o mérito de permitir a autonomia política da cidade, cujo governo pôde, com verdadeiro empenho, tentar, ao menos, recuperar a qualidade dos serviços básicos, enfrentando, com êxito parcial, alguns dos mais agudos problemas de infraestrutura herdados da

\footnotetext{
${ }^{19}$ José Augusto Assumpção Brito apresenta uma longa trajetória de atuação como técnico e dirigente de instituições vinculadas à economia da Guanabara e do antigo estado do Rio de Janeiro. Nos anos 1960, trabalhou como técnico na Copeg. Na primeira metade dos anos 1970, atuou vinculado à Companhia de Desenvolvimento Industrial do antigo estado do Rio de Janeiro. A partir de 1975, com a fusão, dirigiu a Codin, Companhia de Desenvolvimento do novo estado do Rio de Janeiro, por um período de dez anos. Posteriormente, participou dos governos Saturnino Braga, Moreira Franco e Marcelo Alencar, tendo sido ainda, no início dos anos 1990, presidente do Sebrae nacional.
} 
época da dominação federal.

A verdade é que a simples autonomia política não bastava para a viabilização de um projeto de restauração substitutiva da base produtiva da cidade e da sua região, afetada com a perda irreversível da condição de metrópole nacional. [...]

Redescobrir funções reorganizadoras das atividades econômicas continua sendo, assim, desde a década dos 1950, o verdadeiro desafio para a cidade e sua região. Identificá-las, agora, se inscreve, além do mais, no complexo contexto de nosso tempo, que deve considerar a globalização da economia e a necessidade vital de nova forma de articulação do Brasil com os centros decisórios internacionais (Magalhães, 2001, pp. 4-5).

\section{Um golpe que favoreceu o clientelismo e a degradação econômico-social do Rio de Janeiro}

Entendemos que a trajetória econômica pós-1960 do Rio de Janeiro foi decisivamente influenciada pela transferência da capital para Brasília; pela história de capitalidade da cidade do Rio; pela constituição de seu desenho político-institucional local; e pela consequente carência de reflexão e pelos equívocos nas estratégias regionais. Além disso, a cidade e o estado do Rio de Janeiro sofreram profunda degradação em sua lógica política a partir do golpe de 1964 e das cassações, que atingiram, com particular gravidade, a cidade do Rio.

De fato, pela centralidade política do Rio de Janeiro no cenário brasileiro, sua representação federal foi fortemente atingida no processo de cassaçōes. A polarização existente no debate político nacional e o papel central do Rio nesse debate, principalmente nos anos 1950 e na primeira metade dos anos 1960, redundaram em que a representação federal da cidade apresentasse a marca da radicalização e se circunscrevesse a poucos partidos, basicamente o PTB e a UDN.

Assim, logo após o golpe de 1964, por um lado, o PTB e a esquerda como um todo sofreram pesadamente o processo de cassaçóes, sendo que, no caso da cidade do Rio, entre os dez deputados federais eleitos pelo PTB, em 1962, oito foram cassados. Por outro lado, pelo fato de Carlos Lacerda romper com o regime militar ao longo da década de 1960, a UDN carioca também foi fortemente atingida pelas cassações, provocando-se, no conjunto, desarticulação da lógica nacional nessa região e abrindo-se espaço para que Chagas Freitas e sua política de clientela articulada à lógica local conquistassem particular hegemonia, primeiro na cidade e posteriormente no estado do Rio. ${ }^{20}$ Essa lógica fez história ao longo dos anos, conforme se verifica na declaração da governadora Rosinha Garotinho (2003-2006), publicada no jornal $O$ Globo, de 10 de outubro de 2003, em que ela analisa que, na região fluminense, após o chaguismo e o brizolismo, "por que não o garotismo?”. Ou seja, na cidade do Rio

\footnotetext{
${ }^{20}$ Sobre o assunto, ver dissertação de mestrado de Maria Helena Versiani (2007), em que se analisam os posicionamentos da bancada federal de representação da cidade do Rio de Janeiro, nos anos de 1962 e de 1970. Os discursos da bancada eleita em 1962 eram hegemonicamente referenciados no debate brasileiro. Já os discursos da bancada federal eleita em 1970, tendo em vista as cassaçóes ocorridas, apresentavam uma linha de defesa de questóes pontuais e clientelistas.
} 
de Janeiro e, posteriormente, no novo estado do Rio, viria a ocorrer, através dos processos históricos de permanências e mudanças, a coexistência entre uma lógica nacional cada vez mais inorgânica e uma lógica clientelista e fragmentária crescentemente hegemônica no plano estadual. Tal realidade gera um marco institucional que desestrutura, com particularidade, o poder público na região, dificultando a organização consistente de estratégias e políticas regionais.

Assim, a transferência da capital para Brasília, em 1960, e a consolidação dessa transferência no correr da década de 1970, junto com a carência de reflexão regional e de adequadas estratégias regionais de fomento ao desenvolvimento, bem como a particular degradação política que a cidade e o estado do Rio sofreram em consequência do golpe de 1964, todos esses são fatores absolutamente centrais no processo de degradação econômico-social do atual estado do Rio de Janeiro no cenário brasileiro.

Do ponto de vista econômico, esse processo de degradação pode ser verificado a partir de um conjunto de indicadores. Através das Contas Regionais do Brasil, divulgadas pelo IBGE, por exemplo, entre 1970 e 2013, o PIB do atual estado do Rio de Janeiro passou de uma participação no PIB nacional de $16,7 \%$ para uma participação de $11,8 \%$, a maior perda entre todas as unidades federativas brasileiras. ${ }^{21}$

Na mesma linha, de acordo com dados do Ministério do Trabalho (RAIS/MTE), o estado do Rio de Janeiro apresentou, entre 1985 e 2014 (a série mais longa disponível com a mesma metodologia), um crescimento do emprego formal de $73,6 \%$, contra um crescimento no total do país de $141,9 \%$, o menor índice entre todas as unidades federativas brasileiras.

A particular estagnação do conjunto da economia carioca e fluminense evidencia-se também no fato de que o estado do Rio de Janeiro, que apresentava, em 1985, a segunda posição, entre todas as unidades federativas brasileiras, no que tange ao número de empregos formais gerados no conjunto das atividades públicas e privadas, estando atrás apenas de São Paulo, tenha sido, desde 1999, ultrapassado por Minas Gerais, caindo para a terceira posição no ranking das unidades federativas.

No que se refere, especificamente, ao emprego na indústria de transformação, a perda revelou-se ainda mais acentuada. O Rio de Janeiro passou da segunda posição, em 1985, para a sexta posição, em 2014, sendo ultrapassado por Minas Gerais, Rio Grande do Sul, Paraná e Santa Catarina. Igualmente expressivo é o fato de Minas Gerais haver ultrapassado, em 2004, o estado do Rio de Janeiro no que diz respeito à receita gerada pelo imposto estadual de ICMS, ampliando, assim, a dependência do estado do Rio de Janeiro em relação às receitas de royalties do petróleo. ${ }^{22}$

Nesse processo, o estado do Rio de Janeiro ficou com ralo adensamento produtivo e grande concentração em refino de petróleo e siderurgia. Essa rala densidade produtiva pode ser vista principalmente

\footnotetext{
${ }^{21}$ Em 1975, como sabemos, ocorreu a fusão entre a Guanabara e o antigo estado do Rio de Janeiro. Dessa forma, segundo os dados do PIB aqui apresentados, referentes ao ano de 1970, o PIB do antigo estado do Rio de Janeiro está somado ao PIB da Guanabara, permitindo a comparação com o PIB do estado do Rio pós-fusão.

${ }^{22}$ Esse dado foi calculado a partir de indicadores sistematizados pelo Conselho Nacional de Política Fazendária do Ministério da Fazenda (Confaz), em pesquisas realizadas pelo Observatório de Estudos sobre o Rio de Janeiro, grupo de pesquisa cadastrado no CNPQ e vinculado ao Programa de Pós-Graduação em Direito da Universidade Federal do Rio de Janeiro.
} 


\section{Rio de Janeiro: trajetória institucional e especificidades do marco de poder}

na periferia metropolitana e no interior fluminense. ${ }^{23}$ No ano de 2014, através de dados da Rais/MTE, verificamos que, no Brasil e na Região Sudeste, os empregos formais públicos representavam, respectivamente, $20,05 \%$ e $15,41 \%$ do total de empregos formais. Já entre os 91 municípios do interior fluminense e da metrópole (excluindo-se a cidade do Rio de Janeiro), encontravam-se 56 municípios com o peso do emprego público superior ao encontrado para o Brasil, sendo que 43 deles apresentavam percentual acima de 30\%; 19 municípios exibia percentual acima de 40\%; e, em dez municípios, o peso do emprego privado no total do emprego formal municipal não chegou a representar $50 \%$.

Deve-se destacar que a cidade do Rio de Janeiro, apesar de ter sido capital federal por quase duzentos anos e da forte presença em seu território do serviço público federal - como, por exemplo, das forças armadas e de universidades públicas federais -, apresentava, em 2014, um peso do emprego no setor público no total de empregos formais de $18,65 \%$.

Com relação aos indicadores sociais e de infraestrutura, também verificamos particular degradação da região fluminense no cenário federativo. Dados do Censo do IBGE de 2010 mostram, por exemplo, uma situação particularmente grave do ponto de vista habitacional. Organizando-se um ranking, por estado brasileiro, do percentual de pessoas moradoras de favelas, em relação ao total de habitantes, verifica-se que o estado do Rio apresentou, em 2010, um percentual de 12,7\%, o terceiro maior entre todas as unidades federativas, melhor apenas do que o Pará e o Amapá, que apresentaram o primeiro e o segundo maiores percentuais, respectivamente. Esse percentual era de 6,62\% no estado de São Paulo e de apenas 3,07\% em Minas Gerais.

Outro exemplo, também com base nos dados do Censo de 2010 do IBGE, é o expressivo percentual de jovens entre 18 e 24 anos que não estudam nem trabalham na cidade do Rio e principalmente nas áreas periféricas. Na Zona Suburbana, esse percentual, em 2010, chegava a ser de 38,8\% na área do Jacarezinho; de 32,9\% no Complexo do Alemão; de 32,5\% na Penha; de 30,1\% em Anchieta; de 30,0\% na Pavuna; e de 29,5\% na Maré. Na Zona Oeste, atingia 38,4\% em Santa Cruz, $35,1 \%$ em Bangu e 33,0\% em Guaratiba. Além disso, enquanto na Região Sudeste o percentual de nem-nens entre os jovens com 18 a 24 anos era, em 2010, de 24,2\%, entre os 21 municípios da RMRJ, 16 apresentavam percentual superior a 30\%, sendo que, em oito municípios da metrópole carioca, o número de jovens sem estudar ou trabalhar era igual ou superior a um terço dos jovens. No interior fluminense, 62 dos 71 municípios da região apresentavam percentual de nem-nens superior ao verificado para o conjunto da Região Sudeste.

$\mathrm{Na}$ área de educação, é possível verificar o péssimo posicionamento do estado do Rio de Janeiro no cenário federativo; da cidade do Rio de Janeiro comparativamente às demais capitais brasileiras; e dos municípios fluminenses em face à situação nos municípios da Região Sudeste e do Brasil, no ano de 2013, por exemplo, com base nos resultados do Índice de Oportunidades da Educação Brasileira-Ioeb, organi-

\footnotetext{
${ }^{23}$ A Região Metropolitana do Rio de Janeiro é composta pelos seguintes 21 municípios: Belford Roxo; Cachoeiras de Macacu; Duque de Caxias; Guapimirim; Itaboraí; Itaguaí; Japeri; Magé; Maricá; Mesquita; Nilópolis; Niterói; Nova Iguaçu; Paracambi; Queimados; Rio Bonito; Rio de Janeiro; São Gonçalo; São João de Meriti; Seropédica; e Tanguá.
} 
zado pelo Centro de Liderança Pública-CLP, com o apoio das Fundações Lemann e Roberto Marinho. ${ }^{24}$ Organizando-se um ranking dos resultados do Ioeb para as unidades federativas em 2013, vemos que o estado do Rio de Janeiro encontrava-se apenas na décima quinta posição. Na mesma direção, em um ranking das capitais, a cidade do Rio encontrava-se na décima primeira posição.

Com base nesse mesmo índice, o município fluminense mais bem colocado entre os 1.620 municípios da Região Sudeste é Comendador Levy Gasparian (região Centro-Sul Fluminense), na 500ª posição. Em segundo lugar, aparecem os municípios de Santo Antônio de Pádua, na 713a posição, e Aperibé, na 993 $3^{a}$ posição (ambos da Região Noroeste Fluminense). ${ }^{25}$ Todos os demais 89 municípios fluminenses encontravam-se além da $1.000^{a}$ posição, sendo que 61 deles encontravam-se atrás da $1.500^{a}$ posição. Por último, entre os vinte municípios que ocupam as últimas posiçôes no ranking dos 1.620 municípios pesquisados da Região Sudeste, infelizmente 18 são do estado do Rio de Janeiro.

A trajetória do estado do Rio de Janeiro no pós-1960 também conduziu a uma situação particularmente grave no que tange à questão da segurança pública, com a constituição de "estados paralelos" na metrópole carioca, em um nível de institucionalização inexistente em outras metrópoles brasileiras e mesmo da América Latina, sendo consequência da particular desestruturação ocorrida na polícia fluminense, com a instauração do marco institucional que passa a existir no Rio após o golpe de 1964. A respeito disso, vale citar dois artigos analíticos: o de Mauro Osorio, intitulado "Estado do Rio de Janeiro: estagnação de longo curso e possibilidades de reversão", publicado no Jornal dos Economistas, do Corecon/RJ, em 2008, e o do jornalista Xico Vargas, intitulado "O caminho de ouro", publicado no site No Mínimo, em 2006.

No primeiro, destaca-se o fato de policiais de outros estados brasileiros - incluindo estados muito violentos, como, por exemplo, Pernambuco - que vieram para o Rio de Janeiro compor a Força Nacional, por ocasião do Pan-Americano em 2007, terem, de acordo com os jornais da época, ficado estupefatos com o nível de armamento apurado nas áreas dominadas pelo tráfico no Rio e também com o elevado grau de rejeição dos moradores de favelas em relação às forças policiais estaduais.

No segundo artigo, Xico Vargas aponta o alarmante nível de institucionalização da corrupção então verificada na estrutura de segurança pública estadual. Em suas palavras: "De qualquer maneira, para policiais (os da banda boa) não há dúvida de que todas as delegacias têm dono e quotas de arrecadação".

\footnotetext{
${ }^{24}$ Esse índice procura observar a qualidade da educação em cada município brasileiro, levando em consideração os dados disponíveis no que diz respeito aos resultados da educação pública e privada, de ensino fundamental e médio. Leva em conta ainda informações como o número de crianças e adolescentes em idade escolar e fora da sala de aula. Procura também dar ênfase à necessidade de integrar os ensinos fundamental e médio, dentro da lógica de estimular a criação, em cada localidade, de um sistema municipal de educação. A metodologia completa desse índice está disponível no link http://www.ioeb.org.br/pagina/metodologia.

25 Em algumas análises e debates sobre o estado do Rio de Janeiro, a região Noroeste Fluminense é apontada como a mais complicada do ponto de vista socioeconômico. De fato, essa região é a que apresenta o menor PIB per capita, entre todas as oito regiōes de governo do estado do Rio de Janeiro. No entanto, ao olharmos com mais cuidado para o conjunto dos indicadores socioeconômicos dos 92 municípios fluminenses e das regiôes de governo, verificamos que a região com maior degradação socioeconômica é a metropolitana, em particular, a periferia. Sobre o assunto, ver Sobral (2015).
} 


\section{0 Rio no século XXI: potencialidades, dilemas e desafios}

No início do século XXI, a economia do estado do Rio de Janeiro volta a apresentar, após várias décadas, aproximação com a trajetória da economia brasileira. Isso tem relação com a atração de investimentos para a região, que tem início em meados dos anos 1990 e começa a impactar os indicadores econômicos, principalmente a partir do final da primeira década do século XXI. Entre os grandes investimentos que têm lugar no estado do Rio de Janeiro, destacam-se, por exemplo, a chegada de montadoras de automóveis à região do Médio Paraíba; a implantação da Rio Polímeros, em Duque de Caxias, com vistas à criação, na região, de um polo de gás-químico; ${ }^{26}$ a reativação da indústria naval; a ampliação de investimentos pela Petrobras até o ano de 2014; a instalação, na cidade do Rio de Janeiro, de novas empresas petrolíferas; a consolidação do parque tecnológico da UFRJ, em torno do complexo de petróleo e gás; a instalação de uma planta siderúrgica no distrito industrial de Santa Cruz; investimentos na Fiocruz e no Instituto Vital Brazil; além dos investimentos derivados da política de atração de megaeventos.

A aproximação do estado do Rio de Janeiro com a trajetória econômica brasileira pode ser verificada, por exemplo, pelo crescimento em 25,0\%, entre 2008 e 2014, do emprego formal, enquanto na Região Sudeste e no Brasil os índices foram, respectivamente, de 21,6\% e 25,7\%. No entanto, o conjunto dos indicadores apontados mostra a continuidade de uma grave situação socioeconômica no estado do Rio de Janeiro, que é reforçada pela crise a partir de 2015, atingindo particularmente esse estado, não só pela herança ainda existente da trajetória pós-1960, como também pela forte queda do preço internacional do petróleo e por seu impacto para as receitas públicas de royalties no âmbito do estado do Rio de Janeiro e de seus municípios, em especial as regióes norte e das Baixadas Litorâneas.

Para a superação definitiva dessa condição de precariedade e a constituição de um círculo virtuoso no estado do Rio de Janeiro, deve-se levar em conta que é necessário mobilizar mais a academia no que diz respeito às reflexões sobre o estado e seus municípios. De fato, a tradição no estado do Rio, até os dias atuais, de se ter especial preocupação com os temas nacionais vis-à-vis os temas locais, é confirmada, por exemplo, no fato de que inexistem, em quaisquer dos programas de mestrado e doutorado em Economia das universidades instaladas no estado, linhas permanentes de pesquisa em Economia Regional.

${ }^{26}$ Em 1995, o governo Fernando Henrique Cardoso, em face da decadência econômico-social do estado do Rio de Janeiro e da importância social e simbólica dessa região, criou um Conselho de Açôes Federais no estado, chefiado pelo presidente da República e tendo como secretário-executivo o advogado Raphael de Almeida Magalhães. Entre suas prioridades, esse Conselho definiu: a criação de um polo petroquímico com base no gás natural, em Duque de Caxias; o desenvolvimento de um porto de contêiner em Itaguaí, cujo projeto consistia em ser o maior porto da América Latina; e a criação de um grupo de trabalho para atuar em prol da conquista, pelo Rio de Janeiro, da função de sede das Olimpíadas de 2004. Essa iniciativa contribuiu para a política de atração de megaeventos, que redundou no fato de o Rio de Janeiro ser a sede dos Jogos Pan-Americanos, em 2007; dos Jogos Mundiais Militares, em 2011; da Rio+20, em 2012; da Jornada Mundial da Juventude, em 2013; uma das principais sedes da Copa do Mundo, de 2014; e também sediar as Olimpíadas de 2016. 
A carência de reflexão dificulta o debate na sociedade sobre uma real agenda que permitiria a constituição de um círculo virtuoso no Rio de Janeiro e a diminuição das desigualdades sociais e territoriais. Além disso, possibilita particular liberdade para a atuação de lobbies e grupos de interesse, como ocorreu nos anos 1960 e na primeira metade dos anos 1970, quando os governos Lacerda, Negrão e Chagas incorporaram a tese equivocada de que a indústria guanabarina estaria migrando para o antigo estado do Rio e a prioridade da política econômica local seria estabelecer condições que permitissem retê-la no território carioca. Em período mais recente, um bom exemplo é o forte lobby dos grupos Multiterminais e Libra, proprietários dos terminais de contêineres localizados no Porto do Rio, o que dificulta uma política de apoio ao crescimento do terminal de contêiner localizado em Itaguaí e que pode ser uma peça-chave para atrair atividades produtivas para a periferia metropolitana, fazendo, assim, com que a região deixe de ser dormitório.

Do ponto de vista setorial, no que diz respeito ao adensamento produtivo, é importante examinar e aprofundar as pesquisas e os debates acerca das atividades e dos complexos produtivos com maior potencialidade no estado do Rio de Janeiro. Em primeiro lugar, é fundamental ampliar a discussão sobre o papel que o setor do petróleo e o que podemos denominar de complexo do petróleo e gás - extração de petróleo; partes, peças e equipamentos; indústria naval; inovação; projetos de engenharia; convençôes, eventos e turismo de negócios em geral; serviços de apoio etc. - podem significar para o desenvolvimento socioeconômico do estado do Rio de Janeiro nas próximas décadas. É óbvio que a prioridade absoluta deve ser a busca de energias renováveis e o estímulo às atividades econômicas, como, por exemplo, o desenvolvimento de carros elétricos. No entanto, o que afirmam alguns especialistas, como, por exemplo, o professor Adilson Oliveira, da UFRJ, é que o mundo ainda continuará dependente do petróleo nas próximas décadas. Além disso, algumas análises, não só da academia, mas também de empresas do setor petróleo, como a Shell, que mantêm como prioritários seus investimentos no Brasil, apontam que a produtividade na extração do petróleo no pré-sal tem crescido muito, e que essa extração permanece absolutamente viável. Sobre a competitividade e a produtividade do pré-sal, vale a pena reproduzir um trecho da entrevista concedida por Guilherme Estrella, ex-diretor de Exploração e Produção da Petrobras, e chefe, entre 2003 e 2012, da equipe que descobriu o pré-sal. A entrevista foi publicada no jornal Estado de S. Paulo, de 2 de março de 2016:

A Petrobras produz 2 milhôes de barris por dia nas Bacias de Santos e Campos, na frente do mercado consumidor. Nós produzimos a US\$ 8 o barril no pré-sal, por usar a infraestrutura vizinha da Bacia de Santos. É uma vantagem competitiva. As grandes empresas mundiais produzem 4 milhōes de barris por dia em campos espalhados no mundo, com operação caríssima.

Assim, deve-se identificar cuidadosamente qual é a real presença do complexo de petróleo e gás no Rio de Janeiro, definindo-se a política que deve ser aprimorada/buscada, com vistas a atrair novas empresas, emprego e renda para a região com o desenvolvimento do pré-sal. Entendemos que, com frequência, o debate sobre petróleo no estado do Rio de Janeiro é desfocado. O problema é ter o complexo de petróleo e gás ou ter apenas a extração de petróleo em alto-mar, os royalties, sedes administrativas de empresas vinculadas ao complexo e a uma parte da indústria naval? Ou seja, talvez estejamos, no estado do Rio de Janeiro, em situação mais próxima à da Venezuela, que extrai e vende petróleo bruto, do que 


\section{Rio de Janeiro: trajetória institucional e especificidades do marco de poder}

à situação de algumas regiôes como a Noruega, em que o complexo de petróleo e gás é adequadamente aproveitado e responsável por um em cada nove empregos existentes naquele país.

É claro que parte das demandas do pré-sal será atendida pela indústria já instalada em São Paulo. No entanto, conforme pesquisas realizadas quando da organização do Plano Diretor do Arco Metropolitano, ${ }^{27}$ a exploração do pré-sal e sua nova escala permitirão a presença, no Brasil, de novas atividades produtivas para atender às demandas desse complexo. Podemos, então, desenhar uma política que permita identificar as novas oportunidades e atraí-las para o Rio de Janeiro, preferencialmente para a periferia metropolitana, quando se tratar de atividades industriais.

A crise política e econômica que se instaurou no Brasil em 2015 teve como um de seus eixos centrais a Petrobras e o conjunto do complexo, impactados pela queda do preço internacional do petróleo e também pelas investigações de corrupção do Ministério Público e da Polícia Federal. O Rio de Janeiro vem apresentando um desempenho, na crise, pior do que o Brasil no que diz respeito à questão fiscal, principalmente pela forte queda das receitas de royalties. No entanto, no que tange ao conjunto dos indicadores econômicos, como, por exemplo, evolução do comércio, da indústria e do emprego, não se verifica, em 2015, uma situação do estado do Rio de Janeiro pior que a do Brasil. Não seria uma pista de que importante parte do complexo de petróleo e gás não se encontra no território fluminense?

Outro bloco econômico importante no território fluminense, que ainda pode ser muito potencializado e que apresenta sinergia entre suas atividades, é aquele vinculado às atividades de turismo, entretenimento, cultura, multimídia, esporte e lazer. ${ }^{28}$ Isso porque a cidade e o estado do Rio de Janeiro têm clara potencialidade para o turismo, em virtude de suas belezas de mar e montanha; pela presença, no estado, de três entre os quatro parques nacionais mais importantes do país: Parque da Tijuca; Serra dos Órgãos e Itatiaia; pela importância histórica de regiões como a cidade do Rio; pela região do Médio Paraíba, com suas fazendas de café e a cidade imperial de Petrópolis; e pela potencialidade do que podemos denominar de turismo de convivência - aquele que se faz para conhecer a cultura, o estilo de vida e as especificidades de uma região.

A carência de planejamento no estado do Rio torna o turismo ainda pouco aproveitado. $\mathrm{Na}$ cidade do Rio, o total de empregos em hotéis e pousadas representa apenas cerca de $1 \%$ do total de empregos formais da cidade (MTE/Rais, 2014). ${ }^{29}$ Além disso, algumas pesquisas que fizemos apontam para o fato de que a atividade turística nas demais 91 cidades fluminenses só é significativa para a economia municipal em Armação dos Búzios, Parati e Itatiaia.

A história do Rio também leva à importante presença de atividades culturais e das áreas de cinema e vídeo na região. Além disso, as áreas de cinema e vídeo têm apresentado forte crescimento, por causa da política de conteúdo nacional e fomento ao setor implantada pelo governo federal no início do século XXI, com a aprovação de uma legislação específica à criação da Ancine e de um fundo a ela

\footnotetext{
${ }^{27}$ Osorio et al., 2011.

${ }^{28}$ Uma análise detalhada sobre esse complexo econômico, suas potencialidades e proposiçôes de políticas pode ser vista em Osorio e Sobral (2013).

${ }^{29} \mathrm{O}$ dado do total de empregos em hotéis e pousadas na cidade do Rio de Janeiro, em 2014, já incorpora boa parcela dos novos hotéis abertos em função dos megaeventos que ocorrem na cidade, desde o Pan-Americano de 2007.
} 
vinculado. No entanto, no que diz respeito às atividades de entretenimento, esporte e lazer, deve-se buscar um adequado aproveitamento dos complexos esportivos criados ou aprimorados no Rio de Janeiro, tendo em vista os megaeventos. Nesse aspecto, uma das possibilidades consiste em buscar uma política que transforme a cidade do Rio na capital do esporte da América Latina.

Outra posibilidade é que, atualmente, os complexos esportivos não funcionam apenas como palco para competiçôes, atendendo também a outras atividades de entretenimento e lazer. Deve-se ter em conta ainda que a cidade do Rio de Janeiro, além de receber bem seus visitantes, desde a Eco 92, já tem importante experiência na organização de megaeventos, o que, com a realização das Olimpíadas de 2016, permitirá a geração de uma imagem internacional positiva para a cidade e contribuirá para a alavancagem do turismo. ${ }^{30}$

Outra área em que se pode definir uma política de adensamento produtivo no estado do Rio de Janeiro está vinculada ao que podemos denominar de complexo da economia da saúde. O Sistema Único de Saúde brasileiro é o maior comprador público, entre todos os países do mundo, de insumos para atendimento na área de saúde. Assim, a partir de 2004, o governo federal iniciou o desenho de uma política de criação ou atração para o país de novas atividades produtivas desse setor, com base no poder de compra do governo.

O Rio de Janeiro é um espaço privilegiado para atrair essas novas atividades. O estado abriga significativa indústria farmacêutica e há uma importante área de pesquisa nesse setor. Além disso, tem o privilégio de sediar a Fiocruz, instituição-chave nessa nova política, inclusive do ponto de vista de absorção de novas tecnologias. ${ }^{31}$ Também conta com presença importante na área de cirurgia plástica, atraindo moradores de outras regiōes brasileiras e do exterior. Registre-se que a vinda de pessoas do exterior para o Rio de Janeiro, a fim de aproveitar a expertise em cirurgia plástica, pode ser ampliada, a partir de 2016, se for mantido o fim da sobrevalorização cambial.

Por último, é importante aprofundar os benefícios econômicos que podem advir da presença das Forças Armadas no Rio de Janeiro, não só pelos recursos que essa instituição injeta na economia, por meio do pagamentos de salários e das compras de insumos que realiza para a manutenção de suas atividades, mas também pelas atividades de ensino, pesquisa e produção que empreende em nosso território, como, por exemplo, com o estaleiro nuclear da Marinha, que está sendo instalado no município de Itaguaí.

\footnotetext{
${ }^{30}$ Do ponto de vista do custo e dos investimentos gerados pela realização das Olimpíadas, diversos questionamentos podem ser feitos. Em primeiro lugar, começa a haver um entendimento crescente de que a forma como se organizam as Olimpíadas deve ser simplificada. Em segundo lugar, a realização do evento em região de expansão territorial da cidade do Rio de Janeiro, na Zona Oeste, ao contrário do que ocorreu em Londres e Barcelona - em geral, apresentadas como exemplos bem-sucedidos do ponto de vista urbano -, pode gerar uma série de efeitos negativos, como a ampliação dos custos em infraestrutura, pela expansão territorial da cidade, e o maior distanciamento entre trabalho e moradia, o que representa o oposto do que os urbanistas hoje em dia hegemonicamente recomendam. Maior detalhamento dessa discussão, no entanto, não cabe no escopo deste artigo.

${ }^{31}$ Sobre o assunto, ver Hasenclever e Paranhos, 2015.
} 
No que diz respeito ainda ao adensamento produtivo no estado do Rio de Janeiro, é importante desenhar uma estratégia de fomento territorializada, com vistas a aumentar a endogenia da economia fluminense. De acordo com essa estratégia, deve-se pensar a cidade do Rio de Janeiro como um espaço de coordenação da economia regional. Entre as oito regiôes de governo, os desafios mais complexos estão na Região Metropolitana do Rio de Janeiro e em sua periferia. Não só pelo fato de a RMRJ concentrar 74,3\% da população fluminense; $77,4 \%$ dos empregos formais do estado; e $64,7 \%$ do PIB do estado, mas também por ser a região, no território fluminense, que apresenta os maiores desafios do ponto de vista socioeconômico e de desigualdade social (IBGE e MTE).

Em primeiro lugar, a periferia metropolitana ainda é basicamente dormitório, o que gera diversos problemas, como, por exemplo, a existência, na quase totalidade de seus municípios, de uma diminuta base produtiva para a arrecadação de receita pública municipal. Por exemplo, enquanto o município de São Caetano do Sul, da periferia da RMSP, que apresenta forte densidade produtiva, apresentava, em 2014, uma receita pública per capita de $\mathrm{R} \$$ 6.832,86, o município de Duque de Caxias (RMRJ), muitas vezes percebido no imaginário popular como um município rico, apresentava uma receita pública per capita de apenas $\mathrm{R} \$ 2.012,51 .^{32}$ Isso porque, embora a refinaria Duque de Caxias e outras poucas grandes empresas estejam em seu território, o conjunto de sua estrutura produtiva é extremamente ralo (Finbra/STN/MF).

Da mesma forma, ao analisarmos os indicadores sociais na RMRJ e principalmente em sua periferia, vemos resultados bastante preocupantes, sejam em comparação com os municípios fluminenses das outras sete regiôes do governo, sejam em comparação com o total dos municípios da Região Sudeste brasileira, ou ainda nos rankings dos municípios com mais de cinquenta mil habitantes das periferias das RMRJ, RMSP e RMBH.

Entre os exemplos para o ranking dos resultados na educação através do Índice de Oportunidades da Educação Brasileira-Ioeb (2013), verificamos que os piores resultados pertencem aos 18 municípios da periferia da RMRJ com mais de cinquenta mil habitantes.

No quesito segurança, novamente comparando-se os municípios das periferias das RMRJ, RMSP e RMBH com cinquenta mil habitantes ou mais, têm-se São Caetano do Sul e São Bernardo, ambos da RMSP, como os municípios com os dois melhores resultados, apresentando, em 2013, taxas de homicídios por cem mil habitantes de 4,48 e 6,20, respectivamente. Por outro lado, vários municípios da RMRJ apresentavam elevadas taxas de homicídios, superiores a quarenta por cem mil habitantes: Japeri, 41,67; Itaguaí, 51,06; Belford Roxo, 54,23; Duque de Caxias, 60,30; e Nova Iguaçu, 63,62 (Datasus).

A precarização da periferia metropolitana também pode ser observada pelo ranking dos 59 municípios com mais de cinquenta mil habitantes das periferias das metrópoles do Rio de Janeiro, São Paulo e Belo Horizonte em relação ao percentual de domicílios atendidos por rede de água, em 2010. Entre os 18 piores resultados, estão 14 municípios da periferia da RMRJ. Além disso, os dados revelam que a qualidade e a periodicidade da chegada de água aos domicílios não são boas (IBGE, 2010).

${ }^{32}$ Sobre o assunto, ver Sobral (2015). 
Uma estratégia e uma agenda que permitam o início de um círculo virtuoso para a RMRJ e, principalmente, para a periferia devem pensar, de forma integrada, políticas sociais, de infraestrutura e de atração de investimentos. Essa estratégia e essa agenda devem levar em conta a questão da melhoria da educação e da formação profissional, bem como das políticas públicas de saúde; a criação de recursos de amenidades, como parques públicos, hoje inexistentes na periferia metropolitana, exceto em Niterói; a organização do zoneamento urbano e a regularização de terrenos para a instalação de empresas; e melhoria da logística e da infraestrutura de telecomunicações, energia elétrica e saneamento. E tudo isso deve ser pensado tanto para os cidadãos quanto para as empresas.

Um primeiro exemplo da necessidade de se pensar, de forma integrada, a questão da qualidade de vida na RMRJ e na periferia metropolitana está evidente em alguns depoimentos de gestores públicos, no sentido de que empresários que visitam o Rio de Janeiro, quando da avaliação da viabilidade de instalarem atividades produtivas no estado, ficam impressionados com a falta de cidades organizadas na periferia metropolitana em que seus funcionários possam trabalhar e viver bem. Outro bom exemplo é o depoimento de um empresário que produz materiais de construção e possui três plantas industriais - duas em São Paulo e uma na Baixada Fluminense. Esse empresário afirma que, embora o Arco Metropolitano tenha melhorado a logística, ele ainda pensa em transferir a planta que possui na Baixada para São Paulo, levando em conta que, com frequência, a energia cai na região e, assim, não só a produção fica paralisada, como se perde o que estava em produção. Além disso, quando chove, o sinal de internet cai e não se pode sequer emitir uma nota fiscal eletrônica.

O último exemplo paradigmático das dificuldades na atração de empresas, encadeamentos e adensamento produtivo na RMRJ, excluindo-se a cidade do Rio de Janeiro e Niterói, é o fato de que a instalação da indústria Rio Polímeros em Campos Elíseos, no município de Duque de Caxias, não atraiu praticamente nenhuma nova indústria de plástico. Ocorre que a criação da Rio Polímeros, planta petroquímica de primeira e segunda gerações, foi desenhada com vistas a funcionar como âncora de um polo de gás químico que também incorporaria a terceira geração petroquímica, ou seja, a indústria de plásticos. Sem dúvida, a terceira geração petroquímica é fundamental, pois não só é intensiva em mão de obra, como também é composta, de forma hegemônica, por pequenas e médias empresas. A não atração de indústrias de plástico para a periferia metropolitana deveu-se fundamentalmente à não existência de áreas com infraestrutura adequada à sua instalação.

Se a RMRJ é a região de governo do estado do Rio de Janeiro que apresenta os maiores desafios em políticas sociais, infraestrutura e adensamento produtivo, as outras sete regiōes estão longe de apresentar um quadro confortável quando se compara sua situação socioeconômica com a da maioria dos municípios das regiōes Sudeste e Sul brasileiras. Nesse sentido, é imperioso ampliar a reflexão sobre o estado do Rio de Janeiro e suas especificidades territoriais, de forma sistemática, com vistas ao devido conhecimento e à socialização das informações sobre a atual realidade fluminense, definindo-se qual agenda possibilitará a superação das precariedades estruturais e da crise atual, com o início de um círculo virtuoso no conjunto do estado. 
Rio de Janeiro: trajetória institucional e especificidades do marco de poder

\section{Referências}

BARROS, Frederico Robalinho de. Economia industrial do novo estado do Rio de Janeiro. Rio de Janeiro: APEC/IDEG, 1975.

BERNARDES, Lysia Maria Cavalcanti (org.). O Rio de Janeiro e sua regiāo. Rio de Janeiro: IBGE/ Conselho Nacional de Geografia, 1964.

DINIZ, Eli. Voto e máquina política: patronagem e clientelismo no Rio de Janeiro. Rio de Janeiro: Paz e Terra, 1982.

DULCI, Otávio Soares. Em busca da Idade de Ouro: as elites politicas fluminenses na Primeira República (1889-1930). Niterói: UFF/Instituto de Ciências Humanas e Filosofia, 1991.

—_ (org.). Crônica política do Rio de Janeiro. Rio de Janeiro: FGV, 1998.

- Política e recuperação econômica em Minas Gerais. Belo Horizonte: Ed. da UFMG, 1999.

FIANI, Ronaldo. "Estado e economia no institucionalismo de Douglass North", Revista de Economia Politica, v. 23, n. 2, abr./jun. 2003.

FREIRE, Américo. Uma capital para a República: poder federal e forças políticas locais no Rio de Janeiro na virada para o século XX. Rio de Janeiro: Revan, 2000.

GUANABARA. Secretaria de Ciência e Tecnologia. Comissão do ano 2000. Rio Ano 2000. Rio de Janeiro, 1970.

HASENCLEVER, Lia e PARANHOS, Julia. "Complexo da economia da saúde no estado do Rio de Janeiro: uma oportunidade de ampliar o desenvolvimento do estado?”. In OSORIO, Mauro et al. (orgs.). Uma agenda para o Rio de Janeiro: estratégias públicas para o desenvolvimento socioeconômico. Rio de Janeiro: FGV, 2015.

HIRSCHMAN, Alberto. Estratégia do desenvolvimento econômico. Rio de Janeiro: Fundo de Cultura, 1958.

HODGSON, Geoffrey M. Economia e evolução: o regresso da vida à teoria econômica. Oeiras: Celta, 1997.

IDEG. Instituto de Desenvolvimento da Guanabara. Tendências de crescimento da Guanabara. Rio de Janeiro: Senai, 1974.

KRUGMAN, Paul et al. Economia espacial: urbanização, prosperidade econômica e desenvolvimento humano no mundo. São Paulo: Futura, 2002.

LESSA, Carlos. O Rio de todos os Brasis: uma reflexão em busca de autoestima. Rio de Janeiro: Record, 2000

MAGALHÃES, J. P. A. et al. Rio século XXI: perspectivas e propostas para a economia fluminense. Rio de Janeiro: JB, 1991.

MAGALHÃES, Raphael de Almeida. Breve histórico sobre a estruturação física e econômica da cidade e sua região. S.l., 2001. (mimeo)

MELLO, João Manuel Cardoso de. O capitalismo tardio. São Paulo: Brasiliense, 1982.

- Saudades da Guanabara. Rio de Janeiro: FGV, 2000.

MOTTA, Marly Silva da. Rio de Janeiro: de cidade-capital a Estado da Guanabara. Rio de Janeiro: Alerj, 2001. 
MOULAERT, Frank. Globalization and Integrated Area Development in European Cities. Nova Iorque: Oxford University Press, 2000.

MYRDALL, Gunnar. Teoria econômica e regiōes subdesenvolvidas. 2 ed. Rio de Janeiro: Saga, 1968.

NORTH, Douglass C. Instituciones, cambio institucional y desempeño económico. México: Fondo de Cultura Económica, 1993.

OSORIO, Mauro. Rio nacional, Rio local: origens e especificidades da crise carioca e fluminense. Estratégias, instituições e desenvolvimento (tese). UFRJ, 2004.

- Rio nacional, Rio local: mitos e visóes da crise carioca e fluminense. Rio de Janeiro: Senac, 2005.

— e SOBRAL, Bruno. A capacidade indutora dos serviços no estado do Rio de Janeiro. Relatório de pesquisa. Rio de Janeiro: Sebrae, 2013.

— e VERSIANI, Maria Helena. "O papel das instituições na trajetória econômico-social do estado do Rio de Janeiro", Cadernos do Desenvolvimento Fluminense, n. 2, 2013, pp. 1-23.

— et al. Análise da dinâmica espacial dos complexos logistico-produtivos e recomendaçôes para o maior impacto positivo dos empreendimentos estruturantes. Plano Diretor Estratégico de Desenvolvimento Sustentável da Meso-Região do Arco Metropolitano do Rio de Janeiro. Relatório Final da Política de Desenvolvimento Econômico e Social -PDES. Rio de Janeiro: Governo do Estado do Rio de Janeiro, 2011.

— et al. (orgs.). Uma agenda para o Rio de Janeiro: estratégias públicas para o desenvolvimento socioeconômico. Rio de Janeiro: FGV, 2015.

PACHECO, Carlos Américo. Fragmentação da nação. São Paulo: Unicamp/IE, 1998.

RIBEIRO, Luiz Cesar de Queiroz (org.). Rio de Janeiro: transformaçôes na ordem urbana. Rio de Janeiro: Letra Capital/Observatório das Metrópoles, 2015.

ROSA, Luiz Pinguelli e OSORIO, Mauro (orgs.). "O gás natural na América Latina, no Brasil e no estado do Rio de Janeiro: algumas consideraçôes”, Cadernos de Energia, Rio de Janeiro: Energe/ Coppe/UFRJ, n. 8, jun. 1995.

SOBRAL, Bruno Leonardo Barth. Metrópole do Rio e projeto nacional: uma estratégia de desenvolvimento a partir de complexos e centralidades no território. Rio de Janeiro: Garamond, 2013.

—. "A questão metropolitana em perspectiva: o desafio de tornar a periferia da RMRJ mais densa produtivamente e com melhor infraestrutura básica”. In OSORIO, Mauro et al. (orgs.). Uma agenda para o Rio de Janeiro: estratégias públicas para o desenvolvimento socioeconômico. Rio de Janeiro: FGV, 2015, pp. 17-44.

VEBLEN, Thorstein. The theory of the leisure class. Nova Iorque: Modern Library, 1934.

VERSIANI, Maria Helena. Padróes e práticas na politica carioca: os deputados federais eleitos pela Guanabara em 1962 e 1970 (dissertação). UFRJ, 2007. 


\section{Em busca de cidades mais justas por meio da tributação imobiliária: um olhar sobre as cidades fluminenses ${ }^{1}$}

Angela M. S. Penalva Santos ${ }^{2}$

\section{Introdução}

0 Brasil experimentou grande avanço normativo para ordenar o crescimento urbano desde a entrada em vigor da Constituição de 1988: o município foi institucionalmente fortalecido ao ser considerado "ente federativo" e responsável pela execução de políticas sociais descentralizadas. É também o ente responsável pela política urbana, tendo sido criados vários novos instrumentos de controle do uso do solo urbano, todos regulados pelo Estatuto da Cidade em 2001.

Tal avanço normativo não se manifestou na melhora do ordenamento urbanístico nas grandes cidades. Ao contrário, a intensificação da urbanização da população brasileira seguiu espacialmente polarizada, o que tornou ainda mais desafiadora a gestão dessas cidades. Além do já tradicional problema de inadequação de infraestrutura urbana, a insegurança pública, combinada com a falta de mobilidade urbana, tornou mais difícil a vida nessas cidades, ainda que sigam oferecendo as maiores e melhores oportunidades de emprego, o que alimenta os fluxos migratórios em sua direção (Santos, 2012 e 2014a).

O crescimento da população nas grandes cidades se expressa pela extensão da malha urbana, inclusive para além das fronteiras municipais, o que implica a necessidade de que os municípios expandam suas redes de infraestrutura urbana. Ressalta-se que, à medida que aumenta a responsabilidade financeira dos municípios, a terra urbana se valoriza nos terrenos mais bem localizados. Nessas

1 Este artigo sintetiza parte das conclusões do Grupo de Pesquisa sobre Tributação Imobiliária que coordenei no Programa de Pós-Graduação em Direito, na linha Direito da Cidade. Participaram do grupo os pós-graduandos Pedro Vasques, Natália Sales, Diego Ximenes, Álvaro Carlos Barbosa e Carmem Silvia Mattos.

2 Professora associada da Faculdade de Ciências Econômicas da Universidade do Estado do Rio de Janeiro. Pós-doutora em Planejamento Urbano. 
condições, as prefeituras alimentam um processo de valorização fundiária que desempenha o papel de redistribuir regressivamente a renda real da população. ${ }^{3}$

O aumento do preço da terra urbana é um fenômeno que não se restringe às nossas cidades, parecendo ser generalizado, como sugerem as análises de Thomas Piketty a respeito das mudanças na estrutura da riqueza nos últimos três séculos. Com base em dados sobre França e Reino Unido, esse autor mostra que, no início do século XVIII, a terra rural representava mais da metade da forma como a riqueza se manifestava. A Revolução Industrial levou à diversificação dessa riqueza no século XIX e, desde a segunda metade do século XX, é a riqueza em forma de terra urbana (moradias) que mais tem crescido, correspondendo a cerca da metade do patrimônio acumulado em 2010 (Piketty, 2014, pp. 118-9).

O processo de urbanização com polarização espacial nas grandes cidades, associado ao aumento do preço da terra urbana, produz efeitos socioespaciais negativos. Segregação urbana, insegurança pública e aumento dos movimentos pendulares são alguns desses efeitos que pesam, de forma significativa, sobre as condições de vida da população urbana mais vulnerável. E são fatores que desafiam os governos locais a buscarem melhorar a gestão urbana.

Este artigo visa a defender o avanço na tributação imobiliária como uma forma de: i) aumentar as receitas próprias dos municípios, elevando suas receitas orçamentárias, de modo a permitir o financiamento da expansão da infraestrutura urbana; e, principalmente, ii) ser utilizado como instrumento de política urbana comprometida com cidades mais sustentáveis e inclusivas.

Divide-se na presente introdução, seguida por uma seção sobre a normatividade do IPTU para fins de política urbana, em que se apresenta uma síntese dos estudos sobre o emprego desse tributo na América Latina. Na terceira seção, apresentam-se dados que caracterizam as finanças públicas municipais, destacando o papel da tributação imobiliária nos municípios brasileiros, com foco para aqueles que têm população superior a duzentos mil habitantes, em particular os localizados no estado do Rio de Janeiro. Por fim, a quarta seção é destinada às considerações conclusivas, apontando para a enorme distância entre a norma e a efetividade no uso do IPTU como instrumento de política urbana ou arrecadatória.

\section{A tributação imobiliária no Brasil}

A Constituição Federal brasileira proclama o caráter social que deve ser conferido à propriedade, regrando, repetidas vezes, em vários dispositivos, sua função social. ${ }^{4}$ Ademais, influenciado pelo

3 Renda real é um conceito que não se restringe à renda monetária, incluindo o conjunto de acesso às condições de vida, que podem ser ampliados por meio da disponibilidade de infraestrutura urbana provida pelo poder público.

${ }^{4}$ Art. 5, XXII: é garantido o direito de propriedade; XXIII - a propriedade atenderá à sua função social; Art. 170: A ordem econômica, fundada na valorização do trabalho humano e na livre iniciativa, tem por fim assegurar a todos existência digna, conforme os ditames da justiça social, observados os seguintes princípios: II -propriedade privada; III - função social da propriedade; Art. 182, $\$ 2^{\circ}$ : A propriedade urbana cumpre sua 


\section{Em busca de cidades mais justas por meio da tributação imobiliária}

tratamento constitucional, o artigo 1.228 do Código Civil veio acrescido de um parágrafo que traduz o caráter socialmente funcionalizado da propriedade. ${ }^{5}$ Desse modo, ao direito da propriedade, necessariamente está agregado seu predicado legitimador, que é o princípio da função social. Ou, dito de outro modo, o aspecto estrutural da propriedade - uso, gozo, disposição e direito de reaver o bem por detenção injusta - somente é assegurado pelo sistema brasileiro na medida em que esteja consentâneo com os interesses coletivos contemporâneos ao ambiente em que se situa o bem.

Considerando a referida atmosfera, um princípio próprio do Direito Urbanístico que se intensifica à medida que os problemas urbanos vão-se tornando cada vez mais evidentes é aquele presente no artigo $2^{\circ}$, incisos IX e X, do Estatuto da Cidade. Esse artigo estabelece, como diretriz da política urbana, a "justa distribuição dos benefícios e ônus decorrentes do processo de urbanização", complementado pela "recuperação dos investimentos do Poder Público de que tenha resultado a valorização de imóveis urbanos".

Tais diretrizes da política urbana deveriam ser seguidas principalmente pelas cidades de médio e grande portes. Vale destacar que, segundo a atual dinâmica econômica, aquelas cidades tornaram-se economias de serviços após a perda de peso na geração do PIB pela indústria (Santos, 2012). O resultado disso é a intensificação da polarização espacial, tornando-as polos que seguem atraindo capital e população. Nessas condições, a terra urbana passou a ser mais disputada e valorizada, tornando-se uma fronteira para a aplicação de grande rentabilidade pelo capital imobiliário. E a produção de moradias deixou de ser considerada uma necessidade vital, passando a ser tratada como patrimônio a ser valorizado (Rolnik, 2015).

Quando a valorização das propriedades imobiliárias decorre de intervenção e investimentos públicos, é preciso avaliar quem ganha e quem perde para, então, se imporem mecanismos de compensação de benefícios e ônus criados. A partir da lógica distributiva, que emana das referidas diretrizes urbanísticas, busca-se levar ao alcance da coletividade em geral, e não apenas de proprietários isolados, os efeitos do desenvolvimento urbano, bem como desestimular ações contrárias a um eficiente aproveitamento de espaços bem aprovisionados de infraestrutura e serviços públicos. É nesse contexto que a tributação sobre a propriedade imobiliária deve ser utilizada, não apenas como instrumento de arrecadação fiscal, mas também para estimular o uso da terra urbana em conformidade com os princípios do Direito Urbanístico.

função social quando atende às exigências fundamentais de ordenação da cidade expressas no plano diretor. Art. 186: A função social é cumprida quando a propriedade rural atende, simultaneamente, segundo critérios e graus de exigência estabelecidos em lei, aos seguintes requisitos: I - aproveitamento racional e adequado; II - utilização adequada dos recursos naturais disponíveis e preservação do meio ambiente; III - observância das disposições que regulam as relações de trabalho; IV - exploração que favoreça o bem-estar dos proprietários e dos trabalhadores.

$5 \$ 1^{\circ}-O$ direito de propriedade deve ser exercido em consonância com as suas finalidades econômicas e sociais e de modo que sejam preservados, de conformidade com o estabelecido em lei especial, a flora, a fauna, as belezas naturais, o equilíbrio ecológico e o patrimônio histórico e artístico, bem como evitada a poluição do ar e das águas. 


\subsection{Tributação imobiliária na América Latina e Brasil: uma sintese $e^{6}$}

A implantação do imposto sobre a propriedade imobiliária foi efetivada na maioria dos países da América Latina. Entretanto, é possível observar, a partir de uma análise sistemática e comparativa entre os países, uma grande diversidade na forma de gestão e instituição do imposto. Outro ponto identificado é a desestrutura na divulgação de informações sobre seu desempenho. Por vezes, o próprio poder público desconhece as principais características dos sistemas implantados e seus mecanismos de reforma.

Estas são as principais conclusões de um estudo elaborado pelo Lincoln Institute of Land Policy entre os anos de 2000 e 2008 (Cesare, 2010), comparando-se a administração do imposto territorial em 13 países da América Latina, perfazendo-se um total de 66 jurisdições avaliadas. A análise a seguir foi fundamentada a partir dos dados coletados na realidade tributária de 12 países da América Latina: Argentina, Brasil, Chile, Colômbia, Costa Rica, Guatemala, Honduras, México, Panamá, Paraguai, Peru e República Dominicana. Observe-se o desempenho geral desse imposto nos países citados, analisando-o como fonte de recurso, sua relação com o PIB per capita, sua relação com o tamanho da população, sua representação em porcentagem do PIB e, por fim, as características essenciais do imposto em cada localidade.

A carga tributária total na América Latina encontra-se em torno de 19\% do PIB. O imposto sobre propriedade imobiliária representa, em média, 1,6\% dessa carga tributária, sendo que os ganhos máximos obtidos nessa região giram em torno de $0,60 \%$ do PIB. Em geral, nos países mais desenvolvidos, a arrecadação desse imposto representa pelo menos 1\% do PIB, atingindo limites de 3\% a 4\% no Canadá, Estados Unidos e Reino Unido. Em contraste, na América Latina, em vários países, os ganhos com o imposto de propriedade são mais baixos que $0,50 \%$ do PIB.

Como tendência geral, verificou-se que, à medida que o PIB per capita medido por Paridade de Poder Aquisitivo (PPA) aumenta, a arrecadação com o imposto predial também cresce, excetuando-se apenas México, República Dominicana e Costa Rica, países nos quais o PIB medido por PPA fica acima da média e a arrecadação por imposto territorial está abaixo da média dos outros países.

Quanto aos impostos cobrados pelos estados, ${ }^{7}$ observa-se que representam, em média, 0,29\% do PIB, mas com grande diferença entre essas esferas de governo. As receitas advindas do imposto de propriedade recolhido pelos municípios como percentagem do PIB são mais elevadas do que a média registrada para os estados. Considerando cinquenta casos observados, os municípios recolhem, em média, 0,72\% de seu PIB em imposto predial. A arrecadação mais alta em 2004 foi a do município de

\footnotetext{
${ }^{6}$ Esta parte do artigo se baseia na síntese elaborada por Natália Sales e Carmem Matos para o grupo de pesquisa sobre Tributação Imobiliária, sob minha coordenação.

7 Governos regionais são aqueles que administram territórios menores do que estados nacionais, porém maiores do que os governos locais, podendo ser chamados de governos estaduais, provinciais ou departamentais.
} 


\section{Em busca de cidades mais justas por meio da tributação imobiliária}

São Paulo (1,49\% do PIB). Existe uma variação considerável entre os municípios estudados e não se detectou tendência clara em relação ao comportamento fiscal no período em análise.

Após a análise da performance em geral, destacam-se as características desse imposto e os pontos de divergência em cada localidade. Inicialmente, salienta-se que o imposto costuma ser de responsabilidade local. No entanto, dependendo do critério de competência adotado, pode ficar a cargo do estado. Há uma grande diversidade na fixação da responsabilidade tributária nos países da América Latina. Algumas vezes, ocorre descentralização de sua instituição e cobrança, como, por exemplo, nos casos de Brasil e Venezuela. Outras vezes, o imposto é centralizado na esfera federal e distribuído aos demais entes, como no caso do Chile.

Em segundo lugar, nota-se que a inclusão do possuidor de imóvel como contribuinte é fundamental para expandir a natureza universal do imposto, em função do grande número de assentamentos informais na América Latina. À exceção de Equador e de Baruta (município da Venezuela), outros países como Argentina, Bolívia, Brasil, Chile, Colômbia, Costa Rica, Guatemala, Honduras, México, Peru, Uruguai e Venezuela incluem a propriedade e a posse como fato gerador da incidência do imposto sobre a propriedade. No Peru, considera-se que o possuidor e o detentor são titulares da obrigação tributária. Na Argentina e na Guatemala, os detentores de bens do Estado são contribuintes para fins de obrigações fiscais. No caso do México, o imposto é aplicado aos bens públicos quando utilizados por entidades privadas.

Quanto à base de cálculo, que se apresenta como um dos poucos pontos de convergência entre as jurisdições, é fixada pelo valor de mercado do solo e da construção. Em relação às alíquotas, um dos critérios mais empregados para a fixação de taxas é a classificação de acordo com o uso do imóvel (terreno baldio, imóvel comercial ou residencial). De acordo com as situações identificadas, o número de classes estabelecidas para a aplicação de taxas varia entre 1 e 19. A estrutura dos critérios é complexa e, usualmente, apresenta definiçóes subjetivas, induzindo o contribuinte a omitir informaçóes. Entretanto, muitas jurisdiçóes optam pela taxa única.

Os dados apontam uma tendência em se tributarem mais os imóveis vazios, já que a média das taxas aplicadas aos terrenos baldios excede em 165\% e 75\%, respectivamente, às médias das propriedades residenciais e não residenciais. Esse resultado sugere a existência de um nítido incentivo ao desenvolvimento urbano por meio do combate à especulação imobiliária com a instituição de sobretaxas, cuja aplicação é relativamente comum nas jurisdições analisadas, podendo representar aumento de $100 \%$ da taxa inicial. Em geral, essas sobretaxas são fixadas para sancionar os imóveis subutilizados, não utilizados ou com a construção paralisada, ou ainda aqueles que não cumprem as normas pertinentes.

Uma característica importante para a configuração da performance desse imposto é a concessão de benefícios tributários. Em todos os casos estudados, os imóveis do Estado estão livres de impostos. Somente no México e no Peru, esses benefícios estão vinculados a prédios que exerçam atividades essenciais. As escolas, igrejas e embaixadas também são contempladas. Embora seja possível conceder isenção para famílias de baixa renda e propriedade de baixo valor, essa questão não é tratada com a relevância necessária. À revelia disso, entre 2000 e 2006 houve concessão de anistia ou descontos entre $15 \%$ e $27 \%$ a 96 casos estudados, sendo identificados benefícios fiscais em cerca de $30 \%$ deles, incluindo descontos para pagamento antecipado. 
O cadastramento, embora ocupe posição de destaque na gestão pública, não é elaborado ou atualizado satisfatoriamente. $\mathrm{Na}$ maioria dos casos, não se realizam inspeçôes periódicas nos imóveis registrados, ocorrendo apenas pontualmente, a fim de atender à demanda de planos. Em alguns países, as inspeções acontecem a cada cinco anos. A maioria não apresenta frequência fixa para inspeção. Apesar de ser essencial para as atividades municipais, não é raro encontrar cadastros que não podem executar as atividades fiscais, nem mesmo as básicas.

Cabe destacar que os valores defasados afetam diretamente a eficiência do imposto como promissora fonte de recursos, provocando erros e distorções que afetam a justa distribuição da carga tributária e a confiança no sistema. O nível médio para avaliação e cálculo do imposto gira em torno de $60 \%$ do valor de mercado dos imóveis. Em média, a arrecadação atinge somente $67 \%$ dos impostos instituídos. Cabe ressaltar ainda que a falta de resposta a muitas perguntas das pesquisas realizadas sugere que o problema é maior do que os resultados obtidos.

Por fim, evasão fiscal é uma questão preocupante e muito presente na realidade da América Latina. A administração pública atribui à cultura de "não pagar” o resultado da pouca arrecadação, mas o estudo do Lincoln Institute sugere que é mais correto considerar que essa prática esteja atrelada à cultura do "não cobrar". Essa avaliação corresponde bem ao caso brasileiro, como se observa na seção a seguir.

\section{0 cenário brasileiro: municípios fluminenses e arrecadação tributária}

Esta pesquisa utilizou os dados secundários disponíveis no sítio eletrônico da Secretaria do Tesouro Nacional. ${ }^{8}$ Trata-se de valores que constam nos orçamentos municipais e que permitem a elaboração de um cenário brasileiro e sudestino para a análise do caso dos municípios fluminenses. O foco do estudo é o IPTU, mas também foram levantadas informações sobre a arrecadação de outro tributo imobiliário, o ITBI, apurado a cada transação que envolve a transmissão de bens imobiliários intervivos.

O estudo partiu da premissa de que existem melhores condiçôes técnicas e econômicas para arrecadar tributos em geral onde a atividade econômica é maior. E essa maior atividade econômica está concentrada nas cidades maiores, aquelas que necessitam contar com instrumentos de ordenação urbanística, pois sentem maior pressão demográfica, em virtude das oportunidades de emprego que oferecem (Santos, 2012 e 2014a). Tais condições estão presentes nos estados das regiões Sudeste e Sul, sendo que o estado de São Paulo segue como a "locomotiva do país", como foi chamado na década de 1970. Ainda que, desde então, seu peso no PIB brasileiro tenha declinado de mais da metade para menos de uma terça parte, trata-se da principal força produtiva do Brasil $(32,1 \%)$, com praticamente três vezes mais importância que o estado do Rio de Janeiro (11,8\%), a segunda maior economia estadual. ${ }^{9}$

\footnotetext{
${ }^{8}$ No link Finbra (Finanças do Brasil - Dados Contábeis dos Municípios). Disponível em http://www.tesouro. fazenda.gov.br/pt_PT/contas-anuais.

9 IBGE - Contas Regionais do Brasil, 2013.
} 
A pesquisa focou-se nos municípios com população superior a duzentos mil habitantes e no campo, e a investigação foi centrada nos municípios fluminenses. O critério do tamanho da população foi estabelecido pelo Censo Demográfico de 2010, o que inclui municípios que, em 2000, ainda não haviam atingido duzentos mil habitantes.

\subsection{Os municípios fluminenses no cenário brasileiro}

A segunda maior economia estadual brasileira conta com 13 municípios que têm população superior a duzentos mil habitantes, sendo o maior deles sua capital, que foi capital do país de 1763 até 1960, quando, então, inaugurou-se Brasília.

$\mathrm{Na}$ Tabela 1, apresenta-se um pequeno perfil desses municípios, sendo que apenas três deles não estão situados na Região Metropolitana do Rio de Janeiro (Campos dos Goytacazes, Macaé e Volta Redonda). Vale dizer que os outros dez fazem parte de uma mesma aglomeração urbana nucleada pela capital estadual.

Tabela 1. Perfil dos municípios fluminenses

\begin{tabular}{|l|c|c|c|c|}
\hline Municípios & $\begin{array}{c}\text { PIB per capita } \\
\mathbf{2 0 1 2}(\mathbf{R} \mathbf{\$})\end{array}$ & $\begin{array}{c}\text { Incidência de po- } \\
\text { breza (\%) 2003 }\end{array}$ & $\begin{array}{c}\text { Arrecadação de } \\
\text { IPTU (mil reais) } \\
\mathbf{2 0 1 4}\end{array}$ & $\begin{array}{c}\text { Arrecadaçáo de } \\
\text { ITBI (mil reais) } \\
\mathbf{2 0 1 4}\end{array}$ \\
\hline Rio de Janeiro & 34.572 & 23,85 & 2.002 .165 & 741.677 \\
\hline São Gonçalo & 11.787 & 39,86 & 51.920 & 18.179 \\
\hline Duque de Caxias & 31.280 & 53,53 & $53.551\left(^{*}\right)$ & $12.219\left(^{*}\right)$ \\
\hline Nova Iguaçu & 13.303 & 54,15 & 39.993 & 15.747 \\
\hline Niterói & 30.729 & 12,47 & 232.784 & 87.061 \\
\hline Belford Roxo & 15.893 & 60,06 & $9.763\left(^{*}\right)$ & $2.341\left(^{*}\right)$ \\
\hline Campos dos Goytacazes & 95.552 & 33,26 & 31.340 & 20.759 \\
\hline São João de Meriti & 12.406 & 47,00 & $\mathrm{ND}$ & $\mathrm{ND}$ \\
\hline Petrópolis & 30.732 & 15,97 & 50.533 & 15.985 \\
\hline Volta Redonda & 35.310 & 10,90 & 51.156 & 5.115 \\
\hline Magé & 10.899 & 64,02 & $\mathrm{ND}$ & $\mathrm{ND}$ \\
\hline Itaboraí & 13.912 & 59,43 & 16.175 & 10.090 \\
\hline Macaé & 66.344 & 14,65 & $27.218\left(^{*}\right)$ & $20.720\left(^{*}\right)$ \\
\hline
\end{tabular}

Fonte: Cidades/IBGE. Acesso em 6/10/2015.

(*) Dados referentes ao ano de 2013.

ND - Dados não disponíveis nos anos 2014 e 2013 
Como os dados indicam, os municípios de Campos dos Goytacazes e Macaé possuem um PIB per capita muito acima dos demais municípios, o que se deve ao peso do petróleo na economia local. O caso de Campos dos Goytacazes se destaca porque sua população pouco cresceu, mesmo depois de as receitas petrolíferas (royalties e participações especiais) terem tornado o município campeão de recebimento dessa fonte orçamentária (Santos, 2016). Ainda assim, a taxa de incidência de pobreza desse município foi superior ao dobro da apresentada por Macaé.

Os municípios já consolidados ${ }^{10}$ de Niterói, Petrópolis e Volta Redonda, além da capital, apresentam valores semelhantes de PIB per capita e também apresentaram incidência de população de baixa renda semelhante. Os demais apresentaram um produto que equivale a pouco mais de uma terça parte dos primeiros. A exceção é Duque de Caxias, cujo PIB per capita, próximo do produto da capital, está assentado na economia do petróleo, por causa da Refinaria Duque de Caxias. Apesar disso, o percentual de pobres em sua população o aproxima dos outros municípios de baixo PIB per capita.

Ao se lançar o olhar para a arrecadação dos tributos incidentes sobre a propriedade imobiliária, contudo, verifica-se que Rio de Janeiro e Niterói se destacam dos demais. Somente nesses dois municípios, a atual capital e a capital do antigo estado do Rio de Janeiro, ${ }^{11}$ a arrecadação desses tributos se mostrou expressiva. Nos demais, foi baixo o valor arrecadado com IPTU e ITBI, sendo que dois desses municípios (Magé e São João de Meriti) nem informaram os valores arrecadados. Esses resultados, portanto, sugerem a existência de três grupos de municípios com capacidades distintas de arrecadar os tributos considerados: i) o primeiro é constituído das "duas capitais", com melhor desempenho; ii) o segundo é o grupo dos municípios consolidados, ou seja, cuja população é elevada mas estável, não sofrendo influência da economia do petróleo; e iii) os municípios positivamente afetados pelo petróleo. Acreditamos que os municípios integrantes do primeiro e do terceiro grupos têm condições de melhorar a arrecadação sobre a propriedade imobiliária, mas não os do segundo grupo, cuja elevada incidência de pobreza impõe limites mais estreitos, para que sua população suporte o aumento da carga tributária.

$\mathrm{Na}$ Tabela 2, apresenta-se a distribuição dos municípios brasileiros com mais de duzentos mil habitantes segundo regióes (Censo de 2010), além do peso do conjunto de todos os municípios na arrecadação total do país em relação aos dois principais tributos incidentes sobre a propriedade imobiliária, o IPTU e o ITBI, em 2013, último ano para o qual havia informações disponíveis.

\footnotetext{
${ }^{10}$ Foram considerados "municípios consolidados" aqueles cuja população já se estabilizou.

${ }^{11}$ Niterói foi capital do estado do Rio de Janeiro até 1975, quando foi instituída a fusão entre os estados da Guanabara (antigo Distrito Federal) e o Rio de Janeiro. A partir de então, a cidade do Rio de Janeiro deixaria de ser a cidade-estado da Guanabara e passaria a ser a capital do novo estado do Rio de Janeiro.
} 
Em busca de cidades mais justas por meio da tributação imobiliária

Tabela 2. Participação percentual dos municípios com mais de 200 mil habitantes na arrecadação do IPTU e do ITBI dos municípios brasileiros

\begin{tabular}{|l|c|c|c|c|}
\hline Regióes/Estados & $\begin{array}{c}\text { Número total de } \\
\text { municípios }\end{array}$ & $\begin{array}{c}\text { Número de muni- } \\
\text { cípios } \mathbf{2 0 0} \text { mil } \\
\text { habitantes }\end{array}$ & $\begin{array}{c}\text { IPTU 2013 (> 200 } \\
\text { mil hab.) \% sobre } \\
\text { o total }\end{array}$ & $\begin{array}{c}\text { ITBI 2013 (> 200 } \\
\text { mil hab.) \% sobre } \\
\text { o total }\end{array}$ \\
\hline Norte & 450 & 10 & 1,50 & 2,43 \\
\hline Centro-Oeste & 467 & 7 & 4,84 & 7,20 \\
\hline Nordeste & 1.794 & 26 & 7,25 & 12,12 \\
\hline Sudeste & 1.668 & 69 & 73,24 & 58,82 \\
\hline MG & 853 & 13 & 7,24 & 10,07 \\
\hline RJ & 92 & 13 & 12.15 & 12,51 \\
\hline SP & 645 & 39 & 53,00 & 34,55 \\
\hline Sul & 1.191 & 21 & 13,16 & 19,43 \\
\hline Brasil & 5.570 & 133 & 100,00 & 100,00 \\
\hline
\end{tabular}

Fonte: Elaboração própria, com base nos dados STN/Finbra. Finanças do Brasil - Dados Contábeis dos Municípios, 2013.

O maior número de municípios com população superior a duzentos mil habitantes encontra-se na Região Sudeste, onde a rede municipal é grande, porém menor do que a da Região Nordeste, que, com seus 1.794 municípios, têm apenas 26 com mais de duzentos mil habitantes. A distribuição mais capilarizada desses grandes municípios pode ser considerada um indicador de maior dinamismo regional do Sudeste em comparação ao Nordeste.

O IPTU e o ITBI são os principais tributos incidentes sobre a propriedade imobiliária. ${ }^{12}$ Conforme já mencionado, o ITBI só incide no ato da transferência da propriedade intervivos e, portanto, de modo pontual. É diferente o caso do IPTU, um tributo anualmente pago pela propriedade de imóveis prediais ou territoriais urbanos. Nesse caso, importa sobremaneira a forma como o tributo é administrado e em que âmbito se destaca o valor do patrimônio imobiliário, considerado na Planta Genérica de Valores. Não causa surpresa, assim, que, nos locais em que há maior peso no PIB brasileiro, também o patrimônio imobiliário seja mais elevado, como ocorre na Região Sudeste. Nos estados do Sudeste, foram arrecadados três em cada quatro reais do tributo $(73,24 \%$ do total), sendo os municípios paulistas responsáveis por mais da metade de toda a arrecadação do país (53\%). Os municípios fluminenses vêm em segundo lugar, porém com muito menos peso, equivalente a $12,15 \%$, quase o mesmo percentual de sua participação no total de ITBI arrecadado no Brasil.

\footnotetext{
${ }^{12}$ Além do IPTU e do ITBI, incidem sobre a propriedade imobiliária as contribuições de melhoria e o Imposto Territorial Rural (de competência federal), ambos com participação muito pequena na arrecadação fiscal, conforme apontado por Santos (2014b).
} 
É muito instigante verificar que o peso do Sudeste no ITBI $(58,82 \%)$ é maior que nas demais regiōes, embora bem menos concentrado do que ocorre com o IPTU $(73,24 \%)$, devido à menor participação dos municípios paulistas (34,55\% em relação aos 53\% do IPTU). Em todas as demais regiōes - inclusive entre os demais estados do Sudeste -, o peso percentual de arrecadação do ITBI foi superior ao percentual do apurado do IPTU nos municípios com mais de duzentos mil habitantes. Esse resultado deve estar associado à dificuldade que os municípios enfrentam de melhorar a arrecadação do IPTU, enquanto o ITBI, por ser pago apenas no momento da transação imobiliária, deixa os governos municipais com melhores condiçôes políticas de impor uma base de cálculo mais elevada. ${ }^{13}$

O maior peso dos municípios paulistas - e a equivalência entre os fluminenses - na arrecadação do IPTU em comparação ao ITBI sugere que há melhor administração desse tributo - o principal sobre a propriedade imobiliária nos municípios que se situam nas principais economias estaduais. ${ }^{14}$ Também é em São Paulo que se concentra o maior número de municípios de grande porte, ou seja, aqueles com mais de duzentos mil habitantes (como considerado neste estudo). São justamente os municípios populosos que mais precisam de instrumentos de política urbana com vistas a ordenar o respectivo crescimento.

Na tabela a seguir, apresenta-se a evolução da participação percentual do IPTU e do ITBI no PIB dos anos 2000, 2005, 2010 e 2013.

Tabela 3. Evolução da participação percentual do IPTU e ITBI no PIB dos anos 2000, 2005, 2010 e $2013(\%)$

\begin{tabular}{|l|c|c|c|c|c|c|c|c|}
\hline Municípios & \multicolumn{4}{|c|}{ IPTU } & \multicolumn{4}{c|}{ ITBI } \\
\hline & 2000 & 2005 & 2010 & 2013 & 2000 & 2005 & 2010 & 2013 \\
\hline Brasil & 0,45 & 0,46 & 0,42 & 0,43 & 0,09 & 0,09 & 0,14 & 0,17 \\
\hline Sudeste & 0,35 & 0,34 & 0,30 & 0,31 & 0,06 & 0,06 & 0,08 & 0,10 \\
\hline $\begin{array}{l}\text { Estado do Rio de } \\
\text { Janeiro }\end{array}$ & 0,08 & 0,07 & 0,05 & 0,05 & 0,02 & 0,01 & 0,02 & 0,02 \\
\hline $\begin{array}{l}\text { Municípios brasileiros } \\
\text { com } 200 \text { mil } \\
\text { habitantes }\end{array}$ & 0,33 & 0,34 & 0,32 & 0,33 & 0,06 & 0,06 & 0,10 & 0,12 \\
\hline $\begin{array}{l}\text { Municípios flumi- } \\
\text { nenses com > 200 mil } \\
\text { habitantes }\end{array}$ & 0,06 & 0,06 & 0,05 & 0,05 & 0,01 & 0,01 & 0,02 & 0,02 \\
\hline
\end{tabular}

Fonte: Elaboração própria com base nos dados STN/Finbra. Finanças do Brasil. Dados Contábeis dos Municípios, 2013.

\footnotetext{
13 A transferência da propriedade só ocorre após o registro em cartório, o que estimula os novos proprietários a aceitarem o valor arbitrado pelo Poder Público.

${ }^{14}$ Economias dos estados de São Paulo e Rio de Janeiro.
} 
O desempenho dos dois tributos incidentes sobre a propriedade imobiliária correspondente à proporção do PIB nos anos selecionados sugere a existência de espaço para se melhorar a administração do IPTU, especialmente entre os municípios com população superior a duzentos mil habitantes. Afinal, houve significativo avanço na arrecadação do ITBI, dobrando sua participação percentual ao longo do período, enquanto o peso da arrecadação do IPTU diminuiu.

Como este estudo focaliza os municípios fluminenses com população superior a duzentos mil habitantes, dos quais apenas a capital tem peso significativo em relação ao PIB, a próxima tabela apresenta os valores per capita arrecadados em relação aos dois tributos imobiliários. Objetiva-se comparar o desempenho deles no início e no fim da década, quando houve informação censitária suficiente a permitir o cálculo dos valores arrecadados per capita.

Tabela 4. Arrecadação per capita do IPTU e ITBI nos municípios fluminenses com população superior a duzentos mil habitantes

\begin{tabular}{|l|c|c|c|c|}
\hline Município & IPTU 2000 & IPTU 2010 & ITBI 2000 & ITBI 2010 \\
\hline Rio de Janeiro & 106,22 & 226,54 & 22,32 & 78,63 \\
\hline São Gonçalo & 25,61 & 35,81 & 2,41 & 8,20 \\
\hline Duque de Caxias & 21,03 & 56,92 & 1,83 & 4,77 \\
\hline Nova Iguaçu & 13,17 & 35,76 & 1,39 & 7,91 \\
\hline Niterói & 129,84 & 371,46 & 27,18 & 114,96 \\
\hline Belford Roxo & 8,24 & 13,46 & 0,37 & 3,72 \\
\hline Campos dos Goytacazes & 11,24 & 39,11 & 3,11 & 16,17 \\
\hline São João de Meriti & 14,30 & 30,88 & 0,56 & 1,24 \\
\hline Petrópolis & 72,69 & 141,83 & 7,21 & 32,14 \\
\hline Volta Redonda & 79,29 & 150,36 & 3,71 & 15,24 \\
\hline Magé & 7,84 & 24,49 & 1,12 & 2,82 \\
\hline Itaboraí & 10,31 & 48,49 & 2,68 & 23,18 \\
\hline Macaé & 14,11 & 53,31 & 7,63 & 48,24 \\
\hline $\begin{array}{l}\text { Média dos munićpios } \\
\text { fluminenses }\end{array}$ & 63,37 & 132,86 & 13,38 & 43,34 \\
\hline $\begin{array}{l}\text { Média dos municípios } \\
\text { brasileiros }\end{array}$ & 33,53 & 86,34 & 7,05 & 29,39 \\
\hline
\end{tabular}

Fonte: Elaboração própria com dados dos censos demográficos 2000 e 2010 e STN/Finbra - Finanças do Brasil. Dados Contábeis dos Municípios, 2013.

A arrecadação per capita dos dois tributos imobiliários acompanha a divisão dos municípios fluminenses naqueles três grupos antes mencionados, destacando-se, mais uma vez, as "duas capitais". Chama a atenção, contudo, o fato de os municípios fluminenses apresentarem, em média, pior de- 
sempenho que o do conjunto dos municípios brasileiros com mais de duzentos mil habitantes ao longo da década 2000-2010. Em 2000, por exemplo, os municípios de Niterói e do Rio de Janeiro foram os que apresentaram valores per capita superiores a cem reais, bem acima da média dos demais municípios. Desses, apenas Petrópolis e Volta Redonda se destacaram, resultado que deve estar relacionado à presença de uma população que, se não cresce a taxas superiores à média estadual, pelo menos sustenta um índice já consolidado nos centros urbanos microrregionais. Os outros são municípios cuja dinâmica depende da capital estadual, uma vez que se situam na região metropolitana. Isso porque, apesar de que alguns virem experimentando o fortalecimento dentro da rede urbana metropolitana, ${ }^{15}$ sua população conta com expressivo contingente de pessoas com baixo rendimento, o que limita a capacidade de os governos imporem uma carga tributária própria de maior peso.

Os valores apurados em 2010 sugerem que a situação vigente em 2000 mudou pouco, exceto pelos destaques positivos de Niterói e Itaboraí, ao lado do crescimento acima da média dos municípios de Campos dos Goytacazes e Macaé. No caso de Itaboraí, o resultado deve estar associado ao impacto positivo na economia municipal, devido às obras do Complexo Petroquímico do Rio de Janeiro (Comperj). Em relação a Campos dos Goytacazes e Macaé, o resultado deve estar relacionado à necessidade de se diversificarem as fontes de arrecadação municipal, diante da mudança iminente na legislação das receitas petrolíferas. ${ }^{16}$ Cabe ainda destacar que o aumento generalizado da arrecadação per capita do IPTU não acompanhou o aumento do PIB na primeira década do século, como exposto na Tabela 3. A evolução do ITBI no período ocorreu num ritmo mais intenso que o do IPTU, ainda que a distribuição desse avanço entre os municípios fluminenses tenha acompanhado o desempenho desse último imposto.

A análise das informações sugere espaço suficiente para se melhorar a administração do principal tributo incidente sobre a propriedade imobiliária, o IPTU. Isso fica claro quando se compara com o melhor desempenho do ITBI. Como já mencionado, tal resultado deve ser atribuído ao maior poder de enforcement dos governos municipais em imputar um valor superior para fins de arrecadação do ITBI em relação aos valores venais referentes ao IPTU.

Um estudo realizado por Carvalho Jr. (2011) sobre a administração do IPTU no município do Rio de Janeiro concluiu que sua baixa participação na arrecadação fiscal não se devia às alíquotas do tributo, mas a uma gestão inadequada. A desatualização da Planta Genérica de Valores (PGV) em relação aos preços de mercado dos imóveis era maior entre os imóveis mais antigos do que em relação aos novos. No entanto, mesmo nos novos, prevalece uma grande diferença entre os preços praticados no mercado imobiliário e no cadastro da prefeitura. E, sem dúvida, a análise dos resultados apresentados nas "duas capitais" sugere que a capital fluminense é o município que conta com melhor suporte técnico na gestão municipal, bem acima da média dos municípios fluminenses. Ainda assim, os demais municípios do estado do Rio de Janeiro precisam avançar muito para se aproximar do desempenho dos municípios paulistas, aqueles de melhor resultado arrecada-

\footnotetext{
${ }^{15}$ Caso do município de Nova Iguaçu.

${ }^{16}$ Em 2012, entrou em vigor a Lei n. 12.734, que alterou a partilha das receitas petrolíferas entre os entes federativos, anteriormente muito concentrada nos estados e municípios considerados "produtores", casos de Campos dos Goytacazes e Macaé.
} 
tório do IPTU. Nesse sentido, destaca-se que a capital paulista já tornou obrigatória a atualização a cada quatro anos de sua PGV, o que já deveria ter sido realizado na cidade do Rio de Janeiro, onde um grande conjunto de obras públicas preparatórias para os Jogos Olímpicos de 2016 dinamizou o mercado imobiliário. Sem melhorar a administração dos tributos imobiliários, a prefeitura deixa de captar parte dessa valorização da terra urbana.

A importância na melhora da administração do IPTU não é apenas uma necessidade para aumentar a arrecadação fiscal, ainda mais no contexto de crise fiscal que o país atravessa. Sua relevância também é acentuada porque se trata de um tributo com função extrafiscal incluída na política urbana brasileira, além de ser uma parte importante da política tributária comprometida com a justiça fiscal e social.

\subsection{Pesquisa de campo realizada nos municípios fluminenses ${ }^{17}$}

A pesquisa de campo sobre a administração do IPTU abrangeria oito dos 13 municípios fluminenses com mais de duzentos mil habitantes: Niterói, Rio de Janeiro, Petrópolis, Volta Redonda, São Gonçalo, Duque de Caxias, Campos dos Goytacazes e Macaé. Entretanto, após diversas tentativas de contato, inclusive realizando-se reuniōes com membros das secretarias de fazenda, foi possível obter dados apenas em São Gonçalo, Duque de Caxias e Macaé. Em conversa com o subsecretário de Administração e Gestão Fazendária do município de Niterói, foi-nos sugerido, inclusive, que a pesquisa fosse conduzida no sentido de priorizar análises sobre a gestão do ITBI, que, segundo afirmado por ele, seria um tributo mais fácil de manejar do que o IPTU.

Uma abordagem normativa a respeito da adequada administração do tributo aponta para a necessidade de: a) atualizar a lei de perímetro urbano; b) que o cadastro imobiliário abranja todos os domicílios; e c) que a planta genérica de valores esteja atualizada conforme a valorização do mercado imobiliário. Não foi esse o quadro apurado nos três municípios que aceitaram responder a essa investigação.

Tabela 5. Grau de cobertura do cadastro imobiliário nos municípios selecionados

\begin{tabular}{|l|l|l|l|}
\hline Municípios/Unidades & São Gonçalo & Macaé & $\begin{array}{l}\text { Duque de } \\
\text { Caxias }\end{array}$ \\
\hline Total de unidades cadastradas & 466.080 & 81.475 & 354.910 \\
\hline Unidades residenciais cadastradas & 289.261 & 33.074 & 205.406 \\
\hline Unidades não residenciais cadastradas & 101.083 & 23.727 & 31.652 \\
\hline Unidades territoriais cadastradas & 75.736 & 24.679 & 117.852 \\
\hline
\end{tabular}

\footnotetext{
${ }^{17}$ Este trecho se baseia na síntese elaborada por Pedro Vasques para o Grupo de Pesquisa sobre Tributação Imobiliária, sob minha coordenação.
} 


\begin{tabular}{|l|l|l|l|}
\hline Municípios/Unidades & São Gonçalo & Macaé & $\begin{array}{l}\text { Duque de } \\
\text { Caxias }\end{array}$ \\
\hline Unidades residenciais/unidades cadastradas (\%) & 62,1 & 40,6 & 57,9 \\
\hline Unidades não residenciais/unidades cadastradas (\%) & 21,7 & 29,1 & 8,9 \\
\hline Unidades territoriais/unidades cadastradas (\%) & 16,2 & 30,3 & 33,2 \\
\hline
\end{tabular}

Fontes: IBGE - Censo Demográfico 2010 e Pesquisa de Campo 2015.

Conforme se verifica na tabela acima, em nenhum dos três municípios há cobertura da totalidade das unidades cadastradas, sendo que o de Macaé não atinge nem a metade, o que sugere o elevado grau de desconhecimento desse município em relação ao próprio território. Nessas condições, não é possível cumprir adequadamente com sua responsabilidade pela política urbana, nem mesmo com a arrecadação potencial de sua tributação própria. Macaé também apresentou o menor grau de dependência de seu cadastro imobiliário em relação às unidades residenciais (41\%), percentual pouco maior que aquele relativo às unidades não residenciais $(29,1 \%)$ e territoriais $(30,3 \%)$.

São Gonçalo apresentou dados mais próximos do que se espera de um município preocupado em melhorar a gestão de seu território: maior percentual de cobertura cadastral de suas unidades residenciais, que, por sua vez, representam um percentual superior aos $60 \%$ do total das unidades cadastrais.

Tabela 6. Participação percentual entre o montante lançado e o arrecadado do IPTU nos municípios selecionados

\begin{tabular}{|l|l|l|l|}
\hline & São Gonçalo & Macaé & Duque de Caxias \\
\hline Unidades residenciais & 46,95 & 40,65 & 46,78 \\
\hline Unidades não residenciais & 28,34 & 57,12 & 60,71 \\
\hline Unidades territoriais & 10,13 & 42,58 & 18,22 \\
\hline Total & 36,43 & 45,87 & 46,92 \\
\hline
\end{tabular}

Fonte: Pesquisa de campo, 2015.

A partir dos dados coletados, verificou-se que, ao menos no ano de 2013, a arrecadação relativa ao montante lançado variou entre $36,43 \%$ e $46,92 \%$, revelando-se baixa no que diz respeito a seu potencial, especialmente no que se refere ao caso de Macaé, que, conforme já mencionado, apresenta índice de pobreza inferior ao dos outros dois municípios aqui considerados.

É importante notar que, tanto em São Gonçalo como em Duque de Caxias, os menores percentuais entre o que foi cobrado e o que foi arrecadado fazem referência às unidades territoriais. Em outras palavras, o primeiro arrecadou apenas $10 \%$ do que efetivamente foi lançado para mencionada categoria. Já no caso do segundo município, embora ainda apresente valor percentual reduzido, esse 


\section{Em busca de cidades mais justas por meio da tributação imobiliária}

montante sobe para 18\%. Levando-se em conta que esses municípios são densamente ocupados, os dados identificados reforçam o baixo interesse das administrações municipais em conduzir esforços para cobrar o imposto nas áreas não edificadas, o que representa uma reduzida parcela de seus territórios. Também em conformidade com as expectativas, os municípios de maior peso econômico, Duque de Caxias e Macaé, arrecadaram, respectivamente, 57\% e 61\% do montante efetivamente cobrado para as unidades não residenciais, ou seja, os imóveis comerciais. Mas, de modo geral, a relação percentual verificada nos municípios entrevistados apontou para uma distância substantiva entre o que foi lançado e o que foi efetivamente arrecadado nesse ano, o que nos permite questionar se os mecanismos de gestão e cobrança atualmente empregados por esses municípios são realmente eficientes.

Sobre as medidas referentes à diminuição e à inadimplência do IPTU, levando-se em conta o percentual antes verificado, é possível afirmar que algumas estratégias tradicionais, como, por exemplo, parcelamento, desconto, possibilidade de pagamento na maior parte da rede bancária e nas lotéricas, cobrança judicial - apontadas pelo três municípios como ferramentas utilizadas - aparentam haver atingido o limite máximo na capacidade de ampliação da arrecadação, sendo, portanto, necessário desenvolver outras estratégias para otimizar a gestão desse tributo. Até mesmo o emprego de ferramentas menos tradicionais, como, por exemplo, sistemas georreferenciados de informação, restrições de transferência/venda de propriedades em dívida, inclusão do contribuinte inadimplente em cadastros (da prefeitura, $S P C^{18}$ e Serasa) ${ }^{19}$ protestos da dívida ativa em cartório e realização de leilōes públicos, parece não surtir efeito significativo na melhora da arrecadação. Isso porque, mesmo no caso de São Gonçalo, que aplica todos os mencionados instrumentos, verificou-se a pior relação percentual, com uma arrecadação de apenas 36,43\% do montante total lançado no ano de 2013. Ainda que o referido ano possa não ser representativo, essa análise - em comparação aos dados gerais coletados entre os anos de 2000 e 2013, na seção anterior - confere mais certeza à afirmação de que é necessário desenvolver alternativas que melhorem a gestão do tributo municipal, com vistas a ultrapassar os percentuais existentes.

Outro dado importante acerca dos limites da arrecadação diz respeito às isençôes e imunidades. Ao contrário do que acontece, por exemplo, no município do Rio de Janeiro, em que isençôes e imunidades representam um percentual significativo do valor venal de todas as propriedades inseridas em seu território (65\% para uso residencial e 91\% para territorial, segundo Carvalho Jr [2013]), nos municípios estudados as propriedades imunes e isentas não só representam um percentual baixo de unidades $(0,1 \%$ do total de propriedades em São Gonçalo e 5,37\% do total em Macaé), como também equivalem a um pequeno montante em relação ao valor venal total das propriedades nos respectivos municípios $(0,04 \%$ e $1,72 \%)$.

Sobre a atualização da Planta Genérica de Valores, novamente o município de São Gonçalo se situa atrás dos demais, com a última atualização ocorrida em 2003 (Lei no 41/2003). Em 2011, o município de Macaé atualizou os valores através de alteração na Lei municipal no 133/09. Por fim, Duque de Caxias - que, embora não disponha de registro do último recadastramento de suas proprie-

\footnotetext{
18 Serviço de Proteção ao Crédito.

19 Serasa Experian é uma empresa certificadora de crédito.
} 
dades, segundo informações prestadas por um funcionário da Secretaria de Fazenda - foi o município que atualizou, com mais recenticidade, sua PGV, por meio da Lei no 2.595/13.

\subsection{Municipios fluminenses: um longo caminho a percorrer para avançar na tributação imobiliária}

A análise das informações coletadas por meio de pesquisa de campo e coleta de dados sugere que a melhora na administração do IPTU pode ser verificada com a adoção de medidas já usualmente empregadas por outros municípios, como, por exemplo, condução de recadastramentos periódicos. No caso de São Gonçalo, que apresentou o pior desempenho entre lançamento e arrecadação nas unidades territoriais, não há registro de seu último recadastramento. Como consequência direta desse comportamento por parte da administração municipal, dos três municípios analisados, São Gonçalo foi o que apresentou pior desempenho, arrecadando apenas 36,43\% do total efetivamente lançado. Por outro lado, até mesmo a utilização dos tradicionais instrumentos de cobrança aparenta encontrar um limite em sua eficiência, como se verifica no desempenho dos outros dois municípios estudados.

No que diz respeito à implantação de mecanismos alternativos de cobrança, como, por exemplo, leilão de imóveis ou inclusão em cadastros de inadimplentes, apesar de todos os municípios entrevistados afirmarem a adoção desse recurso, faz-se necessário conduzir novos estudos, a fim de observar de que forma esses instrumentos vêm sendo aplicados. Somente depois de obtidas informaçóes mais detalhadas, será possível analisar os limites de sua eficiência.

Por fim, observa-se que, a despeito das várias discussōes sobre as possíveis aplicaçōes extrafiscais do IPTU, sua gestão é precária, e a arrecadação do tributo encontra limites vários no interior da própria burocracia municipal, dentre os quais destaca-se a dificuldade de se negociar com o Legislativo a atualização dos instrumentos normativos. Quando nem mesmo os elementos básicos da gestão do tributo são observados, sua aplicação em uma perspectiva extrafiscal se apresenta como um horizonte ainda muito remoto.

\section{Conclusões}

Os resultados desta investigação estão alinhados com os apurados por De Cesare (2010), Carvalho Jr. (2011 e 2013) e Luft e Santos (2012): os municípios não exploram com o máximo de eficiência seu potencial arrecadatório sobre a propriedade imobiliária, o que esvazia o conteúdo de instrumento de política urbana do instituto extrafiscal do IPTU. Nessas condições, por que seguir pesquisando o tema da tributação imobiliária no Brasil?

Creio que existem dois motivos principais.

O primeiro deles diz respeito ao longo tempo decorrido entre o lançamento de uma agenda de política urbana e sua disseminação com apreensão pela sociedade, passando a ser cobrado do sistema político. A assembleia da Agência ONU/Habitat II, ocorrida em Istambul, pode ser uma boa referência. A atual Constituição brasileira já estava em vigor desde 1988, com sua inovadora submissão da propriedade 


\section{Em busca de cidades mais justas por meio da tributação imobiliária}

ao cumprimento de uma função social, que ainda se encontrava sujeita à regulamentação do artigo 182, relativo à política urbana, de responsabilidade do município, que foi elevado à condição de ente federativo.

A agenda da política urbana definida pelas Nações Unidas, por meio da Agência Habitat, contribuiu para nortear as políticas urbanas em escala nacional, o que se refletiu na aprovação do Estatuto da Cidade regulando o capítulo da política urbana, mas isso ocorreu apenas em 2001. Muitos dos instrumentos de ordenamento urbanístico regulados nessa lei, contudo, precisam ser novamente regulados, agora em escala municipal. E, quando isso ocorrer, essa regulamentação ainda depende do interesse das prefeituras em conferirem efetividade àqueles instrumentos, como é o caso do IPTU progressivo.

Esse longo período transcorrido entre as inovações normativas e sua efetividade decorre de um processo de reposicionamento - lento - dos atores envolvidos nas políticas públicas. Entre os principais, destacam-se o município, institucionalmente fortalecido na federação, bem como a autonomia conquistada pelo Ministério Público e o protagonismo da Defensoria Pública em relação aos direitos sociais. A crescente expectativa dos direitos de cidadania, por sua vez, resultou na judicialização das políticas públicas, levando o Poder Judiciário a atualizar suas decisões no contexto normativo em que o Estado ampliou seus compromissos com o cidadão. Por isso, não se julga adequado abrir mão de um instrumento jurídico já amplamente regulado em todas as esferas de governo ao argumento de que, até agora, não funcionou. Poderá vir a funcionar caso a sociedade (cidadãos, prefeituras, Ministério Público e Defensoria Pública) cobre sua utilização para mitigar os efeitos da crise urbana, em especial a crise da habitação social.

Uma segunda razão para seguir defendendo o uso da tributação imobiliária (IPTU progressivo) diz respeito ao já referido aumento dos compromissos do Estado (não apenas no Brasil) em relação ao bem-estar social. Este não se reduz aos gastos previdenciários, mas vem-se traduzindo em crescentes despesas com saúde, educação e assistência social. Estas já teriam alcançado os percentuais de gastos com aposentadorias e pensões, cada um deles representando $15 \%$ em relação ao produto, o que perfaz um total de $30 \%$ do PIB, segundo estimativas de Piketty (2013). O direito à moradia, no entanto, vem sendo crescentemente reclamado em face da adoção de políticas habitacionais baseadas na propriedade privada, sendo o Estado desafiado a avançar rumo a políticas de moradia desmercantilizadas (Rolnik, 2015).

Um estudo realizado por Kersternetsky (2012) sobre as transformaçōes do estado de bem-estar social aponta na mesma direção: o bem-estar social tem evoluído para a defesa da reprodução social das famílias, e não apenas da renda do trabalhador. E, entre as necessidades das famílias, a habitação tem importância crucial, pois sua localização pode ampliar ou diminuir, por exemplo, o acesso a serviços de saúde, educação, mobilidade e segurança pública. Aumentar a oferta de moradia, especialmente a de interesse social, é, assim, um objetivo que deve ser perseguido por todos os meios, inclusive pela tributação imobiliária das propriedades que não cumpram sua função social, em conformidade com a política urbana já normatizada no Brasil.

As análises de Piketty e Kersternetsky encontram eco no estudo de Raquel Rolnik (2015) sobre a mudança do significado da moradia no início do século XXI. Transformada em fronteira de aplicação rentável para o capital financeiro, também passou a ser considerada fonte para resguardar a renda familiar de aposentados que adquirem imóveis para locação. No entanto, a mercantilização da habitação vem aprofundando a vulnerabilidade de uma parcela crescente da população em todo o planeta, como bem demonstrado pela autora, o que alimenta a crise urbana. Entre as soluções possíveis para enfrentar esse desafio, encontra-se o aumento da tributação sobre a riqueza e, em particular, sobre a propriedade imobiliária 
urbana. Afinal, não soa razoável que aproximadamente 50\% de como se expressa a riqueza atual se refiram à propriedade de moradias, como identificado por Piketty.

\section{Referências}

BRASIL. Constituição da República Federativa do Brasil de 05 de outubro de 1988.

CARVALHO JR, P. H. O sistema avaliatório municipal de imóveis e a tributação do IPTU no Rio de Janeiro (dissertação). UERJ, 2011.

—. "Situação atual do IPTU no Rio de Janeiro e sua possível reforma", Cadernos do Desenvolvimento Fluminense, n. 1, 2013.

CESARE, Claudia M. de. Reseña del Impuesto Predial en América Latina. S.1.: Lincoln Institute of Land Policy, 2010.

KERSTENETZKY, C. L. O estado do bem-estar social na Idade da Razão: a reinvenção do estado social no mundo contemporâneo. Rio de Janeiro: Elsevier, 2012.

LUFT, Rosângela e SANTOS, Ângela Moulin S. Penalva. “Tributação imobiliária e política urbana no Brasil”. In SANTOS, A. et al. Rio de Janeiro: um território em mutação. Rio de Janeiro: Grama, 2012.

PIKETTY, Thomas. O capital no século XXI. Rio de Janeiro: Intrínseca, 2014.

ROLNIK, R. Guerra dos lugares: a colonização da terra na era das finanças. São Paulo: Boitempo, 2015.

SANTOS, Angela M. S. P. “Cidades médias: novas fronteiras de oportunidades”. In —. Rio de Janeiro: um território em mutação. Rio de Janeiro: Gramma, 2012.

. "Política urbana no contexto federativo brasileiro: entre a cidade do plano e a cidade real". In SANTOS, A. e SANT'ANNA, M. (orgs.). Transformaçôes territoriais no Rio de Janeiro do século XXI. Rio de Janeiro: Gramma, 2014.

—. "Tributação imobiliária: um difícil percurso rumo à política urbana", Finisterra: Revista Portuguesa de Geografia, v. XLIX, n. 97, 2014.

—_. "O município como agente de políticas públicas: o caso dos municípios fluminenses". In SANTOS, A. e GERSCHMAN, S. (orgs.). Saúde e políticas sociais no Rio de Janeiro. Rio de Janeiro: Fiocruz, 2016. 


\title{
0 relevo do estado do Rio de Janeiro: cenário de beleza e fragilidade ambiental
}

\author{
Telma Mendes da Silva ${ }^{1}$ \\ Simone Lisboa dos Santos da Silva ${ }^{2}$
}

\section{Introdução}

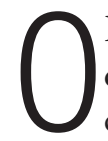
Rio de Janeiro é o menor estado da Região Sudeste do Brasil, com pouco mais de 43 milhões de $\mathrm{km}^{2}$, mas chama a atenção, tanto nacional como internacionalmente, por sua beleza cênica conferida pelos contrastes existentes entre as áreas elevadas e as planícies costeiras que contornam seu litoral, além de ilhas que enriquecem localmente a paisagem. No entanto, esse belo relevo contrastante também se mostra frágil no que concerne à atuação de processos erosivos e deposicionais que, paulatinamente, foram intensificados com o uso inadequado de seu solo e a ausência de uma política adequada de controle ambiental.

Está localizado no extremo leste do denominado Rift Continental do Sudeste do Brasil (RCSB) (Riccomini, 1989 e 1995), estendendo-se da região de serras e de depressões interplanálticas, que corresponde do vale do rio Paraíba do Sul à região dos maciços litorâneos, colinas e terrenos quaternários das baixadas de Guanabara, de Jacarepaguá, de Sepetiba, da Região dos Lagos e da planície costeira de Campos. Caracteriza-se pelo contraste significativo das formas de relevo, resultante da complexa evolução geológico-geomorfológica mesozoico-cenozoica do Sudeste brasileiro e, ainda, do processo acentuado de alteração da paisagem resultante das condições do regime climático tropical úmido.

Dentro da complexa história de evolução geológica, corresponde ao Mesozoico (230 Ma [milhões de anos] a $65 \mathrm{Ma}$ ), o início de um período de instabilidade tectônica (evento sul-atlantiano ou reativação wealdeniana), relacionado ao mecanismo de separação das placas tectônicas sul-americana e africana, e consequente formação do Oceano Atlântico, gerando um episódio de rifteamento seguido de contração termal. $\mathrm{Na}$ fase rift, tem-se a origem das serras do SE e das bacias da margem continental brasileira, onde se inserem os terrenos elevados (serras da Mantiqueira e do Mar) e as

\footnotetext{
1 Universidade Federal do Rio de Janeiro.

${ }^{2}$ Universidade do Estado do Rio de Janeiro.
} 
depressões tectônicas do SE brasileiro (vale do rio Paraíba do Sul, Baía de Guanabara, entre outras) (Asmus e Ferrari, 1978; Riccomoni, 1989; Macedo et al., 1991).

No que se refere à litologia, o território fluminense caracteriza-se por apresentar áreas de sedimentos terciários e quaternários, além de áreas de rochas ígneas e metamórficas pré-cambrianas. As primeiras podem ser observadas de modo mais expressivo na bacia de Resende e no litoral, onde se encontram o Grupo Barreiras, a Formação Macacu e as planícies aluvionares e marinhas. Já as áreas pré-cambrianas, submetidas a intensas deformações, em função de eventos tectônicos, e à ação de fatores climáticos atuais e passados, mostram-se distribuídas. Essas diferentes unidades litológicas foram retrabalhadas em condições de regime tipicamente tropical, caracterizado, em linhas gerais, por altas temperaturas e elevados índices pluviométricos, o que representa elevadas taxas nos processos pedo-geomorfológicos de alteração da paisagem.

A orografia determina uma série de variedades climáticas, tanto no que se refere à temperatura quanto à precipitação. Por sua posição geográfica próxima ao litoral e pelos meses de verão de intensa radiação solar recebida, têm-se, nessa região, elevados índices de umidade do ar e de temperatura, o que leva à ocorrência de chuvas frequentes de distribuição diferenciada, devido, ainda, à existência de inúmeras elevações altimétricas ao longo de sua costa (serra do Mar e maciços costeiros), que contribuem para eventos pluviométricos de elevada magnitude. As chuvas são ainda comuns nos episódios de entradas de frente fria de origem polar, que, ao encontrarem as altas temperaturas e a umidade, resultam em eventos pluviométricos de dimensões consideráveis, gerando à população desagradáveis transtornos com a ocorrência de movimentos gravitacionais de massa e enchentes.

$\mathrm{Na}$ região litorânea e nas serras adjacentes, há um comportamento semelhante com pequenas variações, de acordo com o posicionamento geográfico: municípios localizados nas baixadas costeiras, no sopé ou na baixa encosta da serra do Mar e no reverso da serra do Mar. As amplitudes médias de variação térmica parecem ser ligeiramente maiores somente nas estações que se situam no reverso da serra do Mar, ou seja, mais interioranas, permanecendo com valores bem próximos para áreas localizadas nas baixadas e sopés de elevações (variando acima de $22^{\circ} \mathrm{C}$, nos meses de verão, a aproximadamente $20^{\circ} \mathrm{C}$ nos meses de inverno). Apenas nas áreas que se encontram em altitudes relativamente elevadas (Petrópolis, Teresópolis e Nova Friburgo) é que se observa uma queda geral dos valores das normais térmicas $\left(20^{\circ} \mathrm{C}\right.$ nos meses de verão e cerca de $15^{\circ} \mathrm{C}$ no inverno).

Em relação à distribuição pluviométrica anual, há também uma estação seca bem delineada nos meses de inverno. A baixada caracteriza-se por precipitações médias anuais inferiores a $1.500 \mathrm{~mm}$. No entanto, os municípios localizados no topo da serra do Mar, como Teresópolis e Nova Friburgo, são os que apresentam totais de precipitação bem mais elevados durante os meses de verão e os totais anuais mais elevados: valores médios superiores a $2.000 \mathrm{~mm} / \mathrm{ano}$. Ressalta-se, ainda, que os índices pluviométricos mais elevados, tanto no verão quanto no inverno, recaem sobre as localidades do sopé ou encosta inferior da serra do Mar, ultrapassando $60 \mathrm{~mm}$ mensais nos meses de inverno.

Após esta breve contextualização do estado, neste capítulo procuramos discutir os principais fatos históricos que envolveram a formação e a evolução das formas de relevo, assim como aqueles ligados à ocupação de seus terrenos e que, de uma forma ou de outra, facilitam (ou facilitaram) ou apresentam (ou apresentaram) restrições em função dos recursos naturais existentes e que, por outro lado, podem estar associados a problemas ambientais - alguns deles prolongados ou implicados com questões ainda presentes na atualidade. 


\section{Origem dos contrastes das feições de relevo no estado do Rio de Janeiro}

O estado do Rio de Janeiro, portanto, caracteriza-se pela presença de extensas planícies flúvio-marinhas, também conhecidas como baixadas, que bordejam a costa e se situam pouco acima do nível do mar, apresentando-se, em grande parte, embrejadas e entremeadas por lagoas, além da ocorrência de feições arredondadas e convexas correspondentes a colinas suaves isoladas e morros, que chegam a atingir $200 \mathrm{~m}$ de altitude (Figura 1). À medida que nos aproximamos dos contrafortes da serra do Mar, esses morros se tornam cada vez mais numerosos, com vales mais estreitos entre eles, o que demonstra o intenso processo de dissecação da escarpa serrana (Figura 2).

Figura 1. Mapa das feições de relevo do Rio de Janeiro. 1 - Paraty; 2 - Angra dos Reis; 3 - Itatiaia; 4 - Barra Mansa; 5 - Volta Redonda; 6 - Nova Iguaçu; 7 - Niterói; 8 - Maricá; 9 - Itaboraí; 10 - Araruama; 11 - Três Rios; 12 - Petrópolis; 13 - Cachoeiras de Macacu; 14 - Miracema; 15 - Campos de Goytacazes; 16 - Santa Maria Madalena; 17 - Conceição de Macabu; 18 - Macaé; 19 - Rio de Janeiro.

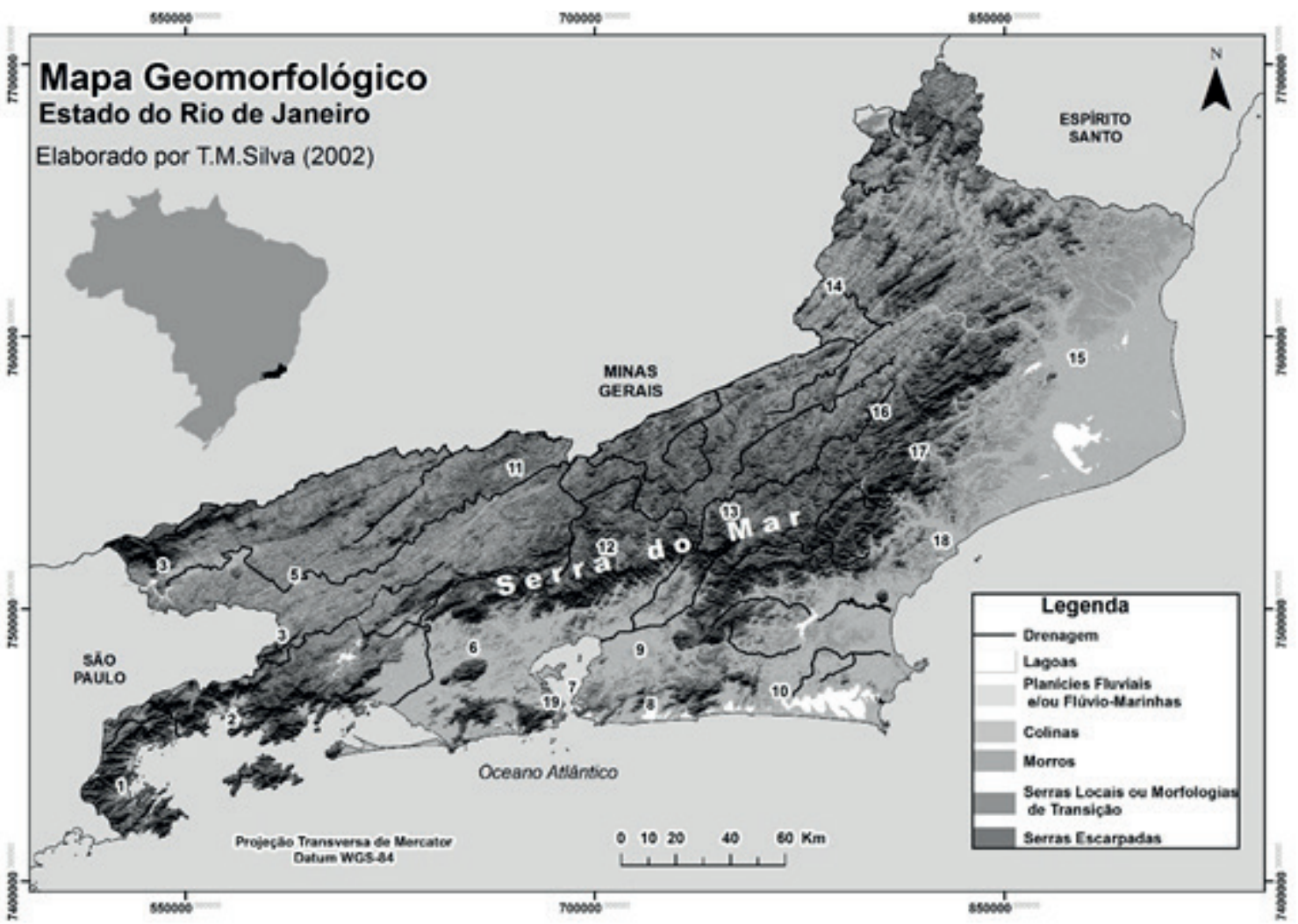

Fonte: Modificado de Silva (2002). 
Figura 2. Imagem demonstrando as feiçōes morfológicas típicas do entorno do estado do Rio de Janeiro: em primeiro plano, as planícies flúvio-marinhas da bacia do rio Guapi-Macacu e as feições de colinas e morros que vão se intensificando à medida que se aproximam da serra do Mar.

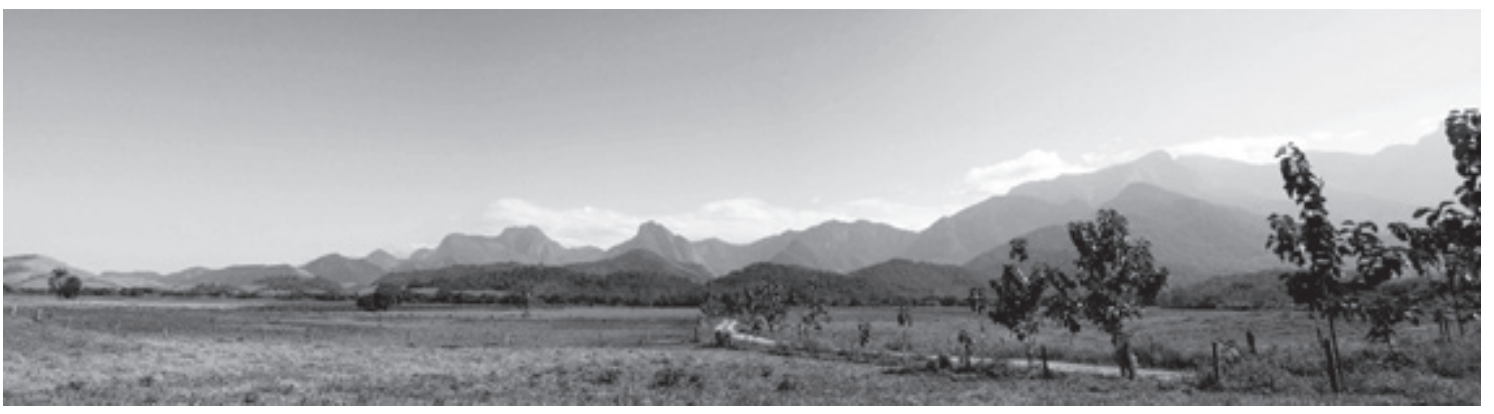

Foto: T. M. Silva (agosto de 2010).

Ainda ao longo da costa, encontram-se os maciços costeiros, correspondentes a elevações isoladas e paralelas, com altitudes entre 500 e 1.000 m. No segmento a leste da Baía de Guanabara, estão as serras da Tiririca, com elevações entre 200 e 410 m, e do Sambé, com altitude máxima de 610 m; no segmento a oeste, encontram-se os maciços de dimensões e formas mais imponentes conhecidos como Gericinó-Mendanha (974 m), Pedra Branca (1.024 m) e Tijuca (1.021 m), estes últimos mais próximos à costa (Figura 3).

Figura 3. Mapa com maciços costeiros e baixadas nos arredores da Baía de Guanabara. Maciços Costeiros: 1) Tijuca; 2) Pedra Branca; 3) Suruí; 4) Região dos Lagos. Maciços Alcalinos: 5) Mendanha; 6) Tinguá; 7) Itaúna; 8) Tanguá-Rio Bonito. A) Forte de São João; B) Forte de Santa Cruz.

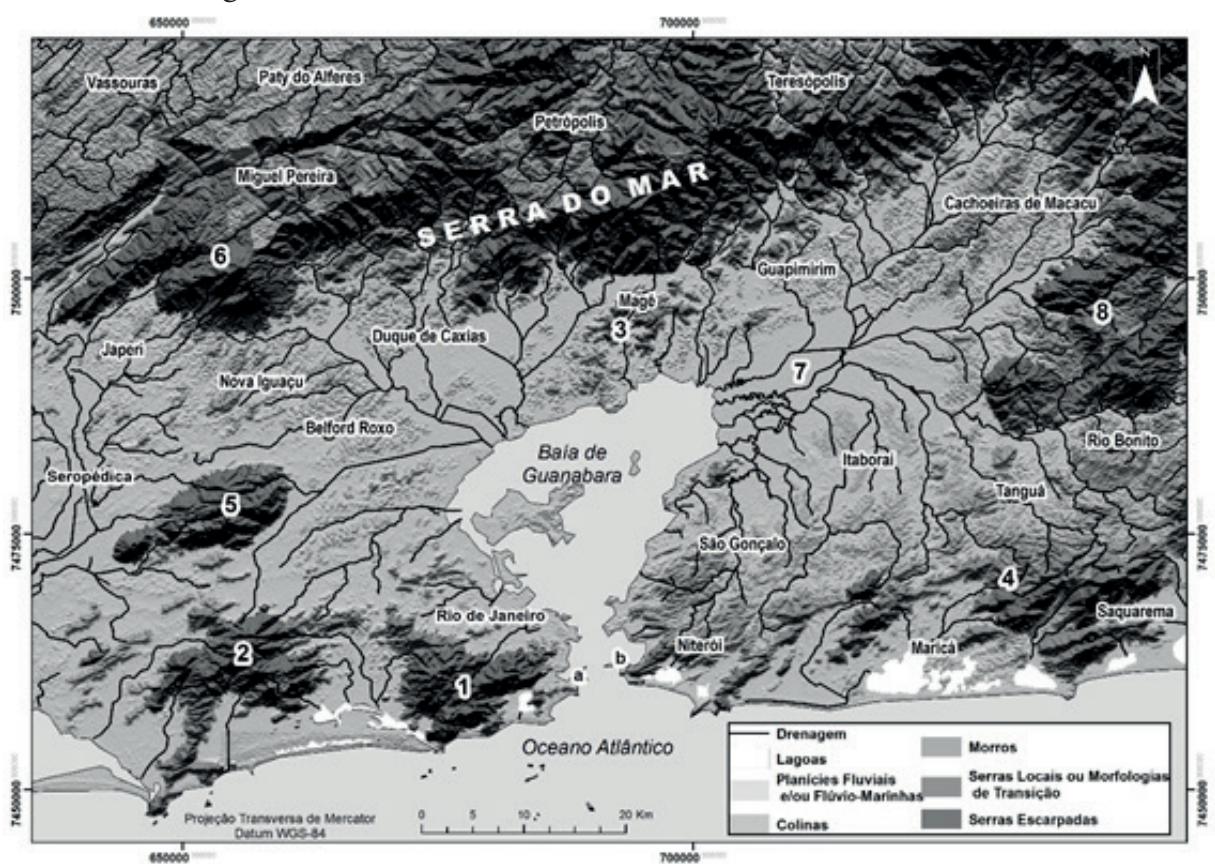

Fonte: Modificado de Silva (2002). 


\section{0 relevo do estado do Rio de Janeiro: cenário de beleza e fragilidade ambiental}

Alguns morros menores isolados são encontrados na região metropolitana do Rio de Janeiro e representam um grande atrativo para a atividade turística, como os morros do Leme, Urubus, Babilônia, Cara de Cão, Viúva, Outeiro da Glória, Pão de Açúcar, entre outros, que moldam o relevo no entorno das águas da Baía de Guanabara e tanto contribuem para a beleza cênica da cidade. Muitos desses morros mergulham diretamente no mar, formando costões abruptos interrompidos por fraturas e diáclases, que são continuamente retrabalhadas pela ação das ondas e fornecem um aspecto ímpar à cidade, conhecida como maravilhosa, devido ao cenário geomorfológico esculpido por milhares de anos (Fernandes et al., 2010).

Figura 4. Fotografia panorâmica que destaca a Baía de Guanabara e as feições de morros e maciços no entorno.

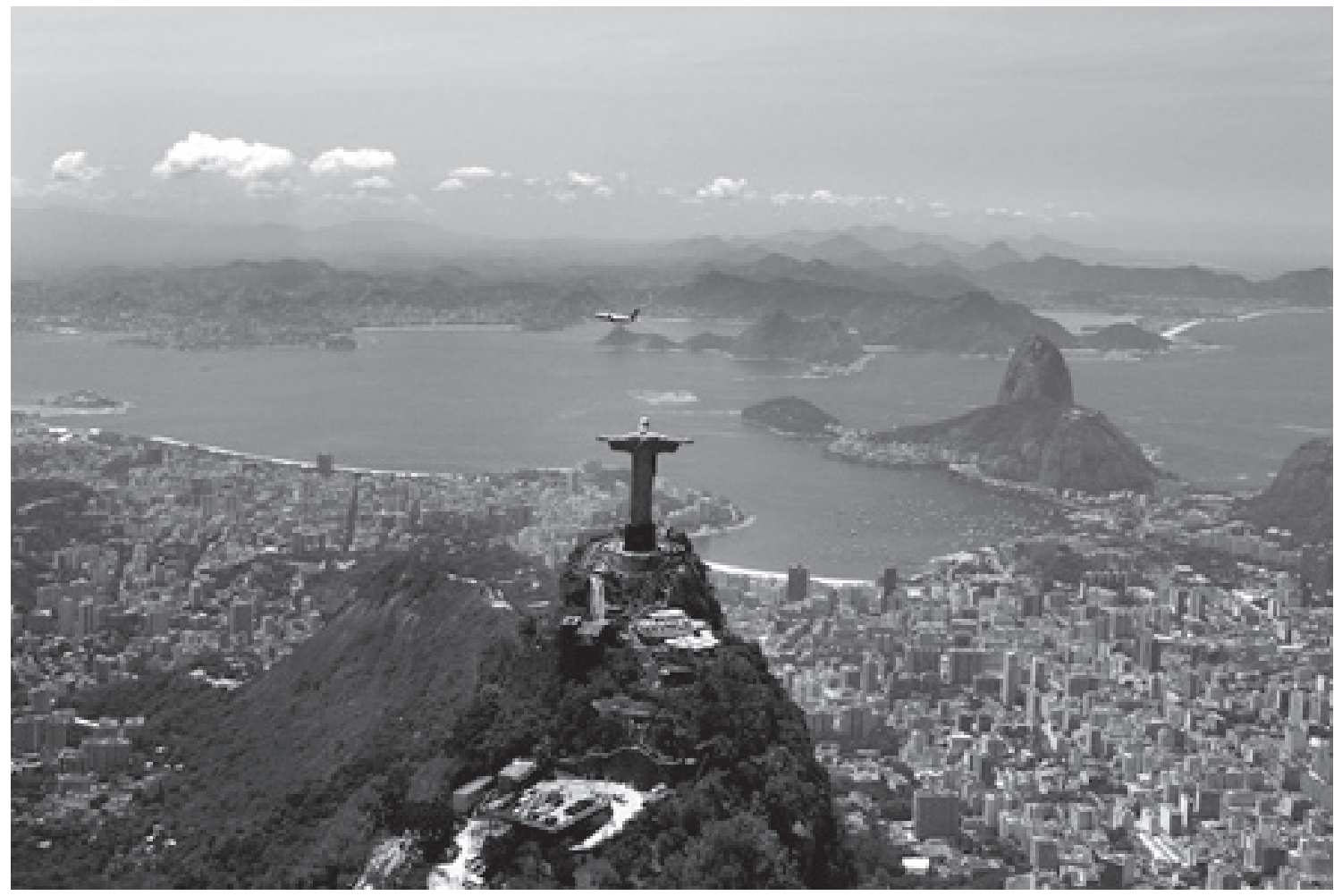

Foto: T. M. Silva (outubro de 2006).

A majestosa feição da serra do Mar, que isola a baixada flúvio-marinha do planalto interior (Figura 1), atinge altitude de $2.316 \mathrm{~m}$, e tem como seu ponto culminante o Pico Maior dos Três Picos, localizado na divisa dos municípios de Teresópolis e Nova Friburgo. Essa escarpa serrana é cortada por uma notável rede de drenagem, que desce torrencialmente pelas encostas rochosas, onde se formam corredeiras e cachoeiras cercadas por uma mata densa e exuberante e que tanto encantam os visitantes.

Essas características gerais do relevo fluminense são fruto de uma história geológica peculiar, pois, apesar de sabermos que nas áreas de choque entre as placas tectônicas é que encontramos as gran- 
des cadeias de montanhas, como a Cadeia Andina, a Cadeia do Himalaia, entre outras, a ocorrência da serra do Mar e dos maciços litorâneos no estado do Rio de Janeiro (fora de uma área previsível para formação montanhosa) provoca a curiosidade de pesquisadores e visitantes, principalmente entre os geólogos (Ferrari, 2012). Além disso, as formas do estado do Rio de Janeiro correspondem a um relevo relativamente jovem, modelado em um terreno geológico muito antigo, ou seja, as rochas que sustentam esse relevo são quase quinhentos milhões de anos (Ma) mais antigas do que as formas de relevo impressas na paisagem, demonstrando que há episódios geológicos distintos que explicam essa morfologia.

A Figura 5 se refere a um mapa simplificado dos dois domínios geológicos que predominam no estado do Rio de Janeiro: o das rochas cristalinas, que cobrem cerca de $80 \%$ de seu território, e o dos sedimentos que preenchem as áreas deprimidas das bacias de drenagem e/ou sedimentos litorâneos distribuídos ao longo de toda a costa. As rochas cristalinas são, predominantemente, compostas por gnaisses e granitos gerados entre 790 a $480 \mathrm{Ma}$, em processos colisionais das placas litosféricas durante a formação do supercontinente Gondwana, de idade entre o Neoproterozoico e o Paleozoico Inferior (Heilbron et al., 2008; Tupinambá et al., 2012).

Figura 5. Os grandes domínios geológicos do estado do Rio de Janeiro: o domínio de rochas cristalinas corresponde aos terrenos pré-cambrianos, enquanto o domínio dos sedimentos é representado pelos terrenos terciários e quaternários.

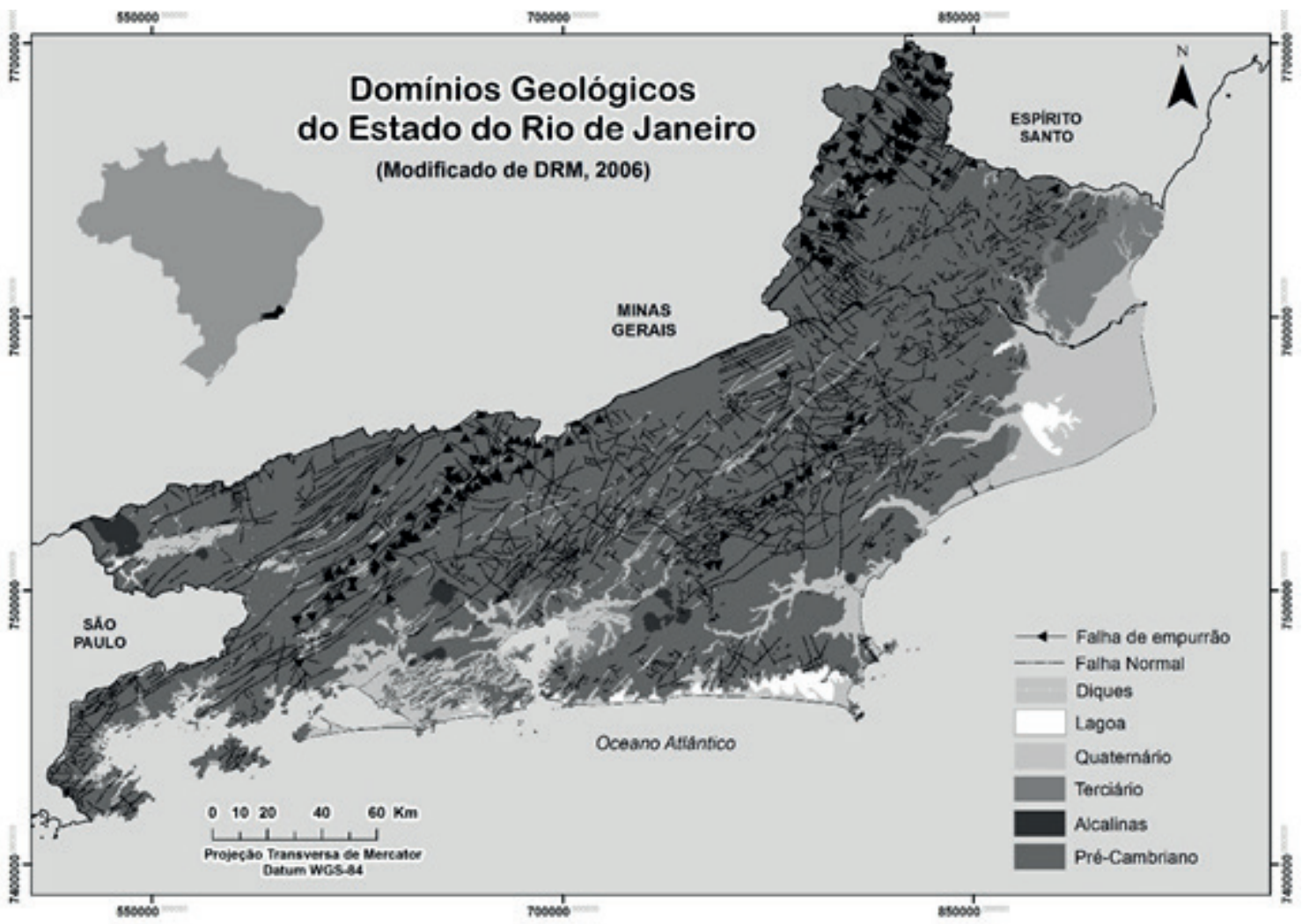

Fonte: Modificado de DRM, 2006. 


\section{0 relevo do estado do Rio de Janeiro: cenário de beleza e fragilidade ambiental}

Outro episódio geológico importante diz respeito à intrusão no embasamento cristalino por um enxame de diques básicos que precederam a quebra do Gondwana e a abertura do Oceano Atlântico Sul durante o Cretáceo Inferior (127 a 130 Ma). No Paleógeno, por sua vez, um regime distensivo desenvolveu importante falhamento em blocos, os quais, associados ao magmatismo alcalino, de idade entre 70 e $50 \mathrm{Ma}$ e caráter raso, estão registrados nos corpos subvulcânicos e intrusivos que se destacam na paisagem, como os maciços do Mendanha, Tinguá, Itaúna e Tanguá-Rio Bonito. Esse regime distensivo também deu origem à feição tectono-estrutural do Gráben da Guanabara, que pode ser identificada pela orientação ENE-WSW da baía, e aos depósitos cenozoicos, que correspondem às feições de planícies flúvio-marinhas mapeadas na Figura 1.

Asmus e Ferrari (1978) interpretam a estruturação do relevo na região que compreende uma estreita faixa, de 50 a $100 \mathrm{~km}$ de largura e com cerca de $1.000 \mathrm{~km}$ de comprimento, entre a cidade de Florianópolis (SC) e o médio vale do rio Paraíba do Sul, como resultado de falhamentos normais, com até $3.000 \mathrm{~m}$ de rejeito vertical, ao longo de linhas de fraqueza pré-cambrianas, as quais, entre o Paleoceno e o Plioceno, deram lugar ao deslizamento gravitacional de blocos, atualmente expressos por escarpas de linha de falha (serra do Mar, serra da Mantiqueira e maciço Carioca) e, entre estas, por semigrábens (vale do rio Paraíba do Sul e Baixada Fluminense) (Figura 6).

Figura 6. Perfil geológico esquemático, sem escala, transversal à área afetada pelo tectonismo cenozoico, ressaltando o caráter escalonado dos falhamentos e o basculamento dos blocos de relevo resultantes da serra da Mantiqueira aos maciços litorâneos (A - A').

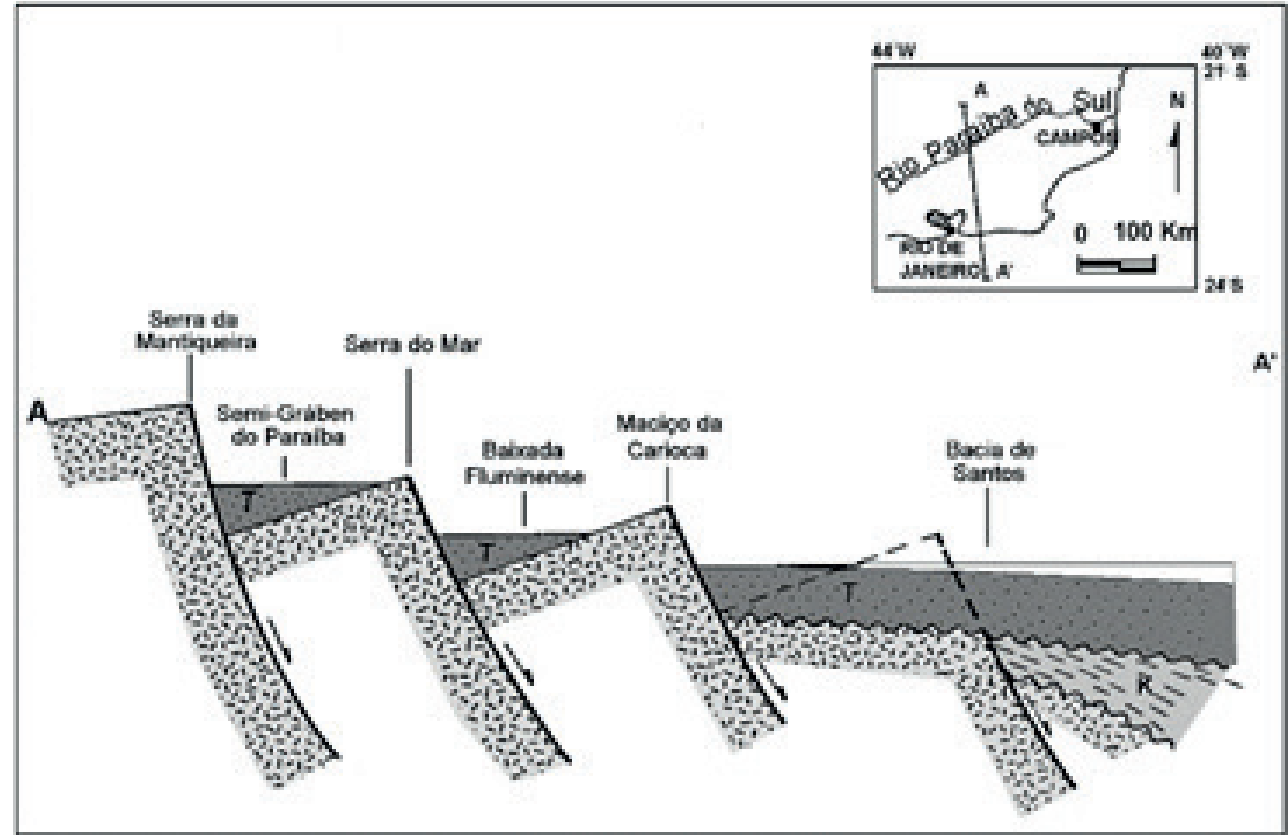

Fonte: Asmus e Ferrari (1978). K - sedimentos cretáceos, T - sedimentos terciários. 
Macedo et al. (1991) assinalam que a Região Sudeste foi - e talvez ainda seja - palco de intensa atividade tectônica durante o cenozoico. A disposição de falhas reativadas profundas, bacias, montanhas, vulcanismo e sismos recentes sugere um complexo de falhas normais/transcorrentes, seguindo subparalelamente à linha de costa do estado do Rio de Janeiro. Todos os autores consultados concordam que o tectonismo cenozoico no Sudeste do Brasil, embora residual, foi e continua a ser fundamental para o entendimento da evolução da paisagem no que diz respeito às mudanças na topografia e nos sistemas de drenagem, divergindo apenas quanto à intensidade dessas mudanças.

Os contrastes litológicos presentes condicionam uma intensa erosão diferencial, com as escarpas mais expressivas sendo suportadas por rochas granitoides, gnáissicas e quartzíticas. Os exemplos mais notáveis seriam as escarpas da Mantiqueira, dos Órgãos e da Bocaina; as intrusões alcalinas também são responsáveis por acentuados desníveis, como os de Itatiaia, Passa Quatro, Tinguá e Rio Bonito.

Nesse contexto, tanto o meio geológico quanto o geomorfológico estão associados a fontes de riquezas minerais, das águas, dos solos férteis, dando origem também a relevos de altitudes distintas e vales. Representam, assim, a base da cultura humana, atuando como suporte físico (substrato) para o desenvolvimento e fornecendo material para sua subsistência (Schmitt et al., 2004). Dessa forma, no próximo tópico, exemplificamos de que forma essas características físico-ambientais do Rio de Janeiro permearam a formação e a organização das atividades socioeconômicas desenvolvidas.

\section{Os condicionantes do relevo e o histórico de uso e ocupação do Rio de Janeiro}

O reconhecimento das características do relevo permite identificar os fatores favoráveis ou desfavoráveis à ocupação, as limitações e as possibilidades de uso dos solos, bem como a suscetibilidade potencial à erosão, revelando-se, portanto, essencial para a definição das áreas de preservação e de indicação de uso restrito e de ocupação urbana e/ou agrícola (Silva, 2009). Dessa forma, a paisagem do estado do Rio de Janeiro não pode ser considerada estática, representando personagem ativa e testemunhal de acontecimentos e intervenções ocorridos ao longo dos séculos de ocupação (Pinheiro, 2005).

No breve histórico acerca da ocupação e do uso dos recursos naturais do estado do Rio de Janeiro, debatemos a importância das características geológico-morfológicas em seu desenvolvimento, bem como nos entraves resultantes do uso inadequado dos recursos existentes.

Quando as naus comandadas por Américo Vespúcio cruzaram a barra do Rio de Janeiro, em $1^{\text {o. }}$ de janeiro de 1502 , desvendaram ao mundo um dos mais belos cenários da face da Terra, a Baía de Guanabara, envolto por pontais, enseadas, praias e uma exuberante mata tropical (Amador, 2012). No entanto, essa área já apresentava vestígios mais remotos da ocupação humana. A partir da investigação sobre os sambaquis, foram encontrados, ao longo da faixa litorânea, em pontos estratégicos do antigo estuário, bem como nas proximidades das lagunas, canais fluviais, manguezais, restingas e florestas, locais em que havia disponibilidade de água potável. Essa forma de ocupação está associada a uma fase de modificações ambientais com crescimento expressivo dos recursos marinhos, chamada de "ótimo climático", ocorrido entre 6.000 e 5.000 anos A.P. (Antes do Presente), quando se registrou 


\section{0 relevo do estado do Rio de Janeiro: cenário de beleza e fragilidade ambiental}

a elevação da temperatura e do nível do mar. Por sua vez, por volta de 3.000 anos A.P., a diminuição dos recursos marinhos típicos da formação dos sambaquis foi compensada na dieta alimentar pela coleta de vegetais, caça a pequenos animais e pesca (Amador, 1992).

Esses assentamentos litorâneos datados até cerca de 1.000 anos A.P. representam importantes marcadores das variações do nível do mar em tempos pretéritos, pois alguns sambaquis foram encontrados até cerca de $5 \mathrm{~km}$ da linha de costa da baía da Guanabara, atribuindo-se a mudança da localização a eventos de transgressão marinha, em que faixas ecológicas foram empurradas terra adentro e os afloramentos rochosos tornaram-se ilhas, com a ocupação humana refugiando-se nesses pontos topograficamente mais elevados. Durante os eventos de regressão marinha quaternária, os indígenas reocuparam antigos habitats, recolonizando mangues secos ou dunas fixas (Prous, 1992). Assim, fazendo nossas as palavras de Serra e Serra (2012), é possível considerar que essa população pré-histórica manteve relação de uso bastante harmônica com os terrenos e os recursos naturais existentes.

Já com o início da ocupação portuguesa, em 1565, houve as primeiras intervenções locais, com a criação de um núcleo urbano que buscou favorecer a definição dos direitos de propriedade da terra e dos recursos naturais encontrados, bem como garantir a segurança da colônia em relação a possíveis invasores. A escolha pelo Rio de Janeiro vinculou-se à importância da conformação de seu sítio para a proteção de ataques inimigos e à possibilidade de estabelecer fortificações em locais como a entrada da baía e ao longo dos rios.

Durante o período colonial, morros e costôes rochosos ofereceram, portanto, um frente bastante eficiente de defesa natural para esquadras que se abrigavam das tempestades, funcionando também como proteção para eventuais inimigos no interior da baía (Pinheiro, 2005). Algumas dessas fortificações ainda podem ser encontradas nos arredores da Baía de Guanabara, como as apresentadas na Figura 7.

Figura 7. A. Forte da Laje e parte do Forte de São João ao fundo, localizado no bairro da Urca; B. Detalhe do forte da Laje.

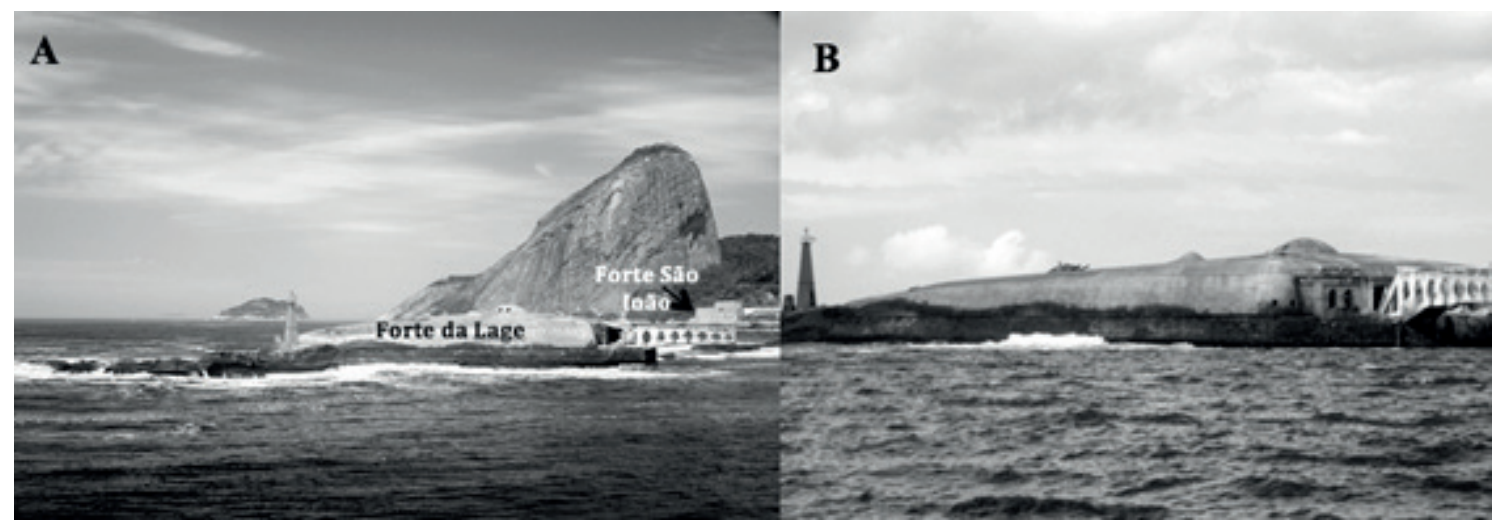

Fotos: T. M. Silva, jun. 2010. 
Nos anos seguintes, houve intervenção direta dos portugueses sobre a cobertura florestal do Rio, com a extração praticamente total da Mata Atlântica, em função do escambo de pau-brasil com os indígenas. Essa atividade extrativa se prolongou até o século XIX, destruindo vastas extensões florestais e, dessa forma, levando à erosão dos solos e à perda de mananciais de água, principalmente aquelas existentes nos maciços litorâneos que abasteciam a população na época colonial.

O século XVII foi marcado pelas experiências agrícolas vinculadas à produção de cana-de-açúcar e a seus engenhos, que marcaram principalmente a região do Norte fluminense, onde foram aproveitados os terrenos suaves (que caracterizam o topo das feiçôes de tabuleiros costeiros desenvolvidos em sedimentos da Idade Terciária - Formação Barreiras), local com um regime climático de estações bem demarcadas. Esses aspectos físico-ambientais são os mais adequados a esse cultivo extremamente rigoroso, que demanda terrenos planos ou ligeiramente inclinados, solos férteis e não sujeitos a encharcamentos, e que apresente um período seco que esteja diretamente relacionado à maturação ideal do cultivo. Nessa área do estado, é possível ainda encontrar representantes das fazendas dos antigos barôes do açúcar e de algumas usinas. Já na área metropolitana do Rio de Janeiro, a cana-de-açúcar também foi introduzida nas áreas das baixadas de Sepetiba (por exemplo, bairro de Santa Cruz) e da Baía de Guanabara (por exemplo, bairro de Bangu), onde houve grandes transformações nesse período. No entanto, atualmente, poucos são os vestígios encontrados nesses terrenos que correspondem à área urbanizada do extremo oeste da RMRJ.

No século XVII, também houve penetração agropastoril, que exigia vastas extensões de terra e levou ao desmatamento e às queimadas das áreas de baixadas pela mão de obra escrava de negros ou indígenas, gerando, consequentemente, acentuada perda da biodiversidade local, além de haver redução do número e do volume dos cursos fluviais, erosão e perda de fertilidade dos solos, bem como assoreamento das lâminas d'água (rios, lagoas e brejos) (Serra e Serra, 2012). Mas, com a descoberta das reservas auríferas das Minas Gerais, houve uma reorganização do povoamento fluminense, e a exploração de ouro influenciou, de forma indireta, a ocupação do território. O escoamento da produção, que descia do planalto das Minas Gerais (em lombos de burros), rumava até Paraty, pelo então denominado "Caminho Velho", e daí pelo mar até o porto do Rio de Janeiro. Desse período em diante, o Rio de Janeiro tornou-se o principal porto e a cidade mais ativa do país.

A atividade aurífera contribuiu para o surgimento de vilas que serviam de passagem pelo interior, em localidades nas quais os vales fluviais se abriam, com a formação de alvéolos que permitiam a ocupação, como ocorreu com a fundação e o crescimento dos municípios de Vassouras, Paraíba do Sul e Paty do Alferes, entre outros. Toda essa gama de atividades levou a Coroa a valorizar os terrenos do estado do Rio de Janeiro, o que culminou com a transferência da sede do governo colonial de Salvador para o Rio de Janeiro em 1763. Isso a transformou na cidade mais importante da colônia, e seu porto, no mais dinâmico de todos os existentes no litoral. Assim, a área correspondente ao que hoje se chama Região Metropolitana do Rio de Janeiro (RMRJ) desempenhou papel de destaque, por ser a sede da capital do Brasil entre 1763 a 1960, sendo a mais populosa do país por quase todo esse período (Abreu, 2006).

No entanto, em fins do século XVIII, com a redução da produção aurífera, boa parte da população que vivia na cidade se viu praticamente obrigada a buscar alternativas para sua sobrevivência, sendo a atividade agropastoril reafirmada como aquela que oferecia melhores e maiores condições para o desenvolvimento do Rio de Janeiro. Mas, à medida que o Império se consolidava, surgia um novo produto-rei na economia fluminense: o café. Essa nova cultura de base exportadora iniciou seu trajeto 


\section{0 relevo do estado do Rio de Janeiro: cenário de beleza e fragilidade ambiental}

na cidade do Rio de Janeiro, mais precisamente no maciço Carioca, nas encostas íngremes das vertentes voltadas para Jacarepaguá, além de ser introduzida nos maciços da Pedra Branca e do Gericinó-Mendanha. Nas encostas íngremes do maciço da Tijuca, esse cultivo acabou por quase destruir os mananciais hídricos que abasteciam a cidade, razão pela qual o governo imperial desapropriou sítios e fazendas para reflorestar a região. Essa área corresponde, na atualidade, à maior floresta urbana do mundo, o Parque Nacional da Tijuca.

Desse modo, com a restrição de plantio na capital federal, o café se expandiu para os terrenos do planalto, em diferentes municípios do território fluminense. Nesse período, houve uma das maiores expressões cafeeiras da antiga província, com o café atingindo "São João Marcos" (parte do atual município de Rio Claro), Piraí e Resende, até alcançar o vale do Paraíba, em seu trecho médio. Assim, no Médio Paraíba fluminense, o café teve seu plantio expandido em várias direções e foi cultivado desde o norte, em Entre Rios (atual município de Três Rios), seguindo por Nova Friburgo e Cantagalo, na Região Serrana, até Itaocara e São Fidélis.

No entanto, no estado do Rio de Janeiro, a produtividade do café não obteve o resultado esperado, mais uma vez devido à elevada declividade dos terrenos e dos solos, mineralogicamente pobres, levando a intensos processos de erosão e perda do solo. Além disso, também o regime climático impróprio foi decisido, pois, dependendo da espécie de cultivo, o café só se desenvolve bem em áreas que apresentem uma média de temperatura entre $18^{\circ} \mathrm{C}$ e $24^{\circ} \mathrm{C}$. Temperaturas muito baixas, mesmo que por poucos dias por ano, não são aceitáveis. E o regime de chuvas ideal é aquele com chuvas bem distribuídas durante todo o ano e com uma precipitação total entre $600 \mathrm{~mm}$ e $1.500 \mathrm{~mm} /$ ano - características que não são encontradas no território fluminense. No entanto, mesmo com todos esses empecilhos naturais, as áreas de cafezais viveram um período áureo de produtividade e grande riqueza, com imponentes sedes das fazendas e instalaçóes de beneficiamento do produto ocupando os segmentos dos fundos dos vales. Muitas dessas instalaçóes, principalmente aquelas do Médio Paraíba, foram resgatadas pela atividade turística nas últimas décadas, procurando-se manter vivo esse período econômico áureo do estado.

Ressalta-se ainda que esse sítio, como, por exemplo, o da RMRJ, que tanto favoreceu a instalação de fortalezas que protegiam o território brasileiro, viria a ser um grande balizador para o desenvolvimento urbano da cidade. Segundo Abreu (2006), essa mesma característica que confere à cidade uma paisagem bela e única também causou diversos problemas, não somente pela falta de espaço, mas também pela ocupação deáreas impróprias, como encostas de morros efundos de vale alagadiços, gerando a constante necessidade de gerenciamento para não desencadear eventuais processos de degradação ambiental.

Dessa forma, houve necessidade de aterrar extensas áreas nesse trecho do estado, levando-se em conta a inexistência de terrenos para a expansão do sítio urbano. A abertura de espaços revelou-se de primordial importância para o desenvolvimento da cidade, efetuando-se, assim, várias modificações na paisagem natural, ou seja, alterações diretas sobre o relevo da cidade, como, por exemplo, o desmonte de morros e o aterro de diversas áreas, com vistas ao crescimento urbano.

As modificações urbanas ocorridas na cidade do Rio de Janeiro tiveram, em sua maior parte, origem nas reformas urbanas. Um dos melhores exemplos foi o desmonte do morro do Castelo, que teve grande significado histórico, pois foi a área escolhida pelos portugueses, logo após a expulsão definitiva dos franceses, que dominavam a Guanabara, para a construção das primeiras casas e fortificaçôes definitivas da cidade (Figura 7). No entanto, com o passar do tempo, os bairros do Castelo e 
da Misericórdia, situados na área do morro, tornaram-se sinônimo de insalubridade e doença, e esses foram os principais motivos de sua destruição.

Tal modificação da paisagem urbana pode ser vista ainda como uma das mais significativas, decorrente dos ideais sanitaristas que alteraram a feição urbana da cidade desde a reforma Pereira Passos, embora tenha ocorrido de fato durante a reforma Carlos Sampaio. Isso porque as reformas empreendidas pela administração do prefeito Carlos Sampaio no Rio de Janeiro (1920-1922) estavam ligadas não somente à sanitarização da cidade, mas também à tentativa de embelezá-la para os festejos de comemoração dos cem anos de independência do Brasil (Abreu, 2006).

Figura 8. Morro do Castelo ainda com sua ocupação original, em 1914.

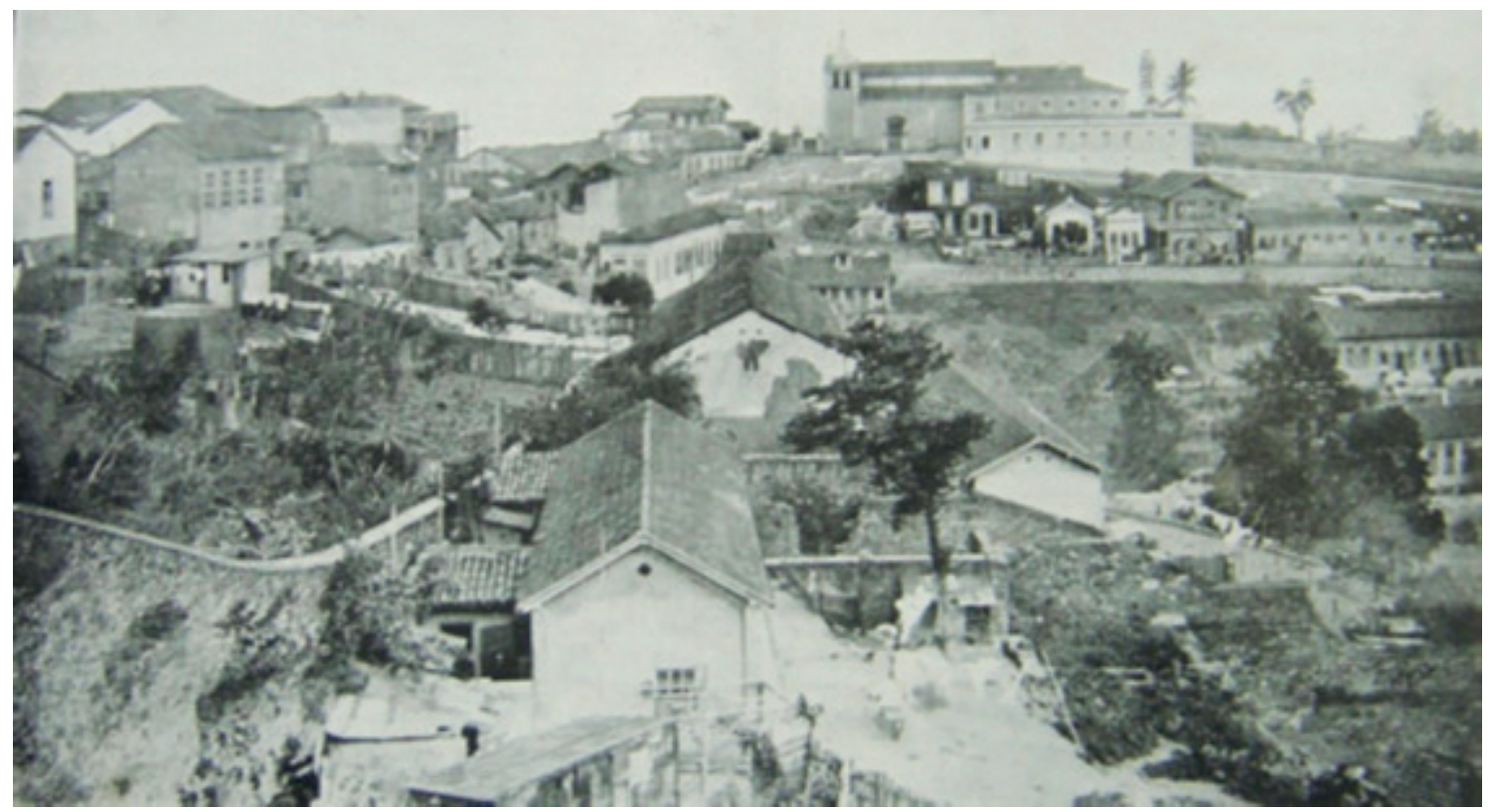

Fonte: http://zrak7.ifrance.com/castello-morro.jpg.

Assim, com o desmonte do Morro do Castelo, pretendia-se dar uma nova funcionalidade à sua área central, que, nesse período, já apresentava significativa importância na política e na economia nacional, de modo que representasse a paisagem-símbolo de uma nação emergente e contemporânea. Em novembro de 1920, então, teve início o desmonte do morro do Castelo, e parte do rejeito foi aproveitada para o aterro da Praça Mauá, do Cais do Porto e da avenida Rodrigues Alves. Além disso, nesse mesmo período, a cidade ainda era a capital do Brasil e, para um país que queria mostrar ao mundo seu crescimento econômico, uma paisagem caracterizada como um centro velho e insalubre não era desejável; ao contrário, requeria-se a abertura de áreas para a instalação de largas avenidas e prédios mais novos, sendo, portanto, necessária a mudança na conformação da paisagem do centro da cidade.

Desse modo, com o desmonte do morro (Figuras 9A e 9B), tornou-se possível a construção da avenida Presidente Antônio Carlos (Figura 9C), evento necessário ao desenvolvimento do transporte 
urbano na cidade, e, com o material do desmonte, foi possível ainda aterrar outras áreas da cidade, inclusive partes da Lagoa Rodrigo de Freitas.

Figuras 9A e 9B. Desmonte do morro do Castelo, iniciado em 1921. Figura 9C. Avenida Presidente Antônio Carlos e urbanização da Esplanada do Castelo em 1944.

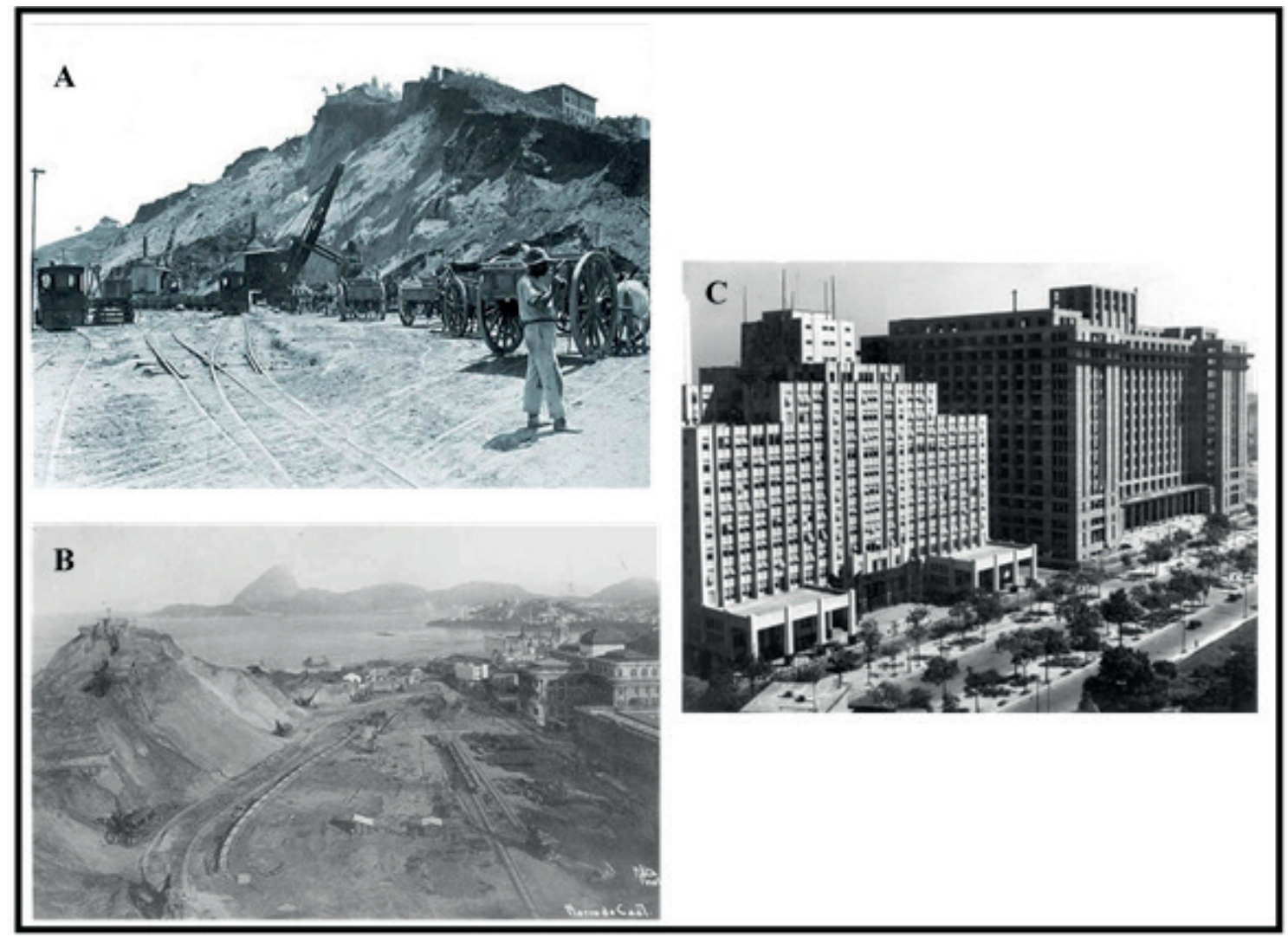

Fonte: Disponível em http://www.rioquepassou.com.br/2009/10/16/av-pres-antonio-carlos-e-ministerios-circa-1944/).

$\mathrm{Na}$ área do entorno da Lagoa Rodrigo de Freitas, também havia uma ocupação desordenada em forma de casebres (Figura 10), em uma área que se encontrava ainda muito pantanosa e insalubre. À época, os olhos das classes mais favorecidas se voltavam para a Zona Sul da cidade e, como os outros bairros já estavam basicamente ocupados, sobrou, como áreas livres, esse local onde a insalubridade era gerada pela existência do pântano. Assim, com o aterro da Lagoa, houve a retirada da população menos favorecida e o loteamento para a construção de moradias de elevado padrão. 
Figura 10. Fotografia da ocupação da Lagoa Rodrigo de Freitas na década de 1940 e o aspecto pantanoso e insalubre do local.

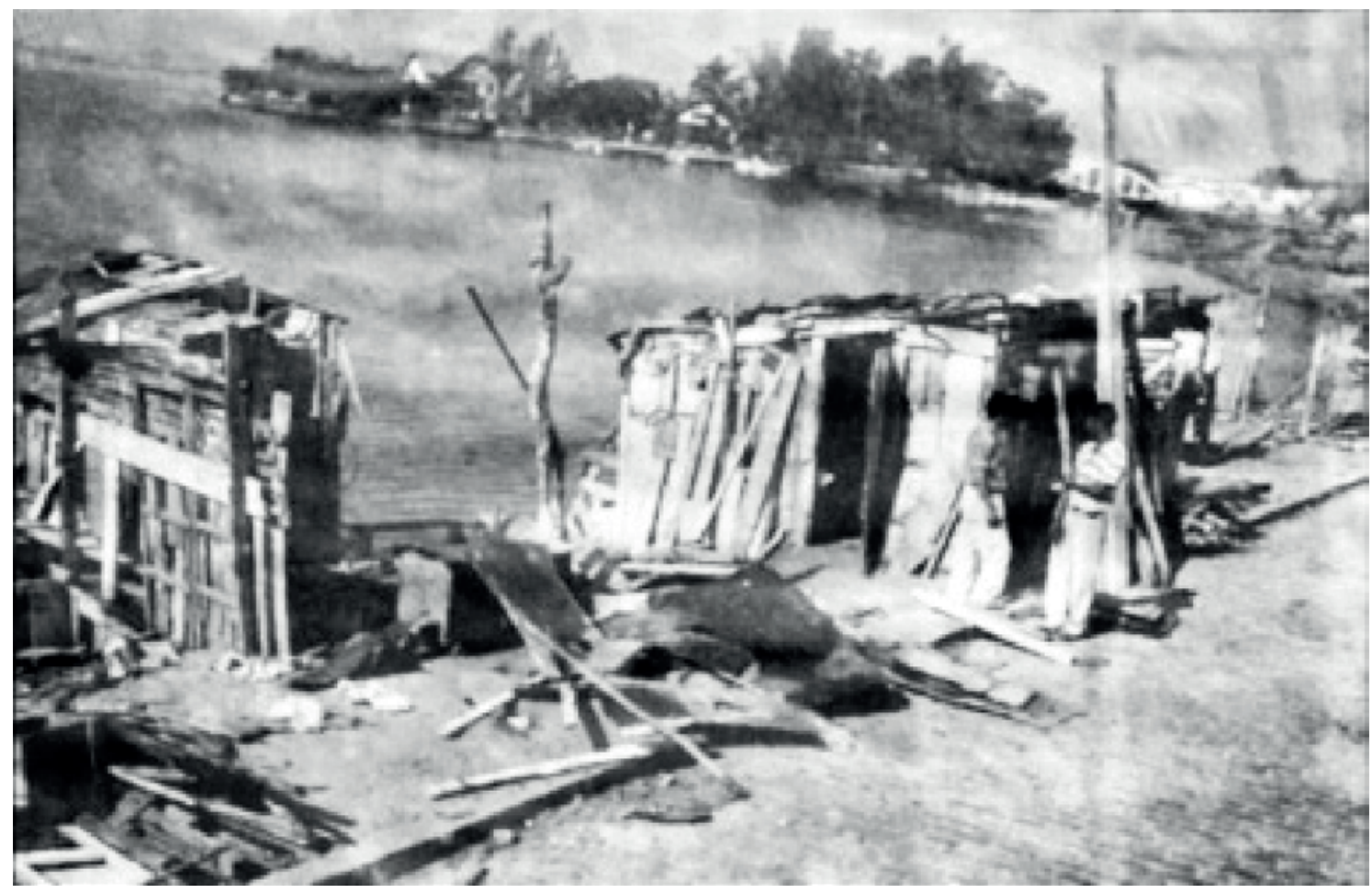

Fonte: Disponível em http://spiritosanto.wordpress.com/ page/9/?archives-list=1.

A Lagoa Rodrigo de Freitas estava localizada em uma área vista como importante para a cidade e, nesse caso, diferentemente da área do morro do Castelo, a importância da paisagem estava associada à moradia, enquanto a área do morro do Castelo tinha importância mais ligada à centralidade, aos negócios, ou seja, à economia nacional. Assim, a paisagem da Zona Sul como um todo passou a ter significado diferenciado, ligado à proximidade do oceano, que passou a ser visto como um "renovador para a alma” (Abreu, 2006). Dessa forma, as intervençōes antrópicas que modificaram essas paisagens urbanas, com a atribuição de novos significados culturais, ocorreram sob duas lógicas parecidas, porém distintas, no morro. A lógica no morro consistia em adaptar a paisagem às novas funçóes exigidas pela cidade, enquanto, na Lagoa, era a criação de uma paisagem com significado positivo, construindo, assim, uma nova área urbana valorizada.

Outros aterros foram realizados na Região Metropolitana do Rio de Janeiro e modificaram, de forma significativa, a paisagem natural da cidade, como foi o caso do Aterro do Flamengo e dos atuais bairros da Gamboa e da Saúde. O aterro junto aos bairros da Gamboa e da Saúde revelou-se de grande importância para a construção do cais do porto do Rio de Janeiro. E, embora a cidade, durante séculos, tenha tido boa parte de sua morfologia alterada pelos processos de ocupação e desenvolvimento, 
ainda hoje o contraste morfológico, as praias, alguns manguezais e ilhas, que ainda resistem a todo esse processo de degradação, são atrativos naturais que continuam a encantar brasileiros e estrangeiros.

\section{Fragilidade ambiental contemporânea no estado do Rio de Janeiro}

Falar de intervenções mais modernas que ocorreram no território fluminense, como, por exemplo, a rodovia Mário Covas (BR-101), e de todo padrão de intervenção que altera, principalmente, as condições hidrológicas sub e superficiais, é fundamental para se compreenderem a organização espacial e as questôes ambientais contemporâneas. E, para nos aprofundarmos na discussão dessas intervenções, é necessário trazer para o debate o conceito de fragilidade ambiental.

Para nós, esse conceito diz respeito à suscetibilidade que o ambiente apresenta a qualquer tipo de intervenção que gere alguma forma de dano, que, por suas características de sensibilidade aos impactos socioambientais adversos, possui baixa resiliência e pequena capacidade de recuperação. Como exemplo, temos as intervençóes em áreas ambientalmente frágeis, como lagos, lagunas, encostas de forte declive, restingas e manguezais (Diccionario de la Naturaleza, 1987). Essas intervenções devem ser muito bem avaliadas quando se pretende aplicá-las em políticas públicas de planejamento e/ou manejo territorial.

O estado do Rio de Janeiro apresenta características físicas de extrema fragilidade, quer sejam as relacionadas a seu sítio (ora terrenos de fortes declives, como as faixas serranas, ora terrenos de baixíssima declividade, como todas as áreas de baixadas quaternárias), quer estejam associadas a questōes de dinâmica atmosférica, pois se encontra posicionado em setores de influência de fatores climáticos extremamentes dinâmicos. Toma-se como exemplo a forte influência das frentes frias provenientes do Polo Sul e/ou a influência da faixa de nebulosidade orientada no sentido noroeste-sudeste, que se estende do sul da Amazônia ao Atlântico Sul-Central e caracteriza a Zona de Convergência do Atlântico Sul (ZCAS), influências que estão diretamente relacionadas aos inúmeros eventos de enchentes e/ou de movimentos gravitacionais de massa em diversos setores espaciais do estado.

Trazemos, aqui, alguns exemplos de mecanismos de uso dos solos, que, somados às características ambientais peculiares do estado, acabam gerando graves problemas à população.

Temos o exemplo do município de Angra dos Reis, situado em área litorânea no sul do estado, com uma beleza cênica reconhecida tanto nacional como internacionalmente. Esse município, contudo, passou por um processo de ocupação em um sítio com poucas áreas de baixo declive, avançando rumo às escarpas da serra da Bocaina (Figura 11). Observa-se que a inexistência de políticas adequadas à expansão urbana deixou a ocupação fora de controle, fazendo com que avançasse para áreas impróprias, pressionando e/ou degradando, dessa forma, a reserva de Mata Atlântica, característica dessa área. Esse processo ocupacional, ocorrido entre os anos 1970 e os anos 2000, foi provocado por diversos fatores, como a presença de estaleiros, da Petrobras, da usina nuclear, além da atração turística local, que corresponde a oportunidades de trabalho e, portanto, levou a uma significativa ocupação populacional, inclusive em áreas de difícil acesso e que apresentavam sérias questôes de fragilidade ambiental. Como resultado disso, é comum encontrar, no local, canais fluviais que sofrem com o 
assoreamento de seus leitos, derivado de processos erosivos nas altas encostas desmatadas, o que, somado a períodos de estiagem pluviométrica, conduz a problemas de abastecimento de água, além de degradação causada pela atividade de mineração ilegal (Figura 12).

Figura 11. Fotografia panorâmica do centro urbano do município de Angra dos Reis, localizado no sul fluminense.

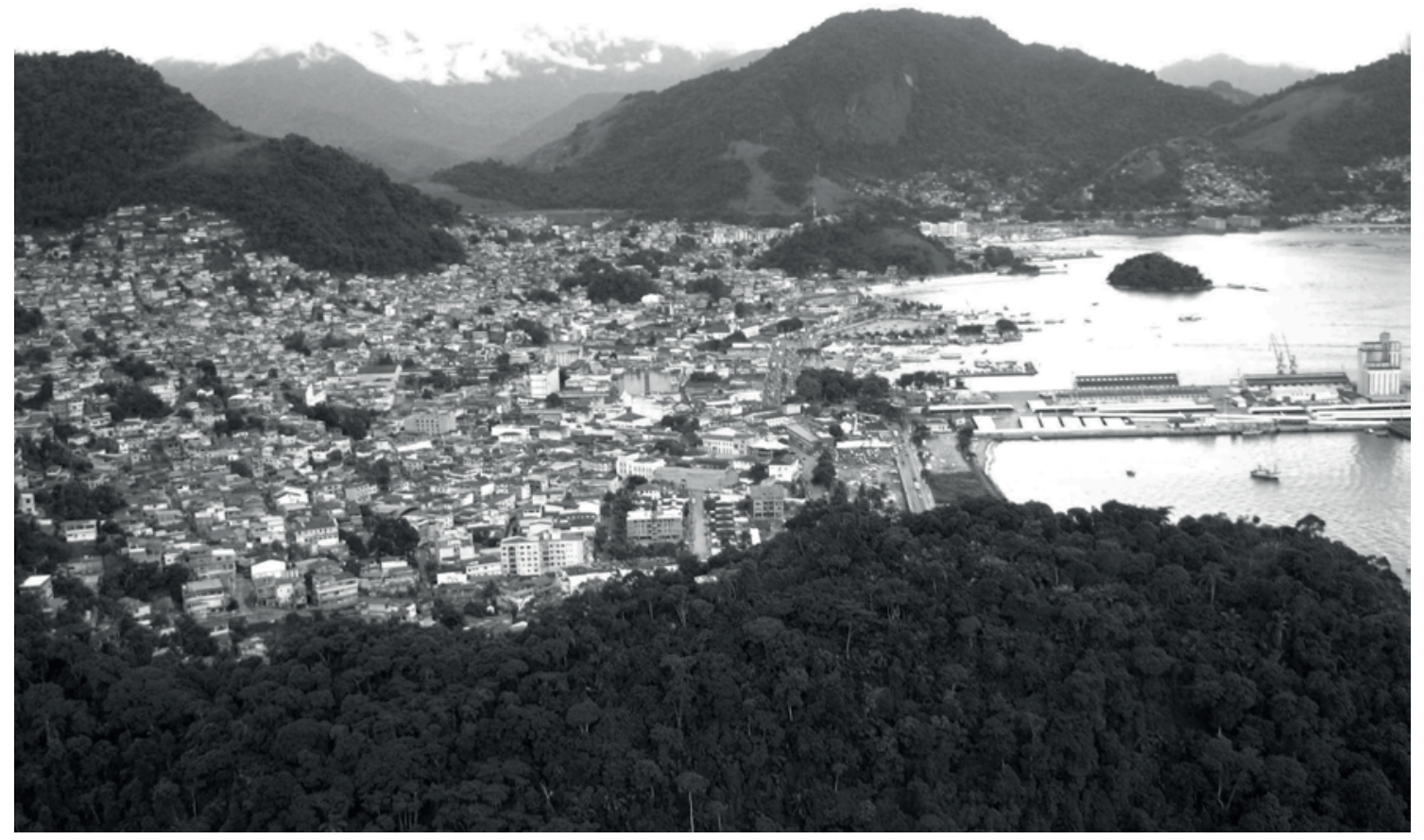

Foto: S. L. S. Silva (dezembro de 2010). 


\section{0 relevo do estado do Rio de Janeiro: cenário de beleza e fragilidade ambiental}

Figura 12. Fotografia do baixo curso do rio Japuíba, que ilustra aporte acentuado de carga sedimentar, com a redução significativa de seu leito fluvial. Observa-se ainda a atividade de extração ilegal de areia do leito fluvial pela presença de um caminhão coletor desse recurso mineral na parte inferior da foto.

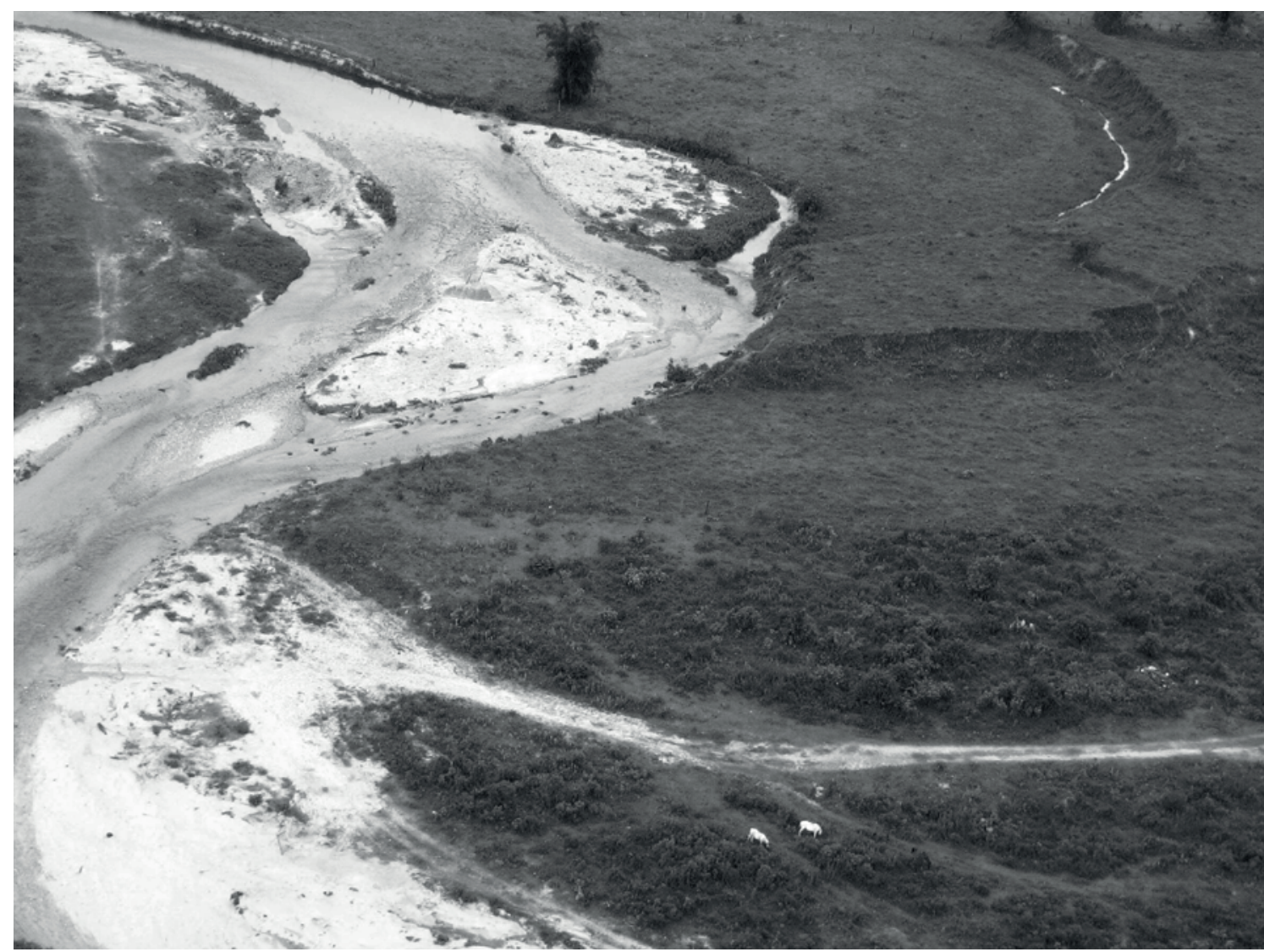

Foto: S. L. S. Silva (dezembro de 2010).

Ainda nesse município, encontramos ações indevidas do uso contemporâneo dos recursos naturais, como, por exemplo, cicatrizes representativas do uso indiscriminado de áreas de extração de material para construção civil, as quais são abandonadas sem nenhuma proposta de recuperação ambiental, como podemos observar na Figura 13A, que apresenta cicatrizes da área de extração mineral e uma voçoroca de grande extensão em sua base, bem próxima à rodovia Rio-Santos. Existe ainda outro exemplo de incoerência de uso, correspondente à construção de um lixão em área de colinas e morros com Mata Atlântica, ao lado de um canal fluvial (Figura 13B). 
Figura 13. A. Área de extração de saibro (produto de alteração de rochas quartzo-feldspáticas, como granitos e gnaisses) em feiçāo colinosa nos arredores da rodovia Rio-Santos (município de Angra dos Reis, RJ); B. Corte em feição de morro para a construção de um lixão a céu aberto pela prefeitura de Angra dos Reis na bacia do rio Ariró.
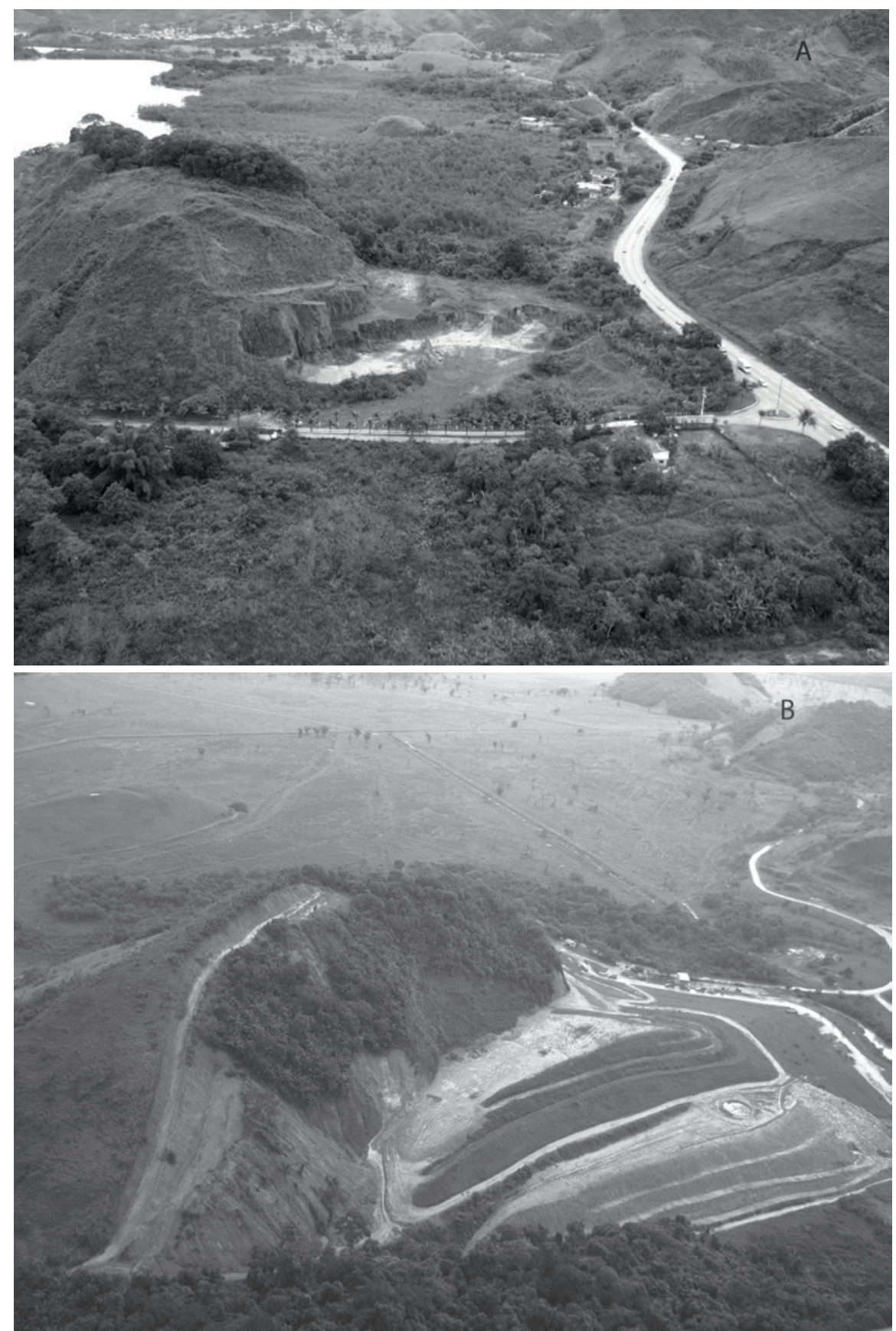

Foto: S. L. S. Silva (dezembro de 2010). 


\section{0 relevo do estado do Rio de Janeiro: cenário de beleza e fragilidade ambiental}

Além desses exemplos, é comum, em episódios de alta pluviosidade no município, assim como em tantos outros do estado, haver graves problemas com o desencadeamento de deslizamentos de encostas e enchentes. Angra dos Reis tem um triste histórico de inúmeros deslizamentos e quedas de blocos que causaram mortes e deixaram muitas pessoas desabrigadas, afetando diretamente a população e a economia local, como, por exemplo, nos eventos de 2002 (129,3 mm) e da virada do ano de 2009 para 2010 (142,9 mm). No entanto, sempre houve - e sempre haverá - eventos dessa magnitude em Angra e nas áreas serranas do estado. E os terrenos, que são naturalmente suscetíveis, por serem extremamente rasos, em razão do forte declive, somado aos elevados índices pluviométricos, são fatores primordiais na geração de tais processos geomorfológicos. No entanto, políticas adequadas e de controle e manejo do uso do solo poderiam amenizar tais catástrofes.

Em janeiro de 2011, a população da Região Serrana do Rio, constituída pelos municípios de Itaipava, Petrópolis, Teresópolis e Nova Friburgo, teve um dos maiores desastres ambientais já vivenciados, com uma série de eventos de deslizamentos, corridas de detritos e enchentes. Tudo isso arrasou, quase por completo, alguns vilarejos, como podemos observar na Figura 14, em que a imagem nos revela a força do agente de transporte, que foi capaz de movimentar blocos rochosos de diversos tamanhos, destruindo o que encontrava pela frente por onde passava, ao longo do eixo do córrego da Posse, em Petrópolis. Esses eventos, contudo, são recorrentes, pois ainda é possível observar in situ, nos barrancos que foram escavados ao longo do antigo leito fluvial, depósitos de blocos de diversos diâmetros acamados em uma matriz areno-argilosa, demonstrando que, nessa área, assim como em quase todas as áreas serranas do estado, esses processos representam mecanismos naturais de evolução da paisagem.

Os elevados índices pluviométricos, que ocorrem, principalmente, nos meses de verão, revelam-se o input de energia. No entanto, dirigentes de órgãos públicos devem estar atentos aos demais fatores ambientais, como, por exemplo, tipo de solo, conformação geomorfológica, direção preferencial dos fluxos d'água, entre outras características do terreno, no momento de colocar em prática as políticas de uso e manejo, buscando sempre evitar, ou pelo menos amenizar, as proporções das catástrofes já anunciadas em um sítio extremamente sensível às fragilidades ambientais. 
Figura 14. Imagem da corrida de detritos no vale do córrego da Posse, município de Petrópolis (RJ), em janeiro de 2011.

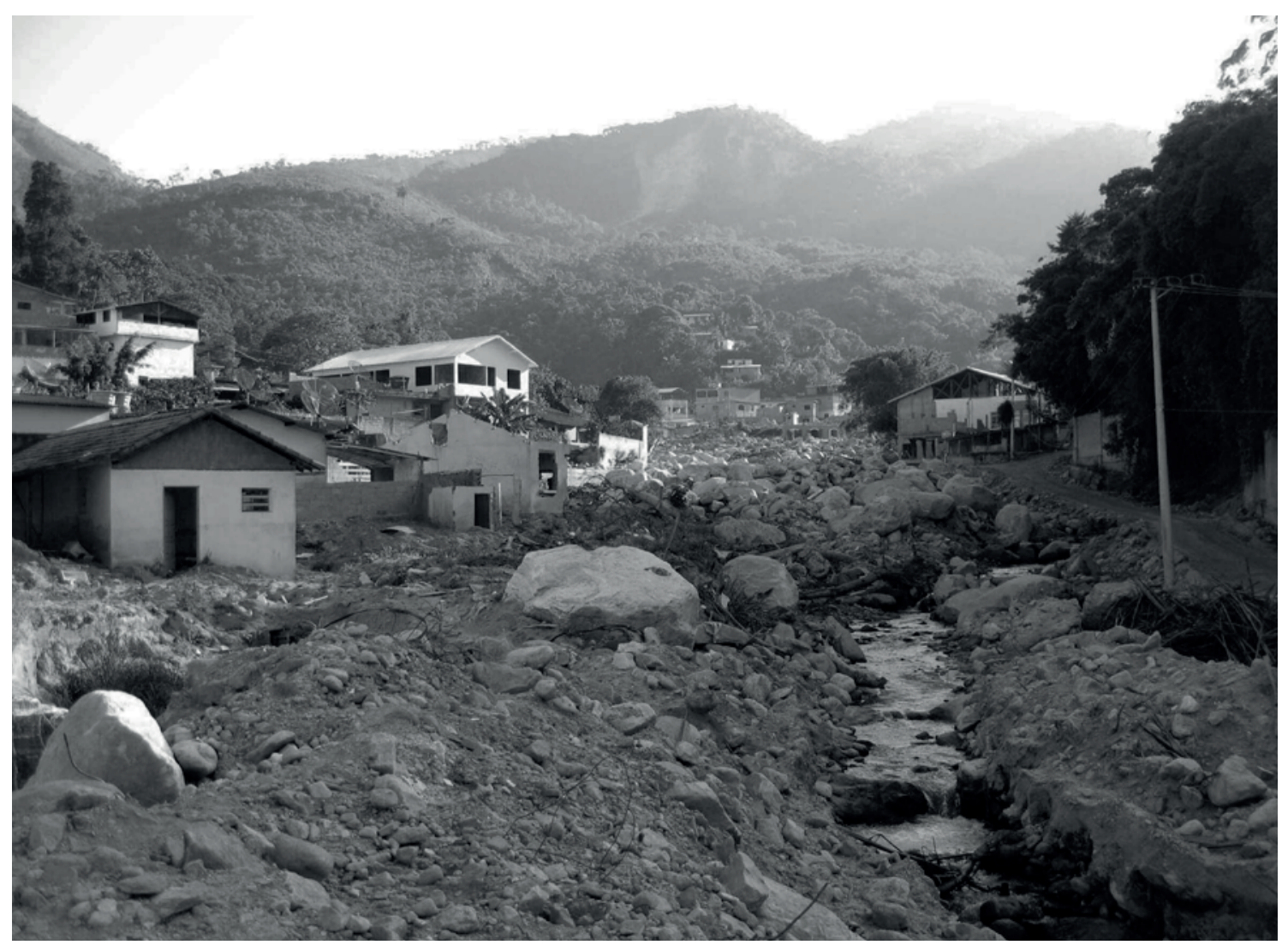

Foto: T. M. Silva (maio de 2011).

\section{Considerações finais}

Por representar uma das mais importantes referências naturais e culturais do Brasil, o estado do Rio de Janeiro sempre terá relevância no país, devendo-se sempre manter sua riqueza físico-ambiental e o bem-estar e a qualidade de vida de seus habitantes (Silva et al., 2015). Embora, na última década, tenha havido um prenúncio de recuperação econômica do estado, em função de sua base industrial expressiva, com a instalação de refinarias de petróleo, estaleiros, indústrias siderúrgicas, metalúrgicas, petroquímicas, entre outras, no último ano uma nova crise econômica se instalou, trazendo muita preocupação no que tange também aos mecanismos de degradação e poluição ambiental. Deve-se, contudo, buscar mecanismos capazes de manter a integridade de uma das áreas mais importantes do país, que desempenha papel fundamental na externalização de uma imagem positiva do Brasil no exterior.

Com a realização da Copa do Mundo de 2014 no Brasil e das Olimpíadas de 2016 no estado, os olhos do mundo se voltaram para nosso país e, dessa forma, há grande interesse em seu desenvol- 
vimento e crescimento sustentável, com vistas a melhorar uma imagem degradada por longos quinhentos anos de mau uso e ausência de manejo adequado. Acredita-se, dessa forma, que, se houver políticas públicas adequadas às condições físico-naturais peculiares dos terrenos fluminenses e, em consequência, dos processos erosivo-deposicionais advindos da relação entre tais características e a entrada de energia no sistema ambiental - que, em geral, está atrelada aos elevados índices pluviométricos -, será possível retomar um crescimento econômico que respeite o belo cenário natural do estado do Rio de Janeiro.

\section{Referências}

ABREU, Maurício Abreu. Evolução urbana do Rio de Janeiro. 4 ed. Rio de Janeiro: Instituto Pereira Passos - IPP/Prefeitura da Cidade do Rio de Janeiro, 2006 [1987]. 156p.

AMADOR, Elmo da Silva. "Baía de Guanabara: um balanço histórico". In ABREU, M. A. et al. (orgs.). Natureza e sociedade do Rio de Janeiro. Rio de Janeiro: Secretaria Municipal de Cultura, Turismo e Esportes, Departamento Geral de Documentação e Informação Cultural, Divisão de Editoração, 1992, pp. 201-58.

- Baía de Guanabara e ecossistemas periféricos: características geoambientais, formaçāo e ecossistemas. Rio de Janeiro: Interciência, 2012. 432p.

ASMUS, Haroldo Erwin e FERRARI, André Luiz. "Hipótese sobre a causa do tectonismo cenozóico na região sudeste do Brasil”. In PROJETO REMAC. Aspectos estruturais da margem continental leste e sudeste do Brasil. Rio de Janeiro: Petrobras/Cenpes/Dintep, 1978, v. 4, pp. 75-88.

DICCIONARIO de la Naturaleza, Hombre, Ecologia, Paisaje. Madri: Espasa-Calpe, 1987. 1.016p. Disponível em http://www.ecolnews.com.br/dicionarioambiental/ referencias_bibliograficas.htm. Acesso em 23 jan. 2016.

FERNANDES, Nelson Ferreira et al. "Rio de Janeiro: a metropolis between granite-gneiss massifs". In MIGÓN, P. (org.). Geomorphological landscapes of the world. Berlim, primavera de 2010, pp. 89-100.

FERRARI, André Luiz. "Geologia”. In SERRA, M. V. e SERRA, M. T. F. Guia de história natural do Rio de Janeiro. Rio de Janeiro: Cidade Viva, 2012, pp. 52-75.

HEILBRON, Mônica et al. "Correlation of Neoproterozoic terranes between the Ribeira Belt, SE Brazil and its African counterpart: comparative tectonic evolution and open questions", Geological Society Special Publication, 2008, v. 294, pp. 211-37.

MACEDO, J. M. et al. "O tectonismo meso-cenozoico da região Sudeste”. In Simpósio de Geologia do Sudeste. Atas... São Paulo: SBG/SP-RJ, 1991, pp. 429-33.

PINHEIRO, Eliane Canedo de Freitas. Baía de Guanabara: uma biografia de uma paisagem. Rio de Janeiro: Andrea Jakobsson Estúdio, 2005. 271p.

PROUS, André. Arqueologia brasileira. Brasília: Universidade de Brasília, 1992. 606p.

RICCOMINI, C. O Rift Continental do Sudeste do Brasil (tese). USP, 1989. 
- Tectonismo gerador e deformador dos depósitos sedimentares pós-gondvânicos da porção centrooriental do Estado de São Paulo e áreas vizinhas (tese de livre-docência). USP, 1995. 100p.

SCHMITT, Renata da Silva et al. "O projeto caminhos geológicos: divulgação científica dos monumentos geológicos do estado do Rio de Janeiro”. In Congresso Brasileiro de Extensão Universitária, 2, Belo Horizonte. Anais... Belo Horizonte, 2004. 8p.

SERRA, M. V. e SERRA, M. T. "Região Metropolitana do Rio de Janeiro: expansão urbana e meio ambiental”. In —. Guia de história natural do Rio de Janeiro. Rio de Janeiro: Cidade Viva, 2012, pp. 12-4.

SILVA, Telma Mendes da. A estruturação geomorfológica do Planalto Atlântico no estado do Rio de Janeiro (tese). UFRJ, 2002.

—. "Geomorfologia do estado do Rio de Janeiro: distribuição espacial das feições morfológicas e contexto evolutivo". In BICALHO, A. M. S. e GOMES, P. C. C. (orgs.). Questóes metodológicas e novas temáticas na pesquisa geográfica. Rio de Janeiro: Publit, 2009, pp. 227-48.

— et al. "The Guanabara Bay, a Giant Body of Water Surrounded by Mountains in the Rio de Janeiro Metropolitan Area”. In VIEIRA, B. C. et al. (orgs.). Landscapes and Landsforms of BrazilWorld Geomorphological Landscapes. Nova Iorque/Londres, primavera de 2015, pp. 389-99.

TUPINAMBÁ, Miguel et al. "Evolução tectônica e magmática da faixa ribeira entre o Neoproterozoico e o Paleozoico Inferior na Região Serrana do estado do Rio de Janeiro, Brasil”, Anuário do Instituto de Geociências, UFRJ, 2012, vv. 35-2, pp. 140-51. 


\section{Uma visão integrada dos impactos ambientais no estado do Rio de Janeiro}

Tereza Coni Aguiar

\section{Introdução}

0 estado do Rio de Janeiro apresenta uma grande variedade de ecossistemas e de paisagens. No entanto, em virtude do processo de ocupação em seu território, iniciado no século XVI, vem sofrendo perdas significativas em seu ambiente natural, além do risco de degradação ambiental. Observa-se que, ao longo de sua formação socioespacial, as atividades ligadas à agricultura, à pecuária, ao extrativismo, ao turismo e à indústria, além da urbanização, expandiram-se pelo território fluminense sem levar em conta a preservação de seus recursos naturais (Galvão, 2009). Houve também uma grande concentração econômica, populacional, espacial e decisória na região metropolitana, especialmente em seu núcleo, a cidade do Rio de Janeiro, o que resultou na fraca articulação entre as diversas regiōes fluminenses (Abreu, 1987; Ribeiro e O’Neil, 2012).

Recentemente, o estado vem passando por inúmeras transformações em sua estrutura produtiva, em função da maior inserção na economia global. As atividades implantadas são conduzidas por empresas e/ou interesses multinacionais, trazendo mudanças significativas ao espaço fluminense. Essa etapa da economia fluminense, em função da nova globalização, caracteriza-se pelo fortalecimento das empresas privadas e o enfraquecimento de iniciativas governamentais em diversos níveis; por mudanças em sua estrutura produtiva e no território, trazidas pelos investimentos externos, nos diferentes setores econômicos, muitos deles relacionados à implantação de projetos de grande porte. O setor de petróleo foi um dos principais atores dessa inflexão econômica, ocorrida a partir da década de 1990 e impulsionada pela Lei $\mathrm{n}^{\mathrm{o}} .9 .478 / 97$, que atraiu numerosas empresas multinacionais ligadas ao petróleo. A fase de exploração do pré-sal, iniciada em meados da década de 2010, veio fortalecer ainda mais o setor de petróleo no ERJ.

\footnotetext{
1 Doutora em Geografia (UFF, 2012).
} 
As atividades ligadas ao petróleo atraíram empresas prestadoras de serviços, aumentaram a circulação de bens e pessoas, elevaram o fluxo migratório e ativaram os setores de construção civil e do mercado imobiliário. Essas atividades não apenas se mostraram fundamentais para a reestruturação econômica e produtiva das regiōes de exploração do petróleo, como o Norte fluminense, como também contribuíram, efetivamente, para alavancar o crescimento econômico e a vida urbana em outras áreas. Tornaram-se, pois, um fator importante no estímulo de novos investimentos nos diversos setores da economia e nas demais regióes do estado.

$\mathrm{Na}$ atualidade, a análise do território fluminense sob o ponto de vista ambiental torna-se oportuna por tornar possível avaliar ações que conduzem a alterações significativas na geografia do estado. Essas ações têm provocado intensa mobilidade espacial da população, modificações na paisagem, em seu uso e suas funçôes, além de gerar problemas ambientais com impacto em diversos recursos naturais, bem como no patrimônio natural e cultural. Também geram conflito ambiental nas diversas regiões em que se localizam (Ribeiro e O’Neill, 2012).

Os problemas ambientais verificados nas diferentes áreas do território fluminense também estão associados à expansão metropolitana, aos setores turístico e imobiliário, à indústria pesada, bem como à sua integração à logística de transporte global. Os locais em que essas atividades ocorrem são os mais afetados pelo contexto de reestruturação produtiva na fase de globalização avançada.

Neste artigo, o interesse se volta para uma visão integrada desses problemas e impactos ambientais, suas possíveis consequências e as possibilidades de se pensarem formas de minimizá-las.

\section{Visão conceitual e metodologia}

As questōes ambientais da atualidade empregam um número consideravelmente amplo de conceitos nas mais diversas situaçóes encontradas. Entretanto, com o propósito de colaborar para a compreensão de um conjunto de problemas relativos ao meio ambiente, num tempo e num espaço determinados, torna-se fundamental aplicar maior precisão nos respectivos enunciados. Assim, este artigo busca, inicialmente, apresentar os principais conceitos que se articulam para melhor compreender a problemática ambiental no território fluminense, especialmente nas três últimas décadas.

Muitos estudos fazem referência a uma visão integrada, buscando entender as relações existentes entre os elementos da natureza e da sociedade entre si e no conjunto. Em outras palavras, traça-se uma abordagem que conecte as diferentes formas de utilização do território, os recursos naturais e os elementos físicos. Essa visão ampla é fundamental para a compreensão dos problemas, impactos e conflitos, bem como para a busca de soluções e políticas adequadas. Uma visão limitada, que discuta apenas os processos de modo isolado, é uma das principais causas para a persistência de problemas (Tucci, 2001). Entretanto, "muitas pesquisas ainda analisam, de forma fragmentada e dissociada, os elementos da natureza e os da sociedade, esquecendo-se de que o homem não vive isolado, mas em sociedade, e interage continuamente com todos os elementos da natureza” (Aguiar, 2014, p. 117). Portanto, a adoção de um foco integrado permite que a análise do ambiente colabore para a reflexão de prováveis cenários, pensando-se em estratégias de médio e longo prazos, com vistas a não agravar a situação encontrada. 
Outro aspecto relevante que a avaliação integrada possibilita é a articulação dos problemas, impactos e conflitos em seu respectivo contexto. O espaço geográfico - chave para se compreender o que se passa na sociedade globalizada - vai-se desvendando pelo entrelaçamento do contexto, dos problemas, dos impactos e dos conflitos em que as dimensões da natureza e da sociedade estão em contínuo inter-relacionamento.

Os problemas ambientais não são fenômenos recentes; acompanham a humanidade desde a Idade do Bronze, ou seja, desde 3.000 a.C. (Chew, 2001). No entanto, o que sobressai na atualidade é a proporção com que atingem, em termos espaciais, os diversos elementos da natureza e da sociedade que os envolvem.

Um problema ambiental pode ser considerado a partir da ausência de determinadas condições no ambiente físico ou na sociedade que venham a afetar a qualidade de vida e do ambiente. Porém, segundo Bolea (1977, p. 13), "diz-se que há um impacto ambiental quando uma ação ou atividade produz uma alteração no meio ou em algum dos seus componentes".

Com o avanço da tomada de consciência em relação ao meio ambiente, proporcionada, principalmente, pelos inúmeros desastres ambientais e por importantes conferências mundiais sobre o meio ambiente, desde Estocolmo, em 1972, cresceu a consciência acerca da necessidade de se ter maior conhecimento sobre os impactos, interessando saber a dimensão alcançada e a intensidade das ações humanas provocadas pelas atividades econômicas (Christofoletti, 1997).

A Resolução no 1, de 23 de janeiro de 1986, do Conselho Nacional do Meio Ambiente (Conama), define impacto ambiental como "qualquer alteração das propriedades físicas, químicas e biológicas do meio ambiente, causada por qualquer forma de matéria ou energia resultante de atividades humanas" (Brasil, 2008). A geógrafa Susan Parker, em The Encyclopaedic Dictionary of Physical Geography (apud Christofoletti, 1997, pp. 131-2), o define como "a mudança sensível, positiva ou negativa, nas condiçôes de saúde e bem-estar das pessoas e na estabilidade dos ecossistemas da qual depende a sobrevivência humana". Segundo Coelho (2001, p. 24), impacto ambiental é, portanto,

\begin{abstract}
o processo de mudanças sociais e ecológicas causado por perturbações (uma nova ocupação e/ou construção de um objeto novo: uma usina, uma estrada ou uma indústria) no ambiente. Diz respeito ainda à evolução conjunta das condições sociais e ecológicas estimulada pelos impulsos das relações entre forças externas e internas à unidade espacial e ecológica, histórica ou socialmente determinada. É a relação entre sociedade e natureza que se transforma diferencial e dinamicamente. Os impactos ambientais são escritos no tempo e incidem diferecialmente, alterando as estruturas das classes sociais e reestruturando o espaço.
\end{abstract}

$\mathrm{Na}$ fase atual da globalização, quando se procura avaliar os impactos ambientais, depara-se com a complexidade advinda da dificuldade de se separar o impacto no ambiente físico do impacto causado à sociedade (Coelho, 2001). Na realidade, os impactos alteram mutuamente as condiçöes naturais, culturais, sociais, econômicas e históricas. Considera-se, portanto, impacto ambiental o resultado de um processo de mudanças causadas no ambiente, em determinada área e por determinado tempo, provocadas por pertubaçōes ou interferências concretas, advindas de novas atividades e ocupações. Com frequência, essas transformações levam a perdas da identidade, do mundo simbólico e das re- 
laçôes sociais afetivas. Dessa maneira, os impactos podem interferir, de forma direta ou indireta, no meio ambiente como um todo ou tão somente em um ou mais elementos da natureza ou da sociedade.

Em virtude da diversidade de ambientes e formas de ocupação, procura-se considerar, ao se estudarem os impactos, as singularidades presentes, levando-se em conta aspectos como: localização, distância dos centros, crescimento populacional, densidade demográfica, atividades predominantes, classes sociais envolvidas, características topográficas, geológicas e da vegetação, entre outros (Aguiar, 2012). Por conseguinte, o estudo do impacto ambiental deve comprometer-se com a análise dessas particularidades, buscando-se o respectivo grau de gravidade.

No que concerne à elaboração de diagnósticos e estudos ambientais, é possível afirmar que a questão dos conflitos nem sempre é identificada e bem avaliada (Agra Filho, 2008). Esse conceito merece maior atenção, pois houve poucos avanços teórico-metodológicos nesse quesito (Bredariol, 2001). Os conflitos ambientais podem ser definidos como decorrentes das formas de relação entre dois ou mais segmentos sociais que apresentam interesses incompatíveis, no uso ou na apropriação de determinado recurso natural, vindo ou não a gerar impacto na natureza (Aguiar, 2012; Cunha, 2003; IBGE, 1997). Embora os conflitos prevaleçam entre atividades econômicas, também ocorrem entre grupos distintos da população e entre a população e determinadas atividades e/ou empreendimentos.

Quando nos voltamos para os efeitos da urbanização sobre o meio ambiente, percebemos ainda a "ausência de uma teoria dos processos ambientais integradora das dimensões físicas, político-sociais, socioculturais e espaciais" (Coelho, 2001, p. 21). De fato, as questôes relacionadas ao ambiente construído das cidades estão longe de ser equacionadas tão somente pelo emprego de metodologias relativas aos diagnósticos geoambientais baseados no levantamento de características físiográficas, potencialidades, vulnerabilidades, estabilidades e usos. Nos estudos ambientais urbanos, não é possível neglicenciar as condições físicas ou as complexas condições socioeconômicas que interagem nas cidades. Concorda-se com Chew (2001) quando ele afirma que a urbanização, ao utilizar intensamente os recursos naturais, conduziu a alteraçôes tanto no entorno imediato quanto nas áreas mais remotas. Com frequência, os espaços nas cidades foram utilizados sem o devido respeito às suas características físicas. Esse uso inadequado causou sérios problemas, como, por exemplo, a alteração da paisagem, enchentes, deslizamento de terras e até mesmo a proliferação de vetores de doenças. A urbanização ainda esteve associada, nas diversas civilizaçóes, ao desmatamento, ao desequilíbrio hídrico e à poluição do ar e das águas dos rios (Aguiar, 2014).

Os estudos que abarcam os problemas, impactos e conflitos ambientais na atualidade, quando os processos de globalização estão intensificados, devem ser avaliados levando-se em conta determinados fatores, como extensão, ritmo, número de elementos envolvidos, capacidade de gerar problemas, gravidade que assumem em relação ao contexto e número de pessoas afetadas, entre outros. Tal exame pode conduzir ao entendimento de fenômenos de alta gravidade, cujas consequências são imprevisíveis, podendo ser definidos como um processo de degradação ambiental. O conceito de degradação ambiental, apoiado na concepção de Chew (2001), pode ser entendido como

a consequência do modo como as civilizações interagem com o meio natural em função da forma como estão organizadas as diversas atividades econômicas e seus modos de vida. O nível intensivo do uso dos recursos naturais, o estilo de vida, o consumo excessivo e extravagante, como ocorreu em diversas civilizações, podem ocasionar o que ele denominou de stress ecológico. [...] O desastre ambiental, ao 
atingir esse nível, pode interferir na capacidade reprodutiva de determinada civilização, ocasionando o seu declínio e a sua decadência (Aguiar, 2014, p. 116).

Chew (2001) atribui ainda a degradação principalmente aos processos de acumulação de capital e de urbanização, bem como ao intenso crescimento demográfico, com o aumento da população de forma exponencial. Esses três fenômenos foram reponsáveis por grandes perdas do ponto de vista ecológico, notadamente o desmatamento e a transformação física da paisagem (idem, ibidem). A degradação ambiental ocorre em situações-limite, quando vários elementos da natureza são impactados, abrangendo o ambiente como um todo.

Entende-se que a degradação ambiental tem uma dinâmica própria e uma evolução de acordo com as características locais, sendo causada por um conjunto de fatores que se relacionam de forma sistêmica (Nascimento, 2013). A degradação é um processo complexo que está associado a formas inadequadas de manejo da terra, à erosão dos solos, às mudanças climáticas, a grandes extensões desflorestadas e à urbanização. Nascimento também enfatiza que as atividades econômicas é que causam impacto e conduzem à degradação. Nas áreas tropicais, por exemplo, a desestabilização do ambiente pode desencadear ou até mesmo acirrar vários problemas, como intemperismo, lixiviação dos solos, instabilidade das encostas e degradação ambiental generalizada (idem, ibidem).

Para a identificação e a compreensão dos impactos e conflitos ambientais no estado do Rio de Janeiro, conta-se com um acervo de pesquisas, estudos e relatórios elaborados pelo meio acadêmico, por órgãos públicos e ONGs, na última década, documentos que contribuíram para o melhor entendimento dos processos que se encontram em curso no território fluminense. Além desse vasto material bibliográfico, contou-se, para a elaboração deste artigo, com informações oficiais, dados e várias reportagens de jornais e revistas pertencentes ao arquivo da autora. Conta-se também com pesquisas realizadas pela própria em diferentes áreas do estado do Rio de Janeiro.

Para a análise da distribuição espacial do impacto ambiental, optou-se pela divisão regional do estado do Rio de Janeiro tal como adotada pela Lei Estadual no 1.227/87. Desde então, esse recorte regional passou por algumas alterações quanto à denominação e à sua composição (Ceperj, 2014). As chamadas regiōes de governo, com seus respectivos municípios, totalizam oito unidades. São elas: Metropolitana, Noroeste Fluminense, Norte fluminense, Baixadas Litorâneas, Serrana, Centro-Sul Fluminense, Médio Paraíba e Costa Verde, englobando 92 municípios (Quadro 1).

Quadro 1. Regiōes de governo, municípios e população do estado do Rio de Janeiro

\begin{tabular}{|l|l|}
\hline $\begin{array}{l}\text { Regiōes/ } \\
\text { População 2010* }\end{array}$ & Municípios \\
\hline $\begin{array}{l}\text { Metropolitana } \\
11.945 .532 \text { hab. }\end{array}$ & $\begin{array}{l}\text { Cachoeiras de Macacu, Rio Bonito, Itaguaí, Seropédica, Rio de Janeiro, Nilópolis, Quei- } \\
\text { mados, Japeri, Paracambi, Nova Iguaçu, Belford Roxo, São João de Meriti, Duque de } \\
\text { Caxias, Magé, Guapimirim, Itaboraí, Tanguá, Maricá, Mesquita, Niterói e São Gonçalo }\end{array}$ \\
\hline $\begin{array}{l}\text { Noroeste Fluminense } \\
317.493 \text { hab. }\end{array}$ & $\begin{array}{l}\text { Varre-Sai, Porciúncula, Natividade, Laje do Muriaé, Itaperuna, Bom Jesus de Itabapo- } \\
\text { ana, São José de Ubá, Miracema, Santo Antônio de Pádua, Aperibé, Itaocara, Cambuci } \\
\text { e Italva }\end{array}$ \\
\hline
\end{tabular}




\begin{tabular}{|c|c|}
\hline $\begin{array}{l}\text { Regióes/ } \\
\text { População 2010* }\end{array}$ & Municípios \\
\hline $\begin{array}{l}\text { Norte Fluminense } \\
849.515 \text { hab. }\end{array}$ & $\begin{array}{l}\text { São Francisco de Itabapoana, Cardoso Moreira, São Fidélis, Campos dos Goytacazes, São } \\
\text { João da Barra, Quissamã, Conceição de Macabu, Carapebus e Macaé }\end{array}$ \\
\hline $\begin{array}{l}\text { Baixadas Litorâneas } \\
700.842 \text { hab. }\end{array}$ & $\begin{array}{l}\text { Rio das Ostras, Casimiro de Abreu, Silva Jardim, Cabo Frio, Araruama, Saquarema, São } \\
\text { Pedro da Aldeia, Iguaba Grande, Arraial do Cabo e Armação de Búzios }\end{array}$ \\
\hline $\begin{array}{l}\text { Serrana } \\
805.627 \text { hab. }\end{array}$ & $\begin{array}{l}\text { Carmo, Cantagalo, São Sebastião do Alto, Santa Maria de Madalena, Duas Barras, Cor- } \\
\text { deiro, Macuco, Sumidouro, Bom Jardim, Trajano de Morais, Nova Friburgo, Teresópolis, } \\
\text { Petrópolis e São José do Vale do Rio Preto }\end{array}$ \\
\hline $\begin{array}{l}\text { Centro-Sul Fluminense } \\
272.227 \text { hab. }\end{array}$ & $\begin{array}{l}\text { Comendador Levy Gasparian, Paraíba do Sul, Vassouras, Engenheiro Paulo de Frontin, } \\
\text { Miguel Pereira, Paty de Alferes, Três Rios, Areal, Sapucaia e Mendes }\end{array}$ \\
\hline $\begin{array}{l}\text { Costa Verde } \\
243.500\end{array}$ & Paraty, Angra dos Reis e Mangaratiba \\
\hline $\begin{array}{l}\text { Médio Paraíba } \\
855.193\end{array}$ & $\begin{array}{l}\text { Barra do Piraí, Barra Mansa, Itatiaia, Pinheiral, Piraí, Porto Real, Quatis, Resende, Rio } \\
\text { Claro, Rio das Flores, Valença e Volta Redonda }\end{array}$ \\
\hline
\end{tabular}

Fonte: Ceperj, 2014; IBGE, Cidades, 2010.

\section{Contexto e distribuição espacial dos impactos ambientais}

Nesta seção, apresenta-se a distribuição dos impactos, problemas e conflitos, bem como o contexto em que ocorrem, levando-se em conta a análise integrada segundo as regiōes de governo. A relação com o contexto torna-se relevante para colaborar com o entendimento das singularidades e dar sentido à problemática identificada.

\subsection{Região Metropolitana Fluminense}

O perfil metropolitano de concentração populacional afirmou-se no passado remoto e eclodiu dos anos 1940 em diante, atraindo um grande fluxo de migrantes, predominantemente nordestinos. Essa concentração metropolitana culminou nos anos 1960, consolidando-se nas décadas seguintes (Galvão, 2009; Ribeiro e O’Neill, 2012;). Em 2010, a Região Metropolitana fluminense contava com um contingente populacional de 11.945.532 habitantes (IBGE, 2010).

Seus principais problemas ambientais, relacionados ao intenso processo de metropolização, estão associados à proliferação de loteamentos sem infraestrutura, falta de saneamento e de destinação adequada do lixo, precariedade dos transportes públicos, baixo nível de renda e de escolaridade da população. Nas áreas de baixadas, verificam-se, com frequência, enchentes e inundaçôes nos períodos chuvosos (Costa, 2001).

No entorno da Baía de Guanabara, coexistem diferentes usos e ocupaçôes: usos residenciais, intensa urbanização, eixos viários, diversas indústrias, refinarias, atividades comerciais e de serviços. Em suas margens, encontra-se o núcleo metropolitano - a cidade do Rio de Janeiro. No seu espelho d'água, circulam transatlânticos e embarcaçôes de pescadores artesanais, bem como aquelas que dão apoio às atividades de extração de petróleo, desenvolvidas principalmente na bacia de Campos. 
Todas as funçōes citadas vêm contribuindo para a ocorrência de inúmeros impactos na Baía de Guanabara, tais como: lançamento de esgoto sanitário sem tratamento e de lixo de todo tipo, com origem nos afluentes da baía ou jogados diretamente no espelho d'água; óleo das embarcaçōes; aterro em suas margens; e retirada de manguezais. As atividades existentes, somadas com aquelas que se estão instalando em suas bordas, em função da nova lógica econômica, vêm afetando, de forma drástica, as atividades de pesca artesanal.

A instalação do Complexo Petroquímico do Rio de Janeiro (Comperj) no município de Itaboraí teve início em 2008, sendo considerado o maior empreendimento da Petrobras e um dos maiores do mundo, envolvendo a instalação de várias indústrias (Secretaria de Estado do Ambiente, 2015). ${ }^{2}$ Com essa construção, novos problemas emergiram na porção leste do núcleo metropolitano, potencializando os problemas já existentes no entorno da baía. Nessa área, chama-se também a atenção para as alterações vindouras no município de Maricá, em função da especulação imobiliária e dos inúmeros empreendimentos previstos (Prefeitura de Maricá, 2016).

O emissário submarino do Comperj, cujas obras estão em fase final, transportará os dejetos químicos provenientes do Complexo Petroquímico, em Itaboraí, lançando-os a dois quilômetros da praia de Itaipuaçu. Ainda haverá outro emissário para efluentes, de construção polêmica e cujo duto também passa por Maricá (Prefeitura de Maricá, 2016).

O processo de licenciamento dos diferentes empreendimentos que integram o Comperj identificou um conjunto de impactos que atingem diversos elementos do ambiente físico e daquele relacionado à sociedade, provocando acentuada alteração na paisagem, intenso fluxo migratório para a área e expansão urbana (Secretaria de Estado do Ambiente, 2015).

O Arco Metropolitano é outro grande projeto levado a efeito nessa porção do território fluminense, ligando o Comperj ao Porto de Itaguaí e passando pelos municípios de Duque de Caxias, Nova Iguaçu, Japeri, Seropédica, Magé, Guapimirim e Queimados. Esse trajeto oferece a vantagem de reduzir os custos de transporte ao encurtar distâncias, o que beneficia a cidade do Rio de Janeiro, por desviar os impactos do fluxo de transporte de cargas. Sua construção impactou quatro unidades de conservação de uso sustentável: a Flona Mário Xavier, a APA Rio D’Ouro, a APA Retiro e a APA do Guandu. Entretanto, alguns estudos apontam para seu potencial em termos de crescimento econômico, considerando esse o projeto viário mais importante para o estado do Rio de Janeiro. Sua implantação é avaliada como um fator favorável ao estabelecimento de indústrias, notadamente aquelas ligadas às atividades de petróleo e gás. Faz parte, portanto, das iniciativas de logística de inserção do Porto de Itaguaí e demais empreendimentos (Secretaria do Estado do Ambiente, 2015).

Sua construção, contudo, gerou um número elevado de impactos à natureza e à sociedade. A referida rodovia também corta numerosas áreas de baixa ocupação e com vazios urbanos. Essas áreas merecem especial atenção, pois podem atrair intenso fluxo de população, tornando-se, assim, vulnerável a ocupaçōes desordenadas (Secretaria de Estado do Ambiente, 2015).

Na porção oeste da Regiáo Metropolitana fluminense, outro grande empreendimento - o Porto de Itaguaí - vem atraindo um grande fluxo de população e novas atividades, provocando um novo surto de crescimento nesse município e nas adjacências. O Porto de Itaguaí vem-se destacando em

2 Este estudo compõe o Projeto ZEE/RJ, que foi elaborado pelo Consórcio Cobrape-Oikos, coordenado pela Secretaria de Estado e Ambiente (SEA). 
importância, sendo considerado um dos mais modernos da América Latina e o primeiro concentrador de cargas do Atlântico Sul (Unacoop, 2011). No município de Itaguaí, também estão em desenvolvimento vários projetos, dentre os quais o que envolve a Petrobras, a Companhia Siderúrgica Nacional $(\mathrm{CSN})$ e a Gerdau, prevendo a construção de um porto compartilhado, no qual se instalará o apoio à exploração do pré-sal (idem, ibidem).

Seropédica é outro município que integra essa região de governo e que tem, na produção de areia para a construção civil, especialmente no rio Guandu, importante atividade. No entanto, nesse município, ocorrem inúmeros casos de extração ilegal. Embora seja uma atividade que assume grande relevância econômica, abastecendo $70 \%$ da construção civil da Região Metropolitana, nem sempre é realizada com respeito às as leis do licenciamento ambiental, que incluem as condicionantes e um plano de recuperação. Entre os problemas ambientais causados por essa atividade, verificam-se impacto visual, assoreamento dos rios e abandono dos terrenos (crateras), deixando para trás um grande passivo ambiental. A retirada de areia, realizada por dragas, interfere diretamente no fluxo de água subterrâneo (Marques, 2006), podendo atingir o lençol freático (aquífero Paranaense) e dando origem a grandes lagoas. Pesquisas realizadas na área ressaltam que essa ação representa um grave problema ambiental, pois os aquíferos, ao serem atingidos, afetam a bacia do rio Guandu, fonte de abastecimento de água do Grande Rio (Tubbs et al., 2011). Essa questão chama a atenção também pela capacidade de gerar conflitos graves, pois as atividades relacionadas à extração de areia, praticadas em um número considerável de rios, geram impactos ambientais que conflitam com as atividades agrícolas desenvolvidas nesse município (Unacoop, 2011).

Outra questão que se deve considerar diz respeito ao lixão de Gramacho, situado no município de Duque de Caxias e que recebeu, durante 35 anos, o lixo da cidade do Rio de Janeiro e dos municípios vizinhos. Considerada uma área de grande impacto, com a formação de chorume, originado da decomposição do lixo depositado, constituiu-se, durantes muitos anos, em um grande causador da poluição da Baía de Guanabara. Em 2012, procedeu-se à transferência do lixão de Gramacho para o Centro de Tratamento de Resíduos, em Seropédica, e à recuperação da área, transformando-se o lixão em um aterro com o reaproveitamento do gás e atuando em um longo processo de eliminação do chorume (Ribeiro, 2016).

\subsection{Região do Médio Paraíba}

A região do Médio Paraíba, área do eixo Rio-São Paulo, apresenta intenso fluxo de mercadorias e de pessoas, com a dinâmica econômica vinculada à expansão industrial, destacando-se as indústrias automobilística e siderúrgica. Inclui-se entre as áreas que receberão o maior número de empreendimentos no estado do Rio de Janeiro. Conta ainda com vários projetos de grande porte, em fase de implantação, ligados principalmente à indústria automobilística. Seus problemas ambientais estão relacionados ao desmatamento, à poluição dos rios e à expansão de periferias urbanas, além de pressão sobre o patrimônio natural: o Parque Nacional de Itatiaia. Em Volta Redonda, há graves problemas decorrentes do despejo em grande quantidade de lixo químico, contaminando o solo e o lençol freático.

Em Volta Redonda, um estudo que teve por objetivo analisar a vulnerabilidade da região e os riscos ambientais envolvidos no que diz respeito ao sistema de drenagem, mostrou as alterações ocorridas na rede de drenagem, os processos erosivos e suas implicações nas enchentes havidas (Castro e Peixoto, 2015). A pesquisa concluiu que os processos erosivos e os movimentos de massa são importantes, mas 
confirmou a situação de risco ambiental nesse município. Tais riscos, associados a obras e intervençōes urbanas "que, em princípio, organizariam novos espaços, potencializam os impactos existentes, além de criar novos" (Castro e Peixoto, 2015, p. 192). Levou-se em conta também que os efluentes domésticos e industriais apresentam situaçôes de risco ambiental para a população da referida cidade.

\subsection{Região das Baixadas Litorâneas}

A área do conjunto das Baixadas Litorâneas se destaca pela expansão do setor de turismo e lazer, assim como o de segunda residência, recebendo também os impactos provenientes das açóes ligadas ao setor de petróleo. Nas últimas décadas, apresentou intenso crescimento populacional, observando-se um grande descompasso entre a demanda e a oferta de serviços públicos.

Seus principais problemas ambientais dizem respeito à ocupação desordenada e ao uso inadequado em ambientes considerados frágeis, como manguezais, praias, costōes e restingas. O município de Rio das Ostras vem sofrendo intenso processo de erosão em sua linha de costa, o que altera sobremaneira a praia, derruba árvores e destrói edificaçōes, conforme se observa na Figura 1.

Outro elemento importante está relacionado ao impacto nos ambientes marinhos, com a ocorrência de desastres ambientais que têm origem nos vazamentos de óleo nas atividades de exploração de petróleo. Em novembro de 2011 e março de 2012, verificou-se um vazamento de óleo causado pela empresa Chevron, ocorrido em uma sonda de perfuração em Campo de Frade, na bacia de Campos (Nitahara, 2013).

Figura 1. Processos erosivos na linha da costa desmatando e destruindo as edificaçôes: Rio das Ostras
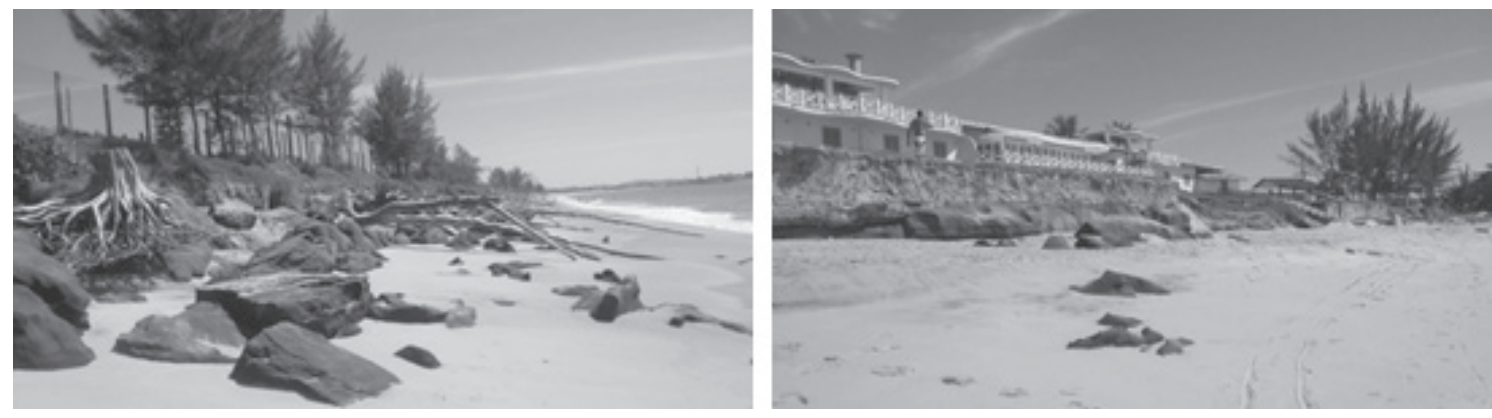

Fonte: Arquivo pessoal da autora, fevereiro de 2016.

A BR-101 é uma das mais importantes rodovias federais do país, cortando praticamente todo o litoral brasileiro. Por atender a importantes centros e áreas econômicas, gera intenso fluxo de bens e mercadorias. Essa rodovia pode ser considerada um eixo de grande impacto, causado pelos inúmeros acidentes envolvendo mortes e longos engarrafamentos. Embora atendendo às áreas mais importantes do país na produção de petróleo e nas atividades turísticas, com relevante papel socioeconômico, só recentemente vem sendo finalizada sua duplicação (Figura 2). 
Figura 2. BR 101: engarrafamento em Rio das Ostras e duplicação em Rio Bonito
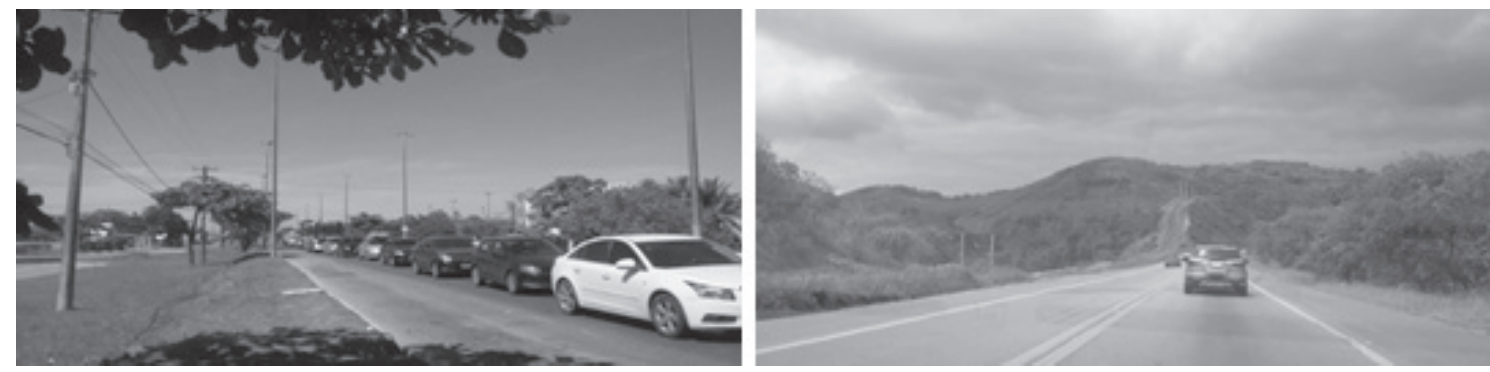

Fonte: Aquivo pessoal da autora, fevereiro de 2016.

\subsection{Região Centro-Sul Fluminense}

A região que compreende o Centro-Sul Fluminense sofreu, durante anos, as consequências da decadência da produção de café. Atualmente, sua economia se baseia nas atividades agropastoris tradicionais, renovadas pelas atividades turísticas fundamentadas em seu patrimônio histórico e cultural, oriundas da cafeicultura.

Três Rios é um importante centro regional, enquanto Vassouras se destaca como centro educacional de expressão nacional. A construção da usina hidroelétrica de Simplício no município de Três Rios é responsável pelo maior impacto ambiental nessa região. O município de Paty do Alferes vem-se destacando pela produção de tomates, embora o uso intensivo e sem controle dos agrotóxicos seja motivo de preocupação.

Nessa área, verifica-se uma perda muito grande da vegetação natural, encontrando-se predomínio das pastagens ralas, muito sujeitas a queimadas nas épocas de seca, e ocorrendo diminuição dos corpos hídricos (Secretaria de Estado do Ambiente, 2011). Essa questão motivou a criação, no município de Vassouras, do projeto "Cadê a Água de Andrade Costa?", desenvolvido pela ONG Vale Verdejante, com o apoio da Assessoria e Planejamento para o Desenvolvimento (Asplande), em face do risco de se extinguirem algumas nascentes e de diminuírem as águas desses córregos. Essa questão assume relevância pelo fato de muitas nascentes e pequenos rios dessa porção do território fluminense serem contribuintes de afluentes maiores do Paraíba do Sul. A caracterização da área no referido projeto destaca esse problema, conforme se observa no seguinte excerto:

Relatos na área relembram que no passado o córrego de Andrade Costa fluía com mais água do que hoje, propiciando banhos em cachoeiras e alagados. Comumente, mesmo na época de chuvas, o volume do córrego não é comparável em volume ao que existia antigamente. Concluímos que, apesar de ser um córrego de expressão local, assume um papel diferenciado, pois é um contribuinte de um dos afluentes do rio Paraíba do Sul integrando-se, desta maneira, a uma bacia hidrográfica de relevância regional e estadual (Asplande e Vale Verdejante, 2014).

O relatório também comprovou que o pequeno núcleo urbano de Andrade Costa, com uma população em torno de 1 mil habitantes, não conta com um sistema adequado de esgotamento sanitário, 
o que prejudica a qualidade de vida da população. O conjunto de problemas ambientais encontrados nessa pequena localidade levou a uma situação crítica, em face de eventuais consequências imprevisíveis (Asplande e Vale Verdejante, 2014).

Figura 3. Andrade Costa - Pastagem com capim ralo/queimadas na estação seca. Rodovia RJ-131, solos erodidos, com a formação de voçorocas

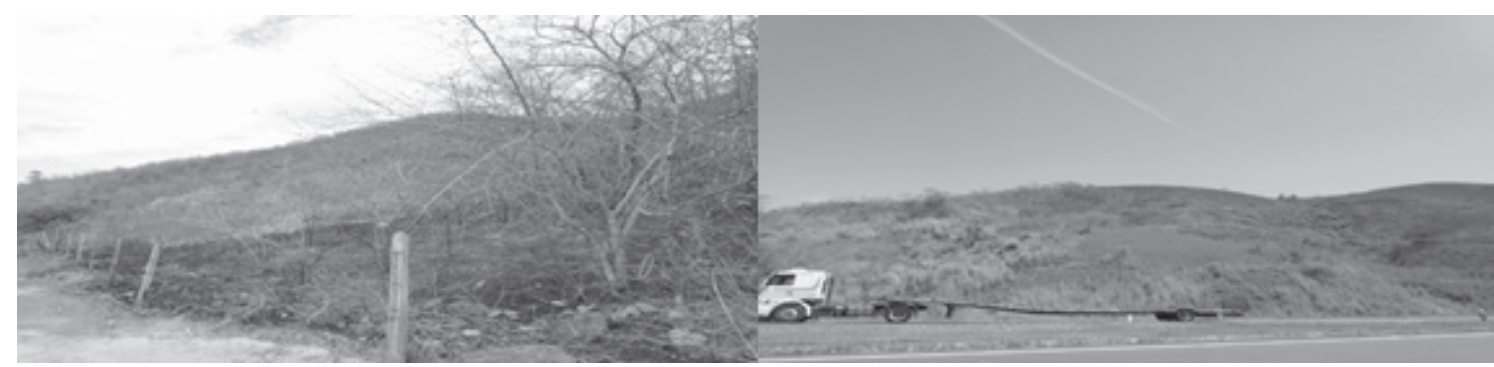

Fonte: Arquivo pessoal da autora, setembro de 2014.

Outra questão relevante diz respeito ao rio Paraíba do Sul, que margeia o território nas regiōes do Médio Paraíba, Centro-Sul, Noroeste e Norte fluminenses, e sofre outros impactos além dos citados, decorrentes do lançamento de esgoto doméstico das cidades ribeirinhas e de várias indústrias. $\mathrm{O}$ efeito desses danos repercute na poluição de suas águas, com a mortandade de peixes e a diminuição da atividade de pesca artesanal. Não menos graves são as alterações verificadas em seu curso e em sua foz.

\subsection{Região da Costa Verde}

O litoral sul do estado, denominado Regiáo da Costa Verde, é uma área que tem passado por transformações decorrentes da expansão dos setores turístico e imobiliário, da implantação de grandes indústrias e das atividades ligadas à logística de transporte global, com a expansão portuária e a construção da Usina Nuclear de Angra 3 (Zuleika, 2012).

Nessa região, há previsão de um grande aporte de recursos financeiros para atender à implantação de inúmeros projetos (Secretaria de Estado do Ambiente, 2015). Entretanto, tais empreendimentos envolvem muitos impactos ambientais e conflitos com as populaçôs tradicionais e as atividades econômicas. Para se ter uma ideia da magnitude dos problemas ambientais que afetam essa área, pode-se citar a lista de impactos relacionados à "Fase de Implantação e Operação de Angra 3", conforme apresentada pela Eletronuclear no processo de licenciamento. $\mathrm{O}$ referido estudo chama a atenção ainda para o raio de ação dos impactos de Angra 3 e para sua proximidade com o Núcleo Metropolitano, área mais densamente ocupada do estado do Rio de Janeiro (Zuleika, 2012).

As instalaçôes termonucleares são empreendimentos polêmicos que devem ser considerados com muito cuidado, por apresentarem impacto elevado e de alto risco. Por essa razão, há exigência legal de planos de evacuação na hipótese de ocorrência de acidentes nucleares. Essa é outra grande 
preocupação na região, devido às dificuldades de acesso, em função da logística da área, que conta com a Rodovia Rio-Santos como único eixo de circulação (Aguiar, 2013; Unacoop, 2011).

A Costa Verde destaca-se ainda pelo aumento da relevância das atividades turísticas, hoje sobressaindo-se no ERJ pela presença de muitos hotéis de luxo, estabelecimentos que atraem turistas de várias áreas do território nacional e do exterior. Apesar dos benefícios que a atividade proporciona em termos de emprego e de renda, deve-se observar que a implantação do turismo está associada a conflitos de uso com as populações tradicionais e a impactos relacionados a aterros nos manguezais, desmatamento, privatização da orla e pressão sobre os serviços urbanos, mais precisamente nos locais em que o fluxo turístico é mais elevado (SEA/INEA, 2015).

A região também é importante para a produção pesqueira, especialmente a pesca artesanal. Suas condições naturais são propícias a essa atividade, o que a coloca em posição de destaque no conjunto do ERJ. Contudo, os vazamentos de óleo na baía da Ilha Grande causam sério impacto ambiental, especialmente à comunidade pesqueira e às populações tradicionais (Aguiar, 2013; Unacoop, 2011). Outro impacto para a atividade de pesca é a retirada de lama para aprofundar os canais que dão acesso a navios de grande calado (SEA/INEA, 2015).

Os problemas ambientais nessa área são bastante complexos. Relacionam-se à expansão de periferias com o uso inadequado do solo urbano, à falta de infraestrutura de saneamento básico, à poluição de baías e à redução de espécies de peixe (Motta, 2011), bem como ao desmatamento em diversas áreas e aterros em manguezais (Unacoop, 2011). Nos últimos anos, a área por sérios problemas de deslizamentos de terra no município de Angra dos Reis, prejudicando um grande número pessoas e atividades (Aguiar, 2013; SEA/INEA, 2015).

A expansão das atividades econômicas provoca ainda prejuízo às comunidades tradicionais, incluindo quilombolas, indígenas, caiçaras e agricultores familiares, levando à perda de suas terras, a conflitos e à alteração de seu modo de vida. O risco de as práticas dessas comunidades se extinguirem é muito grave, pois equivaleria a se perder grande parte dos conhecimentos que dominam, especialmente aqueles relacionados ao meio ambiente. A permanência dessas comunidades tradicionais colabora e garante a sustentabilidade, melhorando o equilíbrio entre as atividades desenvolvidas no conjunto da regiāo (Aguiar, 2013; Unacoop, 2011).

\subsection{Região Noroeste Fluminense}

A antiga área de produção cafeeira, situada na Região Noroeste Fluminense, parece ainda ressentir-se do processo de erradicação dos cafezais. Além da baixa renda de sua população, apresenta problemas de enchentes, inundações e degradação dos solos (Costa, 2001). Em 2003, verificou-se um desastre ambiental de grande proporção, proveniente do derramamento de mais de 1 bilhão de litros de resíduos tóxicos de uma indústria em Cataguases, no rio Pomba, afluente da margem esquerda do rio Paraíba do Sul, afetando-o da confluência à foz.

O Noroeste Fluminense destaca-se na agropecuária, com ênfase para a produção leiteira, e notabiliza-se pelas atividades ligadas às rochas ornamentais (granito e mármore) que se destinam à construção civil. É o principal produtor do estado, com maior relevância para os municípios de Santo 
Antônio de Pádua, Italva e Itaperuna, que abrangem duzentas pedreiras e cem serrarias ${ }^{3}$ em atividade. Nessa região, há exploraçôes ilegais responsáveis por desmatamento e descarte de rejeitos em áreas impróprias, ocasionando impacto ao ambiente. $\mathrm{O}$ modelo de produção com baixa eficiência gera uma série de impactos ambientais: dano à saúde dos trabalhadores, problemas dos efluentes gerados nas serrarias, uso de explosivos (causando ruídos e tremores à população), alteração da paisagem e dos corpos hídricos, poluição do ar, entre outros (Silvestre et al., 2014).

\subsection{Região Norte Fluminense}

A região Norte Fluminense, considerada uma das mais problemáticas do estado do Rio de Janeiro, apresenta inúmeros problemas que advêm dos impactos provenientes das atividades relacionadas à exploração do petróleo, à implantação de grandes empreendimentos e à expansão desordenada de suas cidades. A área apresenta intenso fluxo de pessoas, bens e mercadorias, associado aos problemas de expansão urbana acelerada, como, por exemplo, a precariedade do saneamento básico e do transporte, e o uso inadequado do solo urbano.

A Região Norte Fluminense passou por um processo de modernização do setor sucroalcooleiro, mas mantém suas discrepâncias econômicas e sociais, por não ter levado essas mudanças aos demais setores de atividades da região (Prado, 2015). Contudo, ela teve seu desenvolvimento alavancado a partir dos anos 1970, graças às operaçôes da Petrobras em Macaé.

Essa região vem-se destacando pela retomada do crescimento econômico e pela implantação de vários empreendimentos associados às atividades de petróleo e gás, as quais, contudo, têm suscitado polêmica devido ao significativo impacto ambiental provocado. O Complexo Logístico Industrial Farol Barra do Furado, na divisa de Quissamã e Campos dos Goytacazes, o Complexo do Superporto do Açu, em São João da Barra, e o Terminal Portuário Offshore Canaã, no município de São Francisco do Itabapoana, são exemplos de empreendimentos formados por vários projetos previstos para a área.

Esses projetos foram os grandes responsáveis pelas rápidas transformaçôes que se desencadearam no Norte Fluminense, além de terem causado um grande número de conflitos e impactos no ambiente natural e na sociedade. Como exemplo do impacto causado por essas transformaçóes, observa-se que, com o Projeto do Porto do Açu, o município de São João da Barra passará a ter, como principais atividades, aquelas ligadas à função portuária, enquanto as atividades tradicionalmente tidas como mais importantes (agrícolas e pecuárias) não mais funcionarão como setor econômico básico. Esse projeto muita polêmica, com o questionamento e a solicitação de revisão do licenciamento ambiental (Pacheco, 2015). Prado (2015, p. 125) cita ainda os impactos sociais causados por esse projeto: "A desapropriação em São João da Barra é um nítido exemplo de ações corporativas, legitimadas pelo Estado, que negligenciaram a história dos lugares, a dimensão simbólica/afetiva das relações sociais e, principalmente, os aspectos materiais dos residentes".

3 As serrarias integram o processo de exploração de pedras ornamentais e são responsáveis pelo acabamento final das rochas. 
Prado também destaca o processo de violência que acompanhou as ações de implantação, levando inúmeras famílias a serem deslocadas de suas casas e reassentadas em outras áreas. Os impactos ambientais geram foram muitos, conforme se identifica no processo de licenciamento dos diferentes empreendimentos do Complexo do Açu (Secretaria de Estado do Ambiente, 2015). Entretanto, o projeto vem apresentando um freio em sua inserção, devido à crise na EBX, holding responsável por sua implantação (Pacheco, 2015).

Outros pontos dignos de destaque são o rápido crescimento populacional e a expansão urbana em Macaé (Ribeiro e O’Neill, 2015) como centro das atividades ligadas à exploração de petróleo, conforme se verifica no estudo realizado por Cadena (2012):

[...], o crescimento populacional gerou uma série de outras transformações na geografia macaense, como a intensificação da mobilidade espacial da população (migraçôes e mobilidade interna), os impactos ambientais de toda ordem, as mudanças em sua paisagem urbana, entre outras. A segunda transformação de destaque em Macaé se relaciona ao intenso processo de urbanização socioespacial no município. Nos últimos trinta anos, a taxa de urbanização elevou-se de $72 \%$ em 1980 para $98 \%$ em 2010. A rápida urbanização provocou sérios impactos na configuração do sítio urbano macaense, sobretudo caracterizados pelo processo de periferização da população mais pobre e pela expansão da favelização, acompanhada do vertiginoso aumento das tensões sociais e da violência urbana [...].

As demandas surgidas com as atividades de petróleo em Macaé, especialmente no que diz respeito à moradia, levaram o município a um crescimento extraordinário da população, revelado pelas maiores taxas verificadas no estado: 11,25\% entre 2000 e 2010 (Ribeiro e O’Neill, 2012).

\subsection{Região Serrana Fluminense}

A chamada Região Serrana Fluminense é uma área que se reestrutura em torno de novas organizaçôes industriais, aliando itens tradicionais e modernos, como a agricultura, o turismo, o centro de informática e a tendência às agroindústrias alimentar e têxtil, ambas apoiadas na presença de um grande mercado metropolitano próximo. As enchentes e os deslizamentos de terra ocorridos em 2011 e 2013, que configuraram um desastre ambiental de grandes proporções, foram traumáticos para a população, e as atividades econômicas da região, especialmente nos municípios de Petrópolis, Teresópolis e Friburgo, ainda se ressentem dos impactos sofridos. Além disso, desmatamento, uso inadequado do solo urbano/rural, uso intensivo de agrotóxicos, ocupação desordenada das encostas, falta de fiscalização dos órgãos públicos e desvios de recursos públicos também estão no centro das catástrofes.

Petrópolis vem ampliando, com sucesso, um centro de estudos e desenvolvimento de sistemas de informática, denominado Petropólis-Tecnópolis (Costa Jr., 2012). Essa iniciativa, baseada em empresas de tecnologia, é capaz de modificar a estrutura econômica da cidade, com a vantagem de reunir atividades com menor grau de impacto ambiental. 
No que diz respeito à agricultura desenvolvida na Região Serrana, nota-se a prática intensiva, durante todo o ano, de diversos produtos hortícolas, além da produção de frutas, muitas vezes recorrendo-se a modernos sistemas de produção. Isso envolve o uso de grande quantidade de insumos, cujos produtos químicos são avaliados como inadequados ao ambiente. Essas práticas trazem consigo o risco de poluiçãoo das águas e do solo, comprometendo também a qualidade ambiental. As características da agricultura nessas áreas apontam para a necessidade de acompanhamento e orientação técnica de práticas conservacionistas e de manejo, bem como para o controle do uso de agrotóxicos e de produtos químicos (Barros, 2015).

Igualmente, é necessário dispensar cuidados com as áreas rurais, cuja densidade populacional é elevada, com baixa infraestrutura de saneamento. Esse é o caso, por exemplo, da bacia do Rio Grande, em Friburgo, que, através de pesquisa realizada, identificou, "na maioria das sub-bacias, valores de coliformes totais e fecais acima do permitido pela legislação, o que compromete a utilização da água para o consumo humano. Esse quadro é reflexo da falta de uma rede de esgoto na área" (Barros, 2015, p. 156).

\section{Problemas ambientais decorrentes da urbanização}

O estado do Rio de Janeiro sobressai-se pelo predomínio da população urbana sobre a rural e pela elevada concentração populacional na Região Metropolitana. Destaca-se também pela maior taxa de urbanização do país, tendo em vista que $96,6 \%$ de seus habitantes vivem nas cidades, perfazendo um total de 15.446.996 pessoas (Ribeiro e O’Neill, 2015). A urbanização é considerada o processo mais relevante em termos de organização do território fluminense, sendo a metropolitanização uma de suas características principais. Entretanto, verificou-se que esse fenômeno, com tamanha dimensão, não conta com o apoio contínuo de um órgão de Estado dedicado a questôes urbanas, observando-se, nesse aspecto, uma fraca atuação em termos de políticas públicas urbanas (idem).

Não obstante, do ponto de vista ambiental, a urbanização é responsável por mudanças significativas na paisagem e no ambiente físico, bem como por um conjunto de problemas de alta gravidade no estado do Rio de Janeiro, como desmatamento, poluição de recursos hídricos, pressão sobre áreas de proteção ambiental, expansão de periferias urbanas, favelização, aterros em ambientes frágeis, falta de saneamento, poluição do ar, falta de serviços públicos, enchentes, deslizamento de terra, baixa renda da população, pobreza, desemprego, baixo nível de escolaridade, falta de fiscalização, falta de segurança e violência, entre muitos outros. Um traço marcante no crescimento das cidades fluminenses é que esse processo nem sempre veio acompanhado de bem-estar da população.

Os problemas ambientais urbanos encontram-se disseminados pelas diversas regiōes do território fluminense, associados ao crescimento das atividades econômicas em áreas urbanas e ao intenso fluxo de população oriunda das áreas rurais. As formas de construção e vivência nas cidades, especialmente naquelas de maior populaçãao e de alta densidade demográfica, como, por exemplo, na área metropolitana e nas periferias de cidades como Angra dos Reis, Macaé, Teresópolis, Petrópolis, Friburgo, Volta Redonda e Rio Bonito, entre outras, não atenderam a muitas das condições requeridas para a satisfação de suas necessidades. Outra grande preocupação no que diz respeito às cidades mais populosas do estado do Rio de Janeiro é o abastecimento de água. As cidades exigem água em grande quantidade, seja para as atividades econômicas, como as indústrias, seja para as necessidades da população. Assim, a proteção dos mananciais que suprem esses centros urbanos mais populosos já se tornou uma questão estratégica. 
Merece destaque o fato de que, nessas áreas urbanas, especialmente as maiores cidades e as de características metropolitanas, foram criados ambientes em que as conexōes e os laços afetivos com a natureza estavam enfraquecidos. Algumas abordagens que permitem a identificação dessas perdas, pensando-se em açōes que visam ao maior equilíbrio entre as ocupaçōes humanas e a natureza, sempre serão bem-vindas. No entanto, precisam ser trazidas para o centro das discussões.

\section{Interação dos impactos ambientais e reflexões sobre políticas públicas}

Os numerosos problemas ambientais no território fluminense preocupam porque a permanência deles pode comprometer a qualidade de vida, a saúde da população, atingir patrimônios naturais protegidos pelas convençôes nacionais e internacionais, bem como potencializar os impactos entre si, criando cenários de uma degradação ambiental mais grave e, em consequência, interferir negativamente no crescimento econômico do estado do Rio de Janeiro.

No caso do ERJ, chamamos a atenção para uma particularidade quanto aos Relatórios de Impacto Ambiental (RIMA), que tendem a subestimar os danos causados, uma vez que fazem a avaliação por empreendimento, e não para o conjunto de projetos existentes em uma mesma área. Conforme mencionado, estão em curso, no estado, grandes projetos formados por vários empreendimentos, como é o caso do Comperj, do Complexo do Superporto do Açu, do Terminal Portuário Offshore Canaã, do Complexo Logístico Industrial Farol Barra do Furado e do Porto de Itaguaí.

Após avaliar os impactos causados ao meio ambiente físico e à sociedade, provenientes dos diversos empreendimentos que se instalaram ou se encontram em processo de implantação, foram identificadas sete áreas de maior vulnerabilidade, em função do número e da gravidade que apresentam. Entre elas, destacamos cinco situadas ao longo do litoral e no eixo Rio-São Paulo, cujos impactos estão diretamente associados aos grandes empreendimentos, à instalação de indústria pesada e às ocupaçōes inadequadas em ambientes já degradados ou frágeis (Figura 4). Ainda foram identificadas duas áreas situadas nas Regiōes Serrana e Noroeste Fluminense cujos recortes espaciais envolvem atividades tradicionais que, ao serem dinamizadas nas últimas décadas, também geraram sérios impactos e conflitos ambientais. Trata-se de áreas que já apresentam suscetibilidade à erosão, solos erodidos e impactos potencializados por atividades altamente agressoras ao ambiente.

Nesses conjuntos destacados, é relevante considerar que os efeitos dos impactos devem ser percebidos de forma integrada, levando-se em conta sua complexidade. Neles, são evidentes as transformaçôes no território e na paisagem, surgidas de forma muito rápida e trazendo consequências graves a vários elementos do ambiente físico e da sociedade. Do ponto de vista espacial, esses impactos se caracterizam pela grande extensão e pela possibilidade de afetar áreas mais remotas. A importância de se apontarem essas áreas decorre, como já mencionado, do risco de potencializar problemas e impactos entre si, de gerar cenários mais graves, com tendência à degradação ambiental. Merecem, portanto, cuidados especiais. A preocupação com os recortes indicados se prende ao fato de que, ao desencadear desastres e degradação, o desenvolvimento socioeconômico regional e estadual pode tornar-se seria- 
mente comprometido. Os recortes espaciais apresentados na Figura 4 são tão somente um esboço a ser aprimorado por novas pesquisas e trabalhos de campo.

A grande pressão sobre a infraestrutura dos municípios que não estão preparados para as novas demandas é uma questão relevante. De fato, o poder público municipal, em sua maioria, não está tecnicamente capacitado, mostrando-se, do ponto de vista político, muito frágil como promotor do desenvolvimento econômico ou diante do poder das grandes empresas multinacionais que se instalam no âmbito dos municípios. Nesses municípios fluminenses em geral, os empreendimentos se desenvolveram sem discussão prévia acerca do destino das populações direta ou indiretamente afetadas e das atividades tradicionais que se desenvolviam nessas áreas e com as quais conflitam.

Esses dois aspectos conduzem à reflexão sobre as dificuldades de se atuar de forma planejada e de se promoverem ações que integrem esses megaprojetos às atividades municipais e regionais, articulando, de fato, um processo de desenvolvimento. Embora planejados pelo governo estadual, percebe-se que esses complexos de empreendimentos não encontram sinergia entre si ou, então, tais interdependências não estão claramente explicitadas.

Acresce que, devido ao fenômeno das mudanças climáticas, muitas áreas poderão ter, como consequência, o avanço das águas sobre o território litorâneo, onde foi priorizada a maioria dos projetos considerados estruturantes do estado (Secretaria de Estado do Ambiente, 2015). Assim, são evidentes os riscos que tais empreendimentos podem enfrentar no futuro e os prejuízos que podem trazer para as atividades econômicas que se implantaram nessa área ou estão em processo de implantação. Esses danos não recairão somente sobre as empresas, afetarão também o poder público e a população local ou aquela que se deslocou ao se sentir atraída pelas oportunidades oferecidas. De acordo com Suzana Kahn, os grandes projetos previstos para o estado do Rio de Janeiro vão sujar ainda mais a base industrial do estado nos próximos anos, porque o planejamento para o crescimento econômico do estado do Rio está centrado numa economia que não leva em consideração os efeitos da mudança climática (Melo, 2011; Secretaria de Estado do Ambiente, 2012).

O estado do Rio de Janeiro possui uma extensão significativa do território que é considerada patrimônio natural e, no conjunto, são 446.000 hectares de áreas estaduais protegidas, sendo 19 unidades de conservação de proteção integral (parques, reservas biológicas e estação ecológica), 14 unidades de uso sustentável (áreas de proteção ambiental e reserva extrativista marinha), além de cinco parques nacionais (INEA, 2015). Essas áreas, quando próximas à implantação de novas atividades econômicas e de grandes empreendimentos, correm um risco muito elevado de desencadear problemas relacionados ao desmatamento e à perda da biodiversidade, entre outros impactos. Esse é outro ponto crucial a ser observado, pois as consequências dessas pressões não se restringem exclusivamente à localização de determinado empreendimento e, por isso, requerem uma visão espacial integrada.

Nas diversas regiōes fluminenses também se verificam iniciativas positivas em que se buscam desenvolver atividades que apresentem uma relação mais harmoniosa com a natureza. Esse é o caso, por exemplo, das atividades ligadas ao turismo, em área de patrimônio natural e histórico-cultural, e à produção de produtos orgânicos, na Região Serrana, sendo essas ações de grande relevância para o desenvolvimento com sustentabilidade do estado. Tais práticas, contudo, também ficam expostas a impactos e conflitos. Necessitam, da mesma forma que outras, de cuidados, especialmente quanto ao controle mais efetivo do uso de agrotóxicos e à ausência de saneamento rural. 
Embora esteja previsto, para as próximas décadas no estado do Rio de Janeiro, um grande aumento das atividades de exploração de petróleo, notadamente aquelas associadas à exploração do pré-sal, instalou-se no uma séria crise, provocada por fatores internos e externos, que afetou diretamente o andamento das obras desses empreendimentos e, por conseguinte, todos os setores de atividades dessas áreas. As consequências desse freio ainda terão de ser avaliadas, porém já se observam seus efeitos no desemprego, no fechamento de lojas e serviços ligados ao petróleo, bem como no enfraquecimento dos serviços públicos prestados à população. Outra situação que deve passar por um processo de paralisação é o projeto do Porto do Açu, cuja empresa responsável, a EBX, recuou na aplicação de investimentos.

O certo é que, apesar de esses projetos colaborarem para o crescimento econômico das regiōes do ERJ, também criam muitos problemas para os quais o Poder Público, que os apoiou, tem mostrado baixa capacidade de articular soluções e coordenar ações que evitem seu surgimento e/ou a minimização de seus efeitos. Episódios de enchentes e chuvas intensas em curto período têm-se repetido no território fluminense, onde os problemas ambientais já estavam deflagrados e ocasionaram desastres ambientais de consequências severas. Essas catástrofes trouxeram acentuada perda material, sofrimento para as populações atingidas e espantosos gastos por parte do Poder Público. Em consequência, há o risco de retrocesso no nível de desenvolvimento das regiōes afetadas.

\section{Conclusão}

As avaliações realizadas nas diferentes regiōes de governo apontam para o aumento da vulnerabilidade à degradação e para a ocorrência de desastres em diversas áreas do território fluminense. Entretanto, o ERJ, em virtude de sua dimensão territorial, de suas características naturais e da formação socioespacial, tem condições excepcionais de se desenvolver de modo sustentável e harmônico com a natureza, reduzindo o impacto ambiental e o risco de desastres. Alterar as prioridades e repensar novos caminhos representam a melhor alternativa para o ERJ, direcionando-o progressivamente para a escolha de atividades econômicas que apresentem maior possibilidade de conciliação com o meio ambiente e o bem-estar de sua população. O futuro do ERJ dependerá dessa capacidade de se empreenderem atividades sob uma nova perspectiva e de se encontrarem soluçôes que reduzam as emissões de gases de efeito estufa e os impactos e conflitos ambientais com menor vulnerabilidade.

No processo de planejamento, a compreensão e a espacialização dos problemas, os impactos e conflitos ambientais constituem peça-chave, revelando-se essenciais para se desenvolver uma postura preventiva, diminuindo, assim, a ocorrência desses danos, bem como auxiliando a administração pública, de modo que possa atuar menos nas situaçóes de emergência. $O$ freio verificado nas atividades econômicas, em função da crise pela qual o estado e o país passam, em que pese o prejuízo que acarreta, pode ser um momento oportuno para se repensarem as iniciativas em novas bases. 
Figura 4. Visão integrada dos impactos ambientais

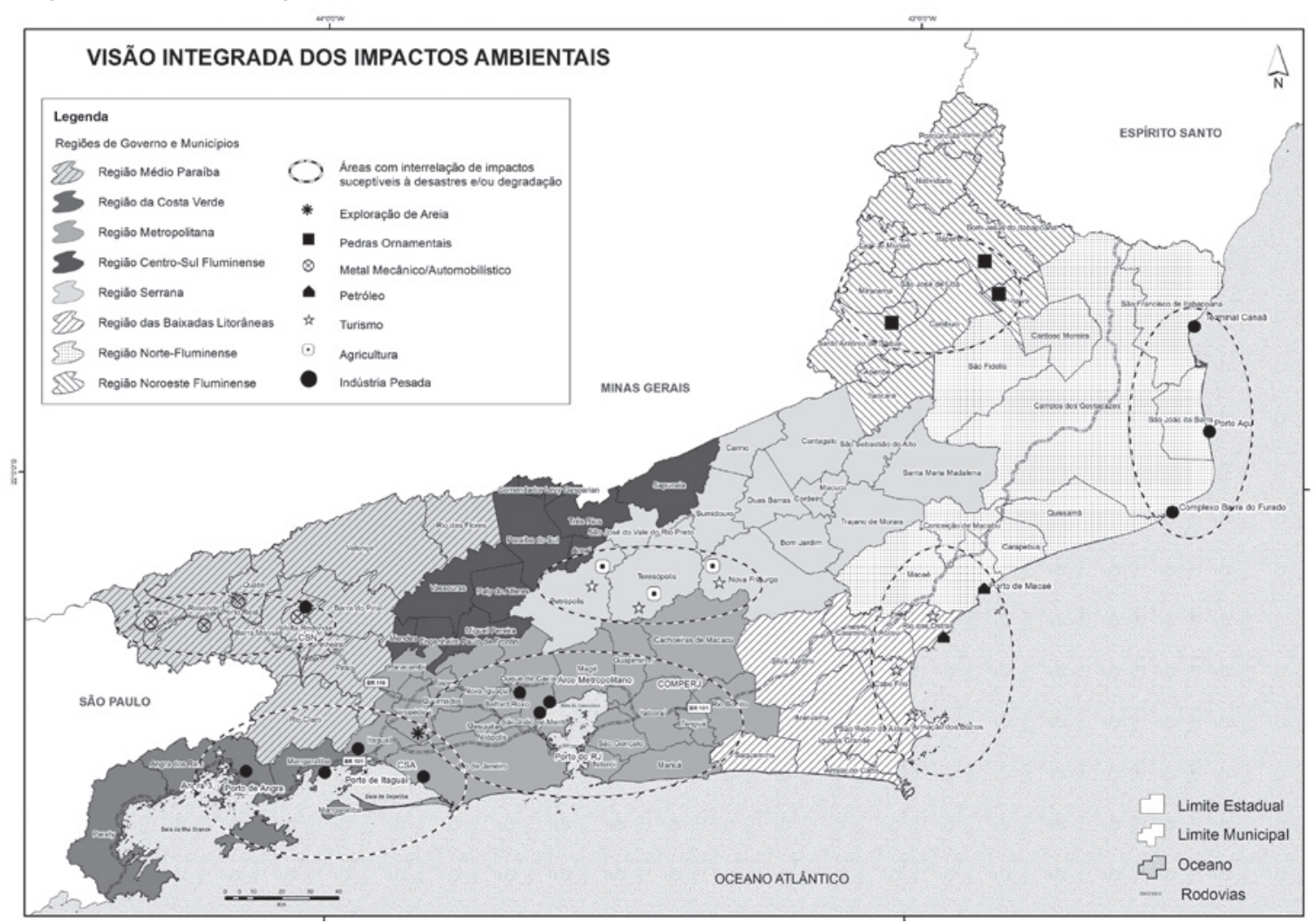

Fonte: a autora, 2016.

\section{Referências}

ABREU, Maurício de. “A evolução urbana do Rio de Janeiro”. Rio de Janeiro: Iplan Rio/Zahar, 1987. $147 \mathrm{p}$.

AGRA FILHO, Severino Soares. Conflitos ambientais e os instrumentos da politica nacional de meio ambiente (tese). UFRJ, 2008.

AGUIAR, Tereza Coni. Metodologia de análise socioeconômica para planejamento ambiental: uma contribuição à interação sociedade/natureza (tese). UFF, 2012.

- "Local impacts and global concerns: environmental issues in the area of Ilha Grande and Sepetiba Bays, Rio de Janeiro - Brasil”. How will rapid global changes transform civilizations? Proceedings of the 2013: Conference International Society for the Comparative Study of Civilizations (ISCSC). Califórnia: Connie Lamb, Brian Wages, Brigham Young University e Peter Hecht, K-12 Educational Innovator. 
ASPLANDE e VALE VERDEJANTE. Relatório Técnico. Cadê a água de Andrade Costa? Rio de Janeiro: Asplande/Vale Verdejante, 2014.

BARROS, Regina Cohen. "Verificação da qualidade da água dos rios da bacia do Rio Grande (Nova Friburgo/RJ). In FERNANDES, Ulisses et al. (orgs.). Velhos saberes, novas abordagens: a geografia à luz da contemporaneidade. 1 ed. Rio de Janeiro: Gramma, 2015. 230p.

BOLEA, Maria-Teresa Estevan. "Las evaluaciones de impacto ambiental”, Cuadernos del Centro Internacional de Formación em Ciencias Ambientales (CIFCA), Madri, 1977.

BRASIL. "Coletânea de legislação de direito ambiental. Constituição Federal”. In MEDAUAR, Odete (org.). RT Minicódigos. 7 ed. São Paulo: Revista dos Tribunais, 2008. 118p.

BREDARIOL, Celso Simões. Conflito ambiental e negociação para uma política local de meio ambiente (tese). UFRJ, 2001.

CADENA, Alberto. "Crescimento populacional e os vetores de expansão urbana em Macaé-RJ”. In MARAFON, Glaucio José e RIBEIRO, Miguel Angelo (orgs.). Revisitando o território fluminense $I V$. Rio de Janeiro: Gramma, 2012.

CASTRO, Cleber Marques e PEIXOTO, Maria Naise de Oliveira. "Urbanização, vulnerabilidades e riscos ambientais associados aos sistemas de drenagem: uma análise a partir de Volta Redonda (RJ)". In FERNANDES, Ulisses et al. (orgs.). Velhos saberes, novas abordagens: a geografia à luz da contemporaneidade. 1 ed. Rio de Janeiro: Gramma, 2015. 230p.

CEPERJ. Fundação Centro Estadual de Estatísticas, Pesquisas e Formação de Servidores Públicos do Rio de Janeiro. Governo do Estado do Rio de Janeiro. Estado do Rio de Janeiro: regióes de governo e municipios - 2014. Disponível em: http://www.ceperj.rj.gov.br/ceep/info_territorios/Reg\%20 Gov_2013.pdf. Acesso em: 24 fev. 2016.

CHEW, Sing C. World Ecological Degradation: accumulation, urbanization, and deforestation 3000 B.C.-A.D. 2000. Nova Iorque: AltaMira Press, 2001.

— e AGUIAR, Tereza Coni. "Book reviews". Tradução de Tereza Coni Aguiar. Comparative Civilizations Review, n. 71, 2014, pp. 115-8.

CHRISTOFOLETTI, Antonio. "Impactos no meio ambiente ocasionados pela urbanização no mundo tropical”. In SOUZA, M. A. A. de (org.). Natureza e sociedade hoje. 3 ed. São Paulo: Hucitec, 1997.

COELHO, Maria Célia Nunes. "Impactos ambientais em áreas urbanas: teorias, conceitos e métodos de pesquisa”. In GUERRA, Antônio José Teixeira e CUNHA, Sandra Baptista da (orgs.). Impactos ambientais urbanos no Brasil. Rio de Janeiro: Bertrand Brasil, 2001.

COSTA, Helder. Enchentes no estado do Rio de Janeiro: uma abordagem geral. Rio de Janeiro: SEMADS, 2001.

COSTA JUNIOR, Aluísio de Araújo. "Arranjos produtivos locais no estado do Rio de Janeiro: o exemplo da Petrópolis-Tecnópolis”. In MARAFON, Glaucio José e RIBEIRO, Miguel Angelo (orgs.). Revisitando o Território Fluminense IV. Rio de Janeiro: Gramma, 2012.

CUNHA, Ícaro. "Conflito ambiental em águas costeiras: relação porto-cidade no canal de São Sebastiāo”, Ambiente \& Sociedade, Rio de Janeiro, v. VI, n. 2, jul.-dez. 2003. 
GALVÃO, Maria do Carmo Corrêa. Percursos geográficos. Rio de Janeiro: Lamparina PPGG/UFRJ, 2009.

IBGE. Projeto Gerenciamento Costeiro. Diagnóstico Ambiental do Litoral de Santa Catarina. Relatório Final setores 1 e 2. Dominio da sociedade: problemas socioeconômicos, setores 1 e 2. Contrato IBGE/MERCOSUL-SED/SC. Rio de Janeiro: IBGE, jun. 1997.

—. Cidades. Rio de Janeiro: IBGE, 2010. Disponível em: http://www.cidades.ibge.gov.br/xtras/ home.php. Acesso em: mar. 2016.

INEA. Instituto Estadual do Ambiente. Unidades de Conservação da Natureza (UCs). Rio de Janeiro, 2015. Disponível em: http://www.inea.rj.gov.br/Portal/Agendas/BIODIVERSIDADEEAREASPROTEGIDAS/UnidadesdeConservacao/index.htm\&lang=PT-BR. Acesso em: jan. 2016.

MARICÁ (RJ). Prefeitura Municipal de Maricá, 2016. "Obras do emissário submarino entram em estágio final em Itaipuaçu”. Disponível em: http://maricainfo.com/2015/04/27/obras-do-emissario-submarino-entram-na-reta-final-em-itaipuacu.html. Acesso em: 24 jan. 2016.

MARQUES, Eduardo Duarte. Impactos da mineração de areia na bacia sedimentar de Sepetiba, RJ: estudo de suas implicaçōes sobre as águas do aquifero Piranema (tese). UFF, 2010.

MELO, Liana. "O futuro próximo é marrom, diz Suzana Kahn, subsecretária de Economia Verde do Rio", O Globo, Rio de Janeiro, "Economia”, 7 mar. 2011.

NASCIMENTO, Flávio Rodrigues do. O fenômeno da desertificação. Goiânia: UFG, 2013. 240p.

NITAHARA. Akemi. "Chevron vai pagar R 95 milhôes para compensar danos ambientais de vazamentos no campo de Frade". Agência Brasil. Disponível em: http://memoria.ebc.com.br/agenciabrasil/noticia/2013-09-13/chevron-vai-pagar-r-95-milhoes-para-compensar-danos-ambientais-de-vazamentos-no-campo-de-frade. Acesso em: fev. 2016.

PACHECO, Wedson Felipe Cabral. "Porto do Açu, o 'X' da questão: a implantação no município de São João da Barra (RJ)”. In: MARAFON, Glaucio José e RIBEIRO, Miguel Angelo (orgs.). Revisitando o território fluminense V. 1 ed. Rio de Janeiro: Gramma, 2015. 376p.

PRADO, Fellipe Silva. "A emergência de novas territorialidades a partir da implantação do Superporto do Açu: o reassentamento Vila da Terra em São João da Barra (RJ)". In MARAFON, Glaucio José e RIBEIRO, Miguel Angelo (orgs.). Revisitando o território fluminense V. Rio de Janeiro: Gramma, 2015, p. 111-129.

RIBEIRO, Miguel Ângelo e O'NEIL, Mônica. "Considerações sobre a dinâmica populacional fluminense: contrastes entre a metrópole e o interior. In MARAFON, Glaucio José (org.). Revisitando o território fluminense IV. Rio de Janeiro: Faperj/Gramma, 2012.

_ . "Contrastes entre a metrópole e o interior fluminense a partir do urbano e do rural". In FERNANDES, Ulisses et al. (orgs.). Velhos saberes, novas abordagens: a geografia à luz da contemporaneidade. 1 ed. Rio de Janeiro: Gramma, 2015.239p.

RIBEIRO, Raquel. "De Gramacho a Seropédica”. Radis, comunicação e saúde, Rio de Janeiro, n. 162, mar. 2016. Disponível em: http://www6.ensp.fiocruz.br/radis/conteudo/de-gramacho-seropedica. Acesso em: mar. 2016.

RIO DE JANEIRO. Secretaria de Estado do Ambiente. O estado do ambiente: indicadores ambientais do Rio de Janeiro. Org. Julia Bastos e Patrícia Napoleão. Rio de Janeiro: SEA/ INEA, 2011. 
- Plano estadual sobre mudança do clima. Rio de Janeiro: SEA, 2012.

- Secretaria de Estado do Ambiente. Elaboração do zoneamento ecológico econômico do estado do Rio de Janeiro. Sintese: tendências de ocupação e uso territorial. Consórcio Ecológico Cobrape-Oikos. Rio de Janeiro, jul. 2015.

—. SEA/INEA. Diagnóstico do setor costeiro da Baía de Ilha Grande. Subsídios à elaboração do zoneamento ecológico-econômico costeiro. Rio de Janeiro: SEA/INEA, 2015. Disponível em: http:// www.inea.rj.gov.br/cs/groups/public/documents/document/zwew/mdcz/ - edisp/inea0073532. pdf. Acesso em: fev. 2016.

SILVESTRE, Carolina Pereira et al. "A produção de rochas ornamentais no Noroeste do estado do Rio de Janeiro: Santo Antônio de Pádua e Italva”, Revista Tamoios, São Gonçalo-RJ, ano 10, n. 1, jan.-jun. 2014, pp. 114-127.

STEPHAN, Gustavo. "Poluição doméstica: a principal agressão ao rio Paraíba do Sul”. O Globo, "Ciência”, Rio de Janeiro, 18 dez. 2012.

TUBBS, Décio et al. "Impacto da mineração de areia sobre a química das águas subterrâneas, Distrito Areeiro da Piranema, municípios de Itaguaí e Seropédica, Rio de Janeiro”. Revista Brasileira de Geociências, São Paulo, v. 41, n. 3, set. 2011. Disponível em: http://wwwppegeo.igc.usp.br. Acesso em: fev. 2016.

TUCCI, Carlos Eduardo Morelli. "Impactos ambientais urbanos no Brasil”. Prefácio. In GUERRA, Antonio José Teixeira e CUNHA, Sandra Baptista da (orgs.). Impactos ambientais urbanos no Brasil. Rio de Janeiro: Bertrand Brasil, 2001.

UNACOOP. "Diagnóstico territorial: território da baía da Ilha Grande, Rio de Janeiro". União das Associações e Cooperativas Usuárias do Pavilhão 30, Ministério do Desenvolvimento Agrário, Secretaria do Desenvolvimento Territorial Convênio SDT-MDA, UNACOOP. Rio de Janeiro, nov. 2011.

ZULEIKA, Alimandro Rosa. "Espaço e questão portuária: o exemplo de Angra dos Reis". In RIBEIRO, Miguel Ângelo e MARAFON, Glaucio José (orgs.). Revisitando o território fluminense IV. Rio de Janeiro: Faperj/Gramma, 2012. 
ERRATA

No capítulo "Uma visão integrada dos impactos ambientais no estado do Rio de Janeiro", do livro Revisitando o território fluminense VI, na página 65, onde se lê:

"Uma visão integrada dos impactos ambientais no estado do Rio de Janeiro."

Leia-se:

"Uma visão integrada dos impactos ambientais no estado do Rio de Janeiro"

[nota de rodapé excluída].

No mesmo capítulo, na página $71, \S 2^{\circ}$, onde se lê:

“(Secretaria de Estado do Ambiente, 2015)."

Leia-se: “(Secretaria de Estado do Ambiente, 2015).2”

"Este estudo compõe o Projeto ZEE/RJ, que foi elaborado pelo Consórcio Cobrape-Oikos, coordenado pela Secretaria de Estado e Ambiente (SEA).” [nota de rodapé incluída].

No mesmo capítulo, na página 83, na fonte do mapa, onde se lê:

"Luiza Boechat, 2016."

Leia-se: “a autora, 2016.”. 


\title{
Sustentabilidade da produção energética no Rio de Janeiro: as Pequenas Centrais Hidrelétricas ( $\mathrm{PCH}$ ) potencializando regionalmente 0 território fluminense
}

\author{
Augusto César Pinheiro da Silval \\ Davi Schulman Miguens ${ }^{2}$ \\ Mônica Coelho Varejāo $0^{3}$
}

\section{Introdução}

0 planejamento e a gestão do território, a partir do recorte espacial "bacias hidrográficas", vêm ganhando força nas discussões acadêmicas desde o final do século XX. O entendimento dessas unidades espaciais é de fundamental relevância para o entendimento dos temas "preservação ambiental", "geração de energia" e "captação e distribuição de água", possibilitando que as bacias sejam identificadas como aquelas que podem modificar, se bem estudadas e apropriadas, os ritmos de escassez de água e, consequentemente, de energia, haja vista que a matriz elétrica brasileira é majoritariamente abastecida por hidroelétricas.

Em relação ao tema "produção energética", as bacias hidrográficas são os depositórios naturais de recursos renováveis (água), o que as torna focais para as políticas públicas nacionais de geração de hidroenergia, fonte ainda parcialmente potencializada no território nacional, apesar da enorme capacidade de produção de energia das bacias brasileiras.

Os padrões atuais de geração de energia no Brasil se baseiam em recursos renováveis (inclusive o grande aporte de água das Unidades Hidroelétricas de Energia [UHEs]), sendo a hidroenergia

\footnotetext{
1 Pós-doutor em Políticas Públicas pela Universidad Autónoma de Madrid e doutor em Geografia pela UFRJ. Professor do Programa de Pós-Graduação em Geografia da PUC-Rio e líder do grupo de pesquisa Gestão Territorial no Estado do Rio de Janeiro (GeTERJ). É bolsista Jovem Cientista Nosso Estado (JCNE), da Faperj.

2 Geógrafo pela PUC-Rio e mestre em Geologia pela UERJ. Trabalha com consultoria ambiental e energética.

3 Engenheira ambiental e sanitária pela PUC-Rio e especialista em Engenharia Sanitária pela UFRJ. Atualmente, é mestranda em Engenharia Ambiental pela UERJ.
} 
detentora da maior parcela de geração elétrica, com 70,6\% de representatividade do total gerado (EPE-BEN, 2014). Todavia, as UHEs causam grandes problemas socioambientais, deixando marcas espaciais expressivas (a remoção de ribeirinhos, que estimula o fluxo demográfico, a inundação de terras agrícolas, florestas e sítios arqueológicos, a formação de microclimas em áreas de barragens, entre outras) que são largamente estudadas por cientistas de diversas áreas, e que buscam alternativas para a geração de energia por meios menos impactantes.

Assim, outras formas de exploração dos recursos hídricos para a geração energética estão sendo ampliadas. Entre elas, destacam-se as Pequenas Centrais Hidrelétricas (PCH), cuja potência instalada é superior a $01 \mathrm{MW}$ e igual ou inferior a $30 \mathrm{MW} .{ }^{4}$ Tais estruturas produtivas potencializam o uso dos recursos nas bacias hidrográficas nacionais, pois apresentam baixo custo de construção e reduzido impacto ambiental durante a construção e a operação, em comparação às demais unidades geradoras.

Entre os fatores que tornam as PCH potenciais investimentos no Brasil, destaca-se a utilização de pequenos reservatórios, que, em relação às gigantescas obras necessárias para a construção de uma UHE, tornam menos complexas e barateiam as obras civis, em virtude do aproveitamento das quedas naturais dos rios. A união dos aspectos potenciais das $\mathrm{PCH}$ explicita seu caráter menos impactante nos âmbitos socioespacial, ecológico e econômico, encaixando-se, assim, no fornecimento de energia para centros urbanos e rurais menores, como se caracteriza a rede urbana fluminense. Ademais, a aplicação desse modelo de usinagem no estado do Rio de Janeiro está adequada aos aspectos hidroenergéticos, socioespaciais e físicos (geomorfológicos, hidrológicos, edáficos e climáticos) da unidade federativa em questão.

A pertinência desse artigo se ancora no crescimento da economia brasileira nas últimas duas décadas (1994-2014) e no Plano Decenal de Desenvolvimento da Energia (2014-2023), sendo as PCH uma forma de conter, ainda que parcialmente, as transformações nocivas que tal expansão tende a promover no espaço "em crescimento", como injustiça social e violência ambiental (eliminação de empregos, redução de mão de obra nos espaços de produção agrícola de pequeno porte, destruição de biomas ribeirinhos etc.), sendo que a opção pelas $\mathrm{PCH}$ pode trazer sustentabilidades diversas para as populações mais pobres e vantagens comparativamente mais amplas para os investidores públicos e privados no território fluminense. Diante disso, deve-se atentar para a atual abertura, em relação às instituições privadas, das condições de implantação de $\mathrm{PCH}$, o que pode ser observado em importantes bacias do estado do Rio de Janeiro e do Brasil.

A literatura utilizada para a elaboração deste artigo conta, entre outros autores, com Iglori (2001), Corò (2003), Castro [et al.] (2009) e Silva (2007, 2014), além de se recorrer a dados oficiais de órgãos e instituiçôes ligados a setores como a Agência Nacional de Energia Elétrica (ANEEL) e a Empresa de Pesquisa Energética (EPE).

\footnotetext{
4 Todavia, em 20 de janeiro de 2015, a presidente Dilma Rousseff sancionou a Lei no 13.097 , resultado do Projeto de Lei de Conversão (PLC) no 18/2014 sobre a Medida Provisória no 656/14, que, apesar de contar com alguns vetos, traz mudanças positivas para o setor elétrico, como, por exemplo, a ampliação do limite de potência das Centrais Geradoras Hidrelétricas (CGH) de $1 \mathrm{MW}$ para 3 MW.
} 


\section{A importância das Pequenas Centrais Hidrelétricas no setor elétrico nacional e no estado do Rio de Janeiro}

Conforme apontado por Gleick (1993), o Brasil apresenta uma das maiores reservas de água doce do mundo, em torno de $8 \%$, sendo parte desse total utilizado como carro-chefe para a geração de energia hidrelétrica. Soma-se a essa condição o aumento significativo do consumo de energia (e de água) no país, com a estabilização e o crescimento da economia, em muitas escalas, nas duas últimas décadas, o que impulsiona as esferas do planejamento e da gestão públicos a buscarem estratégias de geração de energia por múltiplas matrizes, frente às situaçôes conjunturais na sociedade brasileira na atualidade.

De acordo com Castro et al. (2009), por apresentar um expressivo parque gerador de energia hidráulica, o Brasil tem uma oferta de eletricidade competitiva e com reduzida emissão de gases do efeito estufa. Seguindo um movimento contrário em relação à boa parte dos países emergentes e centrais, ${ }^{5}$ os fatores favoráveis apontados desestimulariam políticas nacionais de fontes alternativas e renováveis; todavia, a legislação ambiental mais rígida e impositiva vigente no Brasil (frente aos enormes impactos socioambientais provenientes dos grandes empreendimentos hidrelétricos) ${ }^{6}$ faz com que tais fontes, como a bioeletricidade, a energia eólica e as PCH, ganhem espaço no cenário nacional. Ainda segundo Castro et al. (2009), "a expansão da capacidade instalada via usinas hidrelétricas terá como condição de base do sistema elétrico brasileiro uma contrapartida obrigatória e necessária, a complementação por outras fontes de energia” (p. 3). Por apresentar uma sazonalidade bem definida, as fontes alternativas atuariam complementando a carga nacional em períodos de seca.

No caso das fontes alternativas e renováveis e, especificamente, das PCH (que aumentou sua demanda, na segunda metade da primeira década do século XXI, entre 4\% e 5\% ao ano, EPE-BEN, 2014), as externalidades socioambientais positivas vão além de considerá-las uma fonte limpa, pois o uso de pequenos reservatórios (inferiores a $3 \mathrm{~km}^{2}$ ) diminui as possibilidades de desapropriação e de outros impactos associados às grandes barragens, com a utilização de quedas naturais e o modelo de engenharia "fio d'água"? Esse modelo, de acordo com a Figura 1, permite o uso de pequenos reservatórios que permanecem em níveis constantes, não havendo armazenamento para suprir o escoamento sazonal. Vale ressaltar

\footnotetext{
5 Hoje, o que se vê é o mundo, de modo geral, investindo e buscando fontes renováveis para a geração de energia, e o Brasil investindo no Pré-Sal (muito mais do que em qualquer fonte renovável). O próprio EPE-BEN (2014) aponta que o crescimento da oferta das fontes energéticas foi representado em $80 \%$ por petróleo, gás natural e derivados.

${ }^{6}$ Com a promulgação da Resolução Conama no 001/86 (23/01/1986), que estabeleceu as normas para a Avaliação de Impactos Ambientais, a implantação de empreendimentos de médio a grande porte está condicionada a um processo de licenciamento ambiental e a um Relatório de Impactos sobre o Meio Ambiente (EIA/RIMA).

7 Usinas hidrelétricas "a fio d'água" são aquelas que não dispōem de reservatório de água, ou o têm em dimensões menores do que poderiam ter. Optar pela construção de uma usina "a fio d'água" significa optar por não manter um estoque de água que poderia ser acumulado em uma barragem (Adaptado de Faria, 2011).
} 
que projetos recentes de UHE vêm adotando esse modelo, contemplando-se a estratégia de modernização de seus idealizadores: a de atender a legislação no que diz respeito aos impactos socioambientais.

Figura 1. Exemplo de modelo padrão de fio d' água da PCH Chave do Vaz, instalada no rio Negro, Cantagalo, RJ

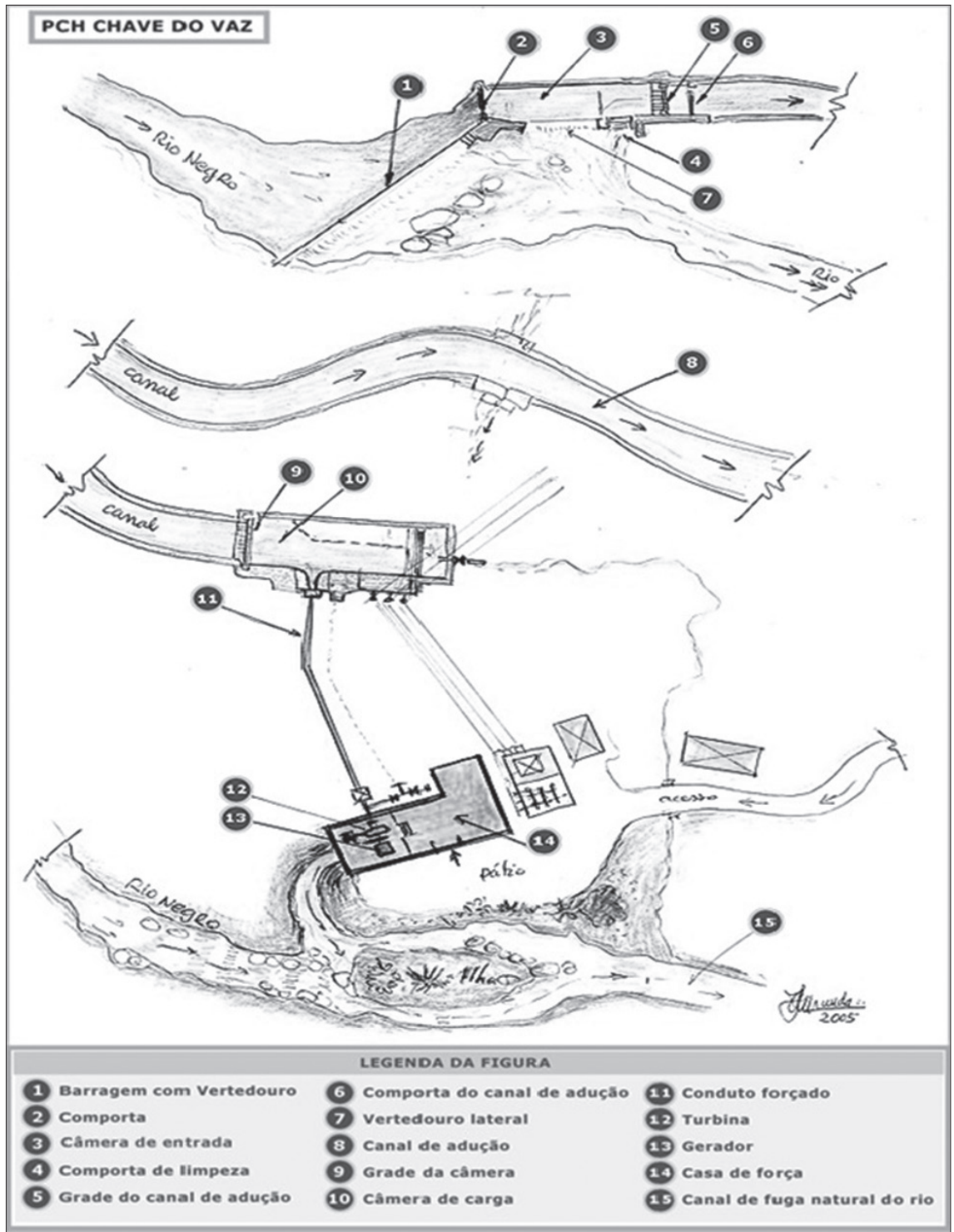

Fonte: Governo do Estado do Rio de Janeiro, 2007.

Outro atrativo das $\mathrm{PCH}$ é o menor tempo para sua construção, fato que permite a rápida expansão da geração de energia elétrica de maneira descentralizada. Essa característica permite que a energia gerada possa ser utilizada em escala local nos pontos em que não há ligação com a 
rede transmissora, diminuindo-se as perdas ao longo de seu transporte para outros espaços de consumo. Nesse sentido, competitivamente, as $\mathrm{PCH}$, assim como os projetos hídricos de forma genérica, são unidades de geração de energia que se caracterizam pelo capital intensivo, com reduzido custo marginal. Tal condição reforça a atratividade econômica de um empreendimento que apresenta vida útil longa. $\mathrm{O}$ esquema padrão de uma $\mathrm{PCH}$ pode ser visto na Figura 1 ( $\mathrm{PCH}$ Chave do Vaz, Cantagalo, Rio de Janeiro), para que se tenha a dimensão espacial do empreendimento, assim como a dos elementos que a compõem e fazem funcionar.

Com relação à sua limitada capacidade de geração de energia, as $\mathrm{PCH}$ apresentam maior adequação para ofertar sua produção em um Ambiente de Contratação Livre (ACL), mais conhecido como Mercado Livre. O ACL envolve diferentes agentes do setor elétrico, como geradores, consumidores livres, comercializadores e importadores/exportadores, segmentos do mercado no qual se realizam as operações de compra e venda de energia elétrica, a partir de contratos bilaterais livremente negociados, conforme regras e procedimentos de comercialização específicos (EPE-BEN, 2014).

\subsection{Panorama atual das $P C H$ na matriz elétrica nacional}

Com um potencial hidráulico inventariado em cerca de $260 \mathrm{GW}$, o Brasil ainda possui $60 \%$ de seu potencial a ser explorado, sendo que apenas um terço de sua capacidade total está em operação ou construção (Castro et al., 2009). Segundo o Balanço Energético Nacional de 2014, que apresenta dados relativos ao ano base de 2013 (Gráfico 1), a capacidade instalada da fonte hidrelétrica para 2013 foi de $86 \mathrm{GW}$. A potencialidade do setor já é um dos pontos centrais das políticas públicas de energia do país, sendo que o parque gerador vem apresentando ritmo constante em sua expansão, como, por exemplo, de 2012 para 2013 a capacidade instalada da fonte hidrelétrica cresceu 2\% (EPE-BEN, 2014). Entretanto, aumentaram os problemas referentes ao consumo exponencial de energia, concomitantemente à escassez de água nos reservatórios do país, nos últimos cinco anos - com agravamentos ampliados entre 2013 e 2015 -, o que afeta o abastecimento doméstico e industrial de água nos grandes centros metropolitanos do país e os custos da energia elétrica, em múltiplas escalas de produção e consumo. 
Gráfico 1. Evolução decenal da composição das fontes geradoras de energia elétrica no Brasil (\%)

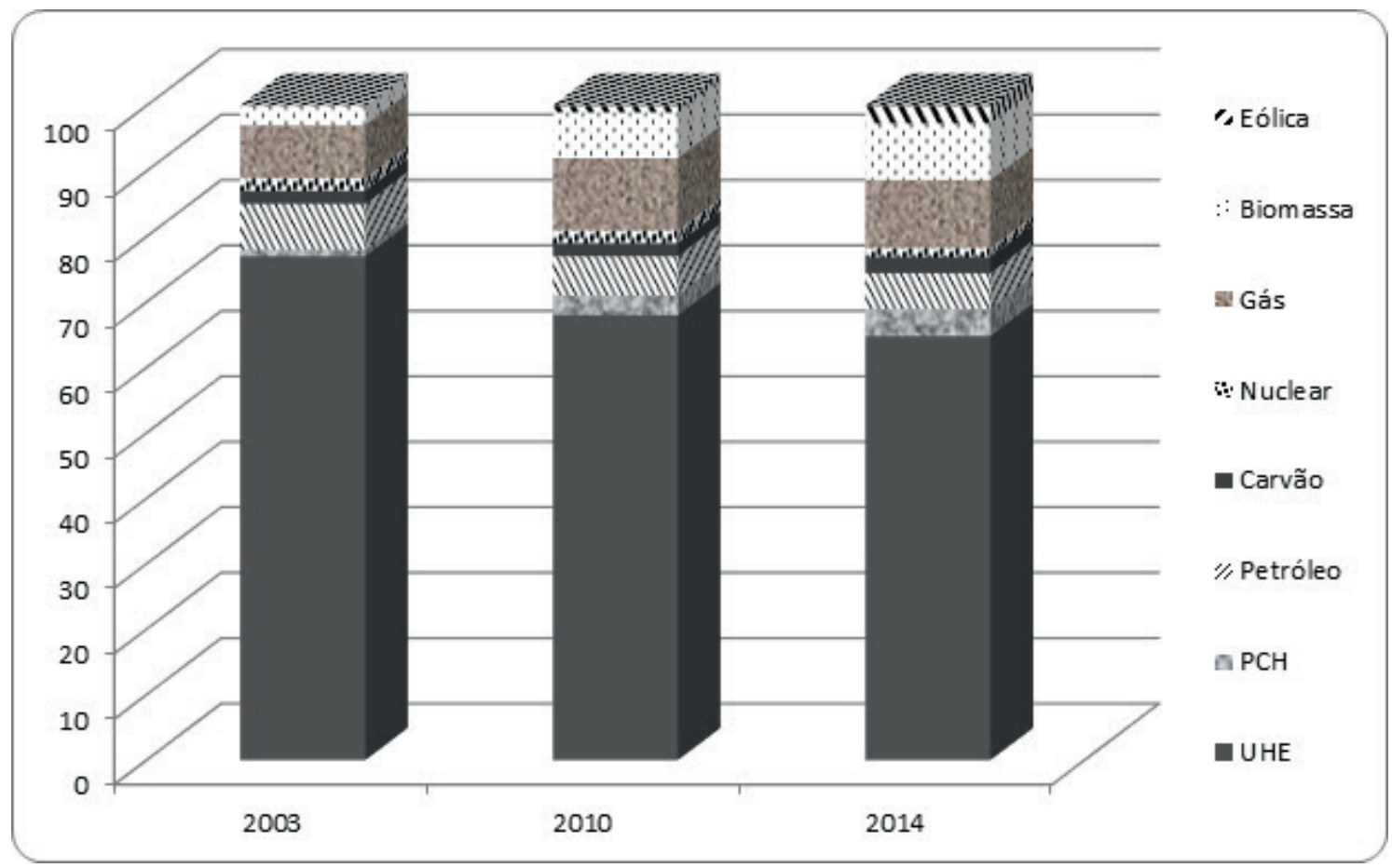

Fontes: EPE-BEN, 2014; ANEEL, 2014.

Vale destacar o aumento da participação das fontes alternativas e renováveis no período compreendido entre 2003 e 2014. Conforme o Gráfico 1, em 2003 apenas 4\% da composição total de energia do país vinha desses tipos de fonte. Já em 2010, esse número aumentou para 11\%, com merecido destaque para a biomassa, e em 2014 subiu para mais de $15 \%{ }^{8}$

De acordo com o Banco de Informaçôes de Geração (BIG) da ANEEL, o Brasil, em 2014, apresentava 463 empreendimentos do tipo PCH em operação, totalizando 4,6 GW de potência instalada. Em escala nacional, esse valor era equivalente a 4,08\% do total do parque gerador de energia elétrica naquele ano. Vale ressaltar ainda que, em maio de 2014, existiam 176 empreendimentos em fase de construção (30) e outorgados (146), o que equivaleria a 2,326 MW a serem acrescidos ao parque gerador nacional (BIG-ANEEL, 2015).

Segundo o Plano Decenal de Expansão de Energia 2023 da EPE, a expansão da fonte PCH já contratada e em construção, com previsão de entrada em operação comercial para os anos de 2014

\footnotetext{
${ }^{8}$ Apesar da clara tendência de aumento da geração de energia por métodos alternativos e renováveis no país, as estatísticas da EPE-PDE $(2019,2010)$ estimam o total de empreendimentos hidrelétricos viabilizados até 2019 em mais 40 UHE.
} 
a 2018, é apresentada conforme Tabela 1. Cabe ressaltar que o acréscimo da potência instalada para cada ano, disposta nessa tabela, refere-se à capacidade contratada nos leilóes de energia de reserva.

Tabela 1. Expansão da PCH contratada de 2014 a 2018

\begin{tabular}{|l|l|c|c|c|c|c|}
\hline Tipo & Região & $\mathbf{2 0 1 4}$ & $\mathbf{2 0 1 5}$ & $\mathbf{2 0 1 6}$ & $\mathbf{2 0 1 7}$ & $\mathbf{2 0 1 8}$ \\
\hline \multirow{5}{*}{ PCH } & \multicolumn{7}{|l|}{ Potência (MW) } & Sudeste/Centro-Oeste & 169 & 71 & 0 & 0 & 286 \\
\cline { 2 - 7 } & Sul & 40 & 30 & 18 & 0 & 113 \\
\cline { 2 - 7 } & Nordeste & 0 & 0 & 0 & 0 & 6 \\
\cline { 2 - 7 } & Norte & 21 & 32 & 12 & 3 & 0 \\
\hline \multirow{2}{*}{ Total } & $\mathbf{2 3 0}$ & $\mathbf{1 3 3}$ & $\mathbf{3 0}$ & $\mathbf{3}$ & $\mathbf{4 0 5}$ \\
\hline
\end{tabular}

Fonte: Adaptado do PDE 2023, 2014.

Em relação à distribuição das $\mathrm{PCH}$ pelo território nacional, as unidades federadas das macrorregiōes Sudeste e Sul do país apresentam maior concentração de empreendimentos (323 PCHs) e maior capacidade instalada (28,4 GW). O estado de Minas Gerais é o carro-chefe nacional desse tipo de empreendimento, por apresentar a maior potência em megawatts (742 MW ou 7,42 GW) e um total de PCH 4,2 vezes maior do que o do total do estado do Rio de Janeiro - 97 PCH mineiras contra apenas 23 delas no território fluminense (BIG-ANEEL, 2013).

Para os próximos anos, o parque gerador de energia nacional continuará a ser consideravelmente diversificado. Vale destacar que essa diversificação possibilitará o crescimento das fontes renováveis, reforçando-se o caráter "limpo" das políticas ambientais no país, como preveem os planos diretores e as políticas interescalares das instâncias de gestão pública do federalismo brasileiro, que ampliaram o poder das esferas locais na geração de recursos sustentáveis para o desenvolvimento nacional (Silva, 2014). Até 2023, 42,5\% da oferta interna de energia será renovável, sendo a maior parte proveniente de derivados de cana-de-açúcar e de energia hidráulica (EPE-PDE 2023, 2014).

Sob essa perspectiva, até 2023 as PCH acrescerão à sua potência instalada mais 2,01 GW. Vale destacar o aumento da participação da energia eólica no parque gerador para os próximos anos, tendo em vista que o potencial estimado para essa fonte gira em torno de $22,44 \mathrm{GW}$, equivalente a $75 \%$ do mercado atual de energia elétrica para as fontes de energia eólica, biomassa, solar e as próprias $\mathrm{PCH}$ (PDE 2023, 2014). 
Diante dessa potencial capacidade de expansão das fontes renováveis, cabe destacar como se comportarão as $\mathrm{PCH}$ no contexto analítico em foco, além de compreender como tal investimento tem condições de potencializar ainda mais o estado do Rio de Janeiro para os investimentos presentes e futuros.

\subsection{Panorama do setor hidrelétrico no estado do Rio de Janeiro: potencialidades}

A macrorregião Sudeste é a maior consumidora de energia elétrica do país, necessitando de aproximadamente $34 \%$ de toda a produção nacional para suprir sua carga (EPE-BEN, 2014). Como é a maior produtora, a malha dos serviços de transmissão é bastante complexa, o que torna a macrorregião (que ainda é a mais industrializada e povoada do país) uma fonte de pesquisas necessárias para que sejam identificadas as potencialidades dos projetos de desenvolvimento local/estadual/regional baseadas em fontes renováveis e alternativas, como, por exemplo, a PCH.

Das quatro unidades federadas da macrorregião, o estado do Rio de Janeiro apresenta-se como um dos maiores produtores de energia elétrica do país, apesar de suas reduzidas dimensões territoriais em relação às outras unidades. Mesmo sendo um importante produtor no conjunto dos estados brasileiros, o Rio de Janeiro não produz energia suficiente para suprir a carga estadual de consumo, o que o torna, portanto, um importador de energia elétrica (EPE-PDE 2023, 2014).

Atualmente, o estado do Rio de Janeiro apresenta 8,7 GW de potência instalada, dos quais $86 \%$ são usinas termelétricas (nucleares e de gás e óleo). O total de $\mathrm{PCH}$ em operação no estado é de 23 empreendimentos, somando $305 \mathrm{MW}$ de potência. De acordo com o relatório de acompanhamento da expansão da oferta de geração de energia elétrica das PCH, o qual fornece informações acerca das usinas já outorgadas e em fase de implantação, o estado do Rio de Janeiro apresenta, nessa situação, cinco usinas: uma se encontra em estágio de obra paralisada, duas em andamento e duas não iniciadas. No Gráfico 2, observa-se a importância das PCH no estado em relação à sua situação por operação, à quantidade de empreendimentos e à respectiva potência.

É importante destacar o potencial apresentado pelo território fluminense para ser explorado. As PCH em projeto básico representam um total de 19 empreendimentos que somam 206 $\mathrm{MW}$, sendo que 18 já tiveram seus projetos básicos elaborados e um apresenta projeto básico em fase de elaboração. Cinco usinas ainda não entraram em operação comercial e se encontram outorgadas, sendo que três delas apresentam problemas com a licença ambiental. Também é grande o número de pequenos empreendimentos no estado que se enquadram como CGH e estão desativados. São mais de cinquenta empreendimentos que, juntos, apresentam uma potência superior a $15 \mathrm{MW}$. Da mesma forma que as $\mathrm{PCH}$, essas CGH podem elevar substancialmente sua potência a partir de estudos que ampliem a perspectiva de sua vazão e da altura de sua queda (ANEEL, 2015). 


\section{Sustentabilidade da produção energética no Rio de Janeiro}

Figura 2. Distribuição da população carioca, metropolitana e total no estado do Rio de Janeiro: superpovoamento relativo na Região Metropolitana do Rio de Janeiro (RMRJ).

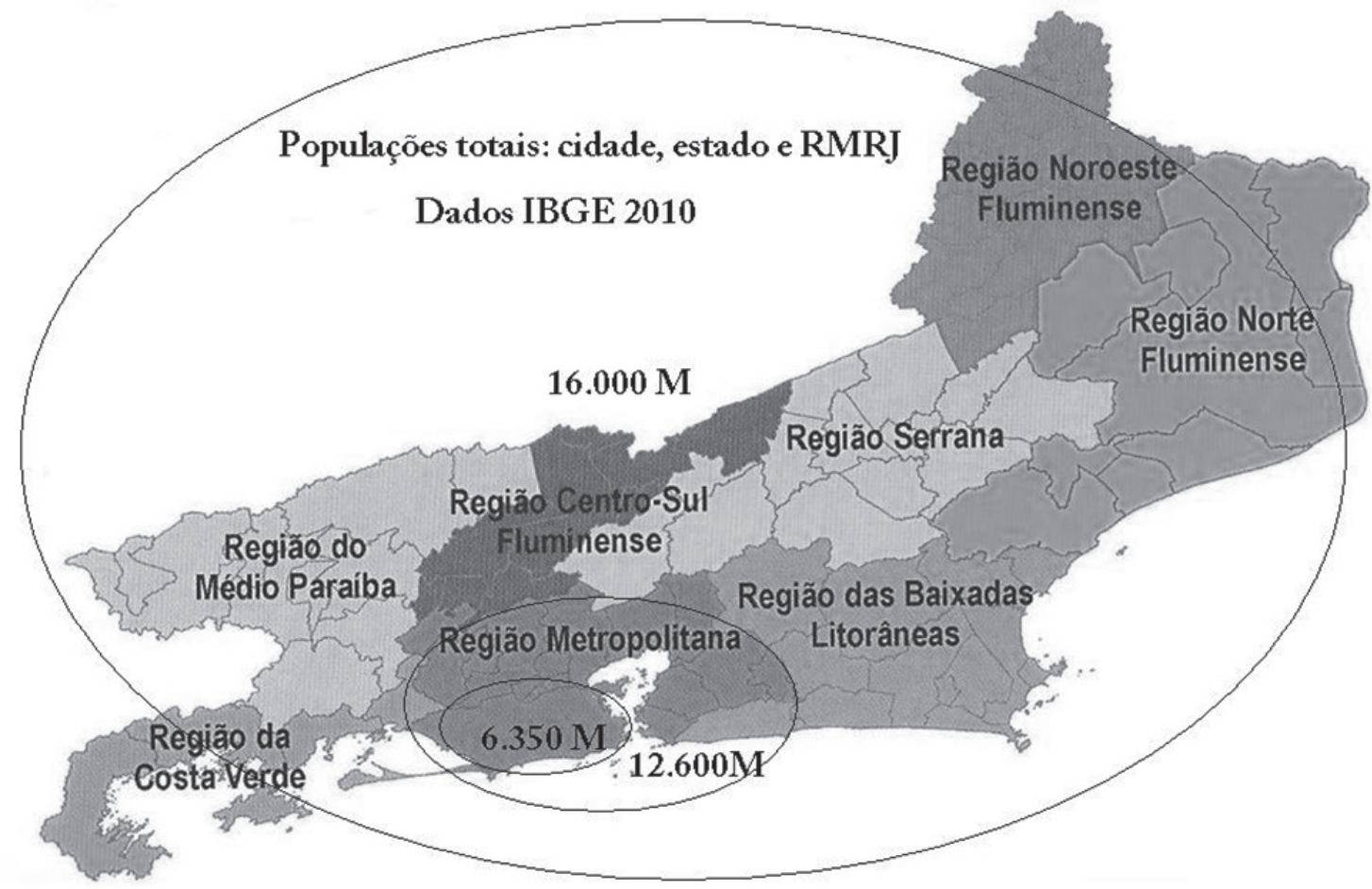

Fonte: Adaptado de Ceperj, 2013, e IBGE, 2010.

Levando-se em consideração tal potencial de investimentos em PCH no estado, é certo que podem favorecer a manutenção e/ou atração de população para as várias regiōes do estado subpovoadas em relação à sua área core, a megarregião metropolitana do Rio de Janeiro (Figura 2). Frente à grande concentração demográfica de população fluminense na faixa metropolitana da cidade carioca (quase $80 \%$ da população total do estado na RMRJ), os investimentos em PCH poderiam tornar as outras sete regiōes de governo, além da metropolitana, capazes de agregar empreendimentos médios e/ou pequenos que alavancassem negócios específicos, diferenciados e pautados nas potencialidades regionais não metropolitanas. As PCH se apresentariam como pequenos grandes investimentos dos setores público e privado, os quais estimulariam negócios diversos e novas fontes de arrecadação de impostos pelos poderes municipais.

A maior parcela do potencial das bacias hidrográficas do estado do Rio de Janeiro, no que diz respeito à capacidade hidráulica, encontra-se em inventário ou projeto básico, sendo que as bacias potencializáveis estão situadas em regiões montanhosas do estado (na faixa de altitude que varia dos trezentos aos oitocentos metros), locais em que é possível utilizar as variações altimétricas na concepção das PCH. 
Deve-se destacar que os rios Macaé e Negro (bacia do Rio Dois Rios) estão com seus inventários em fase de análise pela ANEEL (2013), fato que representa um futuro complemento ao potencial atualmente apresentado. Outro ponto que merece menção é o fato de que os inventários realizados até o presente momento levam em consideração os principais rios da rede de drenagem das bacias do estado. Isso faz com que rios de menor expressão não sejam contemplados nesses estudos, mantendo-se seus potenciais desconhecidos.

Tais dados permitem avaliar a atual organização dos investimentos produtivos no território do estado do Rio de Janeiro. O grande potencial em PCH inventariado seria um importante dinamizador da Região Serrana, possibilitando o direcionamento dos capitais industriais e agrícolas, assim como o fortalecimento dos serviços urbanos, tanto para a referida região como para seu entorno. Isso se observa pelos grandes aportes de investimentos industriais e de serviços nas regióes Metropolitana e das Baixadas Litorâneas, no litoral central do estado. Esses investimentos industriais e logísticos vêm causando grandes transformações na dinâmica territorial fluminense.

De acordo com Coró (2003), deve-se considerar que uma base tecnológica instalada possibilita novas redes sociais, produtivas e geográficas. Portanto, o gerenciamento desses novos vínculos entre as infraestruturas logísticas, capital privado e seus territórios cria um enorme desafio para os gestores locais, em que falhas no planejamento e na gestão produzirão profundas externalidades negativas, tendo a população e o território como principais vítimas.

O grande potencial em PCH inventariado no estado do Rio de Janeiro, principalmente na Região Serrana, pode ser entendido como elemento catalisador da modernização socioespacial em curso no território fluminense desde meados dos anos 1990. Silva (2007) reforça a perspectiva de potencialização não materializada como uma possibilidade para estímulos materiais, humanos e políticos nos espaços com demanda reprimida. A aplicação desses estímulos de maneira correta por agentes de gestão e sua apropriação pelos atores locais resultariam no desenvolvimento de potencialidades espaciais que abririam caminho para a sustentabilidade socioespacial, que estaria baseada em múltiplas visões e perspectivas, para além da visão técnico-produtiva dos territórios. Essas possibilidades serão examinadas a seguir. 


\section{As PCH como potencialidades para o desenvolvimento local: algumas reflexões iniciais sobre sua gestão}

Figura 3: Faixa no território fluminense com grande concentração de PCH.

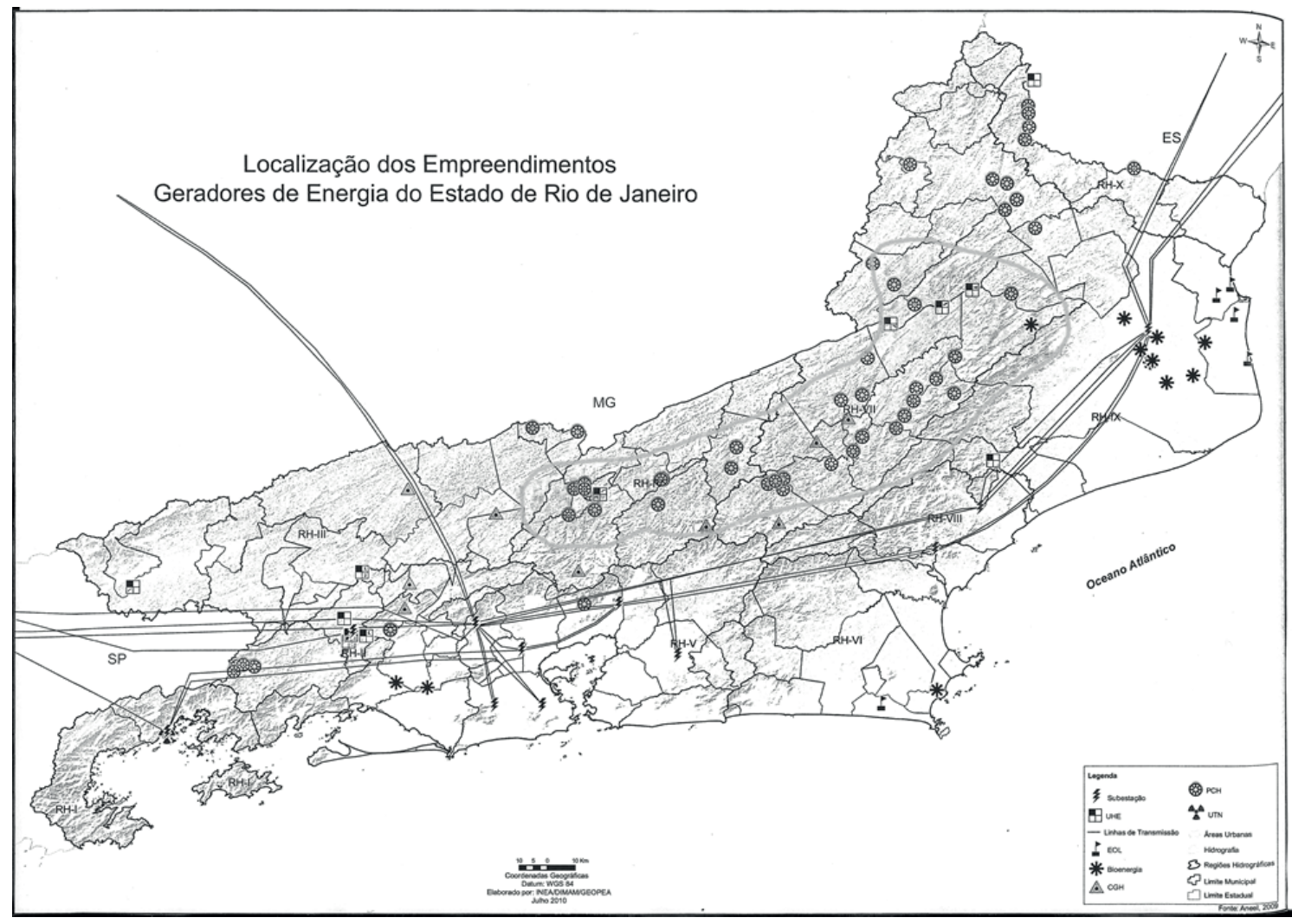

Fonte: Adaptado de SEA/INEA, 2010.

Considerado um setor de base na economia, a geração de energia hidrelétrica no Brasil deve ser profundamente discutida e questionada, notadamente o modelo $\mathrm{PCH}$, pelo fato de poder ser realizado pelas esferas do poder federativo de menor abrangência territorial (estados e municípios), o que o tornará um manancial de formas e estratégias de planejamento e gestão sobre desenvolvimentos sustentáveis e oportunos. Com a implantação das $\mathrm{PCH}$ como projetos de sustentabilidade local, surgirão possibilidades de melhorias socioeconômicas e ambientais em relação a padrões ecológicos diversos. De acordo com Somekh e Campos (2002), essa condição incrementaria os quadros produtivos locais pela diversificação e a dinamização de economias, a partir da geração de emprego e renda. Para atingir a esfera social, deve-se considerar a inclusão de diferentes setores, notadamente aqueles ligados à economia popular, como a pequena produção agrícola, a agroindústria artesanal e o microcomércio de bairro, atividades que movimentam diversos produtos da cadeia produtiva. Além disso, vale lembrar que os programas 
socioambientais implementados para cumprimento da legislação ambiental, como hoje exigem os municípios submetidos a planos diretores e zoneamentos socioeconômicos e ecológicos, trarão benefícios para os meios social, físico e biótico das áreas de influência dos empreendimentos.

Todo empreendimento do tipo PCH possui fortes vínculos com o território e influi positiva e negativamente em seus meios ambientais constitutivos. As transformações geradas pela implantação de empreendimentos hidroenergéticos que afetam, direta e indiretamente, o meio ambiente, a população em seu modo de vida, a dinâmica de trabalho, os hábitos e costumes têm sido pauta constante nos fóruns da sociedade civil organizada e do Poder Público em seus diversos órgãos e escalas. Inevitavelmente, a gestão ineficaz das transformações e da relação com os atores estratégicos envolvidos gera passivos para o território e seus atores.

A falta de um conhecimento mais profundo acerca das variáveis envolvidas nessa dinâmica usualmente contribui para que sejam criados planos parciais e/ou paliativos e, consequentemente, ações pouco eficazes. O direcionamento incorreto ou ineficiente de recursos para a efetiva solução das transformações pode aumentar, de modo significativo, os gastos inicialmente previstos para a implantação de um empreendimento, seja ele hidroenergético ou de qualquer outra natureza.

Como identificado por diversos relatórios oficiais da ANEEL, a dinamicidade do parque gerador hidrelétrico nacional causou um movimento de constante reformulação da legislação ambiental. Atualmente, diversos empreendimentos estão sujeitos ao licenciamento ambiental, e as PCH estão inseridas nesse grupo. E, para que elas alcancem a fase de operação, devem cumprir uma série de exigências provenientes das agências reguladoras de setores dos órgãos ambientais responsáveis. Portanto, a seguir, abordam-se as principais atribuiçôes das empresas para atingirem as licenças ambientais.

Os estudos ambientais provenientes de exigências dos órgãos ambientais podem ser vistos como instrumentos que podem ser utilizados com diversas finalidades. Com a promulgação da Resolução Conama no 001/1986, a elaboração do Estudo de Impacto Ambiental/Relatório de Impactos sobre o Meio Ambiente (EIA/RIMA) passou a ser uma exigência em boa parte dos empreendimentos hidrelétricos para obtenção da licença prévia, representando benefícios em diversos aspectos. Além disso, levam-se em conta as características de engenharia para que seja possível propor medidas mitigadoras e compensatórias diante das externalidades sempre presentes. Vale lembrar que o conteúdo do EIA/ RIMA está em consonância com o termo de referência dos órgãos ambientais responsáveis. Outro aspecto importante é o caráter público do RIMA, o que dá à população interessada acesso às informaçóes do empreendimento, bem como a possibilidade de participação ativa nas audiências públicas realizadas para aprovação do processo de licenciamento ambiental.

Mais um importante instrumento de avaliação para o licenciamento ambiental de empreendimentos hidrelétricos é o Relatório Ambiental Simplificado (RAS), referente à Resolução Conama no 279/2001. Como o RAS surgiu em um período de crise energética nacional e abertura para o investimento do capital privado em PCH, o instrumento contempla os mesmos aspectos do EIA, mas de maneira simplificada, a fim de agilizar o processo de licenciamento. Vale lembrar que esse estudo de avaliação ambiental é voltado somente aos empreendimentos causadores de baixo impacto.

Além dos estudos citados, chama-se a atenção também para o Plano Básico Ambiental (PBA). Segundo a Resolução Conama no . 06/1987, o PBA é o estudo desenvolvido para o cumprimento das condicionantes, com vistas à obtenção da licença de instalação de uma PCH. Esse documento apre- 
senta todas as medidas de controle e os programas socioambientais propostos no EIA, possibilitando a definição das açôes e dos programas a serem desenvolvidos em todas as etapas do projeto, desde o início das obras até a etapa de operação do empreendimento e seu monitoramento.

Para que seja possível um melhor entendimento da aplicabilidade desses instrumentos na gestão pública, foi realizada uma visita às obras de instalação da $\mathrm{PCH}$ Santo Antônio, no rio Grande, ${ }^{9}$ município de Bom Jardim, bacia do rio Dois Rios, Rio de Janeiro. Assim, a partir de entrevista realizada com uma analista ambiental da empresa, foi possível ter acesso ao PBA da PCH Santo Antônio e obter informaçôes sobre os outros empreendimentos nesse mesmo rio.

Figura 4: Localização das PCH visitadas em trabalho de campo (outubro de 2013).

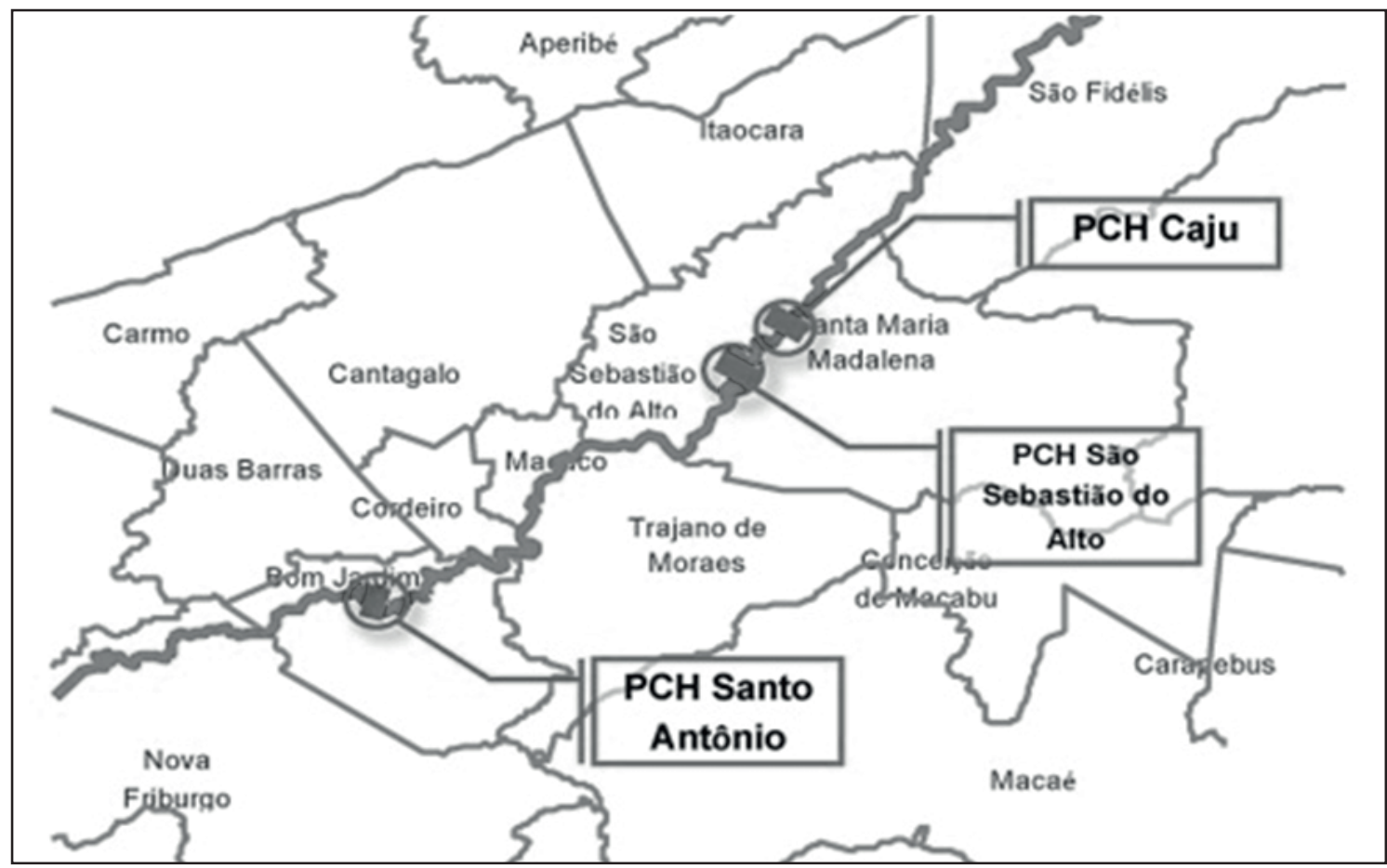

Fonte: Disponível em http://www.grupoenergisa.com.br/Geracao/usinasemconstrucao/pchsriogrande.aspx. Acesso em 7 out. 2013 (adaptado).

Dessa forma, foi possível identificar os programas de cunho socioambiental, seus objetivos e os respectivos resultados para as áreas direta ou indiretamente afetadas pela $\mathrm{PCH}$ :

a. Programa de Gestão Ambiental: promover os programas ambientais de maneira articulada, atender aos requisitos legais e exigências técnicas do órgão ambiental e funcionar como ouvidoria para a população;

\footnotetext{
9 A PCH visitada é a terceira da empresa Energisa Geração Rio Grande S.A (pertence ao grupo Energisa S.A.), a qual também é proprietária das PCH São Sebastião do Alto e PCH Caju, todas alocadas no rio Grande.
} 
b. Programa Ambiental de Construção: estabelecer critérios e requisitos para orientar os construtores em relação ao cuidado com as questôes ambientais no período de construção;

c. Programa de Contratação e Desmobilização de Mão de Obra: priorizar a contratação de mão de obra local (Bom Jardim) para internalizar os efeitos positivos da geração de empregos relacionados ao empreendimento;

d. Programa de Comunicação Social: constituir canais de diálogo entre empreendedor e sociedade, principalmente para a população diretamente afetada pelo empreendimento, de forma a motivar sua participação nas diferentes etapas de implantação;

e. Programa de Educação Ambiental: desenvolver ações educativas formuladas em processo participativo, visando capacitar/habilitar os setores sociais para a efetiva melhoria da qualidade ambiental e de vida na região.

f. Programa de Apoio às Unidades de Conservação: aplicar 0,5\% do custo do empreendimento em Unidades de Conservação na área de influência da $\mathrm{PCH}$;

g. Programa de Indenização de Terras e Benfeitorias: recompor o patrimônio e a economia dos proprietários de terras afetadas, de acordo com as condiçóes encontradas;

h. Programa de Remanejamento da População: garantir que o processo de remanejamento da população atingida ocorra em consonância com as expectativas e demandas dos atingidos, preservando sua qualidade de vida;

i. Programa sobre Patrimônio Cultural: proteger os bens culturais ameaçados de destruição pelo empreendimento;

j. Programa de Monitoramento das Comunidades Aquáticas: complementar o inventário da ictiofauna do rio Grande e reestruturar as comunidades de peixes na área de influência da PCH;

k. Programa de Gerenciamento de Resíduos e Efluentes: monitorar a qualidade da água antes e depois da construção, promovendo medidas para controlar e equilibrar as comunidades faunísticas e aquáticas na área de influência da $\mathrm{PCH}$;

1. Programa de Limpeza da Bacia de Acumulação: mensurar e retirar toda a vegetação da área a ser inundada;

m. Programa de Reflorestamento das Margens do Reservatório: promover a recomposição e a manutenção das matas ciliares do rio Grande;

n. Programa de Controle de Processos Erosivos: mapear e conter os processos erosivos a montante e a jusante do empreendimento a partir do reflorestamento com espécies nativas;

o. Programa de Hidrossedimentologia: monitorar o comportamento hidrossedimentológico antes e depois do enchimento do reservatório.

(Entrevista e consulta realizadas em 18 de outubro de 2013) 


\section{Sustentabilidade da produção energética no Rio de Janeiro}

Ainda de acordo com a entrevistada, as outras duas $\mathrm{PCH}$ receberam os mesmos programas citados, o que possibilitou a obtenção da Licença de Operação pelo INEA. A partir da figura anterior, constata-se a abrangência da atuação da empresa, na bacia do Rio Grande, atingindo os municípios de Bom Jardim, Santa Maria Madalena e São Sebastião do Alto. Os programas dos três empreendimentos são voltados aos meios físico, biótico e social, e estão correlacionados entre si. Devido ao elevado número de programas, destacam-se os resultados mais expressivos obtidos na PCH Santo Antônio.

Inicialmente, cabe destacar o programa de reflorestamento das margens do rio dentro da área de influência do empreendimento. Para a implantação dessa PCH, foi necessária a supressão de 20 hectares de florestas. Em contrapartida, realizou-se o reflorestamento de 300 hectares com mudas nativas provenientes de viveiro construído no local, e parte das mudas virá de sementes catadas das espécies nativas, evitando-se a mudança da carga genética do local. Dessa forma, foram reflorestadas áreas degradadas e improdutivas no entorno do empreendimento, do rio e entre fragmentos florestais, fato que possibilita a formação de corredores ecológicos. Assim, uma nova via foi criada para que houvesse maior fluxo gênico entre as espécies animais e vegetais.

O reflorestamento foi correlacionado com as medidas do programa de controle de processos erosivos, levando-se em conta que a reconstituição da cobertura vegetal trará benefícios, como a minimização de processos intempéricos, erosivos e, consequentemente, de assoreamento do rio Grande. Além disso, o programa de apoio às Unidades de Conservação (UC) vem permitindo investimentos em UC já existentes ou na criação de novas UC (o grupo econômico já criou duas UC classificadas como Reservas Particulares do Patrimônio Natural em dois empreendimentos no estado de Minas Gerais). De acordo com o PBA e a entrevistada, o programa de educação ambiental está em desenvolvimento nas instalações da PCH, na rede de ensino público e na comunidade local. Esse programa busca disseminar novas posturas, hábitos e costumes junto à comunidade de Bom Jardim e, para isso, foi realizada a capacitação de agentes multiplicadores da rede pública de ensino municipal e estadual, bem como da secretaria de saúde do município, para a realização de palestras, oficinas, videodebates e alguns eventos, como o plantio de mudas nativas e oficinas para conhecimento da fauna, da flora e dos recursos naturais da região. Além disso, atividades relacionadas à gestão de resíduos e saneamento básico para diminuir a incidência de doenças de veiculação hídrica estão sendo desenvolvidas nas mesmas oficinas.

O programa de comunicação social apresenta-se como uma ferramenta de aproximação dos três setores produtivos do município de Bom Jardim. Com esse programa, todos os impactos positivos e negativos são comunicados com o intuito de criar um relacionamento construtivo entre o grupo e a sociedade civil, o que faz com que o primeiro passe a ser reconhecido pelo segundo como um novo agente local e regional, com responsabilidades junto aos vizinhos e ao território no qual está alocado.

Para finalizar, vale destacar que a contratação de $95 \%$ da mão de obra da construção foi proveniente do município de Bom Jardim, atingindo mais de trezentos funcionários no pico da obra (2012). Acrescenta-se que a prefeitura do município passou a receber impostos como ISS e ICMS da PCH Santo Antônio.

Com os exemplos citados, percebe-se que as medidas adotadas para fins de licenciamento ambiental são permanentes, pois vão perdurar após o início da operação das PCH. A interrupção dos programas contidos no PBA pode acarretar a não renovação da licença de operação das $\mathrm{PCH}$. 
Portanto, constata-se que o cumprimento dos dispositivos legais do processo de licenciamento ambiental apresenta caráter positivo para o território. O primeiro fator que comprova esse fato é a possibilidade de acesso da população aos estudos desenvolvidos pelo empreendedor, disponibilizando um conteúdo pouco conhecido e enriquecedor para a população local, como, por exemplo, a composição de fauna, flora e elementos naturais de seu território. Outro fator importante é a inclusão da população na política socioambiental da empresa, por meio dos programas do PBA, mostrando uma nova perspectiva, que passa pela consideração dos moradores como interlocutores diretos no território. Além disso, esses estudos podem ser utilizados como subsídios para políticas públicas e estudos de futuros projetos, uma vez que identificam as potencialidades e as vulnerabilidades locais e regionais.

\section{Referências}

BIG-ANEEL - Agência Nacional de Energia Elétrica. Relatórios diversos. Disponível em: http://www. aneel.gov.br. Acesso em: 20 abr. 2015.

BRASIL. Lei no 9.433, de 20 de dezembro de 1997. "Institui a Política Nacional de Recursos Hídricos, cria o Sistema Nacional de Gerenciamento de Recursos Hídricos, regulamenta o inciso XIX do art. 21 da Constituição Federal, e altera o art. $1^{\circ}$ da Lei no 8.001, de 13 de março de 1990, que modificou a Lei no 7.990, de 28 de dezembro de 1989”. Disponível em: http://www.planalto.gov. br/ccivil_03/Leis/L9433.htm.

CASTRO, Nivalde de et al. "A importância das fontes alternativas e renováveis na evolução da matriz elétrica brasileira”, V Seminário de Geração e Desenvolvimento Sustentável, Fundación Mapfre, 2009.

CEPERJ. Mapa das regióes de governo do estado do Rio de Janeiro, 2014. Disponível em: http://www. ceperj.rj.gov.br/ceep/info_territorios/Reg\%20Gov_2013.pdf. Acesso em: 15 mar. 2016.

CORÒ, Giancarlo. "Logística, economia global e desafios para o Made in Italy". In MONIÉ, Fréderic e SILVA, Gerardo (orgs.). A mobilização produtiva dos territórios: instituições e logística do desenvolvimento local. Rio de Janeiro: DP\&A, 2003.

EPE-BEN - Empresa de Pesquisa Energética. Relatórios diversos. Disponível em: http://www.epe.gov. br. Acesso em: 20 abr. 2015.

FARIA, Ivan Dutra. "Ambiente e energia: crença e ciência no licenciamento ambiental, Parte III. Núcleo de Estudos e Pesquisa do Senado Federal". Texto para Discussão no 93. 2011. Disponível em: http://www.senado.gov.br/senado/conleg/textos_discussao/TD99-IvanDutraFaria.pdf. Acesso em: $1^{\circ}$ maio 2015.

FIORI, José Luís. Em busca do dissenso perdido: ensaios críticos sobre a festejada crise do estado. Rio de Janeiro: Insight, 1995.

GLEICK, P. H. Water in crisis: a guide to the world's fresh water resources. S.l.: Editor Book, 1993. $473 \mathrm{p}$.

IBGE - Instituto Brasileiro de Geografia e Estatística. Dados do Censo Demográfico de 2010. Disponível em: www.ibge.gov.br. Acesso: 14 mar. 2016. 


\section{Sustentabilidade da produção energética no Rio de Janeiro}

IGLIORI, Danilo Camargo. Economia de clusters industriais e desenvolvimento. São Paulo: Iglu/Fapesp, 2001.

MME - Ministério do Meio Ambiente. Plano Decenal de Energia (PDE, vários anos). Relatórios diversos. Disponível em: www.mme.gov.br. Acesso em: 20 abr. 2015.

SANTOS JÚNIOR, Orlando Alves dos. Democracia e governo local: dilemas da reforma municipal no Brasil (tese). UFRJ/IPPUR, 2000.

SEA - Secretaria Estadual do Ambiente e INEA - Instituto Estadual do Ambiente. O estado do ambiente: indicadores ambientais do Rio de Janeiro 2010. Rio de Janeiro: Secretaria do Ambiente/Governo do Estado do Rio de Janeiro/SEA/INEA, 2011. 160 p.

SILVA, Augusto César Pinheiro da. "Discursos e práticas institucionais no estado do Rio de Janeiro: paradoxos organizacionais na modernização do espaço rural fluminense”. In OLIVEIRA, Rogério et al. (orgs.). Paisagem, espaço e sustentabilidades: uma perspectiva multidimensional da geografia. Rio de Janeiro: PUC-Rio, 2007. 330 p.

—_ "Geografia e meio ambiente: as políticas de estado na configuração de sustentabilidades no Brasil”, Revista eletrônica ACTA Geográfica, Boa Vista, "Geografia Política e Geopolítica”, 2014, pp. 121-37. Disponível em: http://revista.ufrr.br/index.php/actageo/article/view/2355/1347.

SOMEKH, Nadia e CAMPOS, Candido M. A cidade que não pode parar: planos urbanisticos de São Paulo no século XX. São Paulo: Mackpesquisa, 2002. 


\title{
Transformações no espaço rural fluminense: o papel da agricultura familiar e das atividades turísticas
}

Glaucio José Marafon ${ }^{1}$

\section{Introdução}

$\mathrm{N}$ a atualidade, ao analisarmos as mudanças do mundo rural e as transformações em curso, é necessário remeter ao processo de urbanização (das ocupações não agrícolas, da expansão do consumo, da acessibilidade etc.). Essas mudanças estão, em grande medida, associadas aos espaços de lazer, de produção industrial e dos "processos de produção de valores simbólicos" (Reis, 2001, p. 7). Entre as principais transformações, encontramos maior urbanização, cosmopolitismo dos comportamentos e intensa relação com os mercados de trabalho. Concordamos com Reis (2001, p. 12) quando afirma que

\begin{abstract}
parece claro que as mudanças no meio rural e a maior territorialização das práticas socioeconômicas comportam uma mais intensa relação das práticas socioeconômicas comportam uma mais intensa relação quer com políticas públicas, quer com agentes externos (que seguem essas políticas). Esta dupla abertura do espaço rural (a que lhe é trazida por agentes externos que o procuram segundo novos interesses e novas lucratividades e a que resulta da própria metamorfose dos agentes originariamente locais) é com certeza o grande traço de novidade para o que aí vem. Resta, pois, continuar a observar de que modo abertura e mudança geram novas mudanças.
\end{abstract}

Entretanto, além da produção moderna e integrada aos mercados globalizados, temos a presença expressiva da produção de base familiar no meio rural brasileiro. Em busca de reprodução e sobrevivência, a produção familiar tem apresentado características como trabalho em tempo parcial, em face da diminuição da jornada de trabalho (favorecida pela incorporação das tecnologias de produção), ou seja, há liberação de membros da família para exercer outras atividades, agrícolas e não agrícolas, complementando, assim, a renda familiar.

\footnotetext{
${ }^{1}$ Professor associado do IGEOG/UERJ e bolsista CNPq CNE/Faperj.
} 
Atualmente, entre as atividades não agrícolas presentes no campo, merecem destaque as atividades turísticas, devido à proliferação das áreas de lazer. $\mathrm{O}$ desenvolvimento de atividades turísticas está associado ao processo de urbanização e ao transbordamento do espaço urbano para o espaço rural (Graziano da Silva, 1998). Para esse autor, "novas” formas de ocupação passaram a proliferar no campo. Entre elas, destacam-se: um conjunto de profissões tidas como urbanas (trabalhadores domésticos, mecânicos, secretárias etc); moradias de segunda residência; atividades de conservação; áreas de lazer (hotéis-fazenda, fazendas-hotel, pesque-pague, entre outras). Essas novas atividades demandaram um número crescente de pessoas para dar sustentação à expansão das atividades turísticas no espaço rural, o que possibilitou que os membros das famílias, liberados das atividades rotineiras da exploração agrícola, pudessem ocupar as vagas geradas pela expansão do turismo nos espaços rurais.

Para Rua (2007), há algum tempo o espaço rural é percebido como terra-mercadoria capaz de gerar outras mercadorias. Surgem novas territorialidades resultantes da interação campo-cidade. Essa hibridez está presente nas diversas atividades que encontramos no campo e está associada às atividades rurais. Ainda segundo Rua, existem duas vertentes da teoria social crítica que analisam as relaçóes entre o urbano e o rural. A primeira procura trabalhar com a noção de urbanização do rural, com a incorporação do rural ao urbano, associada à ideia de um continuum, ou seja, haveria graus distintos de urbanização do território. A outrapostula a urbanização no rural e entende a manutenção de especificidades no espaço rural, mesmo com a impactação do urbano.

Nesse sentido, concordamos com Ferrão (2000) ao sinalizar que deveremos levar em consideração que o espaço rural não é somente agrícola. Rompe-se deliberada e explicitamente com dois elementos secularmente associados ao rural: sua função principal não é mais, necessariamente, a produção de alimentos, nem a atividade predominante é a agrícola, reforçando, assim, a noção de hibridez do espaço rural. A dimensão não agrícola vem aumentando e, muitas vezes, está associada à noção de patrimônio, com a renaturalização da paisagem. Enfatizam-se a preservação e a proteção da natureza, valoriza-se a busca pela autenticidade dos elementos paisagísticos locais, a conservação e a proteção dos patrimônios históricos e culturais, o resgate da memória e da identidade. Dessa forma, há uma mercantilização das paisagens, com a consequente expansão das atividades de turismo e de lazer.

$\mathrm{Na}$ atualidade, com a (re)valorização da natureza, com o retorno de pessoas para as áreas rurais, esses territórios passaram a ser alvo de atenção e a merecer uma visão não mais setorial, mas territorial. Em outras palavras, busca-se uma forma de promover o desenvolvimento sob a ótica do território, a fim de romper com a visão setorial até então dominante e com um perfil mais adequado ao período pós-fordista. Reafirma-se a revalorização de temas associados à produção familiar, à conservação do ambiente, às estratégias de sobrevivência dos produtores rurais, à busca pelas múltiplas funções do espaço rural e à proliferação de atividades não agrícolas.

Esses processos ocorrem no estado do Rio de Janeiro, porém não com a mesma intensidade. Em função de seu elevado grau de urbanização, das dificuldades com a mecanização de seus solos e da expansão imobiliária decorrente, sobretudo com as atividades turísticas desenvolvidas, temos muito mais mudanças que permanências no espaço rural fluminense. As permanências seguem o padrão brasileiro de concentração fundiária, precariedade nas relações de trabalho e conflitos pelo acesso à terra. As mudanças, por sua vez, estão associadas à valorização do espaço rural, com a presença crescente de pessoas oriundas da cidade em busca de áreas de lazer ou de uma segunda residência, devido à valorização das terras e ao surgimento de atividades não agrícolas (em geral, 


\section{Transformações no espaço rural fluminense}

de baixa qualificação). Essas terras, então, passam a ser ocupadas pelos integrantes das famílias de produtores rurais.

Este ensaio tem o objetivo de efetuar algumas considerações sobre a permanência da produção familiar e o avanço de atividades não agrícolas no território fluminense, sobretudo aquelas associadas às atividades turísticas no território fluminense. Buscamos embasamento no referencial bibliográfico, em dados censitários e em informações de cunho qualitativo, obtidas nos trabalhos de campo. Tudo isso nos levou a identificar algumas características da produção familiar e das atividades turísticas desenvolvidas no estado do Rio de Janeiro. Assim, apresentamos um debate sucinto sobre a produção familiar e as atividades turísticas, bem como sobre seu rebatimento no território fluminense.

\section{Debate sobre produção familiar}

Existe um consenso em torno do conceito de produção familiar, que se caracteriza pelo trabalho familiar na exploração agropecuária e pela propriedade dos meios de produção. Para Wanderley (1999), atualmente a agricultura familiar se constitui em um conceito genérico, que incorpora uma diversidade de situações específicas e particulares. Dessa forma, o campesinato corresponde a uma dessas manifestações específicas da agricultura familiar.

A concepção que prioriza a agricultura familiar como unidade de análise está centrada nos estudos da FAO/Incra (1994), que divide a exploração agrícola em modelo patronal e familiar, e no estabelecimento do Programa Nacional de Produção Familiar (Pronaf). Objetiva-se estabelecer diretrizes e ações que levem ao desenvolvimento rural e à integração dos produtores familiares ao mercado e, para tanto, realiza-se uma classificação dos agricultores familiares brasileiros. Assim, a agricultura de propriedade familiar se caracteriza por estabelecimentos em que a gestão e o trabalho estão intimamente ligados, ou seja, os meios de produção pertencem à família, e o trabalho é exercido por esses mesmos proprietários em uma área relativamente pequena ou média.

Segundo a classificação da FAO/Incra (2000) e Molina Filho (1979), os agricultores familiares estariam classificados em três eixos: consolidados, em transição e periféricos ou de subsistência.

A valorização do mundo rural e as transformações que ocorrem nas unidades familiares de produção, como, por exemplo, a diminuição do tempo destinado às atividades agrícolas, a diminuição da renda agrícola, a busca por outras atividades para a complementação de renda, o retorno para as áreas rurais de pessoas oriundas do espaço urbano, sobretudo aquelas que se aposentam, que, então, passam a se dedicar também às atividades agrícolas, tudo isso tem levado a uma busca pela caracterização desses fenômenos, os quais, de forma genérica, têm sido denominados de unidades familiares de produção pluriativas.

No Quadro 1, encontramos os principais temas investigados no setor agropecuário brasileiro, a partir da metade do século XX. Nele, é possível observar que a abordagem da agricultura familiar foi-se intensificando a partir de meados da década de 1980 e se consolidou na década de 1990 . A agricultura familiar, embora não seja uma categoria recente, ganhou importância na análise do espaço rural brasileiro apenas na década de 1990. 
Quadro 1. Síntese dos principais temas voltados à agricultura a partir de 1950

\begin{tabular}{|c|c|}
\hline Período & Principais discussóes e vertentes \\
\hline Décadas de 1950 e 1960 & $\begin{array}{l}\text { Três vertentes principais: } \\
\text { 1) Agricultura como entrave econômico } \\
\text { 2) Visão funcionalista da agricultura } \\
\text { 3) Visão descritiva } \\
\text { Nenhuma delas destacava a agricultura familiar. }\end{array}$ \\
\hline Década de 1970 & $\begin{array}{l}\text { A pequena produção e o campesinato ganham destaque nas análises. } \\
\text { Duas vertentes de análise: } \\
\text { 1) Análise da pequena produção como relação não capitalista } \\
\text { 2) Análise da pequena produção em relação à subordinação ao capital } \\
\text { Não trabalha especificamente com agricultura familiar, mas vê a pequena produção como } \\
\text { uma solução para os problemas brasileiros. }\end{array}$ \\
\hline Década de 1980 & $\begin{array}{l}\text { Discussões mais importantes: } \\
\text { 1) Debate sobre a modernização da agricultura e suas consequências para a sociedade } \\
\text { brasileira } \\
\text { 2) Modernização dependente da ação do Estado } \\
\text { 3) Complexo agroindustrial como unidade analítica fundamental } \\
\text { 4) A pequena produção passa a não mais ser vista como uma solução para os problemas } \\
\text { brasileiros } \\
\text { 5) A agricultura familiar começa a ganhar destaque no final da década }\end{array}$ \\
\hline $\begin{array}{l}\text { A partir da década de } \\
1990\end{array}$ & $\begin{array}{l}\text { 1) Agricultura familiar como unidade analítica fundamental } \\
\text { 2) Emergência de um novo paradigma tecnológico (sustentabilidade ambiental) } \\
\text { 3) Agricultura familiar como possibilidade de atingir cidadania e como receptora de políti } \\
\text { cas públicas, com destaque para o Pronaf } \\
\text { Duas vertentes principais: } \\
\text { 1) Agricultura familiar como uma forma de produção camponesa } \\
\text { 2) Agricultura familiar como resultado do processo de modernização da agricultura }\end{array}$ \\
\hline
\end{tabular}

Fonte: Hespanhol, R. A. de M. (2000) e Cortes, C. P. (2008).

Apesar da grande complexidade na elaboração do conceito, algumas características devem basear a análise e definição da chamada agricultura familiar. Assim como Hespanhol (2000) destaca a terra, o trabalho e a família como fatores fundamentais para sua definição, Abramovay (1997) afirma que

a agricultura familiar é aquela em que a gestão, a propriedade e a maior parte do trabalho vêm de indivíduos que mantêm entre si laços de sangue ou de casamento. Que esta definição não seja unânime e muitas vezes tampouco operacional é 


\section{Transformações no espaço rural fluminense}

perfeitamente compreensível, já que os diferentes setores sociais e suas representaçōes constroem categorias científicas que servirão a certas finalidades práticas: a definição de agricultura familiar, para fins de atribuição de crédito, pode não ser exatamente a mesma daquela estabelecida com finalidades de quantificação estatística num estudo acadêmico. $\mathrm{O}$ importante é que estes três atributos básicos (gestão, propriedade e trabalho familiares) estão presentes em todas elas (p. 3).

O conceito de agricultura familiar - ou pelo menos aquilo que assim é considerado nas políticas públicas - foi politicamente construído. Essa construção visou englobar interesses, inclusive a melhoria das condições dos trabalhadores do campo, que, incluídos nessa categoria, teriam a real possibilidade de tentar um financiamento para produção ou aumento de produtividade.

O campo não pode mais ser visto como sinônimo de área em que se desempenham apenas atividades agrícolas, embora estas mantenham a grande importância em sua dinâmica. Porém, a diversidade de atividades desenvolvidas e de condiçôes sociais, culturais e políticas desse espaço contribui para aumentar a complexidade de seu funcionamento, não representando uma área apenas de produção de bens para os grandes centros urbanos ou abastecimento dos complexos agroindustriais. As atividades diversas e as relações envolvidas no espaço rural hoje são tantas que não podem sequer ser entendidas como transformações facilmente padronizáveis. Ocorrem de acordo com as localidades e as realidades envolvidas, o que torna ainda mais complexto seu estudo. Essas transformações não são homogêneas no espaço e apresentam particularidades de acordo com os interesses dos agentes envolvidos, com a disposição de infraestrutura, a atuação governamental e a proximidade com os grandes centros urbanos, entre outros fatores.

De todos os fatores apontados, destaca-se como um dos mais importantes na difusão das transformaçôes no campo a proximidade com os maiores e mais dinâmicos centros urbanos. A proximidade com as regiôes metropolitanas favorece a criação de fluxos em direção às áreas rurais em busca de amenidades, além da construção de casas de segunda residência. As classes média e alta, principais consumidoras dos espaços rurais, atraem investimentos privados e públicos, que melhoram a infraestrutura e os atrativos locais, facilitando, portanto, a reprodução de atividades turísticas e não agrícolas no meio rural.

Nesse sentido, as atividades turísticas merecem destaque na análise das relações existentes nos ambientes rurais, contribuindo para a intensa transformação espacial das áreas em que atuam, principalmente naquelas próximas dos maiores centros urbanos. $\mathrm{O}$ chamado turismo em espaços rurais atrai cada vez mais adeptos e movimenta a economia dos municípios do estado do Rio de Janeiro. Para Marafon (2006, p. 27),

[...] o turismo em espaços rural se afirma como mais uma alternativa que se coloca para os agricultores familiares venderem sua força de trabalho e complementar sua renda, reforçando o caráter pluriativo das unidades familiares de produção e inseridos no processo de produção do espaço. 
O estado do Rio de Janeiro, em virtude de seu alto grau de urbanização e rede de circulação e comunicação, apresenta elevado grau de conexão entre as áreas de produção familiar e as práticas de atividades turísticas.

\section{Agricultura familiar e atividades turísticas: reflexões a partir do território fluminense}

O estado do Rio de Janeiro é o segundo polo industrial do Brasil, produz cerca de $71 \%$ do petróleo nacional e também é o maior produtor de gás natural do país. Além disso, sua produção de pescado é significativa, assim como a olericultura, a horticultura e o leite. Sua paisagem natural é bastante diversificada, mas também muito degradada, devido às atividades socioeconômicas vivenciadas pelo estado. Corresponde ao estado mais urbanizado do país, com $96,7 \%$ da população vivendo em áreas urbanas, e, de acordo com Rua (2007), o território fluminense é marcado por eixos de urbanização nos quais ocorre uma urbanização mais densa. Percebe-se, assim, uma redistribuição populacional e das atividades produtivas (Limonad, 1996).

Tabela 1. População urbana, rural e índice de urbanização no estado do Rio de Janeiro - 1950/2010

\begin{tabular}{|l|c|c|c|c|}
\hline Ano & Total & Urbana & Rural & Índice (\%) \\
\hline 1950 & 4.674 .645 & 3.392 .653 & 1.281 .992 & 72,6 \\
\hline 1960 & 6.709 .891 & 5.300 .629 & 1.409 .262 & 79,0 \\
\hline 1970 & 8.994 .802 & 7.906 .146 & 1.088 .656 & 87,9 \\
\hline 1980 & 11.291 .520 & 10.368 .191 & 923.329 & 91,8 \\
\hline 1991 & 12.807 .706 & 12.199 .641 & 608.065 & 95,3 \\
\hline 2000 & 14.391 .282 & 13.655 .386 & 569.816 & 94,9 \\
\hline 2010 & 15.989 .929 & 15.464 .239 & 525.690 & 96,7 \\
\hline
\end{tabular}

Fonte: Censos Demográficos/IBGE - 1950/1960/1970/1980/1991/2000/2010 (Negef, 2015).

Apesar da ainda acentuada concentração da população fluminense na Região Metropolitana, nos anos 1990 surgem algumas novidades em relação à dinâmica demográfica do estado do Rio de Janeiro. A mais importante diz respeito à simultaneidade de um movimento tendente à despolarização espacial, com a emergência de novos centros de porte médio no interior do estado, e de outro, em sentido inverso, de consolidação dos centros urbanos metropolitanos (Santos, 2003). Apesar de a expansão demográfica nas bordas metropolitanas manifestar-se desde, pelo menos, a década de 1950, esse movimento não resultou em desconcentração da população em direção ao interior.

Rua (2002, pp. 47-8) assinala que, no estado do Rio de Janeiro, "prevalece a projeção da metrópole carioca, que intensifica o processo de urbanização", e essa intensa urbanização marca forte- 


\section{Transformações no espaço rural fluminense}

mente o território fluminense nas "dimensões política, cultural, comportamental e econômica, onde o significado dessa área urbana torna-se esmagador”. O interior fluminense vem-se destacando não somente em termos de crescimento demográfico (ainda pequeno), mas também no abastecimento de produtos agropecuários (hortigranjeiros, leite e produtos com nicho de mercado especializado, como orgânicos, ervas finas, leite de cabra, trutas, entre outros), além de estar servindo como área de lazer para a prática de turismo rural, de ordem contemporânea, com a proliferação de hotéis-fazenda, pousadas, spas e casas de segunda residência. A prática desse turismo em espaço rural segue, em boa medida, os eixos de urbanização na Figura 1, tratando-se de uma prática alternativa ao turismo intenso que ocorre na costa fluminense (Costa Verde e Baixadas Litorâneas).

Figura 1. Eixos de maior densidade de urbanidades no estado do Rio de Janeiro

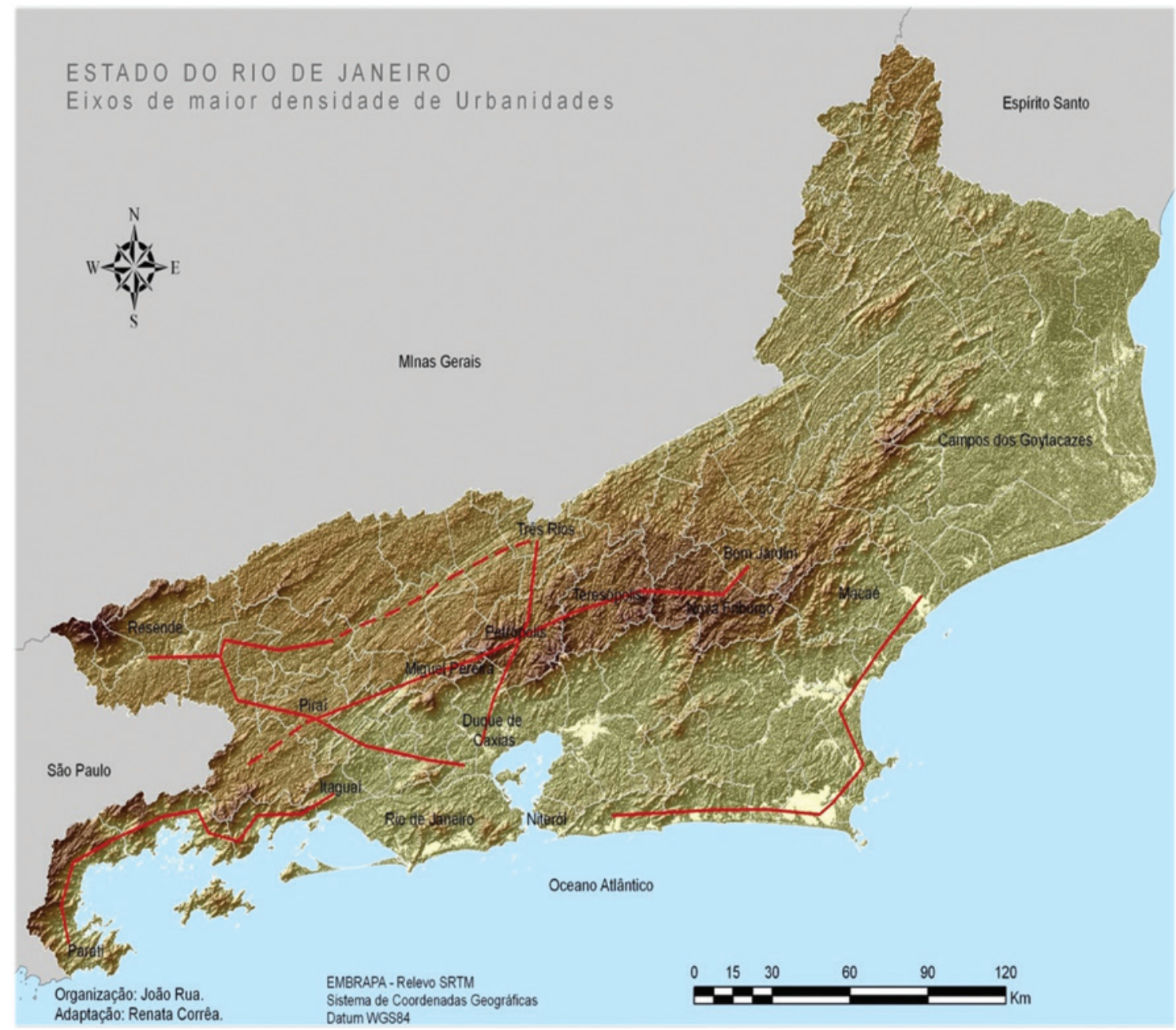

Fonte: Adaptado de João Rua. 
No Quadro 2, tem-se uma radiografia da distribuição dos estabelecimentos agrícolas no estado do Rio de Janeiro para os anos de 1996 e 2006, constatando-se que a maioria desses estabelecimentos apresenta menos de 100 ha. Em 1996, representavam 75\% e, em 2006, 84\%, o que imprime significativa importância à produção familiar e às estratégias que esses agricultores encontram para fazer frente à queda na renda agrícola e ao intenso processo de urbanização. Observa-se, de 1996 a 2006, um aumento do número de estabelecimentos, mas uma pequena diminuição da área ocupada por eles.

Constata-se que a estrutura fundiária é marcadamente concentrada no território fluminense. A exceção são os municípios da Região Serrana fluminense, mais especificamente na área chamada "Alto da Serra” (Teresópolis, Petrópolis e Nova Friburgo). O fato de essa região ter tido sua gênese associada a um projeto de colonização agrícola, a partir da vinda de imigrantes, aliado às condições desfavoráveis ao desenvolvimento de culturas tropicais, acabou por garantir uma organização do espaço rural caracterizada por um processo de ocupação territorial com base em pequenas propriedades de policulturas.

Quadro 2. Distribuição dos estabelecimentos agrícolas no estado do Rio de Janeiro (1996-2006)

\begin{tabular}{|c|c|c|c|c|}
\hline \multirow{2}{*}{ Grupos de área } & \multicolumn{2}{|c|}{ Censo Agropecuário 1996} & \multicolumn{2}{|c|}{ Censo Agropecuário 2006} \\
\hline & $\begin{array}{c}\text { Número de } \\
\text { estabelecimentos }\end{array}$ & Área & $\begin{array}{c}\text { Número de } \\
\text { estabelecimentos }\end{array}$ & Área \\
\hline Menos de 10 hectares & 3.962 & 14.293 & 5.275 & 16.667 \\
\hline $\begin{array}{l}10 \text { a menos de } 100 \\
\text { hectares }\end{array}$ & 13.647 & 659.266 & 14.384 & 653.596 \\
\hline $\begin{array}{l}100 \text { a menos de } 1.000 \\
\text { hectares }\end{array}$ & 5.860 & 1.247 .891 & 7.572 & 1.667 .703 \\
\hline 1.000 hectares e mais & 319 & 1.261 .615 & 376 & 1.153 .317 \\
\hline $\begin{array}{l}\text { Sem informação } \\
\text { ou sem área }\end{array}$ & 0 & 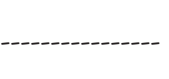 & 1.875 & - \\
\hline Total & 23.788 & 3.183 .065 & 29.482 & 3.491 .283 \\
\hline
\end{tabular}

Fonte: FIBGE. Censos Agropecuários, 1996 e 2006.

De acordo com Ribeiro (2002) apesar de o estado do Rio de Janeiro apresentar totais baixos em relação aos totais nacionais, quanto às variáveis pessoal ocupado, valor da produção, quantidade colhida e modernização, seu quadro agrário apresenta relevância e acentuado contraste no âmbito estadual. Esses contrastes decorrem da agropecuária tradicional, que domina a maior porção do território fluminense, confrontando-se com outra, de caráter moderno. De um lado, os produtos tradicionais, exemplificados pela cana-de-açúcar, além de cultivos de subsistência; do outro, culturas que requerem técnicas aprimoradas, como tomate, horticultura, fruticultura e olericultura, marcando o 


\section{Transformações no espaço rural fluminense}

Cinturão Verde da metrópole e ocupando os municípios integrantes das regiōes Serrana, Centro-Sul e Noroeste Fluminense.

Os agricultores familiares, em sua maioria, passam por uma grave crise, devido à concentração de renda e à falta de políticas agrícolas efetivas. Os estabelecimentos acima de 100 ha correspondem a $26 \%$ e ocupavam uma área de $78 \%$ em 1996 . Em 2006, esse padrão se mantinha, com pouca alteração, uma vez que corresponde a $27 \%$ dos estabelecimentos em uma área de $80 \%$.

Por outro lado, verifica-se que os pequenos proprietários - bastante numerosos no estado do Rio de Janeiro - têm pouca possibilidade de realizar investimentos em suas terras, uma vez que operam com retornos muito reduzidos para permitir a capitalização de suas unidades de produção. Esse é o caso dos pequenos proprietários fornecedores de leite às cooperativas do Noroeste Fluminense, do Médio Vale e Centro-Sul Fluminense, que, embora detenham a propriedade da terra, têm uma forma de inserção na produção regional que implica reduzida autonomia na condução do processo produtivo, e limitação quanto à possibilidade de investir em suas unidades de exploração. Em outros casos, como na Região Serrana, em que há predomínio da produção de hortigranjeiros nas pequenas propriedades, a pluriatividade é adotada como fonte de renda alternativa pelos agricultores. Muitos, além de realizarem suas funções na propriedade agrícola, exercem atividades não agrícolas (como caseiros, motoristas, empregados domésticos, fiscais de rodovia etc.) nas casas de veraneio, nos hotéis e nas prefeituras da região.

Constata-se que, em território fluminense, as transformações no espaço rural, como a prática do turismo rural e a disseminação de empregos não agrícolas, encontram-se associadas ao intenso processo de urbanização, o que pode ser sintetizado da seguinte forma (ver Figura 1): eixo que se desloca da RMRJ em direção a Angra dos Reis e Paraty, a região da baía da Ilha Grande, também conhecida como Costa Verde, em que se destacam as atividades de turismo, o que tem provocado intensa transformação, com grande apelo para o turismo de praia, histórico e ecológico.

Essa região concentra grandes reservas de Mata Atlântica, inúmeras ilhas (entre elas, a Ilha Grande) e cidades históricas, como Paraty. Boa parte do território integra áreas de proteção ambiental, o que inibe a prática de atividades agrícolas. A expressiva ocupação por grandes hotéis de luxo e condomínios fechados tem provocado muita especulação imobiliária, expulsando os produtores familiares de suas terras. A eles, resta inserir-se no mercado de trabalho urbano ou na prática da agricultura extrativista, com a exploração de banana e palmito. Além disso, assessorados pelos técnicos governamentais da Emater e do Ibama, exercem atividades não agrícolas, trabalhando em hotéis e condomínios.

Outro eixo que encontra no turismo um forte vetor de crescimento é o que segue da RMRJ para Cabo Frio, Búzios e Macaé, a região das Baixadas Litorâneas (Costa do Sol). Observa-se intenso crescimento de turismo de massa na direção do litoral norte do estado do Rio de Janeiro, o que provoca intensa urbanização e conduz à proliferação de segundas residências. Isso, por sua vez, leva ao fracionamento da terra e à expulsão das atividades agropecuárias, com vistas à criação de loteamentos e condomínios. A presença da Petrobras em Macaé representa, de acordo com Rua (2002, p. 48), "uma avassaladora especulação imobiliária, com profundas marcas de segregação socioespacial”.

Um eixo adicional de urbanização é o que ocorre no "topo da serra” (Rua, 2002). Seus principais representantes são os municípios de Nova Friburgo, Petrópolis e Teresópolis. Essa área é marcada 
pela produção de hortigranjeiros e flores para o abastecimento da RMRJ. Também apresenta um tradicional e significativo polo industrial (com destaque para a moda íntima), além de haver inúmeros sítios de veraneio, casas de segunda residência, hotéis-fazenda, pousadas e spas, estabelecimentos associados aos aspectos naturais da região. Corresponde a uma região alternativa ao turismo de praia da Costa Verde e da Costa do Sol.

Nessa área, ocorre intensa produção agrícola de base familiar, centrada nos pequenos estabelecimentos, na mão de obra familiar e na baixa tecnificação da lavoura. Esses produtores, na maioria das vezes, ficam à mercê dos atravessadores, que controlam o processo de comercialização da produção. Sua produção consiste em alface, brócolis, couve-flor, tomate, entre outros, e eles acabam tendo uma baixa remuneração por suas atividades agrícolas. Na complementação da renda familiar, inserem-se no mercado de trabalho não agrícola como jardineiros, caseiros e domésticos, ou exercem suas atividades em empresas das cidades da região. Essa área também produz orgânicos e hidropônicos com vistas a um mercado consumidor restrito à Zona Sul da cidade do Rio de Janeiro. Na Região Serrana fluminense, nota-se a presença marcante de atividades relacionadas ao turismo rural contemporâneo e em sintonia com a produção familiar.

O território que engloba as regiōes do Médio Vale do Paraíba e Centro-Sul Fluminense, além de leite, contribui com a produção de hortigranjeiros para o abastecimento da RMRJ, embora apresente, como marca de sua paisagem, a atividade cafeeira, com a presença de grandes casas nas sedes das fazendas. Essa peculiaridade levou os municípios da área a organizarem o "Festival do Vale do Café". No entanto, não se verifica interatividade com os produtores familiares, que continuam a buscar complementação de renda nas indústrias da região, as quais concentram um grande número de empresas do setor metalmecânico.

As regiōes Norte e Noroeste Fluminense, em função da distância da área metropolitana, apresentam fortes características rurais, com a produção de leite, cana-de-açúcar, café e frutas. Esse quadro tem sido alterado com a presença da Petrobras e de seus royalties, que têm gerado emprego também para os agricultores dessas regiōes. O estabelecimento de um roteiro turístico associado à atividade canavieira é incipiente, encontrando resistência por parte dos proprietários das fazendas.

Em termos de permanência e mudança associadas ao território fluminense, o intenso caráter de urbanização e a expansão da metropolização auxiliaram a acirrar as singularidades presentes no espaço rural fluminense e a intensificar os conflitos fundiários no estado. Devido à intensa urbanização, muitos assentamentos se situam em áreas extremamente urbanizadas, articulando atividades agrícolas e não agrícolas, o que aponta para o rompimento de uma concepção limitada de assentamento, empregada na atualidade. Tem-se, assim, um espaço rural em transformação, que, de acordo com Rua (2002, p. 24), conta com a presença de "urbanidades no rural, que seriam todas as manifestaçōes do urbano em áreas rurais sem que se tratem esses espaços formalmente como urbanos”, mas que não se contrapõe à ruralidade, entendida como "um modo particular de utilização do espaço e da vida social" (Moreira, 2005, p. 21).

O desenvolvimento do modo de produção familiar no espaço rural fluminense, bem como suas estratégias de sobrevivência e reprodução, está associado ao processo de urbanização. Existe uma inter-relação, embora assimétrica, entre o rural e o urbano que resulta no transbordamento do espaço urbano para o espaço rural. No entender de Lefebvre (2001), o "tecido urbano" não se limita a for- 


\section{Transformações no espaço rural fluminense}

mas fixas urbanas, consistindo também no suporte de um modo de viver urbano, que se espalha pelo território de forma desigual, deixando setores mais ou menos amplos escaparem. Trazidas pelo tecido urbano, as urbanidades (rede elétrica, carros, serviços e sistema de valores) penetram nos espaços rurais, porém estes não perdem por completo algumas de suas especificidades, como, por exemplo, o modo de produção familiar no campo.

No estado do Rio de Janeiro, de acordo com Rua (2007), a metrópole carioca exerce um poder hegemônico e sua projeção para o território fluminense intensifica o processo de urbanização em seus aspectos políticos, culturais, ideológicos e econômicos, "com uma urbanização difusa, que ultrapassa os limites das cidades, alcançando todo o território do estado” (p. 283).

A intensificação do processo de urbanização no território fluminense vem, portanto, provocando profundas mudanças socioespaciais, e novas formas de ocupação passaram a proliferar no campo, destacando-se: o conjunto de profissões tidas como urbanas (trabalhadores domésticos, mecânicos, secretárias, entre outros); segundas residências; atividades de conservação; áreas de lazer (hotéis-fazenda, fazendas-hotel, pesque-pague, entre outras). Essas atividades demandam uma quantidade crescente de mão de obra não agrícola no espaço rural.

Os agricultores familiares buscam outras atividades para complementar sua renda familiar. É inegável que, nas últimas décadas, houve inúmeras transformações na unidade de produção familiar, como a diminuição do tempo destinado à atividade agrícola, devido à progressiva incorporação das novas tecnologias na produção e à diminuição da renda auferida. Assim, vai-se delineando o fenômeno da pluriatividade no estado do Rio de Janeiro, um fenômeno social e espacialmente desigual, com grande relevância em torno dos eixos de urbanização emanados pela metrópole carioca. Esse fenômeno não atinge, de forma significativa, os produtores que trabalham em áreas mais remotas, que ainda mantêm profunda dependência da renda agrícola e apresentam profunda dificuldade de reprodução e sobrevivência.

Embora, no estado do Rio de Janeiro, existam discrepâncias entre a Regiāo Metropolitana e o interior, ocorre maior dinamização do interior do estado, com o surgimento de novos eixos de desenvolvimento. Isso não significa que a metrópole tenha perdido a hegemonia, mas o fato é que, no interior, desenvolveram-se atividades importantes para a economia e o crescimento do estado como um todo. Entre essas atividades, destacam-se aquelas associadas ao turismo rural, como hotéis-fazenda, fazendas-hotel, agroturismo, turismo de aventura. Rodrigues (2001) classifica essas atividades em duas categorias: tradicionais (de origem agrícola, pecuária e colonização) e contemporâneas (hotéis-fazenda, spas rurais, segunda residência).

Como nosso objetivo é conhecer as características das abordagens da produção familiar e suas estratégias de sobrevivência, por meio de empregos agrícolas ou não agrícolas, bem como o papel que o turismo rural vem desempenhando nesse processo, foi feito um levantamento dos dados relacionados à estrutura fundiária (tabelas e mapas a seguir), à condição legal, ao emprego de tecnologia, aos municípios que desenvolvem atividades de turismo rural e à distribuição da população (urbana e rural). Esse levantamento sobre a agricultura familiar e o turismo rural no estado do Rio de Janeiro foi realizado, fundamentalmente, em bibliotecas de instituições públicas e privadas, além de pesquisas feitas em sítios eletrônicos das prefeituras municipais do estado do Rio de Janeiro. 
Assim, a partir dos dados levantados e das observações de campo, foi possível constatar que, hoje, define-se rural como um espaço híbrido em que as relações tradicionais de produção e existência não são mais suficientes para caracterizá-lo - nesse período que sucede a Revolução Verde. Elementos tidos como urbanos ou rurais extrapolam as fronteiras do campo e da cidade, transformando-os em espaços de interação híbrida.

Nesse sentido, é importante compreender como as novas relações entre cidade e campo são processadas no espaço em suas escalas distintas e como são percebidas pelos diversos grupos sociais envolvidos no processo de ressignificação do rural. Entre as transformaçôes que marcam esse estreitamento entre os espaços rural e urbano, encontra-se o desenvolvimento de atividades turísticas no espaço rural, associadas ao processo de urbanização, culminando no transbordamento para o campo de formas de ocupação, profissōes, atividades e pensamentos predominantemente urbanos.

Percebe-se que a pluriatividade tem-se intensificado, em função da queda da renda agrícola, avançando para as áreas próximas aos grandes centros urbanos, devido ao incremento do fluxo de turistas para os espaços rurais, com a revalorização da natureza, entre outros fatores. Nas áreas mais distantes, os produtores familiares continuam na dependência da renda agrícola e ainda enfrentam inúmeros problemas para a realização de suas atividades.

O processo de urbanização do território fluminense pode ser caracterizado pelos eixos de urbanização (Figura 1) - em que se verificam a prática do turismo rural e a disseminação de empregos não agrícolas - em relação, preferencialmente, às áreas rurais mais distantes desses eixos: o eixo em direção à regiáo da Costa Verde (com destaque para Angra dos Reis e Paraty), saindo da RMRJ, tendo em seus territórios áreas de proteção ambiental (reservas, APAs e parques), as quais, logicamente, restringem as práticas agrícolas.

O turismo ganhou destaque nessa região a partir da década de 1970, com a construção da Rodovia Rio-Santos (BR-101), o que possibilitou um grande fluxo de investimentos, por meio da implantação de hotéis, pousadas e condomínios, verificando-se, então, o aumento da especulação imobiliária e a expulsão dos produtores familiares de suas terras. Restaram-lhes, portanto, o exercício de atividades não agrícolas (ocupaçôes em hotéis e condomínios) e a prática de uma agricultura extrativista, como, por exemplo, a exploração de banana e palmito.

Esse destaque no turismo se estende ao eixo que segue da RMRJ em direção a Cabo Frio, Búzios e Macaé, a região das Baixadas Litorâneas (Costa do Sol). Aqui, a intensa urbanização e a proliferação de segundas residências levaram ao fracionamento da terra e à expulsão das atividades agropecuárias, com vistas à criação de loteamentos e condomínios.

Nova Friburgo, Petrópolis e Teresópolis também configuram um eixo de urbanização marcado pela produção de hortigranjeiros e flores que abastecem a RMRJ. A produção agrícola se baseia na mão de obra familiar, centralizada em pequenos estabelecimentos com baixa tecnificação, em que a comercialização é realizada, em grande parte, pelos atravessadores. A RJ-130, que liga Teresópolis a Nova Friburgo, além de se ter transformado em importante eixo de circulação e escoamento da produção, é palco de um circuito turístico (Circuito Tere-FRI) que contribui para inúmeras manifestaçōes urbanas que transformam a dinâmica desse espaço rural e nos fazem refletir como o capitalismo modifica e particulariza o rural fluminense, adaptando-o para melhor responder às exigências referentes a esse processo. 


\section{Transformações no espaço rural fluminense}

Os produtores familiares das regiões do Médio Vale do Paraíba e do Centro-Sul Fluminense buscam a complementação de renda nas indústrias da região, as quais concentram um grande número de empresas do setor metalmecânico. Suas paisagens são marcadas pela atividade cafeeira, com a presença de fazendas que passam por um intenso processo de refuncionalização, transformando-se, por exemplo, em pousadas. Esse processo, contudo, não ocorre de maneira homogênea nesses territórios, pois é preciso levar em conta a falta de recursos econômicos por parte de alguns proprietários e a ineficiência ou falta de iniciativa do poder público, entre outros fatores determinantes.

As regiōes Norte e Noroeste Fluminense, em função do distanciamento da RMRJ, apresentam fortes características rurais, com a produção de leite, cana-de-açúcar, café e frutas. No entanto, esse quadro tem sido alterado pela presença da Petrobras e de seus royalties, que também têm gerado emprego para os agricultores dessas regiões.

Sobre a prática de atividades turísticas nesses eixos de urbanização, a partir das informações adquiridas nos sítios das prefeituras municipais, é possível tecer algumas considerações:

- Nem todas as prefeituras dispunham de informaçóes sobre essa atividade em seus endereços eletrônicos, o que nos leva a refletir sobre a relevância do turismo e, particularmente, do turismo rural em seus territórios.

- Boa parte dos sítios pesquisados fornecia informações de caráter “atrativo", e não explicativo, acerca dessa prática, o que nos induz a pensar nas políticas ali existentes.

- Há poucas referências sobre serviços de assistência ao produtor rural, como promoção de cursos, projetos e incentivos, no que tange ao seu direcionamento para a atividade turística nas áreas rurais, cabendo, portanto, alguns questionamentos sobre a forma como esses produtores estão inseridos no processo.

- É importante descobrir o efetivo papel do setor público no desenvolvimento das atividades turísticas, pois, nitidamente, percebe-se a preocupação em atrair turistas, mas não em esclarecer a maneira como as atividades se desenvolvem ou suas fragilidades, realçando-se apenas suas potencialidades.

- Há destaque para os atrativos naturais e históricos, omitindo-se quanto aos assuntos relacionados à sustentabilidade socioambiental.

Em face dessas considerações, conclui-se que o interior fluminense, embora tenha pouca expressão em termos demográficos, desempenha papel fundamental na dinâmica territorial do estado, principalmente por causa das variadas iniciativas em curso nas áreas rurais que estão marcadas pelo intenso processo de urbanização. Essas inovações transformadoras ressignificam o rural e modificam as estratégias de sobrevivência e reprodução do modo de produção familiar, com o desenvolvimento de atividades tipicamente urbanas que proporcionam complementaridade da renda familiar no campo.

A atividade turística no estado do Rio de Janeiro segue influenciada pela acentuada diversidade de paisagens, por suas características topográficas e climáticas, além da grande variedade cultural presente no território fluminense. Além disso, observa-se que essa atividade, nas últimas décadas, tem-se mostrado fundamental para o desenvolvimento econômico de alguns municípios e até mesmo do estado, demandando, portanto, avaliação e planejamento pautado nas inúmeras possibilidades das práticas turísticas. Essas práticas surgem de suas potencialidades, que, com frequência, estão escondidas em características advindas de influências cultu- 
rais e/ou naturais. Ressalte-se que o estado do Rio de Janeiro é formado por uma diversidade significativa nas formas de relevo, apresentando ambientes de serra, colinosos e de baixadas fluviais e marinhas, o que também dificulta o processo de ocupação e uso do solo.

O estado do Rio de Janeiro se destaca nacionalmente em relação ao desenvolvimento do turismo, recebendo uma grande quantidade de turistas. É, sem dúvida, uma das portas de entrada para quem chega do exterior e também para aqueles que vêm de outras partes do país. Ribeiro (2003) destaca três condicionantes que influenciam o desenvolvimento da atividade turística no território fluminense: a) suas características físicas ou naturais; b) os elementos históricos de formação cultural e as atividades econômicas; e c) o papel dos transportes.

Alguns autores ligados ao turismo, bem como os agentes propulsores dessa atividade (Embratur, TurisRio, entre outros), ao trabalharem as modalidades desenvolvidas no estado pensaram em tipologias (Ribeiro, 2003) ou caracterizações regionais para os municípios. Em pesquisas recentes e estudos desenvolvidos pelo Núcleo de Estudos de Geografia Fluminense (Negef), foi elaborada uma classificação que define as áreas turísticas no território fluminense. Assim, o estado do Rio de Janeiro estaria subdividido nas seguintes áreas turísticas:

- Ecoturismo: ligado ao desenvolvimento de práticas ecoturísticas no noroeste do estado;

- Praia e ecoturismo: destacam-se os municípios de Angra dos Reis e Paraty;

- Praia e rural: nessas áreas, destacam-se as práticas turísticas relacionadas à praia. Estão incluídos os municípios que reúnem elementos históricos e/ou rurais que permitem o desenvolvimento de atividades relacionadas a esses elementos;

- Praia: desenvolvem-se atividades de praia, sendo marcante a presença de imóveis de segunda residência;

- Serra e mar: encontram-se algumas atividades relacionadas a atividade rural e praia;

- Serra: dividida em serra de turismo consolidado e não consolidado, essa área engloba os municípios serranos, caracterizados pela existência de atividades históricas, pela presença de museus, igrejas e fazendas, além dos espaços rurais que são usados como hotéis-fazenda e pesque-pague, bem como para a prática de atividades voltadas à vida rural;

- Serra da Mantiqueira: o turismo adentra a área serrana da Mantiqueira, pautando-se na questão ecológica. O município de Itatiaia, único constituinte dessa área, guarda estreita relação com a Serra da Mantiqueira, fazendo com que seu clima seja permeado de amenidades advindas da altitude, o que favorece, sobremaneira, a atividade turística;

- Baixada Fluminense: embora não tenha uma prática turística consolidada, essa área apresenta grande potencial de turismo pautado na história e na cultura dos municípios;

- Diversificado: incorporadora dos municípios do Rio de Janeiro e de Niterói, essa área de turismo diversificado configura-se como um território de intenso apelo e interesse turístico;

- Vale do Café: destacam-se as atividades de resgate da memória do período cafeeiro no Brasil. As práticas turísticas estão relacionadas à visitação de fazendas e casarios históricos, ao consumo de produtos de época e produtos rurais, entre outros. 


\section{Transformações no espaço rural fluminense}

O desenvolvimento do turismo no estado do Rio de Janeiro, portanto, tem forte ligação com suas bases geográficas. $\mathrm{O}$ fenômeno turístico é entendido como próprio da modernidade e da sociedade de consumo, a qual, cada vez mais, se apropria dos lugares, em suas diferentes vertentes, para vender momentos, lugares e práticas. Hoje, entendemos a necessidade de se buscar a valorização de áreas interioranas e de promover o turismo como um fator importante e de suporte à economia dos municípios. Mas, para tanto, é necessário pensar em políticas públicas que deem suporte a essa atividade.

A espacialização dessas marcas turísticas nos aponta para algumas áreas em que o turismo se caracteriza pela hibridez. São municípios classificados como áreas turísticas distintas, embora a prática das atividades relacionadas ao turismo ocorra de maneira semelhante. Os espaços híbridos, portanto, se caracterizam, sobremaneira, como espaços em que coexistem características, no caso vertente, de tipos diferentes. Nesses espaços, pode predominar uma característica sobre a outra, porém negligenciar a presença de aspectos relacionados a uma marca diferente significa amputar de nossa análise uma parte importante componente do real. Exemplifica-se com o município de Itatiaia, que apresenta características, principalmente em seu aspecto natural, muito peculiares, que se relacionam às amenidades da Serra da Mantiqueira. Porém, seu processo de formação histórica não está desvinculado dos demais municípios do Vale do Café.

O certo é que o estado do Rio de Janeiro apresenta uma grande variedade de possibilidades para o desenvolvimento da atividade turística, seja pela valorização das paisagens naturais, seja pelo patrimônio histórico cultural ou ainda pelas modalidades de turismo mais recentes, como o ecoturismo e o turismo de aventura. No entanto, o turismo ainda não está consolidado em boa parte do estado. Em uma parcela considerável dos municípios, as diversas possibilidades de atrativos são subaproveitadas ou até mesmo não exploradas, por falta de infraestrutura de transporte, hospedagem e lazer.

Nesse contexto, a atividade turística tem sido considerada um fator relevante para o crescimento econômico do estado, por sua capacidade de atrair investimentos, fluxo de capitais e recursos financeiros, bem como de gerar empregos e renda e de transformar seus espaços. Ribeiro (2003) afirma que essas transformações são influenciadas por três condicionantes: o físico ou natural; o histórico e as atividades econômicas; e o papel dos transportes. Acrescenta que as rodovias são fundamentais para a expansão do turismo no estado, principalmente a partir da década de 1970, com a construção de algumas vias (por exemplo, a ponte Presidente Costa e Silva e a rodovia Rio-Santos) e a duplicação de outras (rodovias Presidente Dutra e Washington Luís).

De forma geral, o turismo se desenvolve no estado apoiado na conjunção desses três elementos, permeados por fatores econômicos, sociais, culturais e políticos. Em cada município, esse inter-relacionamento configura realidades distintas, passíveis de uma compreensão mais sólida, se considerados os contextos em que são construídas, em múltiplas escalas. A presença da produção familiar se insere como mais um elemento atrativo para as práticas de turismo e os espaços rurais no território fluminense.

\section{Considerações finais}

No espaço rural, observam-se inúmeras atividades: as agrícolas, com a produção de matérias-primas para a indústria e a produção de alimentos, com assentamentos e acampamentos de trabalhadores rurais; e as não agrícolas, como a instalação de indústrias e a procura por áreas que têm a natureza preservada para a construção de residências, hotéis e pousadas, gerando a necessidade de mão de obra e proporcionando aos produtores rurais residentes empregos e consequente aumento da renda familiar. $\mathrm{O}$ aumento dessas atividades não 
agrícolas, contudo, ainda está associado à implementação, pelo poder público, de infraestrutura de transporte e comunicação, o que, nitidamente, possibilita a circulação de pessoas, mercadorias, informaçóes e capital.

A maior parte das mudanças corresponde ao espaço rural não incorporado à produção dos complexos agroindustriais e que, em sua maior parte, corresponde à produção familiar nas pequenas propriedades. É nesse espaço não incorporado ao modelo hegemônico que ocorrem as maiores transformaçôes, pois a procura por áreas que têm a natureza preservada e que podem ser transformadas em áreas de lazer, com a construção de sítios para veraneio, hotéis e pousadas, atrai a população das áreas urbanas e proporciona emprego aos pequenos produtores rurais, facultando-lhes exercer outras atividades que não apenas as agrícolas. É nesses espaços que também há incentivo às práticas agroecológicas e alternativas, em detrimento da forma de produção tradicional nas médias e grandes propriedades. Esses locais correspondem ao espaço rural revalorizado em decorrência da natureza mais preservada, tornando-se uma mercadoria a ser consumida pelas populações, sobretudo aquelas de origem urbana.

Alteram-se, assim, as relações entre campo e cidade, com a subordinação do primeiro à segunda, ambos integrados como espaço de consumo. Os espaços da produção de base familiar se alteram também com a presença de inúmeros elementos (indústrias, serviços, pessoas oriundas da cidade, seja para lazer, seja como segunda residência) que associam atividades agrícolas e não agrícolas. Ao pequeno produtor descapitalizado, resta a alternativa de buscar outras fontes de renda nas atividades não agrícolas.

Esse processo está bastante presente no território fluminense, que se encontra marcado por um intenso processo de urbanização, o qual tem provocado profunda transformação socioespacial, como, por exemplo, o turismo rural contemporâneo, com a proliferação de hotéis-fazenda, spas, pousadas e imóveis de segunda residência. Também se verificam a manutenção e até mesmo o aumento da produção familiar, com o estado do Rio de Janeiro apresentando participação expressiva na comercialização agrícola a partir do Ceasa-RJ, especialmente em relação à venda de hortaliças, cuja produção tem aumentado nos últimos anos, especialmente na Região Serrana fluminense.

Certamente, a proliferação dessas atividades possibilitou aos produtores familiares a inserção em atividades não agrícolas e o consequente aumento da renda familiar. No entanto, esse processo tem lugar, principalmente, nas áreas dos eixos de urbanização próximas à RMRJ. Nas áreas mais distantes, os produtores familiares continuam a depender da renda agrícola, enfrentando inúmeros problemas para a realização de suas atividades. Nesse sentido, o espaço rural se transforma em decorrência da valorização de seus aspectos naturais, e a manutenção da produção agrícola familiar se torna importante para a disseminação da imagem desse espaço natural vendido ao turista.

\section{Referências}

ABRAMOVAY, Ricardo. "Agricultura familiar e uso da terra”. São Paulo em Perspectiva, São Paulo, v. 11, n. 2, 1997, pp. 73-8.

—_. "Paradigmas do capitalismo agrário em questão". 2 ed. Campinas: Hucitec, 1998.

CORTES, C. Análise da agricultura familiar no município de Sumidouro/RJ (tese). UERJ, 2008. 
FAO/INCRA. Diretrizes de política agrária e desenvolvimento sustentável. Brasília, 1995.

FERRÃO, João. "Relações entre o mundo rural e mundo urbano: evolução histórica, situação actual e pista para o futuro". Eure, Santiago, v. 26, n. 78, set. 2000.

HESPANHOL, R. A. de M. Produção familiar: perspectivas de análise e inserção na microrregião geográfica de Presidente Prudente (tese). Unesp, 2000.

LEFEBVRE, Henri. O direito à cidade. São Paulo: Centauro, 2001, p. 141.

LIMONAD, E. Os lugares da urbanização: o caso do interior fluminense (tese). USP, 1996.

MARAFON, G. J. et al. Regiōes de governo do estado do Rio de Janeiro: uma contribuição geográfica. Rio de Janeiro: Gramma, 2006. 139 p.

MOREIRA, R. et al. "Estado do Rio de Janeiro". Anais... Niterói: EDUFF, 2001, pp. 127-32.

PROJETO DE COOPERAÇÃO TÉCNICA FAO/INCRA. Novo retrato da agricultura familiar: o Brasil redescoberto. Brasília: MDA/Incra, 2000.

REIS, José. "Observar a mudança: o papel dos estudos rurais". Conferência... $1^{\circ}$ Congresso de Estudos Rurais. Portugal: Vila Real, 2001.

RIBEIRO, M. A. “Consideraçôes sobre o espaço fluminense: estrutura e transformaçōes”. In MARAFON, G. J. e RIBEIRO, M. F. (orgs.). Estudos de geografia fluminense. Rio de Janeiro: UERJ, 2002, pp. 13-26.

RUA, João. “Urbanização em áreas rurais no estado do Rio de Janeiro”. In MARAFON, G. J. e RIBEIRO, M. F. (orgs.). Estudos de geografia fluminense. Rio de Janeiro: UERJ, 2002, pp. 43-70.

—. "As crises vividas pelo estado do Rio de Janeiro e a emergência de novas territorialidades em áreas rurais". In MARAFON, Glaucio José et al. (orgs.). Abordagens teórico-metodológicas em geografia agrária. Rio de Janeiro: EdUERJ, 2007, pp. 271-98. 330p.

SANTOS, A. M. Economia, espaço e sociedade no Rio de Janeiro. Rio de Janeiro: FGV, 2003a, v. 1. 228 p.

- Economia, espaço e sociedade no Rio de Janeiro. Rio de Janeiro: FGV, $2003 \mathrm{~b}$.

SEABRA, R. Comercialização agrícola no estado do Rio de Janeiro: o papel do sistema CEASA-RJ (monografia). UERJ, 2004.

SILVA, J. Graziano. "O novo rural brasileiro". Nova Economia, Belo Horizonte, v. 7, n. 1, 1997, pp. 43-81.

WANDERLEY, M. N. B. “Brasil: exploração familiar ou latifúndio?”. In LAMARCHE, H. A agricultura familiar. Paris: L'Harmattan, 1994, v. 2, pp. 20-7.

—. "Raízes históricas do campesinato brasileiro". In TEDESCO, J. C. (org.). Agricultura familiar: realidade e perspectivas. Passo Fundo: EDUPF, 1999, pp. 23-56.

—. "A valorização da agricultura familiar e a reivindicação da ruralidade no Brasil". Encontro Brasileiro de Economia e Sociologia Rural, XXXVIII. Anais... Rio de Janeiro: Sober, 2000. [CD-ROM]

WOODS, Michael. Rural Geography. Londres: Sage, 2005. 


\section{Os investimentos externos diretos da República Popular da China no território fluminense no século XXI}

Thiago Jeremias Baptista ${ }^{1}$

\section{Introdução}

E ste artigo é produto dos esforços empreendidos na elaboração da dissertação de mestrado, no programa de pós-graduação em Geografia da Universidade do Estado do Rio de Janeiro (PPGEO/ UERJ), no período de 2014-2016, sob a orientação do Prof. Dr. Glaucio José Marafon. Evidencia-se, aqui, a expansão dos investimentos externos diretos (IED) da República Popular da China nos países em desenvolvimento, citando a inserção do Brasil nesse processo. Identifica-se o influxo desses investimentos no estado do Rio de Janeiro no período 2010-2013.

A fim de compreendermos se o influxo de capital sínico no território fluminense conforma uma nova territorialidade no processo de reestruturação territorial, resgatamos a trajetória econômica do estado do Rio de Janeiro ao longo do século XX, evidenciando a perda de centralidade político-econômica entre 1930 e 1980, assim como o processo de reestruturação do território fluminense decorrente da reorganização do influxo de investimentos atrelada à sua interiorização econômica após a década de 1990 . Tecem-se, ainda, algumas considerações sobre a projeção daquele país asiático à condição de investidor internacional, visando relacionar o ingresso e a distribuição espacial dos investimentos chineses com o processo de reestruturação territorial fluminense.

${ }^{1}$ Bacharel e licenciado em Geografia pela UERJ; especialista em História das Relações Internacionais pelo CEHRI/UERJ; pós-graduado em Dinâmicas Urbano-Ambientais e Gestão do Território pela FFP/UERJ; e mestre em Geografia pelo PPGEO/UERJ. 


\section{A trajetória econômica fluminense no século XX e 0 processo de reestruturação territorial do estado do Rio de Janeiro}

Durante o século XX, o território fluminense se caracterizou pela perda da centralidade político-econômica. $\mathrm{O}$ exercício da centralidade política deveu-se ao fato de, durante praticamente duzentos anos (1763-1960), a cidade de São Sebastiāo do Rio de Janeiro ter exercido a capitalidade do Brasil colonial, imperial e republicano. No entanto, a transferência da capital federal para a cidade de Brasília (1960) levou à perda dessa centralidade. Ao período marcado pela perda de centralidade política, soma-se o processo de perda de centralidade econômica, em decorrência do intenso desenvolvimento industrial de São Paulo.

A centralidade econômica exercida pelo espaço fluminense está atrelada à proeminência econômica alcançada nos períodos colonial e imperial do Brasil. Como resultado de sua inserção primário-exportadora, que acompanhou o sistema social movido pelo modo de acumulação agromercatil escravista (Moreira, 2013), o espaço fluminense vivenciou, desde o século XVI, certa preocupação com as questões comercial, portuária e militar, que se somaram às funções administrativa e industrial.

Com efeito, no final do século XIX, o espaço fluminense caracterizava-se tanto por sua expressiva centralidade política quanto por sua capacidade de exercer posição hegemônica no cenário econômico nacional (Marafon et al., 2005). No entanto, ainda que, no início do século XX, o território fluminense exercesse forte influência nos campos político e econômico nacional, tanto em decorrência das funções burocráticas exercidas pela cidade do Rio como capital quanto por ter, na base de seu processo de acumulação, as atividades cafeeiras e apresentar significativo desenvolvimento portuário, comercial, administrativo, financeiro e industrial, o Rio de Janeiro assistiu, ao longo daquele século, a uma trajetória de degradação, sobretudo em função da ascensão de São Paulo, que se tornou o centro dinâmico da economia nacional.

Melo (2001), Melo e Araújo (2014) e Silva (2012) representam referenciais teóricos acerca desse processo, sobretudo por fazerem referência ao período de 1930 a 1980 sob a ótica do esvaziamento econômico e das perdas relativas, denotando uma conjuntura econômica involutiva que, além de abarcar a perda de centralidade, evidencia a menor participação do estado do Rio de Janeiro no PIB nacional e na produção industrial do país.

Os dados apresentados por Melo (2001) e Melo e Araújo (2014) apontam que, no período de 1930 a 1980, o estado do Rio de Janeiro vivenciou um período de esvaziamento econômico, decorrente de sua menor participação na produção industrial brasileira. Portanto, embora tenha sido o berço da industrialização no país, a indústria fluminense assistiu, desde a década de 1930, a um inexorável processo de esvaziamento, perdendo a posição de destaque para a indústria paulista. Para esses autores, o processo de esvaziamento do Rio de Janeiro vem desde o início do século XX, mantendo-se na passagem para os anos 1930 e sendo agravado pela contínua redução da participação do Rio de Janeiro e do Distrito Federal na produção industrial brasileira durante a segunda metade daquele século. Por seu turno, no fim da década de 1930, a participação do Rio de Janeiro, somada com a do Distrito Federal, correspondia a menos da metade da participação de São Paulo na produção industrial do país, mantendo-se essa traje- 
tória de redução da economia fluminense na produção industrial nacional ao longo de praticamente toda a segunda metade do século XX (Gráfico 1).

Gráfico 1. Rio de Janeiro e São Paulo: participação na produção industrial do Brasil entre 1907-2000

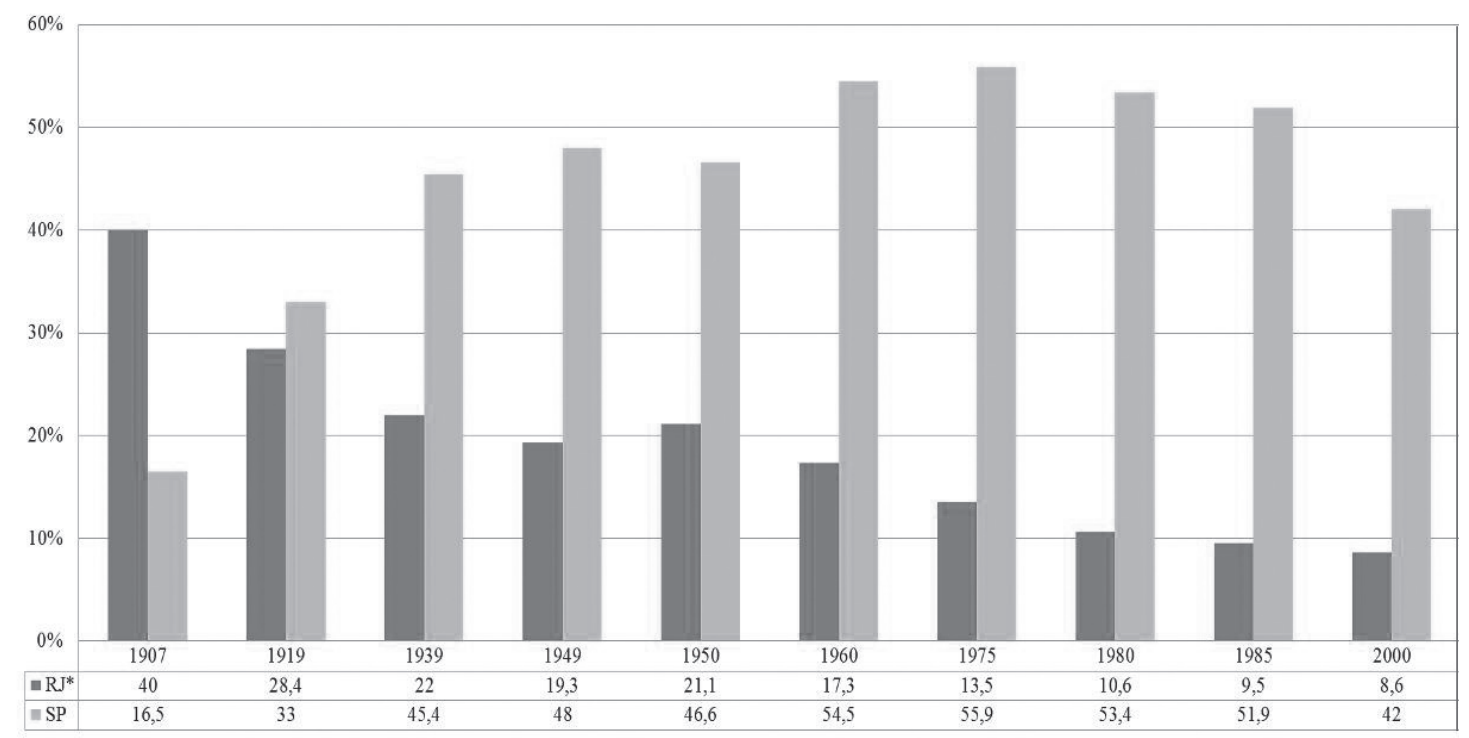

*Soma da cidade do Rio de Janeiro com o estado do Rio de Janeiro no período de 1907-1975.

Fonte: Melo (2001) e Araújo e Melo (2014). Gráfico elaborado pelo autor.

Segundo Silva, as perdas fluminenses resultam, sobretudo, da combinação entre a acelerada expansão industrial no território nacional e as perdas reais de alguns ramos da economia estadual. Assim, “o Rio de Janeiro, como espaço pioneiro de vários setores, não conseguiu acompanhar o crescimento relativo dos novos espaços, perdendo participação relativa no total nacional" (2012, p. 52). Portanto, "se fosse possível sintetizar, em uma frase, o desenvolvimento capitalista fluminense entre 1930-1980, a que melhor sintetizaria esse processo seria, muito possivelmente, crescimento e modernização com perda de importância relativa” (p. 41).

$\mathrm{Na}$ perspectiva desse autor, a dinâmica econômica fluminense foi marcada por um amplo processo de expansão e modernização de sua estrutura urbano-produtiva, caracterizando-se pela inserção mais efetiva na macrodinâmica da economia brasileira. No entanto, sua trajetória se diferenciou das demais economias estaduais do país, o que resultou em um processo de perda de participação regional na renda nacional. Para ele, essa trajetória "passou a ser comumente interpretada como um processo de esvaziamento" e de "decadência econômica regional". Assim, embora o termo esvaziamento econômico tenha sido utilizado por vários acadêmicos para denominar esse processo, segundo sua interpretação, o que ocorreu na economia fluminense foi uma trajetória de redução da participação do estado no PIB nacional. Dessa forma, fica nítido que a redução da economia fluminense apresentou um perfil relativo, ou seja, resultou do descompasso entre suas taxas e a média do país (Silva, 2012). Em consequência, houve uma contínua redução da participação do estado do Rio de Janeiro no PIB nacional durante o século XX, retraindo-se de 21\% em 1939 para 11\% em 1995 (Gráfico 2). 
Gráfico 2. Participação do estado do Rio de Janeiro no PIB nacional entre 1939-1995

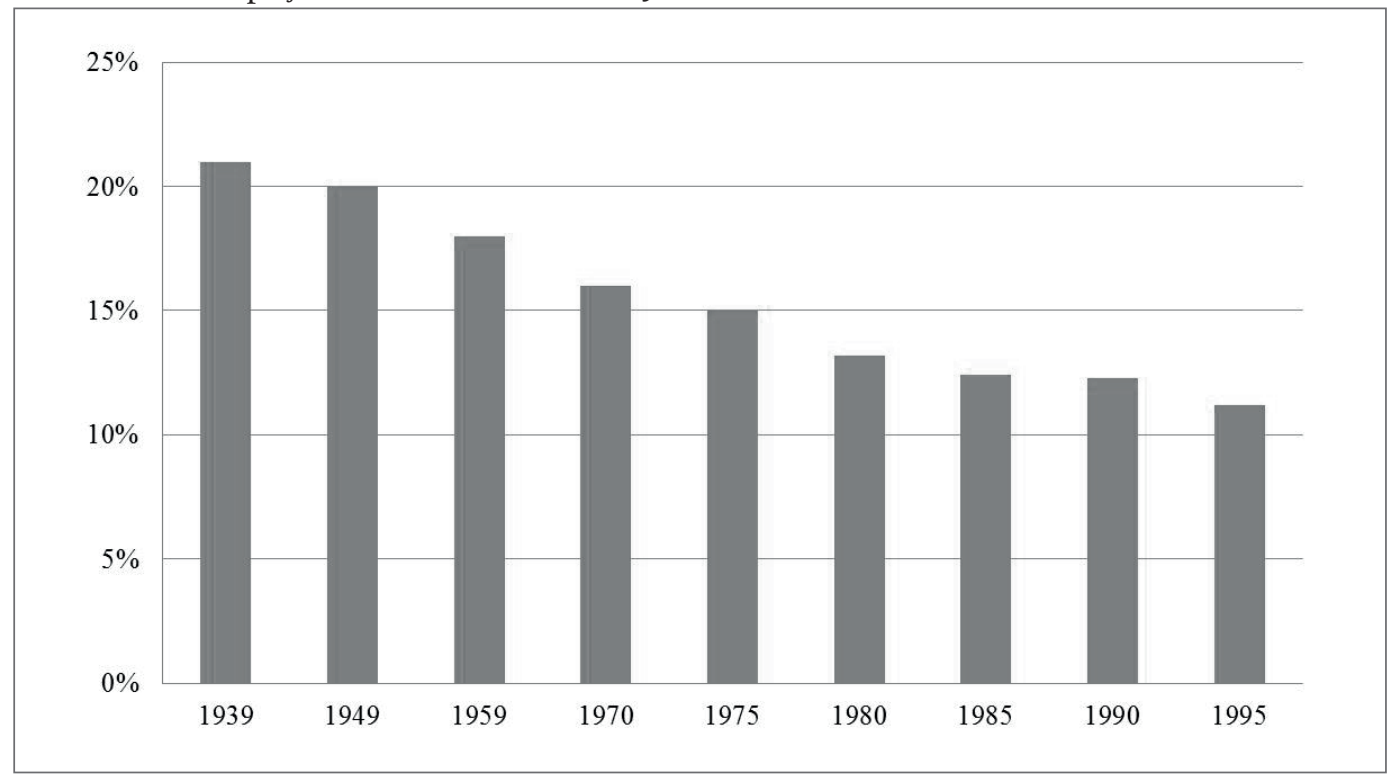

Fonte: Santos (2003); Silva (2012) e Ceperj (s.d.). Pib Estadual 1995-2012. Disponível em: http://www.ceperj.rj.gov.br/ ceep/pib/pib.html. Acesso em: 8 nov. 2015. Gráfico elaborado pelo autor.

Diante do exposto, compreende-se que a trajetória econômica fluminense ao longo do século XX foi marcada pela desestruturação de importantes setores produtivos, pela redução de sua participação na produção industrial nacional e pela consequente retração da contribuição do Rio de Janeiro no PIB nacional, implicando o ingresso do território fluminense no período denominado esvaziamento econômico e/ou de perdas relativas de participação fluminense na economia nacional, dependendo do referencial teórico escolhido (Melo, 2001; Silva, 2012; Araújo e Melo, 2014). No entanto, ainda que marcado por uma conjuntura econômica involutiva, não podemos desconsiderar que o território assistiu aos investimentos em infraestrutura e à implantação de novas atividades produtivas. Mas esses investimentos não foram capazes de reverter sua trajetória de esvaziamento econômico e/ou de perdas relativas na participação do PIB nacional.

Portanto, em consequência do desempenho negativo da economia nacional nos anos 1980, a conjuntura econômica do estado do Rio de Janeiro continuaria marcada pelo agravamento de sua trajetória de redução de participação na produção industrial brasileira e no PIB nacional. Como resultado, o estado do Rio de Janeiro teve de aguardar a década de 1990 para assistir a um conjunto de mudanças em sua base produtiva que desencadearia um processo de reestruturação. Tais mudanças são postas em tela a seguir, quando se volta a atenção à compreensão do processo de reestruturação territorial fluminense e à inserção dos investimentos chineses no estado no início do século XXI.

Compreendida como processo resultante da modificação da estrutura de um espaço material, de forma rápida ou lenta, ocorrendo em diferentes escalas em que os fatores econômicos, políticos e ideológicos, frequentemente combinados, transmitem a noção de ruptura nas tendências seculares, a reestruturação pode ser compreendida como uma mudança estrutural expressiva em direção a uma ordem e a uma configuração significativamente diferente nas vidas social, econômica e política (Soja, 1993; Santos, 2008; Souza, 2013). 
No caso do estado do Rio de Janeiro, a década de 1990 se caracterizou pela superação da trajetória de estagnação pari passu ao processo de retomada de crescimento econômico do estado, revertendo a perda de importância na economia nacional após a fase de esvaziamento econômico e/ ou de perdas relativas entre as décadas de 1930-1980. Como desdobramento desse processo, houve a retomada das atividades produtivas e a emergência de uma conjuntura liderada pelo interior fluminense, em face da dinamização de seu parque industrial, que capitaneou a reestruturação territorial do estado, conformando-o em "um território em mudança". Com efeito pouco visível no espaço metropolitano, uma nova economia regional se constituía a partir do interior do território, marcada por uma trajetória de retomada do crescimento econômico (Oliveira, 2012).

Com uma extensão de 43,7 mil km², o atual estado do Rio de Janeiro (Figura 1) estabelece divisa com outros três estados do Sudeste do Brasil, apresentando uma organização político-administrativa formada por oito regióes de governo e uma malha municipal constituída por 92 municípios.

Figura 1. Estado do Rio de Janeiro: a RMRJ e o interior fluminense

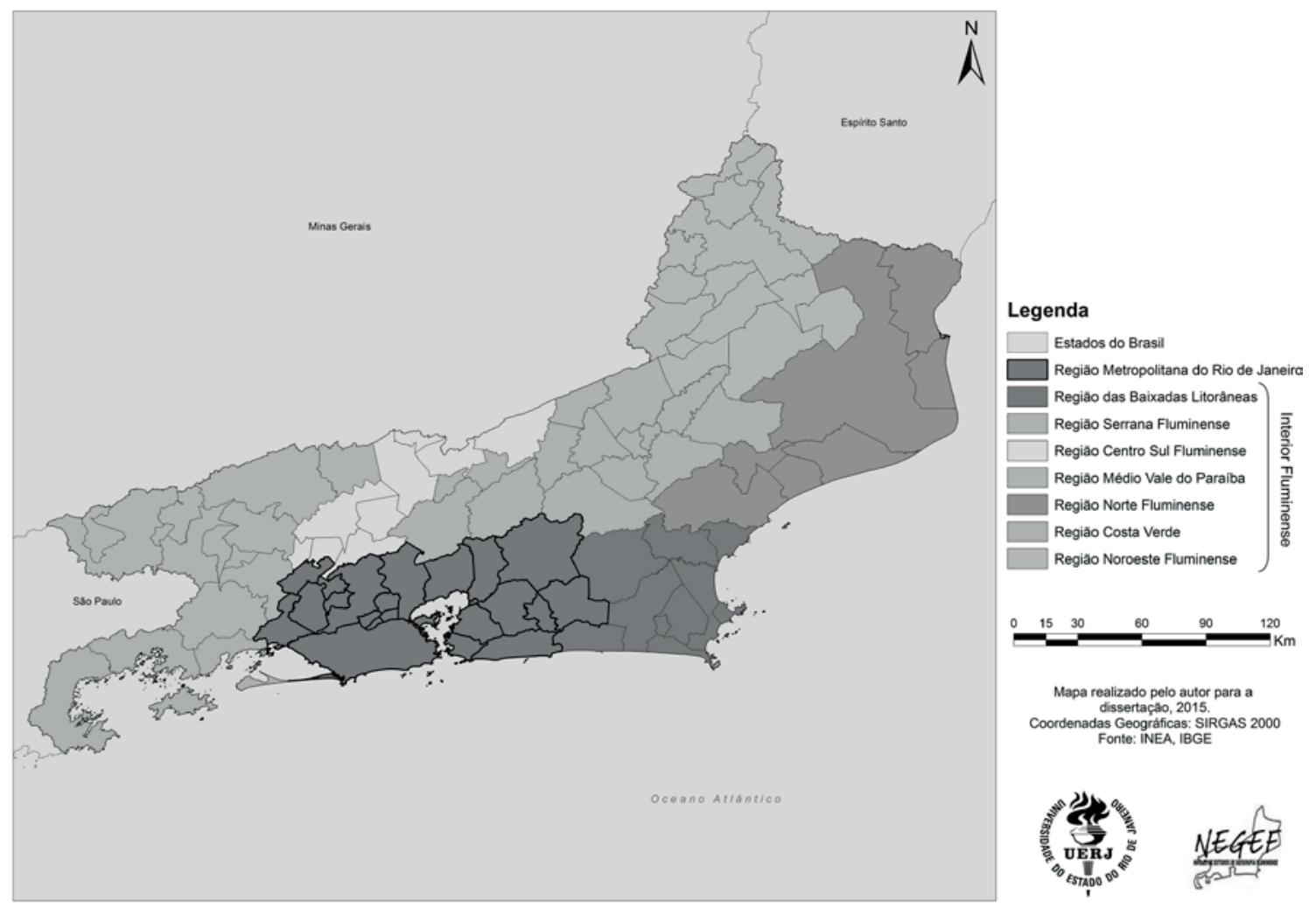

Oliveira (2008) compreende a reestruturação produtiva do território fluminense a partir da superação da crise de um modelo de industrialização centrado na cidade do Rio de Janeiro e em seu entorno, com a consequente dispersão das atividades produtivas para fora da Região Metropolitana do Rio de Janeiro. Essa dispersão decorreu da reorientação do fluxo de investimentos no território e 
da instalação de novas plantas industriais no interior fluminense, o que contribuiu para a reestruturação produtiva e a reconfiguração econômico-regional do Médio Paraíba - metalmecânico, siderometalúrgico e automobilístico - e do Norte Fluminense - onde a indústria extrativo-petrolífera e as atividades de suporte voltadas a esse setor se destacam. ${ }^{2}$

Nesse sentido, consideramos, para efeito de análise, a década de 1990, especialmente a segunda metade, o momento de retomada da economia fluminense, tanto pela continuidade da instalação de novas atividades produtivas quanto por ser um ponto de inflexão na trajetória de crescimento do PIB no estado do Rio de Janeiro. A partir desse momento, a trajetória do PIB fluminense manteve-se crescente e sua participação relativa na economia nacional, embora oscilante, apresentou tendência de crescimento entre 1995-2013, quando o PIB fluminense saltou de $\mathrm{R} \$ 78,9$ milhões em 1995 para $\mathrm{R}$ \$ 626,3 milhões em 2013, ampliando sensivelmente o percentual de participação na economia nacional, de 11\% em 1995 para aproximadamente 12\% em 2012, mantendo-se ainda em 2013 com uma participação ligeiramente superior à contribuição apresentada em meados dos anos 1990 (Gráfico 3).

Gráfico 3. Estado do Rio de Janeiro: PIB e participação no PIB nacional entre 1995-2013

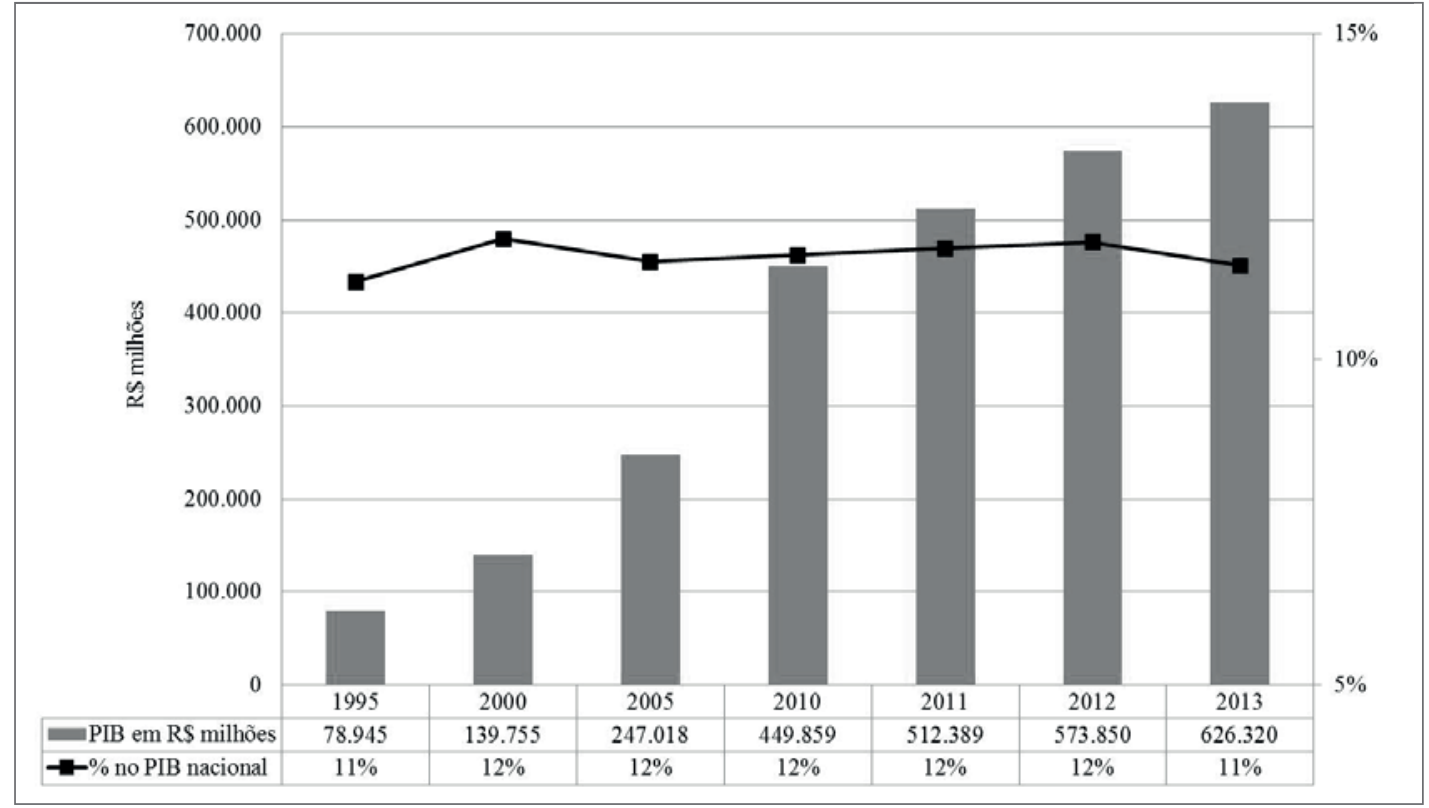

Fonte: Autor, 2015.

${ }^{2}$ Para Oliveira, o marco desse processo foi "o ano de 1994, quando teve início a extração de petróleo em escala comercial nas grandes jazidas da bacia de Campos, no norte do estado, e o anúncio da instalação da indústria automobilística com a montadora de caminhões da Volkswagen, na região do Médio Paraíba” (2012, p. 136). 


\section{Os investimentos externos diretos da República Popular da China no território fluminense}

Nas últimas décadas, a avaliação da trajetória de crescimento do PIB no estado do Rio de Janeiro viabiliza a compreensão da retomada da capacidade produtiva da economia fluminense, não deixando dúvida acerca de uma mudança na conjuntura econômica vivenciada pelo território. Nesse sentido, concordamos com as consideraçôes de Silva (2012), ao assinalar que esse processo decorre da alteração do padrão de esvaziamento para uma retomada da atividade econômica estadual, comandada pela atividade industrial, em especial a indústria extrativa petrolífera, e também por alguns setores da indústria de transformação, que, entre outros aspectos, promoveram a desconcentração das atividades produtivas no território e da produção industrial fluminense, o que contribuiu para a reestruturação da economia estadual.

Para Silva (2012), os padrões de desenvolvimento industrial do interior fluminense compreendem a especialização da produção petrolífera no Norte fluminense e a especialização da produção manufatureira do Sul fluminense. Com efeito, as regiōes de governo que compõem o recorte espacial compreendido pelo interior fluminense ganham expressão com a instalação de novas atividades produtivas, o que influiu na reversão do quadro de estagnação que perdurou até os anos 1980, dando início a um movimento de inversão da concentração de recursos, das atividades produtivas, da população e dos investimentos da Região Metropolitana em relação ao interior. Estabeleceu-se, assim, na passagem para o século XXI, um novo cenário econômico no território fluminense, mantido pela tendência de expansão econômica do interior do estado, em oposição à retração da participação da Região Metropolitana no PIB do estado do Rio de Janeiro (Gráfico 4).

Gráfico 4. Estado do Rio de Janeiro: participação da RMRJ e interior fluminense no PIB (2000-2012)

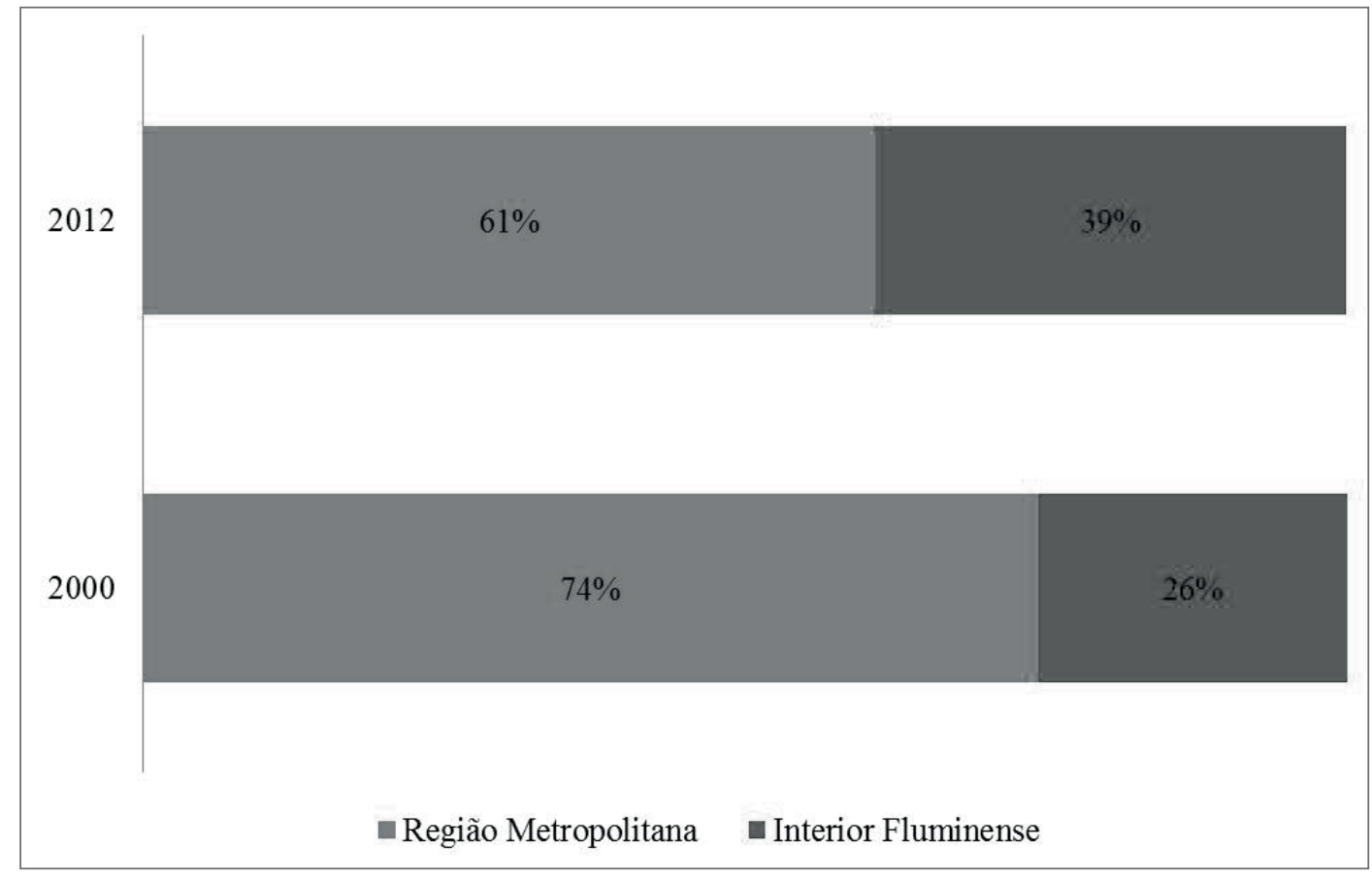

Fonte: Fundação Ceperj. Disponível em: http://www.ceperj.rj.gov.br/ceep/pib/pib.html. Acesso em: 8 nov. 2015. Gráfico elaborado pelo autor. 
A tendência de expansão econômica no interior e a implantação das atividades produtivas nesse território, resultante da reorientação no influxo de investimentos, contribuíram para um processo de reorganização das taxas de crescimento econômico regional, haja vista que, entre 2000-2012 a porção interiorana do estado do Rio de Janeiro aumentou sua participação na economia estadual de 13,5\% para 25,6\%, enquanto a RMRJ assistiu à diminuição de sua participação de $74 \%$ em 2000 para $61 \%$ em 2012. Nesse período, as regióes do interior do estado, como o Norte Fluminense e as Baixadas Litorâneas, apresentaram os maiores percentuais de crescimento, ampliando sua contribuição no PIB fluminense (Tabela 1).

Tabela 1. Estado do Rio de Janeiro: PIB por regiōes de governo (\%) (2000-2012)

\begin{tabular}{|l|c|l|c|c|}
\hline $\begin{array}{l}\text { Regióes de governo } \\
(\mathbf{2 0 0 0})\end{array}$ & $\mathbf{\%}$ & $\begin{array}{l}\text { Regióes de governo } \\
(\mathbf{2 0 1 2})\end{array}$ & $\mathbf{\%}$ & Variação \% \\
\hline Metropolitana & 74,38 & Metropolitana & 60,84 & $-13,54$ \\
\hline Norte fluminense & 7,39 & Norte fluminense & 16,06 & 8,67 \\
\hline Médio Paraíba & 6,76 & Médio Paraíba & 5,54 & $-1,22$ \\
\hline Serrana & 4,06 & Serrana & 3,89 & $-0,17$ \\
\hline Baixadas Litorâneas & 3,88 & Baixadas Litorâneas & 8,35 & 4,47 \\
\hline Centro-Sul Fluminense & 1,21 & Centro-Sul Fluminense & 1,31 & 0,1 \\
\hline Noroeste Fluminense & 1,23 & Noroeste Fluminense & 1,02 & $-0,21$ \\
\hline Costa Verde & 1,10 & Costa Verde & 2,98 & 1,88 \\
\hline Interior Fluminense & 25,63 & Interior Fluminense & 39,15 & 13,52 \\
\hline
\end{tabular}

Fonte: Fundação Ceperj. Disponível em: http://www.ceperj.rj.gov.br/ceep/pib/pib.html. Acesso em: 8 nov. 2015. Tabela elaborada pelo autor com base na participação por atividade econômica e no valor adicionado bruto, segundo as regiōes de governo e os municípios 2000/2012.

Compreende-se, assim, que a reestruturação territorial fluminense caracteriza-se pela retomada do crescimento econômico estadual, ao lado da reconfiguração econômica regional por que passou o interior do estado, em função da reorientação dos investimentos no território com a implantação de novas atividades produtivas capazes de alterar aquela trajetória econômica decadente. Em consequência desse processo, o estado do Rio de Janeiro irrompeu o século XXI desempenhando um novo papel no cenário econômico nacional.

Nos últimos anos, o estado vem aumentando sua participação na economia brasileira e, isoladamente, respondeu por aproximadamente $12 \%$ do PIB nacional. Superado apenas pelo estado de São Paulo (32\%) e seguido por Minas Gerais (9\%) no que tange à participação na economia nacional, ${ }^{3}$ atualmente o território fluminense se mantém como a segunda maior economia entre as

\footnotetext{
${ }^{3}$ Fundação Ceperj. Disponível em: http://www.ceperj.rj.gov.br/ceep/ceep.html. Acesso em: 20 mar. 2015.
} 
unidades federativas, sendo marcado por um forte influxo de capitais produtivos. É esse aspecto que nos chama a atenção, visto que, diante de uma nova conjuntura econômica conformada por seu processo de reestruturação territorial, o estado do Rio de Janeiro destacou-se na carteira de investimentos industriais, logísticos e de serviços (Terra et al., 2012).

Esse processo de ampliação do influxo de investimentos, sobretudo aquele promovido pela inserção de capitais estrangeiros, evidencia a transnacionalização do território e sua constituição como um espaço nacional da economia internacional (Santos, 1996; Santos e Silveira, 2008). Assim, no sentido de preencher uma lacuna no que concerne ao influxo de investimentos internacionais no estado do Rio de Janeiro, é preciso destacar o processo de inserção dos investimentos chineses no território fluminense.

O fato é que a presença desses investimentos no território fluminense contribui para a continuidade de suas transformaçôes econômico-produtivas, evidenciando sua maior inserção na economia globalizada. Embora tragam contribuiçōes importantes em relação à retomada do crescimento econômico do estado do Rio de Janeiro e evidenciem a reestruturação produtiva do território nas últimas duas décadas, os estudos em geral que avaliam a trajetória econômica fluminense na passagem para o século XXI dão pouca ênfase ao influxo dos investimentos chineses no território fluminense no início do século XXI, sobretudo no período de 2010 a 2013.

Sob a ótica da Geografia, esses investimentos são compreendidos como uma nova territorialidade, com a presença de novos atores no processo de reestruturação territorial fluminense, por se tratar de um grupo de empresas estatais chinesas que, ao serem implantadas no território, atuam segundo a lógica do projeto estratégico nacional de capitalismo de Estado oriental, sendo orientadas pelo interesse em controlar novas áreas e recursos, com vistas à manutenção das taxas de crescimento da República Popular da China. Assim, seguindo a lógica do projeto nacional do governo chinês, no início do século XXI houve uma ampliação dos investimentos chineses no Brasil. Com efeito, o período de 2007 a 2013 totalizou US\$28,3 bilhōes desses investimentos confirmados em nosso país (Tabela 2).

Tabela 2. IED chineses confirmados no Brasil entre 2007-2013

\begin{tabular}{|l|l|}
\hline Ano & Valor total em US\$ \\
\hline 2007 & $434.000 .000,00$ \\
\hline 2008 & $20.000 .000,00$ \\
\hline 2009 & $95.000 .000,00$ \\
\hline 2010 & $13.090 .000 .000,00$ \\
\hline 2011 & $8.030 .000 .000,00$ \\
\hline 2012 & $3.449 .000 .000,00$ \\
\hline 2013 & $3.235 .000 .000,00$ \\
\hline Total & $28.353 .000 .000,00$ \\
\hline
\end{tabular}

Fonte: CEBC (2013) e CEBC (2014 e 2015). Tabela elaborada pelo autor.

A inclusão do estado do Rio de Janeiro nesse processo decorreu da participação do capital sínico em alguns setores produtivos da economia fluminense, incluindo o estado nas áreas compreendidas pela expansão dos investimentos daquele país asiático. A espacialização desses investimentos no 
território nacional caracteriza-se por sua concentração na Região Sudeste do país. Ocupando posição de destaque entre as unidades federativas dessa região, entre 2010 e 2013 o estado do Rio de Janeiro projetou-se como um importante receptor dos investimentos chineses, com um influxo de aproximadamente US\$ 18,8 bilhôes desse tipo de investimento (Tabela 3).

Tabela 3. Investimentos chineses no território fluminense: 2010-2013

\begin{tabular}{|l|l|}
\hline Ano & Valor total em US\$ \\
\hline 2010 & $7.109 .000 .000,00$ \\
\hline 2010 & $3.070 .000 .000,00$ \\
\hline 2010 & $20.000 .000,00$ \\
\hline 2010 & $3.500 .000 .000,00$ \\
\hline 2011 & $200.000 .000,00$ \\
\hline 2011 & $3.500 .000 .000,00$ \\
\hline 2013 & $1.500 .000 .000,00$ \\
\hline Total & $18.899 .000 .000,00$ \\
\hline
\end{tabular}

Fonte: Oliveira, A. (2012) e CEBC (2013; 2014; 2015). Tabela elaborada pelo autor.

Esse volume de capital que ingressa no território corresponde a sete projetos da República Popular da China no estado do Rio de Janeiro, especialmente nos setores automotivo, ferroviário, siderúrgico e energético (petróleo e gás). Problematizar o influxo desse tipo de capital nos territórios nacional e fluminense nos exige compreender a abertura econômica e a projeção da República Popular $\mathrm{da}$ China como investidor internacional.

\section{República Popular da China: abertura econômica e projeção como investidor internacional}

A transferência do epicentro da economia política global da América do Norte para a Ásia Oriental, onde a República Popular da China se projeta como novo líder do renascimento econômico asiático, coloca em evidência a constituição de um novo regime e a conformação de um novo ciclo sistêmico de acumulação (Arrighi, 2008; 2012). A espetacular projeção econômica chinesa é entendida, na perspectiva de Gonçalves (2010), como parte das mudanças estruturais pelas quais o sistema internacional passa.

A retomada econômica do país asiático resulta de uma longa trajetória de expansão material articulada desde o período de fundação da República Popular da China, em condições estruturais es- 


\section{Os investimentos externos diretos da República Popular da China no território fluminense}

pecíficas e empreendendo um esforço de planejamento estatal, com a adoção de uma série de medidas voltadas à expansão econômica, principalmente pela via da industrialização (Ribeiro, 2013).

Localizada na porção oriental da Ásia, a República Popular da China é composta por 34 divisões administrativas ${ }^{4}$ e apresenta uma configuração territorial de 9,6 milhões de $\mathrm{km}^{2}$, estabelecendo limite com mais de uma dezena de Estados-nacionais. Com tamanha extensão, o país mais populoso do mundo (1,3 bilhão de habitantes) não carece de recursos, mas o ritmo de crescimento econômico imposto pelo novo ciclo de expansão da República Popular da China lhe conduziu, desde a década de 1990, a uma perda da autossuficiência em recursos energéticos, como petróleo, gás natural e carvão mineral, entre outros (Ribeiro, 2013).

A partir da última década, quando o país entrou nesse ciclo de expansão baseado nos investimentos em infraestrutura e na indústria pesada, suas reservas de fontes minerais aproximaram-se do limite. Como uma forma de solucionar essas demandas, a China vem direcionando seus investimentos externos diretos para diferentes regiōes ao promover a atuação de empresas estatais para além de suas fronteiras, em busca desses recursos em outros territórios.

Antes de se voltar a atenção para os investimentos diretos chineses no exterior, é preciso assinalar que o país asiático teve de aguardar a Revolução Chinesa de 1949 para romper com o século da humilhação, o período de dominação estrangeira, e somente então, instituir a República Popular, entendendo que as profundas transformações econômicas no território chinês viriam com sua abertura ao influxo de capitais estrangeiros no final na década de 1970. Nesse período, a chegada do governo Deng Xiaoping (1978-1992) foi marcada por importantes reformas que conduziram a trajetória de crescimento econômico na China. Gonçalves (2010) assinala que, desde que Xiaoping deu início à reforma econômica, em 1978, a China aumentou seu PIB numa média anual superior a 10\%. Portanto, contribuíram para esse processo as mudanças na política externa ${ }^{5}$ do país, o que lhe conferiu maior projeção internacional, assim como a modernização das estruturas produtivas, com o programa das Quatro Modernizaçóes ${ }^{6}$ e a abertura econômica aos investimentos estrangeiros.

A abertura econômica ocorrida no final da década de 1970 foi um ponto de inflexão na história econômica do país. Na ocasião, o território da República Popular tornou-se viável à instalação de atividades produtivas e à ampliação e à reprodução do capital excedente das grandes corporações, que encontraram, nas vantagens locacionais oferecidas pelo país, um ambiente favorável à reprodução do capital. Assim, as reformas viabilizaram o ingresso de investimentos internacionais nas zonas especiais do território, possibilitando que a taxa de investimento no PIB atingisse aproximadamente 47\%.

\footnotetext{
${ }^{4}$ As divisōes administrativas da República Popular da China compreendem 23 províncias, cinco regiōes autônomas, quatro municípios centrais e duas regiôes administrativas especiais (Hong Kong e Macau). Disponível em: http://portuguese.cri.cn/chinaabc/chapter1/chapter10202.htm. Acesso em: 23 jul. 2015.

5 "Desde então, a política exterior e o modelo de desenvolvimento foram se adaptando ao propósito de promover desenvolvimento interno, ao estilo cada vez mais próximo da modernização alcançada pelo sistema capitalista de produção, consumo e inserção internacional” (Cervo, 2008, p. 278).

6 O programa das Quatro Modernizações da China compreendeu a modernização dos setores de agricultura, indústria, tecnologia e defesa nacional (Kissinger, 2011).
} 
Nos anos 1980, com a promoção de uma política de abertura do território ao capital estrangeiro, a República Popular da China vivenciou um grande influxo de investimentos externos e, a partir da década de 1990, o país asiático alterou sua política de recepção de IDE, abrindo o mercado às empresas estrangeiras ligadas aos setores de serviços de telecomunicaçōes, bancos, seguros e tecnologia avançada, exigindo-se, então, a formação de joint ventures com empresas locais sob o controle estatal. Nesse sentido, com o objetivo de atenuar as desigualdades regionais, o governo chinês adotou, a partir de 1997, políticas de atração de investimentos estrangeiros nas regiōes central e ocidental do país, estendendo a política de abertura a todas as capitais provinciais, às regiōes autônomas e a algumas cidades fronteiriças, o que tornava as ZEEs "menos especiais" ao influxo do capital estrangeiro (Alves, 2014).

Como resultado desse processo, manteve-se crescente o influxo de IED no território chinês entre aquela década e o início do século XXI, o que tornou a República Popular da China um importante país para os investidores internacionais. Assim, o país saltou na recepção de investimentos estrangeiros, de US\$ 1,4 bilhão em 1984 para US \$ 37,5 bilhões em 1995, atingindo US\$ 111,7 bilhōes em 2012 (Gráfico 5).

Gráfico 5. República Popular da China: influxo de IED - 1984-2012

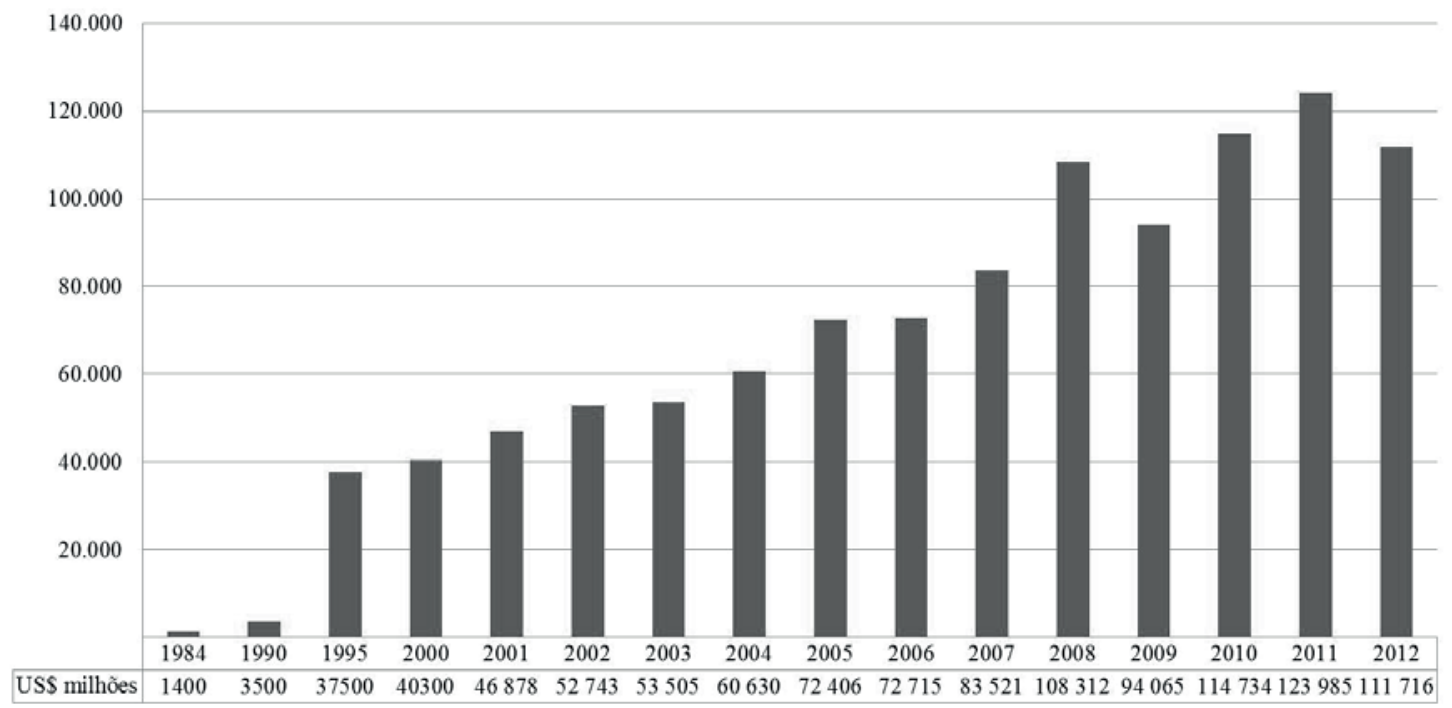

Fonte: Chinability (s.d.) e UNCTAD (s.d.). Disponível em: http://unctad.org/Sections/dite_fdistat/docs/webdiaeia2014d3_CHN.pdf. Acesso em 8 nov. 2015. Disponível em: http://www.chinability.com/FDI.htm. Acesso em: 8 nov. 2015. Gráfico elaborado pelo autor.

Nesse contexto, nas últimas décadas a China projetou-se como um país asiático receptor de investimentos externos diretos estrangeiros, mantendo suas taxas de crescimento econômico bastante elevadas. No entanto, desde o final do século XX, a República Popular da China coloca em prática um conjunto de iniciativas para expandir seus investimentos no exterior e vivencia diferentes fases no processo de evolução de sua política para a saída desses investimentos. Assim, o país alçou à posição de maior investidor internacional entre os países de sua região no início do século XXI. Porém, como bem 
apontado por Buckley et al. (2010) e Oliveira (2012), pouca tem sido a atenção dispensada à República Popular da China como investidor internacional.

Além da projeção como recipiendária de investimentos, a República Popular da China ampliou sua participação no estoque e no fluxo de investimentos em todo o mundo, apresentando trajetória ascensional na condição de investidor internacional. Esse processo despertou a atenção mundial e motivou a realização de pesquisas para identificar a passagem do país da condição de grande receptor de investimentos à de investidor internacional. Entre essas pesquisas, têm-se as realizadas por Buckley et al. (2010), Ribeiro (2010; 2013), Ipea (2011), Oliveira (2012), CEBC (2011; 2013) e Alves (2014).?

Embora a internacionalização dos investimentos chineses já viesse ocorrendo desde 1979 - quando das primeiras concessōes para realizar investimentos no exterior, foi somente a partir da década de 1990 que aquele país ampliou sua participação no fluxo e no estoque de IED no mundo (Buckley et al., 2010; Oliveira, 2012; CEBC, 2013; Alves, 2014). Com efeito, a República Popular da China manteve sua trajetória de ampliação dos investimentos no exterior e, em 2012, atingiu US \$ 531,9 bilhôes em seus estoques de investimentos externos, chegando, em 2014, a US\$ 116 bilhões em fluxos de investimento no exterior (Gráficos 6 e 7).

Gráfico 6. República Popular da China: estoque de investimento direto no exterior entre 1990-2012

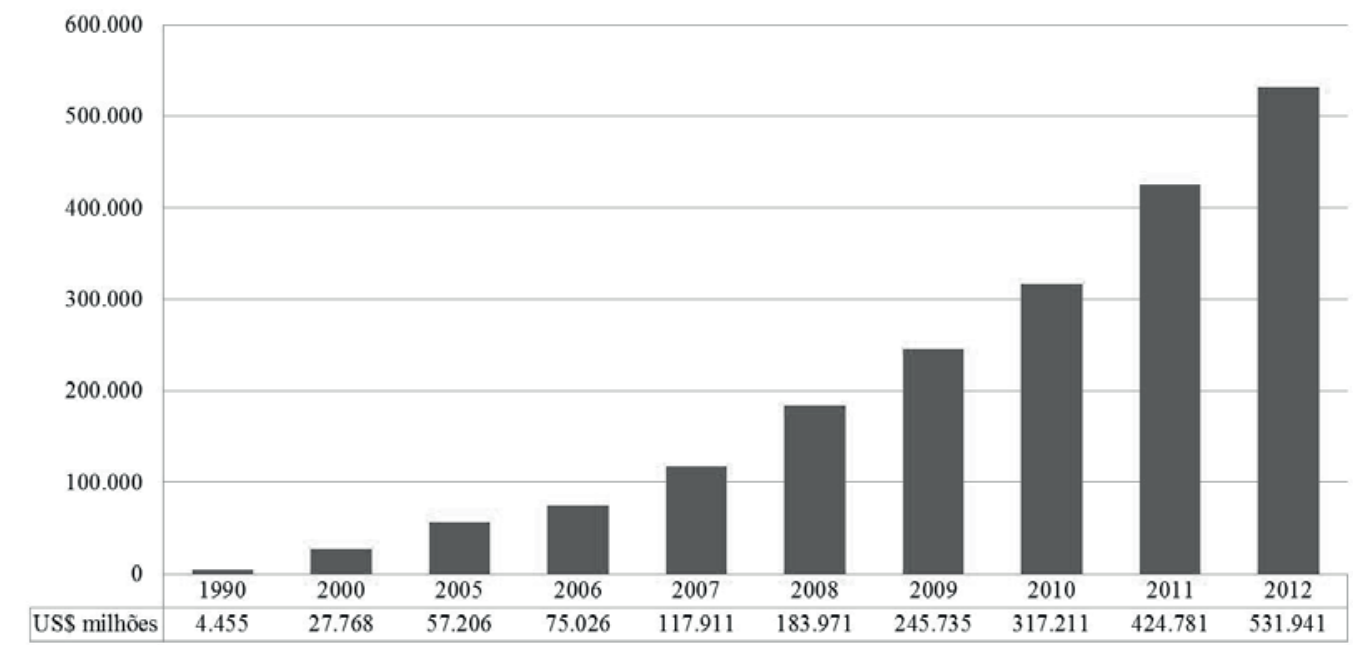

Fonte: Alves (2014) e UNCTAD (s.d.). Disponível em: http://unctad.org/Sections/dite_fdistat/docs/webdiaeia2014d3_ CHN.pdf. Acesso em 8 nov. 2015. Gráfico elaborado pelo autor.

\footnotetext{
7 Muitos estudos abordaram essa temática, em face de sua relevância para a dinâmica daquela economia asiática e também para a economia mundial. Alguns deles são aqui retomados, por representarem referências teóricas acerca da expansão dos investimentos chineses no mundo, subsidiando nossa análise sobre a ascensão da China como investidor internacional.
} 
Gráfico 7. República Popular da China: fluxo de investimentos diretos para o exterior entre 2000-2014

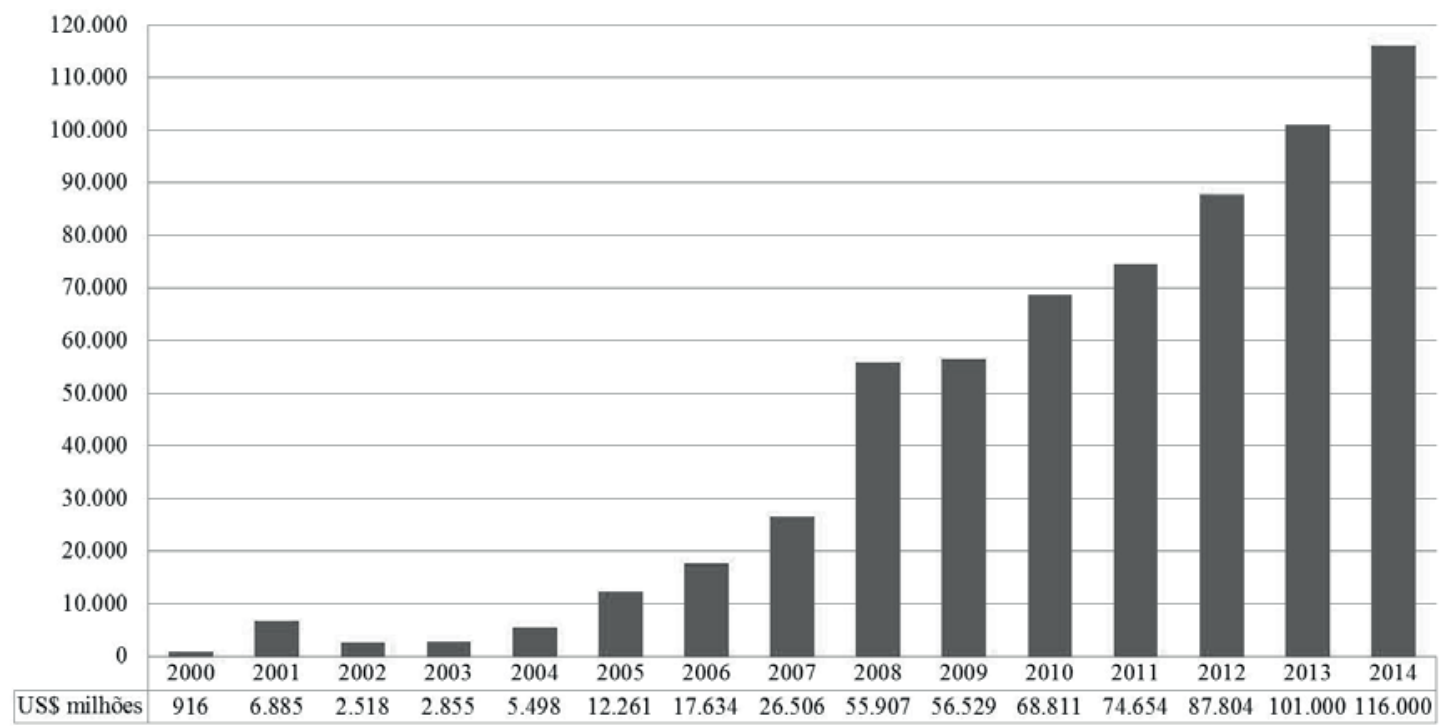

Fonte: Alves (2014); Chinability (s.d.) e UNCTAD (s.d.). Disponível em: http://www.chinability.com/ODI.htm. Acesso em: 8 nov. 2015. Disponível em: http://unctad.org/Sections/dite_fdistat/docs/webdiaeia2014d3_CHN.pdf. Acesso em 8 nov. 2015. Gráfico elaborado pelo autor.

O desempenho alcançado como investidor internacional pela República Popular da China remonta a uma trajetória gradual de expansão de seus investimentos no exterior, dotando-a de capacidade político-econômica para investir em diferentes regiōes do mundo com assertividade e pragmatismo. Assim, a influência do país asiático foi ampliada não pela via da coação, mas por relações econômicas e aumento de seus investimentos nos países em desenvolvimento e nas economias detentoras de recursos.

Oliveira (2012) e CEBC (2013) tomam Buckley et al. (2007; 2010) como referencial para abordar as políticas de desenvolvimento do IED chinês. Seguindo a divisão proposta por esses autores acerca da liberalização dos investimentos chineses no exterior, compreende-se a divisão de cinco estágios de expansão, denominados internacionalização cautelosa, encorajamento governamental, regulação e expansão, Go Global e periodo pós-OMC. Alves (2014), contudo, divide o processo de expansão dos investimentos chineses no exterior em três fases, cujos agrupamento e classificação são compreendidos pelos recortes temporais 1979-1991, 1992-2000 e 2001-até a presente data. Nos quadros 1 e 2, expõem-se, de maneira sucinta, as principais considerações acerca desses estágios e/ou fases de expansão dos IED chineses no exterior. 
Quadro 1. Esquema-síntese do modelo de expansão dos investimentos chineses no exterior segundo Buckley (2010), Oliveira (2012) e CEBC (2013)

\begin{tabular}{|c|c|c|c|c|}
\hline \multicolumn{5}{|c|}{ Estágios de expansão dos IEDs chineses } \\
\hline 1 o Estágio & 2o Estágio & 3o Estágio & 40 Estágio & 5 Estágio \\
\hline $\begin{array}{l}\text { Internacio- } \\
\text { - nalização } \\
\text { Cautelosa }\end{array}$ & $\begin{array}{l}\text { Encorajamento Governa- } \\
\text { mental }\end{array}$ & $\begin{array}{l}\text { Regulação e Expan- } \\
\text { são }\end{array}$ & Go Global & Período pós-OMC \\
\hline 1979-1985 & 1986-1991 & 1992-1998 & 1999-2001 & $2001 \ldots$ \\
\hline $\begin{array}{l}\text { Aprimorar o } \\
\text { acesso aos re- } \\
\text { cursos natu- } \\
\text { rais escassos } \\
\text { na China }\end{array}$ & $\begin{array}{l}\text { Estabelecer filiais em outros } \\
\text { países, cujos objetivos com- } \\
\text { preendiam: apoiar a função } \\
\text { exportadora das grandes fá- } \\
\text { bricas estatais; ajudar a estabi- } \\
\text { lizar a demanda por recursos } \\
\text { naturais; adquirir informação } \\
\text { e aprender como operar no } \\
\text { exterior }\end{array}$ & $\begin{array}{l}\text { Expansão e regu- } \\
\text { lação das empresas } \\
\text { chinesas, investi- } \\
\text { mentos e ações em } \\
\text { bens imobiliários }\end{array}$ & $\begin{array}{l}\text { Explorar novos merca- } \\
\text { dos para seus produ- } \\
\text { tos; melhorar o acesso à } \\
\text { propriedade tecnológica } \\
\text { estrangeira; aprimorar a } \\
\text { competitividade chinesa } \\
\text { por meio da diversifi- } \\
\text { cação de atividades de } \\
\text { negócios realizadas no } \\
\text { exterior }\end{array}$ & $\begin{array}{l}\text { Caracteriza-se pelo } \\
\text { afrouxamento dos } \\
\text { mecanismos de con- } \\
\text { trole do investimento } \\
\text { no exterior }\end{array}$ \\
\hline
\end{tabular}

Fonte: Quadro elaborado pelo autor.

Quadro 2. Esquema-síntese do modelo de expansão dos investimentos chineses no exterior segundo Alves (2012)

Fases de expansão dos IEDs

\begin{tabular}{|c|c|}
\hline 1a Fase (1979-1991) & 2a Fase (1992-2000) \\
\hline $\begin{array}{l}\text { Passos iniciais para a internacionalização das } \\
\text { empresas chinesas, com o objetivo de importar } \\
\text { tecnologia e equipamentos avançados, promo- } \\
\text { ver fontes confiáveis de recursos naturais estra- } \\
\text { tégicos para o desenvolvimento chinês, gerar } \\
\text { divisas para a China e auxiliar na exportação } \\
\text { de bens e serviços }\end{array}$ & $\begin{array}{l}\text { Política de encorajamento do i } \\
\text { presas estatais. Saída de IDE co } \\
\text { i) focar no uso de tecnologias; } \\
\text { ii) obtenção de recursos e } \\
\text { iii) mercados estratégicos }\end{array}$ \\
\hline
\end{tabular}

\section{3a Fase 2001-até a presente data (Go Global)}

Inserção competitiva das empresas chinesas no mercado globalizado, com o objetivo de:

i) elevar a competitividade e ampliar a cooperação econômica e técnica internacional da China;

ii) cooperar com a provisão de mão de obra em outros países; encorajar algumas empresas a explorarem o processamento

e o comércio no exterior; e contribuir para a exportação de produtos, serviços e tecnologias da China;

iii) apoiar a exploração além-mar dos recursos naturais domesticamente escassos;

iv) estabelecer centros de P\&D nos países receptores;

v) desenvolver operaçóes transnacionais;

vi) estabelecer um ambiente satisfatório de investimento no exterior;

vii) aperfeiçoar os mecanismos regulatórios internos voltados à regulação e à supervisão dos investimentos no exterior (Wenbin e Wilkes apud Alves, 2014, p. 352).

Fonte: Quadro elaborado pelo autor. 
Mudando com a maneira planejada de lidar com os investimentos no exterior, instituída desde o final da década de 1970, compreende-se que a estratégia Go Global conduziu a República Popular da China a uma posição de investidor internacional. Desde então, o país asiático aumentou sua participação nos fluxos e estoques de IDE no exterior. Com efeito, "a China ultrapassou o Japão para se tornar a quinta maior fonte global de investimentos em 2010” (CEBC, 2013, p. 23). ${ }^{8}$ Em 2011,

a política Go Global foi reiterada no $12^{\circ}$ plano quinquenal, com provisões para: aperfeiçoar o mecanismo de coordenação geral intersetorial, a fim de fortalecer a implementação da estratégia Go Global, e oferecer macro-orientaçôes às empresas; melhorar o sistema de leis e regulamentos para o investimento estrangeiro e evitar a dupla tributação; negociar acordos bilaterais de investimentos; desenvolver o sistema internacional de recursos energéticos; , e fornecer apoio para os investimentos em Pesquisa e Desenvolvimento (P\&D) no exterior (CEBC, 2013, pp. 26-7).

Segundo CEBC (2013), as novas diretrizes de IED retratam algumas mudanças político-econômicas chinesas, promovem maior integração do país na economia mundial e atendem a alguns objetivos específicos, como, por exemplo, permitir que as empresas chinesas garantam suprimento de energia e matéria-prima no longo prazo, com o acesso a mercados estrangeiros. Embora tracem diferentes propostas temporais de classificação sobre a expansão dos investimentos chineses no mundo, bem como apresentem dados com ligeiras diferenças quantitativas em relação aos apresentados pela Unctad (2014), ${ }^{9}$ as consideraçōes de Jabbour (2010), Buckley et al. (2010), Oliveira (2012), Ipea (2011), CEBC (2013) e Alves (2014) convergem e nos auxiliam na compreensão da China como investidor internacional.

Portanto, há que se salientar que, mesmo mudando seus objetivos ao ampliar seus investimentos no exterior, nota-se que, desde o início da internacionalização de seus investimentos, a República Popular da China teve a intenção de garantir acesso ao suprimento de recursos necessários ao seu desenvolvimento. Com esse objetivo, o país asiático deu início à expansão de seus investimentos no exterior, direcionando-os, inicialmente, aos países desenvolvidos. No entanto, recentemente, os maiores receptores dos investimentos chineses são os países em desenvolvimento situados na Ásia, na América Latina e na África, o que evidencia uma reorganização geográfica na distribuição espacial dos investimentos chineses, temática contemplada nas linhas subsequentes.

A distribuição dos investimentos chineses por região revela que os países desenvolvidos ainda estão inclusos na estratégia de internacionalização das empresas chinesas, embora com objetivos distintos, quando comparados àqueles destinados às regiões compreendidas pelas economias em desenvolvimento. No início do século XXI, os países em desenvolvimento tiveram sua participação consideravelmente ampliada no fluxo e no estoque de investimentos chineses e, entre 2003 e 2012, a

\footnotetext{
8 Antecedida apenas por França, Hong Kong, Alemanha e Estados Unidos (CEBC, 2013).

9 Em consulta ao site da Unctad, verificou-se que os dados acerca de fluxo e estoque de IDE nos países são continuamente atualizados, o que implica algumas ligeiras diferenças quantitativas para os anos mais recentes, em comparação aos estudos tomados como referência neste estudo.
} 
China direcionou o maior volume de investimentos externos para os países que integram as regiōes da Ásia, da América Latina e do Caribe (Gráficos 8 e 9).

Gráfico 8. República Popular da China: distribuição geográfica dos fluxos de investimentos externos diretos chineses, por regiões entre 2003-2012 (em US\$ milhões)

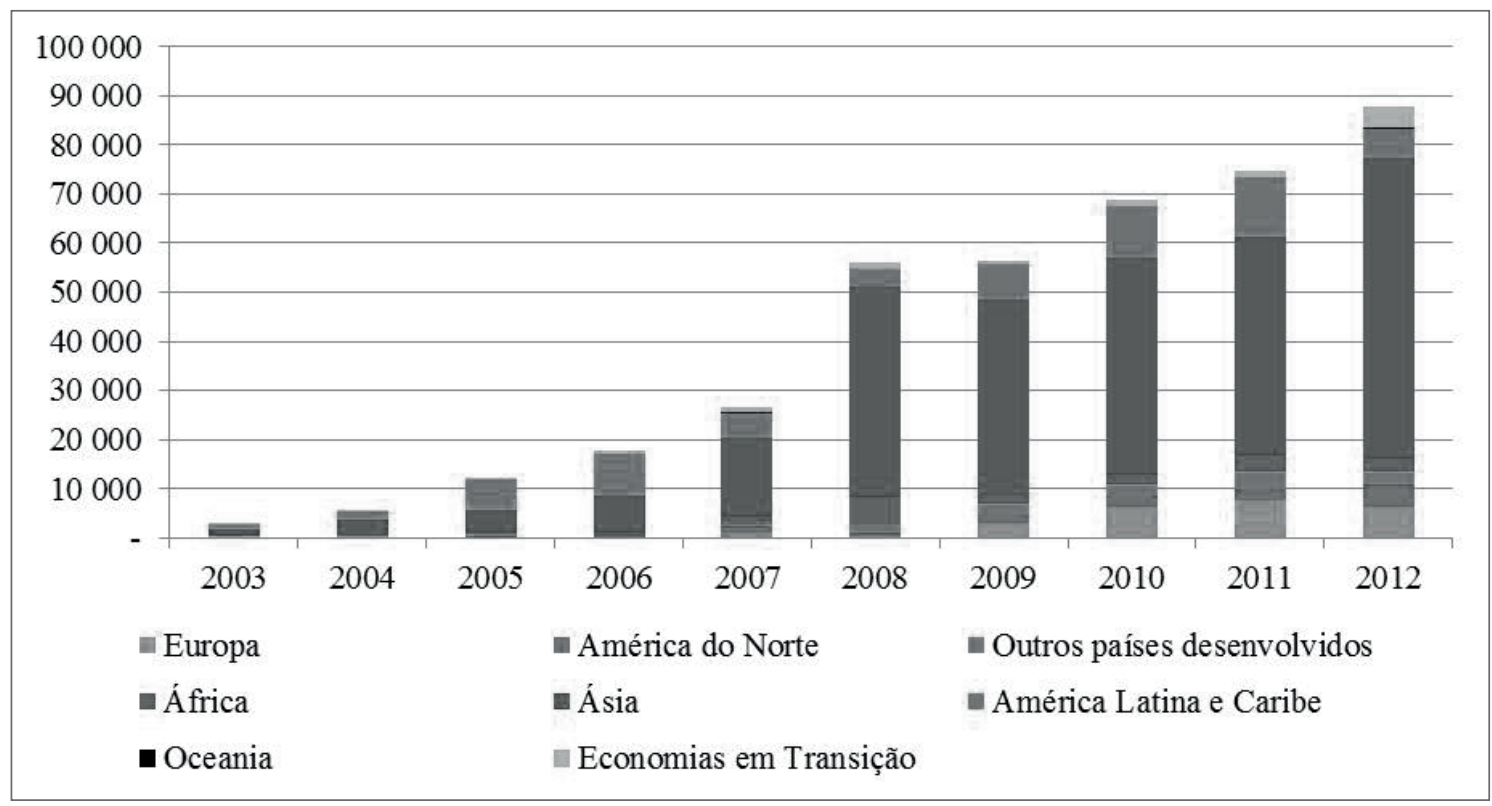

Fonte: Unctad (s.d.). Disponível em: http://unctad.org/Sections/dite_fdistat/docs/webdiaeia2014d3_CHN.pdf. Acesso em: 8 nov. 2015. Gráfico elaborado pelo autor.

Nesse contexto, os estoques de investimentos chineses no exterior tornaram-se maiores nas regiôes compostas pelas economias em desenvolvimento, o que levou a Ásia, a América Latina e o Caribe a se projetarem como as regiões que apresentaram maior estoque de IED chinês. Seguindo essa tendência, também na África, o estoque de investimentos chineses foi ampliado. Em contrapartida, as regióes que formam as economias desenvolvidas, embora tenham mantido os estoques de IDE, estes não foram tão volumosos quanto se mostraram até os anos 1990 (Gráfico 9). 
Gráfico 9. República Popular da China: distribuição geográfica dos estoques de investimentos externos diretos chineses por regiões (2003-2012, em US\$ milhões)

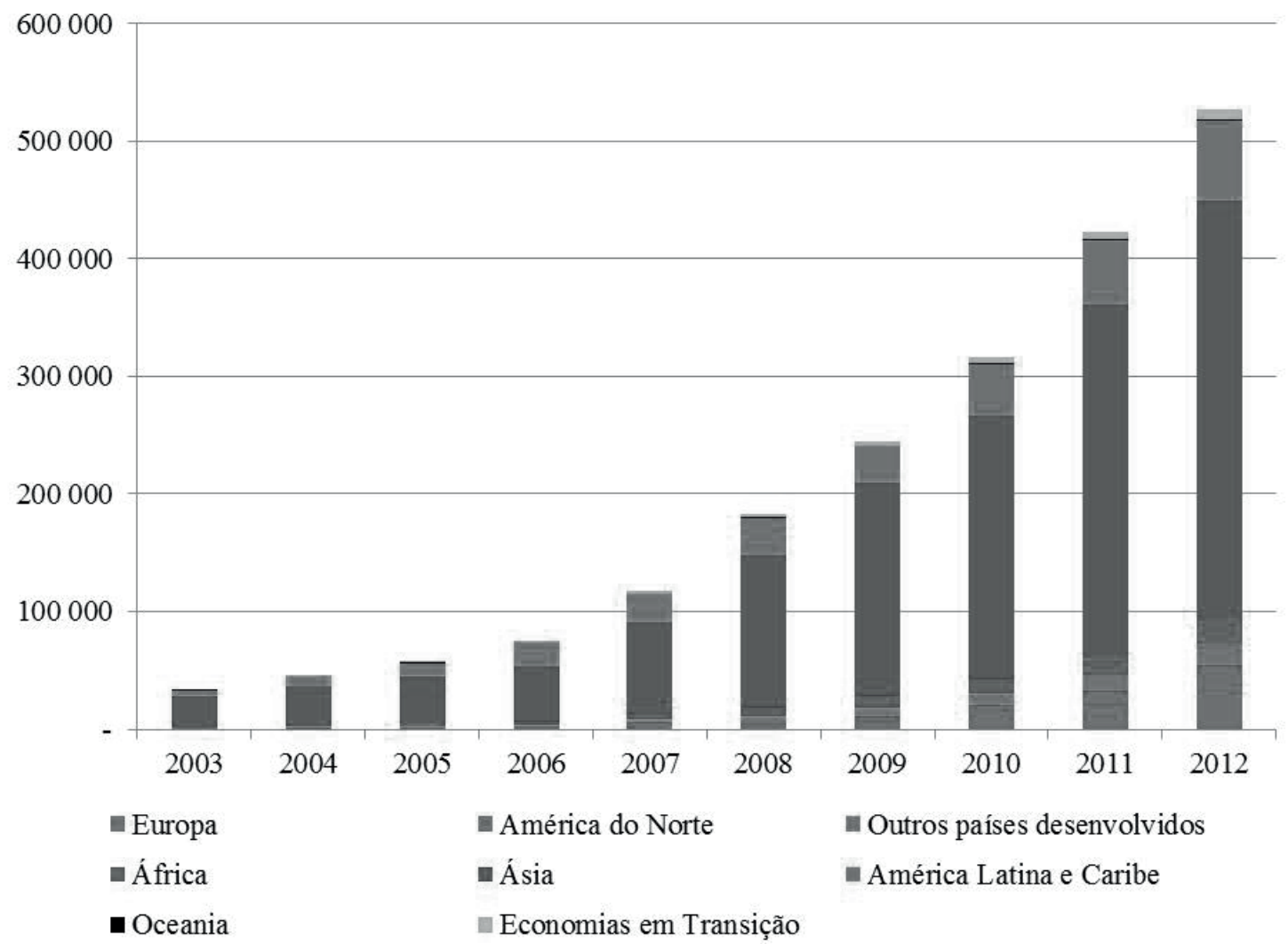

Fonte: Unctad (s.d.). Disponível em: http://unctad.org/Sections/dite_fdistat/docs/webdiaeia2014d3_CHN.pdf. Acesso em: 8 nov. 2015. Gráfico elaborado pelo autor.

A América Latina é uma região em que a presença chinesa torna-se crescente, tanto pelo ingresso de produtos importados desse país quanto pelo incremento dos investimentos no presente século. No que diz respeito aos investimentos chineses nesse recorte regional, observa-se que ocupa a posição de segundo maior receptor desses investimentos, em virtude do incremento no fluxo entre 2003-2012 - de US\$ 1 bilhão em 2003 para US\$11,9 bilhões em 2011, apresentando uma queda em 2012 para US\$ 6,1 bilhões. Por outro lado, o salto de US\$ 4,6 bilhões em 2003 para US\$ 68,2 bilhões em 2012 em relação ao estoque desse tipo de investimento - o que representa cerca de 13\% do estoque de investimento direto no exterior daquele país - leva-nos a concordar com Sutter (2010), quando aponta que, por meio de seus investimentos, a China amplia seu papel de atuação na região.

Anuímos com Gonçalves (2010) quando aponta que a China passou a interagir com mais atores do sistema internacional, expandindo suas relaçôes bilaterais com um número maior de países e criando fortes laços de interdependência com os países de todos os continentes. Também con- 
cordamos com Ribeiro (2013), no sentido de que o governo chinês, através das empresas estatais, vem promovendo diversas abordagens em regiōes que dispõem de amplos recursos naturais, como África e América Latina. Em verdade, o interesse chinês no acesso a recursos primários e energéticos vem motivando seu estímulo à importação e à expansão de investimentos diretos em diversos países dessas duas regiōes. Boniface e Védrine (2009), ao analisarem "o mundo visto pela China" (Figura 2), espacializam o interesse chinês em diferentes regióes do mundo e destacam que esse país asiático "interessa-se hoje [...] pela América Latina, para garantir a energia e as matérias-primas que lhe faltam" (p. 97).

Figura 2. O mundo visto pela China. Municípios receptores de investimentos chineses

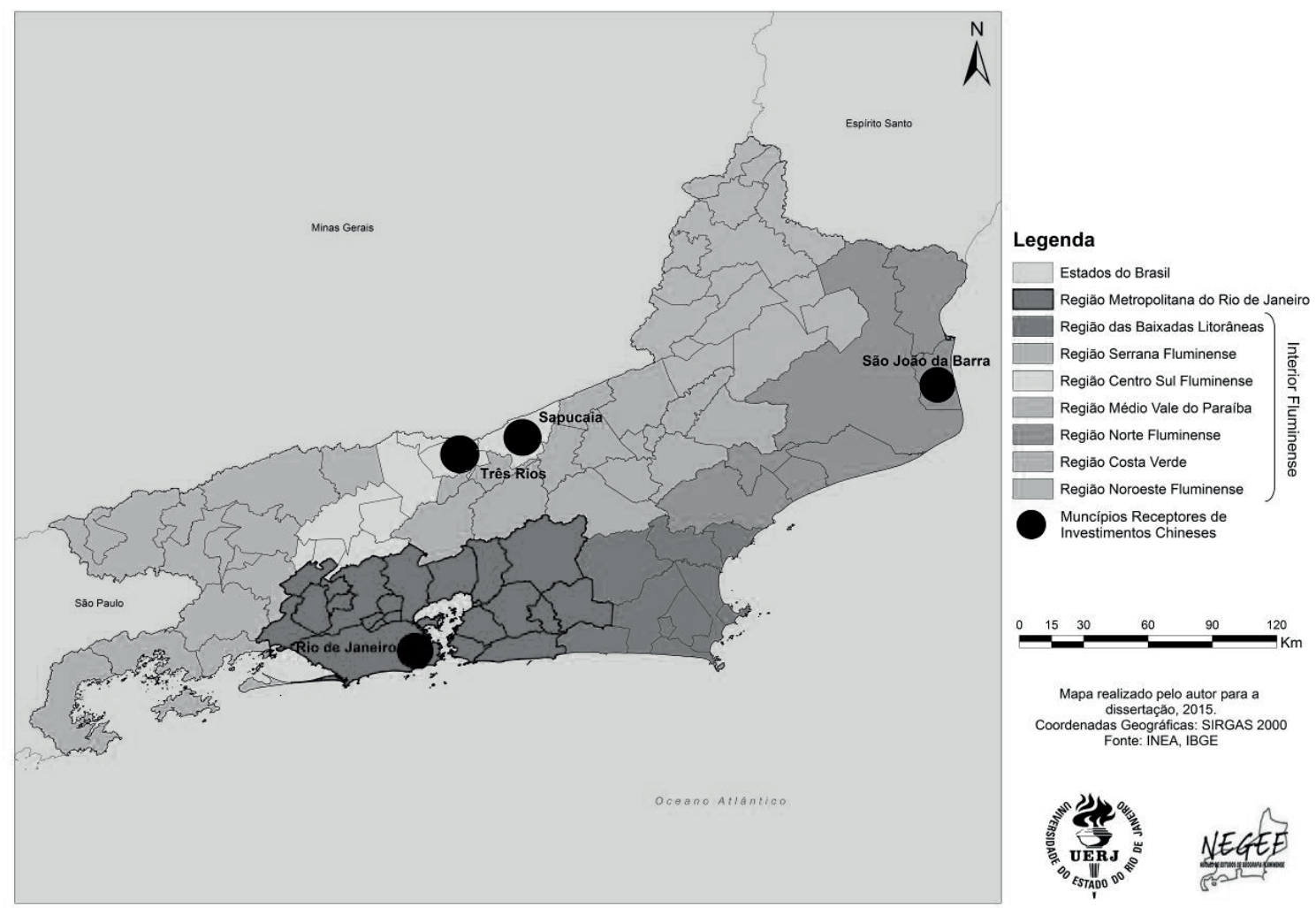

Fonte: Boniface e Védrine (2009).

Assim, América Latina afirma-se como uma região de complementaridade à República Popular da China, por causa da busca pelo acesso a matérias-primas via investimentos. $\mathrm{O}$ interesse chinês volta-se para a aquisição de recursos estratégicos como petróleo, cobre e ferro, a fim de suprir sua demanda interna, tendo o país realizado ainda investimentos na montagem de manufaturados, telecomunicações e têxtil (Ipea, 2011; Oliveira, 2012). Assim como ocorre em relação a outros países da região, o interesse chinês pelo Brasil tem fundamento na busca por novos mercados e recursos, 
sobretudo minério de ferro, soja e petróleo, produtos que ocupam posição de destaque na pauta das exportações brasileiras para aquela economia asiática.

\section{Investimentos chineses no território fluminense no século XXI (2010-2013)}

O ano de 2010 consolidou-se como um marco para o recebimento de investimentos chineses no território brasileiro. Embora já estivessem presentes no período de 2007 a 2009, o influxo de investimentos chineses confirmados no Brasil foi baixo, somando US\$ 549 milhôes. Entretanto, de 2010 em diante, o influxo desses investimentos foi ampliado no território, em face da confirmação do ingresso de US\$ 13 bilhões, sucedidos, nos anos subsequentes, por outros influxos confirmados, como US\$ 8 bilhōes em 2011, US\$ 3,4 bilhões em 2012 e US\$ 3,2 bilhōes em $2013 .^{10}$

Na Região Sudeste, o estado do Rio de Janeiro destacou-se como um dos maiores receptores de capital sínico, com o influxo de US\$18,8 bilhóes entre 2010-2013. Na Tabela 4, apresenta-se o volume de capital investido pela China no território fluminense nesse período, bem como as operaçôes das empresas chinesas, seus modos de entrada e setores de atuação.

Tabela 4. Investimentos chineses no território fluminense entre 2010-2013

\begin{tabular}{|c|c|c|c|c|c|c|c|}
\hline Projeto & Ano & $\begin{array}{l}\text { Empresa de } \\
\text { origem }\end{array}$ & $\begin{array}{l}\text { Valor em } \\
\text { US\$ }\end{array}$ & $\begin{array}{l}\text { Modo de } \\
\text { entrada }\end{array}$ & Setor & $\begin{array}{l}\text { Estrutura de } \\
\text { propriedade }\end{array}$ & $\begin{array}{l}\text { Determi- } \\
\text { nante do } \\
\text { investi- } \\
\text { mento }\end{array}$ \\
\hline 1 & 2010 & $\begin{array}{l}\text { Sinopec Repsol } \\
\text { Brasil* } \\
\text { (Confirmado) }\end{array}$ & 7.109 .000 .000 & $\begin{array}{l}\text { Fusões e aquisi- } \\
\text { ções (parciais) }\end{array}$ & $\begin{array}{l}\text { Energia (petró- } \\
\text { leo e gás) }\end{array}$ & Central SOE & $\begin{array}{l}\text { Busca por } \\
\text { Recursos }\end{array}$ \\
\hline 2 & 2010 & $\begin{array}{l}\text { Sinochem Sta- } \\
\text { toil ASA** } \\
\text { (Confirmado) }\end{array}$ & 3.070 .000 .000 & $\begin{array}{l}\text { Fusões e aquisi- } \\
\text { çóes (parciais) }\end{array}$ & $\begin{array}{l}\text { Energia (petró- } \\
\text { leo e gás) }\end{array}$ & Central SOE & $\begin{array}{l}\text { Busca por } \\
\text { recursos }\end{array}$ \\
\hline 3 & 2010 & $\begin{array}{l}\text { CR Zong- } \\
\text {-shen*** } \\
\text { (Confirmado) } \\
\end{array}$ & 20.000 .000 & Greenfield & Automotivo & Privada & $\begin{array}{l}\text { Busca por } \\
\text { mercado }\end{array}$ \\
\hline 4 & 2010 & $\begin{array}{l}\text { Wuhan Iron/ } \\
\text { Stell Group Co. } \\
\text { (Wisco) } \\
* * * * \\
\text { (Confirmado) }\end{array}$ & 3.500 .000 .000 & Joint Venture & Siderurgia & Central SOE & $\begin{array}{l}\text { Busca por } \\
\text { recursos }\end{array}$ \\
\hline
\end{tabular}

${ }^{10}$ Ver Tabela 1. 


\begin{tabular}{|c|c|c|c|c|c|c|c|}
\hline Projeto & Ano & $\begin{array}{l}\text { Empresa de } \\
\text { origem }\end{array}$ & $\begin{array}{l}\text { Valor em } \\
\text { US\$ }\end{array}$ & $\begin{array}{l}\text { Modo de } \\
\text { entrada }\end{array}$ & Setor & $\begin{array}{l}\text { Estrutura de } \\
\text { propriedade }\end{array}$ & $\begin{array}{l}\text { Determi- } \\
\text { nante do } \\
\text { investi- } \\
\text { mento }\end{array}$ \\
\hline 5 & 2011 & $\begin{array}{l}\text { China Northem } \\
\text { Railway } \\
* * * * * \\
\text { (Confirmado) }\end{array}$ & 200.000 .000 & $\begin{array}{l}\text { Fusões e aquisi- } \\
\text { çōes (completas) }\end{array}$ & Ferroviário & SOE & $\begin{array}{l}\text { Busca por } \\
\text { mercado }\end{array}$ \\
\hline 6 & 2011 & $\begin{array}{l}\text { Sinopec } \\
* * * * * * \\
\text { (Confirmado) }\end{array}$ & 3.500 .000 .000 & $\begin{array}{l}\text { Fusões e aquisi- } \\
\text { çōes (parciais) }\end{array}$ & $\begin{array}{l}\text { Energia (petró- } \\
\text { leo e gás) }\end{array}$ & Central SOE & $\begin{array}{l}\text { Busca por } \\
\text { recursos }\end{array}$ \\
\hline 7 & 2013 & $\begin{array}{l}\text { CNPC e } \\
\text { CNOOC } \\
* * * * * * * \\
\text { (Confirmado) } \\
\end{array}$ & 1.500 .000 .000 & $\begin{array}{l}\text { Fusões e aquisi- } \\
\text { çōes (parciais) }\end{array}$ & $\begin{array}{l}\text { Energia (petró- } \\
\text { leo e gás) }\end{array}$ & Central SOE & $\begin{array}{l}\text { Busca por } \\
\text { recursos }\end{array}$ \\
\hline & Total & & 18.899 .000 .000 & & & & \\
\hline
\end{tabular}

* Compra de 40\% das operaçóes brasileiras da empresa espanhola Repsol (Oliveira, 2012, p. 209).

** Aquisição de 40\% da exploração do campo de petróleo offshore Peregrino (bacia de Campos) (Oliveira, 2012, p. 209).

*** Instalação de fábrica utilizando a marca Kasinski (Oliveira, 2012, p. 210).

**** Instalação de siderúrgica, com $70 \%$ de participação da Wisco na joint venture (Porto do Açu, São João da Barra) (Oliveira, 2012, p. 210).

***** Fabricação de 34 trens para o governo do estado do Rio de Janeiro. O valor será investido na aquisição de maquinário e modernização de planta já existente. A previsão é alcançar 2.500 trabalhadores (Oliveira, 2012, p. 211).

****** 30\% dos ativos da Galp no Brasil (Oliveira, 2012, p. 211).

******* As empresas chinesas CNPC e CNOOC arremataram, em conjunto com a anglo-holandesa Shell, a francesa Total e a brasileira Petrobras, a concessão para exploração de petróleo e gás no Campo de Libra, no pré-sal da bacia de Campos (CEBC, 2014, p. 16).

Fonte: Oliveira (2012) e CEBC (2013, 2014 e 2015). Tabela elaborada pelo autor.

Quando se classificam os investimentos, é possível identificar que, do total dos investimentos direcionados ao território fluminense no mencionado período, 99\% (o equivalente a US\$18,6 bilhôes) dos investimentos chineses têm a busca de recursos como fator determinante. Esse volume de capital corresponde à maior parcela dos investimentos chineses confirmada no território fluminense, sendo sucedido, de longe, pelos US\$ 220 milhôes destinados à busca de mercado, o que corresponde a uma parcela pouco representativa dos investimentos da República Popular no território do estado do Rio de Janeiro (Gráfico 10). 
Gráfico 10. Distribuição dos investimentos chineses no território fluminense em US\$ por determinantes entre 2010-2013

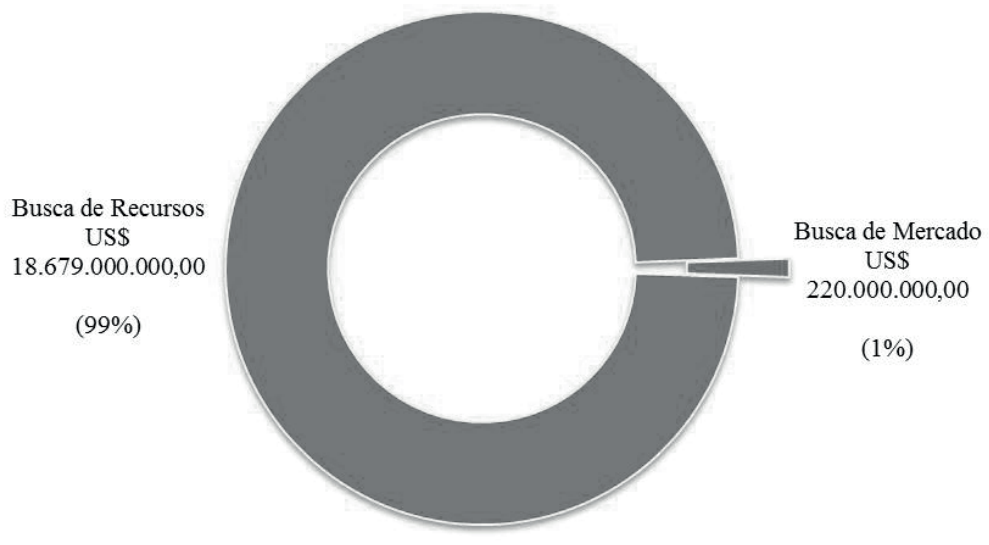

Fonte: Oliveira (2012), CEBC (2013, 2014 e 2015). Gráfico elaborado pelo autor.

A organização dos projetos das empresas chinesas por modo de entrada também possibilita a análise das formas de ingresso desse capital no território fluminense (Tabela 5).

Tabela 5. Formas de ingresso dos investimentos chineses no território fluminense (2010-2013)

\begin{tabular}{|l|l|l|l|l|l|}
\hline $\begin{array}{l}\text { No de } \\
\text { projetos }\end{array}$ & Modo de entrada & Setor & $\begin{array}{l}\text { Estrutura de } \\
\text { propriedade }\end{array}$ & $\begin{array}{l}\text { Determinante do } \\
\text { investimento }\end{array}$ & Valor em US\$ \\
\hline 4 & $\begin{array}{l}\text { Fusóes e Aquisiçōes } \\
\text { (parcial) }\end{array}$ & $\begin{array}{l}\text { Energia (petróleo e } \\
\text { gás) }\end{array}$ & Central SOE & Busca de recursos & 15.179 .000 .000 \\
\hline 1 & $\begin{array}{l}\text { Fusōes e Aquisiçōes } \\
\text { (parciais) }\end{array}$ & Ferroviário & Central SOE & Busca de mercado & 200.000 .000 \\
\hline 1 & Joint-venture & Siderurgia & Central SOE & Busca de recursos & 3.500 .000 .000 \\
\hline 1 & Greenfield & Automotivo & Privada & Busca de mercado & 20.000 .000 \\
\hline 7 & Total & \multicolumn{3}{|l}{} \\
\hline
\end{tabular}

Fonte: Oliveira (2012) e CEBC (2013, 2014 e 2015). Tabela elaborada pelo autor.

A análise da Tabela 5 aponta que os US \$ 18,8 bilhões em investimentos chineses correspondem a sete projetos implementados no território fluminense no período de 2010-2013, concentrando-se no setor de energia (petróleo e gás), em detrimento dos demais setores (ferroviário, siderúrgico e automotivo).

Como assinalado, quando se examina o fator determinante para investimento no projeto, nota-se que grande parte do capital se concentra na busca por recursos, correspondendo a cinco projetos, enquanto a busca por mercado é contemplada por apenas dois projetos. Em consequência desse direcionamento, o setor ferroviário e o setor automotivo contam com apenas um projeto cada, ambos 


\section{Os investimentos externos diretos da República Popular da China no território fluminense}

equivalentes a US\$ 200 milhões (1\%) e US\$ 20 milhões (menos de 1\%), respectivamente. Dos cinco projetos que visam à busca por recursos, apenas um está direcionado ao setor siderúrgico, compreendendo US \$ 3,5 bilhôes e correspondendo a 19\% desses investimentos, enquanto os outros quatro projetos, além de representarem maior volume de capital, ou seja, US\$15,1 bilhões, e corresponderem a 80\%, concentram-se no setor de energia, especialmente no segmento de petróleo e gás (Gráfico 11).

Gráfico 11. Distribuição dos investimentos chineses no território fluminense por setores entre 2010-2013

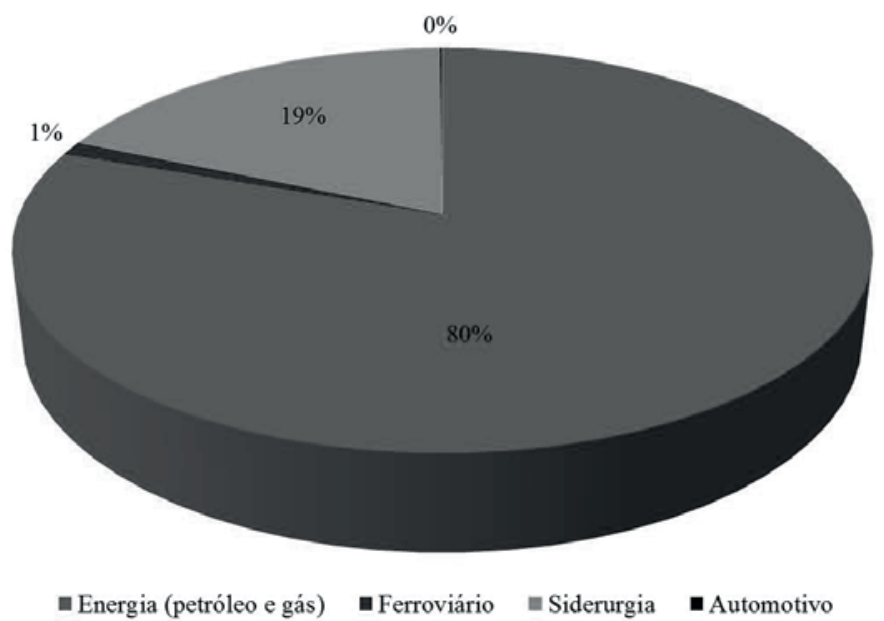

Fonte: Oliveira (2012) e CEBC (2013, 2014 e 2015). Gráfico elaborado pelo autor.

O modo de entrada ${ }^{11}$ dos investimentos em um país compreende Fusões e aquisições, Joint ventures e Greenfield (CEBC, 2011 b). No que concerne ao modo de entrada dos investimentos chineses no território fluminense, identifica-se que o modo Greenfield é contemplado por apenas um projeto, que se faz presente no setor automotivo. Embora apresente valor superior ao modo de entrada Greenfield, o ingresso dos investimentos pela modalidade Joint-venture também corresponde à forma utilizada pelo influxo do capital sínico no estado, com um projeto apenas, no setor siderúrgico. Por outro lado, as Fusóes e Aquisiçôes correspondem ao modo de entrada predominante, totalizando cinco projetos: um no setor siderúrgico e quatro no setor de energia. Ressalte-se que um aspecto importante acerca dessa modalidade de inserção de investimentos diz respeito à estrutura da propriedade (Gráfico 12).

\footnotetext{
11 "Tradicionalmente, distinguem-se três diferentes modos de entrada de investimentos em um país: a) Fusões e Aquisiçôes - compra total ou parcial de empresas situadas no país por um investidor estrangeiro, b) Joint Ventures - parcerias estratégicas entre empresas, que envolvem a participação acionária das empresas na criação de uma nova empresa com uma finalidade específica e c) Greenfield - construção de instalações totalmente novas no país de destino por um investidor estrangeiro, que tem o controle total da construção e operação dos ativos" (CEBC, 2011 b, p. 23).
} 
Gráfico 12. Modo de entrada dos investimentos chineses no território fluminense entre 2010-2013

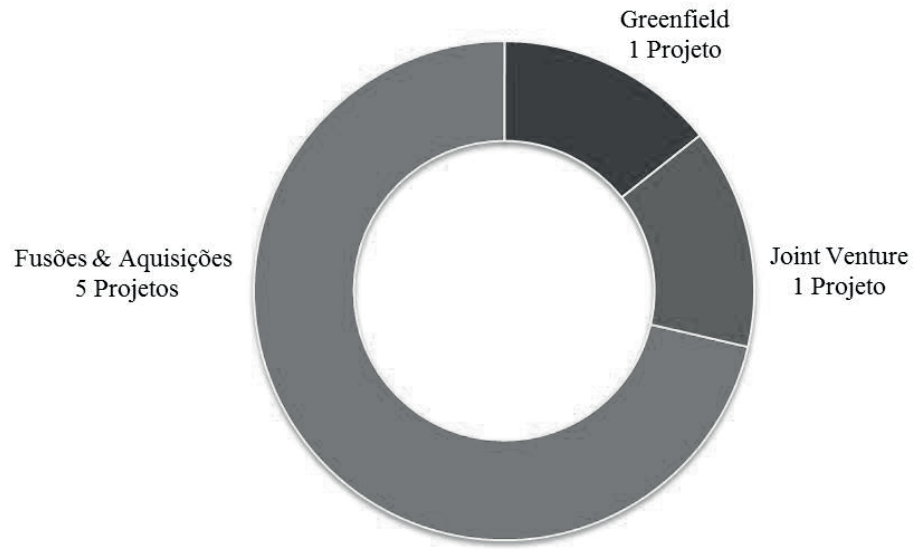

As fusões e aquisições identificadas foram efetuadas, predominantemente, por empresas estatais chinesas, tanto em volume de capital investido quanto em número de projetos. Esse quadro subsidia nossas colocaçôes acerca da inserção fluminense na base de fornecimento de recursos para a República Popular da China, sobretudo quando consideramos que o modo de entrada (Fusōes e aquisiççess), o setor (energia), o fator determinante predominante (busca por recursos) e o maior número de projetos constituem um montante do influxo do capital sínico no território e são coordenados pelas empresas estatais centrais chinesas (Central SOE), que se conformam como novas territorialidades atuantes no processo de reestruturação territorial fluminense. A localização dessas empresas chinesas no território fluminense, ou seja, desses novos atores, é apresentada na Tabela 6 e na Figura 3.

Tabela 6. Empresas chinesas que investiram no território fluminense entre 2010-2013

\begin{tabular}{|l|l|l|l|}
\hline Empresa chinesa & Setor & Município fluminense & Região de governo \\
\hline Sinopec & Energia & Rio de Janeiro & Metropolitana \\
\hline Sinochem & Energia & Rio de Janeiro & Metropolitana \\
\hline CNOOC & Energia & Rio de Janeiro & Metropolitana \\
\hline $\begin{array}{l}\text { Wuhan Iron/Steel Group } \\
\text { (Wisco) }\end{array}$ & Siderúrgico & São João da Barra & Norte Fluminense \\
\hline China Northern Railway & Ferroviário & Três Rios & Centro-Sul Fluminense \\
\hline CR Zongshen & Automotivo & Sapucaia & Centro-Sul Fluminense \\
\hline
\end{tabular}

Fonte: Elaborada pelo autor.

A Tabela 6 evidencia a presença dessas empresas em diferentes municípios e regiōes de governo do estado do Rio de Janeiro, ressaltando-se os seguintes aspectos: i) as empresas que não estão relacio- 
nadas ao setor de energia têm suas plantas localizadas no interior fluminense, ao passo que ii) as estatais chinesas vinculadas a esse setor têm seus escritórios de representação e atividades administrativas na metrópole fluminense, como, por exemplo, a CNOOC, a Sinochem e a Sinopec, com grande parte do capital investido envolvida em atividades de exploração petrolífera offshore. A Figura 3 evidencia a espacialização desses investimentos no território fluminense, identificando Rio de Janeiro, São João da Barra, Três Rios e Sapucaia como municípios receptores dos investimentos chineses destinados ao estado do Rio de Janeiro entre 2010-2013.

Figura 3. Estado do Rio de Janeiro: municípios receptores de investimentos chineses

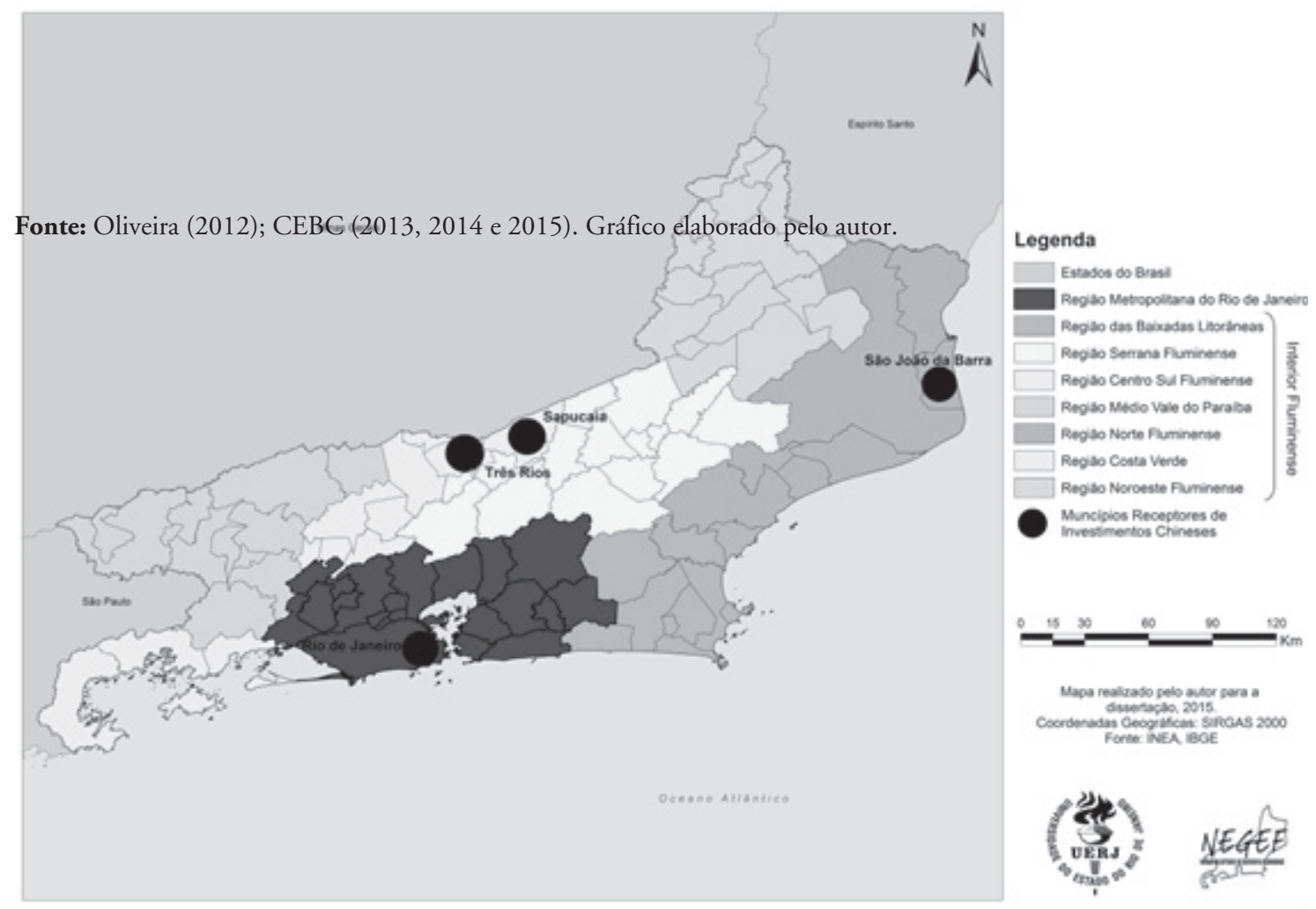

Fonte: Elaborado pelo autor. 


\section{Considerações finais}

Durante o século XX, a trajetória econômica fluminense caracterizou-se pela dupla perda de centralidade, porém, da década de 1990 em diante, o estado do Rio de Janeiro apresentou-se como um território em mutação, caracterizado pela reorientação do fluxo de investimentos em direção ao interior, o que acarretou a dispersão das atividades produtivas no território, com a instalação de novas plantas industriais em suas porções setentrional e meridional. Em consequência, irrompeu o século XXI como a segunda maior economia nacional, tendo seu processo de reestruturação territorial fundamentado na interiorização econômica decorrente da implantação de novas atividades produtivas no território e da reorientação dos fluxos de investimentos.

Observa-se ainda que o processo de reestruturação territorial fluminense, com a recente retomada do crescimento econômico, contou com a participação do influxo de capitais sínicos. A abertura econômica realizada pela República Popular da China nas últimas décadas do século XX, assentada no comércio exterior e nos investimentos internacionais, mostrou-se decisiva. Houve, portanto, aumento de sua participação nos fluxos e estoques de IED no mundo.

Nesse contexto, o aumento do influxo de capital sínico no território nacional marcou uma nova fase nas relações entre China e Brasil, sendo o ano 2010 um ponto de inflexão na trajetória desses investimentos. Nesse mesmo ano, houve considerável aumento na recepção de IED em nosso país, alcançando aproximadamente US\$ 13 bilhões.

Na Região Sudeste, o estado do Rio de Janeiro, entre 2010 e 2013, recebeu US\$ 18,8 bilhões, abrangendo sete projetos, que contemplaram os setores automotivo, ferroviário, siderúrgico e de energia.

O setor automotivo contou com a menor parcela dos investimentos chineses, tendo o Greenfield como seu modo de entrada. Os investimentos realizados nesse setor corresponderam à implantação de uma fábrica, cujo objetivo (tal qual em relação ao setor ferroviário) contemplou a busca por mercado.

O investimento no setor ferroviário ocorreu por Fusão e aquisição por uma empresa estatal chinesa.

O setor siderúrgico, por sua vez, foi contemplado pelo segundo maior volume de investimento no território fluminense, cujo modo de entrada Joint-venture marcou a inserção de uma grande empresa chinesa do ramo. Esse setor foi superado apenas pelos investimentos chineses direcionados ao setor de energia, e o fator determinante foi a busca por recurso.

No setor de energia, os projetos se destacaram tanto em volume quanto em número de projetos coordenados por grandes estatais chinesas, as quais, por meio de Fusão e aquisição, passaram a atuar como novas territorialidades no processo de reestruturação fluminense, sobretudo por terem, como determinante desses investimentos, a busca por recursos.

Registra-se que as empresas estatais chinesas, ao materializarem os IED chineses no território fluminense, visam assegurar o fornecimento e a diversificação dos fornecedores de petróleo à maior economia asiática. 


\section{Referências}

ALVES, André Gustavo de Miranda Pineli. "As relações de investimento direto entre a China e os países de seu entorno”. In (org.). Os BRICS e seus vizinhos: investimento direto estrangeiro. Brasília: Ipea, 2014.

ARAÚJO, Victor Leonardo e MELO, Hildete Pereira de. "O processo de esvaziamento industrial em São Gonçalo no século XX: auge e declínio da 'Manchester Fluminense”. Cadernos do Desenvolvimento Fluminense, Rio de Janeiro, n. 4, mai. 2014. Disponível em: www.e-publicacoes.uerj.br/ index.php/cdf/article/download/11532/9081. Acesso em: 09 jun. 2016.

ARRIGHI, Giovanni. Adam Smith em Pequim: origens e fundamentos do século XXI. São Paulo: Boitempo, 2008.

- O longo século XX: dinheiro, poder e origem de nosso tempo. Rio de Janeiro: Contraponto, 2012.

BAPTISTA, Thiago Jeremias. Os investimentos da República Popular da China no estado do Rio de Janeiro: novas territorialidades no processo de reestruturação territorial fluminense no início do século XXI (2010-2013) (dissertação). UERJ, 2016.

BONIFACE, Pascal e VÉDRINE, Hubert. Atlas do mundo global. São Paulo: Estação Liberdade, 2009.

BUCKLEY, Peter et al. "The determinants of Chinese outward foreign direct investment". Journal of International Business Studies, v. 37, n. 4, 2007, pp. 499-518.

—. "Historic and emergent trends in Chinese outward direct investment". In BUCKLEY, P. J. Foreign Direct Investment, China and the World Economy. Palgrave Macmillan, 2010.

CEBC. Carta Brasil China. Rio de Janeiro, $1^{\circ}$ mar. 2011 a.

- Investimentos chineses no Brasil: uma nova fase da relação Brasil-China. Rio de Janeiro, 2011 b.

- China up date Brazil. Rio de Janeiro, 5 ago. 2012.

—. Uma análise dos investimentos chineses no Brasil: 2007-2012. Rio de Janeiro, 2013.

—. Boletim de Investimentos Chineses no Brasil (2012-2013). Rio de Janeiro, 2014.

- Oportunidades de comércio e investimento na China para setores selecionados. Rio de Janeiro: CEBC, 2015.

CEPERJ. Estado do Rio de Janeiro: regioes de governo e municípios: 2014. Disponível em: http://www. fesp.rj.gov.br/ceep/info_territorios/Reg\%20Gov_2013.pdf. Acesso em: 20 mar. 2015.

—. PIB estadual 1995-2012. Disponível em: http://www.ceperj.rj.gov.br/ceep/pib/pib.html. Acesso em: 8 nov. 2015.

—. PIB estadual 2010-2014. Disponível em: http://www.ceperj.rj.gov.br/ceep/pib/pib.html. Acesso em: 8 nov. 2015.

—. PIB municipal 1999-2012. Disponível em: http://www.ceperj.rj.gov.br/ceep/pib/pib.html. Acesso em: 8 nov. 2015.

CHINABILITY. FDI inflows into China 1984-2014. Disponível em: http://www.chinability.com/ FDI.htm. Acesso em: 8 nov. 2015.

—. ODI from China 1990-2014. Disponível em: http://www.chinability.com/ODI.htm. Acesso em: 8 nov. 2015 . 
GONÇALVES, Williams da Silva. "A presença da China na África”. In JOBIM, Nelson et al. (orgs.). Segurança internacional: perspectivas brasileiras. Rio de Janeiro: FGV, 2010, v. 1, pp. 523-38.

IPEA. "Internacionalização das empresas chinesas: as prioridades do investimento direto chinês no mundo". Comunicados do IPEA, n. 84, 2011.

JABBOUR, Elias Marco Khalil. Projeto nacional, desenvolvimento e socialismo de mercado na China de hoje (tese). USP, 2010.

KISSINGER, Henry. Sobre a China. Rio de Janeiro: Objetiva, 2011.

LYRIO, Maurício Carvalho. A ascensão da China como potência: fundamentos politicos internos. Brasília: Funag, 2010.

MARAFON, Glaucio José et al. Regióes de governo do estado do Rio de Janeiro: uma contribuição geográgica. Rio de Janeiro: Gramma, 2005.

—. Geografia do estado do Rio de Janeiro: da compreensão do passado aos desafios do presente. Rio de Janeiro: Gramma, 2011.

MELO, Hildete Pereira de. "A trajetória da industrialização do Rio de Janeiro". In FREIRE, Américo et al. (orgs.). Um estado em questão: os 25 anos do Rio de Janeiro. Rio de Janeiro: FGV, 2001, pp. 219-48.

OLIVEIRA, A. L. S. O investimento direto das empresas chinesas no Brasil: um estudo exploratório (dissertação). UFRJ, 2012.

OLIVEIRA, Floriano José Godinho de. Reestruturação produtiva e regionalização econômica do território fluminense. São Paulo: Garamond, 2008.

—. "Políticas territoriais e integração do 'novo' território do estado do Rio de Janeiro". In EGLER, Tamara Tania Cohen e TAVARES, Hermes Magalhães (orgs.). Política pública, rede social e território. Rio de Janeiro: Letra Capital, 2012.

RIBEIRO, Valéria Lopes. A China e a economia mundial: uma abordagem sobre a ascensão chinesa na segunda metade do século XX (dissertação). Universidade Federal de Santa Catarina, 2008.

—. "A expansão chinesa na África: o desafio do crescimento e a nova face do imperialismo econômico". Oikos, Rio de Janeiro, v. 9, n. 2, 2010.

—. A expansão chinesa e seus impactos na África na primeira década do século XXI (tese). Universidade Federal do Rio de Janeiro, 2013.

SANTOS, Milton. "O retorno do território". In — et al. Território: globalização e fragmentação. São Paulo: Hucitec, 1996, pp. 15-21.

— e SILVEIRA, M. L. O Brasil: território e sociedade no início do século XXI. 10 ed. Rio de Janeiro: Record, 2008.

SILVA, Robson Dias. Indústria e desenvolvimento regional no Rio de Janeiro. Rio de Janeiro: FGV, 2012. SOUZA, Marcelo Lopes. Os conceitos fundamentais da pesquisa socioespacial. Rio de Janeiro: Bertrand Brasil, 2013.

TERRA, Denise Cunha Tavares et al. "A reestruturação econômica e territorial do Norte fluminense". In MONIÉ, F. e BINSZTOK, J. (orgs.). Geografia e geopolitica do petróleo. Rio de Janeiro: Mauad, 2012.

UNCTAD. China. Disponível em: http://unctad.org/Sections/dite_fdistat/docs/webdiaeia2014d3_ CHN.pdf. Acesso em: 8 nov. 2015. 


\section{Dinâmicas territoriais no estado do Rio de Janeiro: reflexões em torno da região Noroeste Fluminense}

Bruna Piraciaba

Linovaldo Lemos ${ }^{1}$

\section{Introdução}

0 jornal $O$ Globo, em 26/10/2014, buscava sintetizar, por meio do título de uma matéria, o quadro da estagnação vivenciada por uma região do estado do Rio de Janeiro (ERJ): "Noroeste Fluminense enfrenta esvaziamento econômico e dificuldades na geração de renda". Longe de ser uma notícia referente a um quadro sazonal de dificuldade na região, esse título figura como uma espécie de epígrafe que tem sido utilizada, por vezes em tons ainda mais incisivos ou mais opacos, para identificar e singularizar o Noroeste Fluminense vis-à-vis o ERJ.

Analisam-se, aqui, as transformações pelas quais essa região tem passado, situando-as no contexto mais amplo das dinâmicas territoriais do ERJ. Pretende-se, com isso, lançar luz sobre essas dinâmicas e compreender as mudanças por que tem passado o Noroeste Fluminense (NOF), procedendo-se a uma caracterização socioeconômica e ao estabelecimento de diferenciações internas entre os municípios que compõem a região.

Nessa perspectiva, a pesquisa se baseia em dados secundários disponibilizados por: Instituto Brasileiro de Geografia e Estatística (IBGE); Tribunal de Contas do Estado do Rio de Janeiro (TCE/ RJ); Programa das Nações Unidas para o Desenvolvimento (PNUD); Serviço de Apoio às Micro e Pequenas Empresas do Estado do Rio de Janeiro (Sebrae-RJ); Fundação Centro Estadual de Estatísticas, Pesquisas e Formação de Servidores Públicos do Rio de Janeiro (Ceperj); Relação Anual de Informações Sociais (Rais); e Ministério do Trabalho. Também recorre a alguns trabalhos da Federação das Indústrias do Estado do Rio de Janeiro (Firjan). Esses dados são analisados à luz de uma bibliografia que versa, direta ou indiretamente, sobre o tema da dinâmica territorial no ERJ.

\footnotetext{
${ }^{1}$ Instituto Federal Fluminense (Campos).
} 
Ao centrar a análise no NOF, o texto privilegia, como procedimento metodológico, a coleta e a análise de dados capazes de auxiliar no estabelecimento de um perfil geral dos municípios que compõem a região, trazendo indicadores para caracterizá-la e situá-la no contexto do ERJ. Munidos de dados dos últimos censos (1991, 2000 e 2010), este ensaio busca contribuir para a compreensão da atual realidade dessa região, de modo a apontar as principais transformações por que passa, bem como o respectivo papel no contexto estadual.

Acompanham este estudo três pressupostos básicos no que diz respeito às escalas de análise que nortearam a pesquisa e que precisam ser apontados de antemão.

Em primeiro lugar, parte-se do pressuposto básico de que os municípios têm importância como entes federados dotados de prerrogativas constitucionais que o capacitam a formular e implementar políticas públicas em diversas áreas, tendo, por isso mesmo, grande capacidade de intervenção na realidade local e na vida do cidadão. Reside aí, em grande parte, o atual interesse da geografia política no município (Castro, 2005). No entanto, o reconhecimento da importância do município não exclui uma abordagem que procure articular as escalas para além do recorte municipal.

Em segundo lugar, tem-se o pressuposto de que as escalas de ação - no presente caso, a regional - são concebidas como construções históricas e como um foco de contestações e disputas de diferentes atores sociais (Vainer, 2001; Castro, 2005; Cruz, 2003). Pensar o NOF significa conceber a multiescalaridade dos fenômenos em suas imbricações e em seu realizar-se espaçotemporal.

\section{Danças e contradanças de um estado em transformação}

A atual configuração territorial do ERJ resulta de um processo histórico marcado pelo papel de centralidade desempenhado pela capital no contexto da federação e, concomitantemente, pelos desafios que isso trouxe para as relações entre a capital e as partes que compõem o estado - grosso modo, o interior. Para além da questão da forte discrepância entre os pesos econômico, social, político e cultural da capital e da região metropolitana em relação às demais regiōes do estado, tem-se ainda a questão do papel desse interior em face de um estado com forte peso da Região Metropolitana (Alentejano, 2005; Ribeiro, 2013). Em outras palavras, o que está em jogo aqui é a compatibilização das forças de aproximação e o distanciamento entre o todo e as partes que compóem um estado da federação que tem como particularidades: i) o papel de centralidade desempenhado pela cidade do Rio de Janeiro; ii) o peso e a forte concentração da população e das atividades produtivas na Região Metropolitana; iii) o papel desempenhado - e atribuído - ao interior nesse contexto, bem como a integração territorial-produtiva e política desse interior em relação ao centro.

Assim, há um importante pano de fundo representado pelas engenharias territoriais processadas no ERJ (Silva, 2011) e o papel que desempenharam no engendramento da atual configuração territorial. Tomemos, en passant, a transferência da capital para Brasília em 1960, a criação dos estados da Guanabara e do Rio de Janeiro no mesmo período e o processo autoritário de fusão dos dois estados em 1974, em pleno período militar. Entre danças e contradanças, criou-se a situação de um Rio de Janeiro versus o Rio de Janeiro (Motta, 2007), que se traduziu na "inexistência de coesão e de laços de solidariedade territorial" (Davidovich, 2001, p. 2) e numa singularidade em que capital e interior figuraram como "duas vidas, se não autônomas, pelo menos paralelas e relativamente independentes” (Galvão, 2009, p. 89). 


\section{Dinâmicas territoriais no estado do Rio de Janeiro}

É igualmente importante levar em consideração o quadro de crise - real ou imaginada trazido na esteira da perda do papel de capital do país pela cidade do Rio de Janeiro e os desdobramentos com a posterior fusão. De forma aberta ou velada, atribuiu-se ao interior o papel de um espaço arcaico, agrário e conservador, ${ }^{2}$ símbolo do atraso com que a antiga capital agora teria de se confrontar e lidar.

A premência de uma análise mais acurada tem sido repetidamente apontada por pesquisadores dedicados a esse estudo, ponto de vista compartilhado pelo autor deste artigo. Esses pesquisadores advogam a necessidade de uma posição mais nuançada, compreendendo que a tão propalada crise, cujo principal indicador tem sido a redução relativa da participação na composição do PIB da capital e da Região Metropolitana em relação ao conjunto das regiōes do estado, deve ser situada num contexto mais amplo de transformações processadas no território fluminense, principalmente a partir dos anos 1980.

Cabe, portanto, um olhar mais abrangente sobre o território do ERJ, com uma abordagem menos "carioca-centrada" (Cruz, 2013) e mais preocupada com os elementos que, atualmente, promovem a integração do "território fluminense" em torno do "crescimento e da dinamização de certas atividades econômicas" e das redes logísticas que compõem seu território (Lemos e Rodrigues, 2014). No sentido de problematizar e compreender essas transformações é que nos referimos a uma nova ordem territorial (Binsztock, 1999) em andamento no ERJ, com a mudança do papel das diversas áreas que compóem o estado (Limonad, 2004), o que tem promovido um novo ordenamento territorial e uma nova regionalização econômica (Oliveira, 2005).

Ribeiro e Marafon (2009), por seu turno, afirmam que, nos últimos trinta anos, o ERJ “apresenta uma diversidade de situações provocadoras de mudanças geradoras de novas formas de organização representadas por inúmeras inovaçōes” tanto na metrópole quanto no interior. Reconhecer essas novas dinâmicas, contudo, não significa menosprezar o papel desempenhado pela Região Metropolitana do Rio de Janeiro, especialmente pela capital.

De fato, parece que o discurso sobre a crise da cidade do Rio predomina em muitos casos, seja na visão do Rio de Janeiro como uma "baleia encalhada" (Urani, 2008), seja como uma cidade "em busca de autoestima" (Lessa, 2005), seja ainda a visão de uma cidade - e de um estado - que se encontraria na "hora da virada" (Urani e Giambiagi, 2011), em função do avanço das atividades petrolíferas, da expansão dos investimentos públicos e privados, bem como da emergência da cidade do Rio de Janeiro como centro de grandes eventos. ${ }^{3}$

2 A esse respeito, ver o excelente artigo de Limonad (2004), que analisa, situa e contrapóe-se à ideia de um esvaziamento econômico no Rio de Janeiro a partir da fusão. Ver também o artigo de Evangelista (2005), no qual ele aponta o que chamou de luta pela fusão e luta pela desfusão, bem como a contraposição de visões contrárias e favoráveis ao processo em pauta.

3 Há que se ressaltar que essas oportunidades trazem consigo uma série de desafios à continuidade do processo de crescimento econômico, à melhora da gestão pública na questão fiscal e orçamentária, bem como nos aspectos sociais, como violência urbana, educação ou acesso aos serviços (Pinheiro e Veloso, 2012). Na mesma direção, alguns pesquisadores têm reiterado a necessidade de cuidados na aplicação dos recursos oriundos do setor petrolífero - em muitos casos, a principal 
Para além da cidade do Rio de Janeiro e da Região Metropolitana, alguns estudos têm demonstrado a crescente importância do chamado "interior" do estado, com a análise de diferentes questôes, experiências e realidades centradas no ERJ, em seus municípios e regiōes (Fauré e Hasenclever, 2003 e 2005; Fauré et al., 2008; Marafon e Ribeiro, 2003, 2008, 2010, 2012). De forma geral, esses estudos vão ao encontro da ideia já referida aqui de que ocorre um processo de transformação nas dinâmicas territoriais do/no estado, com a crescente importância do interior. Esses autores também têm destacado, para além da predominância socioeconômica da capital e da Região Metropolitana, a tendência a uma desconcentração das atividades produtivas e a uma consolidação dos espaços especializados e de crescimento demográfico ao longo das principais rodovias que cortam o estado (Limonad, 2004). Como resultado, tem-se um processo de "desconcentração" das atividades econômicas, com a reorientação de investimentos e a movimentação da população no território fluminense (Medeiros Júnior, 2013).

Focando-se nas áreas rurais, Rua (2007) corrobora essa ideia, ao defender que existe "emergência de novas territorialidades", a partir de "eixos de maior densidade de urbanidades" nas áreas rurais do ERJ. De forma complementar, Lemos e Rodrigues (2014) defendem a ideia de que "vem ocorrendo uma transformação na dinâmica territorial do estado” capaz de, progressivamente, imprimir maior coesão às "suas diversas regiões, em função do crescimento e da dinamização de certas atividades econômicas, bem como do papel desempenhado pelas redes logísticas articuladas aos portos" (Lemos e Rodrigues, 2014, p. 45).

A identificação dos setores e atividades econômicas responsáveis por essas transformações, bem como a análise e a caracterização das regiões, fogem ao escopo deste artigo. Neste ponto, o que nos interessa de perto é o papel do NOF no contexto das transformações territoriais, o que se fará a seguir.

\section{0 cenário do Noroeste Fluminense e o papel de Itaperuna}

A região NOF foi criada em 1987, a partir do desmembramento do Norte fluminense. Cruz (2007) salienta que, após décadas de reivindicação regionalista, a busca pela "independência” da região Norte Fluminense, mais especificamente em relação a Campos dos Goytacazes, resulta, entre outros fatores, do fato de esse município monopolizar a atenção e os recursos da iniciativa privada e dos governos estadual e federal na escala da outrora região Norte-Noroeste Fluminense.

Em meio a essa busca por emancipação, foram criadas "formas próprias de organização, buscando construir um discurso e uma pauta própria, ancorados na identidade territorial do NOF” (Cruz, 2003, p. 238). No entanto, alguns autores como Costa (2012) ressaltam que, mesmo com a cisão ocorrida em 1987, não houve o fim da periferização do NOF em relação

fonte de arrecadação. A esse repeito, vejam-se as publicações disponíveis no site do mestrado em Planejamento Regional e Gestão de Cidades da Universidade Candido Mendes (http://cidades. ucam-campos.br/index.php/producoes/publicacoes), bem como na revista do referido programa (http://royaltiesdopetroleo.ucam-campos.br/). 


\section{Dinâmicas territoriais no estado do Rio de Janeiro}

ao Norte Fluminense e ao município de Campos dos Goytacazes, questão que será abordada mais adiante.

Atualmente, a região é composta por 13 municípios: Aperibé, Bom Jesus do Itabapoana, Cambuci, Italva, Itaocara, Itaperuna, Laje do Muriaé, Miracema, Natividade, Porciúncula, Santo Antônio de Pádua, São José de Ubá e Varre-Sai, conforme se observa na Figura 1.

Figura 1. Cartograma do estado do Rio de Janeiro, regiōes de governo e municípios da região Noroeste Fluminense.

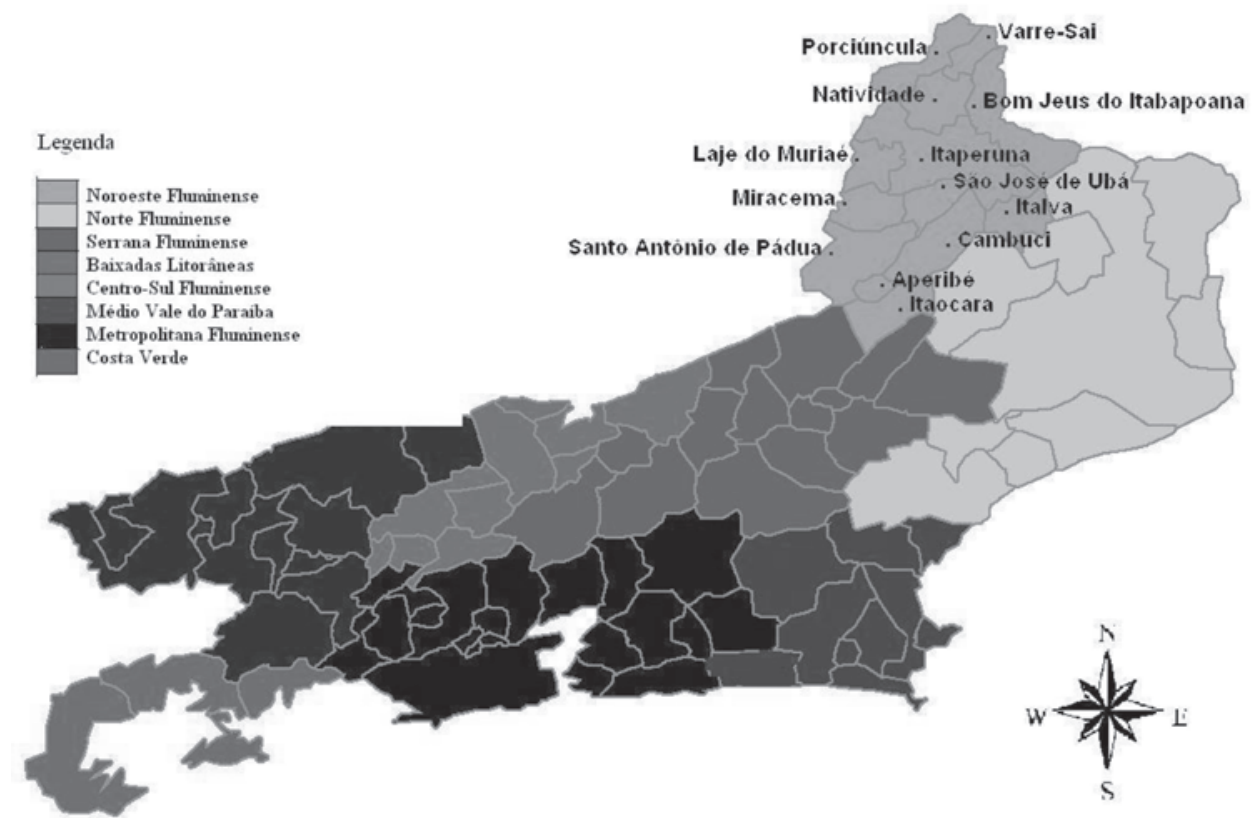

Fonte: Elaborado pelo autor.

Os desmembramentos municipais podem ser identificados em três momentos: final do século XIX, com a criação dos municípios de Santo Antônio de Pádua, Itaperuna e Cambuci; anos 1930-1940, com a criação dos municípios de Bom Jesus do Itabapoana, Miracema, Natividade e Porciúncula; e o último período, nos anos 1980 e 1990, com a emancipação de Italva (1986), Aperibé (1993), Varre-Sai (1993) e São José de Ubá (1997), desmembrados, respectivamente, de Campos dos Goytacazes, Santo Antônio de Pádua, Natividade e Cambuci.

O exame dos dados relativos aos períodos de 1991/2000 e 2000/2010 nos esclarece que o NOF é a região de menor densidade demográfica, com as menores taxas de crescimento populacional e a menor taxa de urbanização das regiōes administrativas do estado (Tabela 1). 
Tabela 1. Taxa média geométrica de crescimento anual, taxa de urbanização e densidade demográfica, segundo as regiōes de governo e municípios do estado do Rio de Janeiro (1991-2000 e 2000-2010)

\begin{tabular}{|l|c|c|c|c|}
\hline Regiōes de governo & $\begin{array}{c}\text { Taxa média } \\
\text { geométrica de } \\
\text { crescimento } \\
\text { anual (1991- } \\
\mathbf{2 0 0 0 )}(\mathbf{\%})\end{array}$ & $\begin{array}{c}\text { Taxa média } \\
\text { geométrica de } \\
\text { crescimento } \\
\text { anual (2000- } \\
\mathbf{2 0 1 0 )}(\mathbf{\%})\end{array}$ & $\begin{array}{c}\text { Taxa de urba- } \\
\text { nização (2010) } \\
\text { (\%) }\end{array}$ & $\begin{array}{c}\text { Densidade } \\
\text { demográfica (1) } \\
\left(\mathbf{h a b} / \mathbf{k m}^{\mathbf{2}}\right)\end{array}$ \\
\hline Estado & 1,32 & 1,06 & 96,7 & 365,23 \\
\hline Região Metropolitana & 1,17 & 0,86 & 99,5 & $2.226,43$ \\
\hline Região Noroeste Fluminense & 0,97 & 0,65 & 82,6 & 59,16 \\
\hline Região Norte Fluminense & 1,51 & 1,97 & 88,1 & 87,21 \\
\hline Região Serrana & 1,02 & 0,69 & 85,8 & 116,15 \\
\hline Região das Baixadas Litorâneas & 4,17 & 3,76 & 87,6 & 160,56 \\
\hline Região do Médio Paraíba & 1,39 & 0,86 & 95,6 & 138,22 \\
\hline Região Centro-Sul Fluminense & 1,20 & 0,69 & 85,5 & 89,64 \\
\hline Região da Costa Verde & 3,54 & 3,44 & 91,6 & 115,79 \\
\hline
\end{tabular}

Fonte: Adaptado da Fundação Centro Estadual de Estatísticas, Pesquisas e Formação de Servidores Públicos do Rio de Janeiro (Ceperj).

A análise da Tabela 2 permite acompanhar a oscilação da população absoluta dos municípios entre os anos de 1991 e 2010 . Note-se, em primeiro lugar, que, em 2010, somente Itaperuna se aproximava dos cem mil habitantes, pois os demais municípios estavam na faixa inferior a cinquenta mil habitantes, alguns até com pequena população, como, por exemplo, São José de Ubá, Laje do Muriaé e Varre-Sai, com menos de dez mil habitantes.

Tabela 2. População total dos municípios da região Noroeste Fluminense (1991-2010)

\begin{tabular}{|l|c|c|c|}
\hline Municípios & $\mathbf{1 9 9 1}$ & $\mathbf{2 0 0 0}$ & $\mathbf{2 0 1 0}$ \\
\hline Aperibé & - & 8.018 & 10.213 \\
\hline Bom Jesus do Itabapoana & 29.873 & 33.655 & 35.411 \\
\hline Cambuci & 21.011 & 14.670 & 14.827 \\
\hline Italva & 12.764 & 12.621 & 14.063 \\
\hline Itaocara & 22.933 & 23.003 & 22.899 \\
\hline Itaperuna & 78.000 & 86.720 & 95.841 \\
\hline Laje do Muriaé & 7.464 & 7.909 & 7.487 \\
\hline Miracema & 25.091 & 27.064 & 26.843 \\
\hline Natividade & 21.765 & 15.125 & 15.082 \\
\hline Porciúncula & 14.561 & 15.952 & 17.760 \\
\hline Santo Antônio de Pádua & 39.600 & 38.692 & 40.589 \\
\hline São José de Ubá & - & 6.413 & 7.003 \\
\hline Varre-Sai & - & 7.854 & 9.475 \\
\hline
\end{tabular}

\footnotetext{
Fonte: IBGE.
} 
Dados organizados por Neves (2006) a partir dos Censos Demográficos de 1950, 1970 e 1980, aliados àqueles apurados na presente pesquisa (Censos de 1991, 2000 e 2010), demonstram um quadro de municípios que enfrentaram estagnação, lento crescimento ou até mesmo a perda de população (em maior ou menor grau), ao longo de todo esse período. Parte da explicação para esse baixo crescimento demográfico e para a queda da população em alguns municípios da regiáo Noroeste está nas emancipações e na consequente divisão da população, conforme já citado. No entanto, cabe ressaltar que o principal fator desse quadro deve ser buscado em questôes ou problemas estruturais da economia regional, caracterizada por baixo dinamismo e pela incapacidade de reter a força de trabalho ao longo das décadas (Oliveira et al., 2005), o que pode ser sintetizado na ideia do NOF como uma região-problema (Cruz, 2003; Natal e Oliveira, 2004; Silva, 2006; Oliveira e Natal, 2004).

Se tomarmos em conjunto os dados dispostos nas Tabelas 1 e 2 e acrescentarmos os dados apresentados na Tabela 3, que demonstra a diminuição relativa da participação do PIB da região NOF no conjunto das regiōes do ERJ entre os anos de 2000 e 2010, teremos alguns elementos apontando para o esvaziamento econômico da regiáo. Tal esvaziamento é refletido na baixa participação do Noroeste no PIB estadual: em 2000, a participação era de 1,23\%, diminuindo para 1,05\% em 2010, representando, assim, o menor PIB entre as regiōes do estado do Rio de Janeiro.

Tabela 3. Produto Interno Bruto das regiōes do estado do Rio de Janeiro (R \$ 1.000)

(2000-2010)

\begin{tabular}{|l|c|c|c|c|}
\hline Regiōes de governo & $\begin{array}{c}\text { PIB 2000 (R\$ } \\
\mathbf{1 . 0 0 0 )}\end{array}$ & $\begin{array}{c}\text { Participação da } \\
\text { região (\%) }\end{array}$ & $\begin{array}{c}\text { PIB 2010 (R\$ } \\
\mathbf{1 . 0 0 0})\end{array}$ & $\begin{array}{c}\text { Participação da } \\
\text { região (\%) }\end{array}$ \\
\hline Estado & 118.711 .624 & & 344.405 .425 & \\
\hline Região Metropolitana & 88.298 .966 & 74,38 & 223.424 .276 & 64,87 \\
\hline $\begin{array}{l}\text { Região Noroeste Flu- } \\
\text { minense }\end{array}$ & 1.454 .906 & 1,23 & 3.630 .073 & 1,05 \\
\hline $\begin{array}{l}\text { Região Norte Flumi- } \\
\text { nense }\end{array}$ & 8.771 .009 & 7,39 & 43.039 .118 & 12,5 \\
\hline Região Serrana & 4.820 .355 & 4,06 & 14.127 .379 & 4,1 \\
\hline $\begin{array}{l}\text { Região da Baixadas Li- } \\
\text { torâneas }\end{array}$ & 4.601 .532 & 3,88 & 20.473 .343 & 5,94 \\
\hline $\begin{array}{l}\text { Região do Médio Pa- } \\
\text { raíba }\end{array}$ & 8.023 .542 & 6,76 & 25.322 .904 & 7,35 \\
\hline $\begin{array}{l}\text { Região Centro-Sul } \\
\text { Fluminense }\end{array}$ & 1.434 .809 & 1,21 & 3.943 .155 & 1,14 \\
\hline Região da Costa Verde & 1.306 .506 & 1,1 & 10.445 .178 & 3,03 \\
\hline
\end{tabular}

Fonte: Ceperj.

A principal explicação para o baixo dinamismo econômico do NOF consiste, em sua origem, nos problemas do setor agrário. Tradicional área produtora de café (parte de uma grande área produtora que se estendia da Zona da Mata Mineira ao sul do Espírito Santo), a região passou a sofrer os reveses da erradicação desse cultivo a partir da primeira metade do século XX. Com uma produção de café considerada de qualidade inferior e inadequada à exportação, minguaram paulatinamente os recursos governamentais e, com isso, assistiu-se à instauração de um quadro de crise já nos anos 1960. 
Itaperuna, o principal produtor de café de então, foi o município mais prejudicado (Cruz,2003). Nesse contexto, a atividade leiteira surgia como substituta para a decadente cultura cafeeira: em 1941, foi fundada a Cooperativa Agropecuária de Itaperuna Ltda. (Capil), congregando os produtores de leite da região. Em 1961, com a instalação da fábrica de leite instantâneo Leite Glória em Itaperuna, a pecuária leiteira passou a figurar como uma possível alternativa ao café (Silva, 1997 e 2006), muito embora não tenha conseguido, isoladamente, reverter o quadro de baixo dinamismo econômico da região. Assim, buscando caracterizar a economia local, o município de Itaperuna tem como uma das fontes de geração de renda para a população a produção leiteira, liderando essa produção, segundo o IBGE, com 28.920 mil litros no ano de 2010. Atualmente, Itaperuna conta com a instalação da empresa paulista Quatá, que já opera em São Paulo, Minas Gerais e Paraná, e também com a empresa de laticínios Marília. Além das fábricas de lacticínios, o município tem a Fábrica Boechat Ltda., voltada ao mercado de freios para veículos pesados, além de pequenas e microempresas no setor de confecção. Marafon et al. (2011) assinalam que, no decorrer da década de 1970, a região já vinha se firmando como uma das principais produtoras de produtos lácteos do estado, produzindo leite, iogurte, manteiga e leite em pó, entre outros. Apontam que, além da atividade de agropecuária, a região se destaca na produção de tomate e cana-de-açúcar; nos municípios de Varre-Sai, Porciúncula e Bom Jesus do Itabapoana, acrescenta-se a produção de café.

No contexto do ERJ, o NOF é a região com maior peso da agropecuária na composição de seu PIB regional (5,1\%), segundo dados do Tribunal de Contas do Estado do Rio de Janeiro (2014), representando uma porcentagem bastante superior à média do estado, o que está em consonância com a importância da pecuária e da agricultura para a economia dos municípios que compóem essa região. No entanto, a despeito de sua importância, hoje a agricultura enfrenta sérios problemas socioambientais, relacionados, primordialmente, ao desmatamento. Incluídas por Gomes et al. (2009) como parte do conjunto dos municípios do ERJ que são áreas de vulnerabilidade e de pressão antrópica, as ínfimas áreas florestais remanescentes encontram-se dispersas e correm risco de desaparecer.

Para Soffiati (2015), o desmatamento é o principal problema da região Noroeste Fluminense, na medida em que comporta, ao mesmo tempo, uma questão ambiental e uma questão social. Para ele, o desmatamento é responsável não só pela destruição do ecossistema, com a perda de sua rica biodiversidade, como também gera empobrecimento social, na medida em que desempenha papel relevante no êxodo rural e nas dificuldades da agricultura.

Nesse contexto de problemas ambientais, a região também enfrenta problemas drásticos de abastecimento de água, o que prejudica a população local e as atividades econômicas. A bacia hidrográfica do rio São Domingos, que abrange os municípios de São José de Ubá e Itaperuna, representa uma das áreas mais secas e degradadas no Noroeste. O desmatamento, a erosão dos solos e o assoreamento dos corpos d'água alteram o ciclo hidrológico e prejudicam a reposição dos aquíferos (Gonçalves, 2008), o que colabora para esse quadro de crise do setor agrário.

Apesar do peso da agropecuária no contexto estadual, é o setor de comércio e serviços que concentra a maior participação da atividade econômica na região NOF, com a administração pública ocupando o segundo lugar na região (35\% de participação no valor adicionado bruto em 2010) (Sebrae, 2015). Ao se comparar a participação de seus setores de atividade econômica com o ERJ, percebe-se, na região, maior participação da administração pública (18\% no ERJ e 35\% na região 
Noroeste) e da agropecuária, e menor da indústria (30\% no ERJ e 14\% na região), do comércio e de serviços ( $51 \%$ no ERJ e $46 \%$ no Noroeste).

O peso da administração pública se reflete na geração de empregos formais, sendo o percentual de funcionários públicos em relação ao total de empregos formais maior na região em 2012 (24\%) do que no estado do Rio de Janeiro (17\%). A administração pública desempenha papel fundamental na geração de empregos formais nos municípios de Varre-Sai (64\%), São José de Ubá (63\%), Laje do Muriaé (60\%) e Natividade (50\%) (Sebrae, 2015).

Analisando a região pelo Índice de Desenvolvimento Humano Municipal (IDHM), disponibilizado pelo Programa das Nações Unidas (PNUD), ${ }^{4}$ percebe-se que todos os municípios da região apresentam índices inferiores ao do estado do Rio de Janeiro, muito embora tenha havido uma melhora no período de 1991 a 2010.

Tabela 4. Índice de Desenvolvimento Humano Municipal: estado do Rio de Janeiro e municípios do Noroeste Fluminense. Ranking do IDHM nos anos de 1991, 2000 e 2010

\begin{tabular}{|c|c|c|c|c|c|c|}
\hline & $\begin{array}{c}\text { IDHM } \\
1991\end{array}$ & $\begin{array}{c}\text { Ranking } \\
1991\end{array}$ & $\begin{array}{c}\text { IDHM } \\
2000\end{array}$ & $\begin{array}{c}\text { Ranking } \\
2000\end{array}$ & $\begin{array}{c}\text { IDHM } \\
2010\end{array}$ & $\begin{array}{c}\text { Ranking } \\
2010\end{array}$ \\
\hline Estado do Rio de Janeiro & 0,573 & & 0,664 & & 0,761 & \\
\hline Aperibé & 0,483 & $46^{\circ}$ & 0,62 & $30^{\circ}$ & 0,692 & $64^{\circ}$ \\
\hline Bom Jesus do Itabapoana & 0,49 & $43^{\circ}$ & 0,625 & $26^{\circ}$ & 0,732 & $22^{\circ}$ \\
\hline Cambuci & 0,464 & $58^{\circ}$ & 0,599 & $51^{\circ}$ & 0,691 & $65^{\circ}$ \\
\hline Italva & 0,462 & $61^{\circ}$ & 0,561 & $73^{\circ}$ & 0,688 & $68^{\circ}$ \\
\hline Itaocara & 0,497 & $35^{\circ}$ & 0,627 & $19^{\circ}$ & 0,713 & $41^{\circ}$ \\
\hline Itaperuna & 0,511 & $26^{\circ}$ & 0,624 & $28^{\circ}$ & 0,73 & $23^{\circ}$ \\
\hline Laje do Muriaé & 0,435 & $73^{\circ}$ & 0,561 & $73^{\circ}$ & 0,668 & $78^{\circ}$ \\
\hline Miracema & 0,502 & $30^{\circ}$ & 0,615 & $37^{\circ}$ & 0,713 & $41^{\circ}$ \\
\hline Natividade & 0,481 & $50^{\circ}$ & 0,626 & $23^{\circ}$ & 0,73 & $23^{\circ}$ \\
\hline Porciúncula & 0,464 & $58^{\circ}$ & 0,572 & $69^{\circ}$ & 0,697 & $60^{\circ}$ \\
\hline Santo Antônio de Pádua & 0,493 & $37^{\circ}$ & 0,611 & $44^{\circ}$ & 0,718 & $35^{\circ}$ \\
\hline São José de Ubá & 0,416 & $78^{\circ}$ & 0,542 & $85^{\circ}$ & 0,652 & $88^{\circ}$ \\
\hline Varre-Sai & 0,385 & $88^{\circ}$ & 0,522 & $88^{\circ}$ & 0,659 & $83^{\circ}$ \\
\hline
\end{tabular}

Fonte: Atlas de Desenvolvimento Humano no Brasil/PNUD.

4 O Índice de Desenvolvimento Humano Municipal (IDHM) é medido pelos indicadores de três dimensōes do desenvolvimento humano: longevidade, educação e renda. Esse índice varia de 0 a 1; quanto mais próximo de 1 , melhor é o desenvolvimento humano do município. As faixas de desenvolvimento humano variam entre muito alto e muito baixo: muito alto $(0,800-1,000)$; alto $(0,700-0,799)$; médio $(0,600-0,699)$; baixo $(0,500$ $0,599)$ e muito baixo $(0,000-0,499)$. 
Em 1991, Itaperuna apresentava o IDHM mais elevado dos municípios da região (0,511). Em 2010, o IDHM mais elevado era o de Bom Jesus do Itabapoana $(0,732)$ e o mais baixo era o de São José de Ubá, com 0,652. No ranking municipal de 2010 disponibilizado pelo PNUD, nenhum município da região Noroeste ocupou os primeiros lugares; somente Bom Jesus do Itabapoana alcançou o $22^{\circ}$ lugar, seguido por Natividade e Itaperuna, ambos no $23^{\circ}$ lugar. Entre os mais baixos no ranking municipal, estão São José de Ubá $\left(88^{\circ}\right)$ e Varre-Sai $\left(83^{\circ}\right)$. Assim, nesse contexto de baixo dinamismo econômico, Itaperuna é o município que mais contribui para o desenvolvimento da região (Cruz, 2007; Lumbreras, 2010), destacando-se na extensão territorial, na concentração da população e em relação ao Produto Interno Bruto regional (PIB), com forte presença do setor de serviços (IBGE, 2010), o que se pode constatar pela concentração de empregos formais, sendo esse setor o maior empregador, com 8.180 empregos diretos em 2010.

Em 1991, o setor de comércio era responsável por 1.623 empregos, passando para $2.711 \mathrm{em}$ 2000 e, após, em 2010, aumentando a oferta para 5.572. Vale destacar que a geração de empregos formais no setor da indústria teve sua participação aumentada entre 1991-2010. O setor de agropecuária teve crescimento no estoque de empregos formais entre 1991 e 2000, mas permaneceu praticamente inalterado de 2000 até 2010, como se observa na tabela a seguir.

Tabela 5. Empregos formais por setores de atividade econômica no município de Itaperuna (1991, 2000 e 2010)

\begin{tabular}{|l|c|c|c|}
\hline Setores de Atividade Econômica & $\mathbf{1 9 9 1}$ & $\mathbf{2 0 0 0}$ & $\mathbf{2 0 1 0}$ \\
\hline Indústria & 1.636 & 2.603 & 3.817 \\
\hline Construção civil & 234 & 263 & 826 \\
\hline Comércio & 1.623 & 2.711 & 5.572 \\
\hline Serviços & 3.524 & 3.355 & 8.180 \\
\hline Agropecuária & 51 & 654 & 656 \\
\hline
\end{tabular}

Fonte: Rais/Ministério do Trabalho.

$\mathrm{Na}$ região, Itaperuna é o município que apresenta os melhores indicadores socioeconômicos: melhor PIB per capita, menor percentual de pobres e maior renda domiciliar per capita (Sebrae, 2015). O município também é referência na oferta de serviços, tanto na área de saúde (a cidade conta com o Hospital São José do Avaí, que realiza mais de dez mil atendimentos por mês e emprega diretamente mais de seiscentas pessoas) $)^{5}$ como no setor de serviços educacionais, abrigando universidades como a Redentor, a Fundação Universitária de Itaperuna (Funita), a Faculdade de Filosofia de Itaperuna (Fafita) e o consórcio Cederj. Além disso, Itaperuna oferece diversos serviços urbanos, o que confere

5 Dados extraídos do site do Hospital São José do Avaí. Disponível em: http://www.hsja.com.br/. Acesso em: 24 de ago. 2015. 


\section{Dinâmicas territoriais no estado do Rio de Janeiro}

ao município posição de destaque na rede urbana fluminense, já que "sua área de atuação extravasa os limites estaduais, exercendo influência sobre municípios capixabas e mineiros” (Ribeiro, 2012, p. 7), ao lado da influência regional no Noroeste-Norte fluminense.

\section{Perspectivas de uma região em mudança?}

Os dados apurados demonstram que a região Noroeste Fluminense apresenta um dinamismo relativamente fraco, o que resulta, entre outros fatores, na menor taxa de crescimento populacional entre as regiōes do estado e em sua baixa participação no PIB estadual. Como assinalado, o município de Itaperuna desempenha papel de centro regional, com destaque para sua extensão territorial, a concentração da população regional e a maior participação no Produto Interno Bruto (PIB) regional. Também é digna de nota a diversificação de suas atividades econômicas, especialmente na oferta de serviços de saúde e educação.

De modo geral, a literatura sobre o ERJ vem apontando para uma recuperação da participação do setor industrial no contexto nacional (Oliveira apud Siqueira, 2015). No entanto, assinala-se o caráter concentrador da distribuição das atividades econômicas no ERJ, já que, entre 2000 e 2010, a melhora mais significativa na área de emprego nas indústrias ocorreu, principalmente, no Norte fluminense, no Médio Paraíba e nas Baixadas Litorâneas (Medeiros Júnior, 2013).

Por um lado, há que se ter sempre em mente o peso da Região Metropolitana, não só em relação à sua histórica concentração política e econômico-social, como também na projeção dos investimentos que se delineiam na atualidade. Com base nisso e tomando-se os estudos da Federação da Indústria do Estado do Rio de Janeiro (Firjan), Silva Neto e Rocha (2014) analisaram o impacto dos investimentos na dinâmica de emprego nas regiões do ERJ. Os autores apontaram que os investimentos - previstos ou em andamento - apresentam forte tendência à concentração na Região Metropolitana do ERJ, o que poderia indicar uma perda de importância relativa do interior e uma "reconcentração no entorno da capital” (p. 11). No que se refere ao emprego formal, prossegue o estudo:

As regiōes do interior do ERJ que mais contribuíram para a geração de empregos no período analisado [...] foram as regiōes: Norte, Médio Paraíba, Serrana e, com expressivo crescimento, Baixadas Litorâneas. As regiōes Costa Verde, Centro-Sul Fluminense e Noroeste continuam apresentando pouco dinamismo econômico e pequena capacidade de geração de novos postos de trabalho frente às demais regiōes do Estado (Silva Neto e Rocha, 2014, p. 13).

Desse modo, o papel do Noroeste Fluminense no contexto das transformações territoriais faz emergir o debate a respeito das perspectivas de desenvolvimento e da capacidade de reversão do quadro de baixo dinamismo econômico pelo qual a região tem passado, bem como seu papel num contexto regional mais amplo, próximo daquilo que Cruz (apud Siqueira, 2015) chamou de "grande região fluminense de produção petrolífera", englobando o Norte-Noroeste Fluminense e as Baixadas Litorâneas.

Existem três aspectos que consideramos importantes para a análise do NOF numa perspectiva que seja capaz de englobar diferentes escalas geográficas. Em primeiro lugar, historicamente, o NOF 
foi relegado a um papel secundário nos planejamentos regionais, o que tem trazido uma marca de periferização em relação ao Norte fluminense e, recentemente, foi reforçado pelo efeito polarizador do complexo petrolífero do NF em relação aos atuais investimentos no setor portuário (Costa, 2012).

A observação das transformações - e permanências - por que tem passado o NOF nos leva ao segundo aspecto: a escala a ser privilegiada nos processos e nas expectativas de desenvolvimento socioespacial. Olhando-se por uma perspectiva interna, é preciso ter em mente os avanços setoriais, tanto no que se refere a certas atividades econômicas e ao destaque dado a certos municípios da região (Sebrae, 2015; Andrade, 2001) como no que diz respeito às melhorias em alguns indicadores sociais, como, por exemplo, o IDH. Da mesma forma, vale ressaltar, conforme estudo de Costa (2012), que, entre os anos 2000 e 2010, houve melhora na dinâmica demográfica da região, com aumento significativo da população com idade acima dos 25 anos, o que pode significar maior capacidade de fixação da população mais jovem na região. Por outro lado, a identificação e a análise dos desafios e a capacidade de projeção de uma "visão do futuro" da região (Firjan, 2015) encontram seus limites na própria capacidade da escala local de promover processos duradouros de transformação socioespacial. Embora se reconheça que o município apresenta amplo escopo de atuação como implementador de políticas públicas, cabe dispensar a devida atenção ao estudo recente de Siqueira (2015), que, ao analisar o caso do NOF, afirma que há um esgotamento daquela concepção localista de valorização excessiva das vocaçôes internas como elemento capaz de deflagrar processos de desenvolvimento. Cada vez mais, segundo Siqueira, a perspectiva deve ser transescalar e pensada em função de um projeto nacional de desenvolvimento (que, portanto, extrapole os limites locais), com ênfase para as políticas regionais numa perspectiva cooperativa, integrada às diversas escalas do território e sob a coordenação do governo federal (Siqueira, 2015).

Por fim, mas não menos importante, verifica-se que, atualmente, há um elemento político e econômico representado pela acentuada queda nas receitas dos royalties do petróleo, pela redução drástica dos investimentos da Petrobras na bacia de Campos e nos efeitos deletérios que isso tem significado para o orçamento municipal e para a futura dinâmica do ERJ e das regiōes em destaque. Diferente do caso do Norte fluminense, o NOF não possui municípios que figurem como grandes recebedores de royalties e de participações especiais do petróleo, portanto não compartilham da situação de municípios que têm suas receitas baseadas, majoritariamente, nessa fonte de recursos. ${ }^{6}$ Se, por um lado, isso significa menor disponibilidade de capitais, por outro, também representa melhores perspectivas de gestão fiscal e financeira, além de menor dependência em relação a um recurso finito e sujeito à oscilação internacional (como, por exemplo, aquelas que, atualmente, ocorrem em função da queda dos preços internacionais do barril do petróleo).

\footnotetext{
6 A título de comparação, de acordo com o site inforoyalties (http://inforoyalties.ucam-campos.br/), o maior recebedor de royalties e participaçôes especiais do ERJ é Campos dos Goytacazes. Itaperuna ocupava a 42a posição num ranking de 2014 entre os 87 municípios do ERJ que têm direito a esses recursos. No entanto, como demonstram os "Estudos socioeconômicos dos municípios do estado do Rio de Janeiro", disponibilizado pelo TCE-RJ, em 2013 os royalties representavam 55,7\% da composição das receitas correntes do município de Campos, contra 6,5\% para Itaperuna.
} 


\section{Dinâmicas territoriais no estado do Rio de Janeiro}

Nesse sentido, cabe pensar, nesta parte final, nas perspectivas para o desenvolvimento em nível regional a partir de alguns indicadores e elementos atuais. Falar em perspectivas significa ingressar em uma seara difícil, em função dos inúmeros fatores que intervêm, em maior ou menor intensidade, nessa esfera. Não sem motivo, em duas ocasiōes, Cruz (2007 e 2013), se referiu a desafios no que se refere a desenvolvimento, tanto em escala regional (NOF) como em nível estadual (ERJ).

\section{Referências}

ALENTEJANO, Paulo Roberto R. "A evolução do espaço agrário fluminense”. GEOgraphia, ano 7, n. 13, 2005.

ANDRADE, Maria Alice A. Transformaçôes em curso no perfil econômico e socioespacial de cidades de pequeno porte: o exemplo de Bom Jesus de Itabapoana no Noroeste Fluminense (dissertação). UFRJ, 2001.

BINSZTOK, Jacob. "Crise e construção de uma nova ordem territorial no estado do Rio de Janeiro". GEOgraphia, ano 1, n. 2, 1999.

CASTRO, Iná Elias de. Geografia e política: território, escalas de ação e instituições. Rio de Janeiro: Bertrand Brasil, 2005.

CEPERJ - Fundação Centro Estadual de Estatísticas, Pesquisas e Formação de Servidores Públicos do Rio de Janeiro. Disponível em: http://www.ceperj.rj.gov.br/. Acesso em: 16 jun. 2015.

COSTA, Luciana Machado da. Noroeste Fluminense: integração, diferenciação e fragmentação (dissertação). Universidade Candido Mendes, 2012.

CRUZ, José Luis Vianna da. Projetos nacionais, elites locais e regionalismo: desenvolvimento e dinâmica territorial no Norte fluminense (tese). UFRJ, 2003.

—_. "Os desafios do Norte e do Noroeste Fluminenses frente aos grandes projetos estratégicos". Vértices, v. 9, n. 1-3, jan.-dez. 2007.

—. "Os desafios da construção do desenvolvimento no Rio de Janeiro". Cadernos do Desenvolvimento Fluminense, Rio de Janeiro, n. 2, jul. 2013.

DAVIDOVICH, Fany. "Metrópole e território: metropolização do espaço no Rio de Janeiro". Cadernos Metrópole, n. 6, 2o sem. 2001, pp. 67-77.

EVANGELISTA, Hélio de Araújo. "A luta pela fusão dos estados da Guanabara e do Rio de Janeiro. A luta pela desfusão no atual estado do Rio de Janeiro". Revista Geo-paisagem, ano 4, n. 8, jul.-dez. 2005. Disponível em: http://www.feth.ggf.br/Luta.htm. Acesso em: 08 set. 2015.

FAURÉ, Yves A. e HASENCLEVER, Lia (orgs.). O desenvolvimento local no estado do Rio de Janeiro: quatro estudos exploratórios no interior fluminense. Rio de Janeiro: E-papers, 2003.

_- e - (orgs.). O desenvolvimento local no estado do Rio de Janeiro: estudos avançados nas realidades municipais. Rio de Janeiro: E-papers, 2005.

— et al. (orgs.). Novos rumos para a economia fluminense: oportunidades e desafios de crescimento do interior. Rio de Janeiro: E-papers, 2008. 
GALVÃO, Maria do Carmo Corrêa. "Rio de Janeiro: contradiçôes e ajustes de um espaço desigual". In PIRES, G. A. e COELHO, M. C. N. (orgs.). Percursos geográficos. Rio de Janeiro: Lamparina/ PPGG/UFRJ, 2009.

GOMES, Louyse Martins et al. "Análise da cobertura florestal da Mata Atlântica por município no estado do Rio de Janeiro”. XIV Simpósio Brasileiro de Sensoriamento Remoto. Anais... Natal, 2530 de abril de 2009, pp. 3.849-57.

GONÇALVES, Mônica Athayde. Conhecimento e cidadania: um estudo sobre a construção da consciência ambiental no contexto do desenvolvimento sustentável (dissertação). Universidade Estadual do Norte Fluminense, 2008.

IBGE - Instituto Brasileiro de Geografia Estatística. Disponível em: http:/www.ibge.gov.br/home/. Acesso em: $1^{\circ}$ maio 2015.

LEMOS, Linovaldo Miranda e RODRIGUES, Rejane C. de A. "Logística portuária e integração do território fluminense”. Cadernos do Desenvolvimento Fluminense, n. 5, jul. 2014, pp. 31-44.

LESSA, Carlos. Rio de todos os Brasis: uma reflexão em busca de autoestima. Rio de Janeiro: Record, 2005.

LIMONAD, Ester. "Rio de Janeiro, uma nova relação capital-interior?”. In LIMONAD, Ester et al. (orgs.). Brasil, século XXI, por uma nova regionalização? Agentes, processos e escalas. Niterói: Max Limonad, 2004, pp.78-92.

LUMBRERAS, Marlúcia Junger. "Noroeste Fluminense: da estagnação a novas oportunidades?”. In SANTOS, Angela Moulin S. Penalva et al. (orgs.). Rio de Janeiro: um olhar socioespacial. Rio de Janeiro: Gramma, 2010, pp. 317-35.

MARAFON, Glaucio José e RIBEIRO, Miguel Angelo (orgs.). Revisitando o território fluminense. Rio de Janeiro: Negef, 2003, v. 1. 251p.

- Geografia do estado do Rio de Janeiro: da compreensão do passado aos desafios do presente. Rio de Janeiro: Gramma, 2011.

- Revisitando o território fluminense IV. 1 ed. Rio de Janeiro: Gramma, 2012. 312p.

—. Revisitando o território fluminense III. 1 ed. Rio de Janeiro: Gramma/Faperj, 2010. 354p.

- Revisitando o território fluminense II. 1 ed. Rio de Janeiro: Gramma/Faperj, 2008. 332p.

MEDEIROS JUNIOR, Hélcio de. "Desconcentração econômica e atratividade regional no estado do Rio de Janeiro entre 2000 e 2010". Cadernos do Desenvolvimento Fluminense, Rio de Janeiro, n. 1, fev. 2013. Disponível em: http://www.epublicacoes.uerj.br/index.php/cdf/article/ view/9059/6937. Acesso em: 13 set. 2015.

MINISTÉRIO do Trabalho e Emprego. Relatório Anual de Informações Sociais (RAIS). Disponível em: http://portal.mte.gov.br/portal-mte/. Acesso em: 20 ago. 2015.

MOTTA, Marly. "Rio de Janeiro versus Rio de Janeiro: o lugar da capital no cenário político fluminense”. In GOMES, Ângela Maria de Castro (org.). Direitos e cidadania: memória, politica e cultura. Rio de Janeiro: Fundação Getúlio Vargas, 2007, pp. 175-96.

NEVES, Delma Pessanha. "Norte fluminense: índices de pobreza e reivindicações políticas", Revista Rio de Janeiro, n. 18-19, jan.-dez. 2006, pp. 9-38. Disponível em: http://www.forumrio.uerj.br/ documentos/revista_18-19/Cap-1-Delma_Pessanha.pdf. Acesso em: 24 set. 2015. 


\section{Dinâmicas territoriais no estado do Rio de Janeiro}

OLIVEIRA, Alberto et al. "Crescimento econômico, desigualdade e condiçôes de vida: estudo do interior fluminense nos anos 90". Espacio Abierto Cuarderno Venezolano de Sociologia, v. 13, n. 4, out.-dez. 2004, pp. 533-65.

OLIVEIRA, Antonio Tadeu R. et al. "Deslocamentos populacionais no espaço fluminense: duas décadas". IV Encontro Nacional de Migração, 2005, Rio de Janeiro. Anais... Disponível em: http:// www.abep.nepo.unicamp.br/docs/anais/outros/4EncNacSobreMigracao/ST5-4.pdf. Acesso em: 18 jun. 2015.

OLIVEIRA, Floriano José Godinho de. “Uma nova urbanização no espaço regional: a lógica não metropolitana da cidade-região no estado do Rio de Janeiro". Scripta Nova, v. IX, n. 194 (109), $1^{\circ}$ ago. 2005. Disponível em: http://www.ub.edu/geocrit/sn/sn-194-109.htm. Acesso em: 2 maio 2014.

PINHEIRO, Armando Castelar e VELOSO, Fernando (orgs.). Rio de Janeiro: um estado em transição. Rio de Janeiro: FGV, 2012.

PNUD - Programa das Nações Unidas para o Desenvolvimento. Disponível em: http://www.pnud. org.br/. Acesso em: 25 ago. 2015.

RIBEIRO, Luís César de Queiroz. "As necessidades do planejamento urbano para o estado do Rio de Janeiro". Revista de Economia Fluminense, ano VII, n. 14, out. 2013.

RIBEIRO, Miguel Angelo. "Transformaçôes socioeconômicas e mudanças nas redes de localidades centrais no Rio de Janeiro: o papel de Campos dos Goytacazes, Macaé e Itaperuna (1966-2007)". Espaço e Economia, ano 1, n. 1, 2012. Disponível em: http://espacoeconomia.revues.org/131. Acesso em: 5 out. 2015.

- e MARAFON, Glaucio José. A metrópole e o interior fluminenses: simetrias e assimetrias geográficas. Rio de Janeiro: Gramma, 2009.

RUA, João. "As crises vividas pelo estado do Rio de Janeiro e a emergência de novas territorialidades em áreas rurais". In MARAFON, Glaucio et al. (orgs.). Abordagens teórico-metodológicas em geografia agrária. Rio de Janeiro: EdUERJ, 2007, pp. 271-98.

SEBRAE. Painel regional: Noroeste Fluminense. Rio de Janeiro, 2015.

SILVA, Augusto César Pinheiro da. "A produção acadêmica sobre a gestão do território no Estado do Rio de Janeiro: o projeto Faperj 2008-2011 no GETERJ da PUC-Rio". Revista do Departamento de Geografia da PUC-Rio, ano 4, n. 7, 2. sem. 2011.

"As estratégias de modernização do espaço rural fluminense: técnica, planejamento e gestão no campo do Rio de Janeiro". Campo-Território: Revista de Geografia Agrária, v. 1, n. 2, pp. 92-122, ago. 2006. Disponível em: http://www.seer.ufu.br/index.php/campoterritorio/article/viewFile/11786/8292. Acesso em: 24 set. 2015.

—. "Gestão e território: o caso da empresa Fleishmann \& Royal no Noroeste Fluminense”. Revista Território, ano II, n. 3, jul.-dez. 1997, pp. 53-75.

SILVA NETO, Romeu e ROCHA, Maria das Dores. "Avaliação dos impactos dos grandes projetos de investimentos na dinâmica do emprego formal no estado do Rio de Janeiro", Espaço e Economia, dez. 2014. Disponível em: http://wspacoeeconomia.revues.org/1345. Acesso em: 12 jun. 2015. 
SIQUEIRA, Fábio G. Viana. Noroeste Fluminense: arranjos regionais e perspectivas de desenvolvimento (dissertação). Universidade Cândido Mendes, 2015.

SOFFIATI, Arthur. "Florestas, pererecas e peixinhos”, Revista Visão Socioambiental [on-line]. Disponível em: http://www.visaosocioambiental.com.br/site/index.php?option=com_frontpage\&Itemid=1. Acesso em: 21 set. 2015.

TCE/RJ - Tribunal de Contas do Estado do Rio de Janeiro. Estudos socioeconômicos dos municípios do estado do Rio de Janeiro. Disponível em: http://www.tce.rj.gov.br/web/guest/estudos-socioeconomicos1. Acesso em: 20 jul. 2015.

URANI, André. Trilhas para o Rio: do reconhecimento da queda à reinvenção do futuro. Rio de Janeiro: Campus/Elsevier, 2008.

- e GIAMBIAGI, Fabio (orgs.). Rio: a hora da virada. Rio de Janeiro: Campus/Elsevier, 2011. VAINER, Carlos B. “As escalas do poder e o poder das escalas: o que pode o poder local?". Encontro Nacional da ANPUR, 9, 2001. Anais... Disponível em: http://unuhospedagem.com.br/revista/ rbeur/index.php/anais/issue/view/88/showToc. Acesso em: 25 set. 2015. 


\section{0 bairro de Santa Cruz, RJ: uma configuração socioespacial construída no decorrer do tempo}

Vânia Regina Jorge da Silva

\section{Introdução}

- ste artigo analisa e caracteriza as condições socioeconômicas e fisiográficas do bairro ${ }^{1}$ de Santa Cruz, situado no extremo oeste da cidade do Rio de Janeiro. A importância desta análise se deve a dois fatores.

O primeiro, porque esse bairro, assim como a área em que se encontra inserido, a Zona Oeste carioca (Figura 1), apresenta baixa densidade demográfica em relação a outras da urbe, constituindo-se, portanto, em extensão com prognóstico de expansão urbana.

O segundo fator diz respeito à sua localização em relação a importantes investimentos de infraestrutura: a instalação da Companhia Siderúrgica do Atlântico (CSA); a remodelação do Porto de Itaguaí; e a construção do túnel Vice-Presidente José Alencar (da Grota Funda), da TransOeste e do Arco Rodoviário Metropolitano do Rio de Janeiro (ARMRJ), alguns já em operação e outros ainda em construção nesta segunda década do século XXI.

Esses fatores se consubstanciam em autênticos indutores de mudanças na configuração socioespacial na direção oeste tanto do município do Rio de Janeiro como da Região Metropolitana homônima. Assim, nas pesquisas realizadas, ${ }^{2}$ reconhecemos que a Zona Oeste carioca está passando

${ }^{1}$ Referimo-nos ao bairro como a menor porção delimitada e reconhecia pela divisão político-administrativa do município do Rio de Janeiro.

2 Este artigo integra a tese desenvolvida no Programa de Pós-Graduação em Geografia da UERJ, intitulada "O bairro de Santa Cruz-RJ no contexto da metropolização: escalas, dinâmicas e processos socioespaciais (2005-2015)”. 
por um momento de expansão urbana específica, que demanda maior exame em comparação com processos anteriores.

É necessário, contudo, retroagirmos um pouco, a fim de entendermos os diversos tempos espacializados em justaposição que explicam a atual configuração espacial desse recorte de estudo. Tomamos como referência teórica Milton Santos (2008) quanto à evolução histórica, à modernização e às inovações tecnológicas, como elementos que conferem periodização ao espaço, a fim de apreendê-lo como produto e condiçãao eficaz e ativa para a concreta realização de produção, influenciando os momentos seguintes. Entende-se, portanto, que o espaço não é tão somente reflexo social, mas também resultado de contextos específicos pretéritos, que se tornam condicionantes e intervenientes em relação aos processos posteriores. Em outras palavras, em conjunturas político-econômicas nacionais específicas, podemos observar estratégias que impactaram o território fluminense como um todo, e o bairro de Santa Cruz em particular, atribuindo-lhe uma estrutura que intervém no presente momento. A esse respeito, acrescentamos que, de acordo com Léfebvre (1994), o espaço também é um campo de ação, um instrumento político, produto social que intervém na produção capitalista, na reprodução da sociedade e na reprodução das relações sociais de produção, ou seja, é produto e também condição.

Nesse contexto, com o objetivo de apreender a realidade atual como resultante de contextos específicos de urbanização anteriores e de observar como esse quadro interfere na atual fase de expansão urbana, são consideradas a localização e as condições socioeconômicas do bairro de Santa Cruz frente à composição espacial da cidade do Rio de Janeiro, de parte da Região Metropolitana e do estado do Rio de Janeiro. Além disso, apresentam-se um quadro fisiográfico da área em estudo que interfere em sua ocupação e também sua posição dentro do recorte denominado bacia de Sepetiba, que reconhecemos como uma retroárea do Porto de Itaguaí. Consideram-se ainda os principais agentes intervenientes, os dados apurados quanto à população absoluta e à densidade demográfica, bem como aqueles que dizem respeito a renda e escolaridade. Ou seja, elaboramos um quadro socioespacial descritivo que serve de base à análise dos processos espaciais em curso.

Este artigo encontra-se organizado em três partes. A primeira remete à localização de nosso recorte e à posição estratégica que ocupa na bacia de Sepetiba e no estado do Rio de Janeiro. Na segunda parte, examinamos a atual configuração socioespacial, remetendo-nos a períodos anteriores, com um breve painel da ocupação histórica dessa área e da ação estatal que lhe conferiu especificidade no contexto carioca. Fazemos também um apanhado da ocupação do solo na atualidade, com seus diferentes usos. Por fim, na terceira parte, consideramos a composição socioeconômica do bairro de Santa Cruz. Esperamos, assim, traçar um panorama que sirva de base para futuras pesquisas sobre o oeste carioca.

\section{Localização do bairro de Santa Cruz em contextos esca- lares diferentes}

O bairro de Santa Cruz encontra-se na Zona Oeste carioca (Figura 1), ladeado, a leste, pelo bairro de Paciência; ao sul, pelos bairros de Guaratiba e Sepetiba; a oeste, pela baía de Sepetiba; e, ao norte, pelos municípios de Itaguaí e Seropédica. Com a edição do Decreto-Lei no 898/1962, foi 


\section{0 bairro de Santa Cruz, RJ}

regulamentada a organização administrativa do então estado da Guanabara, hoje cidade do Rio de Janeiro. Esse decreto foi sucessivamente modificado para incluir novas divisões, até chegar à atualidade com cinco Áreas de Planejamento (AP) e $33^{3}$ Regiōes Administrativas (RA), nas quais se encontram agrupados os 161 bairros oficiais. Desse modo, Santa Cruz está inserido na Área de Planejamento 5 e, junto com os bairros de Sepetiba e Paciência, localiza-se na XIX RA de Santa Cruz.

Figura 1. Zoneamento da cidade do Rio de Janeiro

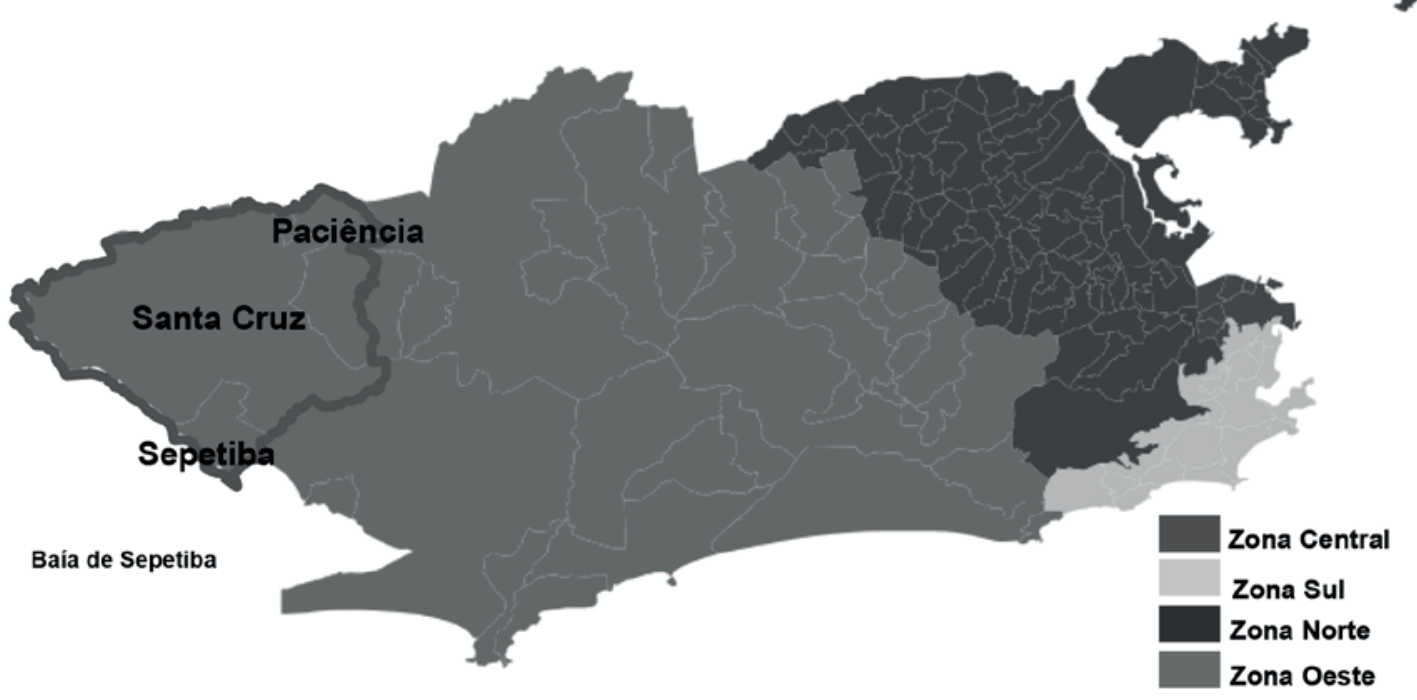

Fonte: Freire, 2011.

A extensão territorial do bairro de Santa Cruz é de 126,85 $\mathrm{km}^{2}$, representando $10,36 \%$ do território da cidade do Rio de Janeiro. Portanto, é o terceiro maior bairro carioca, sendo superado em extensão apenas por Campo Grande, com 136,52 km², e por Guaratiba, com 138,26 km². Ressaltamos que, no contexto da XIX RA de Santa Cruz, o bairro que lhe confere nome equivale a 77,32\% de sua área territorial.

Ao considerarmos a posição estratégica do bairro de Santa Cruz, remetemo-nos a dois recortes. O primeiro, o contexto do bairro na bacia de Sepetiba, e o segundo, em relação ao estado do Rio de Janeiro. Então, buscamos a análise de Machado e Castro (1996), estudo feito com o objetivo de servir

\footnotetext{
3 A XXXII RA da Colônia Juliano Moreira foi aprovada pelo Projeto de Lei no 446/96, mas não chegou a ser implementada. Portanto, até a presente data, constam 33 RAs devidamente instituídas. O projeto de lei complementar no 15/2013 tramita com a proposta de criar mais nove regiōes administrativas, desmembradas das já existentes, o que resultará no aumento da máquina administrativa, com a criação de cargos de gerência, chefia, coordenadoria e assessoria.
} 
de base a projetos de políticas de desenvolvimento, como, por exemplo, a expansão do Porto de Itaguaí. Nesse contexto, Machado e Castro tomaram como referência uma abordagem sistêmica que leva em conta os aspectos fisiográficos, econômicos e políticos-institucionais da área denominada bacia de Sepetiba, da qual o bairro de Santa Cruz faz parte. Cabe esclarecer que esse recorte é composto, em sua inteireza, pelos municípios de Seropédica, Itaguaí, Japeri, Queimados e Paracambi; por alguns dos distritos dos municípios de Engenheiro Paulo de Frontin, Mangaratiba, Miguel Pereira, Nova Iguaçu, Piraí, Vassouras e Rio Claro; e também pelas RAs de Campo Grande, Santa Cruz e Guaratiba, todas no município do Rio de Janeiro.

A importância de considerarmos o bairro de Santa Cruz nessa escala de observação nos possibilita perceber não só sua especificidade diante do todo, mas também inferir como os processos anteriores e atuais organizam e reorganizam o espaço, promovendo relações sociais que ora se espacializam em uma configuração, ora transformam-na em outra. Como exemplo, temos a localização do bairro de Santa Cruz em relação ao núcleo da metrópole e, agora, em relação a outras centralidades, que podem ser formadas e/ou reforçadas pelos processos atuais.

Machado e Castro (1996) consideram toda a área da bacia de Sepetiba como de "fronteira metropolitana”. Ou seja, essa região vem passando por um processo de urbanização que se caracteriza pela expansão da metrópole no que diz respeito a atividades econômicas e dinâmicas populacionais. A esse respeito, é interessante observar as especificidades do bairro de Santa Cruz compondo essa espacialidade. Por ser entrecortado pela av. Brasil, que faz parte da BR-101, e pela ferrovia do ramal de Santa Cruz, até a década de 1960 tinha uma função suburbana de cunho rural, com um ritmo lento de ocupação, sendo visto como parte de um "cinturão verde" composto por vários sítios e chácaras que produziam hortigranjeiros para o abastecimento do mercado carioca. Com os melhoramentos tanto da rodovia Rio-Santos como da av. Brasil, que servem como eixos de ocupação, essa área sofreu uma expansão urbana de caráter industrial, o que resultou na superposição de uma população ligada à anterior economia agrícola com melhor renda e de uma população de baixa renda devido a processos de invasão e ocupação irregular dos terrenos vazios.

Para Machado e Castro, a bacia de Sepetiba se apresenta como propícia ao desenvolvimento de uma retroárea, ou seja, uma área com estrutura logística de apoio para o porto de Itaguaí e as atividades relacionadas. Nesse contexto, percebe-se o bairro de Santa Cruz com um relevo que favorece os diferentes tipos de ocupação pelos quais o bairro tem passado desde o início da colonização, com atividades agropastoris, uso residencial, uso industrial e de comércio e serviços. Também devido aos aspectos topográficos do bairro em estudo e à ocupação irregular e clandestina para habitação, as favelas têm uma configuração horizontal.

Após tecermos essas considerações acerca do bairro em estudo no contexto da bacia de Sepetiba, devemos fazer seu enquadramento no estado do Rio de Janeiro. A esse respeito, são importantes as observações de Davidovich (2010), no sentido de que os investimentos em rodovias e portos, como os que se observam no estado, remetem-nos à ideia de que essa unidade federativa está sendo instrumentalizada como uma plataforma de exportação principalmente para produtos siderúrgicos e minerais, sobretudo de Minas Gerais, uma inflexão relativa aos momentos anteriores, pautados no mercado nacional. Ou seja, por meio de ações conjugadas por interesses públicos e privados, a cidade e o estado do Rio de Janeiro tornaram-se estratégicos para a economia globalizada. Portanto, podemos aludir ao conjunto de obras de infraestrutura, que têm o potencial de promover acentuadas alterações no recorte espacial. Como 
exemplo, citamos o ARMRJ (rodovia em construção), que não pode ser considerado isoladamente, mas apenas quando inserido em uma gama de construções, que incluem a CSA, a remodelação do porto de Itaguaí e o Comperj, entre outras, conforme visualizamos na Figura 2.

Figura 2. Investimentos no estado do Rio de Janeiro

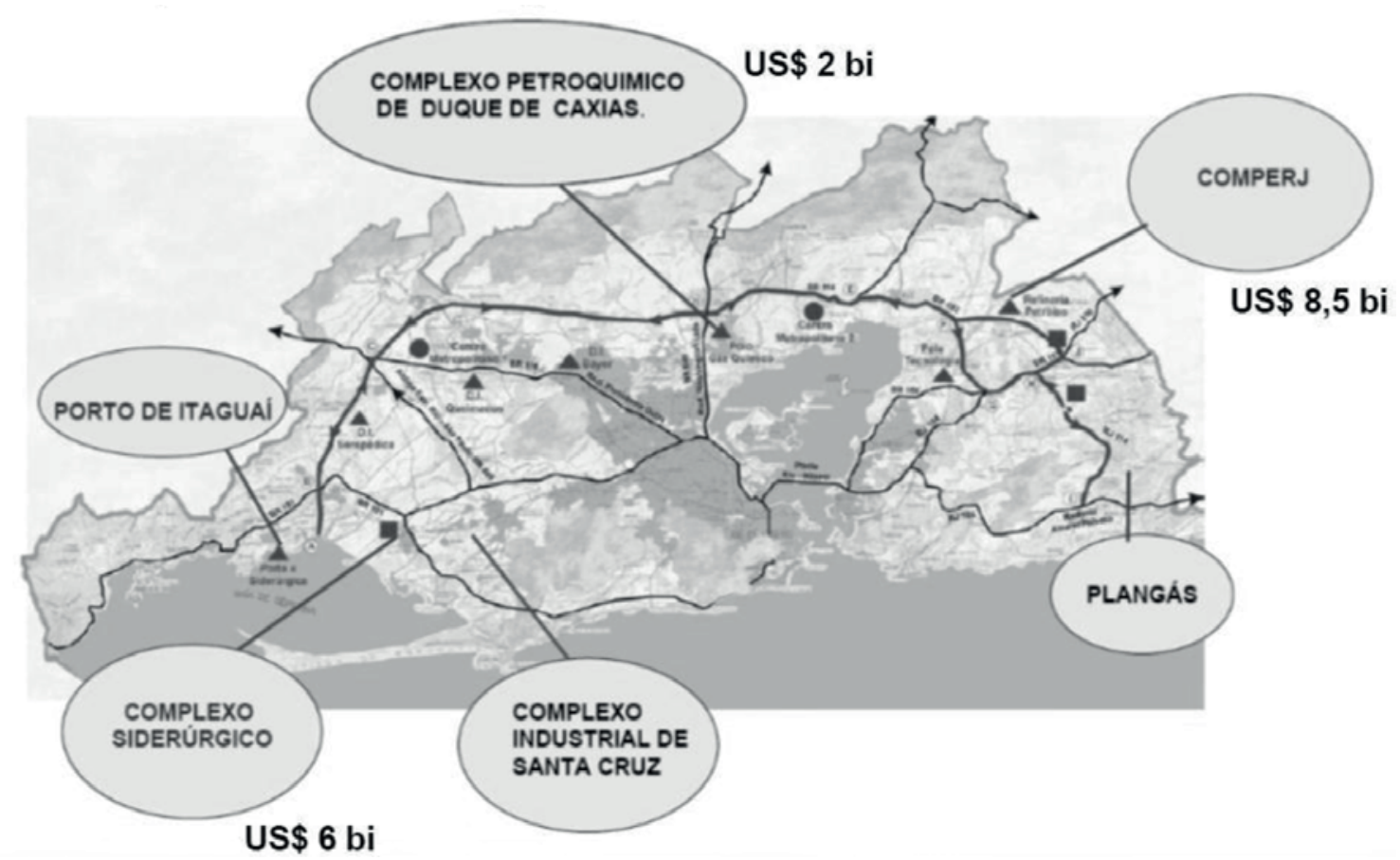

Fonte: Secretaria de Obras do Estado do Rio de Janeiro (2009).

O traçado projetado para o ARMRJ passa por oito municípios do estado do Rio de Janeiro, de Itaboraí a Itaguaí, promovendo o respectivo aumento de acessibilidade. A principal função apontada para sua construção é o acesso ao porto de Itaguaí e à malha rodoviária do país por cinco eixos rodoviários que são conectados pelo arco: a BR-101/RJ sul (Rio-Santos), a BR-465 sul (Rio-São Paulo), a BR-040/RJ (Rio-Juiz de Fora), a BR-101/RJ norte (Rio-Vitória) e a BR-116 (Rio-Bahia). De acordo com o relatório do projeto da Secretaria do Tesouro Nacional (STN), a construção dessa via é apontada como uma demanda das lideranças empresariais no estado do Rio de Janeiro, com o objetivo de ampliar a competitividade, possibilitando, assim, melhor acesso rodoviário ao porto de Itaguaí e redução dos custos de exportação de várias indústrias de Minas Gerais, Bahia e Espírito Santo.

Ao discorrermos acerca de alguns empreendimentos atrelados ao ARMRJ, remetemo-nos ao projeto de remodelação e modernização do porto de Itaguaí, que é de águas profundas, ou seja, comporta embarcaçôes com calado superior a 15 metros. Esse projeto se desdobra em diversas etapas, com investimentos do governo federal, como parte do Programa de Aceleração do Crescimento (PAC) 
desde 2008. Embora apresente ligações ferroviárias, o acesso rodoviário ainda é precário, apontando, assim, para a necessidade de se executar o projeto do ARMRJ.

Quanto à CSA, sua construção teve início em 2006 e já está em operação desde 2010. Está localizada no município do Rio de Janeiro, no distrito industrial de Santa Cruz. Essa localização se deve às inúmeras vantagens logísticas, incluindo a proximidade com algumas ferrovias e a abertura para o Oceano Atlântico (através do porto de Itaguaí), além da demanda interna por subprodutos que a usina produz, como cimento e energia, através de uma termelétrica instalada com capacidade para 490 megawatts. Observa-se que metade dessa produção é ofertada ao mercado interno. Essa empresa produz, em solo brasileiro, placas semiacabadas de aço para o suprimento de instalaçóes na Europa e nos Estados Unidos. Mais uma vez, remetemo-nos a Davidovich (2010), que ressalta o fato de que o projeto de fabricação de aços longos em Itaguaí reforça a inserção do estado Rio de Janeiro nos mercados globais, destacando a importância do recorte em estudo.

Após examinarmos o bairro de Santa Cruz nos contextos escalares do estado do Rio de Janeiro e da bacia de Sepetiba, que faz parte da RMRJ, veremos as ações relacionadas à administração pública e aos empreendimentos públicos e privados de infraestrutura que corroboram o cenário de mudança. Neste ponto, retroagimos no tempo, a fim de analisar o espaço do bairro historicamente construído.

\section{A ocupação histórica do bairro de Santa Cruz: de fazenda jesuítica a área urbana}

O bairro de Santa Cruz está situado em uma baixada formada na falha entre a serra do Mar e os maciços rochosos costeiros. As áreas deprimidas entre esses dois sistemas rochosos foram preenchidas por sedimentos que vieram das partes mais altas do relevo fluminense durante os vários ciclos de erosão-deposição correspondentes às épocas de progressão e regressão marinhas (Gama, 1998).

Em uma escala mais próxima, a da cidade do Rio de Janeiro, encontram-se alguns alinhamentos do relevo próximos ao bairro de Santa Cruz conhecidos como serra de Inhoaíba e serra da Paciência. Entre elas, estende-se uma área de baixada formada pela superposição de uma planície aluvial e uma planície litorânea. Desde o período colonial, o bairro de Santa Cruz e a área adjacente sempre estiveram funcionalmente integrados no contexto socioespacial da cidade do Rio de Janeiro e do estado homônimo. Sua principal função desde as primeiras ocupações foi a de atuar como produtor de agropecuários para a subsistência e o abastecimento da cidade (Fridman, 1999). Segundo a autora, esse recorte fazia parte da Sesmaria de Guaratiba, extensão de terras que abrigava de Itacuruçá a Guaratiba e Santa Cruz. Tratava-se de uma área estratégica, devido ao acesso à capitania de São Vicente e à rota da prata, que vinha de Buenos Aires, servindo, mais tarde, para o escoamento de ouro.

Parte dessas terras foi doada aos jesuítas, que, então, formaram uma fazenda baseada na policultura, a Fazenda de Santa Cruz. De acordo com Fridman (1999), na época em que essa área estava sob o domínio dos jesuítas, a fazenda era um grande "centro agrofabril”, funcionando como um produtor autônomo dos excedentes que escoavam por caminhos, estradas, valas, canais e rios navegáveis em direção ao mar, até chegarem à então corte, localizada no atual centro da cidade do Rio de Janeiro, e aos engenhos que existiam na então província do Rio de Janeiro (p. 188). Na Fazenda de Santa 


\section{0 bairro de Santa Cruz, RJ}

Cruz, eram desenvolvidas atividades, por exemplo, de ourives, prateiros, tecelagem, olaria, engenho, curtume, carvoaria, entre outras.

Em 1759, com a expulsão dos padres jesuítas pelo marquês de Pombal, a Fazenda de Santa Cruz tornou-se propriedade real e, em seguida, imperial. Nesse período, por distar cerca de sessenta quilômetros do centro do Rio de Janeiro, o local servia de residência de veraneio para a família imperial. Por essa razão, instalaram-se residências para os membros do governo e fornecedores de bebida, coches e animais de montaria. Dessa forma, formaram-se povoados com residências, vendas e casas de comércio, até que se alterou o estatuto de fazenda para o de povoação.

Com a abolição da escravatura, chegaram imigrantes estrangeiros para trabalhar nessa área segundo um novo modo de produção, agora plenamente capitalista, com mão de obra livre e assalariada. Em 1815, já tinham vindo os chineses, que puseram em prática a criação de bicho-da-seda e o plantio de chá. Os espanhóis também ali chegaram, formando uma aldeia de empregados nos curtumes e olarias. Muitos portugueses da região do Minho também vieram para essa área, a fim de promover a agricultura.

As modernizações também chegaram a Santa Cruz, demonstrando sua importância no modo de produção vigente. Podemos citar o fornecimento de água e a iluminação a gás e luz elétrica desde o final do século XIX. Também data dessa época a instalação de meios de transporte ferroviário, como o bonde para Sepetiba, da empresa Ferro Carril (de 1879), e o ramal de Santa Cruz da Estrada de Ferro Central do Brasil, inaugurado em 1881, a princípio com a finalidade de transportar o gado abatido no matadouro público para o centro do Rio de Janeiro.

Fridman (1999) observa que toda aquela área que compunha a Fazenda de Santa Cruz havia sido, essencialmente, propriedade pública, passando por alguns parcelamentos através de foreiros, posseiros e doaçôes. Apresentava um misto de enormes áreas com poucos retalhamentos, de modo que, no início do século XX, o que hoje é o centro de Santa Cruz pôde desenvolver-se com as atividades comerciais, ditas urbanas e de serviços. Esse centro estava envolvido por glebas de terras rurais. Ainda corroborando o que vimos em Santos (2002), sobre o espaço ser produto e condição para a reprodução da sociedade, Fridman (1999) considera que,

embora estas localidades só viessem a tomar ares verdadeiramente urbanos neste século $[\mathrm{XX}]$, todo o processo de divisão de suas terras, verificado ao longo do século XIX e mais acentuadamente nos últimos anos, foi ditado pela dominação de modo capitalista de produção, que implicou também o fim da escravatura e a proclamação da República (p. 223).

A expansão da ocupação ocorreu em momentos sucessivos, como, por exemplo, durante o governo Getulio Vargas, na década de 1930, época em que a região de Santa Cruz passou por profunda transformação, com as obras de saneamento objetivando valorizar aquelas terras. Porém, extensas terras do bairro de Santa Cruz que fizeram parte da Fazenda Nacional de Santa Cruz ainda são de propriedade pública. Desse modo, temos ali algumas instalaçôes estatais, como a Base Aérea de Santa Cruz, o antigo aeroporto Bartolomeu Gusmão, construído em 1934 para operar uma linha aérea entre Brasil e Europa, pela Luftschiffbau Zeppelin. Ainda hoje, é possível ver o marco histórico desse aeroporto, com o Hangar do Zeppelin, localizado nas dependências da base. Essa edificação foi tombada 
pelo Instituto do Patrimônio Histórico e Artístico Nacional (Iphan) em 14/03/1998 (Processo no 994-T-8). Em 1941, o aeroporto foi transformado em base aérea, que ainda está ativa nos dias atuais, abrigando as unidades do $1^{\circ}$ Grupo de Aviação de Caça (1 $\left.{ }^{\circ} \mathrm{GAvCa}\right)$ e do $1^{\circ}$ Esquadrão do $16^{\circ}$ Grupo de Aviação (1\%/16 GAv), ambos da Força Aérea Brasileira (FAB).

Com as obras de saneamento e a promoção de salubridade, foram criadas colônias agrícolas, as quais proporcionaram dinamismo econômico para os produtores. Em 1938, chegaram as primeiras famílias japonesas de Moji das Cruzes (SP) para ocupar o recém-criado Núcleo Colonial e colocar em prática novas experiências na agricultura local. Essa colônia fica entre as estradas Reta do Rio Grande e Reta de São Fernando, as quais compõem a atual zona agrícola. A produção era tão grande que abastecia toda a cidade do Rio de Janeiro, conferindo a Santa Cruz o título de celeiro do então Distrito Federal (Fridman, 1999, p. 225).

Nessa primeira metade do século XX, havia ainda produção citricultora em sítios e chácaras, ou seja, houve um fracionamento das fazendas existentes, promovendo, assim, a intensificação do uso do solo na década de 1940. Após, com a crise da citricultura, promoveu-se mudança no uso do solo, de rural para urbano, havendo um surto de urbanização. Essa crise, segundo Soares (1952), estava associada à queda da exportação de laranja para a Europa, principal comprador do produto, com a eclosão da Segunda Guerra Mundial. Além disso, não havia uma infraestrutura frigorífera no porto para conservar os produtos até o momento da exportação, o que gerava perdas e levava ao encarecimento da produção local em comparação aos outros países. Passada essa fase, nas décadas de 1950 e 1960, observa-se o parcelamento das chácaras citricultoras em lotes sem benfeitorias e, portanto, acessíveis a uma camada da população com condições de arcar com os custos de uma compra parcelada de terrenos no mercado informal de terras, pois eram vendidos, pelos pequenos proprietários, sem infraestrutura, registro geral de imóveis etc.

No contexto urbano, cabem algumas considerações sobre as atividades agrícolas implementadas em nossa área de estudo. Sobre a agricultura que persiste no ambiente urbano, dentro do limite da cidade, e "resiste ao avanço da cidade", Bicalho (1992) afirma que tal fenômeno está integrado a um processo maior, o do próprio crescimento urbano. A autora ainda observa que isso deve ser entendido de forma mais abrangente, em relação à capitalização da agricultura em geral. Portanto, o comportamento do que denominou agricultura metropolitana é resulta da influência da cidade, que tanto pode ser positiva como negativa, e ainda das condiçóes da própria agricultura. Embora a autora veja no produtor rural a atuação dessas forças, através de sua tomada de decisão, devemos observar que esse não é o único determinante, nem está deslocado do contexto. Na realidade, segundo a concepção do espaço político (Léfebre, 2008), são vários os agentes que, por meio de suas decisões e interesses, determinam o espaço social e sua materialização.

$\mathrm{Na}$ cidade do Rio de Janeiro, temos visto a força do capital imobiliário e do Estado, ao promover a reestruturação da cidade, bem como da RMRJ, como salientado por Abreu (2006). Deve-se acrescentar o fato de eles também serem agentes portadores de interesses diversos, ora atuando como produtores, ora como especuladores imobiliários. Deve-se levar em conta o fato de que, antes de tudo, são proprietários de terras cujos lucros são exponenciados na conversão do solo para uso urbano. Isso é corroborado pela existência de muitas propriedades precárias com produtores absenteístas, a indicar uma espera pela especulação imobiliária, com a mudança de uso do solo, de rural para urbano. 


\section{0 bairro de Santa Cruz, RJ}

Tanto no espaço urbano como no entorno, as atividades agrícolas frequentemente simbolizam o interesse em manter a propriedade da terra, à espera de uma eventual valorização, a fim de auferir lucros elevados, com a transformação do solo, de rural para urbano. $\mathrm{Na}$ área oeste da cidade do Rio de Janeiro, incluindo o bairro de Santa Cruz, no período de 1930 a 1960, observaram-se políticas de assentamento agrícola de pequenos produtores rurais e políticas de intervenção associadas à instalação das colônias agrícolas. A partir de então, Santa Cruz e adjacências vêm passando por várias fases de urbanização.

$\mathrm{Na}$ década de 1930, com o aumento das moradias para pessoas de baixa renda, associado à eletrificação da linha férrea, a urbanização já estava em curso, pois esses fatores possibilitavam aos trabalhadores morarem em áreas mais distantes do Centro do Rio de Janeiro. Além disso, é importante lembrar que tudo isso estava associado aos problemas com a citricultura. Já na década de 1960, o processo pode ser associado à remoção de favelas das áreas nobres da cidade, o que acabou por confirmar esse processo de transformação. Na década de 1970, com as obras de extensão da av. Brasil até a Zona Oeste, no empreendimento de formação da BR-101, foi possível incrementar o parcelamento do solo, promovendo, mais uma vez, uma fase de urbanização. Para a década de 1970, Carvalho (1999, p. 36) descreve a Zona Oeste da seguinte maneira:

A Zona Oeste permanece como espaço de transição, onde convivem processos modernos e arcaicos de ocupação [...] e onde a produção imobiliária se caracteriza pela convivência de diferentes formas de produção, tais como: autoconstrução, conjuntos habitacionais e comerciais, loteamentos com casas [...].

Os conjuntos habitacionais, assim como a construção do distrito industrial, correspondem à política estatal das décadas de 1960 e 1970 no contexto de industrialização do país. Entre esses conjuntos, citamos três: o de Antares, que apresenta uma grande favelização à sua volta; o conjunto residencial Doutor Otacílio de Carvalho Camará, mais conhecido como "Cesarão", em virtude de sua localização, ao longo da av. Cesário de Melo; e o conjunto habitacional João XXIII. Temos, então, como resultado dos processos históricos de ocupação, uma área com diversas formas de produção imobiliária justapostas, ladeadas por propriedades de cultivo e pecuária na zona agrícola, e o distrito industrial pouco ocupado. Ao todo, são 62 loteamentos irregulares e 17 favelas; dessas favelas, quatro formam complexos de favelas (Sabren - Armazém de Dados da prefeitura do Rio de Janeiro, 2000).

Com isso, podemos considerar as intervençōes do Estado no que diz respeito ao ordenamento territorial para uso do solo. Segundo o Decreto Municipal no 322, de 3 de março de 1976, o bairro de Santa Cruz possui uma extensa zona industrial, conhecida como Distrito Industrial de Santa Cruz. Em seu território, também está estabelecido o Distrito Industrial de Palmares, que se estende até o bairro de Paciência. Além disso, o bairro apresenta uma Zona Especial de administração e governo (ZE 7), parte de uma Zona Especial de reserva florestal (ZE 1), que corresponde uma pequena parte da serra do Cantagalo, na divisa do bairro com Guaratiba. Possui ainda uma extensa Zona Residencial (ZR 2, ZR 4 e ZR 6).

$\mathrm{Na}$ área central do bairro, encontramos exemplo de uma das situações que interferem na possibilidade de reprodução do espaço de acordo com os interesses capitalistas: a formação de uma circunscrição denominada Apac (Área de Proteção do Ambiente Cultural), de acordo com o Decreto Municipal no 12.524 , de 9 de dezembro de 1993. Isso porque a área contém valiosos exemplares arquitetônicos como testemunho das várias fases de sua ocupação, desde a época da Fazenda Santa 
Cruz, no século XVI, passando pela instalação do centro urbano no século XIX, até a década de 1960. Assim, em virtude desse histórico, os elementos arquitetônicos não podem ser demolidos, o que gera competição acirrada com novos usos. É um bom exemplo o antigo solar da família Araújo, hoje incorporado ao shopping Santa Cruz (Foto 1). Esse quadro nos permite perceber os conflitos no espaço para a produção e a reprodução de acordo com os interesses de cada agente social.

Entre os fixos que compõem a referida Apac, destaca-se a ponte dos Jesuítas, que data de 1752 (Foto 2) e foi construída com a finalidade de regular o volume de água das enchentes, portanto, é uma ponte-represa. Com quatro arcos que serviam de comportas para o controle do regime de águas do Rio Guandu, a ponte está ornamentada com colunas de granito e capitéis em forma de pinhas portuguesas, possui na parte central belas esculturas barrocas com um brasão que exibe o símbolo da Companhia de Jesus (IHS). Outro destaque é o Palacete Princesa Isabel, construído para ser sede da Fazenda Imperial de Santa Cruz em 1881. Esses abrigou a Escola Santa Isabel e hoje funciona como Centro Cultural Municipal de Santa Cruz no qual se localiza o NOPH (Núcleo de Orientação e Pesquisa Histórica) com a finalidade de manter a riqueza histórica e arquitetônica de Santa Cruz. Por fim, o Matadouro de Santa Cruz que jaz em ruínas, sendo uma parte de sua área aproveitada para abrigar as diversas instituições públicas de ensino mencionadas na página anterior.

Foto 1. Shopping Santa Cruz, solar dos Araújos

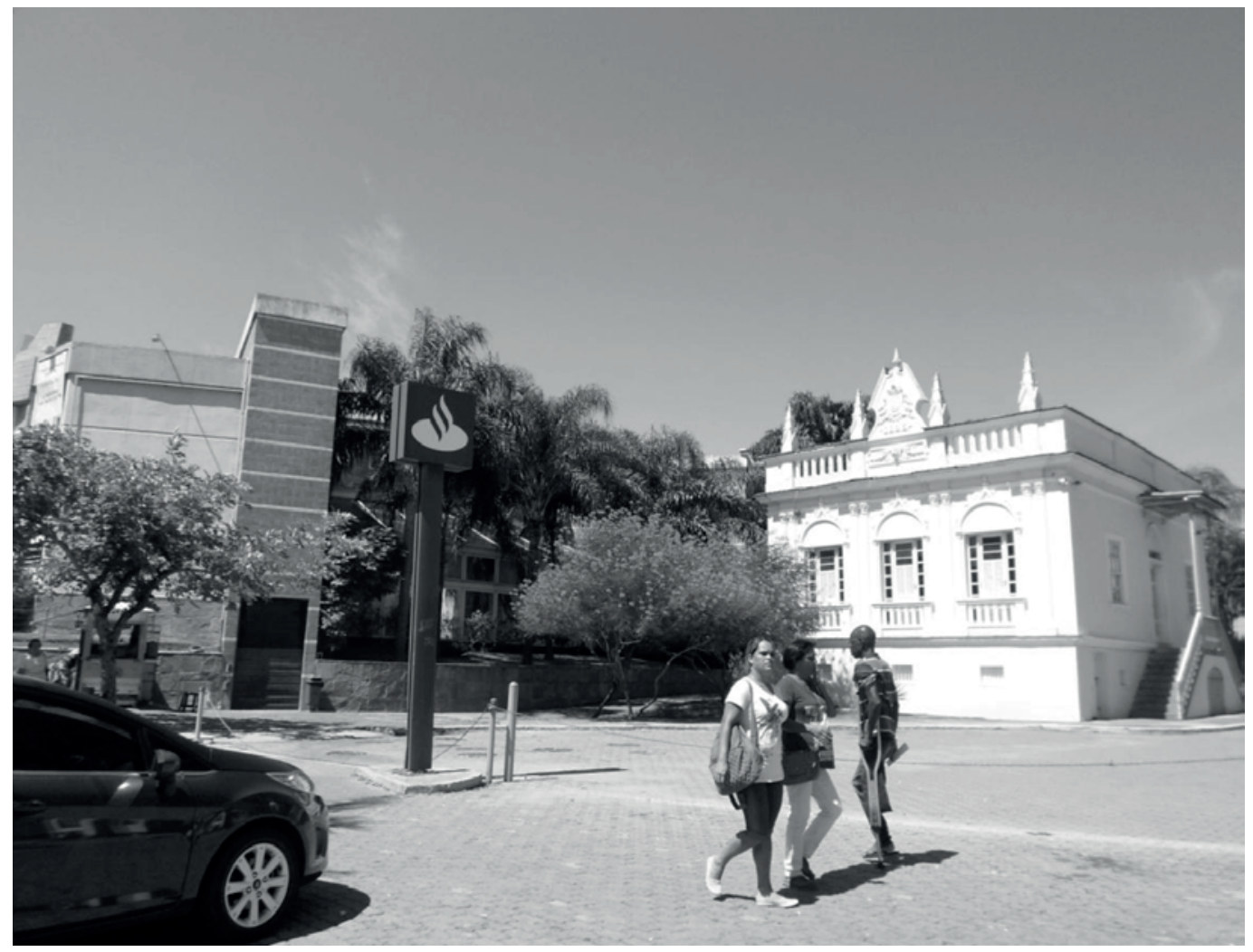

Fonte: Silva, 2016. 


\section{0 bairro de Santa Cruz, RJ}

Foto 2. Ponte dos Jesuítas, Santa Cruz (RJ)

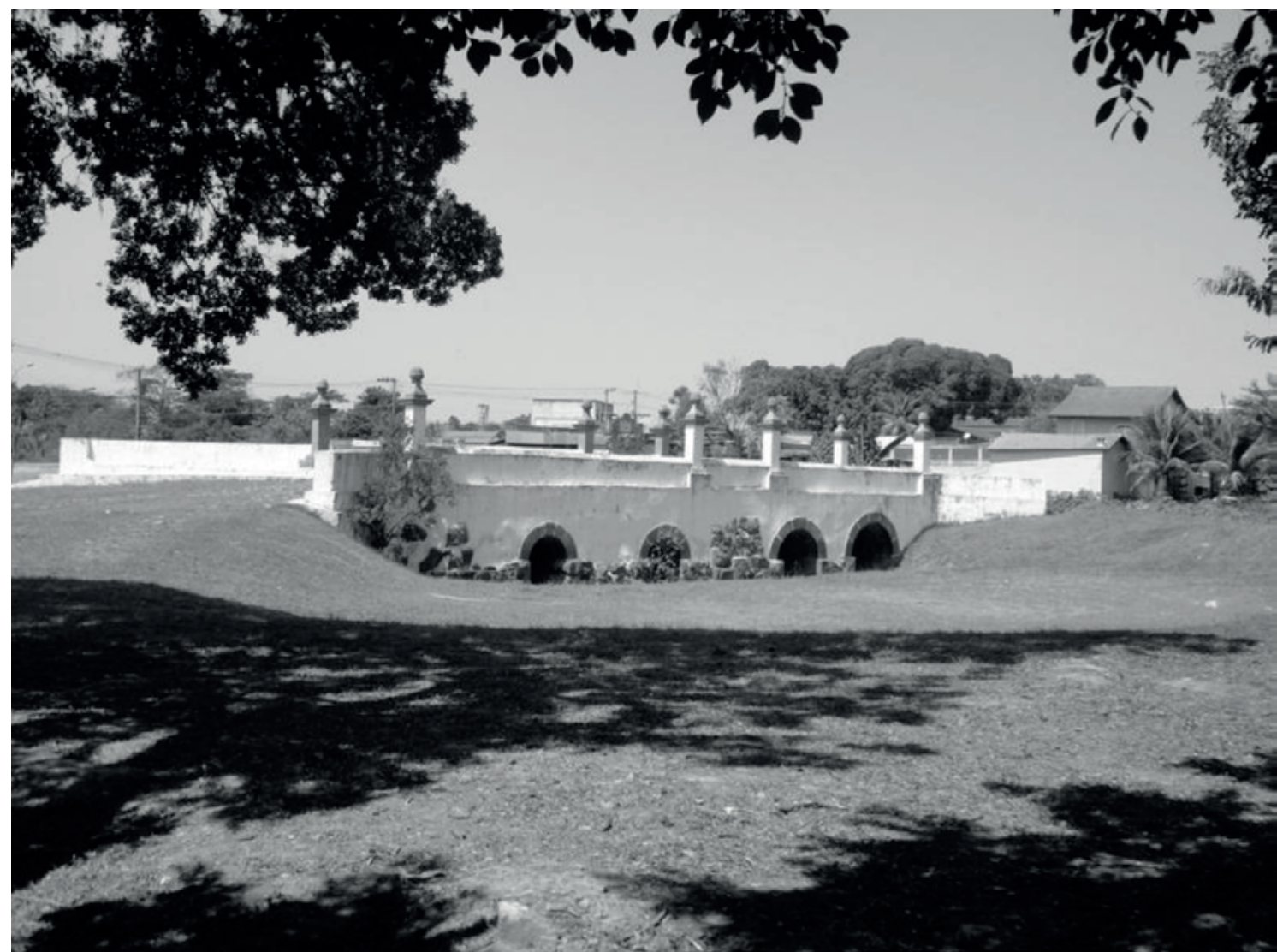

Autor: Ivo Korytowski, jun. 2006.

Essas considerações quanto ao controle de uso do solo são importantes porque configuram ações do Estado que impõem circunstâncias muitas vezes questionadas por outros agentes sociais do espaço. Por exemplo, em entrevista com o gerente Alexandre Vilela, da $8^{\text {a }}$ Gerência de Licenciamento e Fiscalização (GLF), situada na rua Álvaro Alberto Luiz, 665, Santa Cruz, fomos informados de que, diferente do bairro de Campo Grande, que tem apresentado elevados índices de construção imobiliária, o bairro de Santa Cruz apresenta alguns fatores impeditivos para empreendimentos imobiliários destinados às classes sociais média e média alta. $\mathrm{O}$ primeiro deles diz respeito à zona agrícola, que, embora possua, em sua maior parte, titulação de propriedade, não autoriza uso diverso, exceto, por concessão, como empreendimentos do Programa Minha Casa Minha Vida (PMCMV) ou a construção de galpões para armazenamento.

Por uma brecha na legislação vigente, ou seja, por não haver especificação do tipo de galpão que pode ser construído, têm-se edificado galpões para a logística de grandes lojas, que conseguem terrenos amplos a baixo custo e se comprometem a instalar infraestrutura na localidade, como, por exemplo, abertura, drenagem e pavimentação de estradas. Quanto ao problema de titulação das pro- 
priedades, observa-se que remonta às primeiras ocupações da área, que, por ter sido, após a proclamação da República, Fazenda Nacional, ${ }^{4}$ de propriedade do governo federal, era administrada pelo Incra (Instituto Nacional de Colonização e Reforma Agrária).

Um edital publicado em 18/11/2013, envolvendo a Superintendência Regional do Incra no Rio de Janeiro, lançou uma chamada pública para a restauração do acervo fundiário FNSC, situado na Zona Oeste do município do Rio de Janeiro. Conforme relatos, há mais de três mil processos de regularização da Fazenda, além de livros fundiários, livros com os nomes dos foreiros, mapas e documentos que remontam ao período imperial. Além disso, a dificuldade para a regularização decorre das diversas situações jurídicas no local. Desse modo, as áreas destinadas à atividade agrícola, como já mencionado, encontram-se, em sua maior parte, regularizadas. As áreas destinadas a uso residencial, que, por sinal, ultrapassam $50 \%$ de todo o bairro, em sua maioria não possuem títulos de propriedade. Dessa forma, tanto a falta de titulação como o zoneamento formam um elemento socioespacial que condiciona a reprodução do espaço, no que diz respeito ao setor imobiliário, nos moldes capitalistas atuais. Além disso, observa-se a prática de loteamentos irregulares e ilegais, principalmente ao longo das principais vias.

Com as recentes obras de infraestrutura, há um prognóstico de transformação local no que diz respeito à construção de novas moradias e a instalação de novos equipamentos de comércio e serviços que precisam ser analisados.

Após observarmos os aspectos da ocupação histórica do bairro de Santa Cruz, que se transfiguram em condicionantes espaciais para as dinâmicas que se vislumbram diante dos mencionados empreendimentos de infraestrutura, destacamos os dados socioeconômicos que servirão de base à análise do bairro em questão e da área na qual se encontra inserido, em um processo atual de urbanização.

\section{A caracterização socioeconômica de Santa Cruz: população, renda e educação}

Neste tópico, trazemos alguns dados referentes ao bairro de Santa Cruz em comparação com outros da cidade do Rio de Janeiro. Por acreditarmos que as condições socioespaciais construídas em tempos pretéritos permanecem e interferem na reprodução social da atualidade, percebemos dois períodos significativos: um, entre 1970 e 1980, devido aos projetos estatais que promoveram a formação da BR-101, de acordo com o quadro político-econômico desenvolvimentista do Brasil, que impactou o processo urbano na cidade do Rio de Janeiro. O outro período, entre 1990 e 2000, que Lago (2000) e Davidovich (2010) consideram como de mudanças sociais no Brasil, com implicações espaciais.

Entre as alterações no processo político e econômico, citamos a crise fiscal e financeira do Estado Nacional; o processo de privatização, que afetou diversas empresas estatais e privadas do

\footnotetext{
${ }^{4}$ A Fazenda Nacional de Santa Cruz ocupa uma área com mais de oitenta mil hectares, em nove municípios fluminenses (Rio de Janeiro, Itaguaí, Seropédica, Paracambi, Japeri, Engenheiro Paulo de Frontim, Mendes, Piraí e Rio Claro). Aproximadamente oitocentas mil pessoas vivem nessa região.
} 


\section{0 bairro de Santa Cruz, RJ}

território fluminense; a precarização do trabalho e o crescimento da vulnerabilidade do trabalhador; o aumento da desigualdade de renda; a crise habitacional, que promoveu o aumento do número e do tamanho das favelas no Rio de Janeiro. Todavia, não foi possível reunir os dados desmembrados relativos a 1970 e 1980 quanto a renda e escolaridade por bairro no município carioca. Então, embora concordemos com Lago (2000) e Davidovich (2010), no sentido das mudanças socioespaciais ocorridas após a década de 1980, consideramos que os dados referentes a 1991 e 2000 ainda exemplificam a estrutura construída nos períodos anteriores.

Nesse contexto, ao comparar nosso recorte de estudo com os bairros representativos na cidade do Rio de Janeiro, iniciamos com os dados referentes à renda. O Quadro 1 se refere aos censos demográficos de 2000 e de 2010. Assim como destacado pelos estudos de Santos e Bronstein (1978) e de Abreu (2006), observamos uma estratificação social do espaço carioca. Assim, as áreas que concentram os maiores rendimentos estão na Zona Sul e na Barra da Tijuca.

Quadro 1. Rendimento nominal familiar per capita segundo bairros (2000)

\begin{tabular}{|l|c|c|c|}
\hline Bairros & $\mathbf{2 0 0 0}$ & $\mathbf{2 0 1 0}$ & Variação em \% \\
\hline Bangu & 305,57 & 653,26 & 53,2 \\
\hline Campo Grande & 392,49 & 878,61 & 55,3 \\
\hline Centro & 737,22 & $1.533,38$ & 51,9 \\
\hline Copacabana & $1.887,34$ & $3.768,69$ & 49,9 \\
\hline Jacarepaguá & 369,77 & $1.049,42$ & 64,8 \\
\hline Madureira & 468,53 & 980,13 & 52,2 \\
\hline Méier & $1.091,88$ & $2.236,11$ & 51,2 \\
\hline Santa Cruz & 234,36 & 509,71 & 54,0 \\
\hline Guaratiba & 260,43 & 556,62 & 53,2 \\
\hline Tijuca & $1.438,51$ & $3.023,42$ & 52,4 \\
\hline Botafogo & $1.556,12$ & $3.759,53$ & 58,6 \\
\hline Barra da Tijuca & $2.722,13$ & $5.940,31$ & 54,2 \\
\hline
\end{tabular}

Fonte: IBGE, via BME (2000). Dados da Amostra do Censo 2000. Armazém de dados do Rio de Janeiro (prefeitura do Rio de Janeiro). Em 2000, o salário mínimo era de R\$ 151,00; em 2010, passou para R\$ 510,00.

No Quadro 2, observamos que a Barra da Tijuca apresenta concentração na faixa salarial entre cinco e vinte salários mínimos. Botafogo, Copacabana, Tijuca e Méier, por sua vez, apresentam certo equilíbrio, situando-se na faixa de um a cinco salários mínimos e de cinco a vinte salários mínimos. Jacarepaguá, Madureira, Bangu e Campo Grande apresentam o maior quantitativo na faixa de um a cinco salários mínimos. Santa Cruz e Guaratiba demonstram certa equivalência entre as faixas de menor renda de até um salário mínimo e de um a cinco salários mínimos. Essa análise é corroborada pelos dados apresentados no Quadro 3, no que diz respeito à média de anos de estudo por bairro, segundo o Censo de 2000. Mais uma vez, observa-se a espacialização de forma estratificada, o que aponta para certa recorrência entre renda e escolaridade, dotando o espaço de uma estrutura que se apresenta e tende a se manter e ser reproduzida. 
Quadro 2. Classes de rendimento nominal mensal segundo bairros. Município do Rio de Janeiro (2010)

\begin{tabular}{|l|c|c|c|c|c|}
\hline Bairros & Total & até $\mathbf{1}$ & $\mathbf{+ 1} \mathbf{a} \mathbf{5}$ & $\mathbf{+} \mathbf{5}$ a 20 & $\mathbf{2 0}$ \\
\hline Centro & 38.448 & 5.403 & 19.713 & 5.336 & 236 \\
\hline Botafogo & 76.628 & 4.754 & 23.611 & 25.658 & 4.486 \\
\hline Copacabana & 137.710 & 7.822 & 45.728 & 44.846 & 7.975 \\
\hline Tijuca & 150.744 & 13.374 & 51.335 & 42.738 & 4.569 \\
\hline Méier & 46.410 & 3.689 & 18.043 & 11.217 & 664 \\
\hline Madureira & 44.534 & 7.418 & 18.677 & 3.270 & 66 \\
\hline Jacarepaguá & 133.315 & 25.640 & 54.818 & 8.196 & 731 \\
\hline Barra da Tijuca & 122.947 & 3.520 & 24.293 & 43.874 & 14.892 \\
\hline Bangu & 211.068 & 44.086 & 77.412 & 8.391 & 162 \\
\hline Campo Grande & 286.527 & 51.573 & 105.927 & 19.963 & 524 \\
\hline Santa Cruz & 182.722 & 41.760 & 57.467 & 4.171 & 122 \\
\hline Guaratiba & 92.428 & 20.497 & 30.401 & 2.024 & 58 \\
\hline Total & 5.560 .655 & 943.026 & 2.019 .784 & 611.350 & 77.929 \\
\hline
\end{tabular}

Fonte: IBGE. Censo demográfico (2010). Armazém de dados do Rio de Janeiro. Prefeitura do Rio de Janeiro.

Quadro 3. Média de anos de estudo das pessoas responsáveis pelos domicílios particulares permanentes

\begin{tabular}{|l|c|}
\hline Bairros & $\begin{array}{c}\text { Média de anos de } \\
\text { estudo }\end{array}$ \\
\hline Centro & 8,96 \\
\hline Botafogo & 11,77 \\
\hline Copacabana & 11,76 \\
\hline Tijuca & 11,28 \\
\hline Méier & 11,07 \\
\hline Madureira & 7,92 \\
\hline Jacarepaguá & 6,08 \\
\hline Barra da Tijuca & 13,25 \\
\hline Bangu & 6,95 \\
\hline Campo Grande & 7,63 \\
\hline Guaratiba & 5,63 \\
\hline Santa Cruz & 6,15 \\
\hline Total & 8,29 \\
\hline
\end{tabular}

Fonte: Instituto Brasileiro de Geografia e Estatística (IBGE),

Censo 2000. Armazém de dados do Rio de Janeiro (prefeitura do Rio de Janeiro). 
O Quadro 4 aborda o Índice de Desenvolvimento Humano, que é obtido pela média aritmética simples de três índices referentes às dimensões longevidade (IDHM-longevidade), educação (IDHM-educação) e renda (IDHM-renda). Observamos que, entre os bairros com o IDH mais elevado (acima de 0,9), encontram-se Barra da Tijuca, Copacabana, Botafogo, Méier e Tijuca. Em uma condição elevada (de 0,8 a 0,89), temos os bairros do Centro, Madureira e Campo Grande. Por fim, em uma classificação média, encontram-se os bairros de Jacarepaguá, Guaratiba e Santa Cruz. Através dos dados apresentados, concluímos que o padrão socioeconômico do bairro de Santa Cruz, assim como dos demais bairros dessa parte da Zona Oeste carioca, em relação ao núcleo central da cidade e à metrópole do Rio de Janeiro, constituído no contexto desenvolvimentista, passou por algumas mudanças pontuais até a década de 2010, como é o caso de Campo Grande no que diz respeito ao aumento do número de estudantes com ensino superior e ao seu IDH, em uma classificação elevada, superando até mesmo o bairro de Jacarepaguá.

Quadro 4. Índice de Desenvolvimento Humano (IDH) por bairros

\begin{tabular}{|c|c|c|c|c|c|c|c|c|c|}
\hline 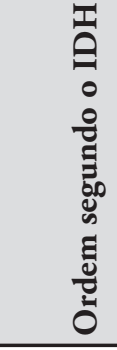 & 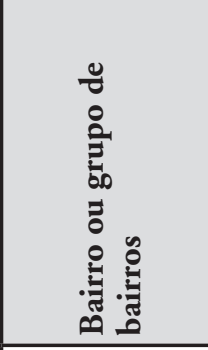 & 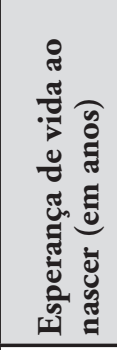 & 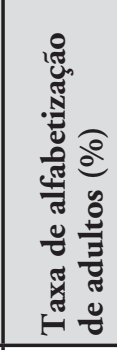 & 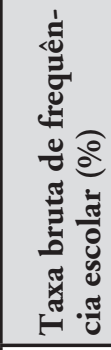 & 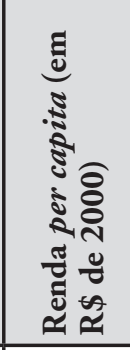 & 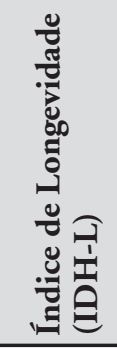 & 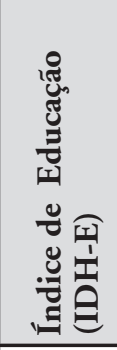 & 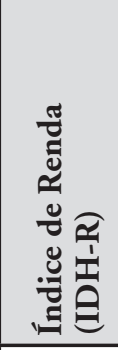 & 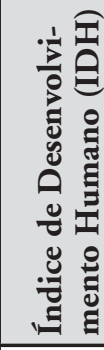 \\
\hline 8 & Barra da Tijuca & 77,84 & 99,38 & 110,09 & $2.488,47$ & 0,881 & 0,996 & 1,000 & 0,959 \\
\hline 11 & Copacabana & 77,78 & 98,48 & 107,54 & $1.623,42$ & 0,880 & 0,990 & 1,000 & 0,956 \\
\hline 13 & Botafogo & 78,25 & 98,46 & 113,01 & $1.376,47$ & 0,888 & 0,990 & 0,979 & 0,952 \\
\hline 17 & Méier & 77,37 & 99,01 & 108,63 & $1.000,16$ & 0,873 & 0,993 & 0,926 & 0,931 \\
\hline 18 & Tijuca & 75,04 & 98,02 & 107,38 & $1.204,61$ & 0,834 & 0,987 & 0,957 & 0,926 \\
\hline 32 & Centro & 76,12 & 97,58 & 99,24 & 633,36 & 0,852 & 0,981 & 0,850 & 0,894 \\
\hline 67 & Madureira & 70,97 & 96,81 & 90,42 & 419,81 & 0,766 & 0,947 & 0,781 & 0,831 \\
\hline 82 & Campo Grande & 69,80 & 95,98 & 87,42 & 351,11 & 0,747 & 0,931 & 0,751 & 0,810 \\
\hline 96 & Bangu & 69,78 & 95,45 & 82,95 & 296,55 & 0,746 & 0,913 & 0,723 & 0,794 \\
\hline 104 & Jacarepaguá & 67,51 & 90,18 & 77,14 & 331,44 & 0,709 & 0,858 & 0,742 & 0,769 \\
\hline 118 & Guaratiba & 66,66 & 90,74 & 74,37 & 234,37 & 0,694 & 0,853 & 0,684 & 0,744 \\
\hline 119 & Santa Cruz & 65,52 & 93,19 & 79,82 & 206,23 & 0,675 & 0,887 & 0,662 & 0,742 \\
\hline
\end{tabular}

Fonte: Dados básicos: IBGE, microdados dos Censos Demográficos 1991 e 2000.

Cálculos: Convênio IPP/IUPERJ/IPEA e FJP-MG.

Armazém de dados do Rio de Janeiro (prefeitura do Rio de Janeiro). 

de estudo.

Observamos alguns contextos históricos político-econômicos que exercem influência na área

Até a década de 1960, verificamos que nosso objeto de estudo sempre esteve funcionalmente integrado como produtor de alimentos na cidade do Rio de Janeiro.

No período de 1970-1980, constatamos o final do modelo econômico nacional, caracterizado pela atuação e o financiamento estatal do desenvolvimento econômico, pautado na industrialização tanto de base como de bens de consumo. Para tanto, verificamos que houve investimento na construção e ampliação de importantes rodovias, como, por exemplo, a BR-101. Esse contexto influenciou a formação de um espaço metropolitano de modelo dual: o núcleo e suas sucessivas periferias, ou centro-periferia. Temos, então, o bairro de Santa Cruz com uma composição populacional de baixa renda e um grau de instrução que reafirma a descrição de Santos e Bronstein (1978) e de Abreu (2006).

O período que vai de 1990 a 2000, segundo Lago (2000), resulta: da reestruturação social e econômica vivenciada no Brasil a partir da década de 1980, percebida como uma crise fiscal e financeira; da privatização das empresas estatais; da precarização do trabalho; do empobrecimento da população e do aumento da desigualdade de renda, entre outros fatores, com as implicações espaciais na estrutura metropolitana anterior. Além disso, o momento atual é identificado por Davidovich (2010) como aquele em que os investimentos em infraestrutura de rodovias e portos alçam o Rio de Janeiro à condição de local estratégico para a economia globalizada.

Assim, podemos afirmar, de acordo com nossas observações, que a cidade do Rio de Janeiro apresenta um quadro de desigualdade espacial em diferentes escalas no tocante aos bairros e às regiōes administrativas, com diferentes variáveis apontando para um modelo extremamente centralizador. No contexto socioeconômico e em relação ao centro, a área em que se insere o bairro de Santa Cruz é classificada como periferia, apresentando grande discrepância em relação às áreas centrais no que diz respeito a renda e educação.

O investimento em infraestrutura de transporte aponta para uma transformação no bairro que se denomina expansão urbana. Podemos traçar um paralelo entre essa discussão e o que Silva (1996) afirma quando da análise da expansão urbana na cidade do Rio de Janeiro entre as décadas de 1970 e 1980. Silva assinala que a ação do capital imobiliário redistribuiu as camadas da população de acordo com determinadas estratégias, com vistas à incorporação de novas áreas. Desse modo, observou o deslocamento da atuação do capital incorporador da Zona Sul para a Zona Norte carioca em dois setores: região da Tijuca e subúrbios da Central; e para a parte sul da Zona Oeste carioca, compreendida por Barra da Tijuca, Jacarepaguá e Recreio.

Tal movimento consistiu na redução de investimentos nas áreas mais tradicionais, com vistas à intensificação nos bairros considerados indesejáveis, distantes do Centro ou de difícil acesso. Nesse sentido, houve uma ação do Estado, no sentido de promover a construção e a reforma de algumas vias, como, por exemplo, a estrada Lagoa-Barra na década de 1960; a duplicação da estrada Grajaú-Jacarepaguá; a pavimentação da av. Alvorada; melhorias na estrada da Grota Funda, ligando essa área a Guaratiba, Campo Grande e Santa Cruz, propiciando, assim, a valorização de terras anteriormente apropriadas por empresas privadas. Quando falamos da Grota Funda, imaginamos que essa é uma antevisão do que ocorre na atualidade. As novas bases materiais de infraestrutura relacionadas ao túnel da Grota Funda e à TransCarioca abre áreas ao norte do maciço da Pedra Branca para 


\section{0 bairro de Santa Cruz, RJ}

o mercado imobiliário, o que demanda pesquisas que investiguem as especificidades de cada recorte constituinte.

Assim, percebemos que existem novos conteúdos a indicar que o processo envolve mais do que expansão urbana. Considerando que existem outros processos que extravasam a cidade e a Região Metropolitana, Pereira (2015) registra que os novos artefatos nos apontam a emergência do metropolitano como condição para a reprodução do capital. Exemplifica com os grandes empreendimentos imobiliários, como centros empresariais, escritórios, flats, shopping centers, hotéis etc. Em conformidade com essa teoria, em Santa Cruz temos a proposta de construção de um complexo com usos múltiplos na av. Brasil, o que sugere o potencial dessa localidade, em virtude do acesso direto à rodovia e ao ARMRJ, além de sua proximidade com a Barra da Tijuca, viabilizada pelo túnel da Grota Funda. O projeto do Complexo Nova Santa Cruz, executado pelo Grupo Creative (empresa brasileira do segmento imobiliário e da construção civil com sede em São Paulo e atuação nacional), faz referência à ação estatal para dotar a área da infraestrutura necessária de conexão, criando um novo eixo de desenvolvimento, já integrado também aos municípios vizinhos e ao novo porto de Itaguaí - leia-se um novo eixo de expansão para especulação imobiliária.

Destaca-se, ainda, que está prevista a instalação de uma universidade, visto que uma das características atuais da metropolização e do reforço da metrópole é a dotação de equipamentos para a produção de conhecimento. Nessa mesma direção, a Bio-Manguinhos está se expandindo e vai operar uma nova planta no Distrito Industrial de Santa Cruz - o Complexo Industrial de Biotecnologia em Saúde (CIBS) -, com o objetivo de ampliar a oferta de vacinas e biofármacos para os programas públicos de saúde. $\mathrm{O}$ novo campus abrigará um centro de processamento final e áreas dedicadas a garantia e controle de qualidade, visando aumentar a possibilidade de parcerias voltadas ao desenvolvimento tecnológico e à transferência de tecnologia, aumentando, assim, a competitividade do Brasil no setor de Biotecnologia.

Ademais, nos anúncios do Codin, percebemos acentuado interesse em Santa Cruz para instalar diversas indústrias, como Rolls-Royce, Champion Technologies, Jeumont, Oil States, o Grupo Lafarge e a Gypsum Drywall, pertencente ao grupo Etex. Ou seja, a partir de um espaço historicamente construído, Santa Cruz se apresenta como uma área que apresenta um contexto específico, que, em face de sua localização, torna-se atraente para investimentos com características de metropolização. Sua diferenciação em relação às demais áreas é a localização, nas proximidades do porto de Itaguaí e de importantes rodovias. Além disso, possui extensas áreas que estão se voltando aos mais diversos usos, de modo que observamos certa concentração dos investimentos relacionados a equipamentos industriais nesse bairro mais do que nas demais áreas da bacia de Sepetiba. Essa dinâmica reforça a concentração no núcleo metropolitano, ainda que seja na periferia interna.

Segundo a SMU do Rio de Janeiro, de 2009 até julho de 2015, tivemos no bairro de Santa Cruz 16.064 novas unidades construídas, sendo que 1.804 são destinadas à faixa de renda entre três e seis salários mínimos; ${ }^{5}$ 1.563, para os que ganham entre seis e dez salários mínimos; e a maioria,

\footnotetext{
5 Tomamos como referência o salário mínimo nacional de 2011 (quando a segunda fase do PMCMV foi implementada), de acordo com a MP no 516/10 e o DOU de 31/12/2010. A partir de 1/1/2011, o valor passou para $\mathrm{R} \$ 540,00$. Após, tivemos mais quatro reajustes do salário mínimo nacional (SM), sendo que o
} 
12.697, voltada à renda entre zero e três salários mínimos. Se compararmos esse quantitativo com o total de empreendimentos MCMV no mesmo período para a cidade do Rio de Janeiro - 35.121 unidades -, concluímos que, em média, 50\% estão em Santa Cruz, com ênfase na produção voltada à faixa de renda mais baixa. Podemos pensar que essa é uma estratégia para levar os mais pobres para bem longe das áreas mais proeminentes da cidade carioca, porém afirmamos que esse é um modo de pensar reducionista, que não leva em conta os diversos elementos aí envolvidos.

Neste ponto, indagamos quanto à sobreposição de espacialidades que demandam investigação e nos suscitam as seguintes questões: em quais aspectos esse momento se diferencia dos anteriores? Quais são seus contextos políticos e econômicos, nacionais e estrangeiros? De acordo com a estrutura espacial de ocupação urbana resultante de momentos pretéritos, quais mudanças observamos atualmente no bairro em estudo ou na periferia intermediária, como na Região Metropolitana do Rio de Janeiro? Essas questões tornam-se a base para pesquisas futuras, com vistas a investigar o bairro de Santa Cruz no contexto dos processos de urbanização/metropolização no Rio de Janeiro.

\section{Considerações finais}

Ao analisarmos o espaço do bairro de Santa Cruz na cidade do Rio de Janeiro, deparamos com alguns elementos que nos instigaram. Entre eles, aqueles que nos remetem a momentos anteriores, como, por exemplo, alguns dos conjuntos habitacionais que datam do período industrial da década de 1970, época em que os investimentos urbanos industriais se caracterizavam por melhoria nos acessos e nas vias, bem como na promoção de habitação formal e informal para a força de trabalho.

Concomitantemente, observou-se a formação de loteamentos irregulares e clandestinos no entorno desses conjuntos habitacionais e em outras extensões do bairro. Com a precarização das condições de trabalho a partir da década de 1980, houve adensamento desses últimos, de modo que, no bairro de Santa Cruz, existem muitas favelas e complexos de favelas que se estendem horizontalmente, acompanhando o relevo da região, com predomínio das planícies flúvio-marinhas e poucas elevações residuais no alinhamento dos maciços costeiros. Essa conformação é permeada por áreas vazias ou com algumas atividades agrícolas, demandando análise tanto da configuração espacial atual como das mudanças em curso. Isso porque também notamos alguns elementos atuais, como, por exemplo, a construção do túnel da Grota Funda, a implantação da linha de BRT TransOeste e a implantação da CSA, ao mesmo tempo que, no município limítrofe de Itaguaí, temos a remodelação do porto de Itaguaí e a construção do Arco Rodoviário Metropolitano, o qual liga o referido bairro e adjacências à refinaria de Duque de Caxias e ao Comperj.

último passou a vigorar em 1/1/2015, no valor de R $\$ 788,00$. No site http://www.brasil.gov.br/economia-e-emprego/2015/07/ há uma divulgação da fase três do programa, na qual haverá reajuste. Porém, a fase dois, que ainda está em vigor, estabelece as faixas de renda tomando por base o salário mínimo de 2011, portanto a faixa 1, de zero a três salários, engloba as famílias que ganham até $\mathrm{R} \$ 1.600,00$; a faixa 2, de três a seis salários mínimos, para os que ganham entre $\mathrm{R} \$ 1.600,00$ e $\mathrm{R} \$ 3.725,00$; e a faixa 3 abrange aqueles que têm renda familiar entre $\mathrm{R} \$ 3.725,00$ e $\mathrm{R} \$ 5.000,00$. 


\section{0 bairro de Santa Cruz, RJ}

Todo esse cenário nos leva a entender Santa Cruz como um espaço híbrido (Santos, 2004), em que se observa uma justaposição de temporalidades. Porém, com a pretensão de entender o processo que promove essa formação, detivemo-nos no exame da metropolização, que ocorre de acordo com várias dinâmicas e escalas, aí incluída a do bairro.

Como especificidades locais, temos o fato de o bairro apresentar extesnsas áreas destinadas a usos específicos, como o Distrito Industrial de Santa Cruz, as zonas agrícolas, que permitem a construção de galpões e de moradias para fins sociais, e ainda as zonas residenciais, que, em grande parte, não tem titularidade, atendendo a empreendimentos imobiliários. Essa última circunstância possibilitou ampla ocupação por loteamentos irregulares e clandestinos, o que complexificou o espaço, apresentando, inclusive, certo grau de dificuldade para se reconhecer a posse legal de seus ocupantes.

Em face de sua localização, no extremo oeste carioca, e das circunstâncias aqui expostas, até 2005 não havia muito interesse no bairro para expansão imobiliária. Na visita que fizemos à 8a GLF, o gerente local, sr. Alexandre Vilela, relatou-nos a dificuldade de licenciamento para esses empreendimentos, em virtude da já citada falta de titularidade de propriedade dos terrenos.

Diante de todo o exposto, no futuro será necessário pesquisar o recorte espacial de Santa Cruz, a fim de fazer um levantamento da situação fundiária dos terrenos, com o objetivo de mapear as áreas residenciais que possuem ou não titularidade. Também será preciso visitar as áreas agrícolas, buscando entender de que modo ocorre a produção agrícola urbana local, bem como os conflitos e interesses entre a manutenção do espaço rural no urbano e o espaço urbano avançando sobre o rural, como vimos em Bicalho (1992).

Analisamos, aqui, o recorte de Santa Cruz no contexto da cidade do Rio de Janeiro, inserido na conjuntura socioeconômica em relação à Área Central. O bairro é considerado periferia e apresenta inúmeras desigualdades no que diz respeito à renda e à educação. Buscando analisar em quais aspectos o atual momento se diferencia dos anteriores nos sentidos político e econômico, de acordo com os dados apurados quanto às licenças concedidas, observamos que o bairro de Santa Cruz se destaca potencialmente para novas construçôes imobiliárias em comparação a outros bairros da cidade do Rio de Janeiro.

Ressaltamos que o bairro de Santa Cruz, mesmo sendo uma área interna do núcleo metropolitano, dispõe de terrenos amplos e acessíveis que, embora apresentem alguns impeditivos, representam uma área propícia para a expansão urbana, despertando interesse para fins de capital imobiliário. Devido à sua localização estratégica em relação aos investimentos de infraestrutura, o bairro constitui área de interesse para a instalação de indústrias, galpões logísticos, equipamentos de comércio e serviços e lazer. Os empreendimentos imobiliários decorrem, inclusive, do número crescente de empresas que estão sendo implantadas na região.

Sua localização no espaço intraurbano do Núcleo Metropolitano lhe confere maior tendência a receber investimentos do que os municípios que, junto com ele, integram a bacia de Sepetiba. Esse quadro promove a ideia de que, ao longo do processo, teremos outras mudanças que irão demandar acompanhamento e verificação quanto a mobilidade, densidade, crescimento demográfico e composição socioeconômica. 
Diante do exposto, pensamos em uma agenda de futuras pesquisas, como, por exemplo, como já dito, examinar e mapear os aspectos relacionados aos problemas fundiários no bairro, contrapondo a legislação de uso do solo vigente com a titularidade de propriedade ou sua ausência nos terrenos destinados a uso residencial. Temos em mente ainda analisar as áreas de uso agrícola, a fim de entender eventuais mudanças no futuro, diante da produção imobiliária local. A esse respeito, também pretendemos mapear os conjuntos habitacionais, as zonas residenciais com e sem titularidade, as zonas agrícolas, as industriais e as zonas destinadas a fins especiais. Outra ação visada como continuidade das pesquisas em Santa Cruz consiste em levantar dados e mapear o quantitativo e os tipos de empresas que já estão instaladas, bem como aquelas que vêm consultando Codin e $8^{\circ}$ GLF para futuras instalações de seus equipamentos de produção.

Ao realizarmos pesquisas no bairro de Campo Grande e de Santa Cruz, ${ }^{6}$ reafirma-se nosso interesse pela AP5, pois reconhecemos as diferenças entre os bairros que a compõem. A AP5 é subdividida pela administração municipal da seguinte forma: na AP5.3, temos os bairros de Santa Cruz, Sepetiba, Paciência, Guaratiba, Barra de Guaratiba e Pedra de Guaratiba; na AP 5.2, Cosmos, Inhoaíba, Campo Grande, Senador Vasconcelos e Santíssimo; na AP 5.1, Bangu, Senador Camará, Padre Miguel, Realengo, Magalhães Bastos, Vila Militar, Deodoro, Campo dos Afonsos, Gericinó e Jardim Sulacap. Buscamos identificar o que diferencia os bairros da AP 5.3 daqueles que integram a AP 5.2 em relação ao setor imobiliário. Essa indagação decorre da intensa expansão imobiliária em Campo Grande para habitantes de classe média, fato destacado por Macedo (2002), Lago e Mammarella (2009), Miranda e Miller (2010), Cardoso e Lago (2015) e Ribeiro e Ribeiro (2015). Tomando-se a ideia de que a construção do túnel da Grota Funda e do BRT TransOeste abriu uma fronteira para a expansão imobiliária, como entender a produção ainda tímida nos bairros de Guaratiba, Pedra de Guaratiba, Barra de Guaratiba e Sepetiba?

\footnotetext{
${ }^{6}$ A autora vem desenvolvendo pesquisas na Zona Oeste carioca que integra a AP5. No curso de pós-graduação lato sensu em Políticas Territoriais no Estado do Rio de Janeiro, oferecido pelo Instituo de Geografia da Universidade do Estado do Rio de Janeiro, foi examinado o transporte público na urbe carioca, especificamente no bairro de Campo Grande, relacionando-o com o processo de segregação socioespacial. Em 2009, novamente a respeito do bairro de Campo Grande, no curso de Pós-Graduação stricto sensu em Geografia na Pontifícia Universidade Católica do Rio de Janeiro, foi feita uma pesquisa relacionando os processos de segregação e de centralização, com a finalidade de perceber a produção do espaço urbano carioca de acordo com o desenvolvimento geográfico desigual, ressaltando a forma paradoxal em que o recorte analisado se constitui.
} 


\section{Referências}

ABREU, Maurício de Almeida. A evolução urbana do Rio de Janeiro. Rio de Janeiro: IPP, 2006. $156 \mathrm{p}$.

BICALHO, Ana Maria de Souza Mello. "Agricultura e ambiente no município do Rio de Janeiro". In ABREU, Mauricio de Almeida (org.). Natureza e sociedade no Rio de Janeiro. Rio de Janeiro: Secretaria Municipal de Cultura, Turismo e Esportes, Departamento Geral de Documentação, Divisão de Editoração, 1992, pp. 285-316.

CARDOSO, Adalto Lúcio e LAGO, Luciana Correa do. "Dinâmica Imobiliária: Estado e capital imobiliário". In RIBEIRO, Luiz Cesar de Queiroz (org.). Rio de Janeiro: transformaçôes na ordem urbana. 1 ed. Rio de Janeiro: Letra Capital/Observatório das Metrópoles, 2015, pp. 320-53.

CARVALHO, Elsa Esteves. Análise espaço-temporal das RAs de Santa Cruz, Campo Grande e Guaratiba (tese). UFRJ, 1999.

DAVIDOVICH, Fany. "Estado do Rio de Janeiro: o urbano metropolitano. Hipóteses e questões", Geo UERJ, ano 12, n. 21, v. 2, 2. sem. 2010. Disponível em: http://www.e-publicacoes.uerj.br/ index.php/geouerj/article/view/1474.

FREIRE, Quintino Gomes. "Mapa do Rio de Janeiro com a legislação por bairro”. Diário do Rio. Disponível em: http://diariodorio.com/mapa-do-rio-de-janeiro-com-a-legislao-por-bairro/. Acesso em: 7 mar. 2016.

FRIDMAN, Fania. Donos do Rio em nome do rei: uma história fundiária da cidade do Rio de Janeiro. Rio de Janeiro: Jorge Zahar/Garamond, 1999. 304p.

GAMA, Sonia Vidal Gomes da. Mapeamento digital da incompatibilidade de usos do solo na XIX RA de Santa Cruz: municipio do Rio de Janeiro (tese). UFRJ, 1998.

IBGE. Censo demográfico 2000.

- Censo demográfico 2010.

INCRA. "Incra/RJ publica edital para recuperação de acervo histórico da Fazenda Nacional de Santa Cruz. 2013”. Disponível em: http://www.incra.gov.br/. Acesso em: 11 mar. 2015.

KORYTOWSKI, Ivo. "Monumentos de Santa Cruz". 1 jun. 2006. Disponível em: http://literaturaeriodejaneiro.blogspot.com.br/2013/06/santa-cruz-uma-paixao.html. Acesso em: 17 mar. 2015.

LAGO, Luciana Corrêa do. Desigualdades e segregação na metrópole: o Rio de Janeiro em tempo de crise. Rio de Janeiro: Revan/Fase, 2000. 240p.

LÉFÈBVRE, Henri. The production of space. Oxford, UK: Blackwell, 1994, pp. 1-67.

- Espaço e politica. Belo Horizonte: UFMG, 2008. 192p.

MACEDO, Andréia Pereira de. Produção Imobiliária e segregação na periferia do Rio de Janeiro: o bairro de Campo Grande (dissertação). UFRJ, 2002

MACHADO, Lia Osório e CASTRO, Murilo C. de. "Diagnóstico socioeconômico da bacia de hidrográfica de Sepetiba - RJ. 1996”. Disponível em: http://igeo-server.igeo.ufrj.br/retis/in- 
dex.php/autor/lia-osorio-machado/diagnosticosocioecoomico-da-bacia-hidrografica-de-sepetiba/. Acesso em: 18 jul. 2011.

MIRANDA, Gisele dos Santos de e MÜLLER, Clarisse da Cunha. "As transformações locais no 'bairro' Rio da Prata, em Campo Grande, a partir da expansão de condomínios fechados: uma perspectiva multiescalar da dinâmica espacial da cidade do Rio de Janeiro - RJ”. Encontro Nacional de geógrafos, 16, 2010, Rio Grande do Sul. Anais... Rio Grande do Sul: [S.n.], 2010. Disponível em: www.agb.org.br/evento/download.php?idTrabalho=2763. Acesso em: 7 fev. 2015.

PEREIRA, Paulo Cesar Xavier. "Reestruturação imobiliária e produção do espaço metropolitano". Simpósio Internacional de Metropolização do espaço, gestão territorial e relações urbano-rurais, 2, 2014, Rio de Janeiro. Metropolização do espaço: processos e dinâmicas. Rio de Janeiro: Simerger, 2014. Disponível em: http://simegerpucrio.wix.com/simeger. Acesso em: 12 mar. 2015.

RIBEIRO, Luiz Cesar Queiroz e RIBEIRO, Marcelo Gomes. "Segregação residencial: padrões e evolução". In - (org.). Rio de Janeiro: transformaçôes na ordem urbana. 1 ed. Rio de Janeiro: Letra Capital/Observatório das Metrópoles, 2015, pp. 163-92.

RIO DE JANEIRO. Secretaria de Obras do Estado do Rio de Janeiro. Arco Metropolitano do Rio de Janeiro. Disponível em: http://www.mma.gov.br/port /conama/reuniao/dir867/ApresentARCORodv_GovRJ.pdf. Acesso em: 22 abr. 2014.

- Sabren. Portal Geo/Sabren. Disponível em: http://www.armazemdedados.rio.rj.gov.br. Acesso em: 20 jul. 2014.

—. Armazém de Dados da Prefeitura do Rio de Janeiro. Disponível em: http://www.armazemdedados. rio.rj.gov.br. Acesso em: 20 jul. 2014.

—. Câmara Municipal. Decreto Lei n.o 12524 de 09 de dezembro de 1993. "Cria a Área de Proteção do Ambiente Cultural do Bairro de Santa Cruz, XIX Região Administrativa, e dá outras providências". Disponível em: http://mail.camara.rj.gov.br/APL/Legislativos/scpro0711.nsf/449a94f8ca1f12 5a832566ec00172e93/a429f6ca78b4afcb832578b6005c928b?OpenDocument. Acesso em: 21 set. 2015.

SANTOS, Carlos Nelson Fernandes dos e BRONSTEIN, Olga. "Metaurbanização: o caso do Rio de Janeiro". Revista de Administração Municipal, Rio de Janeiro, v. 25, n. 149, pp. 6-34, out.-dez. 1978. SANTOS, Milton. Por uma geografia nova. São Paulo: Hucitec, 2002. 285p.

- A natureza do espaço: técnica e tempo, razão e emoção. 4 ed. 1. reimpr. São Paulo: USP, 2004. 367p.

- Espaço e método. 5 ed. São Paulo: USP, 2008. 120p.

SILVA, Carlos Alberto F. da. "A promoção imobiliária recente no município do Rio de Janeiro", Revista Território, v. 1, n. 1, 1996 , pp. 43-57.

SILVA, Vânia Regina Jorge da. A segregação espacial pela ótica do transporte urbano: o exemplo do bairro de Campo Grande - RJ (monografia). UERJ, 2006.

- Examinando os processos de segregação e descentralização através do transporte público na cidade do Rio de Janeiro: o exemplo de Campo Grande - RJ, 1990-2009 (dissertação). PUC-Rio, 2009.

SOARES, Maria Therezinha Segadas. "Nova Iguaçu: absorção de uma célula urbana pelo Grande Rio de Janeiro". Revista Brasileira de Geografia, ano 24, n. 2, abr.-jun. 1952, pp. 157-241. 


\title{
De povoado a município: transformações socioeconômicas em Nilópolis
}

\author{
Enderson Alceu Alves Albuquerque
}

\section{Introdução}

0

presente artigo apresenta o município de Nilópolis. As primeiras ocupações, populacionais e econômicas, seu processo de emancipação e as implicações de compor a segunda maior Região Metropolitana do país constituem seu cerne. Para tanto, procuramos abordar cronologicamente seu processo de ocupação territorial. Analisar esse espaço, desde as sesmarias até o presente momento, visa expor os sucessivos movimentos socioeconômicos pelos quais o município passou, bem como as consequências em seu território de tais processos.

Este artigo se divide em três partes. A primeira discorre a respeito das primeiras ocupações nos limites correspondentes a Nilópolis atualmente. Essa análise, embora não forneça subsídios para se compreender a atual configuração econômica do município, propõe um resgate cuja importância se deve aos limites territoriais de Nilópolis. Após sucessivos desmembramentos da sesmaria de Braz Cubas, João Álvares Pereira fundou a Fazenda São Matheus em 1634. Os limites dessa fazenda serviram de referência para a delimitação territorial de Nilópolis em 1947, ano de sua emancipação.

A segunda parte, consequentemente, analisa essa emancipação e os motivadores econômicos e demográficos implicados nesse processo, os agentes políticos envolvidos e as consequências iniciais dessa emancipação, além da dinâmica socioeconômica. Considerando a área oficial, Nilópolis, a partir da emancipação, passou a ser o oitavo menor município do país. Considerando apenas a área em que há ocupação de pessoas e atividades econômicas, Nilópolis seria o terceiro menor município do Brasil. Entretanto, quanto ao peso demográfico, nosso recorte espacial ocupa a posição de número

\footnotetext{
${ }^{1}$ Este artigo foi elaborado a partir de dissertação apresentada ao Programa de Pós-Graduação em Geografia da Universidade do Estado do Rio de Janeiro, sob a orientação do Prof. Dr. Miguel Angelo Ribeiro.

2 Mestre em Geografia pela Universidade do Estado do Rio de Janeiro.
} 
177 entre os 5.570 municípios brasileiros. Como essas especificidades influem na dinâmica socioeconômica do município?

Responder a tal questionamento é a intenção da terceira parte deste artigo, no qual buscamos contextualizar nosso recorte espacial na Baixada Fluminense e da RMRJ. Inicialmente, apresentamos uma revisão de literatura a respeito das diferentes concepções territoriais da Baixada Fluminense. A associação imediatista entre a Baixada Fluminense e os grupos de extermínio, os motivadores de seu processo de transformação e o quadro socioeconômico de Nilópolis nesse cenário serão contemplados nessa parte do artigo.

\section{De sesmaria a povoado de São Matheus: a gênese da ocupação territoria| ${ }^{3}$}

Entre os anos de 1530 e 1536, o governo de Portugal transplantou para o Brasil o sistema de capitanias hereditárias. $\mathrm{O}$ modelo de gestão territorial existia em seus domínios atlânticos, como na Ilha da Madeira (Boxer, 1992). As capitanias hereditárias consistiam em delegar à esfera privada a colonização do Brasil. Essa iniciativa da Coroa Portuguesa se devia às condições financeiras de seu reino à época, pois a restrição orçamentária inviabilizava a condução direta desse processo.

Assim, o território brasileiro foi dividido em 14 capitanias hereditárias. A extensão territorial correspondente ao atual município de Nilópolis integrava a Capitania Hereditária de São Vicente e tinha como proprietário Martin Afonso de Souza, em 1531. A ineficiência desse modelo, parcialmente explicado pela incapacidade técnica e humana de gestão dos enormes latifúndios doados aos nobres, a Coroa Portuguesa substituiu o sistema de capitanias hereditárias pelo de sesmarias.

Enquanto, no primeiro modelo, terras imensas foram doadas a pessoas abastadas como forma de protegê-las de conquistadores franceses e holandeses, as sesmarias se propunham a dinamizar a exploração econômica do território brasileiro, dando direito de posse à terra a quem comprovasse a efetiva possibilidade de cultivá-la (Alencastro, 2000). Por esse novo sistema, parte da Capitania Hereditária de São Vicente foi doada pela Coroa Portuguesa a Braz Cubas, em 1568. Essa sesmaria abarcava os limites territoriais que, hoje, compreendem os municípios de Nova Iguaçu, São João de Meriti, Duque de Caxias e Nilópolis (Oliveira, 2000). Nesse período, a região era ocupada por índios de diferentes etnias. Segundo Silva (2007, p. 69), esses índios poderiam ser os jacutingas. Para a autora, os primeiros registros de ocupação populacional da Baixada Fluminense diziam respeito a essa etnia: "As referências encontradas na maioria dos historiadores que escrevem sobre a ocupação dessa parte do território fluminense fazem alusão aos 'jacutingas' como o grupo que habitava essas terras, nomeados assim por conta de uma ave bastante comum naquela região".

\footnotetext{
3 Para esta parte do artigo, encontramos apoio em diferentes historiadores que utilizaram grafias distintas para fazer referência ao nome da fazenda e aos proprietários fundiários da cidade. Mantivemos a grafia de acordo com o autor considerado na citação.
} 


\section{De povoado a município: transformações socioeconômicas em Nilópolis}

A existência de inúmeras etnias nessa região e a inexatidão de sua extensão geográfica podem ter conduzido a análises reticentes por parte dos historiadores quanto às tribos locais. Silva (2007), na citação acima, utiliza expressões como "na maioria" e "alusão", termos descompromissados com a exatidão. Azevedo e Monteiro (2012, p. 51), por sua vez, referindo-se ao nosso recorte espacial específico, também apresentam precaução histórica: "A ocupação inicial das terras que hoje compõem a cidade de Nilópolis parece ter sido realizada pelos índios tupinambás, do grupo tamoio. A palavra tamoio significa, em tupi, os avós, ou os mais antigos, o que sugere a antiguidade desses índios como seus habitantes" (grifos nossos).

Pesquisas históricas estão sujeitas a imprecisões. Consequentemente, adotar diferentes fontes conduz a resultados distintos em relação ao mesmo fenômeno, os quais, contudo, não devem ser entendidos, necessariamente, como análises contraditórias. No caso da população indígena da área, por exemplo, os índios da etnia jacutinga poderiam ser os mais numerosos da região, conforme expõe Silva (2007), ao mesmo tempo que a atual área de Nilópolis era habitada pelos tupinambás, como ponderam Azevedo e Monteiro (2012). O certo é que eventuais divergências são comuns na prática de pesquisas históricas. Em nossa pesquisa para reconstruir o processo de ocupação do município de Nilópolis, outras divergências aparecem em relação a algumas datas.

De acordo com Nogueira (2008, p. 100), Braz Cubas não se apropriou das terras doadas pela Coroa Portuguesa. Entre a doação e os primeiros registros de atividade econômica nessa sesmaria, ficou um hiato: "Depois de desprezar as terras de sesmaria, de 03 de agosto de 1568 até a fundação da São Matheus, em 1634, 66 anos se passaram”. Para Oliveira (2008, p. 205), “em 1621 esta área denominada Fazenda São Mateus veio a pertencer a João Alvares Pereira”. Nogueira (2009, p. 39), por sua vez, esclarece que Pereira, "em 13 de junho de 1621, pediu e recebeu do governador Francisco Fajardo uma sesmaria de 1.500 braças de frente por 3 mil para o sertão, junto à serra do Tinguá. Em 1634, funda a Fazenda de São Matheus [...]”. Desse modo, para Nogueira, as terras recebidas por Pereira em 1621 não corresponderiam aos limites espaciais da Fazenda São Matheus, conforme assevera Oliveira.

A diferenciação de datas suscita discordância entre esses autores. Entretanto, ambos concordam quanto ao ano de construção da Capela São Matheus: 1637. Essa data é ratificada por Pizarro e Araújo (1820), o monsenhor Pizarro, em seu relatos de memória. De acordo com Peres (2010, p. 3), a capela foi construída "pelos índios existentes na região, já escravizados". Como exposto, não é possível definir qual tribo indígena foi responsável pela construção da supracitada capela. Entretanto, dois fatores relacionados à capela e à fazenda são inquestionáveis. $\mathrm{O}$ primeiro diz respeito à relevância produtiva da fazenda como primeira atividade econômica realizada naquele espaço; o segundo se relaciona com a importância simbólica da Capela São Matheus para a formação da identidade nilopolitana em um primeiro momento.

Nomear o povoado no qual estava instalada demonstra a crescente importância econômica da Fazenda São Matheus para a localidade. Os primeiros registros referentes à produção dessa fazenda datam de 1779. A Freguesia de São João Baptista de Trairaponga era composta por nove engenhos, dentre os quais o de São Matheus era o mais produtivo, com "uma produção anual de 30 caixas de açúcar e 14 pipas de aguardente, com 50 escravos negros” (Azevedo e Monteiro, 2012, p. 59).

No tocante aos aspectos simbólicos, a Fazenda São Matheus é de fundamental importância para a identidade do povo nilopolitano, sobretudo por ser o único fixo histórico localizado na par- 
te futuramente urbanizada de Nilópolis. Parte dos documentos históricos desse período se baseia em inspeções eclesiais. Nessa seara, são notórios os documentos atribuídos ao monsenhor Pizzaro. Os relatos aparecem em trabalhos destinados a analisar as primeiras ocupações na Baixada Fluminense, como, por exemplo, Simões (2008), Peres (2011) e Souza (2014). Apesar da pouca relevância desses relatos para o entendimento das forças produtivas, sua importância reside no fato de ressaltar como a Igreja Católica contribuiu para a formação identitária desses municípios da Baixada Fluminense.

Com o propósito de colonizar as terras da orla da Baía de Guanabara após a expulsão definitiva dos franceses protestantes, a Coroa portuguesa doou terras para a Igreja Católica, visando a ocupar a região em nome da "fé cristã e católica", assim como o era o reino português. Dessa forma, as funçôes realizadas pela instituição romana não se limitavam às de natureza religiosa, como casamento e batizados. A Igreja também registrava e validava óbitos e testamentos. Além disso, a partir da área de competência de determinada igreja, eram estabelecidos os limites territoriais civis. Segundo Torres (2004, p. 17), nesse período a Igreja Católica era de singular importância porque, "ao rezar uma missa no momento de posse da terra em 1500, o rei selava o compromisso de, onde quer que o seu poder estivesse, lá estaria a presença da Igreja, organizando, orientando, educando, fortalecendo, dando estrutura e até produzindo para o encantamento do reino".

Dessa forma, algumas localidades tiveram, inicialmente, seus nomes relacionados às primeiras igrejas que surgiram em seus domínios. Nesses casos, inserem-se Nossa Senhora do Pilar, Nossa Senhora de Belém e Menino Jesus, São João Baptista de Trairaponga, São Matheus, Nossa Senhora da Piedade de Magé, entre outras, conforme se observa no Quadro 1.

Quadro 1. Nomenclatura das toponímias selecionadas na Baixada Fluminense

\begin{tabular}{|l|c|c|c|}
\hline Anterior & Criação & Atual & Alteração \\
\hline Nossa Senhora do Pilar & 1612 & Duque de Caxias & 1943 \\
\hline São Matheus & 1637 & Nilópolis & 1921 \\
\hline $\begin{array}{l}\text { São João Baptista de Traira- } \\
\text { ponga }\end{array}$ & 1647 & São João de Meriti & 1660 \\
\hline $\begin{array}{l}\text { Nossa Senhora da Piedade } \\
\text { de Magé }\end{array}$ & 1696 & Magé & 1789 \\
\hline $\begin{array}{l}\text { Nossa Senhora de Belém e } \\
\text { Menino Deus }\end{array}$ & 1762 & Japeri & 1947 \\
\hline
\end{tabular}

Fonte: Prado (2000), Torres (2004), Simōes (2008) e Souza (2014).

Dos exemplos citados, apenas São João de Meriti manteve a toponímia associada à igreja católica. Antes chamada de São João Baptista de Trairaponga, a localidade manteve a homenagem ao santo com o acréscimo da palavra tupi Meriti. No caso de Magé, retirou-se do nome do município a referência religiosa, ficando apenas o termo tupi. Nossa Senhora do Pilar, primeira freguesia instalada na região, em 1612 (Prado, 2000), teve seu nome alterado para Duque de Caxias, em homenagem ao marechal de mesmo nome nascido naquela cidade. Japeri, nome de origem indígena, substituiu Belém. E São Matheus, atualmente, chama-se Nilópolis. 


\section{De povoado a município: transformações socioeconômicas em Nilópolis}

Em um primeiro momento, a identidade dos habitantes nilopolitanos era forjada a partir do pertencimento ao povoado de São Matheus. Entretanto, assim como nos demais exemplos baixadianos, o sentimento de identidade relacionado à primeira instituição católica local foi totalmente esvaziado. Do ponto de vista eclesial, para o historiador Marcus Antonio Monteiro Nogueira, isso ocorreu porque a capela era pequena e de propriedade particular. Em 1920, foi construída a Igreja de Nossa Senhora da Conceição, que passou ser a matriz da cidade, e a santa homenageada, padroeira de Nilópolis.

Do ponto de vista toponímico, a necessidade de atualizar homenagens de acordo com o progresso socioeconômico enfraqueceu as referências da fazenda. Se o esvaziamento toponímico de São Matheus ocorreu somente no início do século XX, o enfraquecimento econômico da fazenda ocorreu bem antes disso. Em 1854, a propriedade da fazenda passou para José Francisco de Mesquita, o barão do Bomfim. Posteriormente, ele passou o controle das terras a seu irmão, Jerônimo José de Mesquita, o barão de Mesquita (Peres, 2011, p. 3).

De acordo com Azevedo e Monteiro (2012, p. 70), a aquisição da fazenda por Mesquita objetivava "ampliar suas terras a serem atendidas pelos trilhos, pois o barão já era proprietário da Fazenda Cachoeira, cujas terras compõem o atual município de Mesquita e que fazia divisa com a São Matheus". A inauguração da estrada de ferro aconteceu somente em 1858, embora, seis anos antes, seu trajeto já fosse conhecido, por conta da divulgação de um edital público. Entretanto, antes da inauguração e somente após um ano da aquisição por Mesquita, a fazenda sofreu um primeiro revés, que, posteriormente, culminou com sua refuncionalização.

Em setembro de 1855, a cólera-morbo manisfesta-se na Freguesia de Meriti, especialmente nas fazendas de São Matheus e Cachoeira, ambas do Visconde de Bomfim, na época barão do Bomfim. Só na São Matheus, foram acometidos 51 escravos, dos quais 21 ficaram em estado grave e nove morreram. A epidemia persistiu até meados de novembro, fazendo mais vítimas. A fazenda recém-adquirida transformou-se num desastre (Nogueira, 2009, p. 64).

Essa epidemia assolou a maior parte da Baixada Fluminense. Trabalhadores livres e escravos, além de senhores de engenho, foram vitimados (Simões, 2008). A produção dos engenhos decresceu por causa da escassez de mão de obra e do esgotamento do solo. A diminuição do número de trabalhadores decorreu do surto epidemiológico, nessa conjuntura específica. Porém, a abolição da escravatura, em 1888, determinou o fim das atividades agrícolas na Fazenda São Matheus. Segundo Cardoso (1938, p. 26), essa fazenda, "que até então fora um campo de extensa e lucrativa produção, passara, a exemplo de muitas outras, a terrenos abandonados ao capricho da natureza, que a transformou em pouco tempo em um capoeirão e depois em mata fechada”.

A epidemia de 1855 e a abolição da escravatura em 1888, aliadas à inauguração da Estrada de Ferro Dom Pedro II (atual Central do Brasil), no ano de 1858, contribuíram para alterar a estrutura agrária da localidade. A impossibilidade de se manter esse modelo de reprodução do capital culminou com o desmembramento da Fazenda São Matheus a partir de 1896, inicialmente com a venda de dois terrenos (Nogueira, 2009).

Em 1900, a parte restante da Fazenda São Matheus, juntamente com suas edificações, foi vendida por Jerônimo José de Mesquita a João Alves Mirandela e seu sócio, Lázaro de Almeida 
(Peres, 2004). Os novos proprietários, então, foram os responsáveis pelo surgimento da cidade de Nilópolis. Em um primeiro momento, não houve alteração significativa na dinâmica social da localidade. João Alves Mirandela e seu irmão, Manuel Alves Mirandela, eram criadores de equinos. Pela natureza de sua atividade, os empecilhos que culminaram na crise da produção açucareira não representaram entrave para as atividades pecuaristas que os Mirandela pretendiam desenvolver. A utilização da área com essa finalidade, contudo, perdurou por apenas três anos, como relata Peres (2011, p. 3):

até 1913, parte da fazenda foi destinada à criação de muares e equinos para atenderem os clientes de Mirandela, até que, aceitando a sugestão do capitão Theodomiro Gonçalves Ferreira, foi levantada a planta da fazenda destinada ao seu loteamento. Dividida em lotes e divulgada sua venda nos jornais diários do Rio de Janeiro, sua procura foi um sucesso para as classes menos favorecidas, que adquiriam terreno barato ao preço de cinquenta mil réis, em módicas prestações mensais.

A divulgação da venda dos lotes foi feita por meio de anúncios pagos em jornais de grande circulação, como o Jornal do Commercio e o Jornal do Brasil. Em junho de 1914, "já haviam sido vendidos mais de 5.000 lotes e, já em princípio de 1915, estava totalmente vendida a área loteada ao lado direito da estação [...] apenas aguardando as construçōes" (Nilópolis, 2007, p. 12). Os preços dos lotes e a possibilidade de parcelamento do valor total favoreceram o êxito da venda, atraindo, sobretudo, as classes de menor poder aquisitivo. Ademais, alguns atrativos foram utilizados para mostrar o incipiente progresso da localidade a compradores em potencial. No material promocional de divulgação, por exemplo, os promotores destacavam a existência na cidade de bondes puxados a burro e já chamavam a localidade de Nilópolis (Azevedo e Monteiro, 2012).

Inicialmente em Nilópolis e, posteriormente, espraiado para outros municípios da Baixada Fluminense, o loteamento de terras se inscreve na estratégia do setor imobiliário para auferir maiores lucros. Para Pacheco (1984, p. 17),

este setor favoreceu o crescimento descontínuo do espaço metropolitano, na medida em que reservou terrenos mais próximos às áreas centrais como o intuito de esperar sua valorização, ao passo que áreas longínquas, além dos limites do então Distrito Federal, foram oferecidas à população de baixa renda, sem a necessária infra-estrutura urbana. É desse modo que desponta e se institucionaliza a periferia como habitat dessas populações pobres: atendendo aos interesses imobiliários.

Um dos representantes do setor imobiliário com atuação em Nilópolis foi Júlio de Abreu. "Homem de elevada importância na sociedade fluminense do início do século XX" (Oliveira, 2000, p. 27), Abreu inaugurou, no contexto nilopolitano, a prática de pressionar o Estado a promover melhorias que elevassem o preço de terras particulares. De acordo com Peres (2011, p. 3),

a falta de uma estação ferroviária no lugar da incômoda "parada" que atendesse a crescente população de São Mateus, evitando que os passageiros saltassem perigo- 


\section{De povoado a município: transformações socioeconômicas em Nilópolis}

samente sobre pedras e dormentes, fez com que seu proprietário se empenhasse junto à diretoria da ferrovia para a construção de uma plataforma com cobertura, evitando que as pessoas ficassem expostas às intempéries [...].

Se, por um lado, a construção da parada de trem atendia a uma demanda legítima da população, por outro servia aos anseios comerciais. Um dos artifícios dos proprietários fundiários consiste em valorizar seu patrimônio sem empregar capital próprio, beneficiando-se de recursos públicos. Corrêa (2004) ressalta, contudo, que tal benefício não se estende a todos os proprietários fundiários, contemplando apenas aqueles que mantêm estreita ligação com o poder público. A construção dessa parada de trem é emblemática quanto ao emprego dessa estratégia pelos proprietários fundiários. Dessa forma, em 8 de novembro de 1914, foi inaugurada a parada de trem Engenheiro Neiva, em homenagem ao engenheiro que a projetou, Lucas Soares Neiva. A localidade, antes chamada São Matheus, a partir do ano seguinte, de acordo com Oliveira (2000), passou a ser conhecida com o mesmo nome da parada de trem: Engenheiro Neiva.

Nesse contexto, Júlio de Abreu fundou o Bloco do Progresso em 1915. Formado por residentes influentes, essa agremiação trabalharia em prol do desenvolvimento local. Presidido por Abreu, o Bloco sugeriu que o lugar trocasse de nome. Seria retirada a homenagem feita a uma figura de importância meramente local, em prol de uma figura de relevância nacional: o ex-presidente da República, Nilo Peçanha. Enquanto, no campo simbólico, a troca apresentava um movimento inicial na tentativa da superar a condição de "aldeia" - batizar um espaço com o nome de um morador local não estava à altura do vertiginoso crescimento da localidade - no campo pragmático essa substituição funcionou como mais uma ação para alavancar a venda dos lotes. Então, com vistas a solidificar o nome, em 1918 o Bloco do Progresso lançou a revista Nilópolis.

Assim, paulatinamente, a localidade, embora ainda de maneira informal, passou a ser chamada de Nilópolis. O nome da parada de trem foi alterado em $1^{\circ}$ de janeiro de 1921 (Azevedo e Monteiro, 2012). A troca oficial do nome ocorreu em 6 de outubro do mesmo ano, pela Lei ${ }^{\circ} 1.705$, de autoria do deputado Manoel Reis. Essa lei registra, no art. 10: "Fica dada definitivamente a denominação 'Nilópolis' ao 70 districto do município de Iguassú [...]”.

De Fazenda São Matheus a Nilópolis, nosso recorte territorial passou por profundas alterações socioespaciais. $\mathrm{O}$ referido período presenciou a mudança de uma estrutura rural-agrária para outra de natureza urbano-comercial. Essa transformação foi fomentada, em um primeiro momento, pelos interesses dos proprietários fundiários, pois, conforme expõe Corrêa (2004, p. 16), eles

atuam no sentido de obter a maior renda fundiária de suas propriedades, interessando em que estas tenham o uso que seja o mais remunerador possível, especialmente uso comercial ou residencial de status. Estão particularmente interessados na conversão da terra rural em terra urbana, ou seja, têm o interesse na expansão do espaço da cidade na medida em que a terra urbana é mais valorizada que a rural. Isto significa que estão fundamentalmente interessados no valor de troca da terra, e não no seu valor de uso. 
Assim, a partir do loteamento, os proprietários fundiários converteram terras rurais em terras urbanas em uma proporção e uma velocidade sem precedentes no contexto local. Em um momento no qual a terra tinha pouco valor de troca, seu valor de uso foi potencializado. Daí em diante, o valor de troca se torna mais atraente que o valor de uso e as terras são fracionadas para loteamento.

O desenvolvimento alcançado por Nilópolis deu maior legitimidade a seu movimento de desvinculação do município de Nova Iguaçu. Sobre a atmosfera existente nesse período, é emblemático o que escreve Max Vasconcelos (apud Torres, 2004, p. 32): "É a Vincennes do Brasil, pela sua proximidade com a grande capital. O povoamento de ontem, mas seu progresso vertiginoso vaticina para breve a elevação desse districto à categoria de cidade". Nesse contexto, em 21 de agosto de 1947, Nilópolis se desvinculou do município iguaçuano. A análise desse processo, bem como de seus agentes e motivadores, é contemplada no próximo tópico.

\section{0 processo de emancipação nilopolitano: problemáticas da limitação territorial}

A inauguração da parada de trem em 1914 contribuiu, de forma, decisiva, para acelerar o processo de urbanização de Nilópolis e sua integração à malha urbana da cidade do Rio de Janeiro (Abreu, 2010). As áreas próximas à linha férrea tiveram imediata valorização, culminando, assim, com sua rápida comercialização. No entorno, surgiram as primeiras casas comerciais e a feira livre da cidade (Nogueira, 2009). A parada de trem gestou o centro comercial e financeiro da cidade. Entretanto, a urbanização nilopolitana não se deveu apenas a essa construção. A adoção de outras políticas públicas contribuiu, de forma significativa, para esse processo. Sobre os fatores que colaboraram para a intensificação dessa urbanização, Simões (2008, p. 84), aponta que

a simples passagem da ferrovia não garante a urbanização de um lugar; é necessário que se criem condições para que a população pobre se instale. A primeira condição é o surgimento do transporte de passageiros nos trens com uma certa regularidade e com preços de passagens mais acessíveis. A segunda condição é a possibilidade de acesso à propriedade da casa. Como as iniciativas de política habitacional popular na cidade do Rio de Janeiro, tais como vilas operárias, conjuntos habitacionais e mesmo a produção pequena burguesa, são insuficientes numericamente para atender à massa de trabalhadores pobres, é necessário criar uma alternativa que seja acessível a esta massa e não custe muito aos cofres públicos, já comprometidos com investimentos nas áreas mais abastadas e na infraestrutura voltada para a indústria. A alternativa será o loteamento popular.

As condições citadas por Simões fomentaram a urbanização de Nilópolis. O preço das passagens de trem foi padronizado. Pagava-se um só valor para viagens até a área central do Rio de Janeiro. Desse modo, essa política tarifária permitia que a população residisse em locais mais distantes de seu trabalho. Esse modelo de separação geográfica entre o local de trabalho e o de 


\section{De povoado a município: transformações socioeconômicas em Nilópolis}

moradia, possibilitado pela linha férrea, juntamente com os projetos de saneamento da Baixada Fluminense executados pelo então presidente da República, Nilo Peçanha, entre os anos de 1909 e 1910, foram os responsáveis iniciais pelo adensamento populacional de uma parte da Baixada Fluminense.

Até então calcadas no setor primário, essas alteraçôes estruturais ampliaram as possibilidades de se desenvolverem atividades econômicas no espaço nilopolitano. A conversão de terras rurais em urbanas gerou considerável crescimento demográfico. Surgiram, assim, novas demandas em Nilópolis. Tais demandas passaram a ser supridas com o surgimento e/ou expansão de novas atividades comerciais. A ampliação dessas atividades alimentou, consequentemente, o crescimento populacional. Nessa dinâmica de retroalimentação entre os processos demográficos e econômicos, o subdistrito iguaçuano alicerçou seu progresso.

Nilópolis compunha o primeiro subdistrito de São João de Meriti. Por sua vez, São João de Meriti era $4^{\circ}$ distrito de Nova Iguaçu. No ano de 1916, por indicação do deputado Manoel Reis, através da Lei no 1.332, Nilópolis passou a ser o sétimo distrito desse município (Azevedo e Monteiro, 2012). Essa mudança revelava a desenvoltura socioeconômica local. Em 1919, foi feito um novo loteamento no distrito. De acordo com Cardoso (1938, p. 12), nesse ano "o dr. Octavio Ribeiro de Faria Braga loteava suas terras do lado direito ferreo, edificando-se e povoando-se em marcha rápida [...]”. Em 1921, Rufino Gonçalves Ferreira loteou a parte remanescente do lado direito da linha férrea (idem, ibidem). Em 1932, a cidade passou a contar com uma linha de ônibus que a ligava ao bairro de Tomazinho (São João de Meriti). Quatro anos depois, Nilópolis ganhou sua primeira agência bancária, o Banco Lavoura (Oliveira, 2000). Em consonância com o dinamismo socioeconômico local, em 1938 foi realizado o último grande loteamento, surgindo, então, o bairro de Nova Cidade (Nogueira, 2008).

A partir de 1940, a questão da terra ganhou extrema relevância. Nesse período, "não havia mais terras disponíveis para loteamento na cidade, restando apenas a ocupação dos loteamentos já comercializados" (Simôes, 2008, p. 92). Nessa configuração fundiária, ocorreu a emancipação de Nilópolis. As bases do movimento foram se delineando naquela década. Em 1945, o deputado Lucas de Andrade Figueira solicitou, no ato das Disposições Constitucionais Transitórias, a criação dos municípios de Nilópolis e São João de Meriti (Torres, 2004). Em 21 de junho de 1946, ocorreu a solenidade de instalação do município de Nilópolis (Azevedo e Monteiro, 2012).

No dia 20 de junho de 1947, o município se desmembrou oficialmente de Nova Iguaçu. Em 15 de março, tomou posse João de Moraes Cardoso Junior, do partido UDN (União Democrática Nacional). Eleito com 2.269 votos, Cardoso entrou para a história municipal como primeiro prefeito eleito de Nilópolis (Torres, 2004). Tanto a emancipação política de Nilópolis quanto a de São João de Meriti - ambos municípios de Nova Iguaçu -foram efetivadas em 21 de agosto de 1947.

No tocante aos limites territoriais dos municípios nascentes, São João de Meriti contou com mais fatores positivos que seus vizinhos nilopolitanos. De acordo com Oliveira (2008, p. 206), ${ }^{4}$ a

\footnotetext{
${ }^{4}$ Há discordâncias quanto ao tamanho territorial de Nilópolis entre o IBGE, a prefeitura e alguns autores. Embora todos concordem com a delimitação de $9 \mathrm{~km}^{2}$ como a área urbanizada, o instituto
} 
Fazenda São Mateus serviria de referência para determinar os limites territoriais de Nilópolis, porém "cometeu-se nesta emancipação uma flagrante injustiça, pois, sendo a área de $22 \mathrm{~km}^{2}$, que era a mesma da Fazenda São Mateus, ficou reduzida a apenas $9 \mathrm{~km}^{2}$, perdendo 5,60 km² para o Gericinó; $5,60 \mathrm{~km}^{2}$ para São João de Meriti e $1,80 \mathrm{~km}^{2}$ para Nova Iguaçu”.

Enquanto para Oliveira (2000) a Fazenda São Matheus serviria como limite para engendrar a delimitação territorial do município de Nilópolis, Azevedo e Monteiro (2012, p. 57) apresentam novos limites territoriais históricos, ao acrescentarem que, "na região onde se situa a atual cidade de Nilópolis, se desenvolveram quatro grandes propriedades rurais, as fazendas São Matheus, Gericinó, Bananal e Cabral, sendo que apenas parte da área da antiga Fazenda São Matheus foi ocupada pela cidade". Para esses autores, os terrenos das antigas fazendas Cabral, Gericinó e Bananal, "apesar de pertencerem ao município de Nilópolis, nunca foram urbanizados”.

Segundo Azevedo e Monteiro (idem, ibidem), com exceção da São Matheus, todas as demais fazendas foram adquiridas ou apropriadas pelo governo federal. A área da Fazenda Gericinó foi comprada em 1908. A Fazenda Cabral, por sua vez, foi dividida e teve a primeira parte vendida para o governo federal em setembro de 1920. Os proprietários da parte remanescente rejeitaram a oferta do governo e tiveram suas terras desapropriadas em dezembro daquele mesmo ano. Já a Fazenda do Bananal foi adquirida pelo Exército em 1923. Dessa forma, os atuais limites territoriais do município de Nilópolis não correspondem fielmente à área da Fazenda São Matheus, pois parte dela foi incorporada ao município de São João de Meriti em 1947. Tampouco correspondem à soma das áreas das fazendas Gericinó, Bananal, Cabral e São Matheus, pois as três primeiras, embora componham oficialmente o território de Nilópolis, foram adquiridas e apropriadas pelo Exército antes do processo de emancipação de Nilópolis, em 1947. Assim, no processo de emancipação, Nilópolis ficou reduzido a apenas $9 \mathrm{~km}^{2}$ de área urbanizada; os outros $13 \mathrm{~km}^{2}$ compóem o Campo de Instrução Militar do Gericinó, conforme se vê na Figura 1.

federal considera 19,157 $\mathrm{km}^{2}$ a extensão total do município, ao passo que, para os demais, essa extensão seria de $22 \mathrm{~km}^{2}$. 


\section{De povoado a município: transformações socioeconômicas em Nilópolis}

Figura 1. Limites territoriais de Nilópolis: área urbana e Campo de Instrução Militar

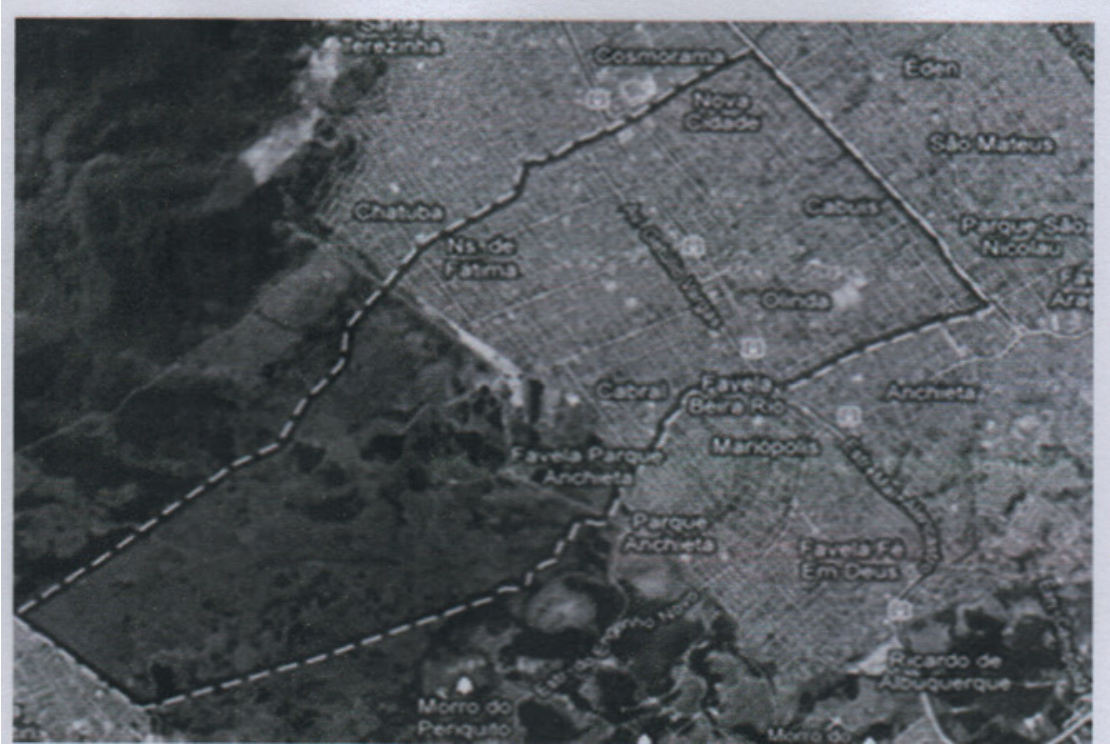

Fonte: Google Earth, 2012.

Desde a emancipação de Nilópolis, os sucessivos prefeitos da cidade reivindicam a municipalização da área ao governo federal. A incorporação dessa área aos limites territoriais de Nilópolis, de acordo o plano diretor da cidade, em seu artigo 14, inciso III, possibilitaria:

a. a melhoria da conexão de Nilópolis e da Baixada Fluminense com a Zona Oeste do Rio de Janeiro, notadamente Bangu e Campo Grande;

b. a consolidação do dique de contenção através de um parque ambiental e de lazer em seu entorno;

c. as funções administrativas e logísticas do Exército Brasileiro, caso queira e precise, sendo estas funções compatíveis e conviventes com um entorno residencial;

d. a previsão para desenvolvimento e fixação de atividades econômicas que necessitam de mais espaço físico, como indústria e logística, preferencialmente aqueles que tragam emprego e renda ao povo nilopolitano;

e. o espaço para habitação de qualidade ambiental urbanística e arquitetônica para todas as classes sociais e especialmente para os militares, populaçôes hoje moradoras da beira-rio e camadas médias e altas num conceito de cidade parque;

f. as vias marginais dos rios Sarapuí e Meriti/Pavuna, ampliando a ligação da Baixada Fluminense à Zona Oeste do Rio de Janeiro, e a própria inserção rápida e dinâmica da área de Desenvolvimento Estratégico de Gericinó às demais áreas das cidades de Nilópolis, Mesquita e Rio de Janeiro. 
Desde 2004, representantes do Exército e da prefeitura de Nilópolis estudavam, em conjunto, a proposta de transformar parte do campo de instrução em um parque de preservação ambiental. Porém, somente em 2009, foi criado o Parque Natural do Gericinó, com a proposta de "impedir o avanço de construções irregulares e propiciar a preservação, conservação e valorização da flora e da fauna do município" (Azevedo e Monteiro, 2012, p. 114). Além da preocupação ambiental, o parque é utilizado para a prática de atividades esportivas e de lazer.

Essa limitação territorial impôs ao município de Nilópolis entraves das mais diversas ordens, como, por exemplo, a impossibilidade de se criar uma área industrial. Também se verifica intensa pressão imobiliária, o que acarreta aumento do valor do solo e elevada densidade demográfica.

Os dados do Censo Demográfico do IBGE revelam que, no intervalo de trinta anos, houve um crescimento próximo de $472 \%$ da população residente em Nilópolis, passando de 22.341 habitantes em 1940 para 128.011 em 1970. Com essa configuração socioeconômica, nosso recorte espacial passou a compor, como unidade autônoma, a Baixada Fluminense em 1947 e a Região Metropolitana do Rio de Janeiro em 1973. As implicaçōes da inserçāo de Nilópolis nessas regiōes administrativas são no próximo tópico.

\section{Nilópolis no contexto da Baixada Fluminense e da Região Metropolitana do Rio de Janeiro}

Refletindo sobre as intervenções realizadas pelo governo de Nilo Peçanha entre os anos de 1909 e 1910, Lago (2000, p. 67) assinala que

essas obras de saneamento e drenagem executadas na Baixada Fluminense nesse período, em vez de impulsionar a produção agrícola para o abastecimento da cidade, abriram novas fronteiras para a expansão imobiliária. Surgia nesse momento um novo padrão de produção do espaço construído urbano, os chamados "loteamentos periféricos", que mudaria, doravante, a forma e o conteúdo não apenas do Rio de Janeiro, mas das demais grandes cidades brasileiras.

A alteração de forma e conteúdo aludida por Lago se manifestou pelo adensamento demográfico dos municípios vizinhos ao Rio de Janeiro. Em consequência, houve expansão da mancha urbana, até então limitada à cidade do Rio de Janeiro. No contexto fluminense, esse processo se materializou juridicamente com a criação da Região Metropolitana do Rio de Janeiro em 1973. Essa RM foi criada com 17 municípios, dentre eles o de Nilópolis, e teve como seu núcleo o então município da Guanabara (Figura 2). 
Figura 2. Localização do município de Nilópolis na RMRJ e na Baixada Fluminense

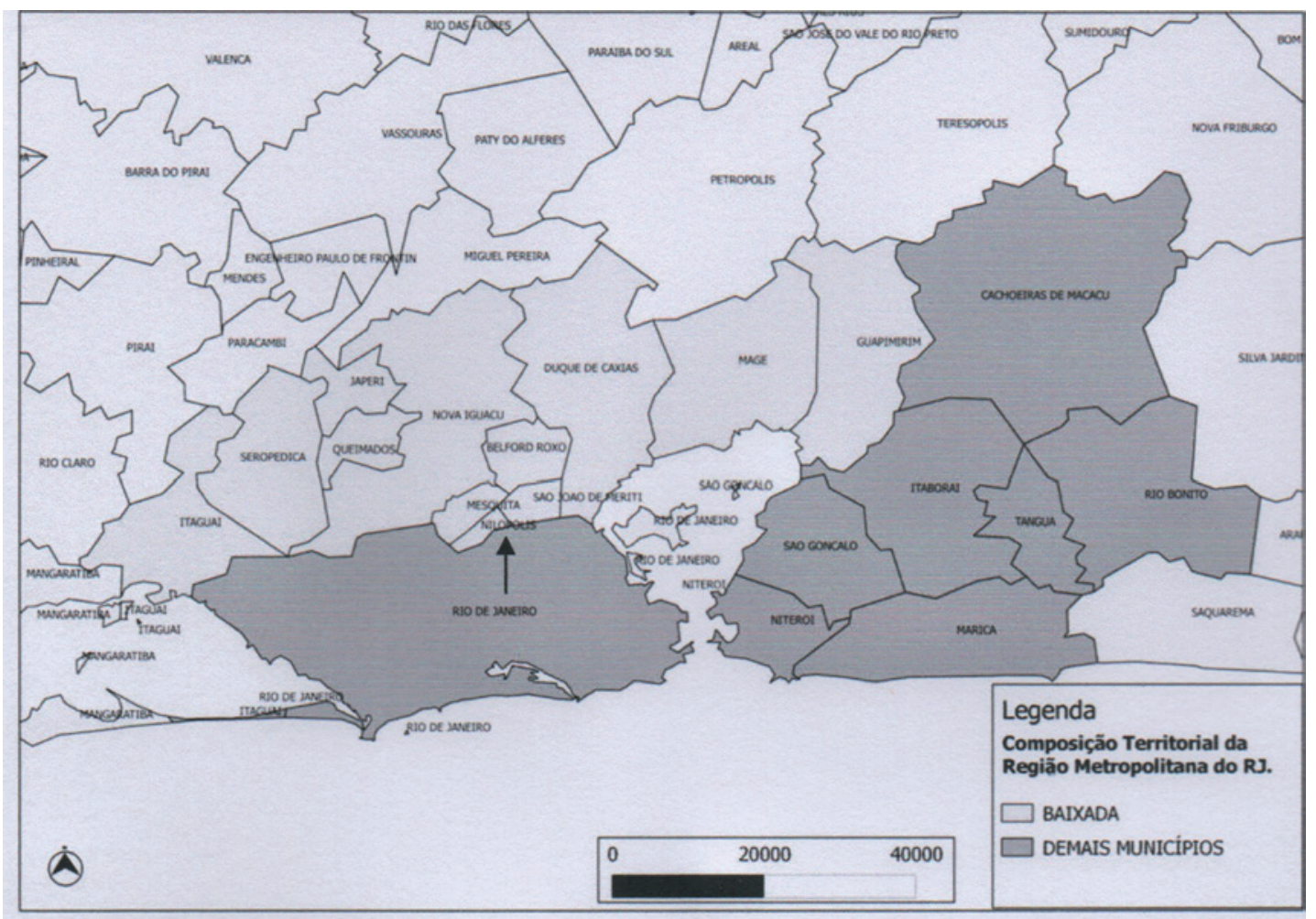

Fonte: Rocha, 2015 (modificado pelo autor).

A área metropolitana fluminense nasceu formada por dois estatutos jurídicos distintos, o do estado da Guanabara e o do estado do Rio de Janeiro. Havia um notório descompasso socioeconômico entre o núcleo da Região Metropolitana e seu entorno, como reforça Santos (2002, p. 13): “[...] separado administrativamente do seu entorno, o núcleo da região metropolitana não financiou a implantação da infraestrutura adequada para atrair investimentos industriais para a Baixada Fluminense".

A fusão do então estado da Guanabara com o estado do Rio de Janeiro, instituída pela Lei Complementar no 20, de $1^{\circ}$ de julho de 1974 , efetivada apenas no ano seguinte, 1975 , visava corrigir a separação entre o núcleo e a periferia da metrópole fluminense e de contribuir para o desenvolvimento da economia do interior fluminense por meio da consolidação de um polo de desenvolvimento obtido pela integração política e econômica dos dois estados. Também objetivava eliminar a barreira político-institucional entre a cidade do Rio de Janeiro e os demais municípios do estado do Rio (Davidovich, 2000).

O último Censo Demográfico do IBGE revela o caráter altamente concentrador do núcleo da RMRJ em comparação com os demais municípios. Essa área concentra $74,1 \%$ da população residente no estado, perfazendo um total populacional de 11.823.752 habitantes. Entretanto, 6.323.037 desses indivíduos residem no município do Rio de Janeiro. Dessa forma, o núcleo da RMRJ abriga, sozinho, 
população superior à soma dos outros 18 municípios que a compõem atualmente. Cumpre assinalar que, desde 2013, mais dois municípios foram incluídos nos limites metropolitanos: Rio Bonito e Cachoeiras de Macacu: "Uma das características fundamentais da região [metropolitana do Rio de Janeiro] é a concentração, tanto do ponto de vista demográfico quanto econômico, bem como o que diz respeito aos serviços referentes aos setores financeiro, comercial, educacional e de saúde, além de órgãos e instituições públicas" (Marafon et al., 2011, p. 94).

Nesse contexto, de uma área metropolitana altamente concentradora, Nilópolis se inscreveu como integrante de sua periferia ${ }^{5}$ (Ribeiro e O’Neill, 2012), a Baixada Fluminense. Essa região, por sua vez, não encontra consenso entre os pesquisadores no tocante a seus limites territoriais. Dependendo do critério adotado, o limite territorial e o número de municípios podem expandir-se ou retrair-se. No que diz respeito ao debate acadêmico, Oliveira (2004) nos apresenta três noçôes distintas das dimensões territoriais da Baixada Fluminense.

A primeira, pautada em critérios geomorfológicos, foi elaborada entre as décadas de 1930 (Góes, 1934) e 1960 (Geiger e Santos, 1955). No entanto, enquanto Góes se atém às características hidrográficas para estabelecer sua delimitação, Geiger e Santos consideram a "relação existente entre a sociedade e o espaço natural, dando ênfase às relações econômicas que predominavam em determinadas localidades” (Magalhães et al., 2013, p. 13), para erigir sua delimitação.

O certo é que a concepção de Baixada Fluminense extrapola a acepção meramente geomorfológica. Nesse sentido, conforme defende Oliveira (2004, p. 24), "o aspecto natural passou a ser associado com os elementos políticos, sociais e econômicos, apresentando construções distintas das verificadas acima”. Afinada com as proposições de Oliveira (2004), a segunda noção, engendrada por Beloch (1986), considera apenas os municípios que mantêm ligaçôes estreitas com o município do Rio de Janeiro - casos de Nova Iguaçu, Duque de Caxias, Nilópolis e São João de Meriti - como pertencentes à Baixada Fluminense.

A terceira conceituação, estabelecida pela Secretaria de Desenvolvimento da Baixada e Região Metropolitana (Sedebrem), considera que 13 municípios pertencem a essa região, como registra o mapa trazido na Figura 2. Essa delimitação territorial será a considerada para a estruturação deste estudo.

Assim, enquanto a primeira conceituação se atém às características naturais para delimitar a região, as demais recorrem a critérios socioeconômicos. Entre os trabalhos empreendidos para delimitar os limites físicos da Baixada Fluminense, merecem destaque ainda os de Segada Soares (1962) e Souza (2014). A primeira autora, por seu trabalho clássico sobre o processo de ocupação da Baixada Fluminense, e a segunda, pela revisão dos trabalhos referentes à região.

A caracterização da região, ao oscilar de acordo com os critérios adotados, como expõe, entre outros, Gomes (2010), abre a possibilidade de delimitaçôes distintas da Baixada Fluminense, tomando como referência os aspectos naturais ou os socioeconômicos. Nesse sentido, a delimitação de

\footnotetext{
5 Ribeiro (2002) subdivide o estado do Rio de Janeiro em dois espaços: a metrópole, constituída por seu núcleo e pela periferia (na qual está incluída a Baixada Fluminense), e o interior.
} 


\title{
De povoado a município: transformações socioeconômicas em Nilópolis
}

Baixada Fluminense apresenta limites nem sempre consensuais entre os pesquisadores que a tiveram como centro de suas reflexões. Simões $(2008$, p. 21) ressalta que

\begin{abstract}
não existe um consenso geral do que seja a Baixada Fluminense, quais os seus limites e os municípios que a compõem. A cada trabalho sobre essa região, reabre-se o debate, pois cada autor se coloca de maneira diferenciada com relação à área a ser delimitada. Contudo, existem alguns consensos que devem ser ressaltados. Os municípios de Nova Iguaçu e Duque de Caxias são apontados, com unanimidade, como núcleos desta região, assim como não há questionamento sobre a inclusão de seus "satélites" imediatos, como Belford Roxo, São João de Meriti, Nilópolis, Mesquita, Queimados e Japeri, que são incluídos como parte da Baixada Fluminense por todos os autores, mas nem sempre são analisados com a mesma profundidade que o "núcleo duro". Os problemas se encontram nos limites leste, oeste e norte. Dependendo dos autores, Magé e Guapimirim podem ser ou não inseridos na Baixada Fluminense, o mesmo ocorrendo com Itaguaí, Seropédica e Paracambi.
\end{abstract}

Independentemente da ausência de consenso no que diz respeito à delimitação territorial da região e de suas respectivas controvérsias, o recorte adotado foi associado à violência por muito tempo. Essa associação é fortemente consolidada no imaginário fluminense. Alves (2003, p. 15), por exemplo, relata o fato de uma deputada federal que, ao tomar conhecimento da chacina ocorrida no dia 30/08/1993 na favela de Vigário Geral, lamentou a tragédia "naquela favela da Baixada Fluminense". A parlamentar, em seu depoimento, associa a favela de Vigário (como é popularmente denominada) à Baixada Fluminense de forma equivocada. Essa declaração demonstra a associação direta estabelecida no imaginário entre violência e Baixada Fluminense. Tal associação começa a ser superada a partir dos anos 1990, quando a região dá início a um processo de transformação socioeconômica e político-partidária. Para Figueiredo (2004), essa condição passa a ser modificada porque,

em decorrência do período econômico favorável, houve investimentos públicos direcionados para a área, com a expansão do sistema de transporte na abertura de rodovias no final da década de 20 do século XX, como: Rodovia Washington Luiz, a antiga Rio-São Paulo, a Avenida Automóvel Club; a expansão da rede elétrica; a implantação do programa de saneamento da baixada (elaborado pelo governo de Getulio Vargas, em 1934), visando solucionar problemas que sempre a assolam, possibilitando o desenvolvimento dos transportes e a ocupação de terras; além da eletrificação da ferrovia ramal Central do Brasil-Japeri em 1938 até Nova Iguaçu, atingindo Japeri em 1943.

Desse modo, a região passa por uma alteração em virtude das transformações ocorridas em alguns de seus municípios. O dinamismo econômico verificado em Nova Iguaçu e Duque de Caxias - compreendido também segundo a lógica do espraiamento da metrópole do Rio de Janeiro - possibilitou o aumento da arrecadação municipal, favorecendo, assim, a infraestrutura local. Além disso, o fortalecimento econômico arrefeceu, em certa medida, as migraçóes pendulares entre a Baixada Fluminense e o núcleo metropolitano e entre os municípios dessa região. 
Quanto ao estereótipo de local violento, desde o início da década de 1990, a região passou a vivenciar o declínio dos grupos de extermínio e congêneres. A "espetacularização" da violência estendeu-se para o município do Rio de Janeiro, com ênfase para as favelas da Zona Norte e da Zona Oeste. Deslocaram-se, assim, os "holofotes" midiáticos de violência, até então centrados na Baixada Fluminense, para os bairros cariocas.

Com efeito, a Baixada Fluminense encontra-se em meio a um intenso processo de busca de identidade. Esse movimento propõe o rompimento com seu passado recente, que tanto contribui para a maneira caricatural como foi vista por tanto tempo. Contudo, enquanto a região passa a atrair novos fluxos financeiros, Nilópolis, na contramão desse processo, não presencia alteração significativa nessa área.

Ao compor uma área extremamente estereotipada como a Baixada Fluminense, Nilópolis também passa por um processo de transformação. Porém, sem a mesma força econômica dos municípios vizinhos, como Nova Iguaçu e Duque de Caxias, e sem a possibilidade de expansão urbana e industrial, por causa de sua pequena extensão territorial. Enquanto o município de Duque de Caxias absorvia 50,7\% da mão de obra local e Nova Iguaçu, mesmo englobando, a época, os municípios de Belford Roxo, Japeri e Queimados, retinha 44,7\%, Nilópolis absorvia, no mesmo período, apenas $35,2 \%$ da mão de obra local (IBGE, 2007).

Um dos elementos caracterizadores do baixo dinamismo econômico de Nilópolis na década de 1980 foi a incapacidade de suas atividades econômicas reterem a mão de obra local. Essa questão assumiu proporçôes drásticas com o aumento populacional, pois, em oitenta anos, segundo dados do Censo Demográfico do IBGE, houve um aumento superior a 3.000\% na população nilopolitana. Como o município tem uma extensão territorial pequena, sua densidade demográfica está próxima de 8.016 .6 hab. $/ \mathrm{km}^{2}$ - segunda maior densidade demográfica do estado, inferior apenas à de São João de Meriti.

Entretanto, a análise dos Censos Demográficos de 1991, 2000 e 2010 aponta para um período de decréscimo populacional em Nilópolis. Em 1991, 158.092 indivíduos residiam na municipalidade. Em 2000, esse número caiu para 153.712, voltando a subir para 157.483 em 2010. Contudo, a posição do município no total populacional do estado vem declinando. Em 1991, Nilópolis era o $14^{\circ}$ município mais populoso do estado. Em 2000, passou a ser o $16^{\circ}$ e, em 2010 , caiu para a $19^{a}$ posição. O esvaziamento demográfico de Nilópolis pode ser explicado, em parte, pelo surgimento de uma área próxima com melhor infraestrutura. Nesse caso, a chegada do metrô ao bairro carioca de Pavuna, mais próximo de São João de Meriti, teria tornado esse município mais atrativo do ponto de vista populacional, em detrimento do município nilopolitano.

Nesse mesmo período, os municípios limítrofes tiveram aumento de população. Porém, não é possível afirmar que o declínio populacional nilopolitano esteja alimentando os municípios vizinhos. Sabe-se, contudo, que foi a única cidade da Baixada Fluminense a perder população nesse período exceção feita a Nova Iguaçu, que apresentou uma perda populacional maior devido à emancipação dos municípios de Japeri (1991), Belford Roxo (1993) e Mesquita (1999).

$\mathrm{Na}$ esfera econômica, Nilópolis apresenta índices econômicos pífios em comparação a alguns municípios da Baixada Fluminense e da Região Metropolitana. Para o ano de 2012, o PIB total da Região Metropolitana, na qual Nilópolis está inserida, foi de R\$261.090.608 (em mil reais). O mu- 
nicípio nilopolitano contribui com apenas 0,74\% desse valor, com um PIB de R $\$$ 1.935.707. Nessa conjuntura, entre os 19 municípios integrantes da RMRJ, Nilópolis apresenta o 11\% PIB da região. Considerando os 13 municípios da Baixada Fluminense, nosso recorte espacial ocupa o sétimo lugar em relação ao PIB (TCE, 2014).

Internamente, a participação dos setores revela o destaque das atividades de serviços na composição econômica municipal, correspondendo a cerca de $90 \%$ do PIB do município (Tabela 1). Uma das explicaçōes para essa concentração pode ser formulada a partir da área urbana de Nilópolis, que inviabiliza a existência de atividades primárias e compromete o rendimento do setor secundário, pois, conforme assinala Corrêa (2004, p. 13), "os grandes proprietários industriais e das grandes empresas comerciais são, em razão da dimensão de suas atividades, grandes consumidores de espaço”.

Tabela 1. Participação das atividades na composição do PIB de Nilópolis (2007-2012)

\begin{tabular}{|l|l|l|l|l|l|}
\hline Ano & PIB (R\$ milhóes) & Agropecuária & Indústria & Serviços ${ }^{[1]}$ & $\begin{array}{l}\text { Administração } \\
\text { pública }\end{array}$ \\
\hline 2007 & 1.198 .642 & $0,0 \%$ & $10,28 \%$ & $89,72 \%$ & $36,51 \%$ \\
\hline 2008 & 1.374 .246 & $0,0 \%$ & $8,09 \%$ & $90,91 \%$ & $37,02 \%$ \\
\hline 2009 & 1.489 .045 & $0,0 \%$ & $10,41 \%$ & $89,59 \%$ & $36,92 \%$ \\
\hline 2010 & 1.685 .587 & $0,0 \%$ & $12,09 \%$ & $87,91 \%$ & $36,76 \%$ \\
\hline 2011 & 1.812 .902 & $0,0 \%$ & $11,81 \%$ & $88,19 \%$ & $37,17 \%$ \\
\hline 2012 & 1.935 .707 & $0,0 \%$ & $10,68 \%$ & $89,32 \%$ & $37,11 \%$ \\
\hline
\end{tabular}

[1] O setor de serviços compreende a administração pública.

Fonte: TCE (2012) e Ceperj (2013).

Como exposto na Tabela 1, Nilópolis apresenta características eminentemente urbanas. Segundo dados do IBGE, o município apresenta $100 \%$ da população residente nessa área. No contexto fluminense, embora a taxa de urbanização estadual seja de 96,6\%, dos 92 municípios, apenas outros dez apresentam taxa de urbanização na ordem de 100\%. Ribeiro e O’Neill (2015), apoiados em outros estudiosos, como Ester Limonad, José Eli Veiga e Angela Penalva Santos, questionam o critério adotado pelo IBGE para definir espaço urbano. Nesse sentido, Ribeiro e O’Neill (p. 9) construíram uma tipologia dos municípios fluminenses "utilizando três indicadores: da dimensão demográfica; do grau de urbanização; e do produto interno bruto (PIB)" para qualificar a questão urbana dos municípios.

Assim, de acordo com a metodologia adotada por esses autores e tomando como base o Censo Demográfico de 2010, Nilópolis, quanto à dimensão demográfica, é considerado um município de pequenas dimensóes (nesse grupo, estão aqueles com população inferior a 250 mil habitantes). Quanto ao nível de urbanização, nosso recorte espacial compõe o grupo dos municípios de grau muito forte (esse grupo compreende os municípios com urbanização acima de 80\%). Considerando a dimensão econômica, Nilópolis se enquadra na categoria fortemente de serviços (municípios em que o setor de serviços compreende mais de $80 \%$ do PIB). 
Para estabelecer a tipologia final, Ribeiro e O’Neill (2015, p. 10) procederam ao “cruzamento matricial da população total do município (dimensão demográfica); da relação entre população urbana e população total do município (grau de urbanização) e do PIB (dimensão econômica)". A partir desses indicadores, os autores dividiram o espaço fluminense em seis tipos. Nilópolis, a exemplo de outros cinquenta municípios, enquadra-se no tipo 1, que, segundo os autores (idem, ibidem), são municípios em que "há um predomínio do setor de serviços. Neste tipo, estão incluídos os municípios nas três classes de dimensão demográfica e com grau de urbanização superior a 45,0\%, predominando 35 com mais de $80,0 \%$ de urbanização [...]. São municípios que têm sua economia pautada no setor de serviços $[\ldots]$ ".

\section{Considerações finais}

Nilópolis passou por um profundo processo de alteração econômica estrutural. Até 1914, predominavam as atividades agrárias, alicerçadas, sobretudo, na produção de cana-de-açúcar. Atualmente, as atividades de serviços passaram a predominar na região. Essas alterações estiveram em consonância com a transformação de sua área de rural para urbano. A passagem da estrutura produtiva de rural-agrária para urbano-industrial gerou consideráveis implicações em nosso recorte.

O crescimento populacional exponencial verificado a partir dos loteamentos propiciou maior dinamismo econômico, e a soma dos incrementos econômico e demográfico culminou com a sua emancipação do município de Nova Iguaçu. Os termos segundo os quais essa emancipação foi efetivada respondem pela pequena extensão territorial do município, exatamente no período em que o processo de industrialização era o principal motor de desenvolvimento econômico no país. Nessa conjuntura, Nilópolis já nasceu excluída das possibilidades industriais. Nesse contexto e com o passar do tempo, suas discrepâncias econômicas aumentaram em relação a algumas cidades da Baixada Fluminense, tornando-a pouco participativa na composição do PIB total da RMRJ.

Dessa forma, a cidade não despontou como protagonista nesse novo cenário, em razão de sua pouca expressividade econômica. Em um primeiro momento, a cidade foi "sufocada" pelo desenvolvimento de municípios como Duque de Caxias e Nova Iguaçu, mais preparados, na ocasião, para receber os capitais antes preferenciais do município do Rio de Janeiro. Tomando como base os dados relacionados à porcentagem de população ocupada (Lago, 2010), podemos afirmar que o setor de trabalho melhorou em Nilópolis, fruto direto do incremento das atividades do comércio local.

Assim, o predomínio das atividades de comércio e serviços no espaço nilopolitano acompanha a tendência de aumento do setor terciário na composição da economia, tanto em escala nacional quanto em escala mundial. Essa alteração estrutural observada em Nilópolis, segundo Lago (2010), se explica pelo maior dinamismo econômico verificado nos centros periféricos da RMRJ. 
De povoado a município: transformações socioeconômicas em Nilópolis

\section{Referências}

ABREU, Maurício de Almeida. Evolução urbana do Rio de Janeiro. 4 ed. Rio de Janeiro: IPP, 2010.

ALECASTRO, Luiz Felipe de. O trato dos viventes: formação do Brasil no Atlântico Sul. São Paulo: Companhia das Letras, 2000.

ALVES, José Cláudio Souza. Dos barôes ao exterminio: uma história da violência na Baixada Fluminense. Duque da Caxias, RJ: APPH-CLIO, 2003.

AZEVEDO, Jorge Baptista de e MONTEIRO, Marcus. Inventário dos bens culturais de Nilópolis. Nilópolis (RJ): Prefeitura de Nilópolis, 2012.

BELOCH, Israel. Capa preta e Lurdinha: Tenório Cavalcanti e o povo da Baixada. Rio de Janeiro: Record, 1986.

BOXER, Charles R. O império maritimo português: 1415-1825. Lisboa: Edições 70, 1992.

CARDOSO, Ernesto. Nilópolis de hontem e de hoje. Nilópolis: L \& J. Berkowitz, 1938.

CORRÊA, Roberto Lobato. O espaço urbano. 4 ed. São Paulo: Ática, 2004.

DAVIDOVICH, Fany. "O estado do Rio de Janeiro: singularidades de um contexto territorial". Território, Rio de Janeiro, n. 9, 2000.

FIGUERÊDO, Maria Aparecida de. "Gênese e (re)produção do espaço brasileiro na Baixada Fluminense”. Revista Geo-Paisagem, Rio de Janeiro, ano 3, n. 5, 2004.

GEIGER, Pedro Pinchas e SANTOS, Ruth Lyra. "Notas sobre a evolução da ocupação humana da Baixada Fluminense". Revista Brasileira de Geografia, Rio de Janeiro, IBGE, ano XVI, n. 3, jul.-set. 1955.

GÓES, Hildebrando de Araújo. Relatório apresentado pelo engenheiro-chefe da Comissão de Saneamento da Baixada Fluminense. Rio de Janeiro: s. e., 1934.

GOMES, Paulo Cesar da Costa. "O conceito de região e sua discussão". In CASTRO, Iná Elias de et al. (orgs.). Geografia: conceitos e temas. Rio de Janeiro: Bertrand Brasil, 2010, pp. 49-73.

IBGE. Diretoria de Pesquisas, Coordenação de Contas Nacionais. Produto Interno Bruto dos Municípios 2007. Disponível em: www.ibge.gov.br.

LAGO, Luciana Corrêa do. Desigualdades e segregação na metrópole: o Rio de Janeiro em tempo de crise. Rio de Janeiro: Revan, 2000.

MAGALHÃES, Alex Lamonica et al. Alma(naque)... da Baixada. Rio de Janeiro: APPH-CLIO, 2013.

MARAFON, Glaucio José et al. Geografia do estado do Rio de Janeiro: da compreensão do passado aos desafios do presente. Rio de Janeiro: Gramma, 2011.

NILÓPOLIS. Revista de aniversário de 60 anos. Nilópolis: Prefeitura de Nilópolis, 2007.

NOGUEIRA, Marcus Antonio Monteiro. Baixada Fluminense: memórias fotográficas. Rio de Janeiro: Inepac, 2008.

- Memorial nilopolitano. Nilópolis: Prefeitura de Nilópolis, 2009.

OLIVEIRA, Cláudio de. Nilópolis: uma feliz cidade. Nilópolis: Fundação Padre Mateus, 2000.

—. "Evolução histórica dos distritos e os processos de emancipação: Nilópolis". In TORRES, Gênesis (org.). Baixada Fluminense: a construção de uma história: sociedade, economia, política. São João de Meriti: IPAHB, 2008. 
OLIVEIRA, Rafael da Silva (org.). Baixada Fluminense: novos estudos e desafios. [s.1.]: Paradigma Editora, 2004.

PACHECO, Susana Mara Miranda. Produção e reprodução de loteamentos na periferia do Rio de Janeiro (tese). UFRJ, 1984.

PERES, Guilherme. "O processo de urbanização: a Estrada de Ferro D. Pedro II”. In TORRES, Gênesis (org.). A contribuição de uma história. 1 ed. São João de Meriti-RJ: IPAHB, 2004.

—_. "Nilópolis, seu povo, sua história". Diário Fluminense, Nilópolis, nov. 2010-mar. 2011.

PIZARRO E ARAUJO, José de Souza Azevedo. Memórias históricas do Rio de Janeiro e das províncias annexas à jurisdiç̧ão do vice-rei do estado do Brasil. Rio de Janeiro: Impressão Regia, 1820-1822.

PRADO, Walter. História social da Baixada Fluminense: das sesmarias a foros de cidade. Rio de Janeiro: Ecomuseu, 2000.

RIBEIRO, Miguel Angelo e O’NEILL, Maria Mônica Vieira Caetano. “Considerações sobre a dinâmica populacional fluminense: contrastes entre a metrópole e o interior”. In MARAFON, G. J. e RIBEIRO, M. A. (orgs.). Revisitando o território fluminense IV. Rio de Janeiro: Gramma, 2012. . "Contrastes entre a metrópole e o interior fluminense a partir do urbano e do rural”. In FERNANDES, Ulisses et al. (orgs.). Velhos saberes, novas abordagens: a geografia à luz da contemporaneidade. Rio de Janeiro: Gramma, 2015.

ROCHA, André Santos da. "Os efeitos da reestruturação econômica metropolitana na Baixada Fluminense: apontamentos sobre o 'novo' mercado imobiliário da regiāo”. Revista Brasileira de Geografia Econômica, Rio de Janeiro, ano III, n. 6, jan.-jun. 2015, pp. 2-17.

SANTOS, Angela Moulin Simóes Penalva. Economia fluminense: superando a perda do dinamismo? S.1., 2002. Disponível em: www2.uerj.br/IPP.

SEGATAS SOARES, Maria Therezinha de. "Nova Iguaçu: absorção de uma célula urbana pelo grande Rio de Janeiro". Revista Brasileira de Geografia, Rio de Janeiro, ano 24, n. 2, abr.-jun. 1962, pp. 157-241.

SILVA, Maria Fatima de Souza. Das terras de Mutambó ao município de Mesquita-RJ: memórias da emancipação nas vozes da cidade. Mesquita/RJ: Entorno, 2007.

SIMŌES, Manoel Ricardo. A cidade estilhaçada: reestruturação econômica e emancipaçôes municipais na Baixada Fluminense. 1 ed. Mesquita-RJ: Entorno, 2008.

SOUZA, Marlucia Santos de. Escavando o passado da cidade: história política da cidade de Duque de Caxias. Duque de Caxias/RJ: APPH-CLIO, 2014.

TCE. Tribunal de Contas do Estado do Rio de Janeiro. Estudos socioeconômicos dos municípios: edições 2007 a 2012. Disponível em: http://www.tce.rj.gov.br. Acesso em: 21 out. 2015.

TORRES, Gênesis. "Baixada Fluminense: o processo de ocupação pela fé". In __ (org.). Baixada Fluminense: a construção de uma história: sociedade, economia, política. São João de Meriti: IPAHB, 2004. 


\title{
Situando Duque de Caxias no contexto metropolitano da Baixada Fluminense: de cidade-dormitório a cidade plena ${ }^{1}$
}

\author{
Leandro Almeida da Silveira ${ }^{2}$ \\ Miguel Ângelo Campos Ribeiro ${ }^{3}$
}

ocalizado na periferia da antiga capital federal Rio de Janeiro, o município de Duque de Caxias
(DC), que pode ser visto na Figura 1, apresenta indicadores econômicos e sociais bastante confli-
tantes. Por um lado, possui o terceiro maior PIB entre os municípios do estado do Rio de Janeiro
e o $24^{\circ}$ entre todos os do Brasil (IBGE, 2015). Ao mesmo tempo, no Índice de Desenvolvimento
Humano Municipal (IDHM), Caxias ocupa as $49^{\mathrm{a}}$ e $1.574^{\mathrm{a}}$ (PNUD, 2013) colocações no estado e
no país, respectivamente. Portanto, nota-se uma situação social extremamente precária e aparente-

1 Dedicamos este artigo à memória do Prof. Dr. Maurício de Almeida Abreu, em agradecimento pela orientação e a participação direta na formação de um de seus autores, por sua enorme contribuiçãoo aos estudos de Geografia do Rio de Janeiro e por ter sido tantas vezes fonte de inspiração para nós e tantos outros geógrafos.

2 Leandro Almeida da Silveira concluiu o bacharelado e a licenciatura em Geografia pela Universidade Federal do Rio de Janeiro (2009), tendo se tornado especialista em Políticas Públicas no Estado do Rio de Janeiro (2013) e mestre em Geografia, ambos pela Universidade do Estado do Rio de Janeiro (2016). Atualmente, é professor do Ensino Básico e Tecnológico no Colégio Pedro II, campus Duque de Caxias.

3 Miguel Ângelo Campos Ribeiro graduou-se em Geografia pela Universidade Federal Fluminense (1971), concluiu o mestrado em Geografia pela Universidade Federal do Rio de Janeiro (1982) e o doutorado em Geografia pela Universidade Federal do Rio de Janeiro (1998). Atualmente é professor associado da Universidade do Estado do Rio de Janeiro. Com experiência na área de Geografia Humana, atua principalmente com o estado do Rio de Janeiro, focando nas temáticas do Turismo Urbano e Rural, na rede de localidades centrais, na regionalização e na organização espacial. Atua também em pesquisas voltadas à atividade de prostituição na cidade do Rio de Janeiro. 
mente contrastante com a grande produção de riqueza de DC. Ademais, é possível observar também profundas disparidades dentro do próprio município.

Figura 1. Localização do município de Duque de Caxias

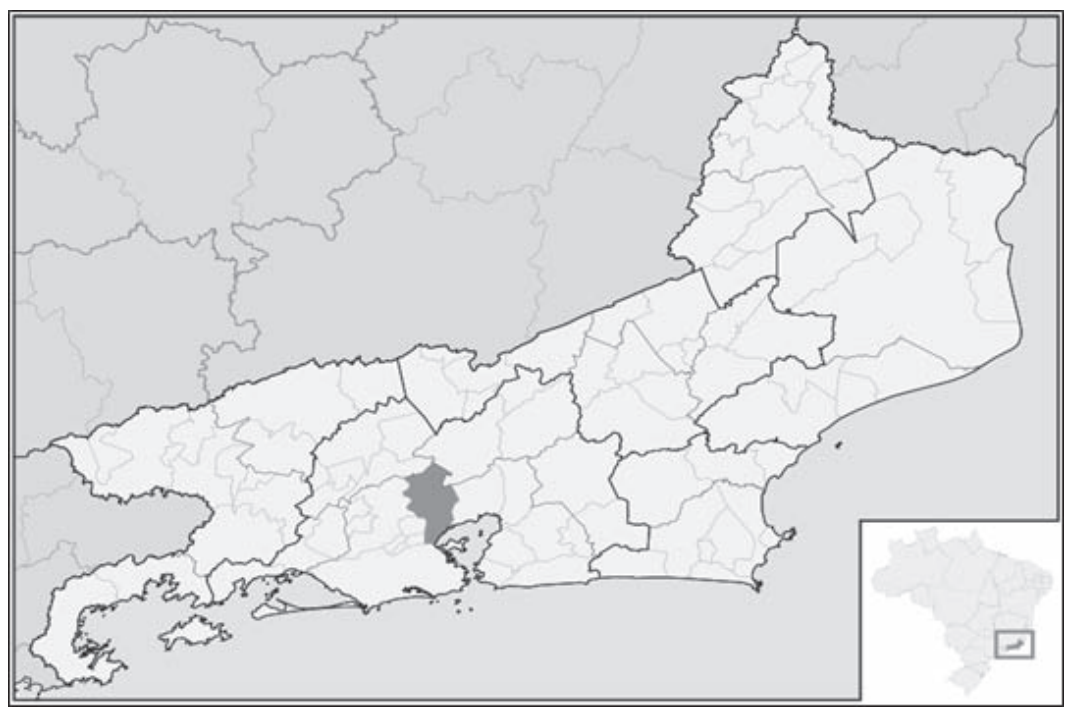

Fonte: http://pt.wikipedia.org/wiki/Ficheiro:RiodeJaneiro_Municip_DuquedeCaxias.svg.

Este artigo traça um panorama socioeconômico do município de Duque de Caxias. Consideramos que é importante entender a dinâmica atual e a espacialidade da economia municipal, incluindo as principais fontes de arrecadação e de que forma essa renda se distribui pelo município, uma vez que o vigor expresso pelos números do PIB é bastante concentrado em determinadas localidades. Assim, buscamos captar os aspectos contemporâneos do município à luz de sua evolução histórica, com destaque para o período do século XX, momento em que a população e a desordem urbana se expandiram de forma acelerada nessa localidade.

No entanto, Duque de Caxias, São João de Meriti, Nilópolis e Nova Iguaçu integravam um único município até a década de 1940. Durante muito tempo, todo o território que "se estende dos limites serranos de Miguel Pereira a Petrópolis e destes até o contorno da Baía de Guanabara, na foz do rio Meriti, e deste aos contrafortes do Gericinó até Itaguaî" (Nogueira, 2008, p.5) fazia parte do 
município de Nova Iguaçu. Em 1943, porém, a emancipação do então distrito de Duque de Caxias deu início a uma sequência de fragmentaçōes ${ }^{4}$ na Baixada Fluminense ${ }^{5}(\mathrm{BF})$.

Portanto, durante a maior parte de sua existência, a história da ocupação do município de Duque de Caxias se confunde com a de seus vizinhos - o município do Rio de Janeiro e sua área de expansão no entorno imediato, ou seja, os demais municípios da Baixada Fluminense. Inseridos na Região Metropolitana ${ }^{6}$ do Rio de Janeiro (RMRJ), tais municípios compartilham entre si uma série de características em comum. Por isso mesmo, para compreender a situação socioeconômica e as desigualdades que surgiram em Duque de Caxias, consideramos necessário revisitar o processo de construção desse município e da BF. Portanto, apresentamos também, de forma breve, a formação histórica e territorial dessa região e suas principais características.

\section{Panorama geográfico e socioeconômico atual de Duque de Caxias}

Situado na Baixada Fluminense, Duque de Caxias tem como limites os municípios de Miguel Pereira, Magé, Rio de Janeiro, São João de Meriti e Nova Iguaçu. Seu território é dividido em quatro distritos: Duque de Caxias $\left(1^{\circ}\right)$, Campos Elíseos $\left(2^{\circ}\right)$, Imbariê $\left(3^{\circ}\right)$ e Xerém $\left(4^{\circ}\right)$, que, por sua vez, se dividem em diversos bairros, como registra a Figura 2.

\footnotetext{
${ }^{4}$ Com mais de $1.500 \mathrm{~km}^{2}$, o município de Nova Iguaçu passou a sofrer grande pressão populacional e política, clamando por melhorias urbanas, como saneamento, água, equipamentos de saúde e de educação, principalmente após a Segunda Guerra Mundial, o que levou ao início do processo de emancipação na Baixada Fluminense. De acordo com Marcus Nogueira (2008, p. 5), "esse fenômeno alijou, de forma rápida e brutal, as históricas e tradicionais famílias que ocupavam a região. Desaparecem os Soares, os Souza e Mello, os Telles de Menezes, os Tavares Guerra, os Coelhos da Rocha, entre outros", consolidando novas elites e forças políticas no espaço da Baixada.

5 O topônimo Baixada Fluminense tem origem no latim flumineus, estando relacionado às expressóes "do rio" e "das águas". Essas expressões foram empregadas pelos colonizadores portugueses por conta do caráter geomorfológico da área, em "cujo terreno pantanoso abrigavam-se os índios tupinambás, da aldeia dos índios jacutingas ou iacotins”(Lima, 2010, p.140). Outras aplicações do termo Baixada Fluminense serão apresentadas mais adiante.

${ }^{6}$ Com o ingresso recente dos municípios de Cachoeiras de Macacu e Rio Bonito em dezembro de 2013, a Região Metropolitana do Rio de Janeiro passou a incluir 21 municípios: Rio de Janeiro, Belford Roxo, Duque de Caxias, Guapimirim, Itaboraí, Japeri, Magé, Maricá, Mesquita, Nilópolis, Niterói, Nova Iguaçu, Paracambi, Queimados, São Gonçalo, São João de Meriti, Seropédica, Tanguá, Itaguaí, Rio Bonito e Cachoeiras de Macacu. Em 2015, esse conjunto de municípios abrigava cerca de 12 milhões de habitantes.
} 
Figura 2. Bairros e distritos de Duque de Caxias

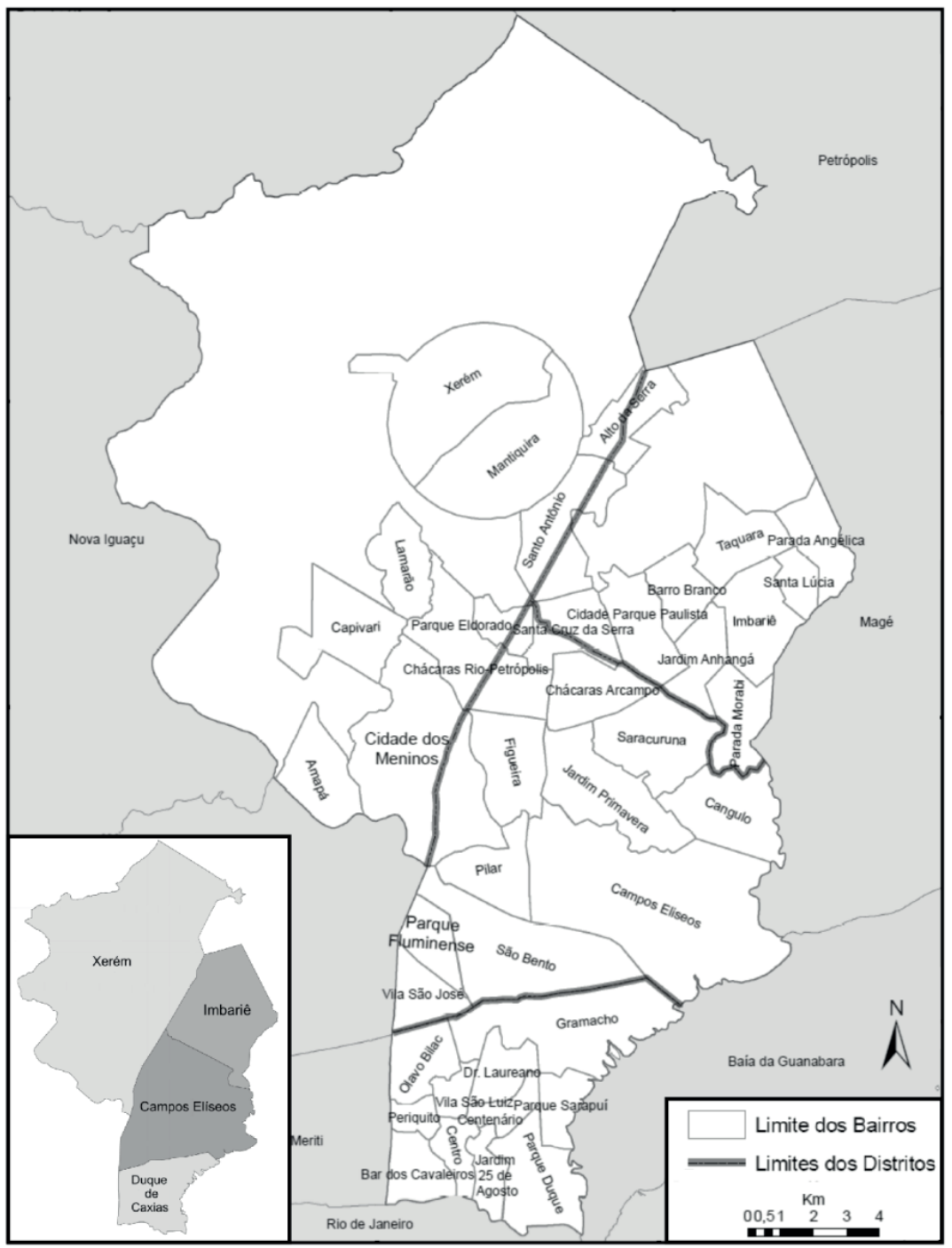

Fonte: Adaptado de Tenreiro (2012, pp. 21-2).

Segundo estimativa atualizada do IBGE (2015), atualmente o município concentra uma população de 882.729 residentes, o que o torna um dos mais populosos do estado do Rio de Janeiro $\left(3^{\circ}\right)$, à retaguarda somente da capital, Rio de Janeiro, e de São Gonçalo; e do Brasil $\left(18^{\circ}\right)$, possuindo mais habitantes do que diversas capitais estaduais brasileiras. A população se localiza principalmente nos bairros situados nos distritos 1 e 2 (Gráfico 1), mais próximos à capital, Rio de Janeiro, e os primeiros a sofrerem o processo de loteamento de suas terras. 
Situando Duque de Caxias no contexto metropolitano da Baixada Fluminense

Gráfico 1. População de Duque de Caxias por distrito (2010)

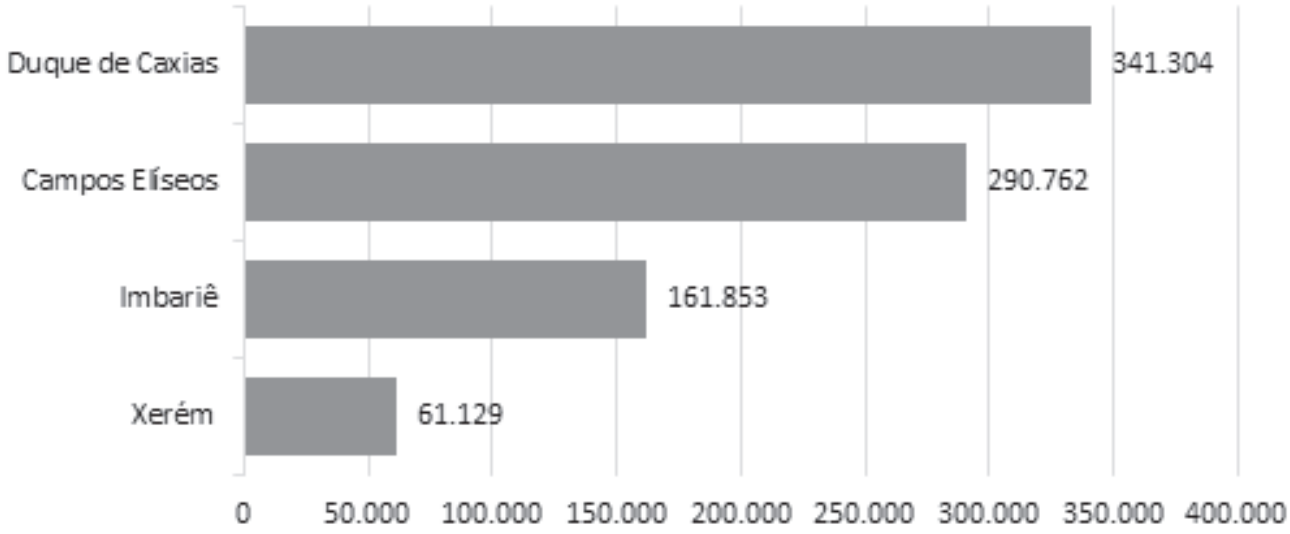

Fonte: Elaborado a partir de dados do TCE (2014, p. 11).

A quase totalidade dos munícipes locais ocupa áreas urbanas (Tabela 1). Essa situação condiz com sua posição de município metropolitano, seguindo o padrão predominante na maior parte das demais municipalidades do estado do Rio de Janeiro, essencialmente urbano.

Tabela 1. População urbana e rural de Duque de Caxias (1940-2010)

\begin{tabular}{|l|c|c|c|c|c|}
\hline Ano & $\begin{array}{c}\text { Populaçáo } \\
\text { Total }\end{array}$ & População Urbana & \% & $\begin{array}{c}\text { Populaçáo } \\
\text { Rural }\end{array}$ & $\mathbf{( \% )}$ \\
\hline 1940 & 28.328 & 23.963 & 84,6 & 4.365 & 15,4 \\
\hline 1950 & 92.459 & 74.565 & 80,4 & 17.894 & 19,6 \\
\hline 1960 & 241.026 & 176.306 & 72,1 & 67.313 & 27,9 \\
\hline 1970 & 431.397 & 404.496 & 93,8 & 26.901 & 6,2 \\
\hline 1980 & 575.814 & 555.208 & 96,4 & 20.606 & 3,6 \\
\hline 1991 & 667.821 & 664.745 & 99,5 & 3.673 & 0,5 \\
\hline 2000 & 775.456 & 772.327 & 99,6 & 3.129 & 0,4 \\
\hline 2010 & 855.048 & 852.138 & 99,7 & 2.910 & 0,3 \\
\hline
\end{tabular}

Fonte: Elaborado a partir de dados dos Censos do IBGE e de Beloch (1986).

Assim como observado nos demais municípios da Baixada, pode-se notar diariamente uma intensa migração pendular de cidadãos caxienses em direção ao Rio de Janeiro. Enquanto isso, a vida social e o comércio de varejo estão concentrados, predominantemente, nos fins de semana. Entretanto, apesar dessas características, atualmente não é adequado classificar Duque de Caxias como uma cidade-dormitório. ${ }^{7}$ Entre suas características, o município se distingue de outros da Baixada e da Região Me-

7 Ver Lacerda (2008). 
tropolitana por apresentar vida econômica relativamente própria e polarizar outros municípios menores do entorno, especialmente Belford Roxo, São João de Meriti e Magé. De acordo com Simões:

Estas cidades externas [...] reproduzem na escala regional o modelo de organização socioespacial da metrópole e da hierarquização das relações sociais, econômicas e políticas que se estabelecem entre esses núcleos e aqueles que acabam por ser polarizados. [...] Desse modo, Nova Iguaçu e Duque de Caxias possuem, cada uma delas, a sua centralidade e um território subordinado, onde as relações socioeconômicas e políticas se instalaram em meio a conflitos entre os grupos de interesse dos núcleos dominantes e dos núcleos dominados (Simōes, 2007, p. 193).

Outra diferença fundamental de Duque de Caxias em relação aos muncípios vizinhos é o tamanho e o peso de sua economia sobre o PIB do estado do Rio de Janeiro, como se nota na Figura 3.

Figura 3. Contribuição dos municípios para o PIB do estado do RJ (2010)

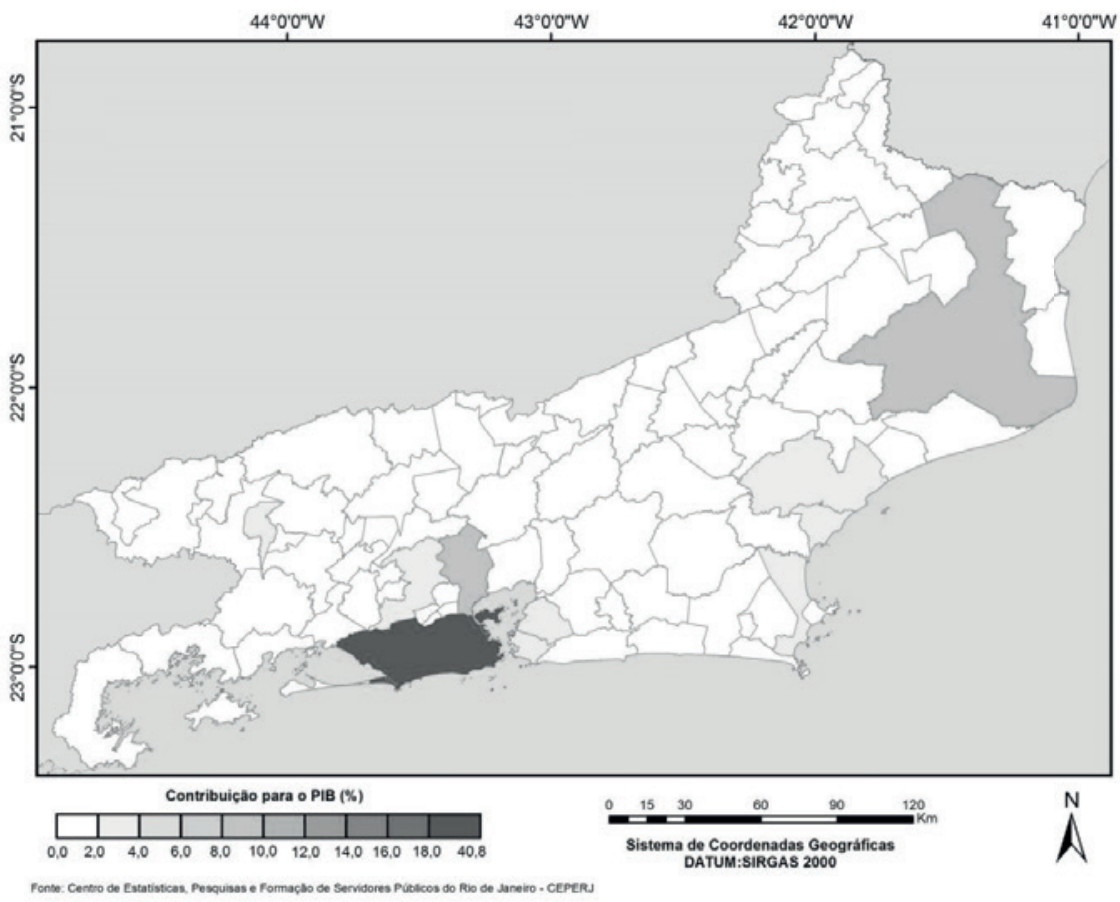

Fonte: Tenreiro (2012, p. 17).

Segundo o IBGE (2015), Duque de Caxias possui um PIB de R \$ 23,4 bilhões, o maior valor de todos os municípios da Baixada Fluminense, o segundo maior da RMRJ, o terceiro do estado do Rio de 
Janeiro e o $24^{\circ}$ entre todos os municípios do Brasil (IBGE, 2015). ${ }^{8}$ Tal destaque no campo da economia já ocorre há algumas décadas, especialmente a partir dos anos 1960, quando ocorreu a instalação da Refinaria de Duque de Caxias (Reduc) na cidade. Durante a década de 1980, o município apresentou crescimento econômico de 32,5\%. No biênio 1997-1998, num universo de mais de cinco mil municípios, foi um dos dez com maior crescimento econômico (Petrakis, 2009). Como se observa no Gráfico 2, a maior parte da economia caxiense corresponde ao setor de serviços. ${ }^{9}$ A indústria ocupa a segunda colocação, enquanto a agropecuária é responsável por uma fatia mínima da geração de riqueza, ${ }^{10}$ sendo praticada apenas em pequenas áreas de Xerém, $4^{\circ}$ distrito do município (Simōes, 2015).

Gráfico 2. Duque de Caxias: participação dos setores da economia no PIB (2013)

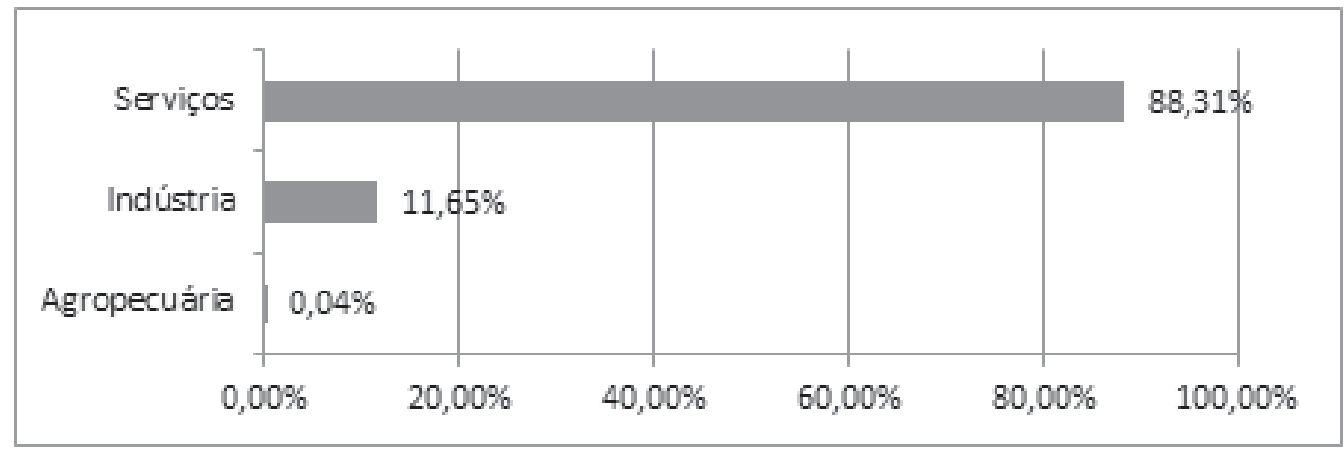

Fonte: Elaborado com dados do IBGE Cidades (2015).

O centro comercial de Caxias é um dos mais importantes e diversificados do estado do Rio de Janeiro, com uma variedade de bens e serviços presente apenas nos maiores centros comerciais dos municípios de Nova Iguaçu, Niterói e Rio de Janeiro. Há também uma série de outras atividades econômicas desenvolvidas no município e em processo de expansão, dentre as quais destacam-se: o forte crescimento dos empreendimentos de transporte e logística; a instalação de grandes centros de distribuição das Casas Bahia, Carrefour e Hortifruti; o parque gráfico do jornal O Globo; as recém-chegadas fábricas da empresa alimentícia Bunge (Moinho Carioca) e da produtora de insumos navais Rolls Royce; a Coca-Cola, cuja fábrica está em fase final de construção; e os centros comerciais Caxias Shopping e Shopping Outlet Premium.

Na Figura 4, observamos a distribuição espacial de algumas das principais empresas e empreendimentos industriais e comerciais instalados ou em instalação no município. Percebe-se que

\footnotetext{
8 Os dados foram obtidos no sítio eletrônico IBGE Cidades em 2015 e podem ser consultados em http://www. cidades.ibge.gov.br, embora correspondam a uma base de dados de 2012-2013.

9 Inclui comércio, administração, saúde e educação pública e seguridade social

${ }^{10}$ Segundo Beloch (1986), desde a década de 1940 a indústria é uma atividade mais importante do que a agricultura em Duque de Caxias.
} 
essas instalações se situam, em sua maioria, nas áreas do $1^{\circ}$ e $2^{\circ}$ Distritos e nas margens da rodovia Washington Luiz (BR-040).

Figura 4. Principais empreendimentos no município de Duque de Caxias

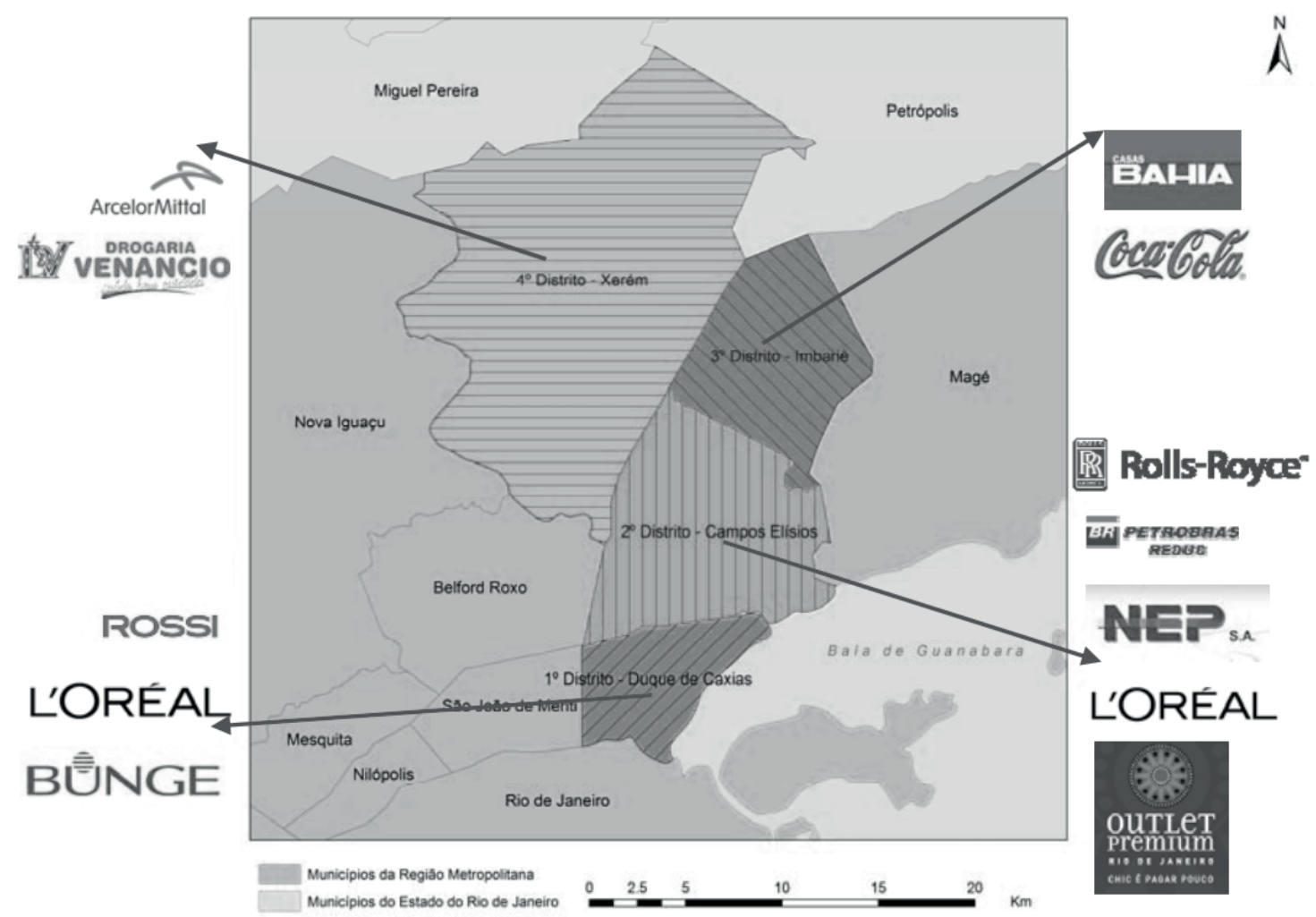

Fonte: Adaptado de Silva (2014, p. 120).

A grande presença de empresas de diversos setores pode ser explicada pela existência de amplos espaços no município, favoráveis à instalação de grandes empreendimentos. Outro elemento diferencial é a privilegiada posição geográfica caxiense, próxima a importantes vias de acesso e ao mercado consumidor do Rio de Janeiro. Tais razões podem ser encontradas na entrevista concedida ao jornal $O$ Dia por Níveo Maluf, diretor da Bunge do Brasil, empresa de alimentos que está investindo R \$ 500 milhões na construção do novo Moinho Fluminense. Segundo Maluf:

[...] A escolha por Duque de Caxias foi estratégica, sendo a cidade que ofereceu as melhores condições de atuação e logística para receber a transferência do atual Moinho Fluminense e o Centro de Distribuição Rio, que serão transferidos para uma área de 90 mil metros quadrados. A rodovia Washington Luiz já é conhecida como a esquina do Brasil (Gimenez, 2014. Publicado em O Dia, 08 de abril de 2014, edição on-line). 


\section{Situando Duque de Caxias no contexto metropolitano da Baixada Fluminense}

Entre as condições favoráve is de logística, estão a distância de apenas $17 \mathrm{~km}$ até o núcleo da metrópole fluminense e a localização limítrofe com municípios como Belford Roxo, São João de Meriti, Nova Iguaçu, Petrópolis e Magé. No que diz respeito à rede de transportes, o município de Caxias se beneficia por ser cortado por duas rodovias federais (a BR-040 e a BR-116) e uma estadual (RJ-071 ou Linha Vermelha); pela proximidade com outras vias importantes, como a avenida Brasil e a Linha Amarela; e pela curta distância até o aeroporto internacional Tom Jobim. Além disso, é possível apontar também a economia de aglomeração formada, uma vez que a chegada de uma série de empresas tem estimulado a instalação de terminais de cargas e de logística.

Também merece destaque o Polo Moveleiro de Duque de Caxias, que atualmente ocupa cerca de $50 \mathrm{mil} \mathrm{m}^{2}$ no município. Sua origem remonta ao ano de 1994, quando houve a instalação de fá-

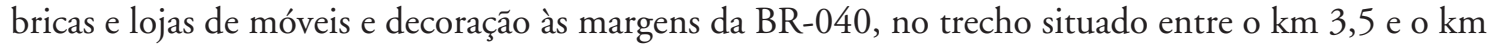
7, nas imediações dos bairros Jardim Gramacho e Vila São Luiz (Figuerêdo, 2010). Cabe mencionar ainda o setor de vestuário, pois diversos bairros do $1^{\circ}$ Distrito ${ }^{11}$ contam com confecções cuja produção de roupas se destina a grandes polos ${ }^{12}$ atacadistas e varejistas. ${ }^{13}$ De acordo com Santos (2015), predominam pequenas unidades industriais com menos de vinte funcionários, repetindo o modelo observado nas empresas do polo moveleiro.

No setor secundário, porém, nenhuma atividade é tão importante para Duque de Caxias quanto a indústria química, responsável por cerca de $78 \%$ do total das atividades industriais estabelecidas no município (Ceperj, 2014; Sebrae, 2015). As responsáveis diretas por tamanho peso econômico são a Refinaria de Duque de Caxias (Reduc) e os polos petroquímico e gás-químico a ela associados, que fazem da cidade o principal espaço de produção de derivados de petróleo do estado do Rio de Janeiro (Ceperj, 2013). Portanto, apesar da relativa diversidade do setor industrial caxiense, formado por "mais de oitocentas fábricas" (Costa, 2012, p.267), é indiscutível a dependência econômica em relação à Reduc, principal empreendimento da cidade e marco do processo de industrialização estabelecido no município.

Localizada à margem direita da Rodovia BR-040, sentido Rio-Petrópolis, a Reduc foi inaugurada em 1961, sendo atualmente responsável por 1.800 empregos diretos e 10 mil vagas indiretas (Lafraia, 2011). Junto a ela, estão o polo petroquímico, criado nos anos 1970 e 1980, e o polo gás-químico, unidade de fabricação de polímeros inaugurada em 2005. Pode-se afirmar que a empresa alavanca a economia caxiense de forma direta e indireta, pois, além de sua grande produção, as in-

\footnotetext{
${ }^{11}$ Segundo Marcelo Santos (2015), destacam-se os bairros Bar dos Cavaleiros, Periquitos e Centenário.

${ }^{12}$ Situados na rodovia Washington Luiz, no calçadão de Caxias e em pequenos centros comerciais dos bairros Santa Cruz da Serra, Saracuruna, Jardim Primavera, Gramacho e Figueira.

${ }^{13}$ Cabe citar que, ao contrário do padrão identificado em outros municípios vizinhos, em Duque de Caxias o comércio atacadista gera maior faturamento do que o varejista (Plantek, 1999). Entre as razões que explicam esse fenômeno, está o fato de que o comércio varejista no município atende a um mercado consumidor composto, em sua maioria, por pessoas de baixo poder aquisitivo. Além disso, um dos fatores é o alto grau de informalidade dos pequenos estabelecimentos que atuam nesse tipo de atividade (Sebrae, 2015). Segundo Costa (2012, p. 269), porém, "a inexpressiva participação do comércio varejista de Duque de Caxias no seu PIB é explicada pelos [mais] altos valores da Refinaria do que pelo seu baixo desenvolvimento".
} 
dústrias que a cercam dependem de suas matérias-primas. Ademais, de acordo com Simōes (2015), o comércio e boa parte dos serviços têm parte de sua renda gerada pela venda de produtos e serviços prestados a essas empresas. Nesse contexto, a elevada riqueza produzida no município acaba por fazer com que a renda per capita (Gráfico 3), de cerca de R \$ 30 mil, seja a segunda maior da RMRJ, mesmo sendo a população caxiense muito numerosa.

Gráfico 3. Ranking do PIB per capita de municípios da RMRJ (2010)

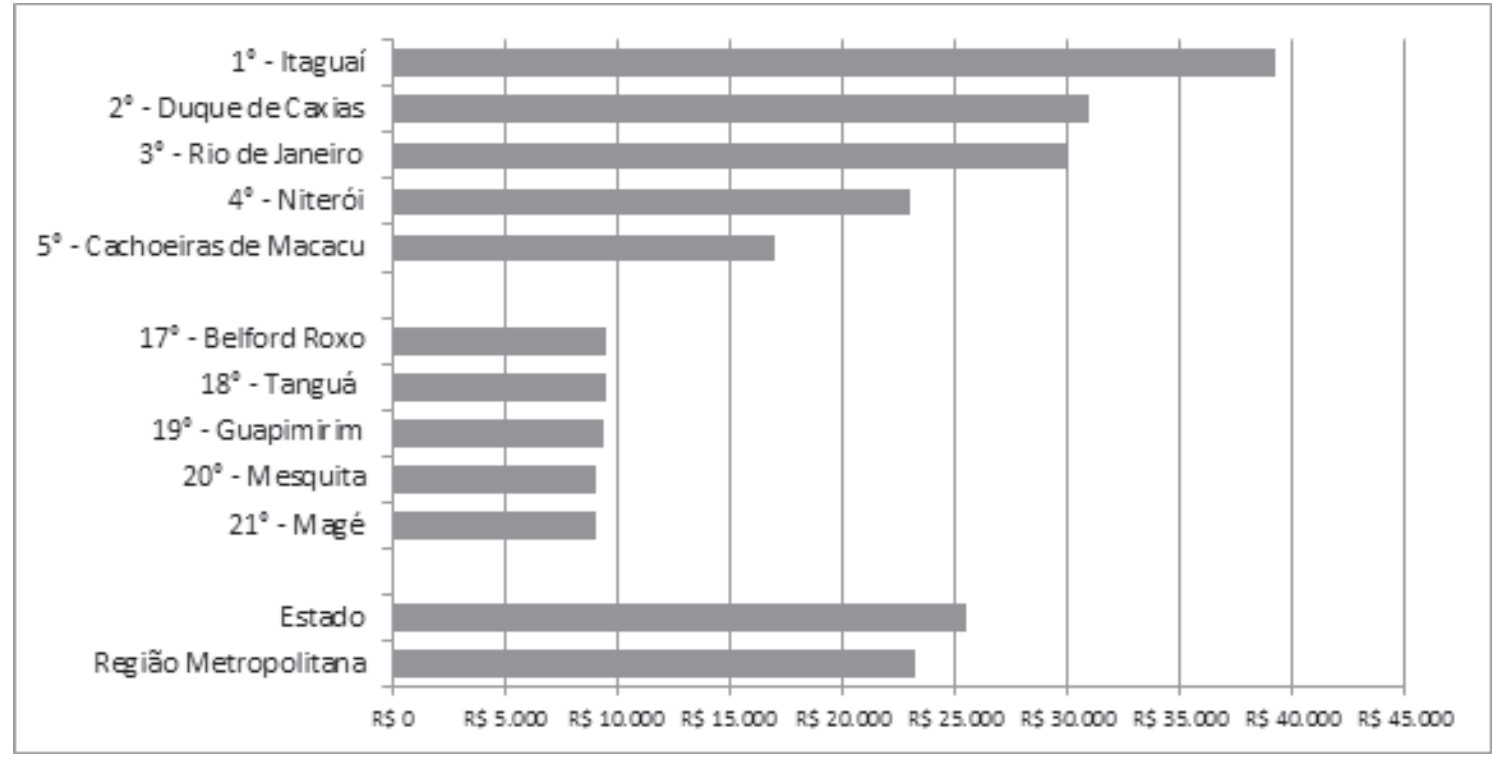

Fonte: Elaborado com dados do Ceperj (2013).

O patamar privilegiado ocupado por Duque de Caxias no ranking do PIB per capita se repete quando comparamos os salários médios pagos na Região Metropolitana. A Figura 5 mostra que DC se encontra em posição superior a vários outros municípios, sendo superado apenas por Rio de Janeiro e Seropédica. ${ }^{14}$

\footnotetext{
${ }^{14}$ Acreditamos que a situação de Seropédica nesse ranking seja resultado da combinação entre população reduzida e salários elevados pagos a professores, técnicos e demais funcionários pela Universidade Federal Rural do Rio de Janeiro, cujo campus principal se localiza no município.
} 
Figura 5. Salário médio nos municípios da RMRJ (2010)

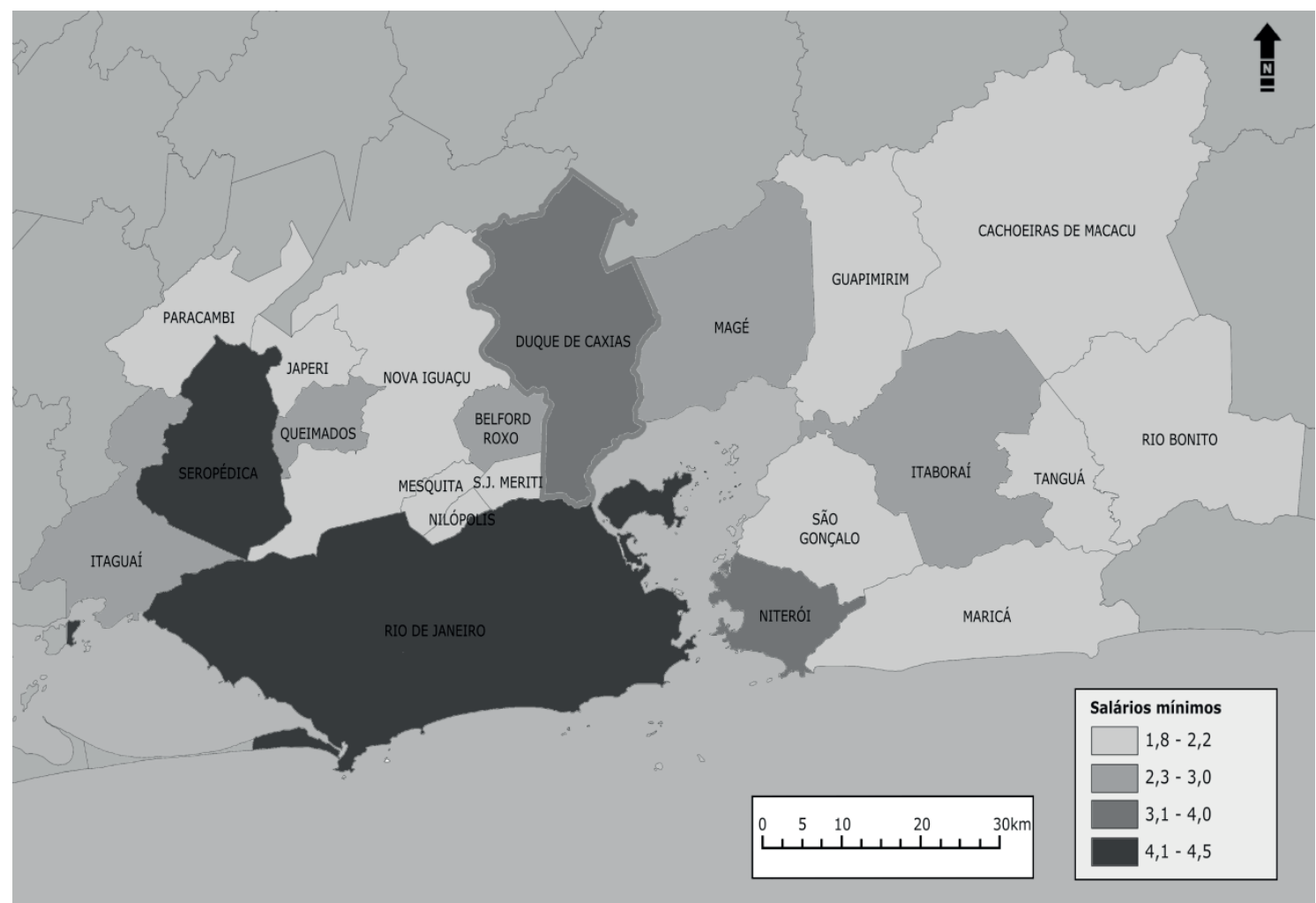

Fonte: Leandro Silveira. Elaborado com dados do IBGE (2010).

Além disso, Caxias se encontra no mesmo nível de salários médios de Niterói, município com qualidade de vida reconhecidamente elevada. Entretanto, a impressão de que ambos desfrutam da mesma situação relativamente confortável é enganosa. Afinal, o maior empregador da cidade de $\mathrm{Du}-$ que de Caxias é a Petrobras, cujo empreendimento central é uma refinaria. Portanto, os demais setores, como administração, gerência e pesquisa científica, responsáveis pela maior parte dos cargos com salários mais elevados, encontram-se fora da cidade, especialmente no centro do Rio de Janeiro e na ilha do Fundão.

Outro indicador que nos leva a refletir a respeito do tamanho do retorno financeiro resultante das atividades da Reduc em Duque de Caxias é o dos valores gerados pelas instituições financeiras. Segundo o TCE (2014), o movimento bancário corresponde a apenas 0,61\% do PIB municipal. A elevada movimentação financeira da Petrobras poderia ser um fator de alavancagem do setor bancário municipal, mas é realizada integralmente nas agências bancárias do Rio de Janeiro (Lafraia, 2011). Além disso, parte significativa dos empregos de alta qualificação - e, por conseguinte, de maior remuneração - gerados pela indústria química municipal acaba sendo ocupada por moradores de outras cidades, notadamente do Rio de Janeiro. A falta de instituiçóes de ensino que formem mão de obra 
qualificada para o setor e a baixa escolaridade média dos cidadãos caxienses acabam, portanto, por reduzir o ganho socioeconômico que poderia ser obtido pelo município com a presença da Reduc.

De modo geral, os moradores de Duque de Caxias são contratados em regime de terceirização e ocupam os cargos de melhor remuneração, como funções de operação, serviços de limpeza e manutenção (Simões, 2015). Com isso, a renda efetiva e a situação real dos habitantes no município não correspondem ao que se mostra na Figura 5, sendo mais bem retratadas quando se analisa a renda média domiciliar (Figura 6).

Figura 6. Renda média domiciliar nos municípios da RMRJ (2010)

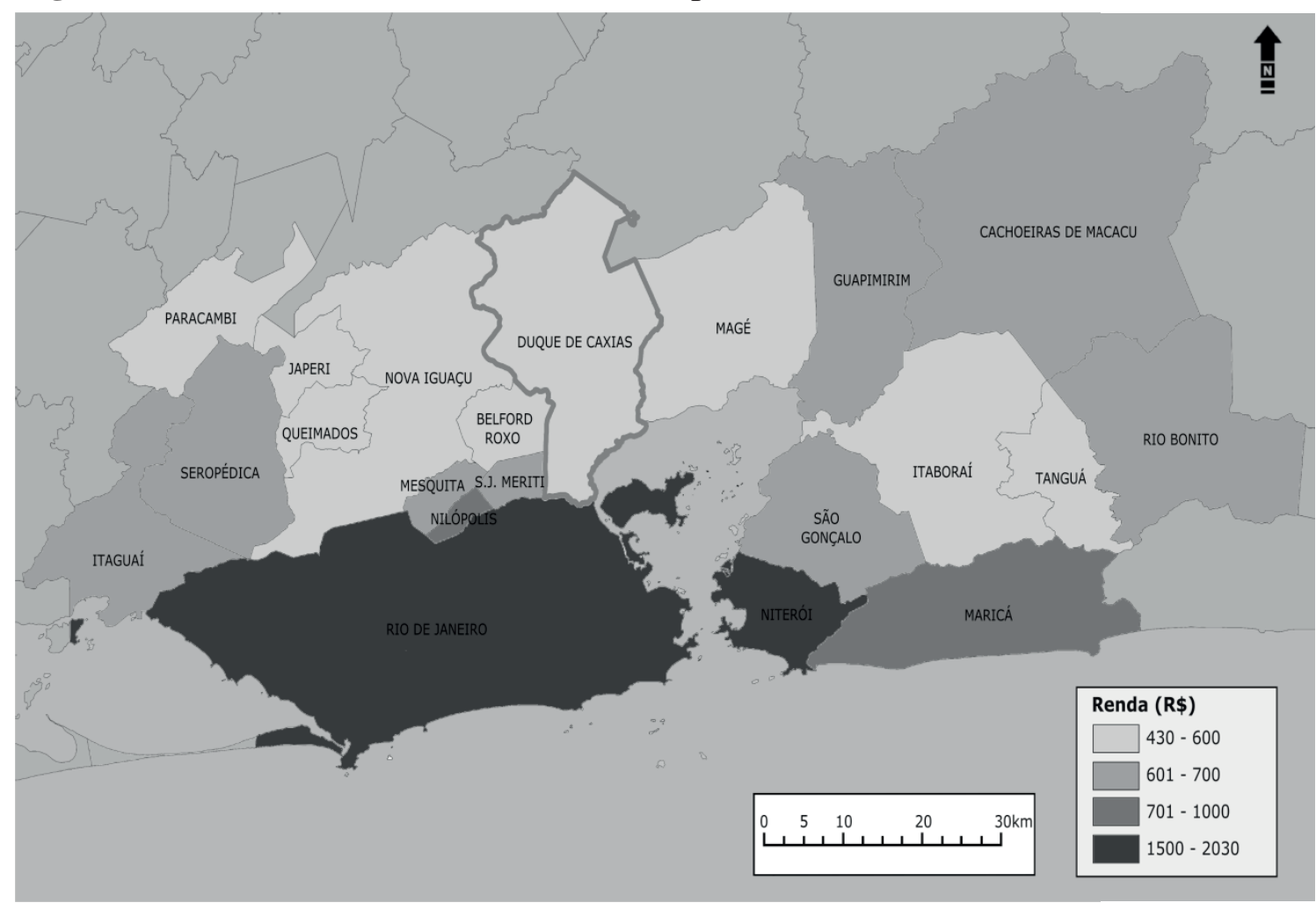

Fonte: Elaborado a partir de dados do IBGE (2010).

Nesse mapa, percebe-se que a situação de Duque de Caxias está piorando de forma significativa, com uma renda média domiciliar inferior à de municípios como Guapimirim, Nilópolis e São João de Meriti, cujas economias são muito menores. Dessa forma, a comparação entre os salários médios pagos e a renda média domiciliar nos leva a afirmar que há uma drenagem da riqueza produzida na cidade para outros municípios, especialmente para a capital, Rio de Janeiro, moradia dos funcionários de maior remuneração, sede da Petrobras e de suas empresas-satélite, além de local em que se processa a enorme movimentação bancária da empresa. 
A baixa renda média domiciliar dos habitantes de DC acaba por influenciar diretamente a qualidade de vida desfrutada pela população, incluindo o tipo de moradia dos cidadãos locais. Além do elevado número de habitações precárias, Caxias possui a maior população absoluta vivendo em favelas de toda a Baixada Fluminense e a segunda maior do estado, como se vê na Tabela 2.

Tabela 2. População residente total e em aglomerados subnormais em municípios selecionados da RMRJ (2010)

\begin{tabular}{|c|c|c|c|c|c|c|}
\hline \multirow{3}{*}{ Municípios } & \multicolumn{3}{|c|}{ População (2000) } & \multicolumn{3}{|c|}{ População (2010) } \\
\hline & \multirow[t]{2}{*}{$\begin{array}{l}\text { Habitantes } \\
\text { (Total) }\end{array}$} & \multicolumn{2}{|c|}{$\begin{array}{l}\text { Residentes em aglome- } \\
\text { rados subnormais }\end{array}$} & \multirow{2}{*}{$\begin{array}{l}\text { Habitantes } \\
\text { (Total) }\end{array}$} & \multicolumn{2}{|c|}{$\begin{array}{l}\text { Residentes em aglome- } \\
\text { rados subnormais }\end{array}$} \\
\hline & & Total & $\%$ & & Total & $\%$ \\
\hline Rio de Janeiro & 5.857 .904 & 1.095 .949 & $18,7 \%$ & 6.320 .446 & 1.393 .314 & $22,0 \%$ \\
\hline São João de Meriti & 449.476 & 11.875 & $2,6 \%$ & 458.673 & 47.322 & $10,3 \%$ \\
\hline Belford Roxo & 434.474 & 1.757 & $0,4 \%$ & 469.332 & 35.480 & $7,6 \%$ \\
\hline Duque de Caxias & 775.456 & 56.659 & $7,3 \%$ & 855.048 & 61.452 & $7,2 \%$ \\
\hline Queimados & 121.993 & 1.286 & $1,1 \%$ & 137.962 & 5.428 & $3,9 \%$ \\
\hline Japeri & 83.278 & 14 & $0,0 \%$ & 95.492 & 2.377 & $2,5 \%$ \\
\hline Nilópolis & 153.712 & 1.616 & $1,1 \%$ & 157.425 & 3.557 & $2,3 \%$ \\
\hline Nova Iguaçu & 920.599 & 5.667 & $0,6 \%$ & 796.257 & 9.541 & $1,2 \%$ \\
\hline Mesquita & - & - & - & 168.376 & 1.061 & $0,6 \%$ \\
\hline
\end{tabular}

Fonte: Elaborado a partir de dados do IBGE Cidades (2015).

A observação dessa tabela nos leva a concluir que os municípios da Baixada Fluminense com as maiores porcentagens de habitantes residindo em aglomerados subnormais são aqueles situados nas imediaçôes da Zona Norte da cidade do Rio de Janeiro, ou seja, São João de Meriti, Belford Roxo e Duque de Caxias. De acordo com Pierre Costa (2012), a proximidade com o núcleo da metrópole e a grande quantidade de terras disponíveis e situadas em áreas de baixo interesse especulativo - muitas delas públicas -, tais como margens de rios, mangues e brejos, são alguns dos fatores que fizeram com que DC se tornasse mais favelizada do que os demais municípios da Baixada.

$\mathrm{Na}$ Tabela 2, também se observa diminuição relativa do número de residentes em aglomerados subnormais em Caxias. Em 2000, 7,3\% da população total do município residia nesse tipo de habitação. Em 2010, o número passou a ser de 7,2\%. Apesar disso, pode-se afirmar que DC possui uma elevada proporção de habitantes vivendo em condições precárias, cuja qualidade de vida se mantém em níveis muito baixos. Portanto, se Caxias ocupa posição privilegiada no estado do Rio de Janeiro e na RMRJ quando se comparam os indicadores econômicos, a situação muda radicalmente quando se 
apresentam os dados sociais. No Gráfico 4, podemos observar o IDHM ${ }^{15}$ de alguns dos municípios da RMRJ, com Duque de Caxias ocupando a 12a colocação - em comparação com os demais municípios do estado, DC se encontra na nada honrosa 49a colocação, de um total de 92 municípios.

Gráfico 4. Índice de Desenvolvimento Humano Municipal (2010)

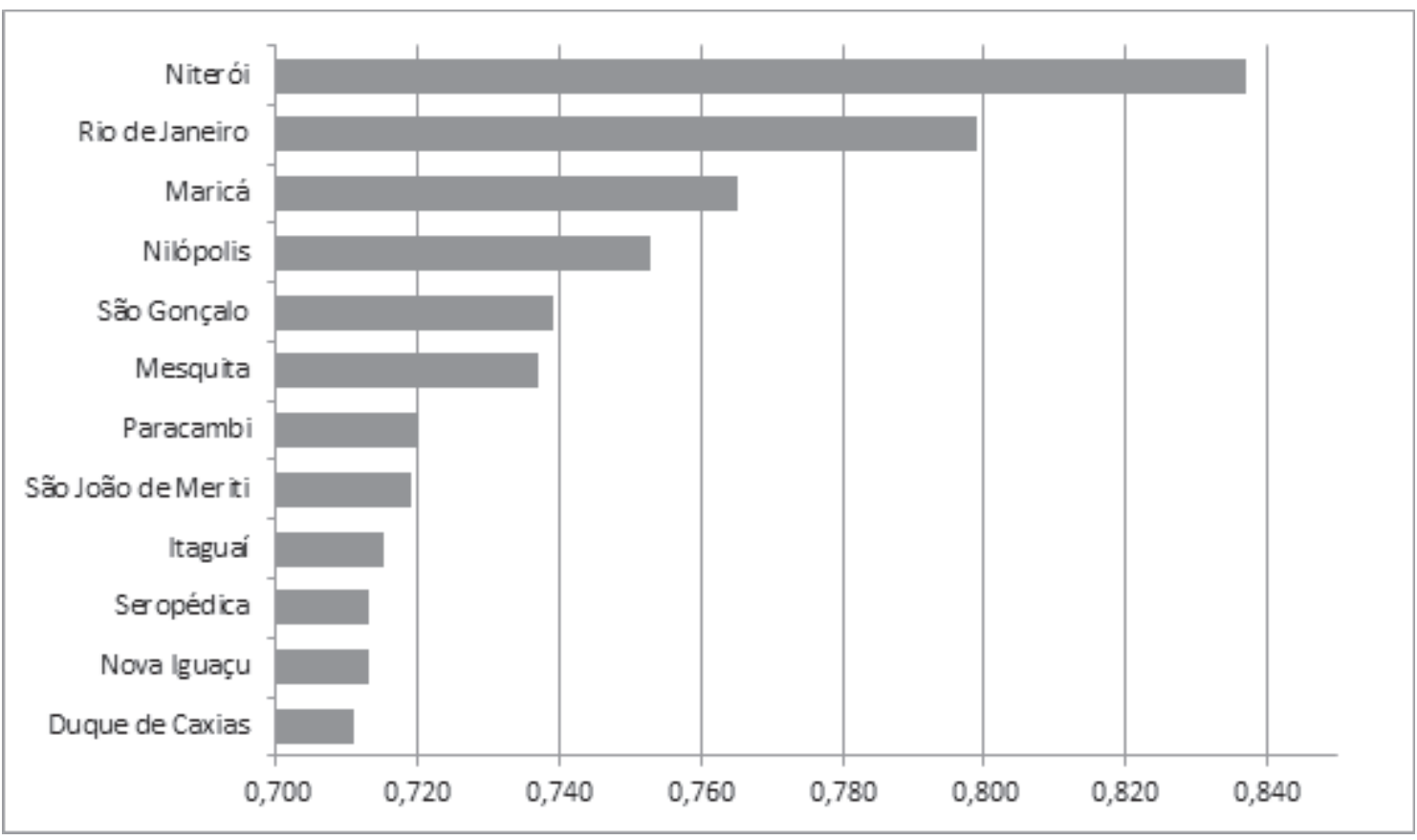

Fonte: Elaborado a partir de dados do PNUD (2013).

Portanto, esses indicadores socioeconômicos gerais do município denotam um forte contraste: por um lado, a elevada produção de riqueza local; por outro, a baixa renda média domiciliar e a péssima situação no ranking do IDH municipal. Contudo, esse dado ainda não reflete plenamente a realidade do município, já que representa uma média de indicadores das diversas localidades e bairros. Podemos realizar uma interpretação diferente de DC quando observamos a Figura 7, que apresenta as diferenças no IDH do interior dos municípios pertencentes à região metropolitana do Rio de Janeiro.

\footnotetext{
${ }^{15}$ O Índice de Desenvolvimento Humano Municipal (IDHM) utiliza cerca de dois mil indicadores de renda, educação e longevidade para estabelecer um parâmetro de acesso a direitos básicos de cidadania, como escola, saúde, saneamento, emprego e serviços públicos, o que, em tese, garante uma boa qualidade de vida. Por outro lado, a ausência ou deficiência desses serviços ou bens implica perda da qualidade de vida, o que se reflete em índices mais baixos.
} 
Figura 7. IDHM dos municípios da RMRJ (2010)

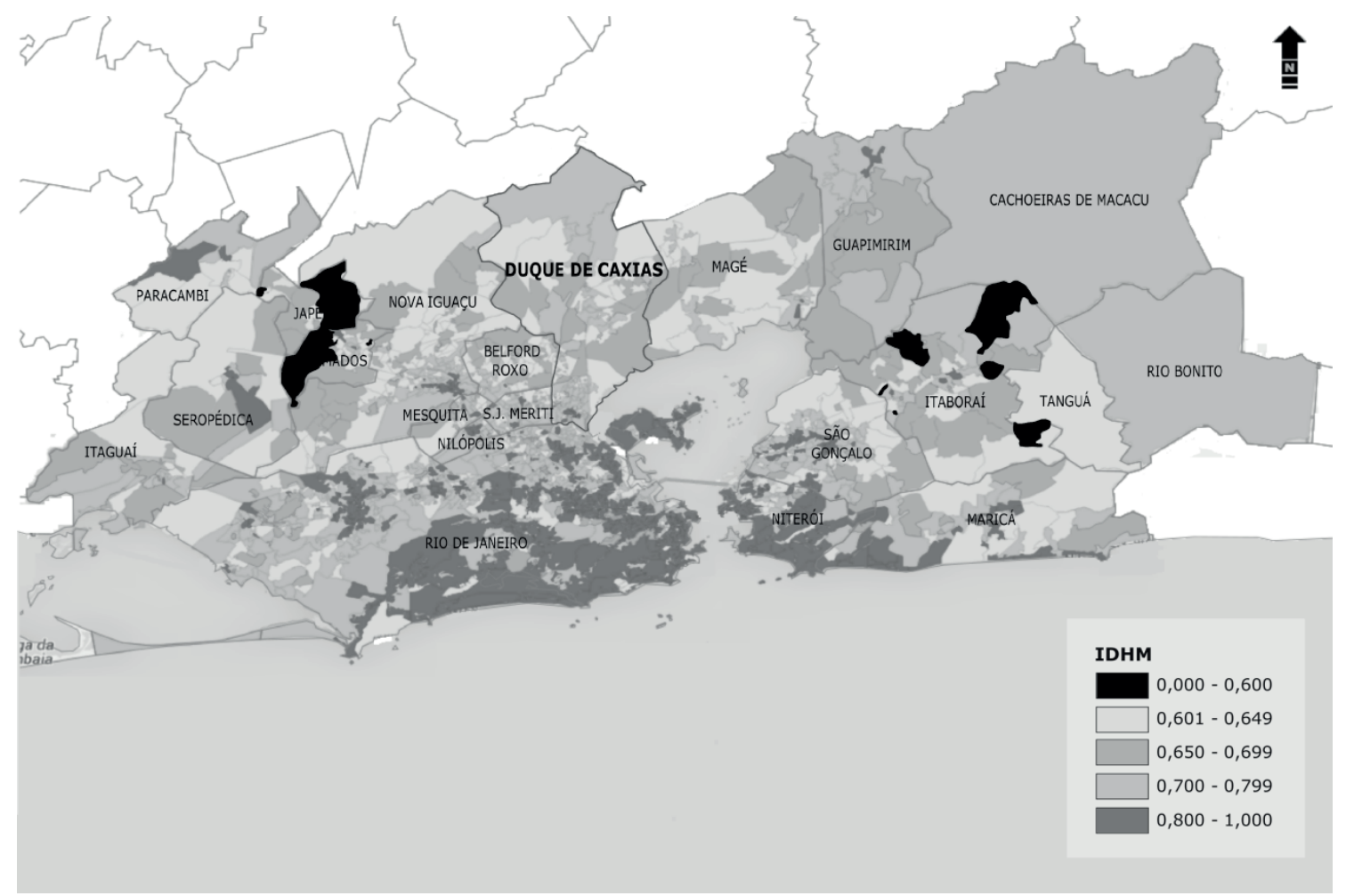

Fonte: Elaborado a partir de dados do PNUD (2013).

Dessa forma, conclui-se que, internamente, no município de DC há uma forte disparidade nos indicadores que medem a qualidade de vida, com predomínio de áreas precárias e muito precárias, embora também existam "ilhas" de prosperidade socioeconômica. Esse padrão, longe de ser exclusividade de Caxias, condiz com o que Mckenzie afirmou no início do século XX (1921): "A distribuição [...] da população [numa] grande cidade é determinada pelos interesses de forças econômicas que tendem a produzir estruturas similares em todas as grandes cidades" (1921, p. 147).

Às palavras escritas por Mckenzie, acrescentamos que esse processo não ocorre apenas nas grandes cidades, mas também na periferia, assim como em cidades de porte médio, como é o caso de Duque de Caxias. $\mathrm{O}$ autor defende que a população tende a se dividir em função de seu status econômico em áreas residenciais com valores diferenciados. Para ele, as disparidades de renda entre as famílias, causadas por diversas razões, estimulam a segregação da população em diferentes bairros. Para compreender o porquê de tais diferenças em Duque de Caxias, julgamos ser necessário revisitar, ainda que de forma breve, o surgimento do município e, inevitavelmente, da própria Baixada Fluminense. 


\title{
2. A gênese do espaço caxiense
}

\begin{abstract}
Quando, no dia 30 de agosto de 1993, a favela de Vigário Geral expunha ao mundo os 21 mortos da maior chacina cometida pela Polícia Militar no Rio de Janeiro, uma deputada federal lamentou, no rádio, a tragédia ocorrida naquela "favela da Baixada Fluminense" [sic]. Assim, o bairro, que, na verdade, pertence ao subúrbio carioca, foi incorporado à Baixada. Esse equívoco, por sua vez, revela o problema dos limites dessa região. $\mathrm{O}$ aspecto geográfico acaba se relacionando com o político e com o social na construção de fronteiras não muito precisas (Alves, 2003, p. 15).
\end{abstract}

De início, é importante frisar que não buscamos propor um conceito do que vêm a ser a Baixada da Guanabara e a Baixada Fluminense, nem lhes estabelecer limites definitivos. O propósito, aqui, é delimitá-las de uma forma mais apropriada no âmbito desta pesquisa, a partir de abordagens existentes, com o fim de justificar o recorte territorial escolhido.

\subsection{Discutindo a Baixada Fluminense}

É importante lembrar que a Baixada não existe oficialmente, pertencendo ao imaginário da geografia política e ao uso no cotidiano. À exceção da Secretaria Especial da Baixada Fluminense, criada e extinta no início dos anos 2000 (Simões, 2011), nenhum órgão público considerado para fins estatísticos ou de planejamento e intervenção estabeleceu uma delimitação oficial dessa unidade territorial. Em diversos trabalhos pesquisados, foram empregados conceitos variados, com a inclusão ou exclusão de alguns municípios de acordo com os critérios ou interesses em questão. Entretanto, mesmo sendo esse um conceito tão fluido, é possível apontar algum consenso a respeito.

Os municípios de Duque de Caxias e Nova Iguaçu aparecem em todas as definições de Baixada, sendo considerados, de forma unânime, os núcleos dessa região. Há consenso também de que pertencem à Baixada os municípios de Belford Roxo, São João de Meriti, Nilópolis, Mesquita, Queimados e Japeri, considerados satélites imediatos dos municípios-núcleo. Assim, as discordâncias giram em torno da inclusão ou não dos municípios mais afastados do núcleo-base: Magé, Guapimirim, Itaguaí, Seropédica e Paracambi.

De acordo com Simões (2015), o termo Baixada Fluminense (BF) não era utilizado pelos moradores, estudiosos, técnicos e membros do governo até o final do século XIX. O autor acrescenta que a expressão provém da geografia física, surgindo no momento em que as recém-criadas comissões de saneamento almejavam efetuar intervenções na região, com o objetivo de reduzir as inundações e as frequentes epidemias que as seguiam.

Do ponto de vista geográfico, a BF é uma planície que se estende paralelamente à costa em corredor entre a serra do Mar e o oceano (Beloch, 1986; Torres, 2008). Portanto, de acordo com esse critério, inclui terras desde Itaguaí até a divisa com o Espírito Santo. Ou seja, num sentido geomor- 


\section{Situando Duque de Caxias no contexto metropolitano da Baixada Fluminense}

fológico amplo, sua área abrange quase integralmente o litoral do estado do Rio de Janeiro (Oliveira, 2004; Simōes, 2011). Por isso, aqui esse recorte espacial será denominado Baixada Estadual.

No entanto, na década de 1930, Hildebrando de Góes propõe uma diferenciação das áreas dentro dessa Baixada Estadual, criando uma classificação fisiográfica que passou a ser usada regularmente por diversos geógrafos. Nela, Duque de Caxias se situaria na Baixada da Guanabara, que incluiria apenas as terras do entorno da Baía de Guanabara, indo de Guapimirim a Itaguaí (Figura 8).

Figura 8. Baixada da Guanabara e Região Metropolitana do Rio de Janeiro

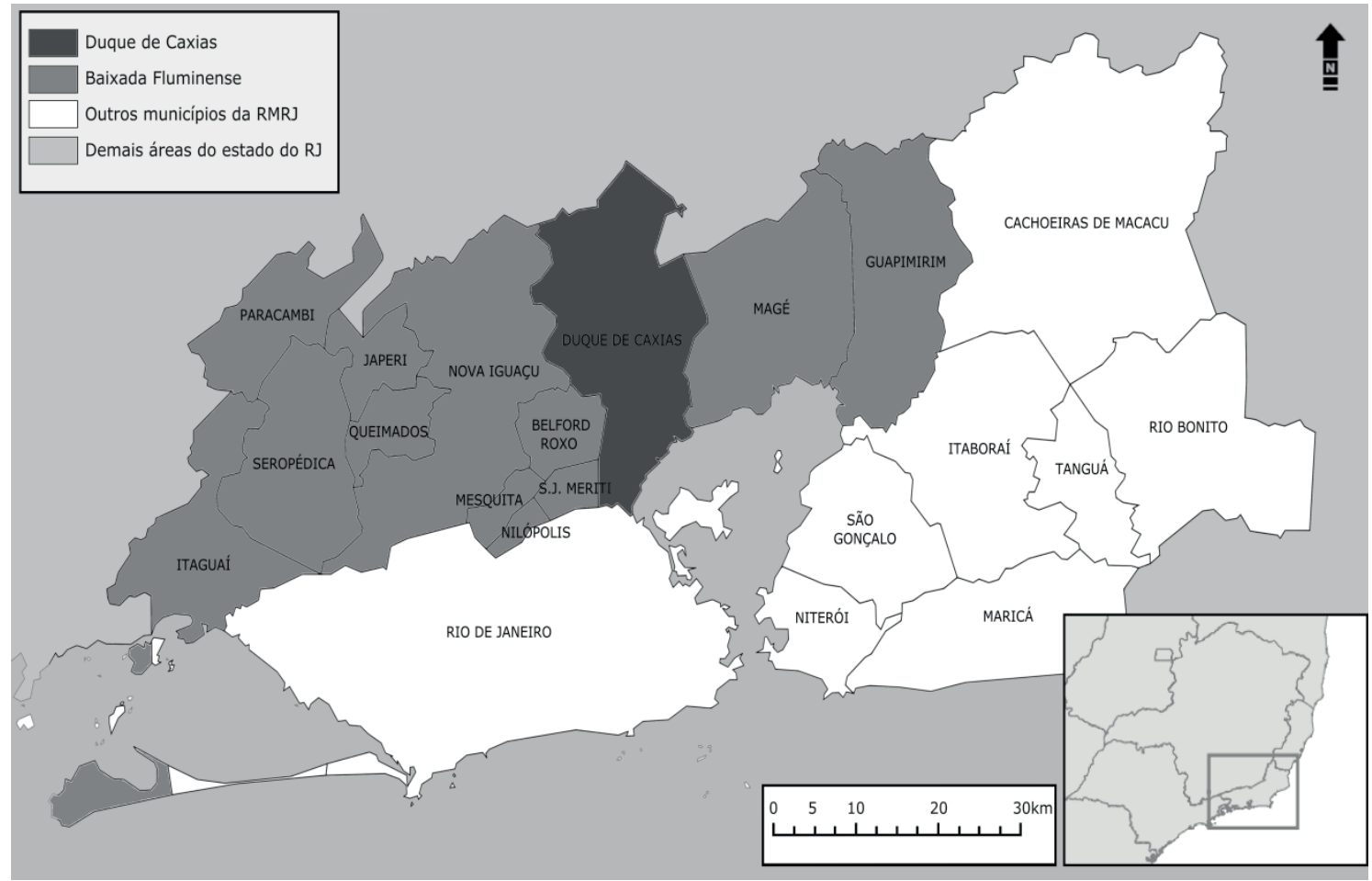

Fonte: Leandro Silveira.

O termo, porém, adquire sua acepção atual entre as décadas de 1940 e 1950, com uma conotação fortemente pejorativa. Isso ocorre porque esse é o período em que a imprensa carioca passa a retratar a regiāo como um lugar violento e miserável, em que faltam bens e serviços públicos. Por isso, a definição se consolida e, na década de 1960, já está fortemente popularizada. Entretanto, os limites permanecem difusos até hoje, pois a inclusão ou exclusão de áreas ${ }^{16}$ da região depende dos interesses envolvidos.

\footnotetext{
${ }^{16}$ Inserção nossa.
} 
Para Simões (2011), no contexto da divisão fisiográfica já apontada como Baixada da Guanabara (Figura 8), é possível efetuar uma subdivisão, segmentando o que o autor denomina como Baixada Núcleo e Baixada Ampliada. A Baixada Ampliada corresponderia ao recorte espacial apresentado como Baixada da Guanabara na Figura 8. Por sua vez, a área em que a população local se identifica plenamente com o pertencimento à Baixada Fluminense é chamada de Baixada Núcleo, formada pelo desmembramento dos antigos municípios de Iguassú e Estrella, hoje fracionados em nove municípios distintos (Figura 9).

Figura 9. Baixada Fluminense Núcleo e Baixada Ampliada

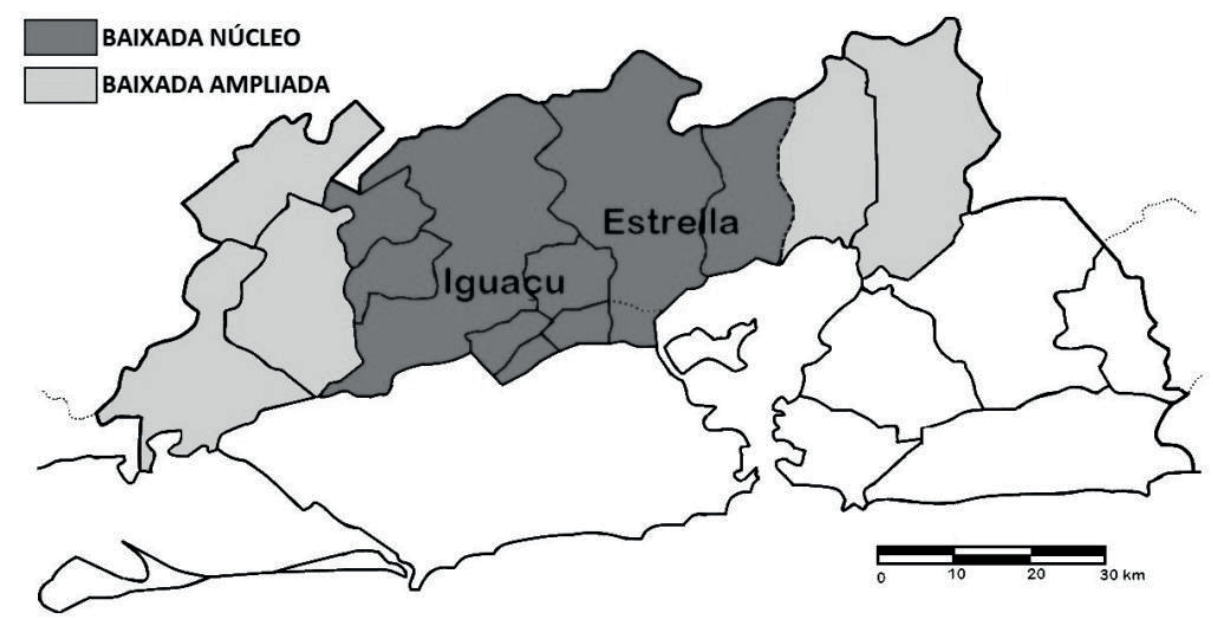

Fonte: Adaptado de Simões (2011).

Ao mesmo tempo, Simões (2004) afirma que, geopoliticamente, o termo Baixada Fluminense é cada vez mais identificado com a área original do antigo município de Iguaçu, ${ }^{17}$ que se formou nas terras da sesmaria de mesmo nome e passou por um processo de desmembramento (Figura 10) ao longo do século XX.

\footnotetext{
${ }^{17}$ Nome original das terras do atual município de Nova Iguaçu, cuja primeira grafia era Iguassú, originada da palavra indígena Igoassú. Em 1943, quando tem início o processo de emancipação de seus distritos, o município já se chamava Nova Iguaçu.
} 


\section{Situando Duque de Caxias no contexto metropolitano da Baixada Fluminense}

Figura 10. Desmembramento do antigo município de Nova Iguaçu

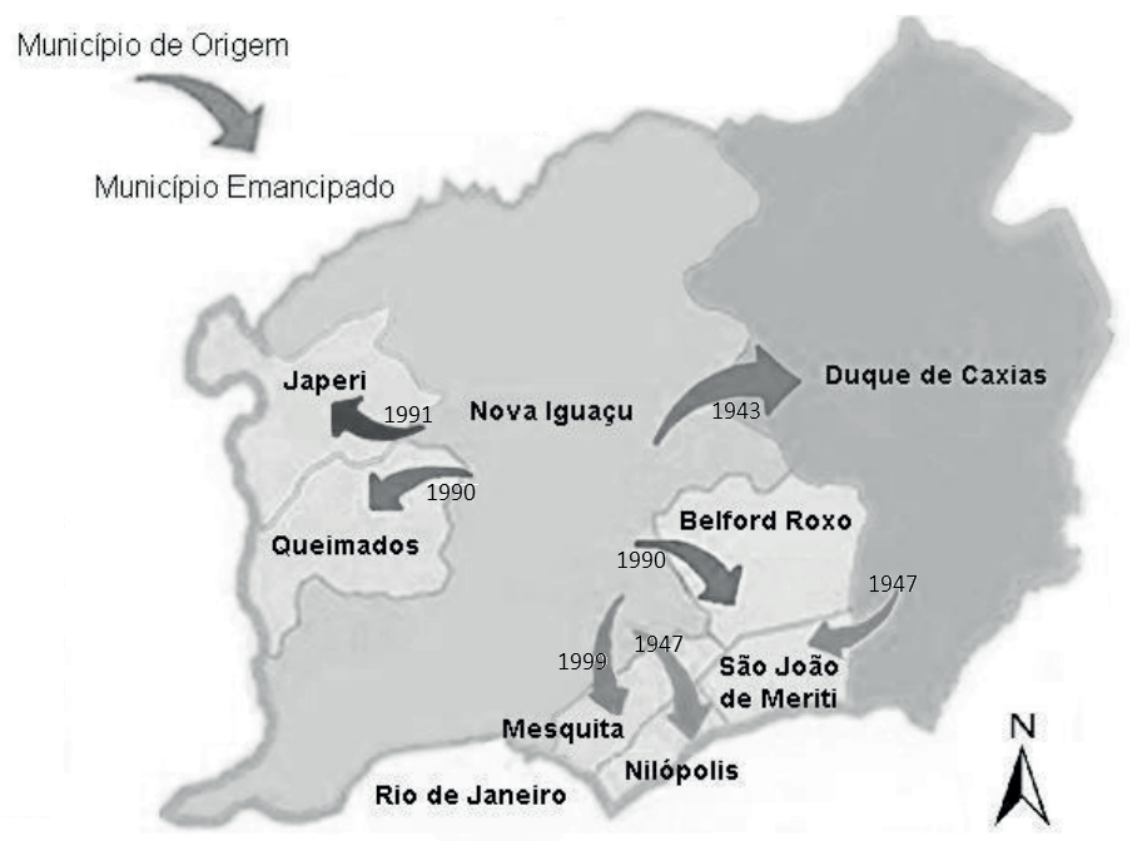

Fonte: Adaptado de Tenreiro (2012, p. 25).

Assim, com base em critérios como grau de urbanização, violência e densidade populacional, a Fundação para o Desenvolvimento da Região Metropolitana do Rio de Janeiro (Fundrem) restringiu a Baixada a oito municípios, sendo dois núcleos - Nova Iguaçu e Duque de Caxias - e seis "satélites" - Belford Roxo, São João de Meriti, Nilópolis, Mesquita, Queimados e Japeri (Costa, 2012). Tal recorte é utilizado com frequência, como afirma Israel Beloch:

[...] [É] comum [...] designar-se como Baixada Fluminense apenas a porção da Baixada da Guanabara mais próxima, e, portanto, mais intimamente vinculada ao antigo Distrito Federal - os municípios de Nova Iguaçu, Duque de Caxias, Nilópolis e São João de Meriti, detentores de uma configuração física, econômica e social que lhes propiciou um dos maiores crescimentos demográficos do país e os tornou alojamento de grandes massas populacionais, constituídas quase exclusivamente de trabalhadores, em boa parte subempregados (Beloch, 1986. p. 16).

Dessa forma, podemos afirmar que a definição mais recorrente é a que recorre a critérios socioeconômicos, incluindo um grupo de municípios, em sua maioria, recém-emancipados, com infraestrutura precária e ocupados por uma população de baixa renda. Apesar de possuir $26 \%$ da população do estado do Rio de Janeiro, a Baixada Fluminense detém apenas 10\% do total da renda familiar (IBGE, 2015), com rendimento médio por habitante em torno de um salário mínimo. Mais de 15\% 
da população local recebe menos de meio salário mínimo; 67\% recebem entre meio e dois salários mínimos; e apenas 18,6\% recebem mais de dois salários mínimos (IBGE, 2015).

Neste artigo, não nos interessa delimitar, com rigidez extrema, o recorte a ser utilizado. Ao citarmos a expressão Baixada Fluminense, consideraremos, na maior parte das vezes, a delimitação apontada por Simões (2011) como Baixada Núcleo. Ao mesmo tempo, preferimos manter os limites fluidos para, quando necessário, utilizarmos o termo para nos referir à Baixada Ampliada. Em nenhum momento, porém, incluiremos qualquer município que esteja fora dos limites apontados pela Figura 8.

\subsection{A ocupação inicial das terras caxienses}

A ocupação das terras em que se encontra atualmente o município de Duque de Caxias ocorreu ao mesmo tempo que surgia a cidade do Rio de Janeiro, ou seja, logo após a vitória dos portugueses sobre os franceses e os indígenas nativos, ${ }^{18}$ depois de dois anos de combate (Cavalcanti, 2010). A partir de então, a Coroa portuguesa buscou colonizar e cultivar as terras às margens da Baía de Guanabara, instalando o regime de sesmarias. ${ }^{19}$ Segundo Lima (2010, p. 139), além da função estratégica de defesa, os portugueses viam potencial agrícola na área para abastecer a cidade recém-fundada.

A primeira sesmaria foi doada pela Coroa portuguesa ao ouvidor-mor Cristóvão Monteiro ${ }^{20} \mathrm{em}$ 1565, dando início ao povoamento da região. Às margens do rio Iguaçu, essas terras deram origem à Fazenda Iguaçu, ${ }^{21}$ que se tornou a primeira propriedade lusitana no território atualmente chamado de Baixada Fluminense. O local foi ocupado com a cultura da cana-de-açúcar e a produção de alimentos para a cidade do Rio de Janeiro (Lamego, 1964; Simões, 2015). Posteriormente, a fazenda foi

\footnotetext{
${ }^{18}$ Enquanto invadiam e ocupavam o Rio de Janeiro, os franceses se aproximaram e fizeram alianças com os índios tamoios, numa estratégia que lhes permitisse ter mais chances de controlar o território já pertencente aos portugueses. Contudo, a aliança feita pelos indígenas viria a se revelar trágica para eles, já que o fim da invasão, com a vitória dos portugueses, teve dois desdobramentos: "o ódio dos portugueses aos índios, então aliados dos franceses, que levou praticamente ao aniquilamento destes, e a decisão de dividir a região em sesmarias, para promover a ocupação populacional e evitar novas invasões" (Cardoso, 2010, p. 27).

${ }^{19}$ Ver Lamego (1964), Abreu (2005) e Cavalcanti (2010).

${ }^{20}$ Em agradecimento à sua atuação na luta contra os franceses, em 5 de setembro de 1565, Estácio de Sá - primeiro governador-geral da capitania do Rio de Janeiro - doou uma grande faixa de terra a Cristóvão Monteiro em ambas as margens do rio Iguaçu (Nogueira, 2008). Cavaleiro fidalgo da Casa Real Portuguesa, Monteiro construiu a fazenda de Igoassu, tornando-a "uma área de plantio de alimentos de subsistência e de cana-de-açúcar" (Lima, 2010, p. 140).

${ }^{21}$ Originalmente, a Fazenda Iguaçu fez parte da sesmaria Igoassu, que correspondia à maior porção da região, chamada de Baixada Fluminense, ou Baixada da Guanabara, como era conhecida nos tempos coloniais. Dado pelos povos originários, o "termo Igoassu faz referência aos rios e pântanos, significando água grande ou muita água" (Lima, 2010, p. 140, grifo do autor) e foi usado para batizar a unidade administrativa que compreendia quase todo o território baixadense delimitado ao longo do século XIX.
} 


\section{Situando Duque de Caxias no contexto metropolitano da Baixada Fluminense}

adquirida pela Ordem de São Bento ${ }^{22}$ e tornou-se um engenho açucareiro, com produção de açúcar, aguardente e garapa, passando a ser chamada de Fazenda São Bento ou São Bento do Iguaçu (Figura 11). É considerada a mais antiga do atual município de Duque de Caxias e se mostrou fundamental no início do desenvolvimento econômico e populacional da região.

Figura 11. Fazenda São Bento (década de 1910)

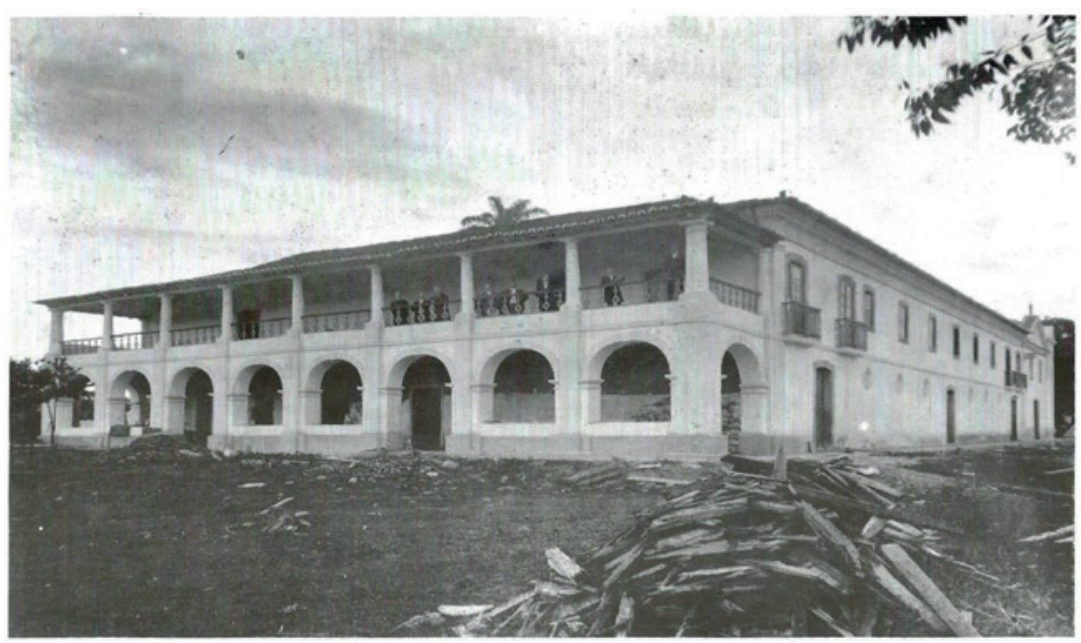

Fonte: Nogueira (2008, p. 57).

Assim, pode-se afirmar que as histórias de Caxias e da Baixada Fluminense estão intimamente conectadas à da metrópole Rio de Janeiro e à sua dinâmica econômica. Afinal, situada às margens da Baía de Guanabara, o desenvolvimento da BF esteve ligado à extensa rede hidrográfica que a cortava. Através dos rios, "realizava-se o escoamento da produção local e estabeleciam-se os elos entre o interior e o litoral, favorecendo a ocupação das cercanias da Baía pelo interior serrano" (Nogueira, 2008, p. 54).

Apesar de a atividade econômica que incentivou a ocupação inicial da região ter sido o cultivo da cana-de-açúcar, a retirada de lenha e a produção de outros alimentos, como milho, feijão, mandioca e arroz, também serviram para abastecer a cidade do Rio de Janeiro (Nogueira, 2008). É fato que a Baixada Fluminense apresenta grande dependência econômica em relação ao Rio de Janeiro, e os grandes fluxos pendulares em direção ao núcleo da metrópole comprovam essa realidade.

\footnotetext{
${ }^{22}$ Em 12 de outubro de 1591, a Ordem de São Bento comprou parte dessas terras. Alguns anos depois, a viúva e o sogro de Cristóvão Monteiro doaram outra porção da antiga sesmaria Iguaçu aos beneditinos. Em 1613, o local recebeu a instalação de um moderno engenho, tornando a fazenda por muito tempo "responsável pela conquista, povoamento e prosperidade da regiāo" (Moraes, 1990, p.73). Esteve sob a administração dos beneditinos até 1920, quando foi desapropriada pela empresa Pró-Melhoramentos para fins de saneamento e colonização.
} 
Com efeito, tal situação não era tão diferente naquela época. O fato é que tanto a ocupação quanto o desenvolvimento econômico da região sempre foram determinados pela atual metrópole carioca (Lamego, 1964).

Os primeiros aglomerados surgiram no entorno de igrejas, como a de São Bento, por volta de 1596, e a de Nossa Senhora do Pilar, em 1612 (Simões, 2015). Ao longo do século XVII, a população da Baixada se manteve reduzida e concentrada principalmente nos engenhos, uma vez que a área era sede, basicamente, de culturas canavieiras, produção de açúcar e aguardente.

No século seguinte, a Baixada Fluminense cresceu de forma expressiva, e sua relação com a urbe carioca se estreitou ainda mais pelos caminhos que ligavam a região das Minas Gerais ao litoral. Com o deslocamento do eixo econômico do Nordeste para o Centro-Sul no século XVIII, surgiu, então, a necessidade de escoar o ouro e abastecer a província mineira. ${ }^{23} \mathrm{O}$ tráfego cresceu muito rápido em 1704, após a abertura do Caminho Novo, ${ }^{24}$ que passou a transpor a serra dos Órgãos (Pinheiro, 2010). Porém, como os "caminhos de terra firme" (Torres, 2008, p.195) eram poucos, precários e perigosos, o transporte fluvial se tornou a principal alternativa para que o trânsito de mercadorias se desenvolvesse. O transporte era feito pelos rios, prolongando-se por via marítima através da Baía de Guanabara até alcançar o porto do Rio de Janeiro. Contando com numerosos rios, a Baixada Fluminense se transformou num ponto de união entre o litoral e os caminhos que subiam a serra em direção ao interior.

Em pouco tempo, a Baixada passou a ter importância estratégica, tornando-se ponto obrigatório de passagem daqueles que se dirigiam à região das minas ou de lá regressavam (Lamego, 1964; Nogueira, 2008), principalmente por conta de seus rios, mas também pelas estradas que foram abertas através das serras. Tais caminhos (Figura 12), que partiam de portos fluviais como Pilar e Estrela, tornaram-se pontos de aglutinação de pessoas e atividades econômicas, o que resultou no surgimento dos primeiros núcleos urbanos (Simões, 2015). E, mesmo após a decadência da mineração, a região ainda se manteve como ponto de parada e abastecimento de tropeiros, assim como local de passagem de mercadorias (Beloch, 1986, p. 17). Por essa razão, o desenvolvimento das áreas no entorno da Baía de Guanabara foi notável desse período até o século XIX.

\footnotetext{
${ }^{23}$ A partir de então, a cidade do Rio de Janeiro ganhou novas funçôes e atividades, tornando-se capital da colônia em 1763 e apresentando forte dependência da rede de portos fluviais e caminhos que atravessavam a Baixada Fluminense.

${ }^{24} \mathrm{O}$ Caminho Novo do Pilar, aberto em função das necessidades oriundas da mineração, entre elas um caminho rápido, econômico e seguro que ligasse o Rio de Janeiro à região das Minas Gerais, "intensificou as relaçôes daquela cidade com os portos Estrela, Pilar e Iguaçu” (Nogueira, 2008, p. 55).
} 


\section{Situando Duque de Caxias no contexto metropolitano da Baixada Fluminense}

Figura 12. Caminhos e estradas da Baixada no início do século XIX

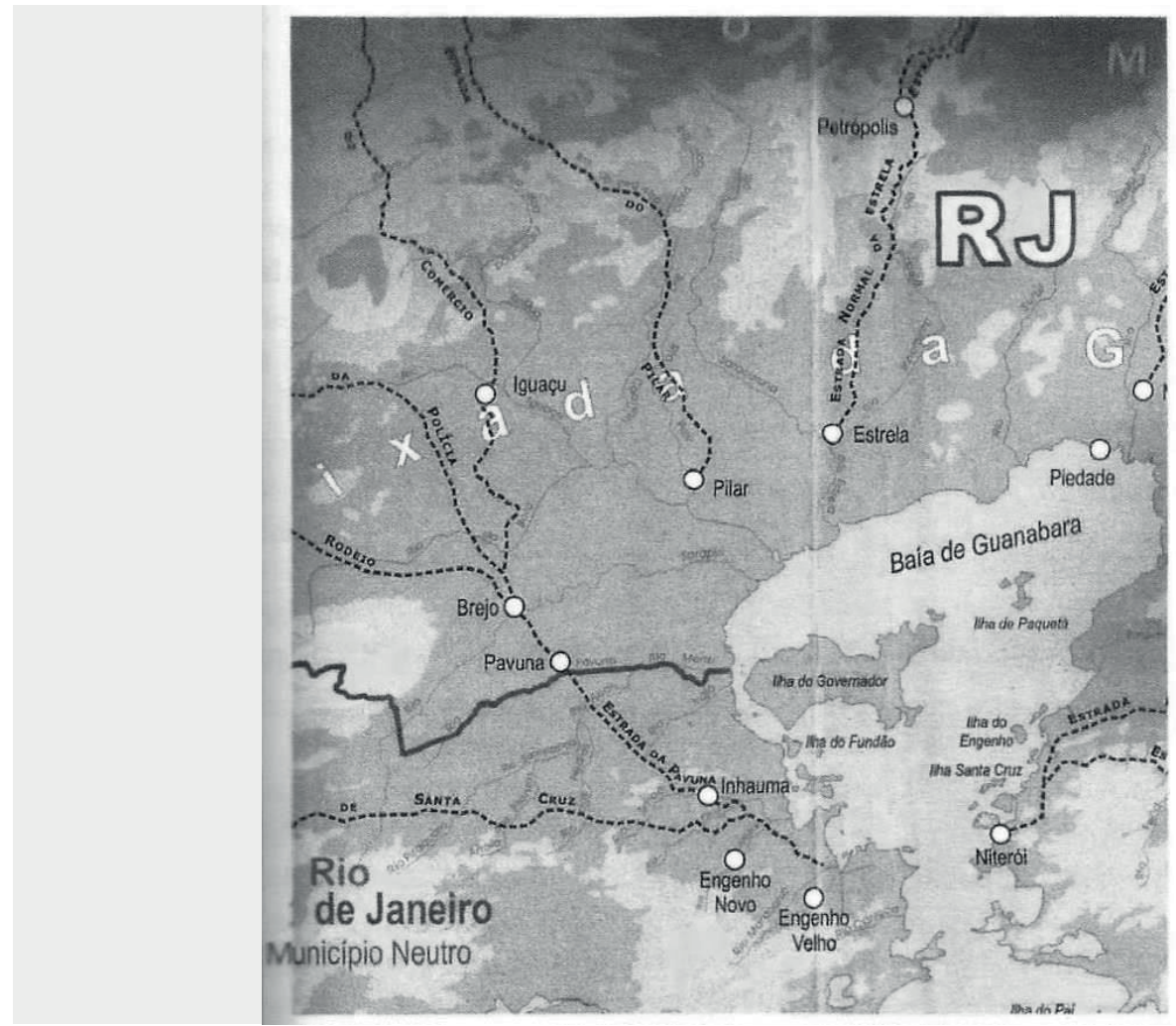

Fonte: Brame apud Simões (2015, p. 25).

No início do século XIX, a expansão da produção de café pelo Vale do Paraíba gerou novo impulso ao fluxo pelos caminhos localizados na BF, promovendo o crescimento populacional em seu entorno e, especialmente, nas imediações dos portos fluviais. Um novo aumento demográfico ocorreria com a chegada da família real e da Corte portuguesa em 1808, o que aumentou ainda mais o fluxo comercial pelos portos fluviais da Baixada (Lamego, 1964; Nogueira, 2008; Simóes, 2015). Entretanto, junto com o século XIX, chegaram também as primeiras ferrovias ${ }^{25}$ (Figura 13), que transformaram profundamente a organização regional, alterando o eixo de ocupação e levando os portos fluviais e seus respectivos núcleos à ruína. ${ }^{26}$

\footnotetext{
${ }^{25}$ A primeira ferrovia do Brasil foi instalada em 1854, em Mauá, parte da atual cidade de Magé. Em seguida, surgiu a Estrada de Ferro D. Pedro II (1858), que, por sua vez, cortava todo o território iguaçuano e, posteriormente, passaria a se chamar Estrada de Ferro Central do Brasil.

${ }^{26} \mathrm{O}$ novo meio de transporte promoveu o abandono dos portos fluviais e dos núcleos que dependiam deles, como a Vila de Estrela, cujos territórios, atualmente, fazem parte de Duque de Caxias, Magé e Petrópolis. Pouco antes da instalação da estrada de ferro, o porto de Estrela havia sido considerado um dos mais impor-
} 
Figura 13. Município de Duque de Caxias e ferrovias no fim do século XIX

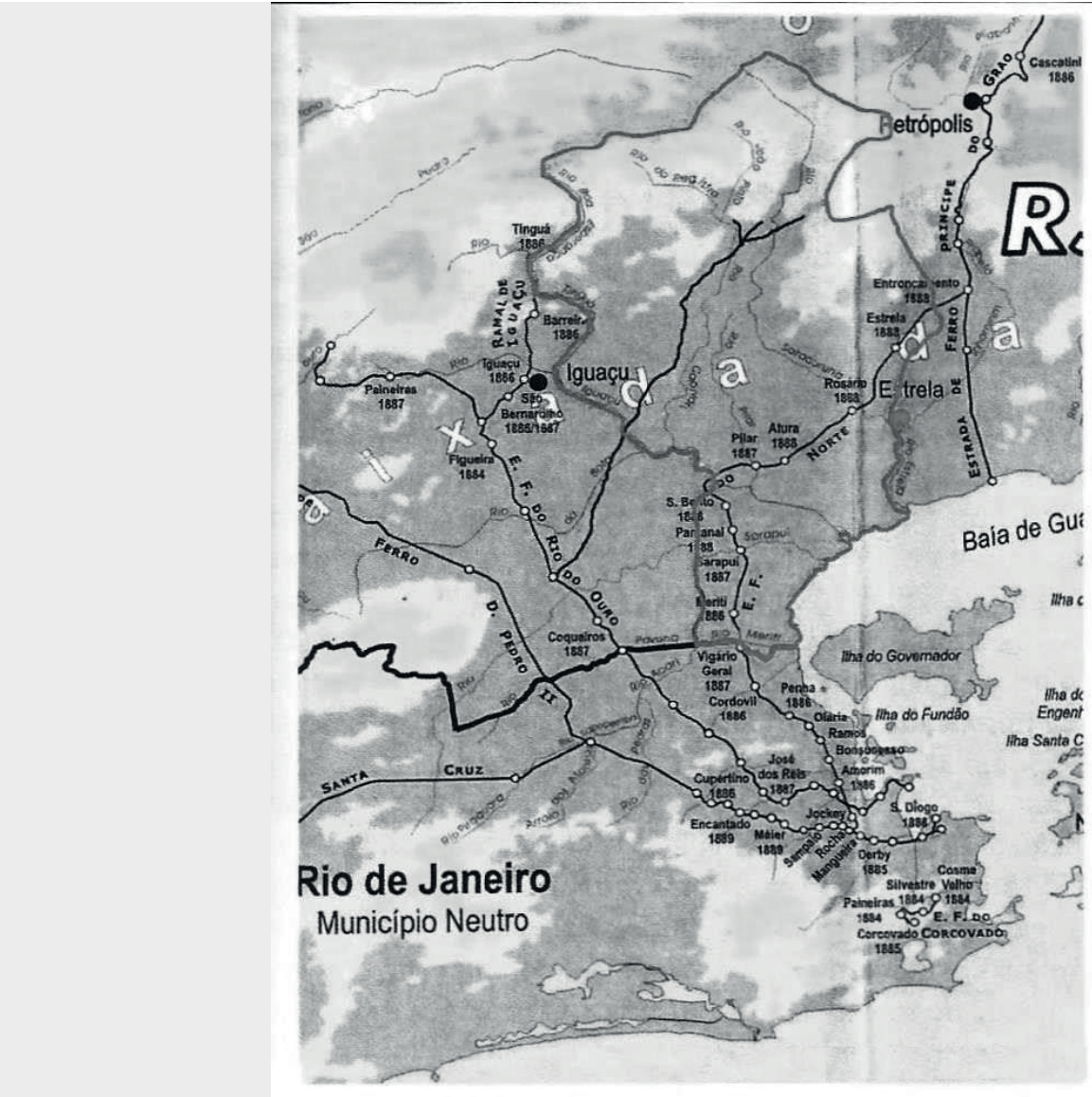

Fonte: Brame apud Simōes (2015, p. 27).

Portanto, as quatro primeiras ferrovias fluminenses desencadearam um forte "processo de desarticulação no transporte fluviomarítimo, até então o principal sistema de transporte de passageiros e mercadorias entre o Vale do Paraíba, a Serra do Mar, a Baixada da Guanabara e a Serra do Mar" (Brame, 2010, p. 371). Segundo Beloch (1986), a maior eficiência do transporte ferroviário

[...] provocou a rápida desativação das vias fluviais. Os rios, utilizados cada vez com menor intensidade, foram sendo assoreados e obstruídos, em decorrência do desordenado desmatamento verificado no período anterior. Cedo começaram a ocorrer inundações e a região se viu pontilhada por charcos insalubres [...]. A

tantes do Brasil, já que era "um dos poucos que podia receber embarcações maiores e o único a contar com embarcações a vapor” (Moraes, 1990, p. 83). 
evasão dos proprietários de terras e o despovoamento provocaram vertiginoso declínio do atual território caxiense (p. 20).

Nas margens dos rios Meriti, Iguaçu e Sarapuí, cada vez mais assoreados, formavam-se brejos imensos, pântanos perigosos e mangues poluídos, cujas águas paradas se tornaram focos do surgimento de mosquitos e de malária (Torres, 2008). Os surtos da doença foram tão graves que, em cerca de cem anos, entre 1795 e 1880, a população de Duque de Caxias diminuiu de 17.022 habitantes para somente quatrocentas pessoas (Prado, 2000). As outrora salubres e cada vez mais povoadas terras tornaram-se mangues praticamente inabitáveis, e as epidemias frequentes levaram os senhores de engenho a abandonar suas propriedades, fugindo para lugares mais seguros.

Moraes (1990) aponta que o fluxo comercial passou a acompanhar a estrada de ferro, e os tropeiros e viajantes deixaram de circular pelo caminho tradicional. Além disso, o iminente fim da escravidão fez com que os escravos abandonassem as fazendas e os engenhos de cana. Para a agricultura da região, baseada no cultivo da cana-de-açúcar, foi um verdadeiro desastre. Por conta disso, a abolição da escravatura, em 1888, representou outro duro golpe para a regiāo. Afinal, a Baixada via-se privada de mão de obra para executar "as tarefas agrícolas e [as obras $]^{27}$ de infraestrutura que mantinham a salubridade local” (Torres, 2008, p. 196).

Em 1891, o município de Estrela foi extinto e o norte de Duque de Caxias ${ }^{28}$ voltou a fazer parte do município de Iguassú. Chamada, à época, de Merity, a área do atual $1^{\circ}$ Distrito de DC era pouco importante, representando apenas um ponto de escoamento de poucos produtos, dentre os quais lenha e carvão vegetal (Nogueira, 2008). Ironicamente, a futura recuperação e o desenvolvimento econômico de Merity aconteceriam com a criação de outra ferrovia: a "The Rio de Janeiro Northern Railway".

\section{Caxias e a Estrada de Ferro Leopoldina: fim do ocaso ou início da desordem?}

Se as primeiras estradas de ferro deram início à decadência de algumas áreas da Baixada Fluminense, outra ferrovia foi responsável pelo desenvolvimento do futuro núcleo do município de Duque de Caxias. Isso ocorreu com a criação, em 1886, da Estrada de Ferro Leopoldina, então chamada de "The Rio de Janeiro Northern Railway". Seu traçado passou a ligar a cidade do Rio de Janeiro à Vila de Merity, ${ }^{29}$ área que corresponde ao atual centro de Duque de Caxias. Porém, enquanto o Rio de

\footnotetext{
${ }^{27}$ Inserção nossa.

${ }^{28}$ Área que corresponde à maior parte do que, atualmente, abrange os distritos de Imbariê $\left(3^{\circ}\right)$ e Xerém $\left(4^{\circ}\right)$.

${ }^{29} \mathrm{O}$ novo caminho criado pela ferrovia modificou por completo as relaçóes comerciais e a ocupação do solo. Foi o início do processo de surgimento de vilas e povoados que se organizaram em torno das estações ferroviárias, origem de muitos bairros de nossas atuais cidades. Segundo as palavras de Torres, "sob a égide da maria-fumaça, de silvo estridente e penacho de fumo negro, tudo se modificou. A ferrovia [...] ditava novos traçados
} 
Janeiro se modernizava, ${ }^{30}$ Merity se encontrava no mais absoluto abandono nesse final de século XIX, com uma população de modestos quatrocentos habitantes e sem qualquer perspectiva de uso urbano (Costa, 2012).

Além disso, os aterros feitos para a obra agravaram a já péssima situação de drenagem na localidade. Por isso, apesar do fôlego econômico trazido pela nova ferrovia, o impacto inicial no povoamento não foi grande, pois a região continuaria a sofrer com a falta de saneamento por várias décadas, o que limitava o seu progresso. Com efeito, apesar de as ferrovias já possuírem estações nos atuais municípios de São João de Meriti, Nilópolis e Duque de Caxias desde o século XIX, sua ocupação urbana só se efetivou nas primeiras décadas do século XX - quando a região foi parcialmente drenada, como uma espécie de continuação da reforma sanitária iniciada na cidade do Rio de Janeiro, permitindo a instalação dos primeiros loteamentos urbanos.

Entretanto, as políticas públicas de saneamento eram marcadas por falta de efetividade e descontinuidade de açôes. ${ }^{31}$ Somente no Governo Nilo Peçanha (1909-1910), foram realizadas as primeiras ações consistentes ${ }^{32}$ para reduzir os problemas de saneamento na Baixada, ao se efetuarem obras de drenagem na parte noroeste da região. Enquanto governou o Rio de Janeiro (1914-1917),

nos caminhos, fazendo surgir à volta de suas estaçôes, povoados que se transformariam em populosas cidades. Quando a ferrovia atinge o vale de Meriti, a região começa a sofrer os efeitos da expansão urbana da cidade do Rio de Janeiro. Com a inauguração da "The Rio de Janeiro Northern Railway", em 23 de abril de 1886, ficamos definitivamente ligados ao antigo Distrito Federal. Era o progresso que novamente se avizinhava” (Torres, 2008, p. 196).

${ }^{30}$ Nesse mesmo período, agora capital federal da recém-proclamada República, o Rio de Janeiro promove uma transformação radical de sua forma urbana. Por meio de uma série de reformas, tem início a modernização da cidade, focada principalmente na área central. De acordo com Augusto Pinheiro (2010, p. 34), "a área central [da cidade do Rio de Janeiro] encontrava-se decadente, apinhada de cortiços e cabeças de porco, habitada por gente na mais extrema pobreza e assolada por epidemias que ameaçavam atingir toda a cidade". Entre as consequências sociais dessas reformas, estão a consolidação de uma estrutura espacial estratificada na cidade, que se disseminaria, no futuro, por Duque de Caxias e pelos outros municípios da Baixada Fluminense mais próximos à capital.

${ }^{31}$ Beloch (1986, p. 21) afirma que ninguém acreditava em saneamento na Baixada, pois "o problema do saneamento das terras da imensa planura fluminense, que circunda a capital da República, estava desmoralizado no seio da opinião pública". O autor aponta ainda que os fracassos nas políticas de saneamento vinham desde 1893, e que "cem mil contos desperdiçaram-se num esforço improfícuo e quase sem resultado até 1930" (Beloch, 1986, p. 21).

32 De acordo com Lucia Silva (2015), a Comissão Federal de 1910, instituída por Nilo Peçanha, em sua rápida passagem pela presidência da república, teve o mérito de consolidar como consenso todas as discussões travadas nas duas primeiras comissões estaduais e serviria de referência aos trabalhos das anteriores. Segundo a autora, "a comissão federal organizou as utopias do momento e tornara inconteste a ideia de saneamento como instrumento civilizatório, agente de modernização e como suporte imprescindível à agricultura. Desta forma, a Baixada adentrava a década de 1930 com a imagem de terra de promissão, desde que saneada" (Silva, 2015, pp. 3-4). 


\section{Situando Duque de Caxias no contexto metropolitano da Baixada Fluminense}

Peçanha continuou a promover outras melhorias no saneamento e acesso à água potável ${ }^{33}$ (Figura 14). Na presidência de Delfim Moreira (1918-1919), a criação do Serviço de Profilaxia Rural representou mais um passo para o controle das endemias na BF (Torres, 2008). Mas, apesar disso, o local continuava a ser um grave foco de malária.

Figura 14. Visita de Nilo Peçanha à estação de Merity (1916)

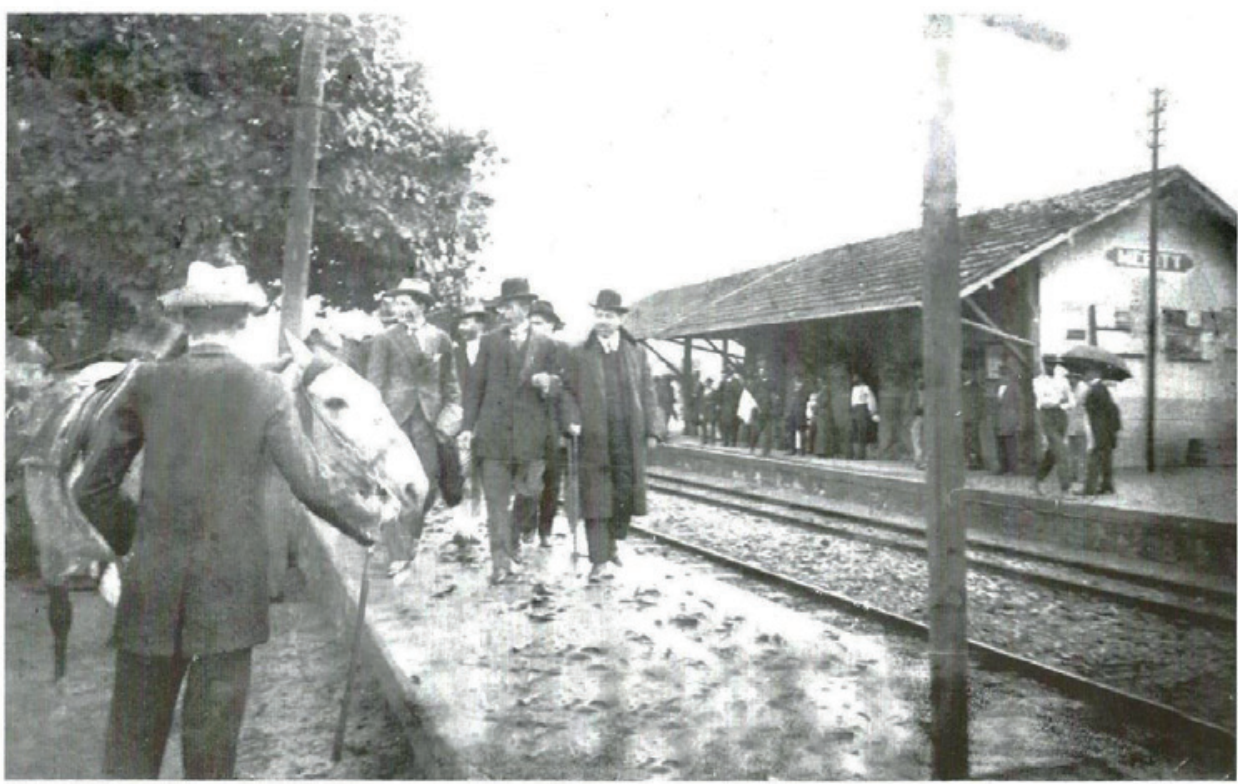

Fonte: Nogueira (2008, p. 63).

Já no governo de Getulio Vargas, os focos de origem da malária foram diretamente combatidos quando "foi instaurado um programa de abertura de canais, dragagem e retificação dos grandes rios que fez com que os pântanos desaparecessem"34 (Cardoso, 2010, pp. 28-9). Porém, Elmo Amador

\footnotetext{
${ }^{33}$ Em matéria do jornal O Municipal (2005), conta-se que, certa vez, de passagem por Merity rumo a Petrópolis, o presidente Nilo Peçanha ficou chocado com a correria de mulheres e crianças em direção ao "suspiro" da locomotiva, onde tentavam aproveitar o excesso de vapor, transformando-o em água potável. Ao saber que o local não dispunha de água potável, Nilo Peçanha determinou que fosse construído um ramal, a partir da rede de água que abastecia Vigário Geral, instalando duas bicas próximas à estação ferroviária, sendo uma na esquina da rua Joaquim Lopes de Macedo com a avenida Plínio Casado, e uma segunda, na esquina da rua Pinto Soares com a então estrada Rio-Petrópolis (O Municipal, 2005, p. 5).

${ }^{34}$ A partir de 1936, a criação do Serviço Nacional de Malária e da Diretoria de Saneamento da Baixada Fluminense permitiu um trabalho mais específico, com as seguintes açôes: desobstrução dos rios através da limpeza e retificação dos leitos, reabertura de canaletas de drenagem e irrigação, identificação dos rios dissimulados pela vegetação, mapeamento geral da região e criação de equipes de manutenção (Beloch, 1986; Cardoso, 2010).
} 
(1992) afirma que esse processo de drenagem foi um dos exemplos mais perversos de agressão à natureza e de reprodução do capital praticado com o dinheiro público. De acordo com o autor, elevadas somas de dinheiro foram utilizadas na valorização das terras de grandes proprietários, que as adquiriram por preço baixo ou através de processos de grilagem, revendendo-as com significativas margens de lucro. Estas passaram a ser loteadas e vendidas para a população proletária, que foi expulsa para locais inóspitos, de modo a se transformar em mão de obra barata para as indústrias (Amador, 1992).

Enquanto isso, o aumento do número de estações e de viagens fez crescer a quantidade de passageiros que passavam pela vila de Merity. Lentamente, a infraestrutura progredia: com a continuação da EF Leopoldina rumo a Inhomirim, em 1911 já estavam em funcionamento, além de Merity, as estações de Gramacho, São Bento, Campos Elíseos, Primavera, Saracuruna e Parada Angélica; ${ }^{35}$ em 1916, foi instalada a primeira bica d'água na "velha estação de Merity" (Moraes, 1990); em 1924, foi instalada a primeira rede elétrica e fundada a Escola Proletária Merity; em 1928, foi inaugurada a estrada Rio-Petrópolis (Moraes, 1990; Cardoso, 2010).

A partir de então, a Baixada Fluminense, com destaque para Duque de Caxias, passou por um notável crescimento demográfico. Tamanha expansão populacional aumentou as demandas sociais, tendo sido acompanhada pelo fracionamento e o loteamento de antigas propriedades rurais que, naquele momento, estavam improdutivas. Tais loteamentos ${ }^{36}$ seguiram modelos diferenciados, o que nos permite considerá-los um dos vetores da segregação socioespacial no município fluminense. Portanto, neste ponto da análise, faz-se necessário analisar a dinâmica populacional e o processo de loteamentos em Duque de Caxias no decorrer do século XX, bem como seus efeitos sobre o território municipal.

\section{Duque de Caxias no século XX: de "cidade-dormitório" a cidade plena}

Até meados do século XX, a área que corresponde ao município de Duque de Caxias era um espaço predominantemente rural. Entretanto, a melhora da infraestrutura, a presença da Estrada de Ferro Leopoldina e o fim da ameaça da malária a partir dos anos 1930 tornaram o espaço baixadense

\footnotetext{
${ }^{35}$ A estação Parada Angélica, que, na época, se localizava em território iguaçuano, posteriormente viria a fazer parte do futuro município de Caxias.

36 Há duas versões para o início dos loteamentos urbanos no atual território de Duque de Caxias. Segundo Rogério Torres (2008) e Pierre Costa (2012), o primeiro loteamento legalizado de que se tem notícia na área do município é o Parque Artur Goulart, aprovado em 1914, junto à estação de Duque de Caxias, ainda chamada de Merity à época. Já de acordo com Guilherme Peres (2008) e Marlucia Souza (2012), "o primeiro loteamento feito em Merity foi realizado pelo engenheiro Abel Furquim Mendes, que, em 1918, dividiu uma área ao longo da via férrea, entre as ruas Pinto Soares e Manoel Reis. Esses lotes foram oferecidos a cinquenta mil réis cada. Entretanto, a venda foi um fracasso" (Peres, 2008, p. 203). Não foi possível identificar qual das duas versões é a correta.
} 


\section{Situando Duque de Caxias no contexto metropolitano da Baixada Fluminense}

relativamente atraente para a população. Em pouco tempo, DC e a Baixada passariam por um processo de ocupação desordenado, recebendo uma numerosa população pobre do Rio de Janeiro e de estados do Nordeste.

Isso ocorreu porque, desde o início do século XX, um conjunto de fatores fez com que as opções de moradia para a população de baixa renda na cidade do Rio de Janeiro diminuíssem. Afinal, o crescimento demográfico, o encarecimento dos terrenos e as políticas de erradicação dos cortiços na área central da então capital do país promoveram uma expulsão populacional. Com isso, os habitantes mais pobres do Rio de Janeiro, além dos muitos migrantes nordestinos, tiveram de escolher entre as favelas ou as recém-saneadas e acessíveis terras da Baixada Fluminense (Abreu, 1987). Em consequência, o intenso processo de favelização nos morros e de ocupação dos subúrbios e áreas mais periféricas ao núcleo da então capital federal pela população de baixa renda promoveu uma expansão horizontal do espaço urbano local. Servidos pelas ferrovias e atuando como palco de processos de loteamento popular e autoconstrução, esses espaços, gradativamente mais distantes, passaram a abrigar a massa trabalhadora do Rio de Janeiro (Pacheco, 1984).

Tal ocupação de áreas cada vez mais afastadas fez com que, em 1930, o tecido urbano já tivesse avançado sobre os limites do Distrito Federal, alcançando a Baixada Fluminense. Assim, suas terras serviam para aliviar a pressão demográfica da cidade do Rio de Janeiro, bem como para abrigar muitos dos expulsos pelo "Bota Abaixo" do prefeito Pereira Passos. ${ }^{37}$ A área da vila de Merity, atual centro da cidade de Duque de Caxias, que, no início do século XX "era uma incipiente estação ferroviária cercada por uma decadente área rural, dominada por uma também decadente classe dominante rural, cada vez mais ausente" (Costa, 2012, p. 217), começa a presenciar a expressiva chegada de novos habitantes. Segundo Torres (2008), a população da então Merity aumentou 365\% de 1910 a 1920 , passando de oitocentos habitantes para 2.920. Em 1930, já eram 28.756 seus moradores. Com isso, houve uma explosão da demanda por terras, que, por sua vez, promoveu intenso fracionamento das antigas propriedades rurais, o que levou ao surgimento dos loteamentos:

[...] diretamente do vazio econômico [...], suscitados pela abundância de terras baratas situadas nas proximidades da capital federal. A abertura [do novo traçado] da rodovia Rio-Petrópolis [paralela e contígua à EF Leopoldina,], inaugurada em 1928 e cruzando as várzeas que viriam a compor o município, desenvolveu extraordinariamente a atividade loteadora, ao facilitar a ligação de tais áreas com a cidade do Rio de Janeiro (Beloch, 1986, pp. 24-5).

\footnotetext{
${ }^{37}$ Segundo Márcio Piñon de Oliveira (2015), a intervenção urbanística conhecida como Reforma Pereira Passos (1902-1906), também chamada de "Bota Abaixo", buscava "solucionar os problemas de saneamento básico, ampliar as vias de circulação, como a abertura da avenida Central (atual Rio Branco) e investir no embelezamento da cidade, tornando-a, na expressão da época, 'digna de ser Distrito Federal', atraindo olhares estrangeiros, deixando para trás a cidade de estrutura colonial mercantil e abrindo espaço para a cidade industrial que se formava" (Oliveira, 2015, p. 2.638). Para mais informaçôes sobre a Reforma Pereira Passos, ver Abreu (1987), Pinheiro (2010) e Oliveira (2015).
} 
Assim, além dos loteamentos - predominantemente às margens da ferrovia -, cresciam as instalações fabris no entorno da nova rodovia. Logo, podemos afirmar que, a partir dos anos 1930, durante a Era Vargas, o território do atual município de Duque de Caxias experimentou intensivo processo de remodelação de sua área, incorporando-se ao modelo urbano industrial.

Cada vez mais desvinculada das atividades rurais e integrada à lógica de acumulação urbana, uma nova elite se forma gradualmente na cidade. Ao mesmo tempo, o tecido social caxiense se torna mais complexo com a chegada maciça de migrantes que ocupam o posto de mão de obra barata nas atividades urbanas locais e da capital federal. E, completando esse panorama, surge o controverso Tenório Cavalcanti, uma das novas lideranças que passa a efetuar um contraponto às elites tradicionais, mas que, em pouco modificou - e para alguns, até mesmo acentuou - a precária situação social da população do município, como veremos a seguir.

\subsection{As elites caxienses e o clientelismo: um entrave ao desenvolvimento local e um impulso para a segregação social}

A histórica política de Duque de Caxias foi fortemente impactada por práticas clientelistas, cujas açôes se basearam essencialmente no uso da máquina administrativa em benefício de poucos. Segundo Souza (2012), tem havido predomínio absoluto de lideranças políticas com perfis populistas e clientelistas ao longo das diversas gestôes e fases da história municipal no século XX. ${ }^{38}$ Longe de ser exclusividade caxiense, esse panorama é recorrente em outros municípios com formação e perfil semelhantes, como afirma Adauto Cardoso:

[...] tradicionalmente as prefeituras dos municípios mais pobres desenvolvem suas políticas dentro de um padrão clientelista tradicional, em que as açōes são fragmentadas e pontuais, atendendo a quase que individualmente às demandas, e segundo uma definição de prioridades que atende principalmente aos interesses político-eleitorais imediatos. Essa forma do "fazer política", que vigora preponderantemente na Baixada Fluminense, incorpora ainda a inadequação técnica, que transforma soluções em problemas futuros (Cardoso, 1998, pp. 1.699-1.700).

Dessa forma, historicamente, a população local tem dependido de quadros políticos que mantêm a popularidade alta por meio da concessão de benefícios pontuais. Assim, alcançam a legitimidade política necessária para permanecer no poder, sem que precisem resolver efetivamente os problemas existentes. Pelo contrário, até mesmo se beneficiam com a perpetuação desses problemas.

\footnotetext{
${ }^{38}$ Para mais detalhes sobre a questão política em Duque de Caxias, ver os trabalhos de Israel Beloch (1986), Rita Sales (1999), Manoel Cantalejo (2008) e Marlucia Souza (2012).
} 


\section{Situando Duque de Caxias no contexto metropolitano da Baixada Fluminense}

Em 1931, Merity foi elevada à condição de Distrito ${ }^{39}$ de Nova Iguaçu, com sede na antiga estação local, cuja placa de identificação já fora informalmente alterada por seus moradores ${ }^{40}$ como uma forma de romper com o passado negativo associado ao nome anterior. A nova configuração política "estabeleceu um novo eixo de poder, consolidando o que a mudança do traçado da Rio-Petrópolis havia começado" (Costa, 2012, p. 218). Assim, o agora Distrito de Caxias, $8^{\circ}$ do município de Nova Iguaçu, continuava a crescer rapidamente. Nas palavras de Costa:

[...] esse crescimento econômico resultou em novos moradores abastados, e se formaram novos grupos de interesse que procuraram se juntar em busca de reconhecimento enquanto lideranças locais. Assim, foi fundada a União Popular Caxiense (UPC) em 1933. [...] [Posteriormente, o] processo de emancipação de Caxias esteve relacionado ao grupo de jornalistas, médicos e políticos locais que organizou a UPC [...] (Costa, 2012, p. 218).

Assim, mesmo com a mudança de status jurídico, aumentava a insatisfação da elite local ${ }^{41}$ caxiense com o governo municipal de Nova Iguaçu. Tal situação aceleraria o processo de emanci-

${ }^{39} \mathrm{O}$ desenvolvimento pelo qual passava Merity levou Manoel Reis, então deputado federal, a propor a criação do município de Duque de Caxias. Dessa forma, através do Decreto Estadual n 2.559, de 14 de março de 1931, o interventor federal Plínio Casado elevou o local a $8^{\circ}$ Distrito de Nova Iguaçu.

${ }^{40}$ Até 6 de outubro de 1930, a primeira estação ferroviária de Caxias tinha o nome de Merity, devido à abundância desse tipo de palmeiras na região, nome que havia sido utilizado para batizar também o rio que nasce no sopé da Serra de Gericinó e deságua na Baía de Guanabara. O nome da estação ferroviária era motivo de chacota pelos moradores e a imprensa carioca, que chamava o lugarejo de "Merity do Pavor", pois a região era uma sucessão de brejos, onde proliferava a malária e onde faltava tudo. Com a chegada da água e de algumas obras de saneamento que melhoraram as condições de vida da população, incluindo o calçamento de algumas ruas e a instalação de um posto dos correios e telégrafos, o apelido de "Merity do Pavor" passou a incomodar. Foi então que um morador do local, José Luis Machado, que todos tratavam como Machadinho, teve a ideia de substituir a placa da estação ferroviária, mudando o nome do local. Com o apoio dos moradores, o nome escolhido foi "Caxias", uma homenagem a Luís Alves de Lima e Silva, o patrono do Exército Brasileiro, que nasceu na Fazenda São Paulo, em Imbariê, atual $3^{\circ}$ Distrito do município. Assim, no dia 6 de outubro de 1930 e numa ação espontânea, o povo acompanhou Machadinho numa invasão à estação ferroviária, onde a placa indicativa de Estação Merity foi substituída por outra, pintada apenas com "Caxias". Nas palavras do jornal O Municipal, "para cometer esse arroubo, Machadinho teve o apoio de Jaime Fischer Gamboa, Oswaldo Gamboa, Américo Soares e Francisco Azevedo, os únicos no grupo que estavam armados e que não enfrentaram qualquer tipo de reação dos funcionários da estação ferroviária. Atendendo à decisão do povo, o então interventor federal no antigo estado do Rio de Janeiro, Plínio Casado, subscreveu a mudança de nome da estação ferroviária, por meio do Decreto Estadual no 2.559, de 14 de março de 1931" (O Municipal, 2005, p. 5).

${ }^{41}$ Alegando que a presença do governo municipal era notada apenas através da coleta de impostos, uma comissão composta por membros da elite e políticos locais encaminhou, em 25 de julho de 1940, um memorial expondo os interesses emancipatórios de Duque de Caxias ao interventor estadual Amaral Peixoto. 
pação de Duque de Caxias, ${ }^{42}$ ocorrido em 1943 - por interesses que ultrapassavam a esfera local e que até hoje não estão plenamente esclarecidos. ${ }^{43}$ Porém, a emancipação de Duque de Caxias não levou à instalação de um aparato local com autonomia. Na prática, a cidade seria governada de 1944 a 1947 por interventores, ${ }^{44}$ nomeados diretamente por Amaral Peixoto e Getulio Vargas, gestores, respectivamente, dos poderes estadual e federal naquele momento. Logo, Caxias se transformou num território com baixíssima autonomia, a serviço do populismo e do discurso nacionalista de trabalho, ordem e progresso (Alves, 2003; Souza, 2012; Costa, 2012). Assim, a falta de infraestrutura urbana e de investimentos em cultura, lazer, saúde e educação consolidava o município como um depósito de trabalhadores braçais, influenciados pelo trabalhismo e pelas práticas clientelistas.

Tal contexto de carência social tornou-se campo fértil para a criminalidade germinar e crescer, o que era agravado pelo frágil sistema de segurança pública regional e local. Além disso, "a cobertura jornalística, centrada nas ações delituosas, ajudou a recair sobre Caxias a pecha de 'cidade do crime"” (Lacerda apud Costa, 2007, p. 113). Contribuiu ainda para essa fama a chegada de Natalício Tenório Cavalcanti (Figura 15), migrante alagoano que se consolidou como forte liderança política no município.

\footnotetext{
${ }^{42}$ Em 31 de dezembro de 1943, através do Decreto-Lei n ${ }^{\circ}$ 1.055, foi criado o município de Duque de Caxias. Somente em 1947, porém, foi eleito o primeiro prefeito por voto popular e instalada a Câmara Municipal.

${ }^{43}$ Há controvérsias sobre as razôes centrais que levaram ao processo de emancipação do município de Duque de Caxias. Manoel Simões (2015) explica que um dos principais fatores que levaram à criação do município foi a instalação da Fábrica Nacional de Motores (FNM) em Xerém, fundada por uma portaria federal de 1940 e inaugurada em 1945. De acordo com Simóes, o interventor federal queria um homem de confiança no comando do território que abrigaria esse empreendimento estratégico. Já Stélio Lacerda (2008) afirma que, ao governo do Estado, interessava conceder a emancipação de Caxias, pois isso permitiria organizar e aparelhar melhor a máquina arrecadatória de impostos e, ao mesmo tempo, ampliar as áreas de dominação política. Helenita Beserra da Silva (2003) defende que a emancipação se deu em função da política de Getulio Vargas, que, consciente das conjunturas de âmbito nacional e mundial, buscou criar na população um sentimento de nacionalidade, ao mesmo tempo que assegurava a organização do quadro territorial do país e podava o excesso de regionalismo, o qual, entre outras coisas, era base de sustentação das oligarquias rurais.

${ }^{44}$ Para consultar a lista de interventores nomeados em Duque de Caxias nesse período, ver Costa (2012, p. 222).
} 
Figura 15. Tenório Cavalcanti caminha pelas ruas de Caxias (1964)

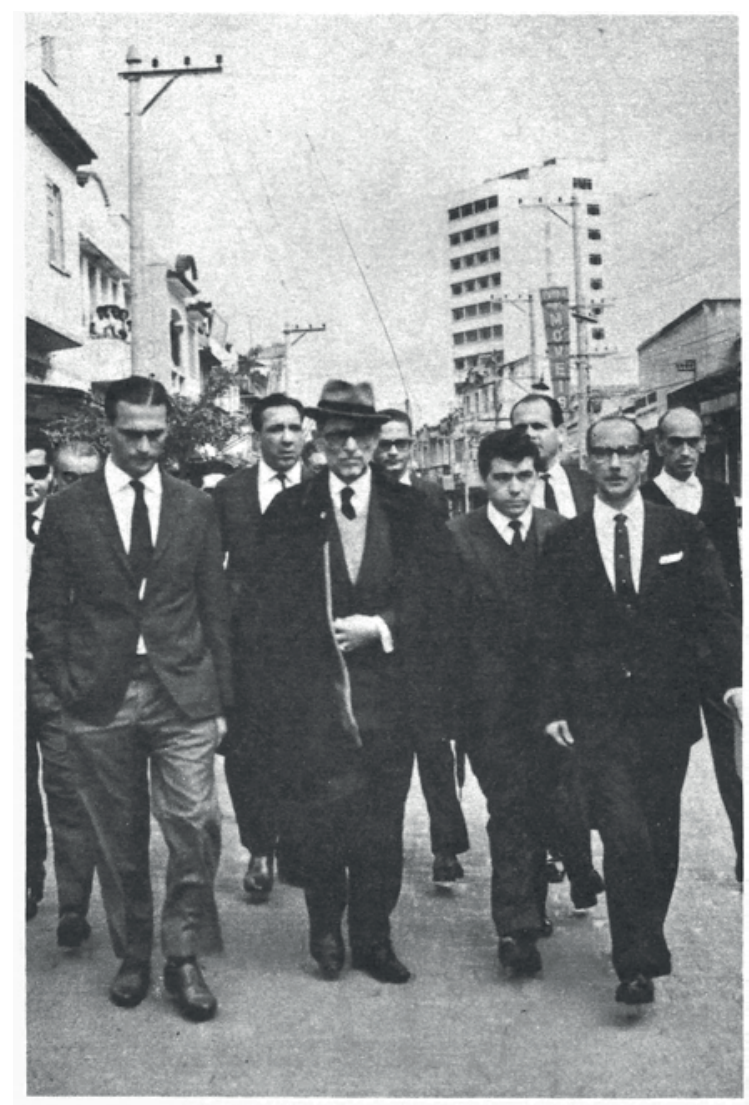

Fonte: Beloch (1986, p. 84).

Conhecido como "Homem da Capa Preta e da metralhadora Lurdinha", 45 Cavalcanti tornou-se um político importante, elegendo-se vereador e, posteriormente, prefeito de Duque de Caxias. Ganhou fama e popularidade também por sua atuação como advogado e jornalista. ${ }^{46}$ Durante a maior parte do tempo, ocupou uma posição política antigetulista, tendo combatido o aliado fluminense de Getulio, o interventor Amaral Peixoto. Essas disputas o fizeram envolver-se em uma série de atos

${ }^{45}$ Beloch (1986) e Alves (2003) afirmam que o apelido da metralhadora foi dado pelo motorista de Tenório, o "Anjo Negro". O nome seria uma associação irônica do som emitido pela arma com o das máquinas de costura, chamadas, carinhosamente, de "Lurdinha" pelas profissionais do ramo. Já Costa (2012) afirma que esse também era o apelido dado às metralhadoras pelos pracinhas da Força Expedicionária Brasileira (FEB) que estiveram nos campos de batalha italianos.

${ }^{46}$ Tenório foi fundador do jornal A Luta Democrática, criado em 1954, de circulação nacional e grande tiragem (Alves, 2003). 
de extrema violência, incluindo a morte de policiais e autoridades ${ }^{47}$ além de assassinatos cometidos por conta de desentendimentos e disputas de terras na cidade. ${ }^{48}$

Tenório migrou do Nordeste para o Rio de Janeiro em 1926, como tantos outros, em busca de oportunidades melhores. Sua trajetória de sucesso político teve início quando recebeu um convite, dois anos depois, para administrar uma fazenda no atual território de Duque de Caxias, então uma área de grande disputa de terras entre grileiros e lavradores. Ali, a resolução bem-sucedida de conflitos por meio da força fez prosperar "sua fama de pistoleiro e de boa pontaria" (Beloch, 1986, p. 46).

Nesse ambiente perigoso e violento, o sonho dos trabalhadores braçais que chegavam ao município de Duque de Caxias, de desfrutar uma vida digna, tornava-se ainda mais distante. Ao mesmo tempo, para proprietários, especuladores, empresas imobiliárias e setores articulados à sociedade política, Caxias representava o acesso a extensas propriedades e à chance real de lucros altos e rápidos. Tenório conseguiu sair do primeiro grupo e adentrar no segundo com grande êxito, tornando-se, ele também, um dos grandes proprietários do município. Seus defensores afirmam que o político colaborou para trazer hospitais, escolas públicas e melhorar o saneamento da cidade. Porém, há indícios claros de que também agiu como fomentador de desigualdades e práticas clientelistas.

Como exemplo, podemos apontar o caso da Vila São José, também conhecida como Vila do Tenório. Em 1971, o local contava com quase 12 mil habitantes, uma escola para cinco mil crianças e alguns cursos profissionalizantes. Porém, apesar de as mais de duas mil casas terem sido construídas com verba federal, passaram a ser de propriedade de Tenório, que cobrava dez cruzeiros de aluguel mensal por residência (Costa, 2012, p. 258). Gestos desse tipo corroboram as críticas de seus detratores, que denunciam sua atuação oportunista e clientelista. Além disso, na maior parte do tempo, sua atitude oposicionista acabou prejudicando a obtenção de verbas federais ou estaduais para financiar as obras públicas, tão necessárias ao desenvolvimento de um município profundamente carente de infraestrutura.

\subsection{Os anos 1940-1960: consolidação da cidade industrial - ou da cidade desigual?}

Nas duas décadas seguintes ao processo de emancipação, Duque de Caxias continuou a sofrer profunda transformação em seu perfil social e econômico. O município, que ainda era um núcleo aca-

\footnotetext{
${ }^{47}$ Segundo Costa (2007, p. 116), "foi dos anos 1950 a mais rumorosa explosão de violência em torno de seu nome: o assassinato do delegado de Duque de Caxias, Albino Imparato, e de outro policial, na madrugada de 28 de agosto de 1953. O atentado teria sido resposta de Tenório a um ataque a tiros que sofrera três dias antes e lhe deixara o chapéu furado à bala. Imediatamente Tenório foi acusado de mandante do crime”.

${ }^{48}$ Tenório Cavalcanti se defendia das acusaçôes dizendo-se alheio à matança ou tendo agido em legítima defesa (Alves, 2003). Internado em hospitais diversas vezes por conta do envolvimento em atos de violência, Cavalcanti "ostentava pelo corpo 47 cicatrizes de bala. Em certo momento, passou a usar colete à prova de bala, mas espalhava que tinha o corpo fechado” (Beloch, 1986, p. 16).
} 


\section{Situando Duque de Caxias no contexto metropolitano da Baixada Fluminense}

nhado no início da década de $1940,{ }^{49}$ tornou-se populoso e industrializado no fim dos anos 1950 . Essas mudanças vieram como resultado da implementação de políticas estatais de caráter nacionalista, uma vez que Caxias foi escolhido para abrigar instalaçōes fabris de grande porte a partir dos anos 1930-1940.

Num contexto marcado pelo início de descentralização da indústria fordista no espaço metropolitano, DC ganhava importância pela grande disponibilidade de terras a preços módicos, o que possibilitava às empresas manterem a proximidade com a capital federal, ao mesmo tempo que reduziam os custos de produção (Silveira, 2014). Por conta dessas vantagens, começaram a se instalar fábricas de pequeno porte dos setores têxtil, vidreiro, químico e farmacêutico (Petrakis, 2009). À mesma época, a União ampliou as áreas sob sua propriedade e nelas deu vazão a projetos como o Núcleo Agrícola São Bento, fundado em 1932; e à Cidade dos Meninos, ${ }^{50}$ núcleo de abrigo e educação para órfãos e crianças carentes criado entre 1942-1943. Contudo, o primeiro dos grandes projetos estatais em Duque de Caxias seria a criação da Cidade dos Motores, na localidade de Xerém, ${ }^{51}$ cujo núcleo central era a construção da Fábrica Nacional de Motores (FNM).

Inaugurada em 1945, a "Fenemê", como ficou conhecida, exigiu altos contingentes de mão de obra durante sua construção, num total de aproximadamente seis mil operários, além de suas famílias. A fábrica também atraiu camponeses do interior do estado fluminense e de outros estados, como Minas Gerais e Espírito Santo, que "vislumbravam a possibilidade de acesso à terra e de venda da produção agrícola para a Fenemê" (Costa, 2012, p. 227), além de muitos outros que passaram a buscar emprego na estatal. Porém, até o fim dos anos 1940, quando foram construídas as vilas operárias, os trabalhadores viviam em acampamentos fortemente hierarquizados e divididos em três classes: a dos operários da obra; a dos funcionários da administração; e a dos operários com formação técnica (Ramalho, 1989). Nas palavras de José Ramalho,

${ }^{49}$ Cabe citar, porém, que, apesar do núcleo urbano diminuto nos anos 1940, o município já apresentava características diferenciadas em relação aos demais vizinhos. Beloch (1986) afirma que Caxias era um dos poucos municípios fluminenses com algum destaque no setor industrial. Portanto, ali a indústria já era incipiente, e o que houve nos anos seguintes foi um desabrochar mais intenso a partir de uma conjuntura favorável.

${ }^{50} \mathrm{O}$ antigo núcleo da Cidade dos Meninos hoje é predominantemente desabitado, uma vez que houve contaminação pelos resíduos produzidos pelo Instituto de Malariologia e por uma fábrica de inseticidas, instalados na região em 1947 e desativados em 1962 (Rio Tóxico Tour, 2012).

${ }^{51}$ Segundo Ramalho (1989), a escolha da localidade de Xerém (atualmente, $4^{\circ}$ Distrito de Duque de Caxias e distante do centro do município) para sediar a FNM envolveu uma série de fatores. Ramalho enumera oito razões principais: Xerém era uma área estratégica, pela presença da estrada de Ferro Rio D’Ouro e da estrada Rio-Petrópolis, o que favorecia a comunicação e a chegada de equipamentos necessários à instalação da fábrica; o terreno no nível do mar diminuiria os custos de construção e logística; havia água em abundância, matéria-prima fundamental para a atividade industrial; havia áreas planas favoráveis à instalação de um campo de pouso; tratava-se de uma extensa área de terras vazias, o que facilitava sua transformação em propriedade da União; a área era protegida por serras e possuía apenas duas vias de acesso, o que a tornava ideal pela possibilidade de defesa de uma fábrica militar; e a proximidade de Xerém com a capital do país facilitava o acesso de técnicos e o escoamento da produção. 
[...] a diversidade de atividades nessa fase da fábrica teria servido de justificativa para a separação dos trabalhadores, assim como as diferentes fontes de recrutamento. [...] Embora predomine a explicação de que a maioria dos trabalhadores da construção civil fora recrutada de Minas e Rio, teria havido trabalhadores de outras regiōes do país, encontrados ou "apanhados" na Baixada Fluminense, principalmente Duque de Caxias, para o serviço duro de desbravar o terreno inóspito e construir os primeiros prédios (Ramalho, 1989, p. 62).

Assim, podemos considerar que muitos dos operários empregados na construção da indústria, bem como os trabalhadores do "chão da fábrica", tiveram de conviver com práticas segregadoras e discriminatórias nos primeiros anos do projeto.

Apesar das grandes expectativas depositadas na Fenemê e de seu relativo sucesso econômico por certo período, a fábrica não conseguiu atrair outros empreendimentos para o entorno. Até os dias de hoje, a localidade de Xerém mantém muitas características típicas de uma área rural. Portanto, podemos dizer que a Fenemê representou pouco para o destino industrial de Caxias, especialmente se comparada com a Reduc.

Foi apenas em 1961 que Duque de Caxias passou a contar com a grande responsável pelo desenvolvimento de sua economia e do setor industrial: a Refinaria de Duque de Caxias (Reduc), que se tornaria a "maior unidade industrial localizada na Região Metropolitana do Rio de Janeiro" (Costa, 2012, p. 230). Também instalada ali por conta da localização estratégica ${ }^{52}$ de Caxias, o peso da Reduc pôde ser sentido rapidamente na economia municipal: no final da década de 1970, a Reduc, o polo petroquímico em formação e a FNM, somados, eram responsáveis por 95,8\% da indústria local e empregavam 42,8\% da mão de obra ocupada no setor secundário (Beloch, 1986). Com isso, entre 1959 e 1970, a participação de Duque de Caxias nas atividades industriais da RMRJ aumentou de 4,4\% para 10,8\% (Beloch, 1986), e o município passou a apresentar a terceira maior arrecadação de impostos do estado. ${ }^{53}$ Ademais, era possível vislumbrar uma expansão ainda maior nos anos seguintes, uma vez que Caxias possuía a maior quantidade de terras livres entre todos os municípios da Baixada em 1970, além de metade de suas terras já ser urbana, o que aumentava as possibilidades de localização industrial (Costa, 2012). Tal panorama fez com que Caxias se tornasse "o município com o mais rápido avanço industrial não apenas na Baixada, mas em todo o antigo estado do Rio de Janeiro" (Costa, 2012, p. 240), cuja capital à época era Niterói. Na Tabela 3, é possível observar essa expansão industrial caxiense e o respectivo aumento das vagas de emprego associadas ao setor.

\footnotetext{
${ }^{52}$ Nas palavras de Costa, "as principais empresas petrolíferas procuram refinar o petróleo perto dos centros de consumo, de forma a reduzir os custos relativos de transporte e garantir a disponibilidade dos produtos nos principais centros consumidores" (Costa, 2012, p. 195). Portanto, tornava-se vantajoso para a empresa situar-se às margens da rodovia Washington Luiz e nas proximidades do segundo maior mercado consumidor do país, o Rio de Janeiro.

${ }^{53}$ Nos anos 1970, Rio de Janeiro, Volta Redonda e Duque de Caxias apresentavam, respectivamente, as três maiores arrecadações do estado do Rio de Janeiro (idem).
} 
Tabela 3. Indústrias e número de empregados em Duque de Caxias (1950-1983)

\begin{tabular}{|l|c|c|}
\hline Ano & Estabelecimentos Industriais & Número de Empregados \\
\hline 1950 & 112 & 3.287 \\
\hline 1956 & 172 & \\
\hline 1960 & 206 & 7.738 \\
\hline 1968 & 370 & \\
\hline 1975 & 504 & \\
\hline 1978 & 605 & \\
\hline 1983 & 826 & 26.000 \\
\hline
\end{tabular}

Fonte: Adaptado de Costa (2012, p. 241).

Com o surto industrial em curso, Duque de Caxias passou exercer a função de subcentro metropolitano, com uma área de influência que ultrapassava os limites do município e atingia até mesmo determinados bairros do então estado da Guanabara (1960-1975), atualmente cidade do Rio de Janeiro. Em consequência, começaram a crescer as vagas de emprego disponíveis em DC, mas ainda se mostravam insuficientes para atender à demanda de mão de obra, uma vez que a população local aumentava num ritmo muito acelerado. $\mathrm{Na}$ Tabela 4, observa-se que Caxias foi o município fluminense com a maior taxa de crescimento demográfico entre os anos 1950 e 1960.

Tabela 4. População nos municípios periféricos do Rio de Janeiro (1950-1960)

\begin{tabular}{|l|l|l|l|}
\hline Municípios & $\begin{array}{l}\text { População } \\
(\mathbf{1 9 5 0 )}\end{array}$ & $\begin{array}{l}\text { População } \\
(\mathbf{1 9 6 0 )}\end{array}$ & $\begin{array}{l}\text { Crescimento } \\
(\mathbf{1 9 5 0 - 1 9 6 0 )})\end{array}$ \\
\hline Duque de Caxias & 92.459 & 241.026 & $161 \%$ \\
\hline São João de Meriti & 76.469 & 190.516 & $149 \%$ \\
\hline Nova Iguaçu & 145.649 & 356.645 & $145 \%$ \\
\hline Nilópolis & 46.406 & 95.111 & $105 \%$ \\
\hline São Gonçalo & 127.267 & 244.617 & $92 \%$ \\
\hline Niterói & 186.309 & 243.188 & $31 \%$ \\
\hline Total & 674.552 & 1.371 .103 & $103 \%$ \\
\hline
\end{tabular}

Fonte: Elaborado a partir de dados de Costa (2012).

De modo geral, sabe-se que a Baixada Fluminense experimentou forte incremento populacional entre as décadas de 1940 e 1960, influenciada pela industrialização do Rio de Janeiro, principalmente nos governos de Getulio Vargas e Juscelino Kubitschek, associada à crescente expulsão dos trabalhadores braçais das áreas mais valorizadas da metrópole fluminense (Silveira, 2014). Contudo, o município de Duque de Caxias recebeu um contingente populacional em proporção maior que seus vizinhos, principalmente de levas de nordestinos em busca de oportunidades de trabalho e moradia. Isso se deve, em 
parte, à maior proximidade com o Rio de Janeiro, o que facilitava o deslocamento pendular diário em direção à metrópole. Como se nota na Tabela 5 , a maior parte da população de Duque de Caxias apenas estabelecia residência na cidade, obtendo seus proventos em atividades fora do município.

Tabela 5. Distribuição da população ocupada (PO) e da população ativa (PEA) nos setores industrial e de serviços em Duque de Caxias (1950-1970) $)^{54}$

\begin{tabular}{|l|c|c|c|c|c|c|}
\hline Ano & \multicolumn{4}{|l|}{ Setor industrial } & \multicolumn{2}{l|}{ Setor de serviços } \\
\hline & PO em DC & $\begin{array}{c}\text { PEA Total de } \\
\text { DC }\end{array}$ & $\begin{array}{c}\text { PEA que trabalha } \\
\text { fora de DC (\%) }\end{array}$ & PO em DC & $\begin{array}{c}\text { PEA Total de } \\
\text { DC }\end{array}$ & $\begin{array}{c}\text { PEA que trabalha } \\
\text { fora de DC (\%) }\end{array}$ \\
\hline 1950 & 3.287 & 11.811 & 72,2 & 2.000 & 14.181 & 85,9 \\
\hline 1960 & 7.738 & 21.770 & 64,5 & 4.730 & 42.512 & 88,9 \\
\hline 1970 & 14.261 & 48.028 & 70,3 & 12.333 & 74.610 & 83,5 \\
\hline
\end{tabular}

Fonte: Adaptado de Costa (2012, p. 246).

Portanto, fica claro que a forte onda migratória dessas décadas promoveu uma explosão demográfica em Caxias, ultrapassando a capacidade de absorção com padrôes mínimos de dignidade da população recém-chegada. Somente entre as décadas de 1940 e 1960, houve um aumento populacional de quase dez vezes, o que configura um crescimento rápido e acentuado. Nesse breve período de vinte anos, a população saltou de 29.618 para 243.626 habitantes, como se nota no Gráfico 5 .

Gráfico 5. Evolução da população do município de Duque de Caxias (1872-2000)

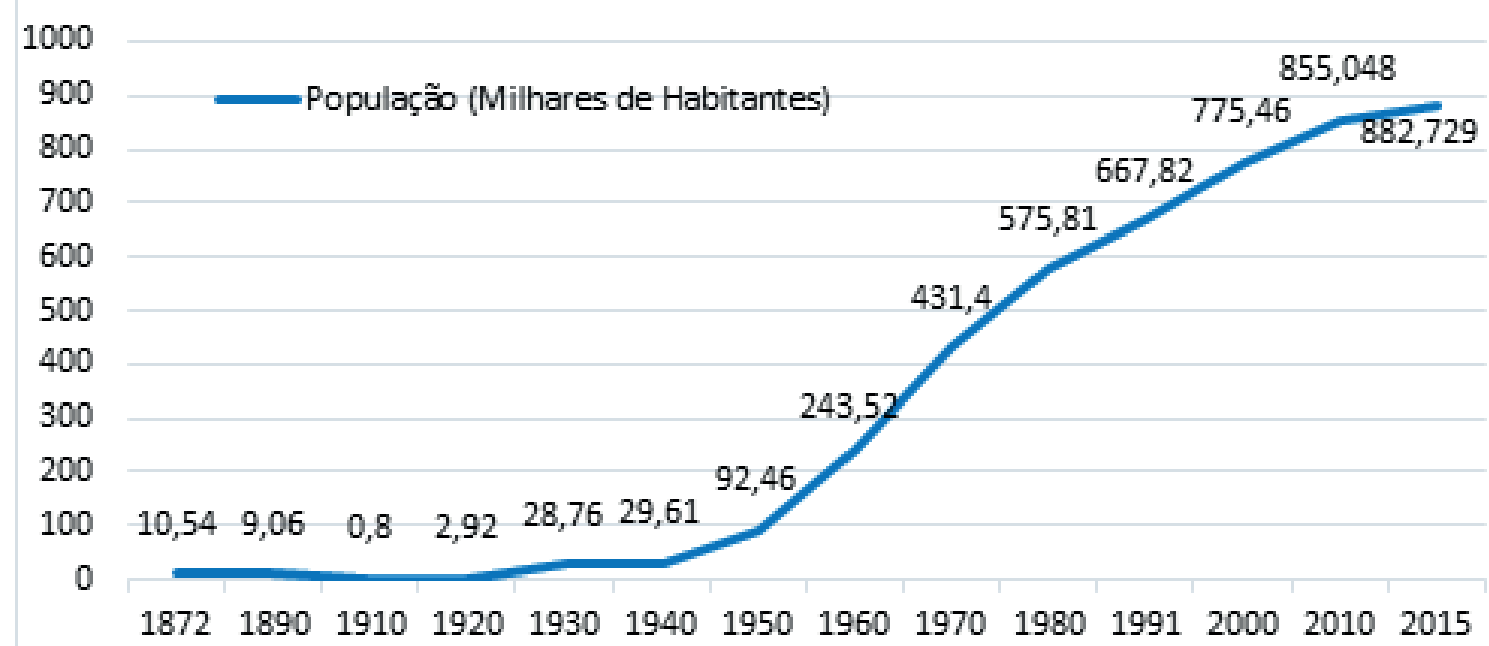

Fonte: Elaborado com dados de Lima (2010) e IBGE (2010 e 2015).

\footnotetext{
${ }^{54}$ Inclui as seguintes atividades: comércio, transportes, finanças, administração, defesa, profissōes liberais e serviços.
} 
Sem estrutura para atender a tamanho crescimento demográfico, Caxias assistiu ao crescimento dos problemas ligados à urbanização rápida e desordenada. De acordo com Braz e Almeida (2010, p. 70), "a precariedade no acesso à água potável, a ausência de uma rede de captação de esgoto e a precariedade nos serviços de energia tornavam a vida no município um flagelo às pessoas". Os censos de 1960 e 1970 mostram que menos de 25\% dos domicílios contavam com um escoamento de dejetos razoável (Beloch, 1986). Segundo Costa (2012), "[...] em 1970, dos 431.397 habitantes caxienses, apenas 30.284 trabalhavam no município. Desses, 12,18\% ocupavam-se na agricultura, $47,99 \%$ na indústria e $40,73 \%$ no comércio e serviços. [...] [Das] 109.513 edificaçôes, somente $40 \%$ eram ligadas à rede de água, $24 \%$ à de esgotos e $70 \%$ à energia elétrica (p. 243).

Dessa forma, o município passou a desempenhar "importante papel na fixação da população de baixa renda, que, face ao alto custo da terra, tem como opção [estabelecer] moradia em áreas periféricas, com reduzido investimento público" (Sales, 1999, p. 50). Consolidava-se uma típica estrutura urbana dicotômica, colocando em lados opostos as áreas centrais do Rio de Janeiro e as áreas periféricas. De modo geral, nas primeiras moravam as classes mais abastadas e o poder público era atuante, tendo criado relativa infraestrutura urbana. Já nos espaços suburbanos, morada das classes populares, os habitantes conviviam com a escassa infraestrutura, além de sofrerem com a indiferença do poder público no atendimento de suas necessidades mais básicas. Como resultado, a omissão - e, de certa forma, o respaldo - do poder público consolidou um espaço urbano caracterizado por forte desigualdade socioespacial. Com efeito, "para que fossem mantidos os ideais de ordem, eram necessárias desordens ignoradas ou imaginadas temporárias, como os loteamentos irregulares ou as favelas" (Petrakis, 2009, p. 51), multiplicando a quantidade de pessoas que viviam em condiçôes aviltantes. Todavia, quando observamos o ritmo de crescimento dessa população, verificamos que vem perdendo a força a partir da década de 1970, sendo relativamente baixo nos dias atuais (Gráfico 6).

Gráfico 6. Taxa de crescimento populacional em Duque de Caxias (1940-2010)

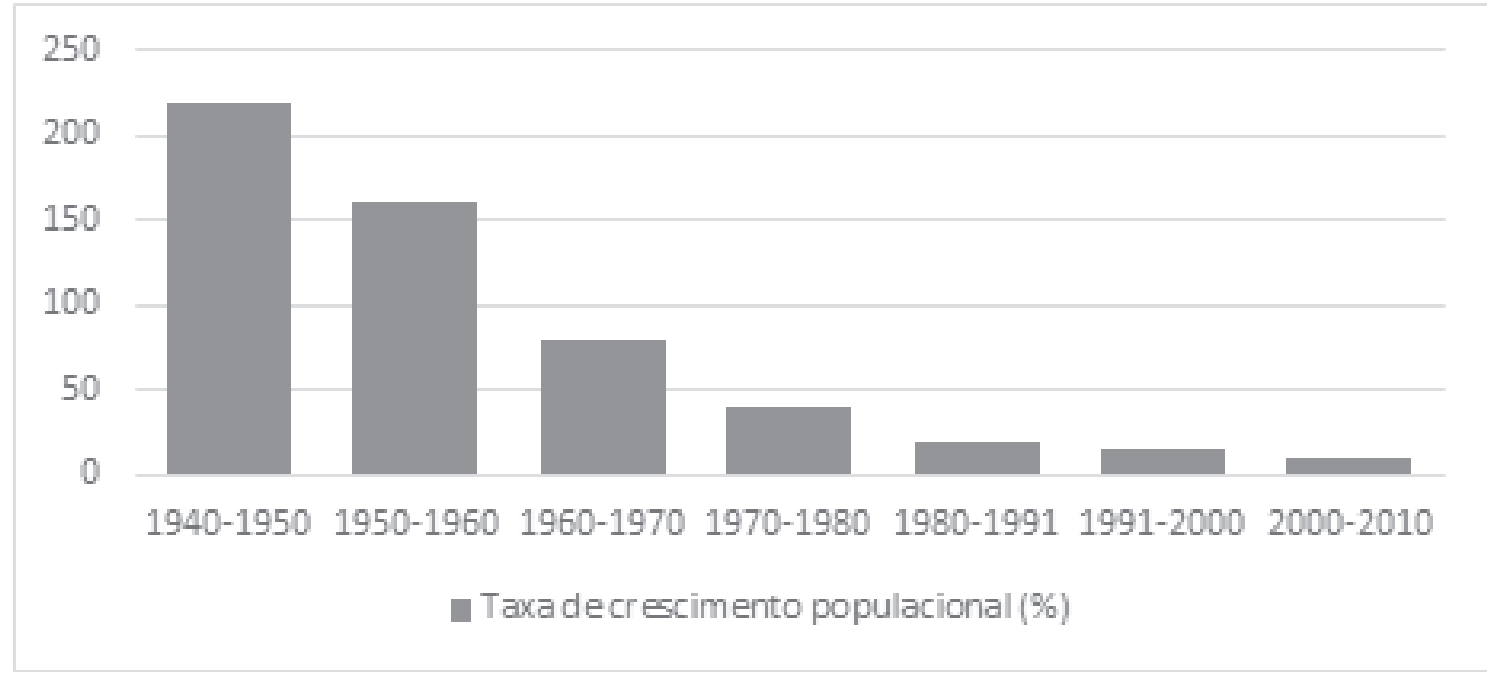

Fonte: Elaborado com dados do Ceperj (2013). 
A leitura do Gráfico 6 nos permite confirmar que o período de maior crescimento populacional no município ocorreu entre as décadas de 1940 a 1960. Nesse período, apesar da industrialização crescente, Caxias passou a apresentar uma ocupação típica de cidade-dormitório, com deficiência em todos os segmentos, tais como insuficiência de infraestrutura e equipamentos comunitários, implantação desordenada dos loteamentos e habitações de baixo padrão construtivo (Beloch, 1986). Portanto, julgamos que o processo de loteamento ocorrido entre as duas décadas promoveu impacto direto no município, acarretando uma grande transformação espacial, com mudanças no padrão de ocupação até então estabelecido e o consequente aprofundamento das desigualdades sociais existentes.

É possível notar que Caxias apresenta uma estrutura urbana no modelo centro-periferia, com infraestrutura, mercado de trabalho e moradia de alto padrão concentrados predominantemente nas áreas centrais, ao passo que a periferia municipal, em seus vários níveis, se mostra em sua maioria empobrecida. Ao mesmo tempo, assim como apontado por Lago (2000), a cidade conta com a presença de enclaves territoriais enobrecidos e outros em processo de enobrecimento, elementos vistos como característicos pela autora no novo padrão de segregação socioespacial na metrópole fluminense.

Nesse contexto, torna-se necessário investigar o fenômeno dos loteamentos em Duque de Caxias, especialmente nas duas décadas em que houve explosão do crescimento populacional, como forma de compreender as disparidades atualmente notadas entre os bairros do município.

\section{Os loteamentos e a produção de padrões de urbanização desiguais}

Segundo Pacheco (1984, p. 62), "a luta pela apropriação de um espaço de reprodução da força de trabalho pela população de baixa renda tem se processado praticamente do mesmo modo [...] desde que os loteamentos foram instituídos como forma de urbanização". Para a autora, as terras loteadas garantiam lucro para os capitalistas que as vendiam e resolviam o problema da moradia para os trabalhadores que desejavam ter um imóvel. Tal aparente simbiose de interesses faria, portanto, com que o padrão de ocupação das terras de áreas periféricas se mantivesse o mesmo por um longo período.

Nas glebas maiores, alguns proprietários que não tinham condições de arcar integralmente com os custos buscavam associar-se a empresas do núcleo metropolitano. Nesses casos, as empresas "assumiam os investimentos em obras de loteamento e venda dos lotes mediante a obtenção de parte dos lucros do empreendimento" (Pacheco, 1984, p. 33). No entanto, a maioria dos loteamentos em áreas periféricas tem como principal característica a pouca ou nenhuma infraestrutura. Costumam ser glebas rurais improdutivas, onde os empreendedores responsáveis apenas demarcam ruas e terrenos antes de efetuar a venda. Uma vez que o capital investido é próximo de zero, os lotes são revendidos a preços módicos. Normalmente, são oferecidas condições acessíveis de pagamento, com uma entrada simbólica, prestações reduzidas e, em geral, sem juros, o que torna os imóveis acessíveis à população de baixa renda (Simões, 2007). Após a compra do lote, os novos donos passam a efetuar a construção 
de suas residências por conta própria. Com a ajuda de amigos e familiares, muitas das vezes contrói-se até mesmo uma parte dos equipamentos coletivos do bairro. Tal regime, conhecido como "autoconstrução", acaba por formar:

[...] um grande número de bairros caracterizados pela baixa qualidade de vida reproduzindo, em parte, os mesmos problemas que haviam sido a causa do surgimento dos loteamentos. Se nestes não há mais amontoamento de pobres em ruas estreitas sem circulação de ar, a precariedade das construções e das condições sanitárias vão continuar assolando [...] [a população] e determinando uma degradação ambiental e das condições gerais de vida (Simões, 2011, p. 117).

Com efeito, a adoção do modelo de ocupação urbano baseado em autoconstruções realizadas em loteamentos permitiu transferir boa parte da pobreza e dos problemas sociais que atingiam a área central do Rio de Janeiro para áreas agora distantes da burguesia. Uma vez que as rápidas industrialização e expansão urbana sofridas pelo Rio de Janeiro promoviam crescimento expressivo da demanda por terras, a Baixada se mostrava uma área propícia a absorver a população excedente da capital federal.

Surgia, então, um movimento em direção às periferias que representou o lançamento das bases do que viria a se configurar a Área Metropolitana do Rio de Janeiro (Abreu, 1987). Nesse sentido, as vias de circulação tiveram participação fundamental, com destaque para as ferrovias. Afinal, a expansão da ferrovia permitiu o surgimento de diversos núcleos suburbanos, os quais passaram a ser habitados pela população pobre, que buscava moradia em locais de baixo custo. Dessa forma, mesmo com a construção de diversas e importantes rodovias na primeira metade do século XX, o trem continuou a ser o principal vetor de expansão populacional ao município de DC. Segundo Maurício de Abreu (1987), o transporte ferroviário facilitou muito o crescimento da metrópole "em pulos" (p. 123), devido às suas tarifas unificadas e subsidiadas pelo governo, o que permitia à população de baixa renda fixar residência em áreas de menor custo e afastadas do local de trabalho. Com isso, já nos anos 1930, diversos loteamentos começaram a ser realizados nas proximidades de estações ferroviárias dos distritos de Duque de Caxias, Nilópolis e São João de Meriti, mais próximos do núcleo metropolitano.

\subsection{Os loteamentos em Duque de Caxias e a "febre loteadora"}

O período de loteamento mais intenso no município de Duque de Caxias varia de acordo com o distrito em questão. Nos $2^{\circ}$ e $3^{\circ}$ distritos Duque de Caxias - Campos Elíseos e Imbariê, respectivamente -, os loteamentos foram feitos, em sua maioria, nas décadas de 1950 e 1970, como se vê na Figura 16. Porém, se, por um lado, Campos Elíseos possui a maior parte do seu território loteado, isso não se repete em Imbariê, uma vez que uma parte significativa de suas terras está em áreas rurais e de reserva florestal. 
Figura 16. Evolução urbana no município de Duque de Caxias

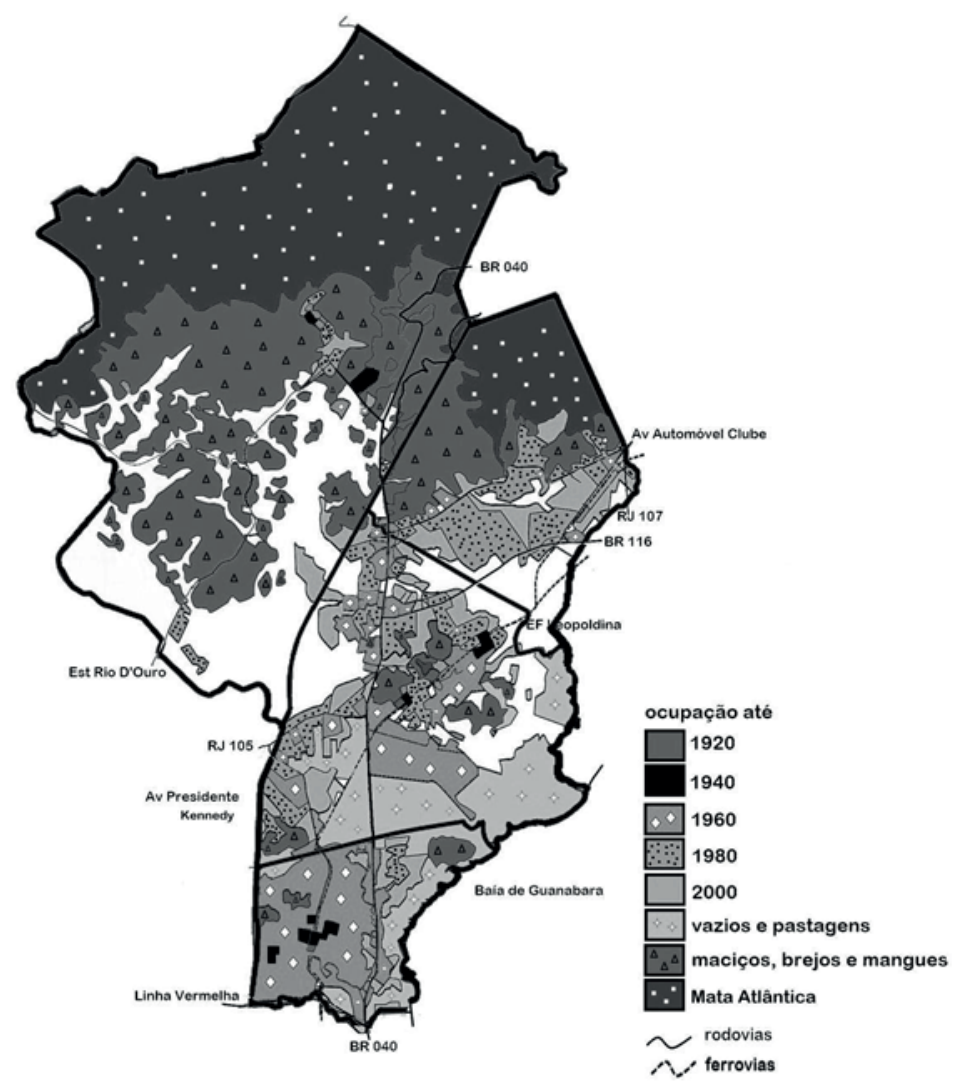

Fonte: Adaptado de Simões (2015, p. 31).

Já no distrito de Xerém, a ocupação esteve ligada inicialmente à construção da Fábrica Nacional de Motores (FNM). Como se nota na Figura 16, esse $4^{\circ}$ Distrito é o de menor área loteada, contando apenas com um conjunto de pequenas terras parceladas em sua sede e alguns bairros próximos. A observação dessa imagem nos mostra também que, atualmente, quase toda a área do $1^{\circ}$ Distrito está loteada. Ocupadas a partir da estação ferroviária central do município, suas terras foram mais parceladas entre as décadas de 1940 e 1960. Porém, é possível notar, nesse distrito, que alguns poucos espaços já estavam parcelados antes da década de 1940.

Isso ocorre porque é a partir dos anos 1920 e 1930 que Caxias começa a sofrer os primeiros efeitos mais expressivos da expansão urbana da cidade do Rio de Janeiro. É importante frisar que, em outras áreas da Baixada Fluminense, a fragmentação de terras começou antes mesmo do período de explosão demográfica. Nelas, o retalhamento de propriedades teve início durante o curto período econômico da citricultura, responsável por multiplicar as chácaras produtoras de laranja (Costa, 2012). Em Caxias, contudo, esse "ciclo" econômico não aconteceu. Essa é uma das razôes que explicam a maior quantidade de terras livres no território caxiense nas décadas de 1940 e 1950 em comparação com seus vizinhos da 
Baixada. Portanto, os loteamentos do município surgiram diretamente do vazio econômico, "suscitados pela abundância de terras baratas nas proximidades da cidade do Rio de Janeiro” (Beloch, 1986, p. 24).

O loteamento de terras, porém, alcançou seu auge entre as décadas de 1940 e 1960, momento em que todos os municípios da Baixada Fluminense apresentaram altas taxas de crescimento demográfico. Os fatores de atração que levaram a esse incremento populacional incluem a construção da rodovia Washington Luiz, ou BR-040 (1928), a inauguração da avenida Brasil (1946), da nova rodovia Rio-São Paulo, ou BR-116 (1951), a instalação da Reduc (1961), o baixo preço dos lotes oferecidos e o reduzido ou nenhum controle sobre as construçôes por parte do Poder Público, ao contrário do que acontecia na capital federal, em que as exigências burocráticas e a cobrança do cumprimento de normas urbanísticas tornavam mais difícil a construção de novos imóveis (Abreu, 1987).

Por causa dessas mudanças, Duque de Caxias passou a apresentar dois processos simultâneos de ocupação espacial: de um lado, aumentava a densidade dos loteamentos nas cercanias das ferrovias e da antiga Rio-Petrópolis; de outro, surgiam novos loteamentos e favelas às margens das novas rodovias construídas. Tal panorama colaborou para acelerar ainda mais o aumento populacional. Ocorreria, então, uma verdadeira "febre de loteamentos", como se pode observar na Tabela 6.

Tabela 6. Loteamentos aprovados pela prefeitura em Duque de Caxias (1949-1978)

\begin{tabular}{|l|c|c|c|}
\hline Período & $\mathbf{N}^{\circ}$ de lotes & Área total (ha) & $\begin{array}{c}\text { Área média dos } \\
\text { Lotes }\left(\mathbf{m}^{\mathbf{2}}\right)\end{array}$ \\
\hline Até 1949 & 57.206 & 6.198 & 1.083 \\
\hline $1950-1959$ & 85.642 & 7.001 & 817 \\
\hline $1960-1969$ & 60.038 & 3.274 & 545 \\
\hline $1970-1978$ & 27.988 & 1.376 & 492 \\
\hline Total & 230.874 & 17.849 & 773 \\
\hline
\end{tabular}

Fonte: Adaptado de Costa (2012, p. 231).

Nota-se que o período de maior intensidade do parcelamento de terras é a década de 1950, embora os loteamentos tenham continuado nas décadas seguintes. Porém, a cada década, as áreas médias dos lotes foram sucessivamente reduzidas. Podemos concluir que esse padrão indica a constante diminuição da oferta de terrenos em relação à demanda e, portanto, sua progressiva valorização. Ao mesmo tempo, demonstra o incessante declínio do padrão de vida dos compradores de lotes, constrangidos a se restringir a espaços cada vez mais acanhados - alternativa única à moradia em favelas (Silveira, 2014).

Essa febre de loteamentos nos anos 1950-1960, em Duque de Caxias, muito se relaciona com o processo radical de remoção das comunidades carentes na Zona Sul, na Zona Norte e no centro da 
cidade do Rio de Janeiro no período. ${ }^{55}$ Nesse momento, as áreas ocupadas pelas favelas começaram a ser disputadas pelo setor imobiliário, que buscava reproduzir seu capital em uma área já consolidada. A partir de então, o Estado assumiu a tarefa de remover as comunidades, o que permitiu liberar áreas para a especulação imobiliária e, ao mesmo tempo, aumentar o valor de troca das propriedades, ao eliminar a presença de algumas externalidades negativas, como a pobreza e a marginalidade ali existentes à época (Pacheco, 1984). Portanto, percebe-se que o Estado e os interesses do capital privado atuaram em conjunto na produção do espaço urbano nesse período, agravando o quadro já problemático da questão habitacional e induzindo a população mais pobre a se afastar do núcleo da metrópole, prejudicando, assim, sua capacidade de vivenciar os espaços mais valorizados da cidade.

Os promotores imobiliários passaram a priorizar a construção de seus empreendimentos em áreas nobres e, para isso, intensificaram a criação de amenidades e outras ações que pudessem aumentar o valor do solo urbano. Com a conivência das autoridades legais, essas medidas acabaram por impedir o acesso da classe baixa à moradia nesses locais, o que, por sua vez, ajudou a impulsionar mais o preço do solo como mercadoria. O Estado agiu da mesma forma, por meio de açóes diretas, como na remoção de favelas; ou indiretas, ao permitir a especulação urbana e os vazios espaciais nas áreas valorizadas da cidade. Com isso, o poder público deixou a uma grande parte da população poucas possibilidades de escolha, restando ir "para conjuntos habitacionais, para outras favelas ou para loteamentos recentes situados em localizações distantes e periféricas. Muitos optaram pela última escolha, dando novo impulso ao processo de periferização" (Pacheco, 1984, p. 18).

Tal processo de periferização atingiu Duque de Caxias de forma acentuada, transformando 38\% da área total do município em loteamentos já no fim dos anos 1960 (Beloch, 1986). Vista anteriormente, a Figura 16 permite notar que esse percentual não é maior porque muitos espaços municipais são ocupados por encostas, várzeas inundáveis, patrimônios públicos e outros terrenos não utilizáveis com esse finalidade, além de não terem sido computados os loteamentos clandestinos nessa estatística. Ao analisar o Quadro 1, constata-se que muitos dos principais bairros do município provêm de antigos loteamentos feitos entre as décadas de 1940 e 1950.

Quadro 1. Bairros caxienses e loteamentos de origem

\begin{tabular}{|l|l|c|}
\hline Bairro Atual & Loteamento de origem & Data de loteamento \\
\hline Imbariê & Vila Ema & 1942 \\
\hline Pauliceia & Parque Pauliceia & 1943 \\
\hline Figueira & - & 1943 \\
\hline Parada Angélica & Fazenda Tapera & 1945 \\
\hline Jardim Primavera & Chácara Rio-Petrópolis & 1947 \\
\hline
\end{tabular}

\footnotetext{
55 Segundo Abreu (1987), até a década de 1950 o Estado não se preocupou em remover as favelas dessas localidades, pela necessidade de manter uma reserva de mão de obra barata para as atividades econômicas ali situadas, pelos interesses políticos populistas e porque tais áreas eram economicamente pouco valorizadas até aquele momento.
} 


\begin{tabular}{|l|l|c|}
\hline Bairro Atual & Loteamento de origem & Data de loteamento \\
\hline Parque Paulista & Fazenda N. S. da Penha & 1948 \\
\hline Gramacho & Vila Leopoldina & 1950 \\
\hline Saracuruna & Vila Vitória & 1951 \\
\hline Jardim 25 de Agosto & Fazenda Engenho Velho & 1952 \\
\hline Dr. Laureano & Vila Caetano Madeira & 1952 \\
\hline Pilar & Nossa Senhora do Pilar & 1953 \\
\hline Lafayete & Parque Lafayete & 1956 \\
\hline Engenho do Porto & Fazenda Engenho do Porto & 1959 \\
\hline Pantanal & Vila Santo Antônio & \\
\hline
\end{tabular}

Fonte: Elaborado com dados de Braz e Almeida (2010, p. 82).

É preciso ter cuidado, contudo, com a generalização do processo de loteamento. Apesar do predomínio de um padrão de periferização constituído por loteamentos nas proximidades de estações ferroviárias e dotados de pouca ou nenhuma infraestrutura, não se pode afirmar que toda a urbanização de Duque de Caxias no período tenha seguido esse modelo. De acordo com Susana Pacheco,

[...] como forma de urbanização, [o loteamento] não tem sido um fenômeno genérico e sincrônico na periferia. Tampouco é provocado pelos mesmos fatores. Generalizar o loteamento a toda a extensão do que hoje denominamos periferia seria o mesmo que cometer o engano de esquecer o papel representado pela ocupação espontânea na configuração do espaço residencial metropolitano, sobretudo aquele que gerou núcleos constituídos a partir de estações ferroviárias (Pacheco, 1984, p. 28).

Logo, o loteamento não é necessariamente o único fator de urbanização de uma periferia, não é provocado pelas mesmas razões, nem segue os mesmos padrões sempre. Por isso, não é possível tratar as periferias e a áreas segregadas como espaços homogêneos. $\mathrm{O}$ interior das áreas periféricas também é palco de vários processos simultâneos e repleto de heterogeneidades socioespaciais, pois "os núcleos residenciais suburbanos também se expandiram criando suas próprias periferias, que, por sua vez, refletem com maior crueza as desigualdades desencadeadas a partir do núcleo metropolitano" (Pacheco, 1984, pp.18-9).

Nesse contexto, presume-se que nem todos os espaços de Caxias possuíam à época e hoje as mesmas precariedades infraestruturais. Isso porque, de acordo com Petrakis (2009, p. 55), o modelo de loteamento popular voltado a uso residencial apresentava duas vertentes distintas: a urbanização de status e a urbanização popular.

Sobre a primeira, pode-se dizer que "essas terras da periferia de amenidades são destinadas à população de status. Como se trata de uma demanda solvável, é possível aos proprietários fun- 
diários tornarem-se também promotores imobiliários; loteiam, vendem e constroem casas de luxo [...]” (Corrêa, 1989, p. 18).

Dessa forma, para atender aos anseios de uma classe mais abastada, surgiram no município alguns loteamentos dotados de melhor infraestrutura. Ali, o Estado se fazia presente, cobrando com rigor a adoção de padrões urbanos que tornavam os lotes mais caros e, por isso mesmo, inacessíveis aos mais pobres. Em Duque de Caxias, o exemplo mais evidente dessa urbanização de status é o bairro Jardim 25 de Agosto. Contudo, a maior parte dos demais bairros caxienses surgiu a partir de loteamentos que seguiram o padrão da urbanização popular. Segundo Corrêa (1989), esse modelo se caracteriza:

[...] [por ocorrer em] um setor periférico, não apenas distante do centro, mas sem amenidades, não atraindo, portanto, grupos sociais de elevado status [...] [Logo,] não resta aos proprietários fundiários senão o loteamento de suas terras como meio de extrair a renda da terra. E se trata de loteamentos populares, com o mínimo de infraestrutura. Tendo em vista o baixo poder aquisitivo da população que aí se desloca, não há interesse desses proprietários em se transformarem em promotores imobiliários. Apenas realizarão o loteamento; as habitaçôes serão construídas pelo sistema de autoconstrução ou pelo Estado (p. 19).

Dessa forma, supomos que, entre as décadas de 1940 e 1960, Caxias possuía poucos bairros com relativo ordenamento territorial. Por outro lado, deduz-se a existência de uma enorme quantidade de loteamentos precários. Afinal, era uma "cidade partida que crescia economicamente e separava-se socialmente em um mesmo movimento contínuo” (Braz e Almeida, 2010, p. 105). Portanto, acreditamos que o período situado entre as décadas de 1940 e 1960 é fundamental para que possamos entender de que forma se processou a produção do espaço urbano desigual no município de Duque de Caxias, uma vez que foi esse o momento de mais intenso crescimento populacional da cidade. Como também foi o auge do processo de loteamento, julgamos que alguns desses lotes receberam melhor infraestrutura e foram ocupados por uma população com renda mais elevada.

Historicamente rotulada como um espaço de alta criminalidade, a cidade de Duque de Caxias é também um ambiente propício para a absorção, por parte de seus moradores de renda mais elevada, da ideia de morar em condomínios fechados ou enclaves fortificados. Embasamos nossa visão a partir de Lago (2000), que apontou ser a periferia, já nos anos 1970, não mais apenas locus da pobreza, mas sim um espaço de precariedades, com a presença de novos enclaves territoriais enobrecidos e de outros em processo de enobrecimento.

Tal processo, ocorrido com a modernização do mercado imobiliário e a chegada de segmentos médios em determinadas localidades da periferia, teria se aprofundado no decorrer dos anos 1980 e 1990 e mantido ao longo dos anos 2000, promovendo, assim, uma contínua fragmentação do tecido socioespacial das cidades e complexificando o padrão de segregação até então observado nas metrópoles e em suas periferias.

Dessa forma, os indicadores de infraestrutura, renda e escolaridade tendem a apontar para a manutenção de uma estrutura urbana dual do tipo centro-periferia nos municípios da Região Metropolitana, embora cada vez mais fragmentada e entremeada por enclaves socioespaciais. Em Duque de 
Caxias, isso se confirma pela presença de núcleos abastados, especialmente no bairro Jardim 25 de Agosto, em que boa parte de seus habitantes desfruta de condições de renda muito superiores aos demais residentes do município. Assim, a ausência do Estado na condição de realizador de políticas efetivas de promoção da igualdade e da qualidade de vida para os cidadãos mais pobres promove também o aumento da mercantilização da segurança, em que as classes dominantes se ocupam da produção de um espaço urbano marcado pelo isolamento dos indivíduos.

\section{Referências}

ABREU, Maurício de Almeida. Evolução urbana do Rio de Janeiro. Rio de Janeiro: IplanRio/Zahar, 1987.

_ . "A luta pelo controle territorial da Baía de Guanabara no século XVI: agentes, alianças e conflitos". In ABREU, Maurício de Almeida (org.). Rio de Janeiro: formas, movimentos, representaçôes. Rio de Janeiro: Da Fonseca Comunicação, 2005, pp. 8-29.

ALVES, José Cláudio Souza. Dos barōes ao exterminio: uma história da violência na Baixada Fluminense. Duque de Caxias: APPH-CLIO, 2003.

AMADOR, Elmo da Silva. "Baía de Guanabara: um balanço histórico". In ABREU, Maurício de Almeida. Natureza e sociedade no Rio de Janeiro. Rio de Janeiro: Departamento de Documentação e Informação Cultural, 1992, pp. 201-58.

BELOCH, Israel. Capa Preta e Lurdinha: Tenório Cavalcanti e o povo da Baixada. Rio de Janeiro: Record, 1986.

BRAME, Fernando Ribeiro Gonçalves. "O desenvolvimento do conceito sociológico de cidade e a estrada de ferro como agente de articulação socioespacial". In SANTOS, Angela Moulin S. Penalva. Rio de Janeiro: um olhar socioespacial. Rio de Janeiro: Gramma, 2010. pp. 371-88.

BRAZ, Antônio Augusto e ALMEIDA, Tânia Amaro Augusto de. De Merity a Duque de Caxias: encontro com a história da cidade. Duque de Caxias: APPH-CLIO, 2010.

CANTALEJO, Manoel Henrique de Sousa. O município de Duque de Caxias e a ditadura militar: 1964-1985 (dissertação). UFRJ.

CARDOSO, Adauto Lucio. "Meio ambiente e moradia: discutindo o déficit habitacional a partir do caso da Região Metropolitana do Rio de Janeiro". Caxambu. Anais... XI Encontro Nacional da ABEP, 1998, pp. 1.671-703. Disponível em: http://www.abep.nepo.unicamp.br/docs/anais/ PDF/1998/a191.pdf.

CARDOSO, Alexandre. Retratos da Baixada Fluminense. Duque de Caxias: Wak, 2010.

CAVALCANTI, Nireu. "Rio, capital da colônia". In PINHEIRO, Augusto Ivan de Freitas (org.). Rio de Janeiro: cinco séculos de história e transformaçōes urbanas. Rio de Janeiro: Casa da Palavra, 2010, pp. 43-75.

CEPERJ. Anuário estatístico do estado do Rio de Janeiro. Fundação Centro Estadual de Estatísticas, Pesquisas e Formação de Servidores Públicos do Rio de Janeiro. Rio de Janeiro: Ceperj, 2013. Disponível em: http://www.ceperj.rj.gov.br/ceep/Anuario2013/index.html. Acesso em: 21 nov 2015. 
- Boletim CEPERJ: a estrutura industrial no Estado do Rio de Janeiro - 2008 a 2014. Ago 2014, ano I, no 3. Disponível em: http://www.ceperj.rj.gov.br/int/boletim\%20ceperj/Boletim_2014/ Boletim\%20n\%C2\%BA\%203\%20-\%20Agosto.pdf. Acesso em: 9 jan. 2016.

CORRÊA, Roberto Lobato. O espaço urbano. São Paulo: Ática, 1989. 94p.

COSTA, Pierre Alves. "Tenório Cavalcanti: entre o mito e a realidade”. In I Workshop Regional de Geografia e Mudanças Ambientais, 2007, Guarapuava. I Workshop Regional de Geografia e Mudanças Ambientais: desafios da sociedade do presente e do futuro. Anais... Guarapuava: Unicentro, 2007, pp. 113-20.

- A cidade do Petróleo: uma geo-história do refino do Petróleo no Brasil. Guarapuava: Unicentro, 2012.

FIGUERÊDO, Maria Aparecida de. A criação de um polo moveleiro no desenvolvimento econômico do município de Duque de Caxias: limites e perspectivas (dissertação). UFRJ, 2010.

GIMENEZ, Aurélio. "Moinho e fábrica naval se mudam para Duque de Caxias", O Dia, Rio de Janeiro, 08 abr. 2014. Disponível em: http://odia.ig.com.br/noticia/economia/2014-04-08/moinho-e-fabrica-naval-se-mudam-para-duque-de-caxias.html. Acesso em: 21 nov. 2015.

IBGE. PIB dos municípios brasileiros. 2010. Disponível em: ftp://ftp.ibge.gov.br/Pib_Municipios/2010/pdf/tab01.pdf. Acesso em: 28 nov. 2015.

LACERDA, Stélio. "De subúrbio dormitório a 'cidade progresso"”. In TORRES, Gênesis (org.). Baixada Fluminense: a construção de uma história. Rio de Janeiro: Inepac, 2008, pp. 199-202.

LAFRAIA, João Ricardo Barusso et al. REDUC 50 anos: entre o passado e o futuro. Rio de Janeiro: Petrobras, 2011.

LAGO, Luciana Corrêa. Desigualdades e segregação na metrópole: o Rio de Janeiro em tempo de crise. Rio de Janeiro: Revan, 2000.

LAMEGO, A. R. O homem e a Guanabara. Rio de Janeiro: IBGE, 1964.

LIMA, Marcos Rangel de. Desigualdades socioespaciais no municipio de Duque de Caxias, RJ: uma abordagem interescalar (dissertação). IBGE, 2010.

MCKENZIE, Roderick. "The Neighborhood: A study of local life in the city of Columbus, Ohio". American Journal of Sociology, v. 27, n. 2, 1921, pp. 145-68. Disponível em: http:// www.jstor.org/stable/2764821?. Acesso em: 06 set. 2015.

MORAES, Dalva Lazaroni de. O município de Duque de Caxias: sua terra, sua gente, sua economia. Rio de Janeiro: Ao Livro Técnico, 1990.

NOGUEIRA, Marcus Antonio Monteiro (org.). Baixada Fluminense: memória fotográfica. Rio de Janeiro: Inepac, 2008.

O MUNICIPAL, edição no 9.045, 21 a 28 de outubro de 2005, p. 5.

OLIVEIRA, Márcio Piñon de. "Cidadania e reformas urbanísticas no Rio de Janeiro: a Reforma Pereira Passos (1902-1906)". In A diversidade da geografia brasileira: escalas e dimensões da análise e da ação. Anais... Presidente Prudente: Anpege/Unesp-PP, 2015, pp. 2.636-48.

OLIVEIRA, Rafael da Silva. "Distintas noções de Baixada Fluminense: a busca do entendimento da constituição política da região - apresentação otimista sobre o seu crescimento latente". In (org.). Baixada Fluminense: novos estudos e desafios. Rio de Janeiro: Paradigma, 2004, pp. 17-47. 
PACHECO, Susana Mara Miranda. Produção e reprodução de loteamentos na periferia do Rio de Janeiro (dissertação). UFRJ, 1984.

PERES, Guilherme. "Notas sobre Duque de Caxias". In TORRES, Gênesis (org.). Baixada Fluminense: a construção de uma história. Rio de Janeiro: Inepac, 2008, pp. 203-4.

PETRAKIS, Giannis Hans Martins. O processo de verticalização e a especulação imobiliária no bairro 25 de Agosto, Duque de Caxias-RJ (monografia). UERJ, 2009.

PINHEIRO, Augusto Ivan de Freitas. "A cidade e o tempo: o Rio de Janeiro através dos séculos". In PINHEIRO, Augusto Ivan de Freitas (org.). Rio de Janeiro: cinco séculos de história e transformaçôes urbanas. Rio de Janeiro: Casa da Palavra, 2010, pp. 21-41.

PLANTEK, Consultores Associados. Planejamento Estratégico Municipal de Duque de Caxias. Duque de Caxias: Prefeitura Municipal de Duque de Caxias, 1999.

PNUD. Atlas do Desenvolvimento Humano no Brasil. Brasília: PNUD/São Paulo: IPEA/Belo Horizonte: Fundação José Pinheiro, 2013. Disponível em: http://www.atlasbrasil.org.br/2013/. Acesso em: 09 jan. 2016.

PRADO, Walter. História social da Baixada Fluminense: das sesmarias a foros de cidade. Rio de Janeiro: Ecomuseu Fluminense, 2000.

PUC. Núcleo Interdisciplinar de Meio Ambiente (NIMA). Atlas geográfico escolar do município de Duque de Caxias. Rio de Janeiro: PUC-RJ/Impressa Oficial do Estado do Rio de Janeiro, 2011.

RAMALHO, José Ricardo. Estado patrão e luta operária: o caso FNM. São Paulo: Paz e Terra, 1989.

SALES, Rita de Cássia Carneiro. Gestão local, saneamento e participação popular: reflexôes sobre o município de Duque de Caxias (dissertação). UFRJ, 1999.

SANTOS, Marcelo Ramos dos. "Duque de Caxias: um estudo da economia local”. In TENREIRO, André (org.). Duque de Caxias: a geografia de um espaço desigual. Nova Iguaçu: Entorno, 2015, pp. 65-87.

SEBRAE. Painel regional: Baixada Fluminense. Rio de Janeiro: Sebrae/RJ, 2015.

SILVA, Elizabeth Pessanha. A nova relação centro-periferia: reflexões a partir do município de Duque de Caxias (dissertação). UFRJ, 2014.

SILVA, Helenita Maria Beserra. "Emancipação política do município de Duque de Caxias”. Revista Pilares da História, Duque de Caxias, ano 2, n. 3, dez. 2003, pp. 28-36.

SILVA, Lucia Helena Pereira da. "A invenção da Baixada Fluminense: UUIO da FUNDREM (1975/89) e a representação de uma região". In XVI Enanpur - Encontro Nacional da Anpur, 2015. Belo Horizonte. Anais... Belo Horizonte, 2015, v. 16, pp. 1-14. Disponível em: http:// xvienanpur.com.br/anais/?wpfb_dl=616. Acesso em: 5 dez. 2015.

SILVEIRA, Leandro Almeida da. "Políticas públicas locais e a produção de desigualdades territoriais: o exemplo dos bairros Jardim 25 de Agosto e Pilar no município de Duque de Caxias”. Acta Geográfica (UFRR), 2014, v. 8, pp. 72-92.

SIMÕES, Manoel Ricardo. "Da Grande Iguaçu à Baixada Fluminense: emancipação política e reestruturação política e reestruturação espacial”. In OLIVEIRA, Rafael da Silva (org.). Baixada Fluminense: novos estudos e desafios. Rio de Janeiro: Paradigma, 2004, pp. 48-61. 
—. A cidade estilhaçada: reestruturação econômica e emancipaçōes municipais na Baixada Fluminense. Mesquita: Entorno, 2007.

- Ambiente e sociedade na Baixada Fluminense. Mesquita: Entorno, 2011.

—_. "Pequeno histórico da ocupação de Duque de Caxias". In TENREIRO, André (org.). Duque de Caxias: a geografia de um espaço desigual. Nova Iguaçu: Entorno, 2015, pp. 21-63.

SOUZA, Marlucia Santos de. "Entre o rural e o urbano-industrial: a produção de uma região moderna e as disputas políticas locais". Hidra de Igoassú: caderno de textos sobre história local e regional da Baixada Fluminense, Duque de Caxias, APPH-Clio, n. 1, fev. 2012, pp. 7-46.

TCE-RJ. Estudo socioeconômico dos municípios do estado do Rio de Janeiro 2014: Duque de Caxias. Rio de Janeiro: TCE-RJ, 2014.

TENREIRO, André et al. Atlas escolar do município de Duque de Caxias. 1 ed. Duque de Caxias: Secretaria Municipal de Educação de Duque de Caxias, 2012.

TORRES, Rogério. "Evolução histórica dos distritos e os processos de emancipação". In __ (org.). Baixada Fluminense: a construção de uma história. Rio de Janeiro: Inepac, 2008, pp. 195-8.

\section{Sítios eletrônicos consultados}

IBGE Cidades. Disponível em: http://www.cidades.ibge.gov.br/xtras/home.php Acesso em: 28 nov 2015.

RIO TOXICO TOUR. Disponível em: http://riotoxico.hotglue.me/caxias. Acesso em: 9 jan 2016. 


\section{A flutuação turística na região das Baixadas Litorâneas (RJ): uma análise centrada nos municípios de Armação dos Búzios, Arraial do Cabo e Cabo Frio'}

Ulisses Fernandes ${ }^{2}$

\section{Introdução}

0

artigo ora apresentado advém de relatório de pesquisa realizado para atender a apoio institucional a recém-doutores da Fundação Carlos Chagas de Amparo à Pesquisa - RJ (Faperj). Sua motivação básica, para além do vínculo com a realidade socioespacial fluminense, está na possibilidade de se manter vínculo com uma das temáticas de maior apelo social dos últimos tempos: a atividade turística contemporânea.

Parte-se da tentativa de entender a abrangência do fenômeno do turismo em uma das porções do território fluminense cuja atividade turística tem despontado como uma das de maior transformação da realidade socioespacial local: a Região das Baixadas Litorâneas. A prática turística, intensificada a partir dos anos 1970, principalmente após a construção da rodovia federal BR-101 e da chamada ponte Rio-Niterói, gerou uma pretensa região turística de forte mobilidade, mesmo em nível internacional, com grande flutuação da mobilidade turística entre os municípios da supracitada região.

${ }^{1}$ Este trabalho resulta de pesquisa com o apoio institucional da Fundação Carlos Chagas de Amparo à Pesquisa - RJ (Faperj).

2 Docente Adjunto do Instituto de Geografia da UERJ; Programa de Pós-Graduação em Geografia da UERJ 
Por entendimento prévio, a pesquisa arbitrou duas porções específicas dentro da região indicada: uma relacionada aos municípios onde, tradicionalmente, há maior presença de turistas de outras unidades federativas do Brasil e até mesmo de outros países, sendo abrangida pelos municípios de Armação dos Búzios, Arraial do Cabo e Cabo Frio; a outra é composta pelos municípios restantes, onde esse fluxo de turistas "externos" é bem menor e, muitas vezes, os veranistas se apresentam em número muito grande.

Neste artigo, trata-se especificamente da primeira porção territorial destacada. Assim, demonstra-se a ocorrência de uma flutuação atrelada à mobilidade turística dentro da porção do território fluminense cujo senso comum reconhece como Regiāo dos Lagos. Daí deriva o principal questionamento a ser feito: se, de fato, há uma interação regional notabilizada pela atividade turística, capaz de estabelecer laços entre os municípios locais quanto à questão da flutuação-mobilidade turística. Por outro lado, como questão secundária, torna-se fundamental definir se há adequação conceitual para tratar o recorte eleito como uma região turística.

Este estudo baseou-se em revisão bibliográfica e pesquisa de campo, com a aplicação de duzentos questionários. Para além do trato quantitativo, também foi feita uma abordagem qualitativa na forma de entrevistas. A redação final, na forma de artigo, pressupõe a análise teórico-conceitual inicial, bem como posterior interação com o recorte empírico, principalmente pela utilização das entrevistas e dos dados coletados em campo.

\section{Turismo: motivações e mobilidade}

O turismo é, decididamente, um fenômeno que passa pela esfera econômica, social, política e cultural, apresentando-se de modo significativo nas "sociedades ditas pós-industriais" (Rodrigues, 1999, p. 17). Desse modo, vem ganhando cada vez mais espaço tanto nas discussões políticas e acadêmicas quanto nas populares. No entanto, há autores que advogam a necessidade de um estudo científico do turismo mais apurado, como nos contam Gareth Shaw e Allan Williams, pois, "embora venha crescendo o número de exceçôes, o estudo científico do turismo ainda é frequentemente descritivo, ateórico e caoticamente conceitualizado, por ser extraído das relações sociais mais amplas" (Shaw e William, 2004, p. 1).

Pensar o turismo implica, entre outras coisas, debater a mobilidade que ocorre durante o fenômeno. É necessário, contudo, atentar para o fato de que a mobilidade turística está interligada a várias formas de mobilidade, "tais como a migração de trabalho ou conhecimento e transferência de capital" (idem, ibidem). A mobilidade de pessoas, no âmbito internacional, foi efetivamente afetada com a globalização. O fluxo turístico, em determinados espaços e lugares, é moldado pelo processo de globalização, requerendo entendimento do turismo como um fenômeno que está estritamente ligado ao cotidiano, à constituição de comunidades e ao funcionamento do sistema social e natural, e não como um fenômeno social independente.

Nosso desafio, na qualidade de pesquisadores do turismo, é buscar entender como o turismo molda e é moldado pelos processos sociais. Para tanto, faz-se necessária uma perspectiva de mudança e, nesse sentido, baseamo-nos no conceito de vias e fluxos, entendido como "rede de máquinas, tecnologia, organizações, textos e atores que constituem vários nós interconectados, ao longo do qual o fluxo pode ser retransmitido" (Urry, 2000, p. 35). Urry, em verdade, propõe uma paisagem do turismo que seria composta por vias e fluxos. Segundo ele, o espaço do turismo é fortemente estruturado por vias - autoestradas, rotas de voo, aeroportos - que facilitam e canalizam o movimento. Assim, 


\section{A flutuação turística na região das Baixadas Litorâneas (RJ)}

as vias mais distorcem do que afirmam ou reforçam as fronteiras, é verdade que muitas viagens ocorrem fora destas, mas são fundamentais para entender o volume dos fluxos do turismo [...]. Essas vias são mais do que apenas rotas de transporte, estas são também compostas pelos investimentos materiais em hotéis, restaurantes e outros serviços que facilitam a viagem (Urry apud Shaw e Williams, 2004, p. 3).

O turismo de massa - que, atualmente, encontramos no Brasil, em cidades como Salvador (BA) durante o carnaval e em Cabo Frio (RJ) na alta temporada do verão, quando os turistas, em geral da classe média, dirigem-se a essas localidades para usufruir de um turismo sazonal e de mais baixo custo, em comparação ao turismo elitista - é particularmente influenciado por essa estrutura constituída por vias que, destarte, vão facilitar o fluxo turístico. Mas não só esse tipo de turismo é constituído por vias e fluxos; existem outros também, como o ecoturismo e o turismo esportivo.

A importância das vias, pois, reside no fato de contribuírem para a predominância da localização relativa sobre a localização absoluta. $\mathrm{Na}$ dita pós-modernidade, a distância direta entre o ponto de origem e o ponto de destino perde importância, caracterizando, lato sensu, o modo de vida do homem moderno, que, no contexto na globalização do turismo, interconecta-se com o mundo de modo ágil e efêmero, o que incide, muitas vezes, na própria flutuação turística. As vias se caracterizam pela inércia, resultando da tecnologia, do capital investido e do conhecimento embutido nelas. No entanto, podem sofrer mudanças que variam de acordo com os interesses do capital. Por isso, as vias estão em constante mutação, sendo (re)construídas e revistas no espaço da globalização do turismo.

Como já assinalado, o turismo de massa é constituído por vias e fluxos que permitem maior mobilidade dos turistas no espaço. No entanto, cabe indagar: a existência dessas vias e fluxos funcionaria também como motivação turística? E essa pretensa facilidade de mobilidade justificaria a flutuação turística, ou seja, o ir e vir entre localidades distintas dentro de uma mesma área? E, se assim funcionarem, são hermeticamente a única motivação para que uma pessoa se desloque? De fato, as vias e os fluxos se encaixam na categoria de motivação turística, mas não estão isoladas; pelo contrário, há muitas outras motivações que, neste artigo, serão englobadas em categorias gerais, apenas para fins didáticos.

Em primeiro lugar, é preciso clarificar o que se entende por motivação. O conceito de motivação sugere que os indivíduos constantemente visam alcançar um estado de estabilidade (Gossens apud Shaw e Williams, 2004). Além disso, "tal equilíbrio é interrompido quando o individuo percebe que necessita de algo. Isso levou à criação das necessidades básicas na experiência dos turistas, tais como: novidades, satisfação sexual, estimulação, relaxamento e a autoexpressão" (Shaw e Williams, 2004, p. 140).

Em segundo lugar, as abordagens concernentes à motivação do turismo apontam para similaridades que emergiram de diferentes autores. Nesse caso, comungamos da mesma metodologia empregada pelos autores supracitados, que defendem que "essas diferentes abordagens podem ser categorizadas em três perspectivas; reducionista, estruturalista e funcionalista” (Shaw e Williams, 2004, p. 140). Deve ficar claro, pois, que essas três perspectivas propostas pelos autores não são as únicas que tentam generalizar as categorias de motivação turística, mas aquelas que sistematizam as abordagens dessa temática de modo mais abrangente.

A perspectiva reducionista, segundo Cohen (apud Shaw e Williams, 2004), entende a motivação do turismo como uma tensão entre a busca por novas experiências e a exigência de algum grau de familiaridade. O turista, de acordo com essa visão, teria como principal motivação a busca por novidades e pela identificação com o lugar. 
A perspectiva estruturalista, por sua vez, concentra-se em identificar uma série de variáveis motivacionais que seriam determinadas por fatores de repulsão e atração. Nos trabalhos que se baseiam nessa perspectiva, dá-se mais ênfase ao fator repulsão, porque seria o condicionante para a decisão do turista de viajar. Nesse sentido, observa-se "motivos mais duradouros, problemas internos ou fatores de repulsão que resultam na vontade do turista de procurar por objetos, eventos e situaçôes" (Gnoth apud Shaw e Williams, 2004, p. 141). Gossens (apud Shaw e Williams, 2004) argumenta que o conceito de emoção é o fator psicológico que conecta os fatores de atração-repulsão da motivação. Nesse sentido, "os turistas são expulsos pelas suas necessidades emocionais e atraídos pelos benefícios emocionais do local de destino" (p. 141). Motivação, para Gossens, tem relação com o consumo hedônico, em que o processo se daria em três estágios: o primeiro seria a fase do envolvimento do turista com o espaço, podendo levar a dois caminhos, a excitação e a consequente atração ou o estresse e a consequente repulsão; o segundo seria o momento em que, após o sentimento inicial, o turista processa as informações; e o terceiro seria o chamado estágio hedônico, que leva ao próprio consumo.

A terceira grande abordagem das motivações turísticas compreende o funcionalismo, proposta por Fodness (1994), que argumenta que tomamos certas atitudes em virtude de necessidades psicológicas importantes. Na perspectiva funcionalista, essas necessidades podem criar certas tensões de natureza psicológica ou física. Tais tensões, como dizem Shaw e Williams (2004), são liberadas por ações que, às vezes, envolvem sair de férias.

Dessas três abordagens, emergem dois problemas-chave: o primeiro seria o fato de essas abordagens não constituírem modelo para uma teoria sólida da motivação turística, tal como defendem Pearce e Butler (1994); o segundo está relacionado à profunda dificuldade em sistematizar as motivaçóes do turismo. No entanto, essa complexidade que reveste a sistematização das motivações turísticas não elimina a proeminente importância das motivações no processo decisório do turista. De fato, as motivaçóes constituem ponto crucial quando se analisa o fenômeno da mobilidade de uma população dentro da lógica turística. Por outro lado, o movimento de população sobre o espaço tem-se tornado cada vez mais importante na determinação das análises socioeconômicas em função dos tipos de mobilidade que estão se configurando.

Alguns autores enfocam a questão da mobilidade como parte importante da investigação em busca de entender a sociedade contemporânea. Nesse sentido, tem-se o exemplo do turismo como forma de lazer (Guimarães, 2001), que pode, por sua vez, ser inserido na categoria mobilidade, fenômeno genérico que pressupõe várias formas de transporte, deslocamento diário entre comunidades - como aqueles relativos ao trajeto casa-trabalho e vice-versa - e outras formas de viagens, assim como suas diversas inter-relações por meio de várias formas de comunicação (Lash e Urry, 1994).

Nesse contexto, as novas condiçôes de mobilidade apontariam para a configuração de um "pós-turismo" associado à presença difusa de signos em todos os lugares (Urry, 1996). Harvey (1996), ao situar as principais tendências do capitalismo, também destaca a importância dos signos, afirmando que vivemos numa dimensão da compressão de tempo/espaço em que se consomem mais símbolos e imagens do que propriamente coisas ao assimilarmos a publicidade e a mídia, dimensões especiais nesse cenário. Para Hannam, Sheller \& Urry (2006), novos lugares e tecnologias, ao mesmo tempo que aumentam a mobilidade de algumas pessoas e lugares, também aumentam a imobilidade de outras - como, por exemplo, pessoas que buscam cruzar fronteiras -, o que envolve estruturas de poder e posição de raça, gênero, classe etc. Dessa forma, tornam-se claros os efeitos da globalização sobre a mobilidade de população, uma vez que, para algumas pessoas, praticar a mobilidade, no caso a turística, consiste em uma atividade comum, enquanto, para outras, essa prática não faz parte de sua dimensão social. 


\section{A flutuação turística na região das Baixadas Litorâneas (RJ)}

Nesse contexto, parte-se para a análise de um recorte específico, o da Região das Baixadas Litorâneas no estado do Rio de Janeiro, como forma de verificar o que até então se advogou. O recorte em si guarda interconexão com o turismo de escala global, sendo objeto de consumo turístico de frequentadores oriundos de diversas porções do planeta, para além da própria escala local-nacional de atração turística. Por outro lado, guarda dimensões do que pode ser chamado de região turística, ou área turística, onde a mobilidade relativamente fácil e a coproximidade de centros turísticos incidem numa flutuação turística dentro de seus limites.

As questôes previamente apresentadas remetem à necessidade de se compreender se essa mobilidade ocorre de forma homogênea dentro de toda a região ou área turística ou se há outras motivações que determinam um uso turístico mais heterogêneo, com segregação turística, em que o fluxo seria mais ou menos intenso conforme a prévia avaliação dos centros turísticos existentes. Para tanto, torna-se necessário categorizar regiāo ou área turística, bem como avaliar sua pretensa configuração, tomando-se por base o recorte espacial eleieto nesta pesquisa.

\section{0 turismo na região das Baixadas Litorâneas do Rio de Janeiro}

Como indica o Caderno de turismo do estado do Rio de Janeiro, a atividade turística no território fluminense "é influenciada pela enorme diversidade de paisagens e características topográficas e climáticas, além das peculiaridades culturais existentes" (Gomes, 2010, p. 50). Decerto, como também preconiza o estudo, essa atividade tornou-se fundamental para o desenvolvimento de algumas porções do estado. Em muitos municípios fluminenses, inclusive, o turismo é a atividade polarizadora do desenvolvimento social e econômico. De fato, como sustenta Miguel Angelo Ribeiro (2003), "o estado do Rio de Janeiro é uma das unidades federadas que apresenta importância para a promoção do turismo brasileiro, atividade esta que merece destaque no contexto do desenvolvimento econômico de nosso estado" (p. 80). Ribeiro também destaca que

a atividade turística não pode ser pensada sem as bases geográficas e, neste contexto, podemos distinguir três condicionantes que influenciam o desenvolvimento da atividade do turismo em território fluminense. Tais condicionantes estão intimamente relacionados. São eles: (a) o elemento físico ou natural; (b) o elemento histórico e as atividades econômicas; e (c) o papel dos transportes (p. 81).

No estudo organizado por Gomes (2010), partindo da apreciação de Ribeiro (2003) quanto à importância da base geográfica, são apontadas áreas turísticas específicas nas quais os condicionantes naturais e históricos ganham destaque: áreas de ecoturismo, de praia e ecoturismo, de praia e rural, de praia, de serra e mar, de serra, serrana da Mantiqueira, Baixada Fluminense, diversificada e o Vale do Café.

Nesta pesquisa, relacionando-se motivação e mobilidade nas práticas turísticas em uma porção específica do território fluminense, a das Baixadas Litorâneas, identifica-se área turística de praia como aquela em que o recorte empírico melhor se dimensiona. A área em si se notabiliza pelas práticas turísticas dimensionadas pela orla litorânea aprazível, cuja paisagem, raiz da motivação turística, é capaz de atrair um quantitativo expressivo de visitantes e o produto turístico passa a ser acessível quando a estrutura - e também a superestrutura - turística é mobilizada nesse sentido (Boullón, 2002). Para esse autor, a paisagem como elemento da apreciação 
turística é preestabelecida na relação entre um objeto estético, que é a praia, com o observador sensível, que é o turista. Define-se, portanto, a paisagem como

uma qualidade estética que os diferentes elementos de um determinado espaço físico adquirem apenas quando o homem surge como observador animado de uma atitude contemplativa dirigida a captar suas propriedades externas, seu aspecto, seu caráter e outras particularidades que permitem apreciar sua beleza ou feiúra (Boullón, 2002, p. 120).

Definindo, pois, a importância da dimensão da paisagem praiana para a caracterização de uma área turística, parte-se para o apontamento das outras atividades turísticas que podem ser correlacionadas ao turismo de praia. No caso específico do recorte espacial deste trabalho, observa-se, ainda em acordo com Gomes (2010), a existência de práticas turísticas classificadas como turismo histórico, turismo de aventura e turismo ecológico.

De fato, na praia incidem outras possibilidades de uso turístico. A orla oceânica, por exemplo, está associada à antiga colonização desse fragmento do território brasileiro, o que, atualmente, possibilita a existência de rugosidades cujo caráter histórico-cultural também mobiliza visitantes em cidades como Cabo Frio, por exemplo. Esse mesmo mar, associado à praia, explica a ocorrência das práticas de mergulho para exploração submarina, como se verifica junto ao litoral do município de Arraial do Cabo. É a praia, enfim, que possibilita a prática de esportes náuticos, como visto, de modo geral, nos municípios supracitados e também em Armação dos Búzios.

O Mapa $1^{3}$ identifica os municípios abrangidos por essa área turística. São eles: Araruama, Armação dos Búzios, Arraial do Cabo, Cabo Frio, Iguaba Grande, Maricá, Rio das Ostras, São Pedro da Aldeia e Saquarema. Como o Caderno de turismo do estado do Rio de Janeiro destaca, "seu ambiente litorâneo é o principal atrativo turístico, tanto que a região de governo que envolve esta área é conhecida como Costa do Sol” (Gomes, 2010). Observa-se que, no Plano Diretor de Turismo do Estado do Rio de Janeiro, os municípios indicados fazem parte da Região Turística da Costa do Sol, onde estão presentes, para além dos municípios já citados, Casimiro de Abreu, Macaé, Carapebus e Quissamã (Mapa 2).

A Secretaria de Turismo do Estado do Rio de Janeiro, através do Plano Diretor de Turismo do Estado do Rio de Janeiro, reconhece 12 regiōes turísticas no estado, das quais seis são consideradas estratégicas: Costa Verde, Agulhas Negras, Vale do Café, Rio de Janeiro e Niterói, Serra Verde Imperial e aquela que representa o objeto deste artigo, a Costa do Sol. Registre-se que o referido plano aponta para regiōes turísticas com características homogêneas, o que difere da proposta organizada por Gomes (2010). Em consonância com o plano diretor,

o mapeamento turístico no estado resultou na aglutinação de um determinado número de municípios, conferindo praticidade à operação conjunta de ações propostas para o desenvolvimento do setor, sem perder de vista a necessária integração das diversas regiōes na realização e promoção do produto turístico de todo o estado. As regiões turísticas foram

\footnotetext{
3 O mapa foi elaborado pelo Núcleo de Estudos de Geografia Fluminense (Negef), vinculado ao Instituto de Geografia da UERJ. O núcleo participou ativamente da elaboração do estudo organizado por Gomes (2010): o Caderno de turismo do estado do Rio de Janeiro.
} 


\section{A flutuação turística na região das Baixadas Litorâneas (RJ)}

identificadas de modo a guardarem, internamente, um sentido de homogeneidade e complementaridade traduzidas pela identidade geográfica, paisagística, territorial e da oferta de infraestrutura e serviços. ${ }^{4}$

Nesse sentido, ao propor um estudo da mobilidade turística na região das Baixadas Litorâneas, decerto haveria uma premissa, a de destacar o conceito de região. Entretanto, considerando-se a análise de uso turístico, como aponta Boullón (2002), esse não é o conceito mais adequado. Boullón entende que os atrativos turísticos presentes em determinado espaço são relativamente pouco significativos e, portanto, só excepcionalmente se tocam. Essa condição impediria a conformação de uma região turística em si:

visto que o espaço turístico é entrecortado, não se pode recorrer a técnicas de regionalização para proceder a sua delimitação porque, de acordo com elas, seria preciso abranger toda a superfície do país ou da região em estudo e, caso isso fosse feito, grandes superfícies que não são turísticas figurariam como turísticas, cometendo-se um erro. Isso significa que regiōes turísticas não existem (Boullón, 2002, p. 79).

Mapa 1. Áreas turísticas no estado do Rio de Janeiro

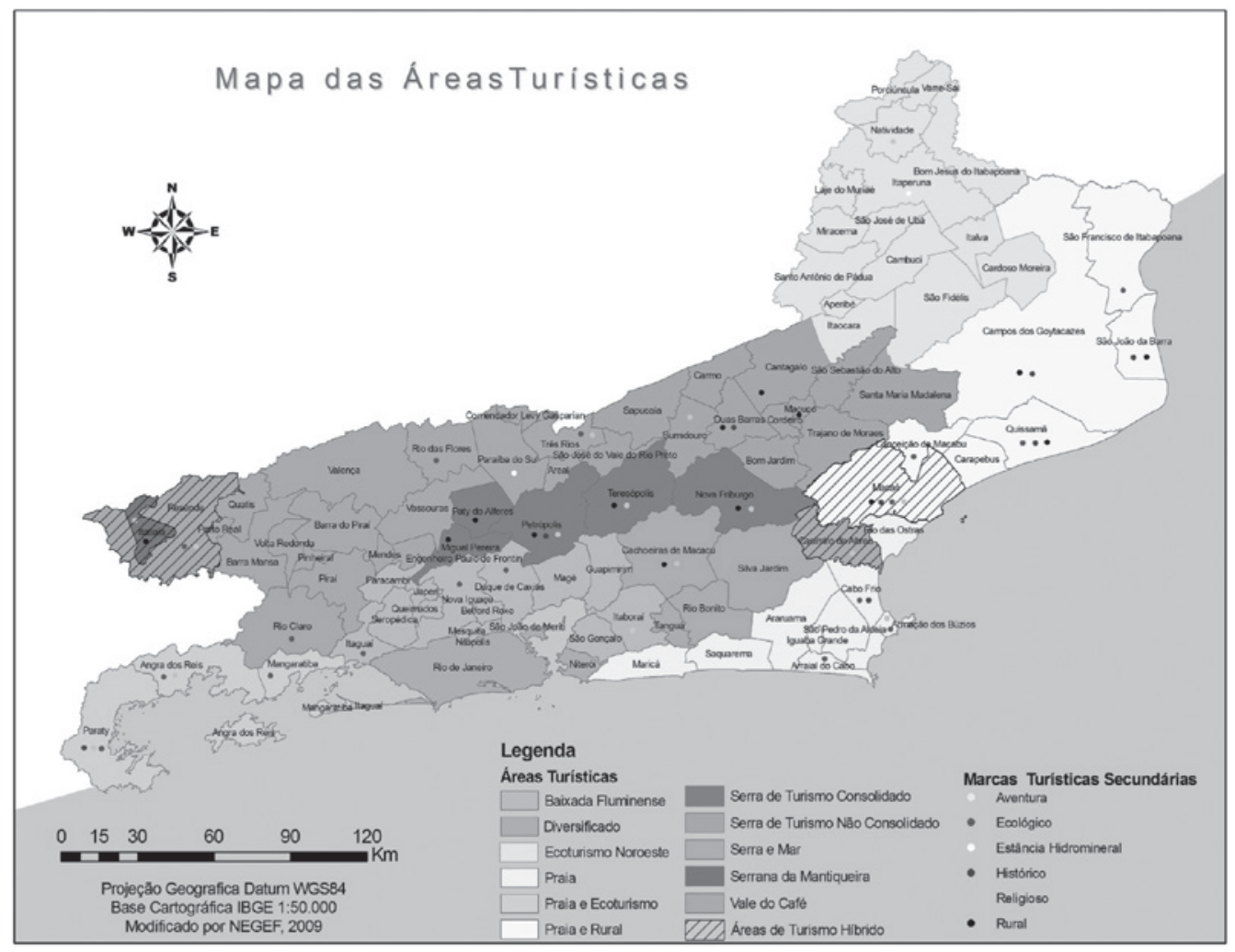

Fonte: Gomes, 2010.

${ }^{4}$ Conforme disposto no sítio eletrônico da SeTur, Secretaria de Turismo do Estado do Rio de Janeiro. Disponível em: http://www.turisrio.rj.gov.br/projetos.asp. Acesso em: 30 de maio de 2012. 
Mapa 2. As regiôes turísticas do estado do Rio de Janeiro

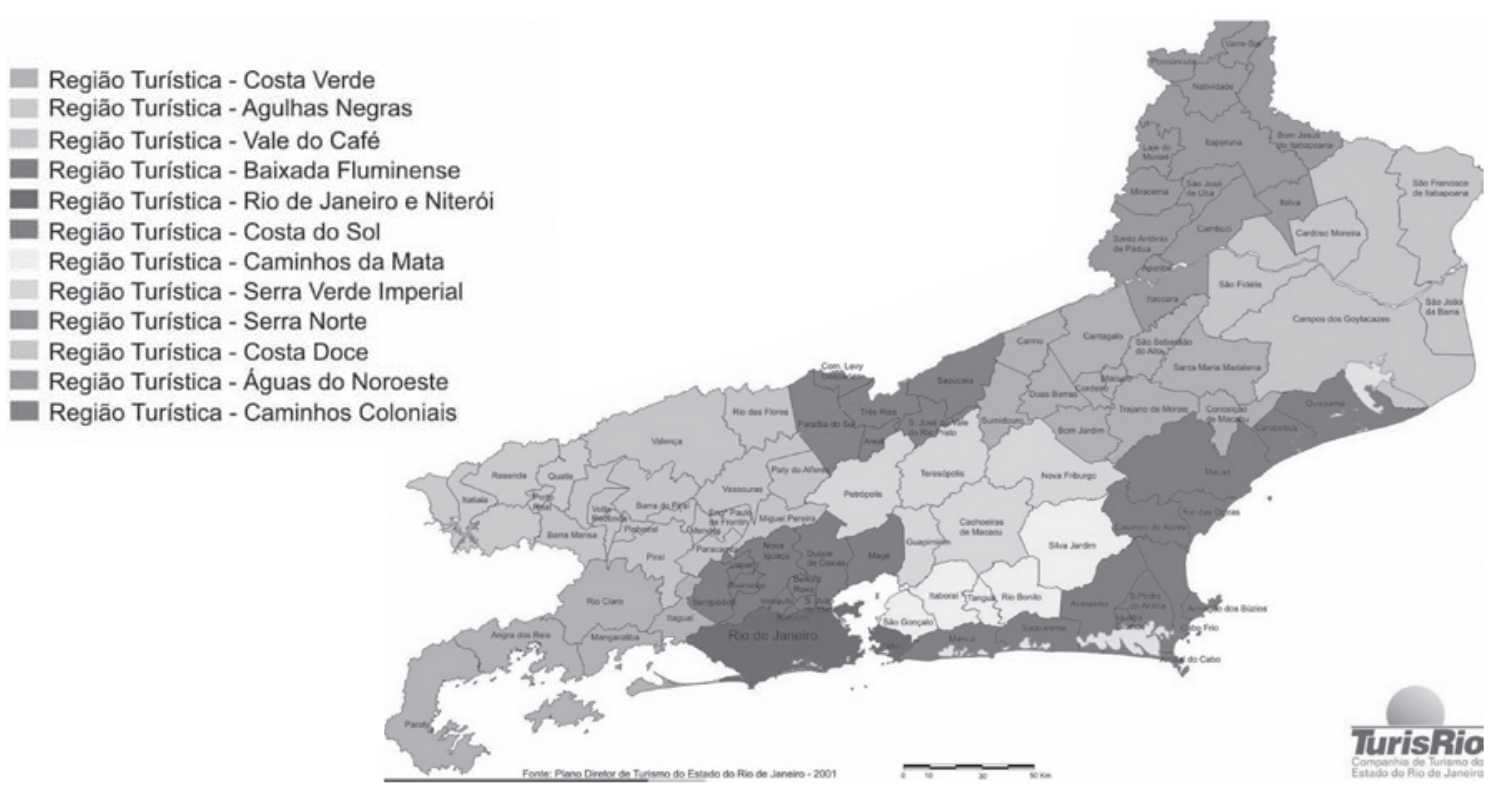

Fonte: Plano Diretor de Turismo do Estado do Rio de Janeiro. TurisRio/Companhia de Turismo do Estado do Rio de Janeiro.

Nesse contexto, a proposta de tratamento da espacialização turística fluminense estaria mais próxima daquela organizada por Gomes (2010) no Caderno de turismo do estado do Rio de Janeiro. Esse é o entendimento de Boullón (2002), que justifica o desenvolvimento da ideia de espaço turístico. A concentração de atrativos turísticos no território, segundo a lógica desse autor, indica a existência de múltiplos agrupamentos e concentrações em que é possível destacar zonas, áreas, complexos e centros turísticos. Essa proposta permite avançar no sentido de compreender, dentro da chamada regiáo das Baixadas Litorâneas, no estado do Rio de Janeiro, as atividades e o aparato turísticos concentrados em três municípios: Cabo Frio, Arraial do Cabo e Armação dos Búzios.

Na verdade, o Plano Diretor de Turismo do Estado do Rio de Janeiro atende a uma necessidade própria do Poder Público fluminense de considerar a regionalização da atividade turística. O Estado, conforme disposto por Marafon et al. (2012), como uma proposta de política pública, dimensiona o espaço fluminense em regiôes de governo. O foco da proposta, então, consiste em direcionar as ações públicas voltadas ao desenvolvimento de acordo com as especificidades geográficas, em sua visão mais abrangente, de cada região fluminense. Seria, portanto, plenamente cabível que o agente público promovesse uma leitura regional para o desenvolvimento turístico do estado. Assim, o entendimento de uma região turística, embora não desmerecido como um todo, deixa de atender aos objetivos desta pesquisa. Por um lado, a pertinência da região das Baixadas Litorâneas como indicativo de uma proposta de política pública de desenvolvimento é determinante para se estabelecer o recorte do presente estudo. Por outro, do ponto de vista teórico-conceitual, não cabe empreender uma leitura da mobilidade turística em dada porção do espaço fluminense considerando o conceito de 
região. Nesse sentido, considerando-se sobretudo as ideias de Boullón (2002), busca-se compreender a dinâmica turística presente no recorte espacial eleito.

\section{A flutuação: mobilidade turística na região das Baixadas Litorâneas (RJ)}

A flutuação-mobilidade turística está atrelada à própria significação turística de dado recorte espacial. O espaço turístico depende, portanto, para além dos próprios atrativos turísticos, do empreendimento turístico em si e da infraestrutura turística disponibilizada. A mobilidade é indicativo daquilo que Boullón (2002) chama de área turística, pois envolve a existência de dois ou mais centros turísticos, conforme observa o próprio autor, pois

as áreas turísticas devem estar dotadas de atrativos turísticos contíguos [...] e necessitam, da mesma forma, de uma infraestrutura de transporte e comunicação que possa funcionar como um subsistema, requerem a presença mínima de um centro turístico e, se sua infraestrutura e recursos de equipamentos e serviços são insuficientes, devem ser registrados como potenciais (p. 83).

O centro turístico, por sua vez, guarda especificidades dimensionadas pelo quantitativo de atrativos capazes de motivar o uso turístico de determinado espaço. Ainda segundo Boullón (2002), observa-se que o centro turístico "é todo o conglomerado urbano que conta em seu próprio território ou dentro de seu raio de influência com atrativos turísticos de tipo e hierarquia suficientes para motivar uma viagem turística" (p. 84).

Nesse sentido, dentro da região de governo das Baixadas Litorâneas, entre os municípios nela encontrados, apenas três guardam atributos suficientes para ser considerados centros turísticos: Arraial do Cabo, Cabo Frio e Armação dos Búzios. Para além do entendimento dos atributos indicados por Boullón (2002), essa assertiva deriva da própria pesquisa empírica realizada. Metodologicamente, houve uma predefinição dos três municípios para a coleta de dados quanto à mobilidade turística. Obviamente, partiu-se das orientações de Boullón (2002) quanto ao fato de que os centros turísticos necessitariam de certos atributos para ser considerados como tal, ou seja, a predefinição dos municípios eleitos não foi aleatória. No entanto, a coleta de dados mostrou que, de fato, esses três municípios guardavam a condição previamente entendida. Na verdade, o atendimento ao objetivo básico da pesquisa envolve demonstrar se há de fato uma flutuação-mobilidade turística entre os municípios da região de governo indicada. Se, por um lado, os dados apontam para uma forte mobilidade entre os três municípios em destaque, por outro, demonstram que os demais municípios da região de governo têm muito pouca interação entre si (Gráficos 2, 5 e 6). Isso, por si só, já é indicativo da análise antes feita, ou seja, de que não era possível tratar o recorte como região turística, mas tão somente como área turística. Em parte, porque os municípios que se destacam no trato turístico são apenas três e, em parte, porque o fragmento de espaço e alocação dos objetos turísticos, de infraestrutura de comunicação e dos empreendimentos encontra-se concentrado na franja litorânea da região de governo. 
Coletaram-se dados nos três municípios, com a aplicação de duzentos questionários. Para as demandas específicas desta pesquisa, destacam-se os dados relativos aos municípios visitados pelos turistas entrevistados. Elegeram-se atrativos turísticos significativos desses três centros turísticos: a Praia do Forte, em Cabo Frio; a Prainha, em Arraial do Cabo; e a Praia de Geribá, em Armação dos Búzios. Essas praias são as mais conhecidas e frequentadas pelos turistas nos respectivos municípios. A coleta, portanto, objetivava saber se seria possível identificar nesses atrativos de maior expoente turistas hospedados de outros municípios da região de governo. Também objetivava saber se os turistas ali presentes se deslocavam para as atrações turísticas de outros municípios da região.

Dos turistas entrevistados em Arraial do Cabo, apenas 2\% dos entrevistados não estavam hospedados em um dos três municípios em foco (Gráfico 4), ou seja, Arraial do Cabo, Cabo Frio e Armação dos Búzios. Também se revelou significativa a informação de que cerca de dois terços dos entrevistados em Arraial do Cabo não estavam hospedados no município, como atesta o mesmo Gráfico 4. Para além disso, observa-se, conforme atesta o Gráfico 6, que a maioria dos entrevistados em Arraial do Cabo passa a maior parte do tempo nos outros dois municípios, Armação dos Búzios e Cabo Frio. A posição geográfica de Arraial do Cabo e as atividades de excelência desenvolvidas no turismo local, como pesca submarina e mergulho de apreciação da paisagem submarina, explicam, em grande parte, o fato de a maior parte dos entrevistados não estar hospedada naquele município. Há um intenso afluxo para o município por essas duas razões. Por outro lado, não se despreza o fato de que os municípios de Armação dos Búzios e Cabo Frio possuírem serviços muito mais diversificados do que aqueles presentes em Arraial do Cabo, razão maior para os dois primeiros terem primazia no quesito hospedagem.

Gráficos. Dados colhidos em Armação dos Búzios

\section{1 - Cidade da Região dos Lagos em que está hospedado}

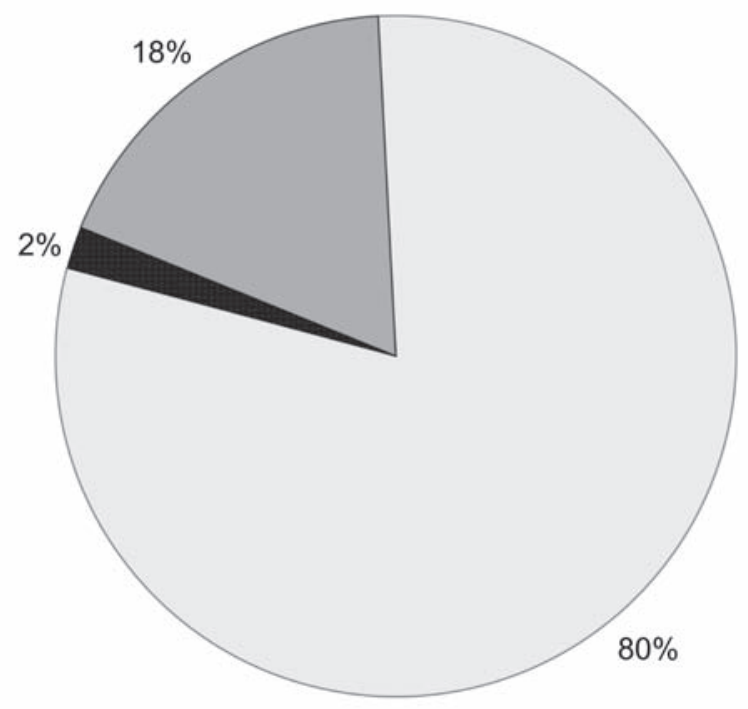

Armação dos Búzios

Cabo Frio

Arraial do Cabo

Produzido por: Thiago Silvestre. Universidade do Estado do Rio de Janeiro Praia de Geribá, Búzios, 29/04/2012 Amostra: 50 entrevistados 


\section{2 - Cidades mais visitadas na Região dos Lagos}

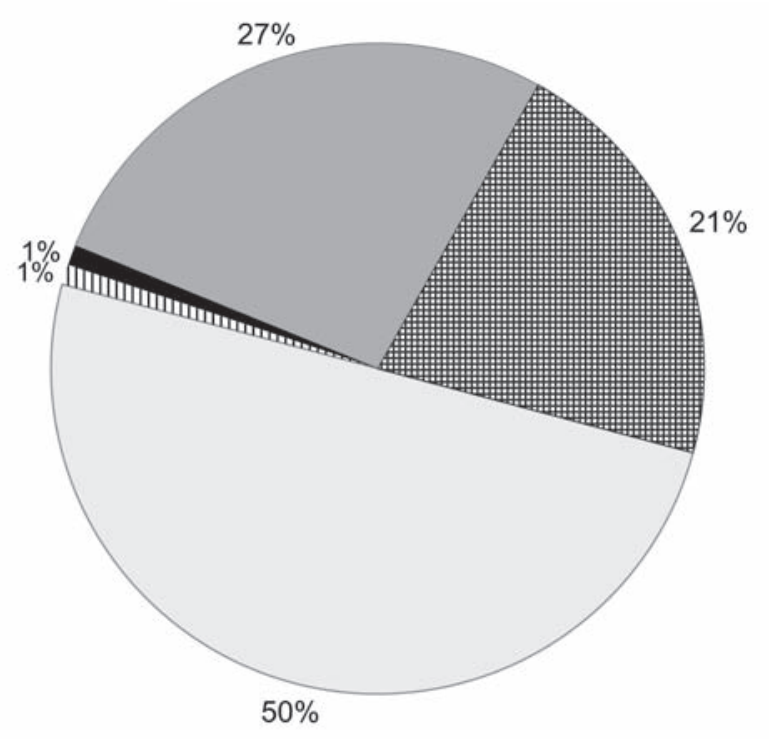

$\square$ Armação dos Búzios

Arraial do Cabo

$\square$ Cabo Frio

- São Pedro D'Aldeia

I Saquarema

Produzido por: Thiago Silvestre. Universidade do Estado do Rio de Janeiro

Praia de Geribá, Búzios, 29/04/2012 Amostra: 50 entrevistados

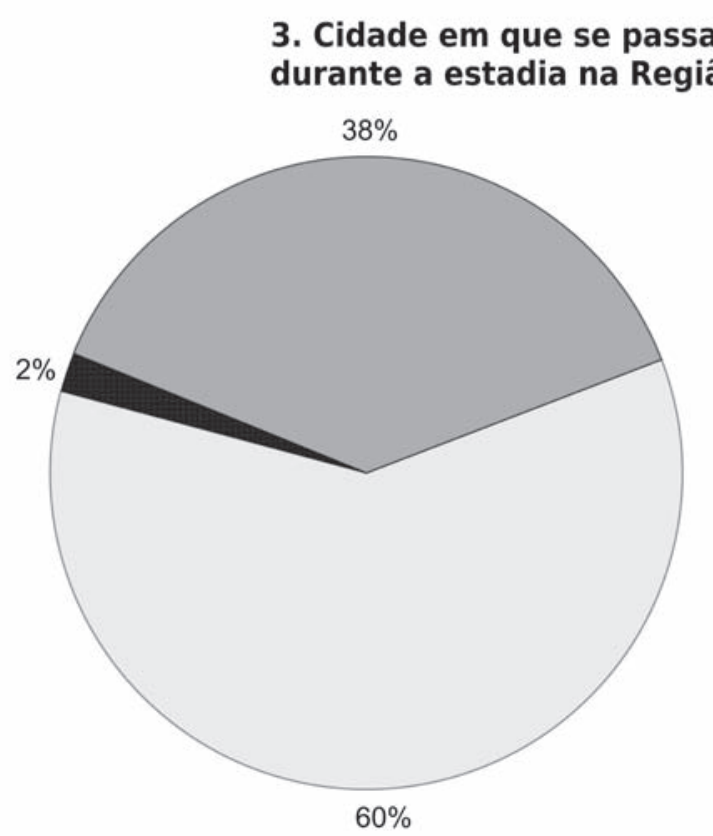

Produzido por: Thiago Silvestre. Universidade do Estado do Rio de Janeiro

Praia de Geribá, Búzios, 29/04/2012 Amostra: 50 entrevistados 
Gráficos. Dados colhidos em Arraial do Cabo

\section{4 - Cidade da Região dos Lagos em que está hospedado}

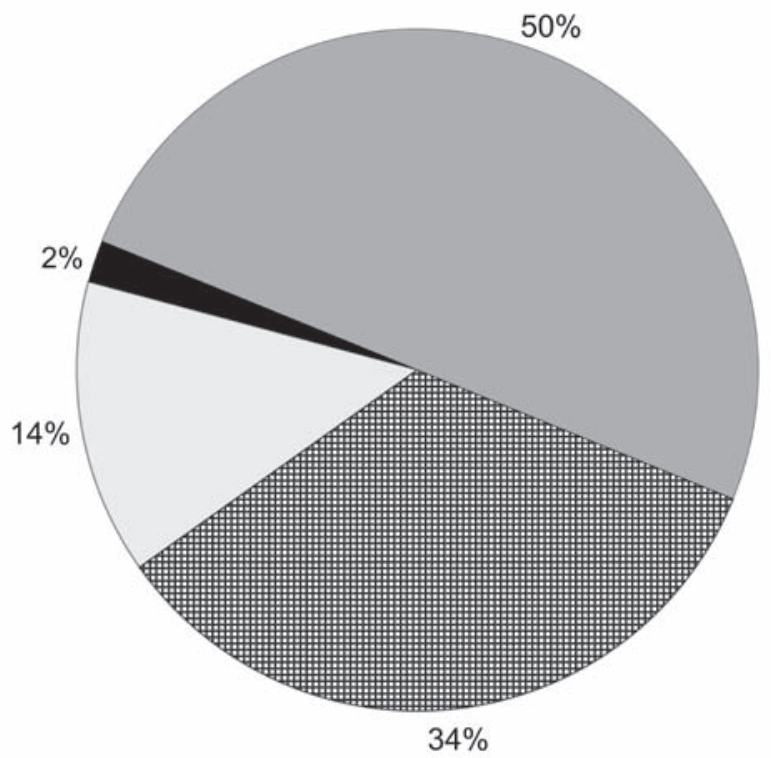

$\square$ Armação dos Búzios

Arraial do Cabo

$\square$ Cabo Frio

- São Pedro D'Aldeia

Produzido por: Thiago Silvestre Universidade do Estado do Rio de Janeiro Prainha, Arraial do Cabo, 07/04/2012 Amostra: 50 entrevistados

\section{5 - Cidades mais visitadas na Região dos Lagos}

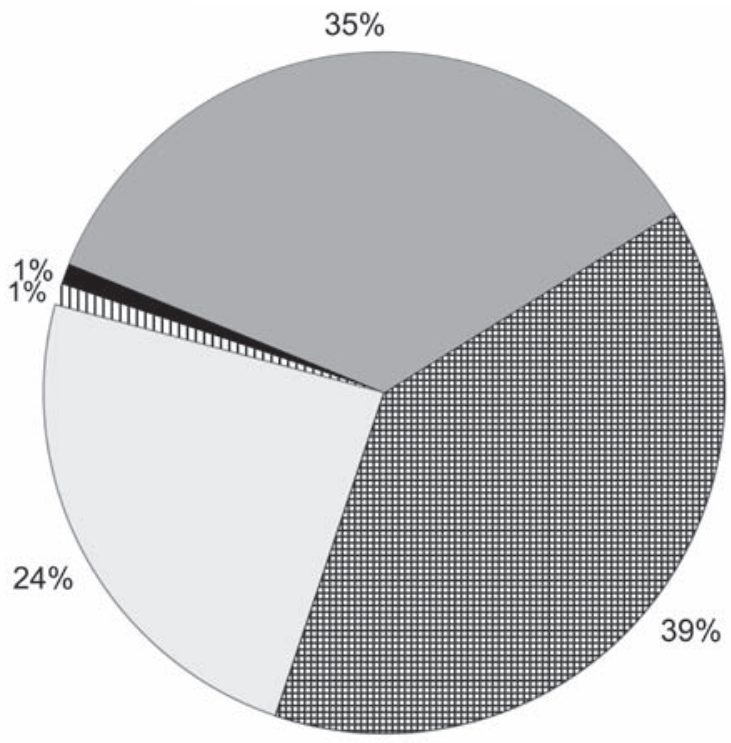

$\square$ Armação dos Búzios

\#\# Arraial do Cabo

$\square$ Cabo Frio

- São Pedro D'Aldeia

II Saquarema

Produzido por: Thiago Silvestre. Universidade do Estado do Rio de Janeiro Prainha, Arraial do Cabo, 07/04/2012 Amostra: 50 entrevistado 
A flutuação turística na região das Baixadas Litorâneas (RJ)

\section{Cidade em que se passa mais tempo durante a estadia na Região dos Lagos}

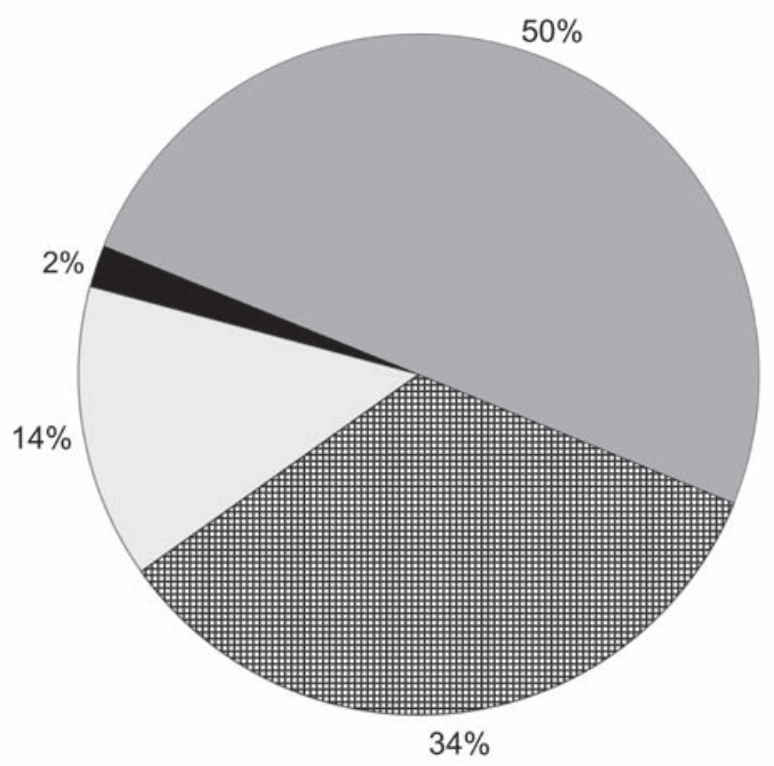

$\square$ Armação dos Búzios

曹 Arraial do Cabo

$\square$ Cabo Frio

São Pedro D'Aldeia

Produzido por: Thiago Silvestre. Universidade do Estado do Rio de Janeiro Prainha, Arraial do Cabo, 07/04/2012 Amostra: 50 entrevistados

Gráficos. Dados colhidos em Cabo Frio

\section{7 - Cidade da Região dos Lagos em que está hospedado}

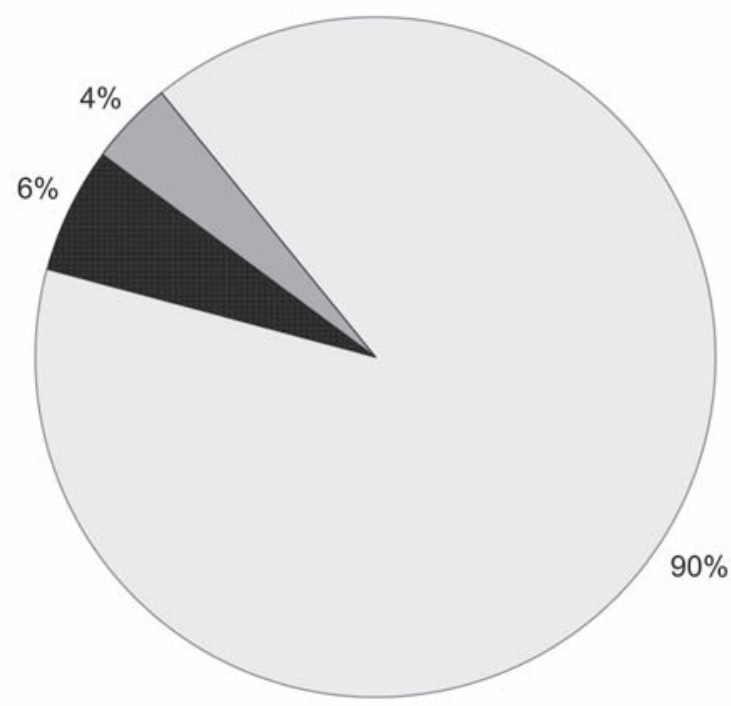

$\square$ Cabo Frio

$\square$ Arraial do Cabo

- Armação dos Búzios

Produzido por: Thiago Silvestre Universidade do Estado do Rio de Janeiro Praia do Forte, Cabo Frio, 06/04/2012 Amostra: 100 entrevistados 


\section{8 - Cidades mais visitadas na Região dos Lagos}

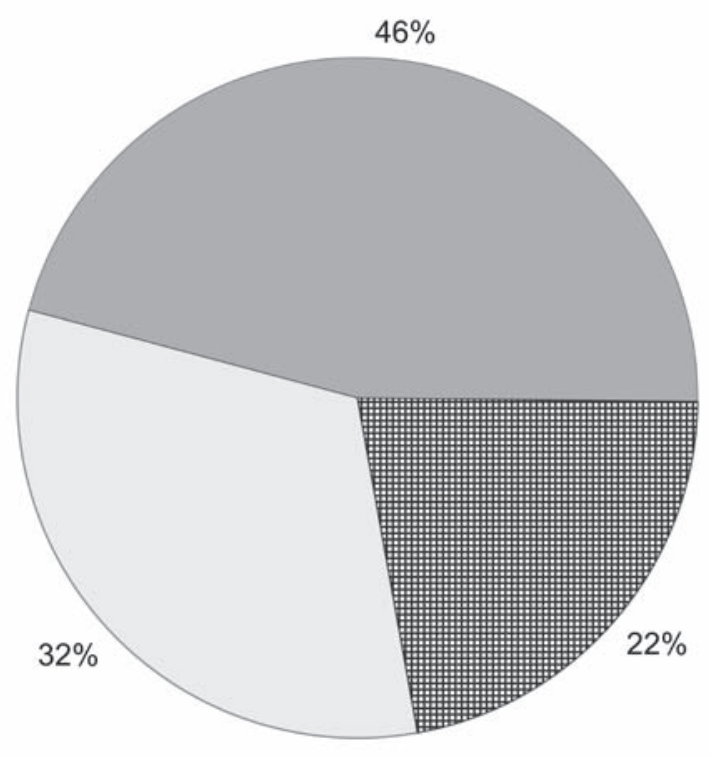

$\square$ Armação dos Búzios

曹 Arraial do Cabo

$\square$ Cabo Frio

Produzido por: Thiago Silvestre. Universidade do Estado do Rio de Janeiro Praia do Forte, Cabo Frio, 06/04/2012

Amostra: 100 entrevistados

9. Cidade em que se passa mais tempo durante a estadia na Região dos Lagos

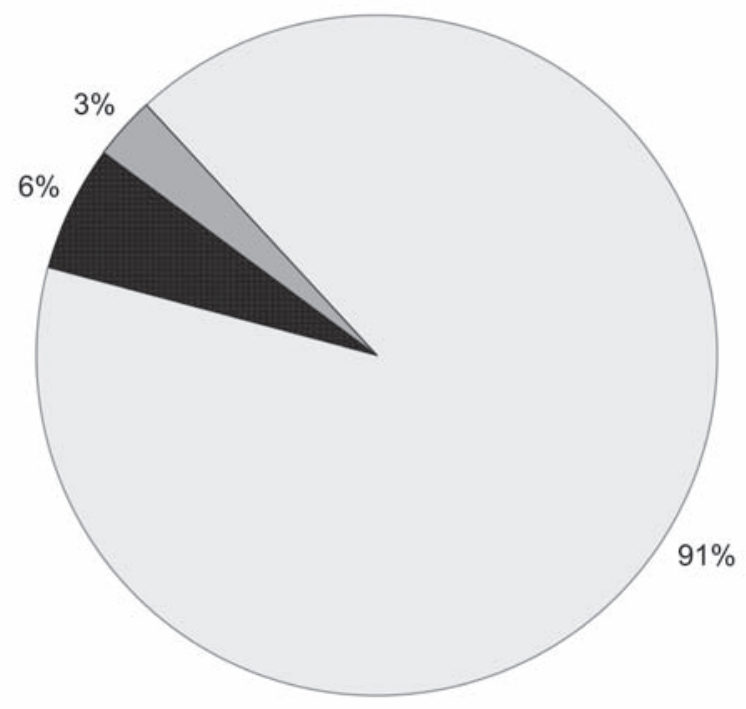

Produzido por: Thiago Silvestre. Universidade do Estado do Rio de Janeiro

Praia do Forte, Cabo Frio, 06/04/2012 Amostra: 100 entrevistados 


\section{A flutuação turística na região das Baixadas Litorâneas (RJ)}

Em Cabo Frio, os entrevistados, em sua grande maioria, estavam hospedados na própria cidade. Nesse município, observou-se, conforme apresentado no Gráfico 7, que raríssimos eram aqueles não hospedados, para além da localidade analisada, fosse em Armação dos Búzios ou em Arraial do Cabo. De acordo com o Gráfico 8, a flutuação-mobilidade identificada diz respeito àquela encontrada em Arraial do Cabo, ou seja, os três centros turísticos se completam em termos de mobilidade, porém os demais dessa região de governo não interagem nesse quesito. Observa-se que os turistas entrevistados em Cabo Frio são aqueles que mais tempo permanecem no município, como apontam os Gráficos 3, 6 e 9.

Em Armação dos Búzios, cerca de três quartos dos entrevistados se encontravam hospedados na própria cidade (Gráfico 1), número tão significativo quanto aquele encontrado em Cabo Frio. Entretanto, quando se considera a mobilidade dentro do conjunto de municípios da região das Baixadas Litorâneas, também em Armação dos Búzios destaca-se a mobilidade interna, que volta a apresentar padrão similar ao dos demais municípios analisados, com ocorrência do fenômeno praticamente limitado a essa trinca de cidades, conforme se constata no Gráfico 2.

É certo que a motivação turística incide, predominantemente, sobre os resultados obtidos. Mas o que leva determinado turista a considerar suas predileções de uso turístico resulta de um conjunto de considerações que passam pelos atributos naturais e histórico-culturais identificados em Ribeiro (2003) e Gomes (2010), pelas análises de Boulón (2002) sobre paisagem, estrutura e superestrutura turística, pela questão da mobilidade proposta por Urry (2000) e pelas motivações turísticas propostas por Shaw e Williams (2004). Corroborando essa ideia e levando em conta todos os turistas entrevistados, raros foram os que não consideraram os municípios de Cabo Frio, Armação dos Búzios e Arraial do Cabo aqueles com as atividades turísticas mais desenvolvidas. De fato, a mobilidade existe, mas apenas na área turística que congrega os três centros turísticos, o que nos leva a verificar que, para além da mobilidade, também existe uma flutuação entre esses municípios, pois a rede viária permite esse tipo de deslocamento e a maior das atrações turísticas é a praia.

\section{Considerações finais}

A análise dos dados coletados à luz da base teórica apresentada no estudo organizado por Gomes (2010) e na obra de Boullón (2002) nos conduz a duas consideraçóes fundamentais: a área turística em foco não concorre com a região de governo das Baixadas Litorâneas, pois é mínima a mobilidade turística que envolve os municípios não destacados; a área turística realmente se concentra nos municípios destacados, pois a mobilidade é imperceptível para além deles.

Os atrativos turísticos presentes tanto em Arraial do Cabo como em Cabo Frio e Armação dos Búzios dimensionam uma qualificação turística para dada porção da região de governo das Baixadas Litorâneas. É certo que os dados demonstram laços por demais significativos entre os três centros turísticos, como também é certo afirmar que ocorre uma interação mínima entre os demais municípios da região de governo. Por outro lado, o avanço nesta pesquisa pressupóe a coleta de dados nos municípios não contemplados nesta primeira análise. Se a escolha preestabelecida dos municípios guarda posicionamento metodológico prévio, também é producente verificar que tipo de mobilidade - se é que realmente existe - ocorre entre os demais municípios da região de governo. 
Acreditamos que algumas condições preexistentes e alguns atributos da paisagem natural condicionaram a maior intensificação do uso turístico nos municípios de Cabo Frio, Arraial do Cabo e Armação dos Búzios. A imaginação analítica permite avaliar que as propostas de ação pública vinculadas aos demais municípios da região devem levar em conta que a maior qualificação das atividades de cunho turístico permitiria maior inter-relação entre eles.

\section{Referências}

BOULLÓN, Roberto C. Planejamento do espaço turístico. Bauru: EDUSC, 2002.

FODNESS, D. "Measuring Tourist Motivation". Annals of Tourism Research: A Social Sciences Journal, 1994.

GOMES, João Carlos (org.). Caderno de turismo do estado do Rio de Janeiro: passaporte para o desenvolvimento do estado. Rio de Janeiro: Fecomércio, 2010.

GUIMARĀES, Vera. "Globalização e mobilidade: as condições de mobilidade contemporânea e as práticas turísticas”. Revista Contemporânea, 18 ed., 2011.

HANNAM, Kevin et al. "Mobilities, immobilities and moorings". Mobilities, Londres, v. 1, n. 1, mar. 2006, pp. 1-22. Disponível em: http://dx.doi.org/10.1080/17450100500489189. Acesso em: 24 maio 2012.

HARVEY, David. Condição pós-moderna. São Paulo: Loyola, 1996.

LASH, Scott e URRY, John. Economies of signs \& space. Londres: Sage Publications, 1994.

MARAFON, Glaucio et al. Geografia do estado do Rio de Janeiro: da compreensão do passado aos desafios do presente. Rio de Janeiro: Gramma, 2012.

PEARCE, Douglas G. e BUTLER, Richard (orgs.). Tourism research: critiques and challenges. Londres: Routledge, 1994.

RIBEIRO, Miguel Angelo. “Turismo no estado do Rio de Janeiro: ensaio de uma tipologia”. GEOgraphia, Niterói, v. 5, n. 10, 2003, pp. 79-91.

RODRIGUES, Adyr B. (org.). Turismo e geografia: reflexões teóricas e enfoques regionais. 2 ed. São Paulo: Hucitec, 1999.

SHAW, Gareth e WILLIAMS, Allan M. Tourism and tourism spaces. 1 ed. Londres: Thousand Oaks/ Nova Déli: Sage Publications, 2004.

URRY, John. O olhar do turista: lazer e viagens nas sociedades contemporâneas. São Paulo: Studio Nobel, Sesc, 1996.

- Sociology beyond societies: mobilities for the Twenty-First Century. 1 ed. Londres: Routledge, 2000 . 


\section{Porto do Açu, entre as forças de conservação e modernidade}

Wedson Felipe Cabral Pacheco ${ }^{1}$

\section{Introdução}

0 estado do Rio de Janeiro é composto por 92 municípios, distribuídos em oito regiōes de governo: Metropolitana, Noroeste Fluminense, Norte Fluminense, Serrana, Baixadas Litorâneas, Médio Paraíba, Centro-Sul Fluminense e Costa Verde.

O território fluminense sempre exerceu forte influência no cenário econômico, político e social do Brasil, influência essa centrada na Região Metropolitana e, em especial, na cidade do Rio de Janeiro. Com as transformaçóes em curso em seu cenário, provocadas pela crescente importância das regiōes do interior, cada vez mais o foco analítico sobre as condiçōes de crescimento do estado se desloca para as cidades de porte médio e para a interpretação dos municípios como agentes das políticas públicas (Marafon apud Piquet, 2010).

O debate contemporâneo em torno do desenvolvimento econômico do estado de segundo maior Produto Interno Bruto (PIB) do país se encontra centrado nos investimentos em transporte e logística, com grandes empreendimentos, como o Complexo Portuário do Açu (São João da Barra), a Linha 4 do metrô carioca e o sistema de Transporte Rápido por Ônibus (BRT), além do Arco Metropolitano que liga o Porto de Itaguaí ao Complexo Petroquímico do Rio de Janeiro (Comperj), também localizado no município de Itaboraí. Esses empreendimentos reforçam a importância logística do Rio de Janeiro nacional e internacionalmente.

$\mathrm{O}$ interior fluminense, notadamente, surgiu como protagonista de um processo de crescimento em força, com exemplos de impacto: os das atividades da indústria petrolífera; o crescimento urbano nas Baixadas Litorâneas; o desenvolvimento da indústria automobilística no Centro-Sul do estado e;

\footnotetext{
1 Prof. Msc. em Geografia pela Universidade do Estado do Rio de Janeiro (UERJ).
} 
também no Norte Fluminense, a implantação do Complexo Logístico e Industrial do Porto do Açu (Clipa), que é um empreendimento porto-indústria, o foco deste trabalho.

Assim, este artigo analisa a construção de um porto privado no município de São João da Barra, litoral norte do estado do Rio de Janeiro: o Porto do Açu. Este trabalho está inserido nas pesquisas do Núcleo de Estudos de Geografia Fluminense (Negef), que estuda as importantes transformações acerca da realidade socioespacial do estado do Rio de Janeiro. Sobre a temática, segundo Alvarenga (2013, p. 3), os abundantes investimentos, as grandes promessas de desenvolvimento e o clamor de urgência de crescimento econômico acabaram por ser usados como armas para a legitimação de tudo o que pudesse estar associado a "progresso". Segundo o autor, também não foram poucas as vezes em que houve açôes que poderiam ser consideradas desrespeitosas no que diz respeito aos direitos das comunidades que viviam nas áreas do $5^{\circ}$ Distrito de São João da Barra, que foram desapropriadas pelo governo do estado do Rio de Janeiro para a construção do Distrito Industrial de São João da Barra (DISJB).

Os grandes projetos continuam a ser portadores de alto potencial de organização e transformação dos territórios, bem como de decompor e compor regiões. Por sua natureza, projetam sobre os espaços locais e regionais interesses nacionais e quase sempre globais, o que faz deles eventos globais-locais (Vainer, 2007).

É certo que a implantação de um megaempreendimento provoca metamorfoses rápidas e radicais na organização do território, acarretando aumento das desigualdades entre campo-cidade, bem como mudança na hierarquia urbana regional e no plano intraurbano. O aparecimento de áreas residenciais e de consumo de alto padrão social, ao lado da expansão dos bolsões de pobreza urbana, marca o descompasso entre os espaços dos trabalhadores inseridos no empreendimento - o que lhes garante emprego assalariado, renda acima da média, equipamentos e serviços urbanos de qualidade - e os espaços das populações que nele não conseguem ocupação. Como esses empreendimentos são tidos como capazes de desencadear "desenvolvimento", transformam-se em objeto de disputa entre regiōes e/ou municípios e, desse modo, no lugar da adoção de parâmetros quanto ao seu funcionamento, o que, em geral, ocorre são concessões do poder público, enfraquecendo ainda mais os cofres municipais (Marafon apud Piquet, 2010).

Assim, por não surgirem do processo de desenvolvimento regional, não expressam as forças políticas, sociais e econômicas endógenas. Nesse sentido, para Piquet (apud Marafon, 2010), tendem romper as relações econômicas e sociais que conformam antigas regionalizações, substituindo-as por outras construídas a partir deles. Segundo a autora, por ocorrer uma ligação das atividades-chave da economia do país e/ou internacional, seus administradores reportam-se diretamente às instâncias supralocais, deslocando para um plano subalterno as instâncias locais, que tendem a perder o controle político e administrativo. As pequenas e médias municipalidades e os próprios governos estaduais têm limitada capacidade de barganha, pois são parceiros de pequena monta frente aos grupos empresariais que manejam esses grandes projetos de investimentos.

O caso em análise não foge a esses condicionantes, e os efeitos não se limitam e/ou limitarão ao município de São João da Barra. A título de exemplo, no território sanjoanense o rápido processo de licenciamento ambiental para a instalação das diferentes unidades que deveriam compor o Clipa, bem como a disponibilização de forças policiais para cumprir os mandados de desapropriação de terras, 
foram possibilitados pela promulgação de quatro decretos pelo governo do Rio de Janeiro, no sentido de viabilizar a construção do DISJB e do denominado Corredor Logístico do Açu (CLA).

Em função da combinação de flexibilização da legislação com uso de força policial contra centenas de famílias de agricultores familiares, houve um inevitável aumento de tensões e conflitos, que passaram a inspirar uma série de questionamentos sobre qual modelo de desenvolvimento o Clipa representa e quais consequências sua construção pode gerar para as comunidades por ele impactadas. Nesse contexto, o Porto do Açu, além de ser um agente da reestruturação espacial, é responsável pela reorganização territorial do município de São João da Barra. As perspectivas de uma explosão demográfica acarretarão um irreversível processo de expansão urbana (Carvalho et al., 2010).

A metodologia adotada neste trabalho apresenta níveis exploratório e descritivo.

Enquadra-se no nível exploratório porque visa proporcionar maior familiaridade com o problema proposto, por meio do aprimoramento de ideias e descoberta de intuiçôes, apresentando um planejamento bastante flexível, de modo a possibilitar que diversos aspectos relativos ao fato proposto sejam levados em consideração.

É descritiva porque envolve a descriçāo das características de um fenômeno em processo de construção, recorrendo à coleta de dados e ao trabalho de campo, bem como relacionando as diversas variáveis identificadas. Ainda de acordo com Gil (2002, p. 10), "as pesquisas descritivas são, juntamente com as exploratórias, as que habitualmente realizam os pesquisadores sociais preocupados com a atuação prática".

O objetivo central que norteia este estudo é verificar como, na prática, se desdobra a relação entre o discurso oficial em torno desse megaempreendimento - que o apresenta como solução para os problemas de estagnação econômica da região Norte Fluminense - e a execução dos mecanismos de desapropriação e reassentamento utilizados pelo governo do estado do Rio de Janeiro.

Diante dessas expectativas e da metamorfose territorial ocorrida em São João da Barra, formulam-se as seguintes questôes: como controlar o comportamento de uma grandiosa corporação com altíssimo poder econômico? O que levou São João da Barra a ser escolhido para locação desse empreendimento? Os mecanismos adotados pelo Estado para reparar o impacto sobre a população que, tradicionalmente, habita o $5^{\circ}$ Distrito de São João da Barra levam em conta o ponto de vista e a necessidade dos atingidos?

\section{0 território de São João da Barra: passado e presente no contexto do Norte Fluminense}

São João da Barra é um município localizado na Região Norte do estado do Rio de Janeiro (Figura 1). Tem uma área de 455,04 km² e uma população de 32.747 habitantes, segundo dados do Censo 2010 (IBGE, 2010). Suas principais atividades econômicas são: turismo, agropecuária, olericultura, fruticultura ativa, artesanato e pesca, porém boa parte da arrecadação municipal provém do repasse de royalties do petróleo (Souza, 2010). 
Figura 1. Cartograma com a localização do município de São João da Barra-RJ

\section{REGIÃO NORTE FLUMINENSE}

MUNGCIPIOS

\section{IS}

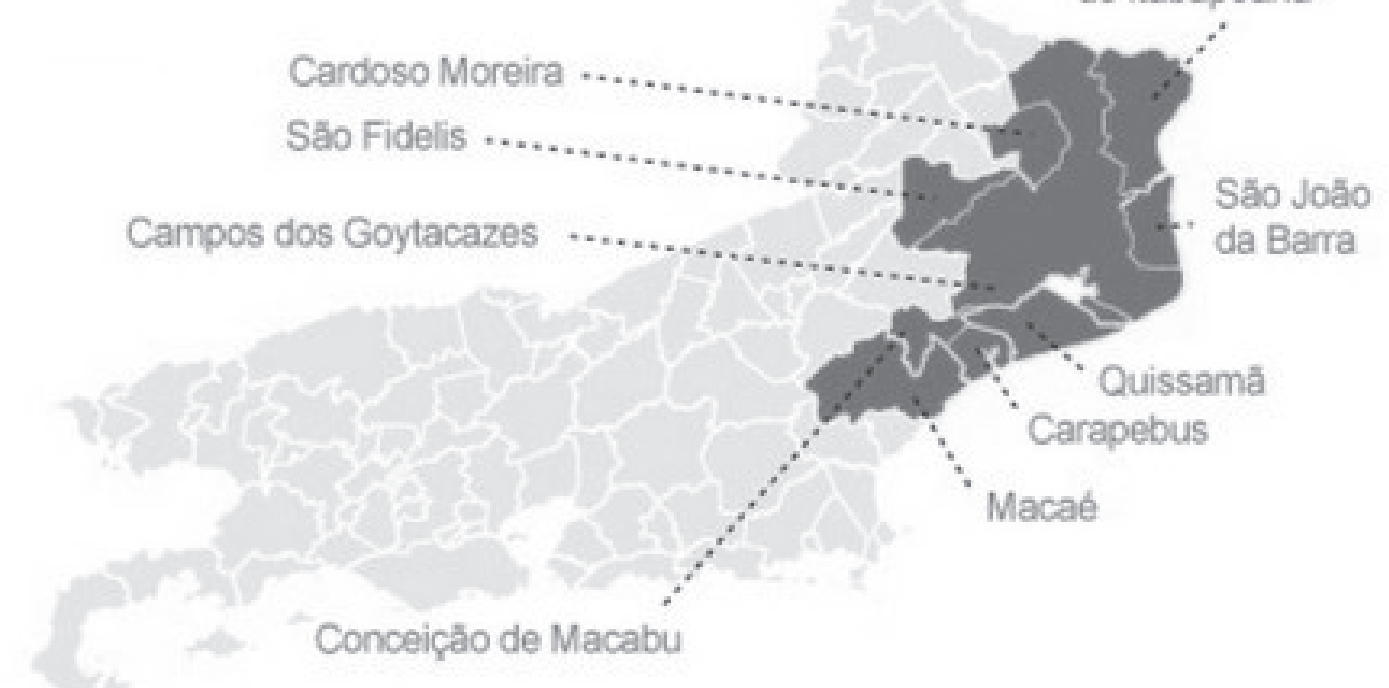

Fonte: Elaborado pelo autor.

Implantado pela holding EBX (do grupo de Eike Batista), o Complexo Logístico Industrial do Porto do Açu (Clipa) é considerado um porto concentrador de cargas, tendo sido projetado dentro da nova tipologia portuária denominada MIDAs (Maritime Industrial Development Areas), pois, na área contígua ao porto, estará um distrito industrial. Quando o complexo portuário foi divulgado, visava construir um terminal portuário de uso misto, composto por berços de atracação de navios, embarcações de apoio à exploração de petróleo e píer off-shore.

No distrito industrial, há previsão para a instalação de um complexo siderúrgico, usina termelétrica, polo metalmecânico, plantas de pelotização de minério, áreas para armazenamento de granéis líquidos e processamento de petróleo, além de uma unidade de construção naval (Coutinho, 2009).

O estudo dessa temática se justifica pela polêmica instaurada com o início da construção do Complexo Logístico Industrial do Porto do Açu (Clipa) no município de São João da Barra/RJ, desde o seu processo de licenciamento. Outrora marcada pela agroindústria açucareira, o território sanjoanense viu-se diante de uma nova oportunidade para alavancar seu crescimento. Assim, embasado nas mudanças mundiais, no surgimento de novas demandas por commodities e na favorável conjuntura político-econômica nacional, o governo do estado do Rio de Janeiro realizou os investimentos necessários para viabilizar o porto no Açu. Os entes privados (as empresas) e os públicos (o governo local e estadual) agiram juntos e de forma coesa para a implantação desse empreendimento. 


\section{Porto do Açu, entre as forças de conservação e modernidade}

Atualmente, a construção do complexo exerce forte pressão sobre os serviços ambientais e a população local, provocando modificação e impacto significativo no entorno. Compreender as expectativas dos agentes locais nesse contexto requer o devido acompanhamento a ser realizado pelos pesquisadores, o que justifica a presente pesquisa.

A história mundial comprova que os portos são elementos cruciais para o sistema econômico-comercial das nações, e seu desenvolvimento está intimamente ligado ao próprio desenvolvimento humano, sendo seus efeitos multiplicadores disseminados por todos os demais setores da economia (Santana Neto, 2005). As últimas décadas do século XX e o início do presente século foram marcados por profundas mudanças no processo produtivo. O processo de globalização traz consigo novas exigências logísticas e organizacionais, razão pela qual também a atividade portuária adquire nova importância no cenário global. E, no que diz respeito ao Complexo Logístico e Industrial do Porto do Açu, quais são os impactos positivos e negativos decorrentes dessa implantação portuária?

Barra do Açu, Vila do Açu ou, simplesmente, Açu já sofre grande pressão devido à proximidade com as atividades diretas do Clipa, e está geograficamente inserida em um território conflituoso, entre a zona industrial, a zona rural e a zona de proteção ambiental. Com aproximadamente 1.500 habitantes, localiza-se no litoral do município de São João da Barra e está a aproximadamente cinquenta quilômetros da sede de Campos dos Goytacazes.

Nosso foco de estudo é a influência do Porto do Açu nas metamorfoses ocorridas no uso da terra, bem como as mudanças territoriais havidas no município de São João da Barra. Discutem-se as peculiaridades do modelo de desenvolvimento ensejado pela instalação do Clipa em relação às suas consequências para as populaçôes que mais recebem seus ônus, ressaltando-se a relação entre os diferentes interesses envolvidos em sua construção e os indivíduos e comunidades que foram desalojados.

Não há como escapar da discussão sobre as relações de poder no território sanjoanense. No entanto, diante dos fortes encadeamentos que os investimentos previstos provocarão em São João da Barra e na Região Norte Fluminense em geral, levando a um elevado número de empregos diretos e indiretos e de receitas aos cofres públicos, o local tem muito a ganhar.

O município de São João da Barra está inserido numa região caracterizada por uma economia pauperizada, resultante de sua base de economia agropecuária pouco produtiva e de uma indústria agroaçucareira em crise constante. Recentemente, tornou-se dependente do repasse dos royalties do petróleo, que chegaram a contribuir com mais de $50 \%$ de toda a receita do município. Até os anos 1970, no Norte Fluminense predominava a agroindústria do açúcar. Com a criação do Programa Nacional do Álcool (Proálcool) - política adotada pelo governo brasileiro para fazer frente à alta brusca dos preços internacionais do petróleo em 1973, conhecida como primeiro choque do petróleo -, essa região perdeu a posição de grande produtora, por não acompanhar as mudanças tecnológicas modernizadoras nacionalmente adotadas pelos principais empresários do setor.

Nesse período, graças aos generosos financiamentos concedidos pelo governo federal, o parque industrial do setor de açúcar e álcool foi quase totalmente modernizado e reestruturado, passando uma boa parte das usinas do Norte Fluminense para as mãos de empresários externos à região, mais interessados na aquisição das cotas de produção dessas usinas que em suas instalações industriais - a maioria, inclusive, já ultrapassada do ponto de vista tecnológico. Uma vez que o setor era regulado pelo Estado nacional, a entrada de novos produtores estava sob seu controle, e cada indústria podia produzir apenas dentro dos limites de 
sua cota estabelecida. Os empresários paulistas, desejosos de ampliar a própria produção, passaram a adotar a estratégia de adquirir cotas de outras empresas para, em seguida, fechá-las e levar o "direito de produzir" para suas usinas. Nesse contexto, a Região Norte Fluminense, vista, desde o século XVII, como grande produtora de açúcar e álcool, foi deslocada de forma gradual porém inexorável do setor.

Esse Norte Fluminense histórico, que tem a cidade de Campos dos Goytacazes como principal polo, passou a apresentar problemas que iam de estagnação e queda dos índices de produtividade de seu principal produto a um elevado nível de desemprego, o que, consequentemente, levou a um processo de pauperização, desenraizamento e deslocamento do trabalhador rural para a periferia das cidades da região. No entanto, nesse momento, a Petrobras, que, desde a década de 1960, vinha desenvolvendo pesquisas na plataforma continental marítima, finalmente viu um de seus esforços resultar em sucesso: em 1974, o poço pioneiro 1-RJS-9A, situado a uma profundidade de cem metros, passou a produzir em vazão comercial e a se constituir em ponto de descobrimento de petróleo na Bacia de Campos (Caetano Filho, 2003, p. 52). Segundo Caetano Filho (2003, p. 47), o procedimento de se nomear uma bacia com o nome de uma cidade próxima ou acidente geográfico é internacionalmente regido pelo Código de Nomenclatura Estratigráfica.

Nesse contexto, a Bacia de Campos recebeu essa denominação em função de as descobertas marítimas terem ocorrido no litoral norte do estado do Rio, cuja principal cidade é Campos dos Goytacazes. A área estratigráfica dessa bacia tem cerca de $100.000 \mathrm{~km}^{2}$, estendendo-se do Espírito Santo até Cabo Frio. É necessário assinalar que a notícia da descoberta de petróleo na Bacia de Campos em um momento de plena crise mundial do petróleo, no auge do regime ditatorial brasileiro, parecia anunciar um novo tempo para a região.

O início da produção petrolífera colocava na ordem do dia a montagem de uma base operacional da Petrobras naquela área, e todos esperavam que isso ocorresse na cidade de Campos. No entanto, em 1978, a Petrobras, por questões logísticas, elegeu a cidade de Macaé, $100 \mathrm{~km}$ mais próxima da capital do estado, como sua base de atividades de prospecção e de produção. Inaugurou-se, então, um novo período econômico regional, dessa vez baseado, direta e indiretamente, nos recursos oriundos da exploração petrolífera. A elite açucareira, que, anos antes, propugnava as políticas para a região em nome dos próprios interesses, assistiu ao declínio de seu prestígio.

Ao longo dos anos, confirmou-se que as maiores reservas brasileiras de petróleo e gás se encontravam nessa bacia, que se tornou a produtora de cerca de $80 \%$ do petróleo e $40 \%$ do gás produzidos no país. Desde então, a Região Norte Fluminense passou por mudanças positivas no volume do PIB, na morfologia do tecido empresarial, na oferta de postos de trabalho, na demografia - com a chegada de trabalhadores qualificados e também de pessoas que buscavam alguma oportunidade -, na infraestrutura urbana, na educação e na saúde, e, principalmente, no aumento dos orçamentos municipais, em função dos generosos repasses garantidos pelo petróleo.

Tratando-se de uma aglomeração industrial baseada na extração de um bem natural não renovável, as empresas estão ali localizadas para explorar os recursos da região. Como as províncias de petróleo e gás apresentam um ciclo de vida - nascimento, crescimento, maturidade e declínio -, quando ambos os produtos se exaurem, as empresas líderes do setor dirigem-se para áreas com perspectivas de novas jazidas. Em situações tais, às empresas de pequeno e médio portes, fornecedoras de produtos ou serviços de alta competência tecnológica, resta a alternativa de se tornarem fornecedoras globais para a 


\section{Porto do Açu, entre as forças de conservação e modernidade}

indústria de petróleo, associando-se a grandes companhias multinacionais em novas províncias minerais. No entanto, para aquelas que atuam nos setores não intensivos, resta-lhes encerrar as atividades ou migrar para uma indústria correlata. Por essas razõse, foram frequentes os debates acerca do futuro econômico da região na era "pós-petróleo". Quis o destino que outras perspectivas surgissem no setor petrolífero: novas reservas de óleo e gás foram descobertas na camada de pré-sal e, em 2007, teve início a obra do Complexo Logístico-Industrial do Porto do Açu, no município de São João da Barra.

\section{Entendendo a economia e o processo de instalação do Porto do Açu}

No início dos anos 2000, mais precisamente a partir de 2003, após décadas de estagnação econômica, o Brasil deu início a um processo de retomada do crescimento, baseado numa mudança da conjuntura econômica mundial em que a China e os chamados Tigres Asiáticos (Coreia do Sul, Hong Kong, Singapura e Taiwan) passaram a ser grandes consumidores de commodities como minério de ferro, soja e insumos agrícolas. Ao mesmo tempo que a economia dos países do hemisfério Norte começava a apresentar traços de estagnação, que culminaram com a crise do sistema financeiro americano em 2008, o Brasil e os demais BRICS (abreviatura para o grupo de países composto por Brasil, Rússia, Índia, China e África do Sul) alavancaram um novo ciclo de crescimento da economia e das exportações.

No âmbito das políticas internas, o Brasil adotou políticas keynesianas como forma de distribuição de riqueza e justiça social, apostando na exportação de commodities a fim de manter o superávit da balança comercial. Pessanha et al. (2013) exemplificam a decisão de retomar os investimentos com o Porto de Suape, em Pernambuco, e com programas sociais como o Bolsa Família. Tais exemplos são uma nítida intenção de prover o país de uma nova e diversificada base de desenvolvimento, melhorando a renda das camadas mais pobres da população.

O processo de retomada econômica, contudo, trouxe à tona conhecidos problemas de infraestrutura, como os gargalos no sistema logístico-portuário nacional, típicos dos ciclos de crescimento da economia brasileira que ocorrem desde a segunda metade do século XIX, em que a infraestrutura só é reorganizada e ampliada após seu colapso. Nessa conjuntura de aumento das exportações de commodities e da necessidade de se contruírem novos terminais portuários, tem início a construção do Clipa no município de São João da Barra.

Em 1999, a Secretaria Estadual de Energia, Indústria Naval e Petróleo começou os estudos para a construção de um terminal portuário e de apoio offshore para a Petrobras no Norte Fluminense, junto à Bacia de Campos. Segundo Victer (2010), a ideia inicial de um porto estruturado para os granéis líquidos e de apoio offshore foi aperfeiçoada para também agregar a movimentação de granéis sólidos e contêineres. Após a realização de estudos de batimetria no litoral Norte Fluminense, chegou-se à conclusão que a região do Açu apresentava grande potencial para a viabilização desse empreendimento, sendo necessária apenas a construção de um extenso píer em direção ao oceano, aproveitando o elevado calado para a movimentação de grandes navios.

Com a escolha do local, o então governador, Anthony Garotinho, assinou o Decreto no 25.455, de 28 de junho de 1999, declarando, como de utilidade pública, para fins de desapropriação, quatro 
áreas desmembradas do imóvel rural denominado Fazenda Saco D’Antas, em São João da Barra. Victer (2010) ainda registra a aprovação de uma lei que delegava ao estado do Rio de Janeiro o investimento de $33 \%$ do valor do projeto, como forma de alavancar a construção do porto.

Em $1^{\circ}$ de setembro de 2000, em reunião pública realizada na Associação Comercial e Industrial de Campos (ACIC), foram divulgados os resultados dos primeiros estudos técnicos de engenharia, que apontavam a viabilidade de se construir o porto no Açu. Os relatórios, que custaram US\$ 500 mil ao governo estadual, também confirmaram a localização do terminal portuário em frente à Fazenda Saco D’Antas, conforme previsto no decreto de 1999 (Pessanha et al., 2013).

No entanto, mesmo com os investimentos iniciais prometidos, o projeto do porto não foi aceito pela Petrobras nem pelas empresas da iniciativa privada que se haviam mostrado interessadas. Desse momento em diante, já no ano de 2004, houve o redirecionamento do projeto para o setor de granéis sólidos, em especial o minério de ferro. As negociações, então, foram feitas com a Vale, que também não se mostrou interessada no projeto (Victer, 2010). Assim, após as recusas pela Petrobras e pela Vale, o então secretário de Energia, Petróleo e Indústria Naval, Wagner Victer, autorizado pela governadora Rosinha Garotinho, entregou o projeto ao empresário Eike Batista. Essa transferência do projeto para um novo investidor contou com a interferência de Eliezer Batista, ex-presidente da Companhia Vale do Rio Doce, pai do empresário Eike Batista e também membro do Conselho de Desenvolvimento Econômico e Social do Rio de Janeiro (CDES-RJ), órgão consultivo que acompanhou, desde o início, os estudos de implantação do porto.

Assim, em 27 de dezembro de 2006, foi colocada a pedra fundamental para a construção do porto, embora, efetivamente, as obras só tenham iniciado em março de 2007 (Pessanha et al., 2013). A partir de então, sob a coordenação do Grupo EBX, o projeto do porto passou por uma nova reformulação, adequando-se à nova realidade de se agregarem atividades industriais a atividades portuárias. Essa nova concepção, denominada MIDAs (Maritime Industrial Development Areas), encontrou no Porto do Açu o ambiente ideal para sua implantação. No entanto, sabe-se que, dentro das estruturas portuárias do tipo MIDAs, são necessárias extensas retroáreas para a construção dos distritos industriais e dos terminais de contêineres, algo quase impossível de se encontrar no litoral sudeste brasileiro. Diante disso, Quinto Jr. et al. (2011) ressaltam outro aspecto importante na escolha do município de São João da Barra para a instalação do complexo portuário industrial: a questão fundiária.

\section{As transformações no uso da terra: mudanças territoriais em São João da Barra}

Fernandes (2008) argumenta que o ponto de partida para a análise do território consiste em se compreender o que é espaço, local onde a vida humana se materializa.

No espaço, natureza e sociedade estariam unidos de forma indissociável, pois as relações sociais no espaço transformam a natureza, e esse mesmo espaço é transformador das relaçôes sociais. Nesse movimento cíclico e ininterrupto é que se formam os territórios, ou seja, o território é construído a partir do espaço, pois, diante da necessidade de garantir sua existência, os homens fragmentam o espaço e criam seus territórios. 


\section{Porto do Açu, entre as forças de conservação e modernidade}

Fernandes propõe a criação de duas categorias para distinguir os territórios: materiais e imateriais, em que os primeiros dizem respeito aos territórios formados no espaço físico, enquanto os segundos são formados no espaço social. Essas duas categorias seriam indissociáveis e dependentes, uma vez que o território formado no espaço físico deveria ser sustentado pelo território material em forma de conhecimento, ideologia e teoria. De forma análoga, Corrêa (1998) argumenta que o território está submetido à organização espacial, ou seja, ao espaço. O território, portanto, seria o espaço revestido de dimensão política e/ou afetiva. Corrêa também sugere que é na ação dos agentes sociais (por exemplo, Estado, grupos sociais e corporações econômicas), com vistas à garantia da apropriação e da permanência em dado território, que se constitui a territorialidade.

Para Fernandes e Corrêa, o território seria, portanto, uma totalidade e, dentro dessa totalidade, estariam as dimensões política, social, natural, cultural e econômica. Assim, cada sujeito ou grupo, ao se apropriar do espaço, construiria seu território, decidindo explorar uma ou mais de suas dimensões, e, assim, outro grupo que também se apropriasse desse mesmo espaço poderia explorar as dimensões de seu próprio interesse. Assim, as ações tomadas que levam em conta o território como espaço de governança teriam de considerar esse território propriedade individual e vice-versa (Fernandes, 2008; Corrêa, 1998). Por outro lado, Haesbaert (2005) chama a atenção para o caráter duplo do território, que, como já vimos, seria composto pelas dimensôes simbólica e material, ambas ligadas à busca pelo poder. A primeira delas seria a apropriação e a dominação da terra, e a segunda, uma consequência desta, a inspiração de terror sobre os que foram dominados, vendo-se forçados a abandonar dado território ou impedidos de entrar e/ou permanecer nele.

Em todas as proposições apresentadas, fica clara a importância do conflito na construção e desconstrução do território. Fernandes (2008), por exemplo, é categórico ao considerar a conflitualidade como parte integrante do processo de formação e desenvolvimento da disputa territorial. Haesbaert (2005), por sua vez, sugere que a busca por influenciar pessoas, fenômenos e relacionamentos é o que mobiliza a tentativa de controle do espaço. Assim, para Haesbaert, a territorialidade não se restringe ao domínio de um lugar físico e à sua dimensão política; ela também representa a capacidade de, através desse lugar, experimentar o mundo e produzir significados, envolvendo, portanto, as dimensões cultural e econômica.

Assim, a disputa permanente seria parte integrante do território, que se deve, principalmente, à impossibilidade de realização de uma classe ou grupo social em um território que já esteja sob o controle de outrem. As diferentes e até mesmo divergentes formas de organização, relações sociais, planos de desenvolvimento e finalidades de cada classe para o território impossibilitariam tal realização. Essas diferentes formas de se apropriar, simbólica e materialmente, do ambiente, as quais revelam diversos modos de produção de seu espaço, são o que Laschefski (2011) caracteriza como territorialidade.

De forma semelhante, para Neves (1988), a territorialidade seria dada pelo conjunto formado por ação e poder dentro do espaço. Nessa perspectiva, o poder é entendido como a capacidade de decidir, a qual pode ser exercida sobre os lugares quando se é adaptável a circunstâncias espaçotemporais contraditórias. Neves também postula que a eficácia e a amplitude desse poder são definidas pela densidade dos fragmentos e pelas obstrução e construção de canais das múltiplas redes vinculadas às condiçōes históricas dadas.

Nesse contexto, as redes são construídas ou desconstruídas sempre por ações políticas, numa disputa entre os locais, mesmo que apresentadas como lutas a favor da democracia e contrárias à opressão. 
Essas lutas também são travadas pela construção do território, uma vez que o que está em jogo é a soberania sobre o espaço. Assim, o exercício de poder sobre o espaço é o que o transforma em território. Não se trata, contudo, apenas do poder como dimensão econômica; trata-se também do poder exercido pela força cultural do grupo, capaz de unificar os fragmentos de um território (Neves, 1988).

Além disso, Corrêa (1988) ressalta que, embora esteja relacionado à ligação de um grupo ao espaço, um mesmo espaço pode apresentar diferentes territorialidades, visto que pode ser apropriado e vivenciado de modo diverso pelos diferentes grupos. Em suma, em um mesmo espaço, haveria vários territórios com múltiplas possibilidades de arranjo. Entretanto, quando há perda desse território apropriado e vivido, o que ocorre, segundo Corrêa, seria a desterritorialidade, fomentada pelas contradições capazes de desfazer um território. A desterritorialidade, por sua vez, pode não ser seguida pela desterritorialização, que viria a ser o deslocamento espacial dos grupos derrotados de seus territórios.

A partir dessas diferentes formulações sobre território, desterritorialidade e desterritorialização, Fernandes (2008) aponta a necessidade de se pensar em políticas territoriais que levem em conta a multiescalaridade e a multidimensionalidade do território. No entanto, contra essa sugestão pesa o fato de a prática comum entender o território como um espaço de governança, anulando seus atributos e considerando-o uma entidade única. $\mathrm{O}$ fato é que, quando as múltiplas dimensões e a totalidade do território são reduzidas, determinado território tem de ser privilegiado para se aplicarem políticas de desenvolvimento.

Assim, considerando as diferentes disputas e relações de poder existentes em dada sociedade, os grupos de maior poder político são os privilegiados. Essa opção está em sintonia com os interesses de reprodução capitalista e com o processo de dominação pretendido pelas classes dominantes. Essa exploração-dominação é ainda pior quando se verifica o uso de um discurso que, contraditoriamente, defende formas de empoderamento a esses grupos socialmente marginalizados quando, na realidade, o que ocorre é o fortalecimento dos interesses das classes detentoras de capital. Por fim, Haesbaert (2005) afirma que, devido à hegemonia da lógica capitalista, a reapropriação é inibida, pois o espaço é considerado único, sendo fadado, portanto, ao domínio pelo aparato empresarial e pelo Estado.

De 2007 a 2014, da construção até a atualidade, o Complexo Logístico e Industrial do Porto do Açu passou por muitas mudanças, com o Grupo EBX, do empresário Eike Batista, investindo, de forma significativa, nesse empreendimento. Anos mais tarde, foi necessário reestruturar o Grupo EBX, em função da falência da OGX, que acabou repercutindo nas outras empresas da holding e na diminuição do valor das commodities no mercado internacional, provocando uma nova reestruturação no projeto.

\subsection{Complexo Logístico e Industrial do Açu: uma nova territorialidade produtiva na Região Norte Fluminense (2007-2014)}

Cobrindo uma área de $90 \mathrm{~km}^{2}$ e localizado estrategicamente no norte do estado do Rio de Janeiro, o Porto do Açu está a cerca de $150 \mathrm{~km}$ da Bacia de Campos, onde quase 80\% do petróleo brasileiro é produzido. Sua construção teve início em outubro de 2007. Atualmente em operação, o porto conta com $17 \mathrm{~km}$ de cais e até $23 \mathrm{~m}$ de profundidade, com capacidade para receber até 47 
embarcações simultaneamente, incluindo navios de grande porte, como Capesize e Very Large Crude Carrier (VLCCs), que transportam até 320 mil toneladas de carga.

Segundo os conceitos mais modernos de porto-indústria, o Porto do Açu contará com um distrito industrial e uma retroárea para armazenamento e movimentação de carga. Essas áreas, em conjunto com o porto, formarão o Complexo Industrial do Porto do Açu, onde serão instaladas indústrias offshore, polo metalmecânico, base de estocagem para granéis líquidos, estaleiros, base para tratamento de petróleo, termelétricas, pátio logístico, terminal de reparo naval, entre outros.

O Porto do Açu foi idealizado para fazer parte de uma gama de projetos interligados e mutuamente viabilizados, e será o maior empreendimento desse conjunto, pois tem a responsabilidade de atrair as principais empresas para São João da Barra, além de viabilizar a exportação do minério extraído pela MMX Minas-Rio Mineração, em parceria com a Anglo Ferrous Minas-Rio Mineração S.A, em Conceição do Mato Dentro/MG (Rima, 2010). O mineroduto é o projeto mais adiantado, iniciado em $2007 \mathrm{com}$ a construção de um píer para a ligação terminal de cargas ao continente (Figura 2). Essa construção já vem provocando impacto em uma das principais atividades econômicas da população local, a pesca.

Figura 2. Traçado do mineroduto Minas-Rio desde a serra (MG) até São João da Barra.

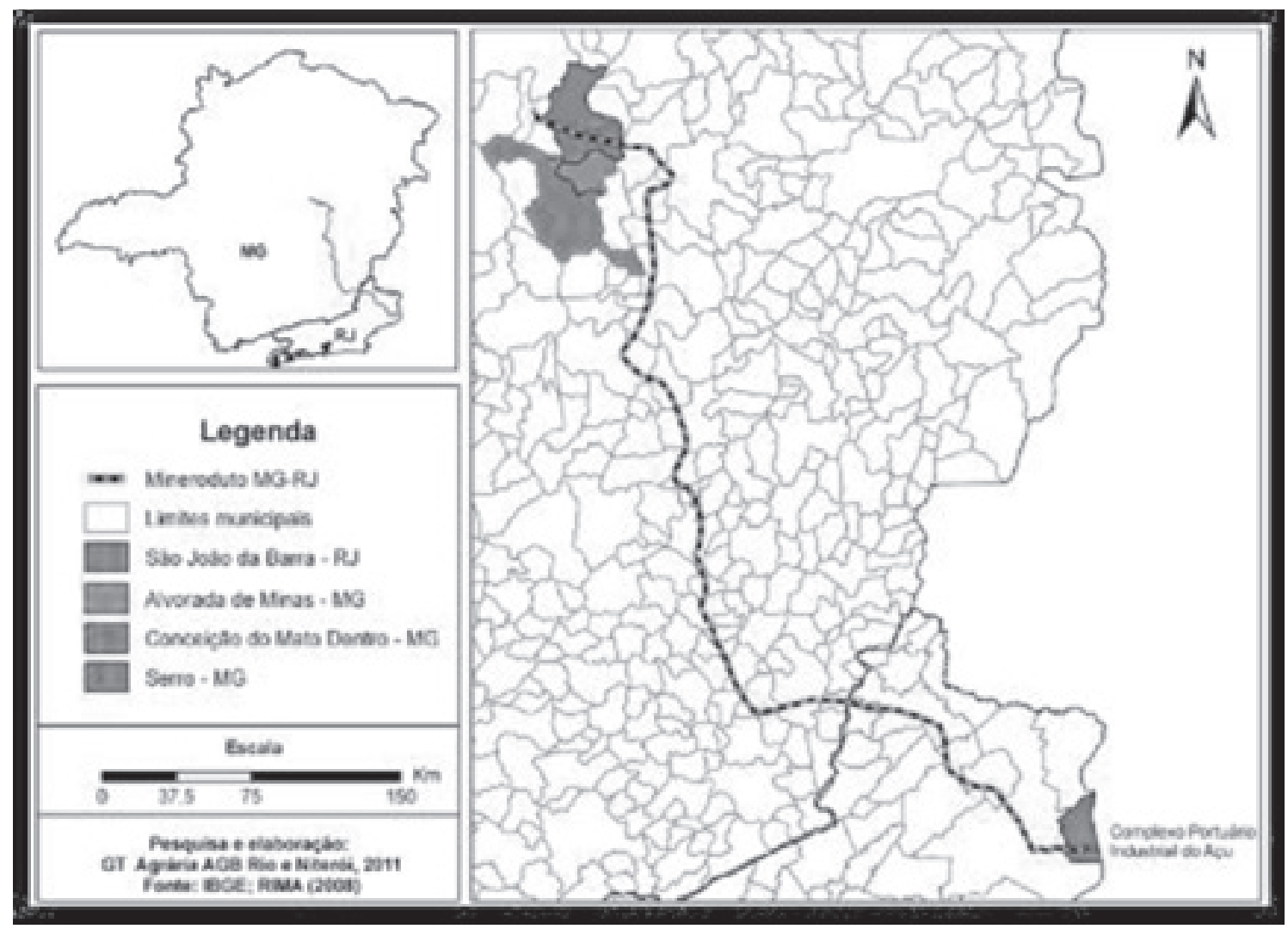

Fonte: AGB, 2011. 
O projeto do Clipa ainda prevê a construção de uma usina termelétrica no condomínio industrial na área de retaguarda do porto, que, pela facilidade de formação de energia elétrica e de saída para exportação, atrairá usinas siderúrgicas e montadoras para a área (AGB, 2011). Além dessas facilidades, o mineroduto levará minério de ferro do interior de Minas Gerais ao Norte Fluminense a baixo custo, por fazer seu beneficiamento no próprio porto, nas siderúrgicas ou nas unidades de pelotização, o que também poderá beneficiar as siderúrgicas, ao agregar valor ao produto e possibilitar maiores ganhos com a exportação de ligas de metal de baixo custo, e não do material bruto.

\subsection{A desterritorialização em São João da Barra}

Com a finalidade de construir o Distrito Industrial de São João da Barra (RJ), os decretos estaduais 42.584 e 41.585, de 05/12/2008, 41.915 e 41.916, de 19/06/2009, e 41.998, de 19/08/2009, desapropriaram, com fins de utilidade pública, a cargo da Companhia de Desenvolvimento Industrial do Estado do Rio de Janeiro (Codin), os imóveis destinados a abrigar o DISJB, numa área total de 7.200 hectares. Segundo dados apurados por pesquisadores da Associação de Geógrafos Brasileiros (AGB, 2011), a área desapropriada era ocupada, basicamente, por pequenos agricultores. Assim, como aponta Haesbaert, ocorreu uma desterritorialização. Durante o processo de audiência pública, promovido pelo Inea e pela Codin, questôes sobre a desapropriação das famílias e informaçôes sobre as garantias previstas no "reassentamento" teriam sido pautas ocultas e pouco esclarecedoras.

Nesse sentido, em parceria com empreendedores privados, a Codin desenvolveu um assentamento rural na área da antiga Fazenda Palacete, localizada no V Distrito de São João da Barra. Essa propriedade passou a ser chamada de Vila da Terra, com a finalidade de abrigar as famílias que atendessem a critérios estabelecidos pela Codin, conforme resultado do cadastro socioeconômico realizado na região. Assim, entre os critérios estabelecidos pela Codin para participação no reassentamento, estavam: 1) Ser proprietário/posseiro e residente no imóvel rural contido no polígono decretado de utilidade pública, com propriedade inferior a 10 ha: 2) Pertencer a famílias em condição de hipossuficiência social atingidas pela implantação do Distrito Industrial de São João da Barra: 3) Ter sido cadastrado na pesquisa socioeconômica aplicada em 2009, atualizada entre janeiro e março de 2011.

Desse modo, construída a partir de uma parceria entre a Codin, a Prefeitura Municipal de São João da Barra e a LLX, a Vila da Terra foi planejada para alocar cerca de noventa famílias numa área que, além das casas, contaria com uma quadra poliesportiva e um centro comercial. A Vila da Terra tem sido apresentada como um modelo inédito de reassentamento rural e, vendida como dentro dos padróes estabelecidos pelo Banco Mundial, referência internacional em reassentamento, contará com cerca de mil hectares.

Segundo informações divulgadas no site e em vídeos promocionais do empreendimento pelo Grupo EBX, na época inicial de implantação do porto, a Vila da Terra foi planejada com ruas pavimentadas, quadra poliesportiva, centro comunitário, iluminação pública, rede de água e esgoto e centro comercial. Os lotes, cujo tamanho variaria entre 2 e 10 ha, apresentariam três diferentes tipologias, com dois, três ou quatro quartos, e áreas de construção entre 68 e $109 \mathrm{~m}^{2}$. No caso dos produtores rurais que possuíssem residência anterior com área superior a $109 \mathrm{~m}^{2}$, a casa seria construída no tamanho da metragem original. Os proprietários com terrenos maiores que 10 ha receberiam os valores correspondentes à desapropriação. 


\section{Porto do Açu, entre as forças de conservação e modernidade}

Inaugurada em outubro de 2011, a Vila da Terra, no momento em que esta pesquisa foi realizada, abrigava vinte famílias, de acordo com dados dos próprios moradores, estando ainda prevista a transferência de um número indeterminado para aquele local, de acordo com o andamento do conturbado processo de desapropriação.

Analisando, em trabalho de campo, as características da Vila da Terra, foi possível perceber sua importância para esses moradores. Em primeiro lugar, por ser seu local de moradia e existência, uma vez que nasceram e constituíram suas famílias ali. Em segundo lugar, a importância daquele chão está no papel que desempenha como fornecedor dos meios de trabalho e condição de subsistência (agricultura).

Essa caracterização rural, marcada pela relação com a terra, chama a atenção para os impactos que a construção do Cipa está causando na região, uma vez que as rupturas com os espaços tradicionais que, historicamente, têm condicionado as formas sociais nas localidades, provocadas pela instalação de grandes empreendimentos, serão mais relevantes quanto mais as estratégias de trabalho e condiçôes de existência estiverem associadas ao meio biótico natural (Acserald e Silva, 2011).

\subsection{Porto do Açu no cenário atual}

Segundo Moreno (2014), em junho de 2012 teve início a queda do empresário Eike Batista e, em consequência, de muitos de seus projetos. No mesmo mês, a holding do empresário recebeu um comunicado de que a produção de petróleo da OGX Petróleo e Gás Ltda. (OGX) estava 50\% abaixo das previsões estimadas, o que prejudicou toda a avaliação da companhia por parte do mercado. Nesse contexto, os investidores passaram a ter um olhar cético sobre o grupo, pois os problemas iam se sucedendo e as empresas mudavam de acionistas ou entravam em recuperação judicial por causa das vultosas dívidas. Em setembro de 2013, a LLX Logística, que geria o porto do Açu, teve o controle acionário repassado para o Grupo EIG, após a assinatura de um contrato de investimentos no valor de $\mathrm{R} \$ 1,3$ bilhão. Em dezembro do mesmo ano, a LLX Logística passou a se chamar Prumo Logística Global.

Atualmente, a empresa mantém seus investimentos na construção do porto do Açu. Em 25 de outubro de 2014, realizou-se o primeiro carregamento de minério de ferro. Um total de 80 mil toneladas do produto foi embarcado para a China. O carregamento desse primeiro navio é um marco para a história do porto e da região, pois concretiza os investimentos e as especulaçóes ali realizados nos últimos 15 anos (1999 a 2014), tornando irreversíveis as mudanças em curso no entorno do Clipa.

A reestruturação do Grupo EBX, em função da falência da OGX, que acabou por repercutir nas outras empresas da holding, e a diminuição do valor das commodities no mercado internacional provocaram uma nova reestruturação do projeto. As indústrias siderúrgicas e cimenteiras foram abortadas, porém as empresas que estão se instalando no complexo retomam a concepção original desenhada no final da década de 1990, que era de um porto de apoio às atividades offshore na Bacia de Campos. Nesse contexto, as áreas destinadas à Codin e ao DISJB deverão ser ocupadas em longo prazo.

Quanto às famílias que passaram pela desapropriação, muitas ainda não receberam da empresa as respectivas indenizaçóes, gerando, no contexto atual, um grande conflito entre o porto e a população. As obras de implantação estão em andamento, com previsão de término para final de 2016. 
As forças conservadoras, que representam a população diretamente atingida pela instalação portuária, ainda lutam por seus direitos, enquanto as forças que defendem a modernidade, movidas pela globalização, seguem, sem pensar nas necessidades dos atingidos, mas tão somente no lucro a ser gerado para a empresa.

\section{Considerações finais}

$\mathrm{Na}$ construção do Porto do Açu, os principais atingidos são os pescadores e agricultores familiares, que estão passando por um período de insegurança e insatisfação, decorrente do processo de desapropriação de suas terras, que ignorou os mecanismos legais estabelecidos pela própria Constituição Estadual. A falta de obediência aos ditames legais por parte do governo do Rio de Janeiro nas desapropriações realizadas também se verificou na emissão das licenças ambientais relacionadas à instalação do Clipa.

Em outro sentido, levando-se em conta as condições que cercaram as desapropriações e a (falta de) negociação com as comunidades e os indivíduos atingidos, afirma-se que o Estado atuou como parceiro dos empreendedores privados, provendo investimentos diretos, melhora nas estradas de acesso e condições para seu pleno estabelecimento. No entanto, não se observou o mesmo tratamento em relação aos agricultores e pescadores. Esse tratamento desigual contribuiu para o surgimento de conflitos que, em última instância, conduziram a atrasos e pendências, com efeito negativo para a própria construção do Clipa.

Certamente, o Complexo Logístico do Açu pode ser relacionado a impactos socioambientais e à precarização das condições de trabalho e de reprodução social das comunidades que moravam no 5은 Distrito. Esse fato corrobora assertivas constantes na literatura de que o modelo neodesenvolvimentista se baseia no uso intensivo dos recursos naturais, ignorando uma avaliação mais profunda do respectivo impacto socioambiental e a falta de alternativa para aqueles que são política e economicamente marginalizados com sua adoção.

Para concluir, assinala-se que, no processo de implantação autoritária de megaempreendimentos, como no caso do Porto do Açu, o que se materializa é a disputa entre duas racionalidades em relação a qual modelo de desenvolvimento e progresso seria mais apropriado. Outro aspecto importante é a persistência da força que a ideologia do desenvolvimento possui até entre aqueles que mais têm a perder, na medida em que os atingidos não querem ser vistos como obstáculos ao progresso, embora sejam os principais prejudicados nas novas relações de poder estabelecidas em seus próprios territórios.

Os resultados desta pesquisa também colocam em xeque a noção de desenvolvimento como um mero processo de crescimento econômico. Esse processo, para ser alcançado em sua plenitude, requer a adoção de medidas que ampliem os mecanismos de participação nos processos decisórios, que sirvam para criar mecanismos de participação efetiva, de modo que os habitantes dos territórios que passam por transformação possam ser ouvidos, em vez de ser tratados como símbolos de formas sociais atrasadas. 
Porto do Açu, entre as forças de conservação e modernidade

\section{Referências}

ACSELRAD, Henri. “Território e poder: as políticas das escalas”. In FISHER, Tânia (org.). Gestão do desenvolvimento e poderes locais: marcos teóricos e avaliação. Salvador: Casa da Qualidade, 2002.

—_. "Rearticulações da terra e do trabalho em áreas de grandes projetos hidrelétricos na Amazônia". In ZHOURI, Andréa (org.). As tensōes do lugar: hidrelétricas, sujeitos e licenciamento ambiental. Belo Horizonte: Editora UFMG, 2011.

AGB. Relatório dos Impactos Socioambientais do Complexo Industrial Porto do Açu. S.1., 2011.

ALVARENGA, F. M. Os deserdados do desenvolvimento: o caso da implantação do Complexo Portuário e Industrial do Açu e seus impactos socioterritoriais (dissertação). UENF, 2013.

CAETANO FILHO, E. "O papel da pesquisa nacional na exploração petrolífera da margem continental na Bacia de Campos”. In PIQUET, R. (org.). Petróleo, royalties e região. Rio de Janeiro: Garamond, 2003, pp. 39-94.

CARVALHO, L. S. et al. "O Porto do Açu no contexto da reestruturação espacial”. Porto Alegre, Encontro Nacional dos Geógrafos, 2010.

CORRÊA, R. L. “Territorialidade e corporação: um exemplo”. In SANTOS, Milton et al. Território: globalização e fragmentação. 4 ed. São Paulo: Hucitec/Anpur, 1988.

COUTINHO, R. R. Avaliação das transformações socioambientais oriundas da implantação do Complexo Portuário Industrial do Açu (dissertação). IFF, 2009.

FERNANDES, B. M. "Entrando nos territórios do território". In PAULINO, Eliane Tomiasi e FABRINI, João Edmilson. Campesinato e territórios em disputa. São Paulo: Expressão Popular, 2008, pp. 273-302.

GIL, A. C. Como elaborar projetos de pesquisa. São Paulo: Atlas, 2002.

HAESBAERT, R. "Da desterritorialização à multiterritorialidade”. Anais... X Encontro de Geógrafos da América Latina. São Paulo, USP, 2005.

IBGE. Censo 2010. Rio de Janeiro, 2010.

LASCHEFSKI, K. "Licenciamento e equidade ambiental: as racionalidades distintas de apropriação do ambiente por grupos subalternos". In ZHOURI, Andréa (org.). As tensóes do lugar: hidrelétricas, sujeitos e licenciamento ambiental. Belo Horizonte: Editora UFMG, 2011.

MARAFON, G. J. e SANT'ANNA, M. J. G. (orgs.). Rio de Janeiro: um olhar socioespacial. Rio de Janeiro: Gramma, 2010.

NEVES, G. R. “Territorialidade, desterritorialidade, novas territorialidades (algumas notas)". In SANTOS, Milton et al. Território: globalização e fragmentação. 4 ed. São Paulo: Hucitec/Anpur, 1988

PIQUET, Rosélia e SERRA, Rodrigo (orgs.). Petróleo e regiāo no Brasil: o desafio da abundância. Rio de Janeiro: Garamond, 2007.

QUINTO JR, Luiz de Pinedo et al. Implantação de um Complexo Industrial Portuário: o caso do Porto do Açu. Agenda Social. Campos dos Goytacazes, 2011. 
SANTANA NETO, J. V. de. A lei 8.630/93 e a modernização portuária no Brasil: um estudo dos impactos da privatização da operação portuária na movimentação da carga conteinerizada no porto público organizado de Salvador (dissertação). UFBA, 2005.

SOUZA, T. N. de. Avaliação dos impactos causados pela implantação do Complexo Portuário do Açu sobre as atividades de pesca artesanal marinha na regiāo Norte Fluminense (dissertação). IFF, 2010.

VAINER, C. "Planejamento territorial e projeto nacional: os desafios da fragmentação". Revista Brasileira de Estudos Urbanos e Regionais, Anpur, 2007, v. 9, n. 1, pp. 9-24.

VICTER, Wagner. "Porto do Açu”. 2010. Disponível em: http://oglobo.globo.com/blogs/wagner/ posts/2010/04/14/porto-do-acu-283776.asp. Acesso em: 26 abr. 2016. 


\section{Urbanismo imperial e planejamento dos barões: a formação da cidade de Petrópolis (RJ) nas origens do processo urbanístico brasileiro}

Ana Paula Silva de Araújo

\section{Introdução}

E ste texto teve origem na dissertação intitulada "Ideologia, patrimônio e memória na (re)produção do planejamento urbano e das políticas culturais e de preservação na cidade imperial de Petrópolis (RJ)”. Visa-se, com este trabalho, compreender as raízes do processo urbanístico brasileiro, tomando como ponto de partida a cidade do Rio de Janeiro, que foi o principal palco da chegada de muitas ideias, além de haver recebido muitos investimentos em infraestrutura urbana.

Assim, tomando-se a cidade do Rio de Janeiro como ponto de partida para entender o nascimento do processo urbanístico no Brasil, analisa-se como esse processo influenciou outras localidades para além dos limites da cidade do Rio, ou seja, especificamente como foram pensados o planejamento e a fundação da cidade de Petrópolis, uma cidade que congregou o urbanismo imperial e o planejamento dos barôes, pertencentes, respectivamente, à concepção da Cidade Nova e da Fazenda de Santa Cruz.

Busca-se, aqui, aprofundar as origens do processo urbanístico no Brasil, tentando entender sua relação com a vinda da Família Imperial e as transformaçōes ocorridas no espaço urbano do Rio de Janeiro, com destaque para o pensamento dos engenheiros militares e dos higienistas. Autores como Andrade (1966) e Fernandes (2008) não foram citados na dissertação, pois o objetivo não era detectar as origens do processo urbanístico brasileiro, nem tampouco e o que distinguia as cidades coloniais portuguesas no Brasil das cidades hispânicas. Foram consultados outros autores, a fim de dar novas e mais profundas contribuições em relação à cidade de Petrópolis.

Nesse contexto, indaga-se: "Quais origens do processo urbanístico brasileiro - que teve a cidade do Rio de Janeiro como centro irradiador de cultura e informações - contribuíram para o planejamento de uma cidade-palácio como Petrópolis?”. Refletir acerca das origens do pensamento urbanístico brasileiro implica contribuir para se repensar o presente com base no passado, com vistas a superar, no futuro, certas correntes e organizaçóes que contribuem cada vez mais para a desigualdade social no espaço urbano que habitamos. 


\section{Urbanismo imperial e planejamento dos barões no processo urbanístico brasileiro}

Para tratarmos, em linhas gerais, do processo urbanístico brasileiro, recorremos a Andrade (1966), autor que faz um levantamento histórico significativo das principais transformações e atores sociais na morfologia de nossas cidades. Para esse estudioso, a presença de dom João VI, a chegada da Família Imperial Portuguesa ao Brasil e a abertura dos portos desempenharam papel relevante no processo urbanístico brasileiro. O certo é que a presença da corte transformou o Rio de Janeiro em um "foco de irradiação de cultura e de civilização" (Andrade, 1966, p. 107). A chegada de instituições, de novos códigos sociais e de equipamentos culturais quando da transferência da corte para o Brasil ganha importância, e Andrade (1966) nos auxilia a entender como se delineou o processo urbanístico brasileiro.

Assim, ao examinar as transformações urbanísticas provocadas pela chegada da corte ao Brasil, Andrade (1966) afirma que as "primeiras tentativas brasileiras no campo do planejamento econômico e territorial” se devem à figura do Visconde de Cairu, pois, em decorrência de suas ideias e açóes, foi possível expandir algumas áreas e a população das cidades (Andrade, 1966). Outro personagem importante foi o Conde dos Arcos, que esteve à frente de grandes melhoramentos públicos e de saneamento, da construção do Teatro São João, entre outros (Andrade, 1966). Ele foi também responsável pela desocupação de imóveis para a acomodação da corte recém-chegada ao Brasil (Abreu, 2014).

Os investimentos em infraestrutura na cidade do Rio de Janeiro visavam que a capital do vice-reino perdesse o aspecto de colônia, de atraso. Assim, contando com a participação de arquitetos e engenheiros em cargos públicos, foram realizadas várias obras, o que nos dá a entender que, através desses feitos, eles impulsionavam os primórdios do processo urbanístico brasileiro. Muitos cargos eram criados para operacionalizar as inúmeras obras e os diversos planos, como, por exemplo, os de arquiteto real e arquiteto das reais obras públicas - que, na época de D. Pedro I, eram chamados de arquiteto da nova inspeção da corte do Rio de Janeiro e arquiteto das obras nacionais e imperiais - e de arquiteto do Senado da Câmara, em substituição à função de mestre geral d'obras públicas, arruador e arquiteto do Senado da Câmara (idem).

Entre os muitos profissionais citados por Andrade (1966), citamos o arquiteto Manuel da Costa (1808 a 1826), responsável pela ordenação arquitetônica e espacial da Quinta da Boa Vista, e o engenheiro José de Souza Soares de Andréia (barão de Caçapava), que efetuou um levantamento das plantas da cidade do Rio de Janeiro, incluindo as de Copacabana. Além dessas duas figuras, segundo Andrade (1966, p. 111),

Morales de los Rios Filho identifica cerca de 50 arquitetos e engenheiros que exerceram funções de ordenação urbana, além do exercício profissional como projetistas e construtores. Os arquitetos dos edifícios administrativos, dos palácios, dos solares e residências foram os maiores modificadores da paisagem urbana carioca, responsáveis, sem dúvida, pelo uso mais racional e o trato mais atualizado dos espaços públicos e pela melhor ordenação física da cidade nos primeiros anos da independência. 


\section{Urbanismo imperial e planejamento dos barões}

Um arquiteto que não pode ser esquecido é Augusto Henri-Victor Grandjean de Montigny (1776-1850), que, de acordo com Andrade (idem, pp. 111-2), procedeu à abertura de avenidas, à regularização de ruas tortas, a construção de projetos de ligação viária entre São Cristóvão, Campo de Santana e Cais de Pina, à projeção de chafarizes para o abastecimento de água da cidade, à ordenação espacial e arquitetônica do Largo do Valongo e a muitas outras realizações. O Rio de Janeiro era, como afirma Abreu (1997, p. 35), "uma cidade apertada" e limitada pelos morros do Castelo, de São Bento, de Santo Antônio e da Conceição. E a ocupação de determinadas partes se dava em função do dessecamento de brejos e mangues (idem, ibidem). Por isso, havia necessidade de um grandioso sistema de engenharia para ocupá-la e adaptá-la aos anseios de uma corte transferida do Velho Mundo. Afinal de contas, como bem afirmou Abreu (2014, p. 363), embora "[...] outras cidades coloniais, como Calcutá, Sydney ou Cairo, possam ter tido aspirações imperiais, elas próprias nunca assumiram o papel de metrópoles imperiais".

Quanto às obras e aos planos associados à alteração da morfologia urbana, destaca-se a promoção de saneamento nos pântanos do Rio de Janeiro, em 1648, que foi o aterro da Lagoa do Desterro e dos mangueirais da cidade baixa (Andrade, 1966). No governo de Gomes Freire (1733-1762), foram realizadas muitas obras nos grandes mangueirais da Cidade Nova pelo Marquês de Lavradio, em 1770. Ainda houve o melhoramento do Passeio Público por d. Luiz de Vasconcelos, que limpou praias e aterrou a faixa marítima, como bem afirmou Andrade (1966).

Na cidade de São Paulo, destaca-se o engenheiro Mar. Daniel Pedro Muller, que trabalhava no saneamento das várzeas, fazendo também um levantamento cadastral e uma planta da cidade. Esse engenheiro mostrou, por meio de sua atuação no início da urbanização paulista, a necessidade de se pensar numa legislação apropriada dos quadros administrativos, contando-se com profissionais da área, no intuito de se obterem resultados programados (Andrade, 1966, pp. 114-5).

O fato é que "as velhas e novas cidades brasileiras" estavam, pouco a pouco, deixando de ser transformadas apenas por portadores de diplomas legais pertencentes à metrópole. Lembramos que, para além da Constituição de 1834 e da Lei de $1^{\circ}$ de outubro de 1828 do Regimento das Câmaras Municipais, as posturas municipais exercidas até a República tomavam por base a antiga Ordenação Filipina (Andrade, 1966, p. 115). A vinda da Missão Artística Francesa de 1816, a formação de novos profissionais em escolas primárias e normais de 1835 em diante, a existência de liceus de artes e ofícios depois de 1856, da Academia Imperial de Medicina em 1829 e do Instituto dos Advogados em 1843 (idem, p. 116), tudo isso contribuiu para a formação dos profissionais envolvidos no processo urbanístico brasileiro.

Sérgio Buarque de Hollanda, Nestor Goulart Reis e Maurício de Almeida Abreu, entre outros, assinalam o aspecto aparentemente desleixado e de atraso das cidades brasileiras em suas plantas, mostrando o começo de sua configuração territorial ainda sob o domínio da metrópole portuguesa. Concordamos com Abreu (2014) no sentido de que as cidades brasileiras não são obra do acaso dos portugueses, que não planejavam suas cidades com planos retilíneos e a localização estratégica de determinados elementos, como, por exemplo, uma praça central. Havia uma estratégia geopolítica que reforçava o papel do Estado português que, como aponta Abreu (2014),

[...] teve um papel muito mais importante na organização territorial e urbana da colônia do que aquele que é geralmente admitido. A fundação de núcleos urbanos nas áreas de fronteira com a América Espanhola durante o século XVIII, 
por exemplo, sempre foi explicada pela historiografia brasileira como evidência da adoção de critérios nitidamente geopolíticos na orientação do processo de ocupação do território (pp. 234-5).

Nélson da Nóbrega Fernandes (2008) afirma que as críticas às cidades brasileiras faziam referência a falta de planejamento, desleixo e formação espontânea, graças à nossa herança portuguesa, algo semelhante ao urbanismo islâmico e medieval. No entanto, não faltam evidências da existência de cidades planejadas com plantas que mostram ruas de traçado retilíneo, com praças e uma setorização quanto à localização de cemitérios e igrejas, bem como em relação à moradia de determinadas classes sociais. No entanto, esses não são os únicos fatores que nos permitem entender e considerar uma cidade como planejada. Devemos atentar também para as lógicas distintas e para as estratégias de expressão espacial de cada cidade. Assim, de acordo com Fernandes (2008),

[...] Procurava-se estabelecer padrões de comportamento mais disciplinados, somados à apreciação estética centrada no conceito da perspectiva oriunda do Renascimento Italiano, que exigia uma arrumação dos objetos arquitetônicos e urbanos de modo que se apresentassem diante do observador expondo a lógica do mundo vigente. A paisagem construída exercia, assim, uma função pedagógica, afirmando na frente de todos os princípios esclarecidos e vigilantes do Estado policial. A avenida permitia tanto a contemplação do palácio como o espetáculo das paradas militares ou o rápido deslocamento das tropas em situações de distúrbio. As praças retangulares foram delimitadas por uma sequência de fachadas que repetiam o mesmo estilo arquitetônico, criando um espaço fechado e simétrico quando visto de qualquer de seus ângulos, como se registra em casos das praças reais de Madri e Paris. Ao contrário da cidade medieval, cuja morfologia heterogênea, complicada e surpreendente exige uma compreensão lenta através de suas diferentes perspectivas, para o ideal do urbanismo barroco a cidade deve aparecer e ser vista de um só golpe.

Qualquer que tenha sido a estratégia das cidades de colonização hispânica e colonização portuguesa, não devemos comparar seus traçados urbanos, que nos impóem duas realidades em que o Poder Imperial se fazia presente no urbano. $\mathrm{O}$ traçado irregular, as ruas tortuosas e as áreas edificadas em relevos acidentados de cidades como o Rio de Janeiro nos mostram uma imagem facilmente associada ao que Abreu (2014, p. 240) denominou como "soluçóes provisórias", que eram adotadas pela iniciativa local das câmaras municipais na longa espera pelas decisóes da Coroa.

O processo urbanístico praticado a partir da chegada da Família Imperial Portuguesa ao Brasil se dava em torno de duas correntes de pensamento urbano, que, segundo Abreu (2014, pp. 241-2), eram o "pensamento dos engenheiros militares" e o "pensamento higienista", os quais estiveram presentes nas intervenções do espaço urbano e perduraram por boa parte do Brasil oitocentista. Ainda segundo Abreu, o primeiro pensamento tinha a cidade como um espaço a ser defendido, vigiado e controlado pela polícia. O segundo, por sua vez, também defendia a necessidade de controle, focando-se ainda na preservação da população pelo Estado com a adoção de medidas médicas. $\mathrm{O}$ pensa- 


\section{Urbanismo imperial e planejamento dos barões}

mento higienista chegou ao Brasil com a vinda da Família Imperial Portuguesa. Abreu explica bem o contexto no qual esse pensamente se insere (2014, pp. 242-3).

A deterioração da qualidade de vida de grande parte da população europeia, a partir da Revolução Industrial, veio reforçar bastante o pensamento higienista. Tentando dar uma resposta às epidemias que assolavam as grandes cidades, os médicos não hesitaram em associá-las a diversos elementos do quadro natural circundante, que seriam os principais causadores das doenças. Entre os grandes vilōes do meio ambiente, destacavam-se os pântanos, elo de ligação entre as "entranhas da Terra" e a "atmosfera", os quais, sendo locais de putrefação de matéria orgânica, acabavam por produzir uma série de "vapores" prejudiciais à saúde, que seriam depois disseminados pelos ventos para outros locais. Esses vapores, chamados de miasmas, eram os verdadeiros causadores das epidemias, mas sua ação patológica era também facilitada pelas péssimas condiçōes de higiene verificadas nas cidades.

Segundo Andrade (1966), a realização de grandes obras de saneamento nas cidades brasileiras, com o intuito de também conter os surtos de febre amarela e cólera, e de combater a insalubridade urbana, contou com figuras como Francisco de Paula Cândido, presidente da Junta Central de Higiene Pública de 1851 a 1863. Cândido foi responsável por recomendar a fundação de hospitais de isolamento e a construção de cemitérios públicos. Destacam-se ainda os médicos Joaquim Antônio de Medeiros, Francisco Lopes de Oliveira Araújo, Luiz de Oliveira Bueno e Alfredo de Sá Pereira, que trabalharam nos campos da climatologia e da topografia entre os anos de 1815 e 1880 (Andrade, 1966). Em 1849, a Comissão de Higiente Pública da Província de Pernambuco publicou importantes trabalhos a respeito da salubridade em Recife.

Nesse contexto, observa-se que essas duas correntes do pensamento urbano compuseram a essência do processo urbanístico no Brasil, que pode ser vista pelo traçado irregular das cidades, pelas já mencionadas "soluções provisórias" e pela realização das obras públicas de saneamento. Também devemos considerar a construção de residências para o monarca e sua corte, que, ao lado da imposição de novos códigos sociais e do intenso investimento na infraestrutura da cidade, compôs aquilo que denominamos urbanismo imperial e planejamento dos baróes (Fridman, 2009). Esse quadro nos ajuda a definir o que, com a chegada da Coroa portuguesa ao Brasil, em um primeiro momento, representou o processo urbanístico brasileiro.

Urbanismo imperial e planejamento dos barôes são expressões utilizadas por Fridman (idem, p. 140) que se referem aos programas de intervenção observados na morfologia urbana e nas políticas de gestão do território nos estudos de caso da Cidade Nova e da Fazenda Santa Cruz.

Entendida no contexto do urbanismo imperial, para Fridman (idem, p. 143), a Cidade Nova,

[...] erigida depois da chegada da família real, não seria um espraiamento do tecido urbano. As açóes naquele território refletiam o desejo de se implantarem hábitos civilizados e firmar o centro de poder da capital do império português através de uma nova imagem que se intentava imprimir em contraposição à cidade velha. Pode-se interpretá-la ainda como uma resposta à urbe sitiada pela subcidade africana que era o Valongo. Ou seja, no novo sítio nasceu uma nova cidade, fruto 
da autonomia econômica dos ricos, que necessitavam de espaço para a sua vida semiurbana com sabor rural, com senzala, chiqueiro, estrebaria, cocheira, horta, pomar e viveiro. Também originada pela difícil comunicação com os engenhos e fazendas, foi retrato da concepção iluminista do projeto político liberal.

O urbanismo imperial estava atrelado à corrente urbana do higienismo com um traçado regular e também deveria reafirmar o poder da metrópole inaugurando os novos hábitos e costumes de um novo modo de vida urbano que deveria instaurar a civilização na colônia. De acordo com Fridman, a Cidade Nova foi um antigo caminho semirrural que ligava o Palácio da Quinta da Boa Vista ao Paço da Cidade. Esse antigo caminho foi adaptado para a passagem de carruagens, chamando-se "Aterrado" ou "Caminho das Lanternas", sendo, posteriormente, transformado nas ruas de São Pedro da Cidade Nova e Senador Eusébio.

Fridman (2009) também afirma que a aparência fétida da cidade, com seus pântanos e brejos, além da presença de escravos, levou o rei a promover obras para desinfetá-la, de modo a ter maior visibilidade para as chácaras que se situavam nos arredores.

[...] Com os charcos dessecados, a edificação de solares e a estruturação da nova sede política abrigando as repartições governamentais, o entorno do Campo de Santana tornou-se nobre, modificando-se sua composição socioeconômica e consolidando-se a ocupação da região, que passou a denominar-se Cidade Nova (p. 142).

Portanto, o urbanismo imperial estava atrelado ao projeto de civilização da colônia, buscando caminhos para uma reflexão urbana higienista. A Cidade Nova, portanto, é apenas um dos muitos exemplos dessa prática.

Em relação ao planejamento dos barôes, relacionado à Fazenda de Santa Cruz, Fridman (2009) cita a distribuição de sesmarias entre determinados segmentos sociais, o que acabou por dar origem a essa propriedade, que, no passado, pertencia aos jesuítas. A Fazenda de Santa Cruz foi a terceira residência dos imperadores, sucedida pelo Palácio Imperial de Petrópolis. A primeira havia sido o Paço da Cidade e a segunda, o Palácio da Quinta da Boa Vista (Lacombe, 2007).

À exceção do Paço da Cidade, os outros palácios serviram para a prática da vilegiatura dos imperadores. A vilegiatura, segundo Ambrozio (2005), deriva de villla, que seria a casa italiana de campo, a villa do ócio dos romanos. Segundo Fridman (2009), as villas de recreio nos arredores da cidade serviam para os ricos, sem saírem da cidade, desfrutarem de contato direto com a natureza.

Nesse sentido, o urbanismo imperial e o planejamento dos barôes não devem ser vistos separadamente, como se fossem dois processos espaciais distantes, pois, juntos, configuraram, em sua morfologia e na lógica de produção do espaço urbano, a gênese do processo urbanístico brasileiro. Em outras palavras, Fridman (2009, p. 148) considera que o urbanismo imperial consolidou a Cidade Nova segundo os moldes higienistas e que a Fazenda de Santa Cruz foi pensada de acordo com a lógica do planejamento dos barōes, criando-se uma povoação que funcionaria como um núcleo para trabalhar com manufatura. 
Assinala-se que a construção de palácios para a prática da vilegiatura dos imperadores e os investimentos em infraestrutura urbana conforme os moldes higienistas não ficariam restritos aos limites da cidade do Rio de Janeiro, acompanhando a descoberta de novos caminhos para a subsequente implantação do projeto de civilização.

\section{Novos caminhos e uma cidade-palácio: a ocupação da região serrana fluminense e o processo urbanístico da cidade de Petrópolis (RJ)}

Segundo Silva (2000), a colonização da região serrana se deu a partir do século XVIII, com a finalidade de se buscar um caminho mais seguro em direção ao porto do Rio de Janeiro e às novas rotas para as Minas Gerais. Isso porque havia apenas um caminho de comunicação, conhecido como "Caminho Velho", que seguia pelos sertôes do Rio de Janeiro até a regiāo do ouro em Minas Gerais.

Em 1699, o capitão-mor Garcia Rodrigues Pais finalizou as obras do "Caminho Novo”, o qual, embora proporcionasse economia de tempo para se chegar às minas, somente ganhou importância no cultivo do café e do algodão na província mineira. $\mathrm{O}$ atalho do Caminho Novo, que veio a ser o Caminho Real das Minas Gerais, ou Caminho da Estrela, foi aquele aberto pelo sargento-mor Bernardo Soares de Proença, que percorria o vale do rio Piabanha em direção ao porto da Estrela, no rio Inhomirim, no fundo da Baía de Guanabara. Esse caminho encurtava ainda mais a viagem, com a vantagem de estar num terreno menos acidentado (Silva, 2000).

A abertura do atalho do Caminho Novo, que levou à descoberta das terras que viriam a ser a cidade de Petrópolis, fez com que surgissem sesmarias em todo o seu percurso, no vale do rio Piabanha e em seus afluentes. Ao todo, foram oito sesmarias, que corresponderiam à área atual da cidade de Petrópolis. O grande incentivador da ocupação dessa localidade, como já assinalado, foi o sargento-mor Bernardo Soares de Proença, que influenciou amigos e parentes a se fixarem naquele local, a fim de fortalecer uma rede social no domínio e na conquista dessas terras.

As oito sesmarias que correspondem à cidade de Petrópolis, incluindo todos os seus distritos e São José do Vale do Rio Preto (Silva, 2000), eram medidas por quadras. Essas quadras eram a "Quadra das Pedras"; a "Quadra de Araras"; a "Quadra do Rio Morto", de onde surgiu a Fazenda do Padre Correia, a mais importante fazenda da região de "serra acima”; a "Quadra da Paciência"; a "Quadra do Alcobaça", de onde surgiram a Fazenda da Samambaia e a Capela de Nossa Senhora da Conceição, pertencente ao sobrinho do Padre Correia, Luiz Gonçalvez Dias Correia; e a "Quadra do Rio Preto", o que vem a ser o município de São José do Vale do Rio Preto, antigo quinto distrito de Petrópolis.

A “Quadra de Itamarati”, pertencente ao primeiro sesmeiro da região, Bernardo Soares de Proença, localizada no vale do rio Itamarati, afluente do Piabanha, corresponde ao que conhecemos hoje como o centro urbano de Petrópolis. Vários sítios e fazendas se originaram dessa sesmaria, como a Fazenda do Córrego Seco e a Fazenda do Itamarati (Silva, 2000). A Fazenda do Córrego Seco era um local de pernoite para os viajantes. O Padre Correia, proprietário da fazenda, era um dos principais lavradores de sua época que mantinham comércio com a capital. 
O palácio de D. Pedro I teve sua construção idealizada na Fazenda do Córrego Seco, situada na Serra da Estrela, na rota de Minas Gerais, que Montalvão (2005) também recuperou em seu trabalho. Essa seria a localidade precisa para receber a construção de um palácio. Nesse mesmo cenário de descobrimentos e aforamentos de diversas terras, e da abertura de novas rotas para o caminho até Minas Gerais, uma malha administrativa foi configurada, e novos arranjos espaciais foram surgindo.

O certo é que Córrego Seco, antes de ser município de Petrópolis, pertencera a Magé, Cantagallo, Parahyba do Sul e Estrella (Lacombe, s.d., p. 73). O município de Cantagallo fora criado por uma lei de 9 de março de 1814, tendo seu arraial e o distrito das Novas Minas de Cantagallo promovidos a vila, a Villa de S. Pedro de Cantagallo.

Com a criação da Villa de Parahyba do Sul, em 1833, foram incorporados ao seu território a freguesia de S. José do Rio Preto e o Córrego Seco. A Lei n. 397, de 20 de maio de 1846, contudo, alterou esse território, criando mais uma freguesia, São Pedro de Alcântara, que se separou da freguesia de São José do Rio Preto, a qual, por sua vez, passou a pertencer à Villa da Estrella, tendo o cônego Luiz Gonçalves Dias Corrêa como vigário e proprietário da Fazenda da Samambaia.

Seguindo com a história de seu território administrativo, foi em 1857 , por meio da Lei n. 961, que Petrópolis se tornou município, passando a ostentar o título de cidade sem ter sido vila. Á época, Petrópolis era formada por somente dois distritos e, somente durante a República, houve a anexação de outros distritos (Lacombe, s.d).

Retomando o cenário de abertura dos novos caminhos que conduziriam às minas e à busca de novos refúgios da febre amarela, a Fazenda do Padre Correia acabou por servir de objeto de desejo de D. Pedro I em suas andanças e exploraçôes. Logo, ele e sua família se tornaram frequentadores assíduos da fazenda, em virtude do clima agradável, com vistas ao bem da saúde de sua filha, a princesa Paula. Como era de se esperar, o imperador tentou comprar a propriedade. No entanto, a proprietária, d. Arcângela Joaquina da Silva, irmã do Padre Correia, não cedeu à proposta do imperador, alegando que a propriedade estava carregada de vínculo familiar.

Assim, D. Pedro I, por indicação de d. Arcângela Joaquina, comprou as terras vizinhas, que pertenciam à Fazenda do Córrego Seco, adquirindo mais tarde, em 1830, um terreno que pertencia a Correia e também um sítio contíguo ao Córrego Seco, propriedade de Vicente Ferreira e Cunha (Silva, 2000). No entanto, os planos de D. Pedro I não se realizaram. A situação política de Portugal se apresentava muito instável e D. Pedro I foi obrigado a abdicar do poder no Brasil. A fazenda adquirida nunca foi vendida, pois ele mesmo se encarregou de hipotecá-la, fazendo com que fosse arrendada. Daí em diante, ela passou de arrendatário a arrendatário, por não contar com terras férteis e produtivas (Lacombe, 2007).

Não tendo a Casa Imperial condições para realizar o levantamento da hipoteca do falecido imperador, a situação foi levada à Assembleia Geral, sendo incluída, na Lei n. 108, de 26 de maio de 1840, uma autorização para o governo brasileiro arcar com a despesa de até 14 mil réis para comprar a Fazenda do Córrego Seco, a fim de não perdê-la para os credores de D. Pedro I (Lacombe, 2007). Assim, recuperada a Fazenda do Córrego Seco, foi dada a largada para a administração da propriedade. A Casa Imperial, coordenada pelo então mordomo-mor, 
Paulo Barbosa, tinha a obrigação de administrar os palácios do imperador. Em 1843, através do Decreto-lei n. 155, de 16 de março, D. Pedro II concedeu ao major Frederico Koeler o arrendamento da fazenda, sob a condição de que construísse um palácio, uma igreja e uma colônia de povoamento (Fridman, 2001). Foi nesse momento que se deu a fundação da cidade de Petrópolis.

São três os personagens considerados importantes na fundação da cidade de Petrópolis, como nos mostra Lacombe (s.d.): o mordomo Paulo Barbosa da Silva, o major Frederico Koeler e o visconde de Sepetiba. Por ter sido um projeto de cidade que envolveria uma colônia de povoamento e a construção de um palácio, Petrópolis ganhou duas administrações: a Superintendência da Fazenda Imperial, submissa ao mordomo, e a Diretoria da Colônia de Petrópolis, submissa ao presidente da província. Ambos os cargos eram ocupados pelo major Koeler, que esteve diretamente ligado ao projeto de colonização de imigrantes alemães em Petrópolis, com vistas à substituição gradativa da mão de obra escrava negra por mão de obra livre branca.

Nesse sentido, segundo Lacombe (s.d.), não foi a chegada dos colonos alemães em 29 de junho de 1845 a responsável pela fundação da cidade de Petrópolis, e sim o projeto de construção da cidade-palácio, que permitiu a vinda de mais brancos para aquele povoamento. Encarregado de conduzir um projeto de tão grande porte, Koeler, como arrendatário da Fazenda do Córrego Seco, apenas deu prosseguimento à prática do projeto de colonização de D. Pedro II, porém em outra localidade.

A construção do Palácio de Verão de Petrópolis começou em 1843, sendo concluída em 1856. Sua construção foi iniciada por Koeler e, em seguida, passou para as mãos dos arquitetos Joaquim Cândido Guilhobel e José Maria Jacinto Rebelo. A decoração interna ficou a cargo do Araújo Porto Alegre. Sua construção contou com os grandes nomes da Academia Imperial de Belas-Artes (Montalvão, 2005). Nessa época, além do próprio palácio, havia a Casa da Cozinha, a Dispensa, a Casa do Arquivo e a Casa da Superintendência, além da Casa dos Semanários - todas situadas nos fundos do palácio. Essas edificações serviam para a administração e o abastecimento do palácio, enquanto a Casa dos Semanários funcionava como dormitório para os trabalhadores.

O jardim do palácio foi projetado pelo botânico Jean Baptiste Binot e abrigava uma mescla de árvores de espécies nacionais e exóticas. Havia fontes de água e viveiros de aves raras estrangeiras para a apreciação particular do imperador (Montalvão, 2005). Na imagem a seguir, é possível visualizar o palácio e seu jardim. 
Figura 1. Vista da frente do Palácio Imperial e do jardim, com uma ponte sobre o rio Quitandinha em Petrópolis.

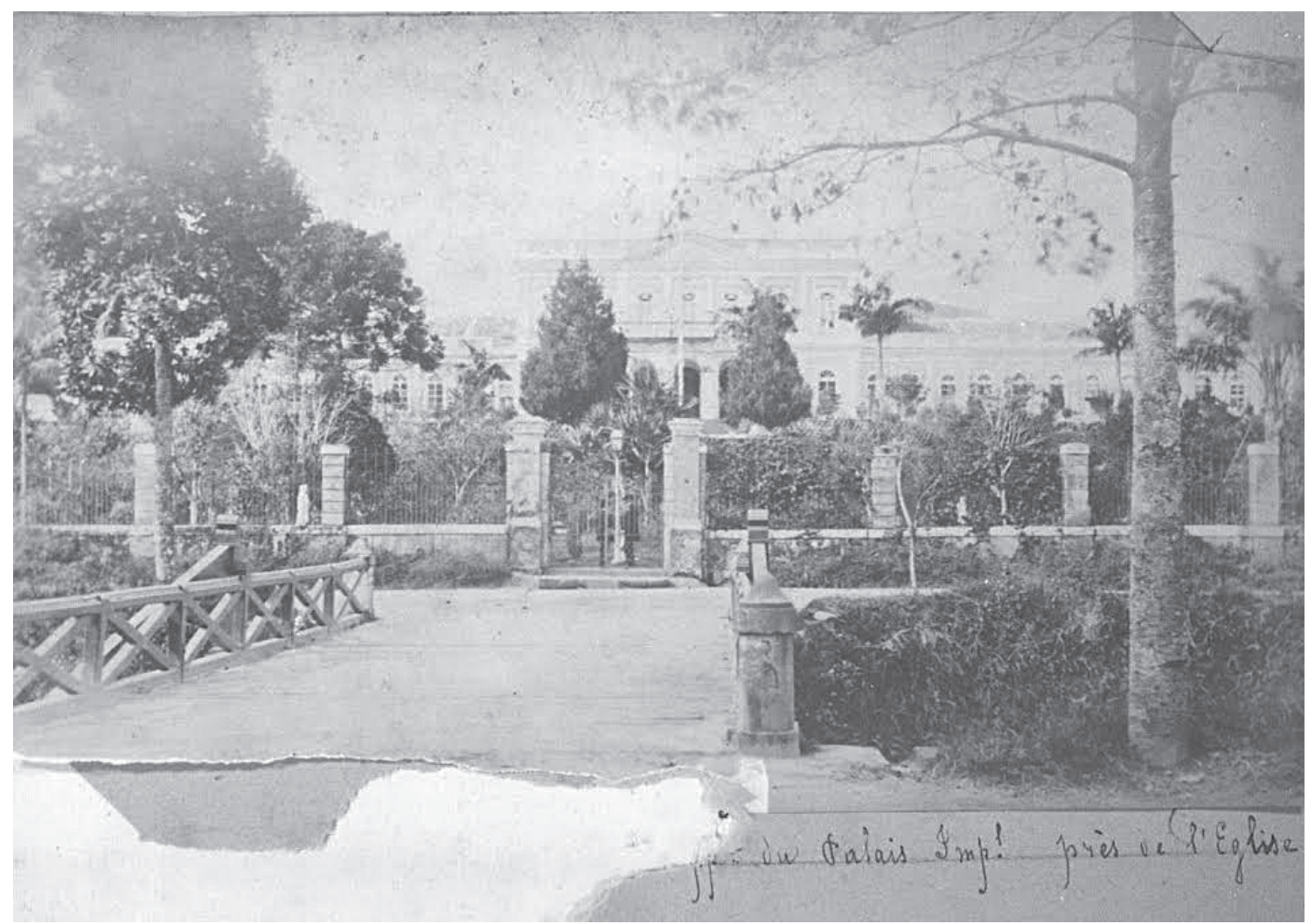

Fonte: Cópia concedida pelo Museu Imperial de Petrópolis para este trabalho. Requerimento de Autorização n. 17/2014, em 10/03/2014.

$\mathrm{Na}$ cidade de Petrópolis havia uma atmosfera de tranquilidade e prazer que permitia longos passeios pelos jardins, entre árvores exóticas. Quando lá estava, o imperador se hospedava em um de seus cômodos preferidos e bebia água da fonte. No entanto, por trás dessa atividade de veraneio, havia um projeto de cidade, um projeto de vida urbana. O palácio e seu jardim não serviram apenas como adereços ornamentais para o imperador; por trás desse projeto, eram irradiados os novos hábitos de uma prática social vinculada à vilegiatura.

Entendida em sua totalidade, Petrópolis era um espaço suburbano produzido pela vilegiatura e concebido como uma obra de arte (Ambrozio, 2005) - uma obra de arte da civilização. Assim, a fundação da cidade de Petrópolis integra o contexto de ocupação do interior fluminense, justificada pela busca do ouro e pela prática da vilegiatura. Lembramos que essa ocupação do interior se deu por meio do sistema de sesmarias, servindo como um dos novos caminhos para a exploração do ouro das Gerais. E, por ser uma cidade planificada, cujo polo central veio a ser a residência do imperador, o quarteirão da Vila Imperial - onde estavam o Palácio do Imperador e os demais equipamentos 


\section{Urbanismo imperial e planejamento dos barões}

coletivos - não deixa de evidenciar uma característica tão cara a esse momento inicial de ocupação e fundação de uma cidade-palácio, que vem a ser o processo de valorização do espaço na formação territorial brasileira. Um espaço valorizado em decorrência da produção do subúrbio vinculado à prática da vilegiatura e da recreação.

Nesse sentido, ao ser fundada, a cidade de Petrópolis tinha, em sua organização espacial, os ideais da corrente do higienismo e uma clara segregação socioespacial, vista pelo local de residência dos moradores de Petrópolis, que estava condicionado ao ofício e ao poder aquisitivo. O poder aquisitivo era o último fator determinante para o potencial de pagamento dos foros estabelecidos, além de forte indicador da posição a ser ocupada na escala social pelo respectivo residente. As residências mais próximas do palácio do imperador eram consideradas as áreas mais valorizadas e, portanto, pertenciam aos nobres mais prestigiados. Assim, seguindo uma ordem decrescente, os pobres ficavam mais afastados do palácio do imperador e de sua corte na organização do espaço interno da cidade de Petrópolis. O quarteirão da Vila Imperial era o ponto de destaque para a formação da cidade, e nesse local as classes socialmente menos abastadas não tinham vez.

Com ruas retilíneas, zonas especializadas segundo as profissóes de seus residentes e muitas praças para a circulação do ar, sem dúvida estamos falando de uma cidade planejada de acordo com os moldes da política higienista e preventiva. Referimo-nos aqui a uma segregação socioespacial promovida por um projeto de cidade-palácio cuja residência de um soberano acabou se revelando o ponto central para o ordenamento das classes sociais naquele espaço (Silva, 2000). Em virtude da possibilidade de as pessoas estarem mais próximas de D. Pedro II, com vistas à aquisição de algum privilégio político ou de receber investimentos em infraestrutura, como, por exemplo, a implantação de uma estrada de ferro pelo barão de Mauá, a cidade de Petrópolis se tornou um local de grande representatividade para figuras importantes do cenário político do Império.

A importância política de Petrópolis, devido à presença do imperador e de sua corte, fez com que seu tecido urbano se expandisse, com a construção de palacetes de propriedade de diplomatas e de figuras políticas do Império. Em alguns casos, as segundas residências foram transformadas em primeiras e, juntamente com essa expansão do tecido urbano, contribuíram também novos equipamentos urbanos instalados para atender às demandas da nova classe social (Schwarcz, 1998).

Desse modo, o tecido urbano petropolitano encheu-se de brilhantismo e pompa. Sua elegância e civilidade revelavam-se nos saraus, festas, bailes, teatros, concertos e conferências. Petrópolis unia uma vida bucólica e distante da cidade grande a uma vida social associada ao imperador (Schwarcz, 1998). A cidade também acolheu eventos sociais de corridas de cavalos, sediados no Jockey Clube de Petrópolis (1857); no Hipódromo de Petrópolis, localizado em Itaipava; no Prado Vila Teresa e no Delby Club, situados em Corrêas.

Para tornar Petrópolis uma cidade ainda mais requintada e moderna, foi construído, a mando da princesa Isabel, um Palácio de Cristal, para a realização de exposições de horticultura e também para sediar a primeira Exposição Universal, em 1851. A vida na cidade era repleta de costumes e hábitos palacianos, de tal modo que "Petrópolis representava, portanto, uma outra corte: repleta das atividades sociais, mas onde a distância do rei era atenuada por seu dia a dia um pouco menos marcado por uma agenda de compromissos e rituais oficiais" (Schwarcz, 1998, p. 244). 
No entanto, todo esse clima de civilização e recreação não duraria para sempre na Cidade de Pedro. A proclamação da República instauraria um novo regime na Cidade de Pedro, exilaria o último imperador das Américas e toda a sua família, e acabaria com nomes de ruas, símbolos e tudo o que remetesse ao ideário da Monarquia. Títulos de nobreza foram anulados, enquanto o imperador e sua família, desprovidos de todos os seus privilégios, eram sustentados por alguns amigos num país estrangeiro. Um monarca que tanto viajara pelo exterior com sua família, participando de exposições universais para promover sua pátria, já não se encontrava mais em casa. Contudo, o declínio da Monarquia no Brasil não enfraqueceu a cidade de Petrópolis, mantendo o status de cidade de veraneio para as figuras políticas importantes da República, que ainda se encantavam com o estilo de vida e os códigos sociais da Família Imperial Portuguesa (Montalvão, 2005).

As fases seguintes da República, do Estado Novo até o período de abertura democrática no Brasil, nos mostram Petrópolis como uma cidade que, em suas decadências e auges de determinadas atividades produtivas, como, por exemplo, a indústria e o turismo, sempre vai procurar construir e manter a grande marca de Cidade Imperial, fazendo com que, em seus planos diretores municipais e de revitalização, a Família Imperial Portuguesa e o modo de vida urbano instaurado se façam permanentemente presentes no imaginário popular.

Assim, o urbanismo imperial e o planejamento de barões, com seus respectivos ideais - o primeiro voltado ao higienismo e o segundo, à instalação da prática da vilegiatura -, estiveram muito presentes no contexto de ocupação da Região Serrana e da fundação da cidade de Petrópolis, que, nos sucessivos regimes políticos brasileiros, ainda manteve, por meio de uma política de preservação do patrimônio histórico e artístico nacional e de seus planos de revitalização do centro histórico, marcas das origens do processo urbanístico que se desenvolvia no país.

\section{Considerações finais}

Os pensamentos dos engenheiros militares e dos higienistas congregaram as muitas transformações na infraestrutura de várias cidades brasileiras, principalmente na cidade do Rio de Janeiro, que recebeu e irradiou muitas influências.

A chegada da Família Imperial Portuguesa ao Brasil representou as origens de um pensamento urbanístico brasileiro ainda em formação. A cidade do Rio de Janeiro, por sua vez, estava completamente aberta a receber essas ideias e técnicas avançadas. Assim, no desbravamento de novas rotas para o caminho do ouro e na fuga das epidemias que assolavam a cidade do Rio, surgiu a cidade de Petrópolis.

A Cidade de Pedro, ou Cidade-Palácio, para além de um projeto de colonização e de uma cidade pensada segundo os moldes higienistas para abrigar a corte e seu imperador em veraneio, foi uma cidade pensada e fundada, dando continuidade às bases do processo urbanístico que amadurecia no Brasil, na descoberta e na abertura de novos caminhos da Região Serrana fluminense. 
O urbanismo imperial e o planejamento dos barões se fundiam na cidade planificada de Petrópolis. Portanto, resgatar as bases de nosso processo urbanístico implica pensar as bases materiais de estratificação social segundo as quais nossas cidades se formaram e contribuir para o avanço das discussōes do pensamento urbanístico, recuperando, no tempo e no espaço, os vários pensamentos responsáveis à sua consolidação.

\section{Referências}

ABREU, Maurício de Almeida. A evolução urbana do Rio de Janeiro. Rio de Janeiro: Iplan-Rio, 1997. __. "Paradoxos da modernidade: o Rio de Janeiro do período joanino, 1808-1821". In FRIDMAN, F. e HAESBAERT, R. (orgs.). Escritos sobre espaço e história. Rio de Janeiro: Garamond, 2014, pp. 359-98.

—_. "Pensando o Brasil do passado". In FRIDMAN, F. e HAESBAERT, R. (orgs.). Escritos sobre espaço e história. Rio de Janeiro: Garamond, 2014, pp. 231-63.

AMBROZIO, Júlio César Gabrich. O presente e o passado no processo urbano da cidade de Petrópolis: uma história territorial (tese). USP, 2008.

ANDRADE, Francisco de Paula Dias. Subsídios para o estudo da influência da legislação na ordenaçãa e na arquitetura das cidades brasileiras (tese). USP, 1966.

FERNANDES, Nélson da Nóbrega. "Capitalismo e morfologia urbana na longa duração: Rio de Janeiro (século XVIII-XXI)". Diez años de cambios en el Mundo, en la Geografía y en las Ciencias Sociales, 1999-2008. 26-30 de mayo de 2008. Actas del X Coloquio Internacional de Geocritica, Universidad de Barcelona. Disponível em: http://www.ub.es/geocrit/-xcol/144.htm.

FRIDMAN, Fania. "De núcleos coloniais a vilas e cidades: Nova Friburgo e Petrópolis". Disponível em: http://www.anpur.org.br/revista/rbeur/index.php/anais/article/view/2187. Acesso em: 14 mar. 2014.

_. "Uma cidade nova no Rio de Janeiro". Encontro da Associação Nacional de Pós-Graduação e Pesquisa em Planejamento Urbano e Regional, 13, 25 a 29 de maio de 2009, Florianópolis. Disponível em: http://linux.an.gov.br/seer/index.php/info/article/view/73/56. Acesso em: 15 set. 2014.

LACOMBE, Américo Jacobina. "Paulo Barbosa e a Fundação de Petrópolis". Centenário de Petrópolis. Trabalhos da Comissão. Petrópolis, s.d., v. II.

LACOMBE, Lourenço Luiz. Biografia de um palácio. Petrópolis: Museu Imperial, 2007.

MONTALVÃO, Claudia Soares de Azevedo. Do Paço ao Museu: o Museu Imperial e a instituição da memória da monarquia brasileira (1940-1967) (tese). UFRJ, 2005.

SCHWARCZ, Lilia Moritz. As barbas do imperador: D. Pedro II, um monarca nos trópicos. São Paulo: Companhia das Letras, 1998, p. 239.

SILVA, Agnaldo Goivinho da. Petrópolis: idealismo e inovaçôes na gênese de uma cidade no Brasil-Império (dissertação). UFRJ, 2000. 


\title{
A espetacularização do lazer em Volta Redonda: os investimentos esportivos ${ }^{1}$
}

\author{
Fábio Salgado Araújo ${ }^{2}$
}

\section{Introdução}

$\mathrm{N}$ as duas últimas décadas, a cidade de Volta Redonda passou por grandes transformações com a privatização da Companhia Siderúrgica Nacional (CSN), ocorrida em 1993. Com isso, houve o afastamento definitivo da CSN do fomento de políticas sociais e dos investimentos em melhorias urbanas, o que levou a prefeitura a assumir maior responsabilidade em relação aos problemas vivenciados pelo município, efetuando intervençōes mais diretas sobre o espaço urbano. Portanto, o poder público municipal estabeleceu um conjunto de políticas e aumentou os investimentos nas áreas de saúde, educação, esporte e lazer.

O objetivo é dinamizar a economia pós-privatização, por meio de investimentos na infraestrutura urbana do município e em políticas sociais. Houve investimentos na construção/recuperação de praças, viadutos, avenidas, monumentos etc., juntamente com os investimentos sociais em saúde, educação, cultura, esporte e lazer; a prefeitura procura descolar a imagem da cidade vinculada à CSN para uma cidade baseada em qualidade de vida, bem-estar e cidadania.

Assim, atualmente o Poder Público municipal procura alterar a imagem da cidade vinculada à empresa (cidade do aço) para a de uma cidade tida como moderna. Busca, assim - através de uma gestão considerada inovadora e do city marketing -, criar uma imagem associada ao bem-estar social e à cidadania, com a realização de investimento em diversas áreas sociais. Entre esses investimentos

${ }^{1}$ Este texto é parte da dissertação intitulada "As transformaçôes do lazer em Volta Redonda-RJ: dos clubes sociorrecreativos vinculados à CSN aos novos investimentos esportivos da Prefeitura”, apresentada ao Programa de Pós-Graduação em Geografia da UERJ, em agosto de 2013, orientada pelo Prof. Dr. Miguel Angelo Campos Ribeiro.

2 Mestre e doutorando em Geografia pelo Programa de Pós-Graduação em Geografia do Instituto de Geografia - Universidade do Estado do Rio de Janeiro (UERJ). 
sociais, destacam-se aqueles associados ao lazer, principalmente os esportivos, com a prefeitura ressaltando seus benefícios para a qualidade de vida da população.

Essa nova orientação da política urbana tem por objetivo promover a cidade e atrair novos investidores, na tentativa de fortalecer a centralidade regional na área de comércio e prestação de serviços. No entanto, os investimentos em lazer, principalmente aqueles ligados aos esportes, apesar dos benefícios que apresentam, precisam ser questionados.

$\mathrm{Na}$ atualidade, o lazer se inscreve no modelo capitalista de produção, sendo utilizado pelo poder público municipal, como já assinalado, para produzir a imagem de uma cidade com boa qualidade de vida. Desse modo, há um lazer espetacularizado, em que a população vive em um simulacro cooptado pelo discurso do poder público municipal.

\section{Volta Redonda: uma cidade em transformação}

O município de Volta Redonda (Figura 1), localizado na região de governo denominada Médio Paraíba, pertence à microrregião do Vale do Paraíba, pertencente à mesorregião Sul Fluminense. Essa região é cortada pelo rio Paraíba do Sul, responsável por seu nome, devido a um acidente geográfico em seu curso.

Figura 1. Mapa com a localização de Volta Redonda (RJ)

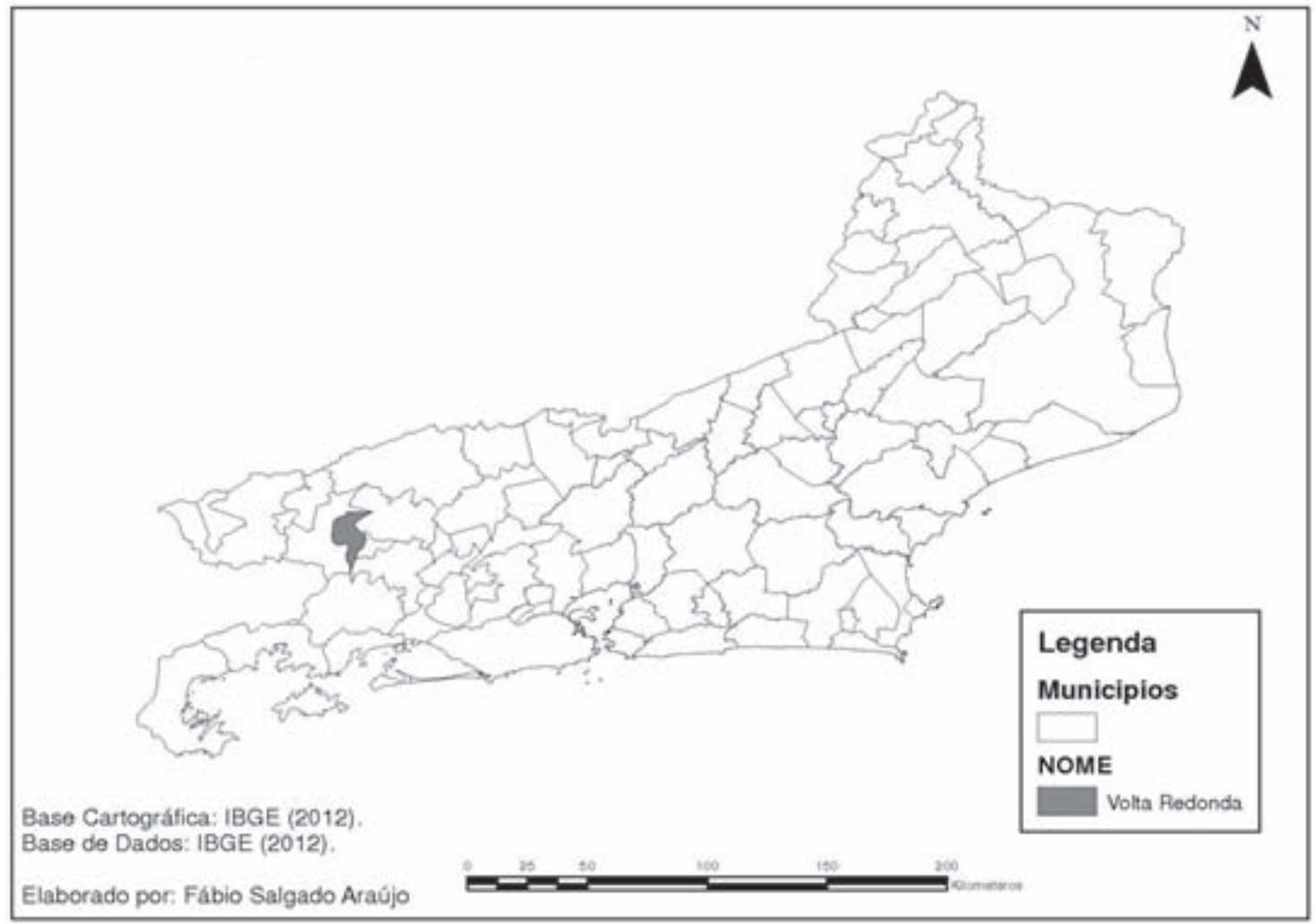

Fonte: Elaborado pelo autor (2012). 
A história do município começou no século XVIII, com a colonização do médio Vale do Paraíba fluminense ligado ao ciclo do café. Entretanto, com a escolha do local para a instalação da Companhia Siderúrgica Nacional (CSN) na década de 1940, grandes mudanças estavam por vir.

A cidade, juntamente com a siderúrgica, foi planejada a partir do modelo de cidade industrial idealizado pelo arquiteto socialista-utópico francês Tony Garnier. Esse modelo foi adaptado pelo também arquiteto Attílio Corrêa Lima, ligado ao autoritarismo populista de Getulio Vargas. O objetivo era transformar Volta Redonda numa cidade-modelo, uma experiência exemplar, com um planejamento residencial que evidenciasse a hegemonia dos mais graduados na empresa.

De acordo com Lopes (1993), o plano de Volta Redonda deveria contribuir para exaltar o industrialismo, sublinhar a política social do governo e espacializar, através do desenho e do equipamento da cidade, o homem novo que estava sendo construído. A elaboração do plano urbanístico da cidade foi influenciada pelo modelo urbanístico norte-americano, com o zoneamento indicando especialização por área e ordenação dos fluxos, inclusive de áreas e equipamentos destinados ao lazer. Previa-se uma cidade linear, com um desenho simples e equilibrado, e suas principais funçôes bem articuladas. A área central seria ocupada pelo centro comercial, desenvolvendo-se paralelamente à usina e concentrando toda a infraestrutura. A CSN seria um modelo autárquico segundo o qual a empresa utilizaria diversas estratégias para educar, vigiar e controlar o trabalhador dentro e fora da fábrica. A estrutura da vila operária, por sua vez, reproduzia a estrutura disciplinar da usina, com um arranjo espacial que representava essa ordem. Havia, dessa forma, um duplo controle dos trabalhadores, configurando uma verdadeira company-town (Calife, 2000; Moreira, 2000; Fontes e Lamarão, 2006; Piquet, 1998).

O não aproveitamento de todos os trabalhadores que construíram a usina gerou uma desmobilização da mão de obra empregada na construção e, por conseguinte, um crescimento desordenado e desvinculado dos interesses imediatos da empresa. Com isso, na margem esquerda do Rio Paraíba, surgia outra Volta Redonda, ocupada de forma não planejada por pequenos comerciantes e por aquela massa de trabalhadores dispensados da CSN. Os dois núcleos originais de Santo Antônio de Volta Redonda tornaram-se o eixo de ligação entre os bairros planejados e os novos bairros que surgiram nesse processo de crescimento.

Assim, Volta Redonda ficaria dividida em duas: à margem direita do rio, desenvolvia-se o núcleo urbano, a partir do projeto dos bairros operários - a chamada "Cidade Nova" -, e, à margem esquerda, a chamada "Cidade Velha", separada da CSN e sem dispor dos serviços da parte planejada. Assim, os trabalhadores não aproveitados pela CSN foram deslocados para a parte "velha" ou para a periferia da cidade, e os proprietários de algumas fazendas da região se converteram em loteadores e especuladores. Com isso, a cidade conheceu uma considerável expansão da malha urbana (principalmente nas décadas de 1950 e 1960), com a implantação de numerosos loteamentos que deram origem a novos bairros, principalmente na margem esquerda do rio Paraíba do Sul.

Nesse contexto, o processo de ocupação de Volta Redonda gerou uma malha urbana descontínua e rarefeita, com grandes vazios e áreas urbanas enquistadas, subindo os morros e instalando-se em pequenas áreas de baixada. Não apenas as características físicas definiram essa ocupação, como também o fato de as melhores terras estarem nas mãos da CSN e de alguns fazendeiros (Calife,; Moreira, 2000; Fontes e Lamarão, 2006). 
Nas décadas de 1960 e 1970, a CSN começou a reduzir seus encargos com moradias para funcionários, vendendo as casas por meio da criação de uma imobiliária. Também se desfez de seu patrimônio público - ruas, praças, serviços urbanos etc. - e dos encargos decorrentes de sua manutenção, passando-os para a Prefeitura Municipal. Assim, no dia $1^{\circ}$ de janeiro de 1968, a prefeitura municipal e a CSN assinaram um termo de entrega e recebimento dos serviços urbanos, dando início ao processo de unificação do espaço urbano, ao reunir, sob a mesma administração, a cidade operária e a cidade velha. Essa medida, contudo, multiplicou os encargos da administração municipal, que não se encontrava preparada para tanto, passando para a responsabilidade da prefeitura o fornecimento desses serviços. O impacto dessa transferência foi significativo, pois até mesmo a água que abastecia os bairros da cidade planejada era fornecida pela CSN (Costa, 2004).

A crise na década de 1980 e o acúmulo de dívidas da CSN foram fatores que contribuíram para a estagnação econômica do município. As políticas governamentais em nível nacional empreendidas desde o fim da década de 1980 levaram ao processo de privatização da usina em 1993, dando origem à maior crise vivida pelo município em sua história. Com essa privatização, diminuiu a intervenção da siderúrgica diretamente sobre a cidade, com sua retirada da dotação de infraestrutura urbana e o encerramento das políticas sociais empreendidas pela empresa.

A CSN continua a ser importante para o município. No entanto, para enfrentar os graves problemas sociais, ambientais e econômicos que culminaram com a privatização, houve um processo de reestruturação de Volta Redonda. Assim, o poder público municipal tem aumentado a presença e o poder no fomento de políticas públicas e sociais.

O poder público municipal, principalmente a partir de 1997, promoveu alterações na estrutura administrativa da cidade, com novos investimentos procurando desenvolver o setor de comércio e serviços. Houve a construção/reforma de equipamentos e mobiliário urbano, principalmente aqueles ligados a saúde, educação, lazer e esporte. Esses novos investimentos em infraestrutura, equipamentos e mobiliário foram mais concentrados nos bairros centrais, que são áreas contíguas à CSN. Assim, reforçou-se a centralidade de determinados bairros, induzindo o setor privado a fazer investimentos em determinadas áreas, enquanto deixava outras desassistidas.

Nesse contexto, no início deste século, Volta Redonda vive um período de grande transformação, em que o poder público municipal procura substituir a imagem vinculada à empresa (cidade do aço) pela imagem de uma cidade moderna, baseada em outros parâmetros, como, por exemplo, cidadania. Para isso, vem investindo na construção e reforma de equipamentos urbanos para criar uma imagem de progresso e construir um consenso junto à população em torno das intervenções urbanas aplicadas. Procura-se, assim, sugerir à população uma recuperação econômica após a crise vivida pelo município depois da privatização. Esse discurso político tem alto poder de legitimação junto às classes trabalhadoras órfãs do paternalismo da CSN, outrora presente. Por essa razão, testemunham-se investimentos em diversas áreas sociais, com destaque para o lazer, principalmente na área esportiva (Oliveira e Mascarenhas, 2007; Souto, 2007; Palmeira, 2012). 


\title{
3. Os novos investimentos em lazer: a espetacularização dos eventos esportivos
}

As mudanças empreendidas pela CSN na década de 1960 também conduziram a uma diminuição de investimentos por parte da empresa em infraestrutura e investimentos em lazer. Desde o final da década de 1960 e o início da década de 1970, não foram mais criados equipamentos de lazer pela empresa. Com o forte crescimento urbano a partir de 1970, teve início um aumento dos investimentos da prefeitura em equipamentos e atividades de lazer para a população da cidade, principalmente para os moradores não vinculados à siderúrgica.

Entretanto, em Volta Redonda os investimentos em lazer ficaram estagnados durante toda a década de 1980 e parte dos anos 1990, sendo retomados apenas no final da última década do século XX. Nesse momento, então, o lazer aparece, em consonância com a Constituição Federal de 1988, como uma preocupação do Poder Público municipal, integrando a Lei Orgânica Municipal (1990), e posteriormente reafirmado no Plano Diretor (2008). Na Lei Orgânica (1990), o compromisso do poder municipal é expresso da seguinte forma:

\begin{abstract}
O município assegurará o exercício ao direito ao lazer, mediante a oferta de equipamento e de área pública de lazer para fins de recreação, esportes e execução de programas culturais e turísticos. O município proporcionará meios de recreação à comunidade mediante reserva de espaços livres e verdes em forma de parques, bosques e jardins. Os serviços municipais de esportes e recreação articular-se-ão com atividades culturais do município (Lei Orgânica Municipal, 1990, p. 76).
\end{abstract}

Assim, não houve apenas o aumento dos investimentos em infraestrutura e equipamentos de lazer por parte do município; o Poder Público municipal também passou a incentivar e fomentar o lazer de caráter privado, atraindo investimentos como lojas de departamentos, shopping centers, restaurantes, hotéis e bares, aliados a eventos e espetáculos, como shows, concertos, exposições, eventos esportivos, entre outros, direcionando o lazer para o consumo e o espetáculo.

Para Debord (1997), o espetáculo é uma forma de expressão da sociedade, em que a vida real é pobre e fragmentada, e os indivíduos são obrigados a contemplar e a consumir passivamente as imagens de tudo o que lhes falta na existência real. Nesse sentido, o autor aponta que a sociedade se resume a um acúmulo de espetáculos em que as situações e as relações sociais formam uma realidade paralela que serve de objeto de contemplação e ilusão para as pessoas. Foi nesse contexto que se seguiram os investimentos em lazer na pós-privatização. Houve um acúmulo de eventos relacionados ao lazer no município, formando uma realidade paralela de boa qualidade de vida com cidadania que não condiz com a realidade socioespacial urbana.

A sociabilidade no espaço urbano do município se caracteriza por esses eventos, que ocorrem de maneira pontual no tecido urbano e de forma presenteísta. Portanto, o tempo do não trabalho na cidade é marcado por eventos em que os moradores da cidade se identificam cada vez mais com o discurso elaborado pela prefeitura. Assim, para se compreender o lazer na cidade, é necessário também compreender o discurso da prefeitura, alardeado, de forma ostensiva, 
nos outdoors espalhados pela cidade e veiculado nos principais meios de comunicação. Os espetáculos apresentam-se como a própria sociedade. Trata-se de uma relação social, resultado do mundo da produção em que a informação voltada ao entretenimento constitui o modelo de vida socialmente dominante. A prática do lazer, seja no espaço público, seja no privado, ganha uma dimensão cada vez maior na sociedade atual - e isso é o que também ocorre no município de Volta Redonda (Debord, 1997).

É por meio de projetos/programas e eventos que a prefeitura apresenta Volta Redonda como um município com qualidade de vida e cidadania, em que os moradores têm acesso a saúde, educação, habitação e lazer - uma tentativa de recuperar a autoestima da população, afetada pela crise gerada com a privatização. Nesse sentido, há uma espetacularização das atividades de lazer na cidade, com ativa participação da população. Assim, cria-se a imagem de uma cidade com boa qualidade de vida e cidadania, um espaço em que todos têm acesso a lazer de qualidade. Essa imagem é uma abstração do real generalizado, consequência de uma sociedade capitalista em que o espetáculo é a forma mais desenvolvida.

Assim, essa cidade imaginada e presente apenas no discurso do poder público municipal não existe de fato; trata-se de um simulacro (Figura 2), que busca minimizar os problemas sociais e ambientais que a cidade enfrenta, como, por exemplo, destinação final do lixo, tratamento de esgoto, ilhas de calor, falta de áreas verdes na cidade, além de questóes relacionadas a trânsito e especulação imobiliária que geram uma sobrecarga na infraestrutura do município. Entretanto, esse simulacro é mais atraente para o cidadão, agora espectador, do que a realidade urbana em si. Os simulacros representam e ressignificam a simulação, a aparência externa, copiando e imitando a realidade. Por outro lado, esses simulacros dão visibilidade às cenas, excluindo a dimensão da subjetividade e tornando tudo visível e público. Desse modo, a realidade deixou de existir e passa-se a viver a representação da realidade fortemente difundida pela prefeitura (Baudrillard, 1981).

Os investimentos em inúmeros projetos/programas destinados ao lazer (que, além de variados, atendem de crianças a pessoas na terceira idade), passando por centenas de eventos anuais nas áreas cultural e esportiva, o tempo vivido e sua linearidade, tudo isso perde sentido no espaço urbano do município. Um bom exemplo é a quantidade de eventos culturais realizados anualmente na cidade. A Tabela 1 mostra a quantidade, os locais e a descrição dos eventos realizados em 2013. 


\section{A espetacularização do lazer em Volta Redonda: os investimentos esportivos}

Figura 2. Outdoor da propaganda institucional da prefeitura

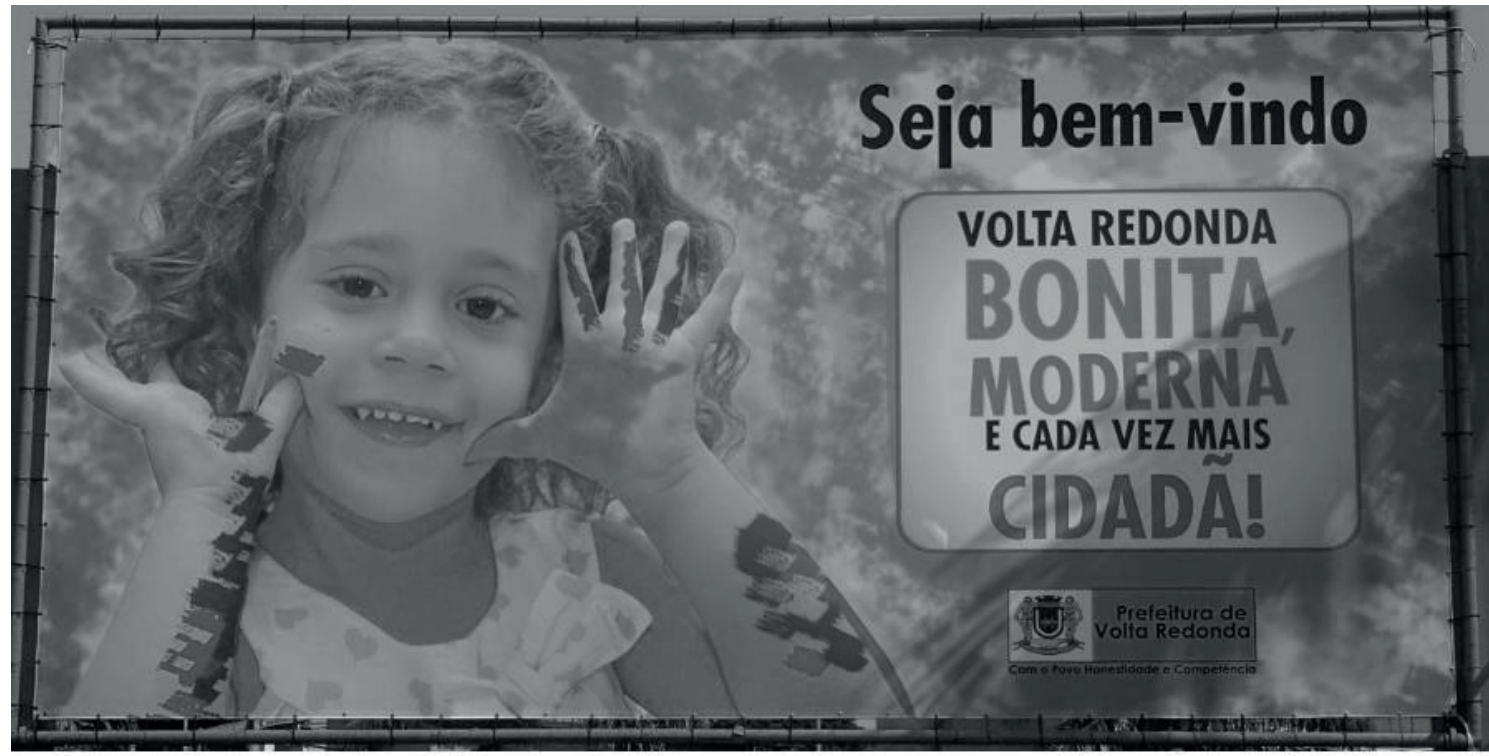

Fonte: Arquivo pessoal, 2015.

Tabela 1. Quantidade, localização e descrição dos eventos realizados pela Secretaria Municipal de Cultura para o ano 2013

\begin{tabular}{|c|c|c|}
\hline $\begin{array}{l}\text { Quantidade } \\
\text { de eventos }\end{array}$ & Localização & Descrição dos eventos \\
\hline 30 & Memorial Zumbi & $\begin{array}{l}\text { Realização de shows musicais, teatro e exposiçôes. Exemplos: "Freakshow", } \\
\text { "Roda de Samba", "Dia da Consciência Negra". }\end{array}$ \\
\hline 200 & Eventos nos bairros & $\begin{array}{l}\text { Duas apresentaçôes semanais de espetáculos nos bairros da cidade. Exemplos: } \\
\text { "Arena de Viola", "Cinema nos Bairros", "Baile Popular", "Seresta no Bairro", } \\
\text { "Roda Musical" e "Palco Sobre Rodas". }\end{array}$ \\
\hline 20 & Espaço Zélia Arbex & $\begin{array}{l}\text { Exposiçôes artísticas relacionadas a fotografia e artes plásticas, entre outras. } \\
\text { Exemplos: "Saláo do Humor", "Olhar } 180^{\circ} \text { ". } \\
\end{array}$ \\
\hline 50 & Ilha São João & $\begin{array}{l}\text { Local para realização de grandes eventos e exposiçōes. Exemplos: "Volta Redon- } \\
\text { da do Rock", "Feira da Primavera", "Folia de Reis", "Feira Regional do Livro", } \\
\text { "Encontro de Carros Antigos". }\end{array}$ \\
\hline 90 & Zoológico Municipal & Apresentações de teatro infantil nos fins de semana. \\
\hline 45 & "Cultura para Todos" & Apresentação gratuita de shows musicais com artistas regionais e nacionais \\
\hline 90 & $\begin{array}{l}\text { Memorial } \\
\text { Getulio Vargas }\end{array}$ & $\begin{array}{l}\text { Realização de eventos diversos. Exemplos: "Feira de Artesanato", "Vila Cultural", } \\
\text { "Grito do Rock", "Banda Municipal". }\end{array}$ \\
\hline
\end{tabular}

Fonte: Secretaria Municipal de Cultura, 2013. 
Em 2013, esses eventos reuniram cerca de duzentas mil pessoas. Planeja-se aumentar em 15\% o número de eventos até 2017 (passando dos atuais 525 eventos anuais para 605), com uma previsão de gasto de cerca de R $\$ 8$ milhões. Os eventos esportivos também aumentaram nos últimos anos, devido à ação da Prefeitura, que tem procurado atrair e incentivar sua promoção. ${ }^{3}$ São promovidos no município torneios esportivos de futebol, basquete e vôlei, competiçôes de natação, atletismo e ginástica artística e torneios esportivos estudantis; para a terceira idade, além de competiçôes para portadores de necessidades especiais, realizam-se eventos esportivos estaduais e nacionais. ${ }^{4}$ Os gastos com esses eventos em 2013 foram de R \$ 3,7 milhões; e a previsão é de que aumente o número de eventos esportivos e o montante de investimentos, que deverá ser superior a $\mathrm{R} \$ 7$ milhões em 2017.5

Esse aumento dos investimentos na área esportiva refere-se tanto aos equipamentos como aos programas e projetos. Tais investimentos estão voltados ao esporte de desempenho, ao esporte-educação e ao esporte-lazer. ${ }^{6}$ A maior parte dos programas/projetos e da construção/reforma de equipamentos esportivos é desenvolvida pela Secretaria Municipal de Esporte e Lazer, com recursos da prefeitura e oriundos de convênios com o governo estadual e o Ministério dos Esportes.

Nos últimos dez anos, Volta Redonda recebeu do Ministério do Esporte cerca de R\$ 30 milhôes para a realização de atividades ligadas ao esporte, sendo R \$ 12 milhões apenas nos últimos quatro anos. Foi o segundo maior número de convênios da prefeitura com a União, perdendo apenas para o Ministério da Saúde, e o segundo maior volume, atrás somente do Ministério das Cidades. Na Tabela 2, verificamos a quantidade de verba recebida pela prefeitura e sua destinação, além da contrapartida realizada pelo poder público municipal.

Tabela 2. Repasses do Ministério dos Esportes para a prefeitura (1997-2013)

\begin{tabular}{|l|l|l|l|}
\hline $\begin{array}{l}\text { No de } \\
\text { registros }\end{array}$ & Projetos Conveniados & Valor do Convênio & $\begin{array}{l}\text { Valor da } \\
\text { Contrapartida }\end{array}$ \\
\hline 38 & Construção e reforma de infraestrutura esportiva & $\mathrm{R} \$ 8.518 .308,42$ & $\mathrm{R} \$ 6.851 .607,64$ \\
\hline 18 & Núcleos de esporte e lazer & $\mathrm{R} \$ 6.234 .985,50$ & $\mathrm{R} \$ 2.834 .759,86$ \\
\hline 10 & Programa "Esporte Solidário" & $\mathrm{R} \$ 1.469 .321,57$ & $\mathrm{R} \$ 1.264 .269 .54$ \\
\hline 15 & Esporte paralímpico & $\mathrm{R} \$ 2.061 .805,05$ & $\mathrm{R} \$ 1.045 .328,68$ \\
\hline
\end{tabular}

3 A Secretaria Municipal de Esporte e Lazer não informou a quantidade de eventos esportivos realizados em 2013.

${ }^{4}$ Mais informações podem ser obtidas no site: www.portalvr.com/smel/secretaria.php

5 Os valores programados foram redimensionados devido à crise econômica por que passa o estado do Rio de Janeiro, porém não foram informados pela secretaria.

${ }^{6}$ Esporte de desempenho: é disputado obedecendo-se rigorosamente às regras e aos códigos existentes específicos de cada modalidade esportiva. É o esporte institucionalizado, do qual fazem parte federações internacionais e nacionais que organizam competiçōes em todo o mundo. Esporte-educação: é a manifestação esportiva como mais um processo educativo na formação dos jovens; uma preparação para o exercício da cidadania. Esporte-lazer: apoia-se no princípio do prazer lúdico e na utilização construtiva do tempo livre e da liberdade, promovendo o bem-estar de seus participantes (Tubino, 2007). 


\begin{tabular}{|l|l|l|l|}
\hline $\begin{array}{l}\text { No de } \\
\text { registros }\end{array}$ & Projetos Conveniados & Valor do Convênio & $\begin{array}{l}\text { Valor da } \\
\text { Contrapartida }\end{array}$ \\
\hline 7 & Aquisição e confecção de material esportivo & $\mathbf{R} \mathbf{6 . 3 3 9 . 6 4 8 , 2 4}$ & $\mathbf{R} \mathbf{8 2 8 . 4 8 8 , 5 5}$ \\
\hline 4 & Programa "Segundo Tempo" & $\mathbf{R} \mathbf{1 . 5 3 0 . 6 8 5 , 0 0}$ & $\mathbf{R} \mathbf{1 . 0 8 1 . 0 9 5 , 0 0}$ \\
\hline 3 & Projetos esportivos para a terceira idade & $\mathrm{R} \$ 243.903,03$ & $\mathrm{R} \$ 67.900,00$ \\
\hline 3 & Núcleos esportivos intermunicipais & $\mathbf{R} \mathbf{3 . 9 5 4 . 6 4 2 , 0 0}$ & $\mathbf{R} \mathbf{7 4 9 . 8 7 8 , 0 0}$ \\
\hline
\end{tabular}

Fonte: Sistema Integrado de Administração Financeira do Governo Federal (Siafi). Disponível em: http://www.portaltransparencia.gov.br/convenios. ${ }^{7}$

A maior parte dos investimentos foi direcionada a construção/reforma e aquisição de equipamentos esportivos, soma que ultrapassa R \$ 22 milhões. Em seguida, está o direcionamento dos investimentos para programas e projetos esportivos voltados a crianças e adolescentes em vulnerabilidade social e para a terceira idade, totalizando mais de $\mathrm{R}$ \$ 11 milhôes. Em contrapartida aos repasses recebidos do Ministério do Esporte, a prefeitura gastou cerca de R \$ 15 milhões. Com recursos próprios de seu orçamento, o município tem aumentado seus investimentos em esportes e lazer. Na Tabela 3, observa-se a evolução das receitas orçamentárias da prefeitura e os gastos com esporte e lazer entre os anos de 2007 a 2011.

Tabela 3. Evolução das despesas totais e de esporte e lazer da prefeitura (2007-2011)

\begin{tabular}{|l|l|l|}
\hline Ano & Despesas totais por função & Despesas de esporte e lazer \\
\hline 2007 & $\mathrm{R} \$ 426.016 .500,00$ & $\mathrm{R} \$ 7.495 .200,00$ \\
\hline 2008 & $\mathrm{R} \$ 500.646 .900,00$ & $\mathrm{R} \$ 13.795 .900,00$ \\
\hline 2009 & $\mathrm{R} \$ 582.812 .800,00$ & $\mathrm{R} \$ 18.915 .100,00$ \\
\hline 2010 & $\mathrm{R} \$ 656.962 .400,00$ & $\mathrm{R} \$ 17.336 .200,00$ \\
\hline 2011 & $\mathrm{R} \$ 776.757 .000,00$ & $\mathrm{R} \$ 25.814 .000,00$ \\
\hline
\end{tabular}

Fonte: Dados Contábeis dos Municípios Brasileiros. Finanças do Brasil (Finbra). Disponível em: http://www3.tesouro.fazenda.gov.br/estados_municipios/index.asp.

Entre os anos de 2007 e 2011, as despesas totais por função no município aumentaram cerca de $80 \%$, enquanto as despesas em esporte e lazer aumentaram em $370 \%$. De acordo com os dados da Prefeitura, para 2012 foram gastos R \$ 23 milhões e a previsão para 2013 é de cerca de R \$ 25 milhões anuais em esporte e lazer. A previsão para 2017 é que os gastos atinjam R \$ 53,5 milhões, ou seja, mais

\footnotetext{
7 De acordo com a Procuradoria-Geral da União, convênio é o instrumento que disciplina os compromissos que devem reger as relaçôes de dois ou mais participantes (como, por exemplo, governo federal e prefeitura) que tenham interesse em atingir um objetivo comum, mediante a formação de uma parceria. Os dados dos convênios estão disponíveis em: http://www.portaltransparencia.gov.br/convenios. Para mais informações, acessar: http://www.tesouro.fazenda.gov.br/siafi.
} 
que o dobro de 2013. No município, os gastos com esporte e lazer ocupam a oitava posição, atrás de gastos com administração direta, assistência social, previdência social, saúde, educação, saneamento básico, energia e transporte, e ficando à frente dos gastos com segurança pública, infraestrutura urbana, comunicações, habitação, cultura, trabalho e patrimônio, entre outros.

Esses investimentos esportivos propiciaram um aumento nos programas e projetos, bem como no número de equipamentos esportivos no município, com o intuito de atender não somente o esporte de desempenho, mas principalmente o esporte-educação e o esporte-lazer. Atualmente, Volta Redonda conta com diversos projetos/programas para o atendimento da população. Há programas como escolinhas de futebol, vôlei, badminton, remo, kart, hipismo e ginástica artística e de trampo$\mathrm{lim}$, com a participação dos alunos em competições nacionais e internacionais. Todos esses projetos são desenvolvidos com equipamentos esportivos da Prefeitura.

Os equipamentos são: 14 ginásios poliesportivos, 254 quadras em diferentes bairros (sendo cinquenta cobertas), cinquenta campos de futebol e futebol society. Existem ainda o parque aquático com piscina semiolímpica, o ginásio municipal de skate, o kartódromo, a arena de hipismo, a sede náutica de remo e o estádio Raulino de Oliveira, com capacidade para 25 mil pessoas. Na Tabela 4, podem-se observar o uso e o local dos principais equipamentos esportivos de propriedade da prefeitura, enquanto a Figura 3 mostra a quantidade de equipamentos nos bairros da cidade. Podemos perceber uma concentração desses espaços junto à curva do rio, perto de áreas urbanas não consolidadas - importante notar que a prefeitura não instalou equipamentos esportivos nos bairros construídos pela CSN.

Assim, com o aumento dos investimentos em esportes nos últimos anos, o município de Volta Redonda foi classificado em primeiro lugar no Índice de Desenvolvimento Esportivo (IDE) criado pela Secretaria de Esporte e Lazer do estado do Rio de Janeiro (SEEL), como se observa na Tabela 5. Essa pesquisa foi realizada pela Superintendência de Desportos do estado (Suderj), que traçou um diagnóstico dos 92 municípios fluminense a fim de conhecer o nível de desenvolvimento esportivo. O índice é composto por oito dimensôes: recursos humanos no esporte; articulação institucional; legislação municipal; recursos públicos; convênios e parcerias; ações, programas e projetos esportivos; eventos esportivos; instalações e equipamentos. Com 91 projetos esportivos, Volta Redonda ficou em primeiro lugar, com 3,58 pontos.

Tabela 4. Localização dos equipamentos esportivos e sua finalidade

\begin{tabular}{|l|l|l|}
\hline Equipamento esportivo & Localização & Utilização \\
\hline $\begin{array}{l}\text { Ginásio Poliesportivo } \\
\text { Darcise José de Carvalho }\end{array}$ & $\begin{array}{l}\text { Rua Jaime Martins, } \\
n^{\circ} 850, \text { Santo Agostinho }\end{array}$ & $\begin{array}{l}\text { Atividades esportivas para crianças e adolescentes e para a } \\
\text { comunidade em geral. Atividades específicas para a terceira } \\
\text { idade. }\end{array}$ \\
\hline $\begin{array}{l}\text { Ginásio Poliesportivo Va- } \\
\text { necina Freitas Henrique } \\
\text { Vicente }\end{array}$ & $\begin{array}{l}\text { Av. Presidente Kennedy, } \\
n^{\circ} \text { 6.090, Siderlândia }\end{array}$ & $\begin{array}{l}\text { Atividades esportivas para crianças e adolescentes e para a co- } \\
\text { munidade em geral. Atividades específicas para a terceira idade. }\end{array}$ \\
\hline $\begin{array}{l}\text { Ginásio Poliesportivo } \\
\text { Francisco Gomes do } \\
\text { Nascimento }\end{array}$ & $\begin{array}{l}\text { Rua Cap. BL. Bragança, } \\
n^{\circ} 888, \text { São Geraldo }\end{array}$ & $\begin{array}{l}\text { Atividades esportivas para crianças e adolescentes e para a co- } \\
\text { munidade em geral. Atividades específicas para a terceira idade. }\end{array}$ \\
\hline $\begin{array}{l}\text { Ginásio Poliesportivo } \\
\text { José Alves “Zinho” }\end{array}$ & $\begin{array}{l}\text { Av. dos Ex-combatentes, } \\
\text { s/no, Santa Cruz }\end{array}$ & $\begin{array}{l}\text { Atividades esportivas para crianças e adolescentes e para a co- } \\
\text { munidade em geral. Atividades específicas para a terceira idade. }\end{array}$ \\
\hline
\end{tabular}




\begin{tabular}{|c|c|c|}
\hline Equipamento esportivo & Localizaçãoo & Utilização \\
\hline $\begin{array}{l}\text { Ginásio Poliesportivo } \\
\text { Carlos Augusto Haasis } \\
\text { Filho }\end{array}$ & $\begin{array}{l}\text { Rua } 43 \mathrm{c} / \text { rua } 35 \text {, Vila } \\
\text { Rica (Jd. Tiradentes) }\end{array}$ & $\begin{array}{l}\text { Atividades esportivas para crianças e adolescentes e para a co- } \\
\text { munidade em geral. Atividades específicas para a terceira idade. }\end{array}$ \\
\hline $\begin{array}{l}\text { Ginásio Poliesportivo } \\
\text { Abraham Medina }\end{array}$ & $\begin{array}{l}\text { Rua Triestes, } \mathrm{s} / \mathrm{n}^{\circ} \text {, Ponte } \\
\text { Alta }\end{array}$ & $\begin{array}{l}\text { Atividades esportivas para crianças e adolescentes e para a } \\
\text { comunidade em geral. Atividades específicas para a terceira } \\
\text { idade. }\end{array}$ \\
\hline $\begin{array}{l}\text { Ginásio Poliesportivo } \\
\text { Heth Lustoza Bastos }\end{array}$ & $\begin{array}{l}\text { Rua Érika Berbet, nº 3, } \\
\text { Vila Rica (Três Poços) }\end{array}$ & $\begin{array}{l}\text { Atividades esportivas para crianças e adolescentes e para a } \\
\text { comunidade em geral. Atividades específicas para a terceira } \\
\text { idade. }\end{array}$ \\
\hline $\begin{array}{l}\text { Ginásio Poliesportivo } \\
\text { Amaro Inácio }\end{array}$ & $\begin{array}{l}\text { Av. Antônio de Almeida } \\
\text { Gama, Retiro }\end{array}$ & $\begin{array}{l}\text { Atividades esportivas para crianças e adolescentes e para a } \\
\text { comunidade em geral. Atividades específicas para a terceira } \\
\text { idade. }\end{array}$ \\
\hline $\begin{array}{l}\text { Ginásio Poliesportivo } \\
\text { Nery Miglioly }\end{array}$ & $\begin{array}{l}\text { Rua Vereador Acácio da } \\
\text { Rocha, nº 82, Açude I }\end{array}$ & $\begin{array}{l}\text { Atividades esportivas para crianças e adolescentes e para a } \\
\text { comunidade em geral. Atividades específicas para a terceira } \\
\text { idade. }\end{array}$ \\
\hline $\begin{array}{l}\text { Ginásio Poliesportivo } \\
\text { Gal. Euclydes Figueiredo }\end{array}$ & $\begin{array}{l}\text { Rua Alexandre Polastri } \\
\text { Filho, n } 761 \text {, Ilha São } \\
\text { João }\end{array}$ & $\begin{array}{l}\text { Treinamento profissional e das categorias de base do vôlei } \\
\text { masculino. Realização de torneios e jogos oficiais. }\end{array}$ \\
\hline $\begin{array}{l}\text { Ginásio Municipal de } \\
\text { Skate } \\
\text { Fernando Schimdt }\end{array}$ & $\begin{array}{l}\text { Rua } 848, \mathrm{~s} / \mathrm{n}^{\circ} \text {, Jardim } \\
\text { Tiradentes }\end{array}$ & $\begin{array}{l}\text { Atividades de treinamento. Atividades esportivas para crian- } \\
\text { ças e adolescentes. Realização de torneios amadores. }\end{array}$ \\
\hline $\begin{array}{l}\text { Estádio Municipal Rau- } \\
\text { lino de Oliveira }\end{array}$ & $\begin{array}{l}\text { Rua } 539, \mathrm{~s} / \mathrm{n}^{\circ}, \text { Jardim } \\
\text { Paraíba }\end{array}$ & $\begin{array}{l}\text { Atividades de treinamento profissional de futebol masculino } \\
\text { e feminino. }\end{array}$ \\
\hline $\begin{array}{l}\text { Parque Aquático } \\
\text { Municipal }\end{array}$ & $\begin{array}{l}\text { Rua Alexandre Polastri } \\
\text { Filho, no 791, Ilha São } \\
\text { João }\end{array}$ & $\begin{array}{l}\text { Atividades esportivas para crianças e adolescentes. Atividades } \\
\text { recreativas para a comunidade em geral. Torneiros amadores } \\
\text { de natação. }\end{array}$ \\
\hline $\begin{array}{l}\text { Kartódromo Municipal } \\
\text { de Volta Redonda }\end{array}$ & $\begin{array}{l}\text { Av. Ministro Salgado } \\
\text { Filho, s/no, Aeroclube }\end{array}$ & $\begin{array}{l}\text { Atividades esportivas para criança e adolescentes. Treinamento } \\
\text { e aperfeiçoamento profissional de pilotos. Realização de campe- } \\
\text { onatos amadores e profissionais. }\end{array}$ \\
\hline $\begin{array}{l}\text { Complexo Esportivo Jor- } \\
\text { nalista Oscar Cardoso }\end{array}$ & $\begin{array}{l}\text { Av. Ministro Salgado } \\
\text { Filho, s/no, Aeroclube }\end{array}$ & $\begin{array}{l}\text { Treinamento para as categorias de base de futebol feminino e } \\
\text { masculino. Treinamento profissional. }\end{array}$ \\
\hline $\begin{array}{l}\text { Centro de Artes Marciais } \\
\text { Mestre Boa Viagem }\end{array}$ & $\begin{array}{l}\text { Rua } 539, \text { s/no }, \text { Estádio } \\
\text { Municipal Raulino de } \\
\text { Oliveira, Jardim Paraíba }\end{array}$ & $\begin{array}{l}\text { Atividades esportivas para crianças e adolescentes. Treinamento } \\
\text { semiprofissional. Realização de torneios amadores e } \\
\text { profissionais. }\end{array}$ \\
\hline $\begin{array}{l}\text { Centro Municipal de } \\
\text { Ginástica Artística }\end{array}$ & $\begin{array}{l}\text { Rua } 539, \text { s/no, Estádio } \\
\text { Municipal Raulino de } \\
\text { Oliveira, Jardim Paraíba }\end{array}$ & $\begin{array}{l}\text { Atividades esportivas para crianças e adolescentes. Realização de } \\
\text { torneios amadores. }\end{array}$ \\
\hline $\begin{array}{l}\text { Miniestádio Edgar de } \\
\text { Carvalho }\end{array}$ & $\begin{array}{l}\text { Rua Alexandre Polastri } \\
\text { Filho, no } 791 \text {, Ilha São } \\
\text { João }\end{array}$ & $\begin{array}{l}\text { Atividades esportivas para crianças e adolescentes. Treinamento } \\
\text { profissional. Realização de jogos e torneios profissionais. }\end{array}$ \\
\hline $\begin{array}{l}\text { Arena Esportiva Professor } \\
\text { Paulo Camargo de Melo }\end{array}$ & $\begin{array}{l}\text { Praça Independência e } \\
\text { Luz II, Aterrado }\end{array}$ & $\begin{array}{l}\text { Atividades esportivas para crianças e adolescentes e para a } \\
\text { comunidade em geral. }\end{array}$ \\
\hline
\end{tabular}

Fonte: Secretaria de Esporte e Lazer (SMEL) da Prefeitura Municipal de Volta Redonda. Disponível em: http://www.portalvr.com/smel/centrosesportivos.php. ${ }^{8}$

8 Dados fornecidos pela Secretaria Municipal de Esporte e Lazer para o ano de 2013. Há outros equipamentos esportivos no município, como, por exemplo, aqueles que pertencem aos clubes sociorrecreativos de caráter privado. O levantamento levou em conta apenas os públicos municipais. 
Figura 3. Mapa com a distribuição dos equipamentos esportivos da Prefeitura Municipal de Volta Redonda-RJ

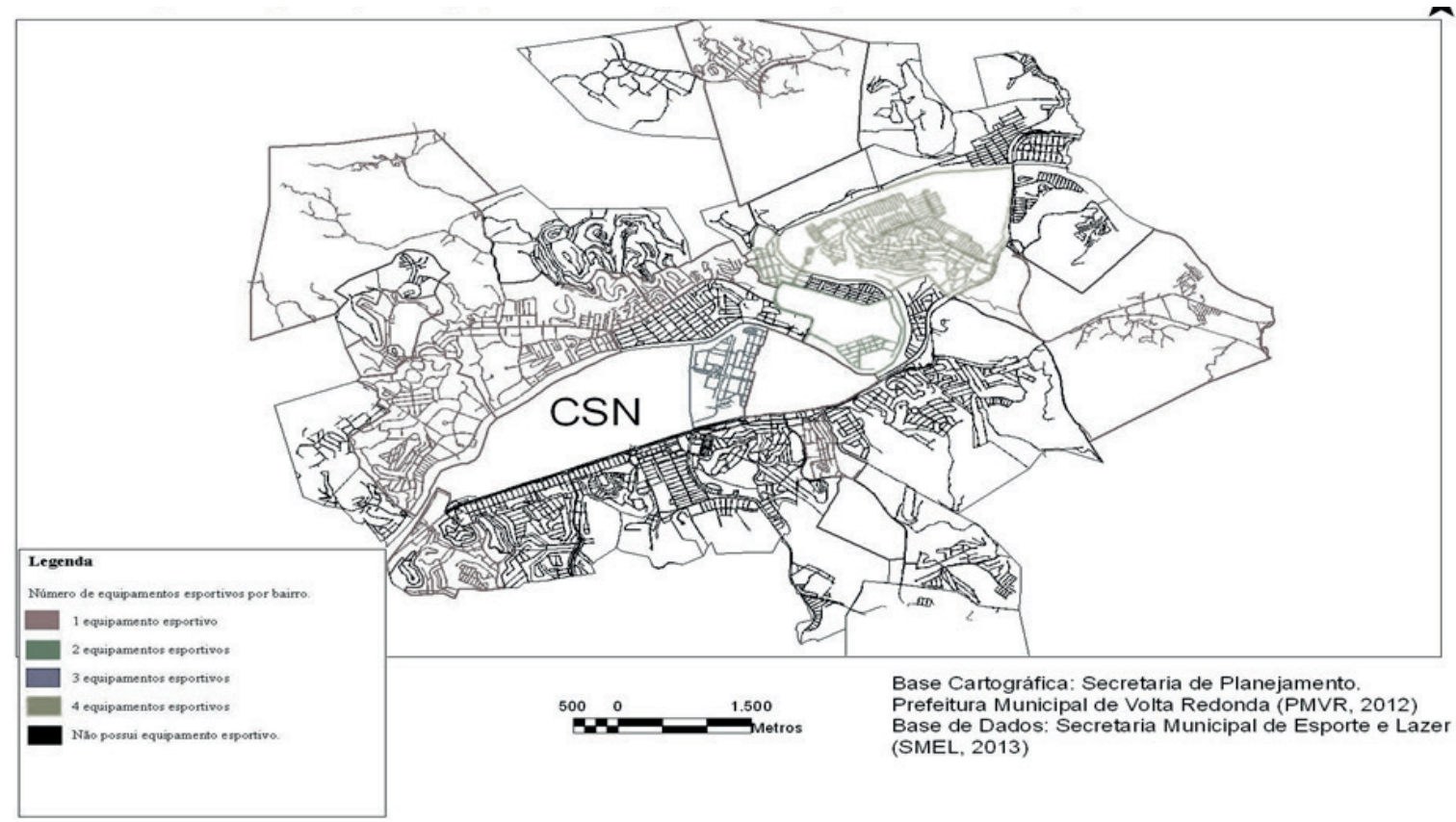

Fonte: Elaborado pelo Autor, 2013.

Tabela 5. Índice de Desenvolvimento Esportivo (IDE) do estado do Rio de Janeiro

\begin{tabular}{|l|l|l|l|l|l|}
\hline Class. & IDE & Município & Class. & IDE & Município \\
\hline 1 & 3,58 & Volta Redonda & 11 & 3,00 & Porto Real \\
\hline 2 & 3,16 & Campos dos Goytacazes & 12 & 2,97 & Niterói \\
\hline 3 & 3,10 & Resende & 13 & 2,97 & Paty dos Alferes \\
\hline 4 & 3,10 & Santa Maria Madalena & 14 & 2,97 & Angra dos Reis \\
\hline 5 & 3,10 & Barra Mansa & 15 & 2,97 & Mangaratiba \\
\hline 6 & 3,03 & Cardoso Moreira & 16 & 2,90 & Conceição de Macabu \\
\hline 7 & 3,03 & Macaé & 17 & 2,90 & São João da Barra \\
\hline 8 & 3,03 & Macuco & 18 & 2,90 & Vassouras \\
\hline 9 & 3,03 & Quissamã & 19 & 2,87 & Rio das Ostras \\
\hline 10 & 3,03 & Rio das Flores & 20 & 2,84 & Barra do Piraí \\
\hline
\end{tabular}

Fonte: Índice de Desenvolvimento do Esporte. Cartilha Elaborada pela Superintendência de Desportos do Estado do Rio de Janeiro (Suderj), 2011. Disponível em: http://www.suderj.rj.gov.br. ${ }^{9}$

9 Índice de Desenvolvimento do Esporte (IDE). Elaborado pela Superintendência de Desportos do estado do Rio de Janeiro (SUDERJ), 2011. Disponível em: http://www.suderj.rj.gov.br. 
Volta Redonda anunciou novos investimentos esportivos para os próximos anos. Está em construção a Vila Olímpica, que contará com um espaço de $35 \mathrm{mil} \mathrm{m}^{2}$ para a prática de atletismo em alto nível, com pistas destinadas a provas de corrida, salto e arremesso, certificadas internacionalmente pela Associação Internacional de Federaçôes de Atletismo (IAAF), em convênio com o governo estadual, no valor de $\mathrm{R} \$ 12$ milhōes. Além disso, está prevista a construção de um ginásio para a prática de ginástica artística no valor de $\mathrm{R} \$ 8$ milhōes. A seguir, apresentamos dois equipamentos esportivos de propriedade da prefeitura e seus usos.

\section{0 estádio Sylvio Raulino de Oliveira}

No final dos anos 1940, o general Sylvio Raulino de Oliveira, então presidente da CSN, financiou, com recursos da empresa, a construção de um estádio de futebol, que veio a ser inaugurado em 1951. Mais tarde, o estádio ganhou o nome de seu mentor. Com o crescimento e a popularização do futebol, o objetivo da empresa era criar um espaço para que os trabalhadores e suas famílias participassem de jogos e também assistissem às partidas. Em 1959, Raulino transferiu a administração do estádio para o Guarani Futebol Clube, por meio de comodato com duração de quatro anos. Na década de 1960, o então presidente da CSN, Osvaldo Pinto da Veiga, determinou que se fizesse a iluminação do estádio.

Na década de 1970, houve a ideia de se criar um time próprio da cidade, e o prefeito à época, Nelson Gonçalves, reformou o estádio, ampliando sua capacidade, pois o novo time jogaria contra outras equipes do estado. Porém, o prefeito queria uma garantia de que efetivamente esse time seria criado. Houve, então, uma reunião entre a Prefeitura, a CSN e a Confederação Brasileira de Desportos (atual Confederação Brasileira de Futebol - CBF) para a reforma do estádio e a criação do time, processo que durou sete meses. Assim, em 1976, após a fusão dos estados do Rio de Janeiro e da Guanabara, nasceu o Volta Redonda Futebol Clube, para a disputa do novo campeonato estadual de futebol.

Em 1976, o prefeito desapropriou o estádio, pois o terreno pertencia à CSN.${ }^{10} \mathrm{O}$ estádio tinha capacidade para 25 mil pessoas, contava com arquibancadas de madeira com estrutura metálica e apresentava características simples. De acordo com a Prefeitura, ${ }^{11}$ em 2001 o prefeito Antônio Francisco Neto acatou a proposta do jornalista e assessor Oscar Cardoso e iniciou a reforma do estádio. Com recursos próprios do município, na ordem de $\mathrm{R} \$ 16$ milhōes, após três anos de obras, surgiu um novo estádio de arquitetura moderna (Figura 4). Com capacidade reduzida para vinte mil pessoas, insere-se nas normas do Estatuto do Torcedor - de acordo com a prefeitura, o novo espaço oferece mais conforto, beleza e segurança em seu interior.

O estádio é considerado o primeiro do Brasil a abrigar um complexo de esportes, lazer, saúde e educação, com acesso gratuito à população. Entretanto, sem contar com um time pro-

\footnotetext{
${ }^{10}$ Informações fornecidas pela Prefeitura Municipal de Volta Redonda (PMVR). Para mais informações, acessar: http://www.portalvr.com/estadiodacidadania/index.php/o-estadio/comeco.

${ }^{11}$ Idem.
} 
fissional que tenha grande torcida e que dispute os principais campeonatos de futebol do Brasil, fica subutilizado no que concerne à realização de eventos esportivos, fato que gera críticas por parte daqueles que o consideram um grande investimento esportivo que não traz retorno para o município. A prefeitura, contudo, alega que o movimento proporcionado pelas partidas de futebol no município, principalmente das grandes equipes da capital, traz diversos benefícios para a economia da cidade. Em dias de jogos, os serviços e comércios recebem um grande fluxo de turistas que chegam para assistir às partidas. Além disso, a imagem da cidade é divulgada em todo o território nacional e também no exterior, com a transmissão das partidas pela televisão. Em 2013, o investimento foi de cerca de R\$ 150 mil em melhorias e manutenção do estádio, como recapeamento, pinturas da pista de acesso ao estádio e nas dependências, além de reforma nos vestiários. Além disso, a operacionalização e a manutenção do estádio custam, de acordo com a prefeitura, cerca de $\mathrm{R} \$ 250$ mil. $^{12}$

Figura 4. Foto da entrada principal do estádio municipal Sylvio Raulino de Oliveira

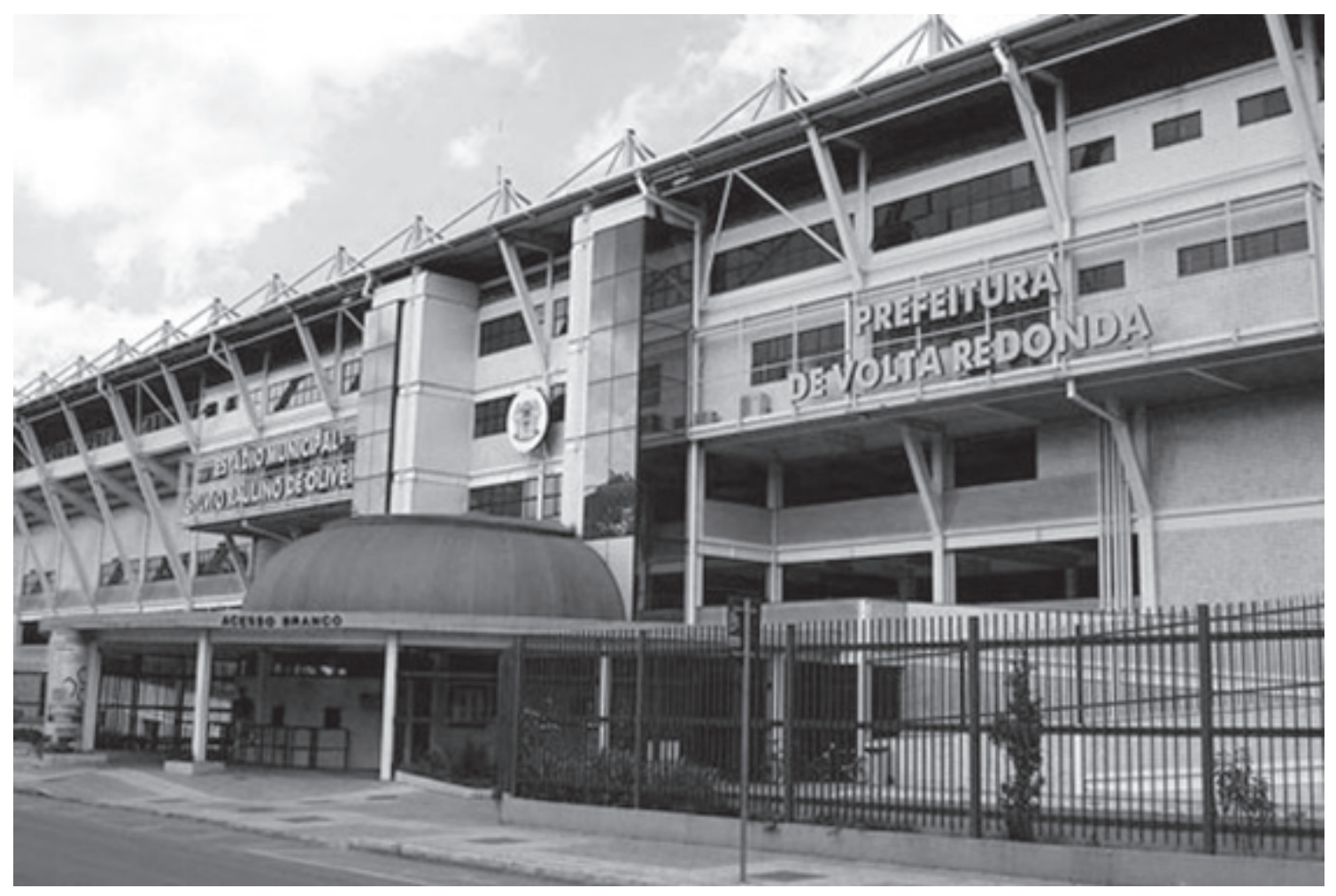

Fonte: Prefeitura Municipal de Volta Redonda. http://www.portalvr.com/estadiodacidadania.

\footnotetext{
${ }^{12}$ Reportagem do jornal Diário do Vale: "Jogos em Volta Redonda trazem visibilidade”, 2013. Disponível em: http://diariodovale.uol.com.br/noticias/1,72947,Jogos-em-VR-trazem-visibilidade.html\#ixzz2Ylg7XnQF.
} 


\section{A espetacularização do lazer em Volta Redonda: os investimentos esportivos}

Na opinião de Carlos Roberto Parente, o Betinho, administrador do Estádio da Cidadania, com a organização desses jogos de futebol, Volta Redonda mostra que tem condições estruturais de receber grandes eventos esportivos, devido ao "movimento financeiro que a cidade recebe, com a vinda dos torcedores. Já no aspecto de divulgação, os jogos ajudam na publicidade de uma imagem positiva da cidade e do Estádio da Cidadania". ${ }^{13}$ Outro argumento comum é a escolha do estádio como subsede da Copa do Mundo de 2014. Em 2012, o local foi alvo de inspeção por parte da Federação Internacional de Futebol (Fifa), que vistoriou todas as instalações e selecionou 54 delas que foram aprovadas como Centros de Treinamento de Seleções (CTS), podendo ser utilizadas pelas seleções de futebol classificadas para a Copa do Mundo. Com isso, o Ministério do Esporte, em convênio com a Prefeitura, liberou $\mathrm{R} \$ 800$ mil para a realização de obras de reparos gerais e modernização, além de reformas para melhorar a acessibilidade. Entretanto, durante a realização da Copa do Mundo, nenhuma das 32 seleções escolheu a cidade como local de preparação para a competição, não dando o esperado retorno para os investimentos realizados.

Mesmo assim, quando há jogo, principalmente das grandes equipes da capital do estado, o que se vê são milhares de visitantes, o que deixa o trânsito no entorno do estádio bastante complicado. Muitos ônibus e vans estacionam ao redor de praças e ruas próximas, tumultuando ainda mais o fluxo de veículos. A maioria vem de cidades vizinhas e da capital do estado. Assim, os estabelecimentos comerciais (bares, restaurantes e lojas) ficam cheios, e as pessoas têm de enfrentar filas e muito tempo de espera. Mas, apesar desses problemas, a prefeitura defende que a organização desses jogos e eventos prova que a cidade já está preparada para a realização de grandes eventos

Gostaria de ressaltar que a divulgação da cidade até para o exterior foi um dos principais benefícios. Volta Redonda sempre foi considerada a Cidade do Aço e nos orgulhamos disso. Mas com essa publicidade podemos nos mostrar como a cidade do esporte, da saúde e da cultura também. ${ }^{14}$

$\mathrm{O}$ administrador do estádio explica que, a cada jogo, o custo operacional gira em torno de $\mathrm{R} \$$ 15 mil - com cerca de duzentos funcionários terceirizados, entre limpeza, bilheteiro, roleteiro e apoio. Conforme veiculado no jornal Diário do Vale, ${ }^{15}$ para Jessé Holanda, secretário de Turismo, a vinda de jogos para a regiāo trouxe visibilidade para Volta Redonda, além de movimentar hotéis, bares e restaurantes, e isso não só pela vinda de torcedores, mas também pelas delegações e jornalistas que vêm para cobrir as partidas. Para o presidente do Sindicato do Comércio Varejista de Volta Redonda, Antônio Borges, eventos que "promovem o movimento de pessoas e o aumento da circulação de dinheiro beneficiam o comércio da cidade" ${ }^{16}$

Por ser um estádio que concentra atividades não somente ligadas ao esporte, mas também a saúde, lazer e educação para a população do município, passou a ser chamado pela prefeitura de "Es-

\footnotetext{
${ }^{13}$ Idem.

${ }^{14}$ Idem.

${ }^{15}$ Idem.

${ }^{16}$ Idem.
} 
tádio da Cidadania". Assim, a prefeitura procura apagar a memória da cidade como ligada à "Cidade do Aço" e reconstruir uma nova imagem, dotando o município de novos significados, como, por exemplo, a cidadania. Um dos principais instrumentos utilizados pela prefeitura nesse sentido é o discurso, cuja dimensão é muito maior que as ações realizadas em termos de políticas públicas. Entretanto, a população, que deveria protagonizar o papel de agente da história do município, muitas vezes se acomoda como receptora das benesses concedidas pela prefeitura.

A reforma do Estádio da Cidadania é um marco na construção da cidade após os anos de crise vividos com a privatização da CSN. A Prefeitura enaltece uma cidadania que é passiva, em que o cidadão se contenta em ter seus direitos civis e políticos tutelados pela intervenção do poder público municipal, através de um forte processo de regulação. Os eventos e espetáculos teoricamente acessíveis a todos constroem, junto à população, essa ideia de cidadania. Além disso, essa imagem se baseia nas ideias de um desenvolvimento sustentado em outras bases que não apenas a indústria, mas também atraindo investimentos nos setores de comércios e de serviços, nos quais aparecem como destaque os eventos esportivos e culturais, visando ao aumento de empregos e da arrecadação tributária (Oliveira e Mascarenhas, 2007).

\subsection{O complexo esportivo da Ilha São João}

O complexo da Ilha São João, cujo nome oficial é Complexo de Atividades Duque de Caxias, foi criado pelo primeiro prefeito nomeado quando da transformação da cidade em área de segurança nacional, durante a ditadura militar - o engenheiro Georges Leonardo, em 1973. Na ocasião, a prefeitura desapropriou as ilhas do complexo com a intenção de tornar a área um local voltado à cultura, ao esporte e ao lazer da população da cidade. No passado, o local pertencera à antiga Fazenda São João Batista. Com a diminuição dos investimentos em lazer por parte da CSN, a Prefeitura considerou que havia necessidade de reformar/revitalizar esse equipamento de lazer com atividades culturais e esportivas para a população.

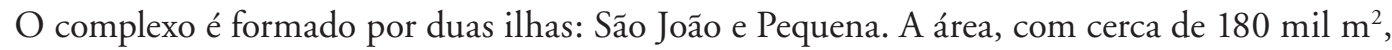
possui ginásio coberto, quadra aberta e quadra de areia, pista de caminhada, pavilhão de atividades múltiplas, centro de exposiçóes, miniestádio, escola de hipismo, minicidade do trânsito, posto médico, sede da Secretaria Municipal de Lazer, da Guarda Municipal e da Defesa Civil, além de um espaço do Detran.

Os principais eventos realizados anualmente estão ligados a esportes, feiras de negócios e exposições culturais e artísticas, como Expo-VR, Expo Agro, Feira Estadual da Indústria Metalmecânica, Médio Paraíba Negócios, Feira da Primavera, Festa do Peão Boiadeiro, carnaval, VR Folia, Encontro de Motoqueiros, Encontro de Carros Antigos, Encontro Nacional de Evangélicos, Olimpíadas das Pessoas Portadoras de Necessidades Especiais, Jogos Estudantis e Copa Regional Diarinho do Vale.

A Ilha Pequena conta com uma área de $25 \mathrm{mil} \mathrm{m}^{2}$, onde se situam as instalaçôes da Escola Municipal de Remo e do Parque Aquático, ambos administrados pela prefeitura, por meio da Secretaria Municipal de Esporte e Lazer. A Escola Municipal de Remo foi inaugurada em 2011, com as raias de treinamento e competição localizadas no rio Paraíba do Sul, junto à Defesa Civil. A escola promove atividades de iniciação à modalidade esportiva de remo e atividades educacionais sobre 


\section{A espetacularização do lazer em Volta Redonda: os investimentos esportivos}

meio ambiente e recursos hídricos, tendo, como público-alvo, jovens em idade escolar e matriculados regularmente na rede pública de ensino. O parque aquático foi construído em 1981, com o objetivo de incluir as faixas sociais carentes no lazer e desenvolvimento do esporte aquático no município. Cinco anos depois, em 1986, foi desativado e, em 1997, foi reformado e reativado, embora só tenha passado a funcionar plenamente em 2001. A Figura 5 mostra a festa de comemoração dos dez anos de funcionamento do parque.

O local conta com uma estrutura física de $11.300 \mathrm{~m}^{2}$, distribuídos entre três piscinas (uma de tamanho olímpico destinada a esportes aquáticos, uma infantil e outra para recreação), cantinas, vestiários, secretaria, sala de professores e uma arquibancada para quinhentos espectadores. De acordo com a prefeitura, são oferecidos gratuitamente à população de Volta Redonda cursos de natação, hidroginástica e polo aquático. Uma das exigências para ter acesso ao parque aquático e aos cursos é comprovar residência na cidade. Assim, são atendidas diariamente cerca de três mil pessoas em atividades recreativas. O local tem um total 5.480 alunos matriculados em seus cursos e conta com 11 professores e seis estagiários. No total, o espaço tem sessenta mil associados.

Os investimentos da prefeitura direcionados à manutenção e à operacionalização do parque aquático para 2013 eram estimados em R \$ 1,5 milhão. Com a escolha do local para a aclimatação das delegações para as Olimpíadas, a Prefeitura tencionava investir anualmente R \$ 1,5 milhão, por meio de convênios com o Ministério de Esportes, para a recuperação e a revitalização do local, a fim de se adequar às exigências do Comitê Olímpico Internacional (COI). Além desses interesses, o parque aquático é apresentado pela prefeitura como um local que preza pela melhor qualidade de vida dos cidadãos de Volta Redonda.

Figura 5. Foto de comemoração de 10 anos de funcionamento do parque aquático

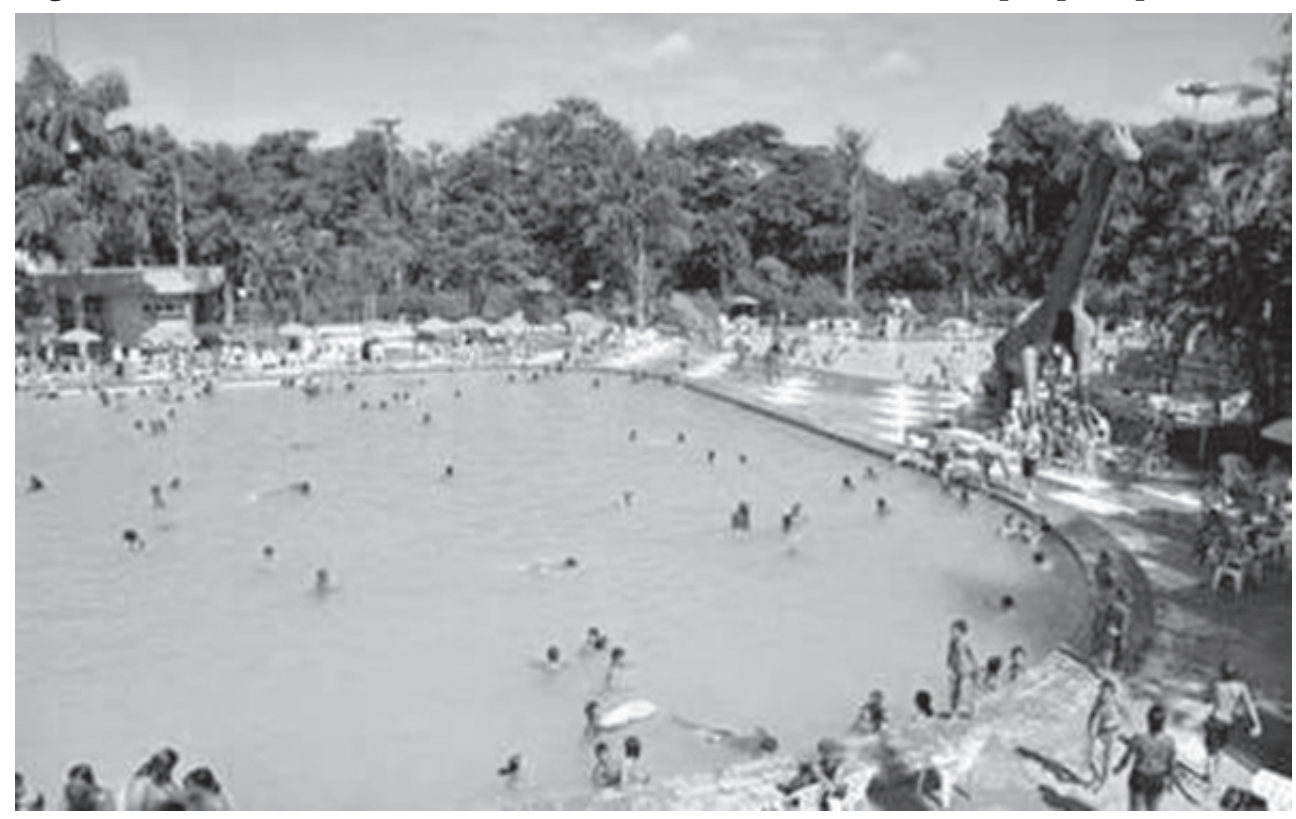

Fonte: Jornal Diário do Vale, 2011. 
O Parque Aquático Municipal proporciona gratuitamente à população de Volta Redonda esporte e lazer, através da prática de atividades aquáticas. Com espaço físico privilegiado por sua estrutura e beleza natural, o Parque Aquático Municipal de Volta Redonda oferece uma excelente opção de lazer, recreação e convívio social, buscando, com isso, melhor qualidade de vida aos cidadãos do município. ${ }^{17}$

O ginásio coberto poliesportivo General Euclydes Figueiredo, inaugurado em 1982, tem capacidade para seis mil pessoas. O local, além de promover a prática de atividades esportivas, por meio de programas/projetos voltados à população, tem como característica principal a realização de eventos esportivos profissionais de alto nível. Na Figura 6, vê-se a infraestrutura do ginásio. O local ainda conta com uma pista de caminhada de $800 \mathrm{~m}$ de extensão e um centro esportivo - o Oscar de Carvalho, inaugurado em 2004 -, que possui uma quadra de futebol society, uma sala de administração, quatro cantinas, quatro vestiários, tribuna de honra e arquibancada para cinco mil pessoas. No local, também existe a escola municipal de hipismo, criada em 2003 para ensinar crianças com até 14 anos, com todas as despesas custeadas pela Prefeitura. A imagem das duas ilhas e de toda a sua infraestrutura pode ser observada na Figura 7.

Figura 6. Fotografia da parte interna do ginásio mostrando a quadra e parte da arquibancada

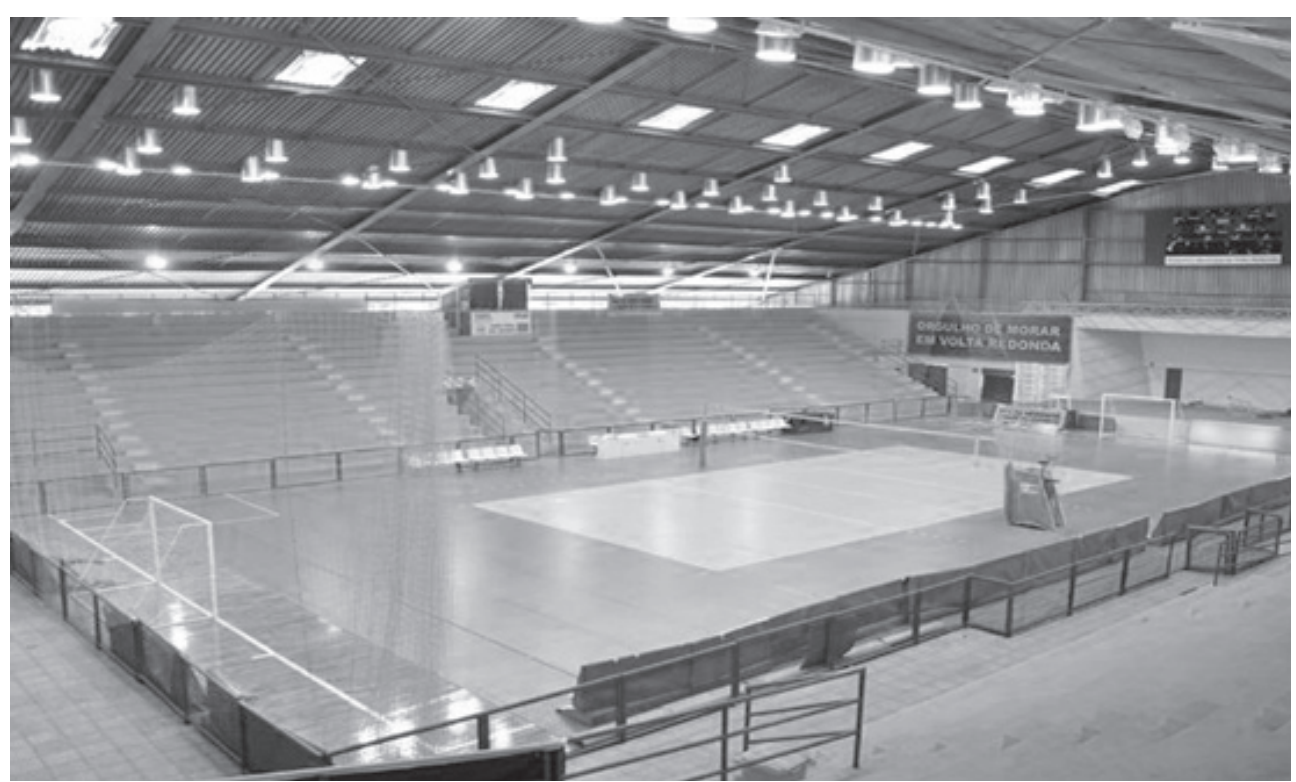

Fonte: Secretaria Municipal de Esporte e Lazer, 2013.

\footnotetext{
${ }^{17}$ Retirado do site: http://www.portalvr.com/smel/parqueaquatico.php
} 


\section{A espetacularização do lazer em Volta Redonda: os investimentos esportivos}

Figura 7. Vista aérea do complexo com a Ilha São João e Ilha Pequena

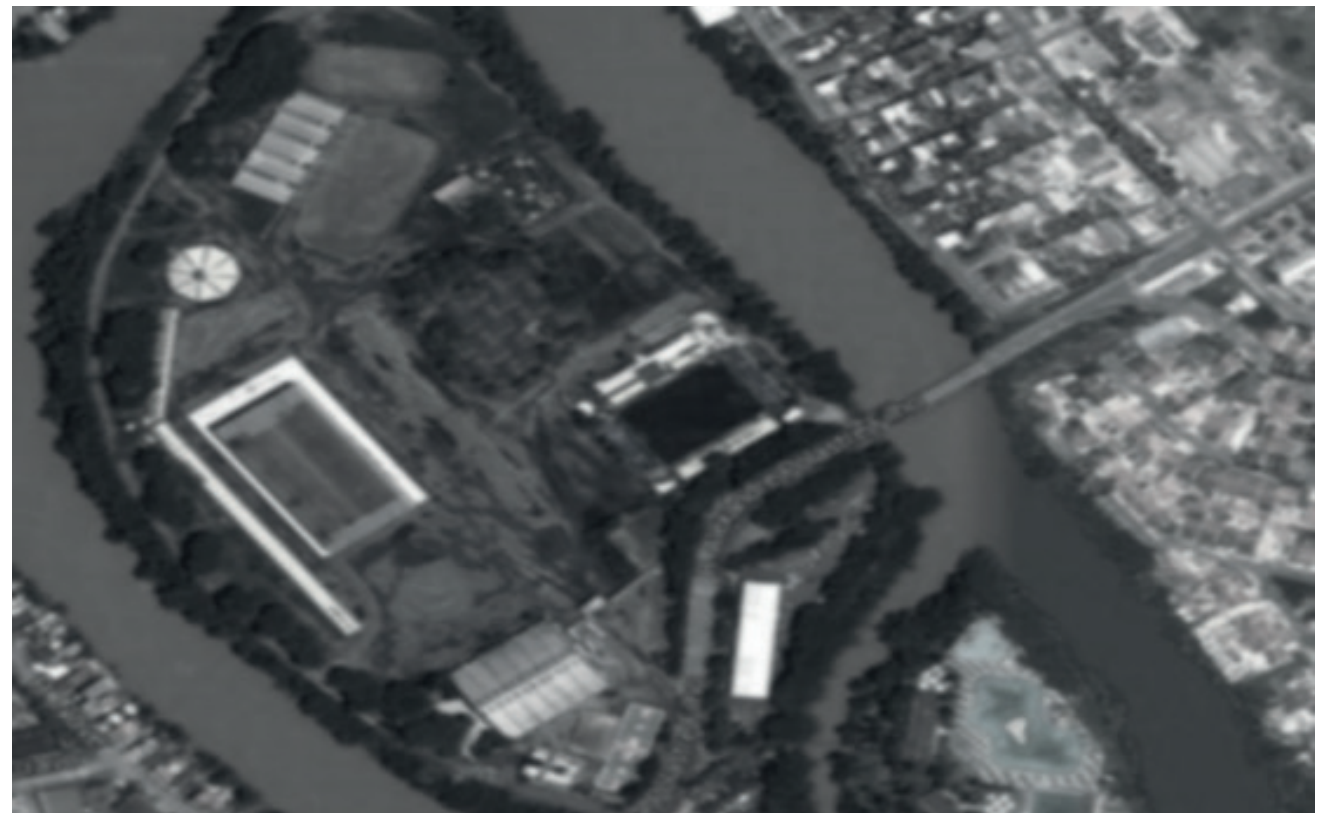

Fonte: Google Earth, 2013.

\section{Considerações finais}

Constatamos que a reestruturação produtiva e territorial por que passa Volta Redonda promoveu alteração nos equipamentos e atividades de lazer, com inúmeras consequências para a dinâmica urbana. $\mathrm{O}$ aumento da atuação do poder público municipal pode ser comprovado pelo elevado número de eventos esportivos e culturais realizados anualmente na cidade.

O lazer insere-se no conjunto de políticas do poder público municipal, com a tentativa de desvincular a imagem da cidade em relação à siderúrgica. Entretanto, os elementos simbólicos ligados à "Cidade do Aço" ainda se mostram muito presentes, como a toponímia das ruas e praças e os equipamentos urbanos da cidade, carregados pelo contexto do aço.

$\mathrm{O}$ conjunto de açōes que visam à transformação da imagem do município é relativamente recente, pois parte das famílias tem suas histórias de vida relacionadas, direta ou indiretamente, à usina ou ao contexto de sua criação, ou seja, à cidade siderúrgica. Por meio de seu discurso, dos investimentos e da recuperação/criação de novos símbolos na cidade (como o Estádio da Cidadania e o Complexo da Ilha São João), o Poder Público municipal procura alterar o paradigma do município para uma cidade de qualidade de vida baseada na cidadania. Nesse sentido, emprega recursos materiais (como estruturas e equipamentos) e imateriais (como serviços, sobretudo os discursos utilizados) para realçar suas novas virtudes, por meio de símbolos elaborados para produzir uma nova imagem para o lugar e utilizá-la para atrair novos investimentos. Essa questão é discutida por Milton Santos (2004), 
segundo o qual essa busca dos lugares para se diferenciar com o objetivo de atrair novos investimentos é chamada "guerra dos lugares".

Sem dúvida, esses investimentos em lazer trazem benefícios para a população, mas precisam ser questionados, pois o lazer da cidade se inscreve no modelo capitalista, com a produção da imagem de cidade com boa qualidade de vida e cidadania, um discurso que, paulatinamente, vai ganhando legitimidade junto à população, assim como a crença de que a prefeitura é responsável por todos os problemas existentes no município. A população, portanto, vive naquilo que Baudrillad (1981) chama de "simulacro", em que tudo parece estar em perfeita harmonia com o retorno do orgulho de uma cidade como exemplo para o país: se antes era por ser uma cidade moderna e industrial, por causa da CSN, atualmente é por ser uma cidade que promove cidadania para toda a sua população.

Assim, a reforma/construção de equipamentos urbanos modernos, inclusive daqueles destinados ao lazer, é apresentada por inúmeras propagandas, que os tornam mais atraentes ao agora cidadão do que o próprio objeto em sua realidade. Por meio de uma série de atividades e eventos de lazer, com destaque para os esportivos, o município passa a se configurar como exemplo de sociedade espetacularizada, o que, para Débord (1998), leva os indivíduos a contemplarem e a consumirem passivamente essas imagens, que, nesse caso, estão fortemente vinculadas à prefeitura, perdendo-se o sentido da vivência no espaço urbano.

Com isso, é possível afirmar que as mudanças do lazer na cidade impactaram a dinâmica urbana do município, com a alteração no fomento da prática de lazer. Enquanto a empresa visava ao lazer em um contexto fordista, atualmente, com o fomento pela prefeitura, esse lazer apresenta aspectos diferenciados, associados ao contexto atual da cidade pós-fordista. Entretanto, as mudanças mais acentuadas não ocorreram nas práticas das atividades de lazer, pois, se antes os principais eventos e atividades eram os socioculturais e esportivos, atualmente ainda apresentam grande relevância. A mudança mais significativa foi na função do lazer, pois, se antes a principal característica era o aspecto funcionalista e utilitarista por parte da empresa para seus funcionários, hoje se apresenta como um simulacro, espetacularizado por parte da Prefeitura para os cidadãos.

\section{Referências}

BAUDRILLARD, Jean. Simulacro e simulaçōes. Lisboa: Relógio D’Água, 1981. 202 p. (Coleção Antropos). CALIFE, Magali Nogueira da Silva. A relação entre capital-trabalho na gênese da CSN (dissertação). Universidade Severino Sombra, 2000.

COSTA, Alkindar. Volta Redonda, ontem e hoje. 3 ed. Volta Redonda-RJ: Masiero's, 1992.

DEBORD, Guy. A sociedade do espetáculo. 2 ed. Rio de Janeiro: Contraponto, 1997. 240p.

DIÁRIO DO VALE. "Comemoração aos 10 anos de Funcionamento do Parque Aquático Municipal de Volta Redonda”, jornal Diário Regional, Volta Redonda, 2011. Disponível em: http://diariodovale.uol.com. br/noticias/0,37608,Parque\%20Aquatico\%20da\%20Ilha\%20Sao\%20Joao\%20completa\%2010\%20 anos.html\#axzz2aOOXTJnY Acesso em: 10 maio 2013. 
—. "Aprovação da Fifa rende R \$ 800 mil a Volta Redonda”, jornal Diário Regional, Volta Redonda, 2013. Disponível em: http://diariodovale.uol.com.br/noticias/6,71529,Aprovacao-da-Fifa-rende-R \$-800-mil-a-Volta-Redonda.html\#ixzz2Ylj1lwxu. Acesso em: 10 maio 2013.

. "Jogos em Volta Redonda trazem visibilidade”, Diário Regional, Volta Redonda, 2013. Disponível em: http://diariodovale.uol.com.br/noticias/1,72947,Jogos-em-VR-trazemvisibilidade. html\#ixzz2Ylg7XnQF. Acesso em: 10 maio 2013.

FONTES, Ângela Maria Mesquita e LAMARÃO, Sérgio Tadeu Niemeyer. "Volta Redonda: história de uma cidade ou de uma usina”. Revista Rio de Janeiro, Niterói, n. 18-9, jan.-dez. 2006, pp. 241-53.

GOVERNO FEDERAL. Portal da Transparência. [Consulta ao Setor de Convênios]. Disponível em: http:// www.portaltransparencia.gov.br/convenios. Acesso em: 10 dez. 2011.

JORNAL AQUI. "Não é mais o mesmo". Diário Local, Volta Redonda-RJ. Disponível em: http://www. jornalaqui.com.br/arquivo/2011/744/paginas/csn3.htm. Acesso em: 15 jan. 2013.

LOPES, Alberto da Costa. A aventura da cidade industrial de Tony Garnier em Volta Redonda (dissertação). UFRJ, 1993.

MOREIRA, Regina da Luz. CSN: um sonho feito de aço e ousadia. 1 ed. Rio de Janeiro: Fundação CSN/ CPDOC/Fundação Getulio Vargas/Iarte, 2000. 191p.

OLIVEIRA, Leandro Dias de e MASCARENHAS, Gilmar. "A criação do Estádio da Cidadania em Volta Redonda-RJ: uma reflexão sobre simbolismo e ideologia na paisagem urbana”. Colóquio Nacional do Núcleo de Estudos em espaço e representações (NEER). Anais... Salvador, 2007.

PALMEIRA, André Franklin. A nova face da Cidade do Aço: crise do capital, trabalho e hegemonia em Volta Redonda (1992-2008) (dissertação). UFF, 2012.

PIQUET, Rosélia. Cidade-empresa: presença na paisagem urbana brasileira. Rio de Janeiro: Jorge Zahar, 1998. 166p.

RIO DE JANEIRO. Secretaria de Esporte e Lazer. Índice de Desenvolvimento do Esporte (IDE). Rio de Janeiro: Suderj, 2011. Disponível em: http://www.suderj.rj.gov.br. Acesso em: 08 dez. 2011.

SANTOS, Milton. A natureza do espaço: técnica e tempo. Razão e emoção. 4 ed. São Paulo: EDUSP, 2002. $384 \mathrm{p}$.

SOUTO, Baiena Feijolo. "Volta Redonda hoje: novos movimentos migratórios, primeiras aproximaçōes". Encontro Nacional sobre Migração, 5. Anais... Campinas, 2007. 22p.

TESOURO NACIONAL. Dados contábeis dos municípios brasileiros, 2010. Finanças do Brasil (Finbra). Disponível em: http://www.stn.fazenda.gov.br/estados_municipios/index.asp. Acesso em: 01 dez. 2011.

—. Sistema Integrado de Administração Financeira (SIAFI) [Consulta execução orçamentária, financeira e patrimonial do Governo Federal]. Disponível em: http://www.tesouro.fazenda.gov.br/siafi. Acesso em: 05 dez. 2011.

TUBINO, Manoel. O que é esporte? 3 ed. São Paulo: Brasiliense, 2006. 55p. (Coleção Primeiros Passos)

VOLTA REDONDA. Prefeitura Municipal. Lei Orgânica Municipal. Volta Redonda, 1992. 103p.

—. Cidade do esporte. Secretaria Municipal de Esporte e Lazer. Volta Redonda, v. 1, 2013. 10p.

—. Estádio da Cidadania. Secretaria Municipal de Esporte e Lazer. Disponível em: http://www.portalvr. com/estadiodacidadania. Acesso em: 10 abr. 2013.

—. Parque Aquático. Secretaria Municipal de Esporte e Lazer. Volta Redonda, 2013. Disponível em: http:// www.portalvr.com/smel/parqueaquatico.php. Acesso em: 10 abr. 2013. 


\section{A importância da mobilidade populacional para a acumulação capitalista no setor petróleo e gás da Bacia de Campos (RJ)}

Denise Cunha Tavares Terra

Joseane de Souza

\section{Introdução}

$\mathrm{N}$ os últimos dois séculos, o petróleo foi fator de transformação significativa da economia, do espaço e da sociedade nos países produtores do mundo periférico e semiperiférico. A atividade de exploração e produção de petróleo e gás proporcionou divisas, energia e matérias-primas, bem como o início do processo de industrialização em muitos desses países. A atual matriz energética mundial ainda é dependente do petróleo. Segundo Egler e Mattos (2012), cerca de 65\% da oferta global de energia primária provém do petróleo e do gás natural, o que permite a compreensão do alcance de sua influência nos rumos da geopolítica global.

No Brasil, o processo acelerado de expansão da indústria petrolífera e os investimentos realizados na última década produziram alterações significativas na espacialização da riqueza nacional, com rebatimentos na conformação da rede urbana brasileira.

No Norte Fluminense, a partir de meados dos anos 1970, com a implantação da Petrobras no município de Macaé, porém mais intensamente a partir do final dos anos 1990, com a quebra do monopólio da exploração e produção de petróleo no país e a consequente vinda de empresas petrolíferas e parapetrolíferas, a economia tem-se alicerçado cada vez mais em torno da economia do petróleo, em especial das rendas petrolíferas (royalties e participações especiais).

O município de Macaé é onde se localiza a base de operações das empresas petrolíferas e parapetrolíferas, bem como de um grande número de empresas fornecedoras de insumos para elas. Nesse município, ampliou-se consideravelmente, ao longo das últimas décadas, a oferta de empregos formais com salários acima da média regional. 
Estudos recentes desenvolvidos por Souza, Terra e Campos (2012 e 2015) e Souza e Terra (2015) apresentam, a partir de análises relacionadas à mobilidade populacional (migrações internas e movimentos pendulares), fortes indícios de que as antigas mazelas de nosso histórico de urbanização estão se reproduzindo nos municípios produtores de petróleo da Bacia de Campos. Macaé, onde as políticas públicas são mais voltadas aos interesses das empresas petrolíferas e parapetrolíferas, obedecendo à racionalidade capitalista, é um claro exemplo de cidade que apresenta sérios problemas de saneamento, moradia, violência, congestionamento de tráfego e poluição, entre outros. Além disso, como nos lembra Piquet (2012), as tensões existentes são muitas vezes provocadas por um crescimento dependente de decisões exógenas, que transcendem o local e geram,

[...] de um lado, a riqueza do petróleo, as perspectivas de novos postos de trabalho, o aparecimento de novas empresas; de outro, a população em crescimento exponencial, os problemas sociais, a violência, o déficit dos serviços urbanos e sociais. Não é trivial a avaliação desses impactos, uma vez que sua influência ultrapassa em muito a esfera local/regional e, conforme comentado anteriormente, dada a importância da indústria do petróleo para qualquer país - seja como fonte energética, seja como elemento catalisador de divisas, seja como setor estratégico ou ainda como base de apoio à industrialização -, sua influência dificilmente irá limitar-se a espaços subnacionais (p. 160).

Nesse sentido, a atividade de exploração e produção offshore de petróleo e gás na Bacia de Campos vem, ao longo de quase quarenta anos, e de forma mais significativa nos últimos 18 anos, produzindo uma nova dinâmica territorial, demográfica e socioeconômica no interior do estado do Rio de Janeiro, em especial nas aglomerações urbanas de Campos dos Goytacazes, Macaé e Cabo Frio, identificadas na recente publicação do IBGE Arranjos populacionais e concentraçôes urbanas no Brasil (2015) como casos especiais de formas urbanas a serem acompanhados. Esses novos espaços regionais são incorporados à dinâmica econômica estadual, que se torna dependente do setor de petróleo e gás.

O objetivo deste artigo é discutir a importância da mobilidade populacional para o processo de acumulação capitalista, na Bacia de Campos, à luz das contribuições teóricas de David Havey (2005). Para esta análise, considera-se, principalmente, o Censo Demográfico de 2010, única fonte para estudo das migrações e pendularidade em áreas não metropolitanas.

Para que a análise se torne mais clara, apresentam-se, nas duas primeiras seções, uma breve caracterização da indústria petrolífera brasileira e alguns elementos para a compreensão da geografia da acumulação capitalista. Na terceira seção, analisam-se os fluxos migratórios e pendulares, as características socioeconômicas dos trabalhadores naturais e também daqueles atraídos pelas atividades econômicas desenvolvidas nos municípios da Bacia de Campos, assim como o nível de dependência desses municípios em relação à mão de obra exógena. Nas consideraçôes finais, articula-se a importância da mobilidade populacional para o processo de acumulação capitalista. 


\section{Breve caracterização da indústria petrolífera brasileira}

O petróleo é um insumo de grande importância para a manutenção da atividade econômica mundial. Como as reservas são distribuídas de forma desigual entre os países e entre regiōes de um mesmo país, o custo de produção varia e a competição é acirrada, gerando fortes disputas geopolíticas.

No Brasil, a busca pelo petróleo foi movida não só por fatores econômicos, mas também por uma afirmação de nacionalidade, tanto que, em 1938, a discussão sobre o tema petróleo já se fazia presente e relevante, tendo sido criado, nesse mesmo ano, o Conselho Nacional de Petróleo, que tratou a questão do abastecimento como de utilidade nacional, passando a controlar a produção, o refino e a distribuição.

Em 1939, teve início a produção de petróleo em um dos poços do campo de Lobato, na Bahia. $\mathrm{Na}$ ocasião, o debate se tornou ainda mais acirrado, pois havia uma polêmica quanto ao fato de o governo brasileiro se tornar responsável pela atividade petrolífera no país, além de dúvidas sobre a existência de reservas que justificassem o volume necessário de investimentos. Naquela época, a exploração era realizada no mundo, em grande parte, por empresas norte-americanas, e o debate sobre a necessidade ou não de capital estrangeiro durou até 1953, quando foi criada a Petrobras, no governo de Getulio Vargas, garantindo-se à União o monopólio da pesquisa, da lavra, do refino e do transporte (Farias, 2003, p. 17).

Caetano Filho (2003, p. 45) aponta que houve períodos em que a exploração de petróleo não era economicamente viável, devido ao preço internacional do barril. Mesmo assim, visóes equilibradas e não apequenadas fizeram com que os investimentos continuassem a ser feitos, com vistas a conquistar domínio tecnológico nesse setor tão estratégico para o país. A decisão se mostrou acertada quando, em 1973, com a primeira crise do petróleo, o preço do barril mais que dobrou no mercado internacional.

À época, despontava a produção da Bacia de Campos, atualmente reconhecida como a maior bacia petrolífera do país, transformando os municípios produtores do estado do Rio de Janeiro nos maiores recebedores de royalties e participações especiais, o que gerou crescente polarização e concentração de recursos nos municípios litorâneos do Norte Fluminense e das Baixadas Litorâneas, em especial a partir da Lei do Petróleo, de 1997. Foi essa legislação que ampliou a alíquota dos royalties de $5 \%$ para até $10 \%$, flexibilizando o monopólio de exploração e produção de petróleo, e permitindo a entrada de outras petroleiras, através da adoção do modelo de concessão em exploração e produção.

A indústria petrolífera exige uma variedade de tecnologias nas fases de perfuração e sondagem, atividades de grande complexidade tecnológica para a exploração e a produção, bem como conhecimentos em áreas multidisciplinares. Apresenta dois importantes segmentos, ambos apresentando atividades intensivas em capital, denominados upstream (fases de exploração, desenvolvimento e produção) e downstream (transporte, refino e distribuição).

As empresas que atuam nesses segmentos apresentam portes diversificados, sendo que as petroleiras (oil companies) desempenham papel central, tornando-se responsáveis pela contratação de serviços como os de sísmica, perfuração e produção; também contratam outras empresas altamente 
especializadas que, devido ao nível de sofisticação tecnológica necessário nas operações, pertencem, em sua maioria, a importantes oligopólios internacionais (Piquet e Terra, 2011).

Percebe-se a existência de uma nítida divisão de mercado nesse setor. As pequenas e médias empresas, de âmbito local/regional, inserem-se de forma subalterna, ofertando uma variedade de produtos e serviços de baixo conteúdo tecnológico, enquanto as empresas transnacionais executam tarefas mais rentáveis e sofisticadas. Essa divisão também existe no mercado de trabalho, como se verá adiante.

A rede logística perpassa a escala local, sendo de fundamental importância para a atividade, pois demanda melhorias e adequação no sistema de transporte, seja para o escoamento da produção, seja para as demandas de equipamentos e peças voltados à própria atividade de exploração e produção, favorecendo, dessa forma, ainda que indiretamente, o deslocamento da mão de obra, essencial ao processo de acumulação capitalista nesse espaço.

Além das melhorias anteriores impostas pela atividade, percebe-se, nos municípios que integram a Bacia de Campos, uma ampliação do sistema de telecomunicações, provedores de internet e linhas telefônicas, o que se torna típico dessa fase de compressão do tempo-espaço. Apoiado nas redes de telecomunicações, nos avanços na rede de transporte e na expansão do mercado de trabalho, trabalhadores de alta e baixa qualificação do próprio estado e dos demais estados brasileiros, e até mesmo trabalhadores internacionais altamente qualificados, são atraídos para a região.

Em 2007, o Brasil entrou em uma nova etapa no setor petrolífero. A Petrobras confirmou a existência de uma grande jazida de petróleo na Bacia de Santos, na camada pré-sal, com potencial para ampliar em até $40 \%$ a extração de petróleo no país. Nesse contexto, diante da expectativa de se ampliar a produção de petróleo e gás, foi proposto um novo marco regulatório para o setor, destacando-se a alteração do modelo de concessão para o de partilha de produção no caso dos contratos de exploração e produção nas áreas ainda não licitadas do polígono do pré-sal, acreditando-se que o novo modelo estaria mais afeito à preservação do interesse nacional, mediante a maior participação nos resultados e o maior controle da riqueza gerada. Assim, a partir de 2010, o Brasil passou a contar com um modelo misto de exploração e produção de petróleo e gás (Terra et al., 2014).

Segundo dados da ANP (2015), em 2014, o Brasil alcançou reservas provadas de petróleo de 16,2 bilhōes de barris, com 13,2 bilhōes dos barris localizados no estado do Rio de Janeiro, ou seja, $81,5 \%$ das reservas de petróleo provadas do Brasil encontram-se nesse estado da federação. Já a produção de petróleo brasileira atingiu 822,9 milhões de barris nesse mesmo ano, sendo o estado do Rio de Janeiro responsável por 563,2 milhões, ou seja, 68,4\% da produção de petróleo nacional. Esses dados revelam a importância presente e futura desse setor para a economia do estado do Rio de Janeiro.

No entanto, levando-se em conta a queda do preço do barril de petróleo no mercado internacional e os problemas atualmente enfrentados pela Petrobras, com o desdobramento da Operação Lava-Jato, está havendo mudanças significativas tanto na capacidade de investimentos diretos e indiretos como no mercado de trabalho desse setor. 


\section{Contribuições da geografia da acumulação capitalista}

A abordagem elaborada por Harvey (2001 [1975]) pode ser útil para nosso entendimento acerca das contradiçôes impostas pelo peso da atividade petrolífera na economia do estado do Rio de Janeiro. Isso porque essa teoria nos ajudaa a refletir e analisar as contradiçôes inerentes às atividades de exploração e produção de petróleo no território fluminense, pois o petróleo, como afirma Costa (2012),

[...] é o maior e mais disseminado negócio, a maior entre as maiores indústrias que se desenvolveram nas últimas décadas do século XIX. Nenhum outro negócio determina de maneira tão completa e radical o significado do risco e da recompensa, e o profundo impacto da oportunidade e do destino (p. 55).

A geografia da acumulação nos traz elementos para compreender as contradições existentes no próprio capitalismo, com seus aspectos de destruição e preservação. Essas contradiçôes é que promovem a dinâmica da circulação e a permanente necessidade de reduzir o tempo de circulação do capital, o que justifica os constantes investimentos em comunicações e transportes, com foco principal no comércio exterior, promovendo a evolução da formação social capitalista para diferentes fronteiras.

Harvey estabelece algumas categorias de análise e articula a teoria da acumulação capitalista, elaborada por Marx, com a dimensão espacial. Segundo Harvey, a necessidade de acumulação implica, consequentemente, a superação das barreiras espaciais. Dessa forma, estimula formas mais baratas e rápidas de comunicação e transporte, auxiliando a inserção de novos espaços para acumulação de capital. De modo recíproco, a acumulação de capital busca ser "geograficamente expansível", resultando em crescente redução do custo de comunicação e transporte. No entanto, como nos adverte, é necessário promover melhora na velocidade de circulação do capital para compensar o acesso a mercados mais distantes e o aumento de seu tempo de giro. Para Harvey (2005, p. 53), “a expansão geográfica e a concentração geográfica são ambas consideradas produtos do mesmo esforço de criar novas oportunidades para a acumulação de capital”. A própria estrutura espacial que surge com o processo capitalista de produção não está isenta de contradições, agindo também como barreira para a acumulação adicional. Isso se deve à crescente dependência do capitalismo ao capital fixo.

Essa paisagem geográfica, que contempla o capital fixo e imobilizado, pode ser vista como valor de uso e incentivadora da acumulação de capital, e também como "inibidora do progresso adicional de acumulação". Isso se deve à própria contradição e à tensão inerentes ao modo capitalista de produção, que "precisa superar o delicado equilíbrio entre preservar o valor dos investimentos passados de capital na construção do ambiente e destruir esses investimentos para abrir espaço novo para a acumulação" (idem, p. 54).

Outro elemento analisado é o crescimento do comércio exterior impulsionado pelo modo capitalista de produção. Para Marx, segundo Harvey (2005), o comércio exterior é, ao mesmo tempo, uma condição prévia para a acumulação capitalista e consequência da expansão do mercado. Além disso, sugere que a tendência histórica do capitalismo "é destruir e absorver modos de produção não capitalistas", concomitantemente à sua utilização para gerar novos espaços de acumulação do capital. A forma como as relações sociais capitalistas se inserem nas economias não capitalistas se dá pela ge- 
ração e a perpetuação do atraso e do subdesenvolvimento, refutando-se, portanto, a ideia de que, no capitalismo, é possível atingir um desenvolvimento equilibrado das diferentes esferas de produção, resultando em melhora de vida para a maior parte da população.

Ao contrário, o desenvolvimento capitalista desigual, ao induzir a expansão geográfica em escala global, gera, como subproduto, o desenvolvimento desigual da luta de classes. Como aponta Harvey (idem, p. 71), "o caminho da acumulação capitalista seguirá por onde a resistência for mais fraca" e mostra como Marx é enfático ao tratar o capital como um processo de circulação entre produção e realização.

Esse processo deve se expandir, acumular, reformar constantemente o processo de trabalho e os relacionamentos sociais na produção, assim como mudar constantemente as dimensões e as formas de circulação. Marx ajuda a entender esses processos teoricamente. No entanto, no fim, temos que fazer essa teoria se relacionar com situaçôes existentes na estrutura das relações sociais capitalistas desse momento da história. [...] Elaborar e reelaborar a teoria da acumulação de Marx como totalidade, numa escala geográfica expansível, requer essa inserção (Harvey, 2005, p.7).

\section{A mobilidade populacional na Bacia de Campos}

Apesar dos vários elementos apontados por Harvey (2005) - transformação das estruturas espaciais e do mercado de trabalho, variações dos investimentos fixos e imobilizados, transformação da paisagem geográfica, criada para permitir a acumulação por meio da produção e da circulação -, optou-se, neste artigo, por compreender o papel da mobilidade populacional - migrações internas e pendularidade -, grande parte direcionada ao atendimento da demanda do mercado de trabalho, por entendê-la de fundamental importância para o processo de acumulação capitalista no setor de petróleo e gás na Bacia de Campos.

O estado do Rio de Janeiro, que, em 1991, tinha uma população de 12.807.195 habitantes, atingiu, em 2010, uma população de 15.989.929 habitantes, tendo experimentado uma taxa de crescimento médio anual da ordem de 1,33\% entre 1991-2000 e de 1,06\% entre 2000-2010 (Tabela 1). O baixo ritmo de crescimento da população estadual se explica, por um lado, pela redução da fecundidade - que, em 2005, segundo o IBGE (2009), encontrava-se significativamente abaixo do nível de reposição e em torno de 1,8 filho por mulher no final do período reprodutivo - e, por outro lado, pela mudança no padrão migratório brasileiro. 
Tabela 1. Rio de Janeiro: população, taxa de crescimento médio anual e participação relativa no incremento absoluto, por mesorregião (1991-2010)

\begin{tabular}{|c|c|c|c|c|c|c|c|c|c|c|}
\hline \multirow{3}{*}{ Mesorregião } & \multicolumn{6}{|c|}{ População } & \multicolumn{2}{|c|}{$\begin{array}{c}\text { Taxa de } \\
\text { Crescimento }\end{array}$} & \multicolumn{2}{|c|}{$\begin{array}{c}\text { Participação } \\
\text { relativa no } \\
\text { incremento absoluto }\end{array}$} \\
\hline & \multicolumn{2}{|l|}{1991} & \multicolumn{2}{|l|}{2000} & \multicolumn{2}{|l|}{2010} & \multirow{2}{*}{$\begin{array}{c}1991 \text { - } \\
2000\end{array}$} & \multirow{2}{*}{$\begin{array}{c}2000- \\
2010\end{array}$} & \multirow{2}{*}{$\begin{array}{c}1991- \\
2000\end{array}$} & \multirow{2}{*}{$\begin{array}{c}2000- \\
2010\end{array}$} \\
\hline & Absoluto & $\%$ & 2000 & $\%$ & 2010 & $\%$ & & & & \\
\hline$\overline{\text { Noroeste }}$ & 273.062 & 2,1 & 297.837 & 2,1 & 317.493 & 2,0 & $\overline{1,0}$ & $\overline{0,6}$ & 1,6 & $\overline{1,2}$ \\
\hline Norte & 611.576 & 4,8 & 699.292 & 4,9 & 849.515 & 5,3 & 1,5 & 2,0 & 5,5 & 9,4 \\
\hline Centro & 425.375 & 3,3 & 452.646 & 3,1 & 481.357 & 3,0 & 0,7 & 0,6 & 1,7 & 1,8 \\
\hline Baixadas & 303.989 & 2,4 & 462.325 & 3,2 & 700.842 & 4,4 & 4,9 & 4,2 & 10,0 & 14,9 \\
\hline Metropolitana & 10.389 .441 & 81,1 & 11.546 .023 & 80,2 & 12.578 .485 & 78,7 & 1,2 & 0,9 & 73,0 & 64,6 \\
\hline Sul & 803.752 & 6,3 & 933.983 & 6,5 & 1.062 .237 & 6,6 & 1,7 & 1,3 & 8,2 & 8,0 \\
\hline Rio de Janeiro & 12.807.195 & 100,0 & 14.392 .106 & 100,0 & 15.989 .929 & 100,0 & 1,3 & 1,1 & 100,00 & 100,00 \\
\hline
\end{tabular}

Fonte: IBGE - Censos Demográficos, 1991, 2000 e 2010.

Segundo Brito (2002), no contexto das migraçóes internas no Brasil, nos anos 1940-1950, 1950-1960 e 1960-1970, o Rio de Janeiro destacava-se, ao lado de São Paulo, do Paraná e da região Centro-Oeste, entre as principais áreas de atração populacional. Porém, como empiricamente demonstrado pelo autor, o estado foi perdendo seu poder de atração populacional, principalmente em decorrência da perda relativa de dinamismo econômico. De acordo com dados de migração de última etapa, apresentados pelo autor, entre 1960-1970 o saldo migratório estadual foi da ordem de 1.030.464 indivíduos, reduzindo-se para 392.614 imigrantes entre 1970-1980 e chegando a apresentar saldo migratório negativo, estimado em -44.100 indivíduos, entre 1981-1991.

Considerando os quesitos de migração nos Censos Demográficos de 2000 e 2010, estimaram-se indicadores da migração de última etapa para o estado do Rio de Janeiro, cujos resultados estão dispostos na Tabela 2. Nas décadas de 1990 e 2000, o Rio atraiu pouco mais de 6\% dos imigrantes internos, não mais se destacando entre as principais áreas de atração populacional. Assim, se, por um lado, o estado voltou a apresentar saldos migratórios positivos, por outro é preciso considerar que são reduzidos e que o impacto dos movimentos migratórios sobre o ritmo de crescimento populacional estadual, dado pela Taxa Líquida de Migração, também é baixo e, inclusive, decrescente. 
Tabela 2. Rio de Janeiro: indicadores da migração interestadual (1990-2000 e 2000-2010)

\begin{tabular}{|l|r|r|r|r|}
\hline Período & Imigrantes & Emigrantes & $\begin{array}{c}\text { Saldo } \\
\text { migratório }\end{array}$ & $\begin{array}{c}\text { Taxa Líquida } \\
\text { de Migração }\end{array}$ \\
\hline $1991-2000$ & 749.087 & 620.496 & 128.591 & 0,89 \\
$2000-2010$ & 676.527 & 565.777 & 110.750 & 0,69 \\
\hline
\end{tabular}

Fonte: IBGE - Censos Demográficos, 2000 e 2010.

Internamente, os ritmos de crescimento populacional variam de modo significativo entre as mesorregiōes de planejamento. Como se pode notar na Tabela 1, a mesorregião Metropolitana, apesar de concentrar a maior parcela da população $(78,67 \%$, em 2010$)$ e de ser a maior responsável pelo incremento absoluto da população estadual (64,62\%, em 2010), é a que cresce mais lentamente (0,86\%, entre 2000-2010). O Centro e o Noroeste Fluminense também apresentaram crescimento populacional reduzido $(0,62 \%$ e $0,64 \%$, respectivamente, entre $2000-2010)$, mas, diferentemente da mesorregião Metropolitana, contribuíram apenas infimamente para o incremento absoluto e concentraram apenas uma parcela irrisória da população estadual.

A Baixada Litorânea é a mesorregião de crescimento populacional mais acelerado. Entre 19912000, sua taxa média anual de crescimento foi da ordem de 4,86\%, reduzindo-se (mas, ainda assim, permanecendo elevada) para 4,25\% no período 2000-2010. Sua participação relativa no incremento absoluto subiu de 9,99\%, entre 1991-2000, para 14,93\%, entre 2000-2010. Também se destacam pelos ritmos de crescimento as mesorregiōes Sul e Norte Fluminense. Note, no entanto, o arrefecimento do ritmo de crescimento do Sul - de 1,71\%, entre 1991-2000, para 1,30\% entre 2000-2010 - e o recrudescimento do ritmo de crescimento do Norte, de 1,53\% para 1,97\%.

Como se pode notar na Figura 1, a maioria dos municípios fluminenses apresentou, entre 20002010, taxas de crescimento bastante baixas, ressaltando-se que sete deles - Cantagalo e Santa Maria Madalena no Centro; Itaocara, Laje do Muriaé, Miracema e Natividade, no Noroeste; e São Francisco do Itabapoana, no Norte - apresentaram taxas negativas, ou seja, reduziram sua população em termos absolutos. Observe, ainda, que a principal frente de expansão urbana concentra-se, atualmente, na faixa litorânea norte, estendendo-se de Maricá, na mesorregião Metropolitana, a Quissamã, no Norte Fluminense. 
Figura 1. Rio de Janeiro: taxas de crescimento populacional médio anual, segundo o município (2000-2010)

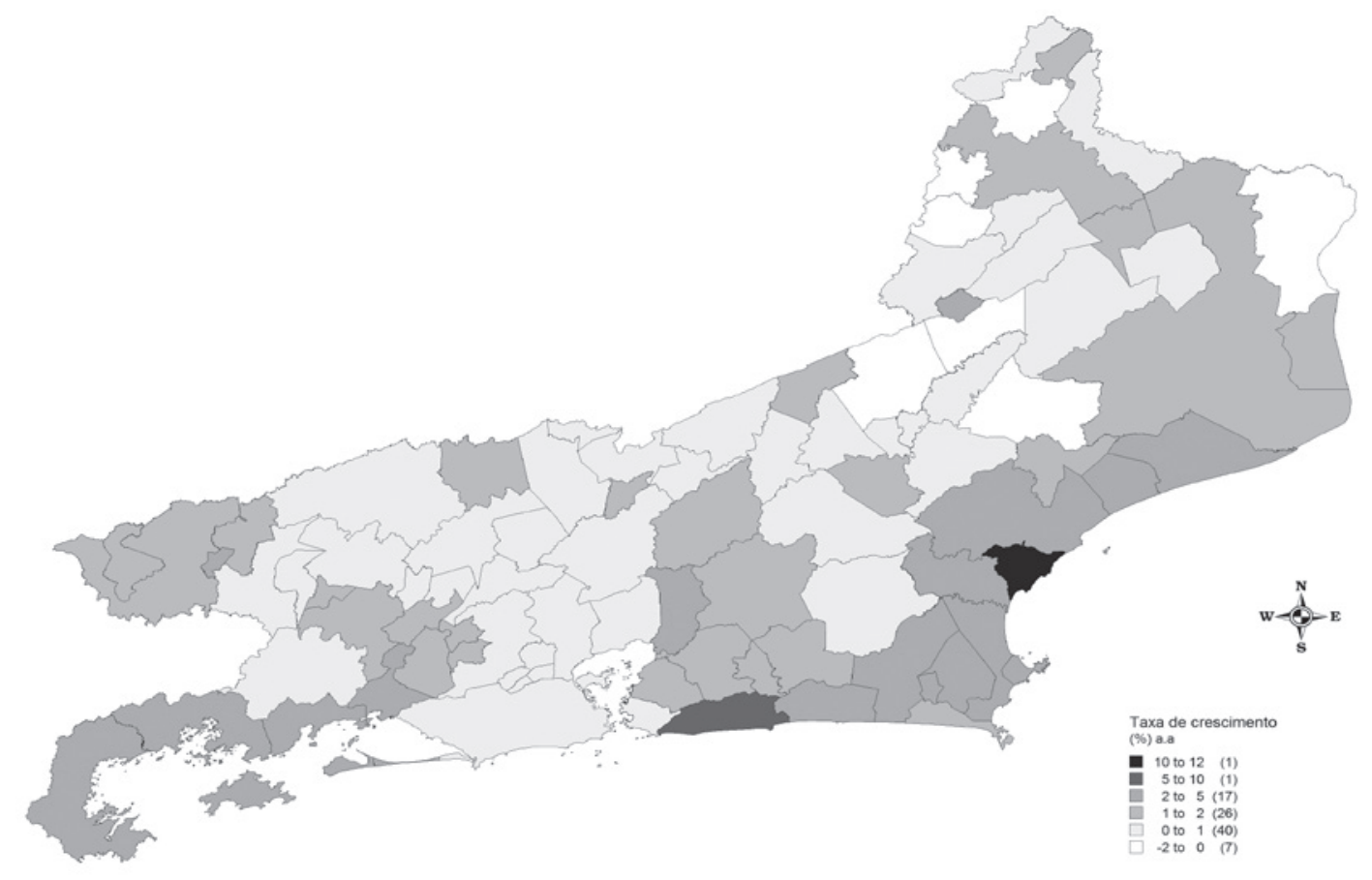

Fonte: IBGE - Censo Demográfico, 2000 e 2010.

Como se pretende analisar a reprodução do capital sob a ótica da geografia da acumulação, entre os municípios localizados na principal faixa de expansão urbana, interessa-nos particularmente aqueles considerados produtores de petróleo, quais sejam: Arraial do Cabo, Armação dos Búzios e Cabo Frio, na aglomeração urbana de Cabo Frio; Macaé, Carapebus, Casimiro de Abreu e Rio das Ostras, na aglomeração urbana de Macaé; e Campos e São João da Barra, na aglomeração urbana de Campos dos Goytacazes. Ficaram excluídos os municípios não produtores: São Pedro da Aldeia e Conceição de Macabu, nas aglomeraçôes urbanas de Cabo Frio e Macaé, respectivamente.

$\mathrm{Na}$ Tabela 3, é possível observar os ritmos de crescimento dos municípios selecionados, assim como a distribuição espacial da população e a participação relativa de cada município no incremento absoluto dessa grande extensão urbana. Note-se que mesmo aqueles municípios com ritmos de crescimento populacional mais lento cresceram a uma taxa superior à média estadual, e que os municípios que mais contribuem para o crescimento acelerado dessa expansão urbana são Macaé (24,6\%), Rio das Ostras (22,9\%), Cabo Frio (19,7\%) e Campos dos Goytacazes (18,7\%). O incremento populacional desses municípios explica praticamente $86 \%$ do incremento populacional de toda essa extensão urbana e é justamente neles que se concentram, praticamente, $86 \%$ da população residente, ressaltando que, em 2010, 41,4\% da população residia em apenas um município: Campos dos Goytacazes. 
Tabela 3. Municípios selecionados: população, taxa de crescimento e participação relativa no incremento absoluto (2000-2010)

\begin{tabular}{|c|c|c|c|c|c|c|}
\hline \multirow{2}{*}{ Municípios Selecionados } & \multicolumn{4}{|c|}{ População } & \multirow{2}{*}{$\begin{array}{c}\text { Taxa de } \\
\text { crescimento } \\
(2000-2010)\end{array}$} & \multirow{2}{*}{$\begin{array}{l}\text { Participação } \\
\text { relativa no } \\
\text { incremento }\end{array}$} \\
\hline & 2000 & $\%$ & 2010 & $\%$ & & \\
\hline Armação dos Búzios & 18.204 & 2,2 & 27.560 & 2,5 & 4,2 & 3,1 \\
\hline Arraial do Cabo & 23.877 & 2,9 & 27.715 & 2,5 & 1,5 & 1,3 \\
\hline Cabo Frio & 126.828 & 15,5 & 186.227 & 16,6 & 3,9 & 19,7 \\
\hline Carapebus & 8.666 & 1,1 & 13.359 & 1,2 & 4,4 & 1,6 \\
\hline Campos dos Goytacazes & 407.168 & 49,8 & 463.731 & 41,4 & 1,3 & 18,7 \\
\hline Casimiro de Abreu & 22.152 & 2,7 & 35.347 & 3,2 & 4,8 & 4,4 \\
\hline Macaé & 132.461 & 16,2 & 206.728 & 18,5 & 4,6 & 24,6 \\
\hline Quissamã & 13.674 & 1,7 & 20.242 & 1,8 & 4,0 & 2,2 \\
\hline Rio das Ostras & 36.419 & 4,5 & 105.676 & 9,4 & 11,2 & 22,9 \\
\hline São João da Barra & 27.682 & 3,4 & 32.747 & 2,9 & 1,7 & 1,7 \\
\hline Total & 817.131 & 100,0 & 1.119 .332 & 100,0 & 3,2 & 100,0 \\
\hline
\end{tabular}

Fonte: IBGE - Censos Demográficos, 2000 e 2010.

Como se mencionou, há uma influência significativa dos movimentos migratórios na definição dessa área de expansão urbana e nos ritmos de crescimento populacional desses municípios.

Para analisarmos as migrações interestaduais, identificamos, nos Censos Demográficos das UFs brasileiras (exclusive Rio de Janeiro) e do Distrito Federal, os emigrantes dos municípios selecionados, ou seja, todos os indivíduos que, no momento do recenseamento, informaram um dos municípios selecionados como o de residência anterior e, no Censo Demográfico do Rio de Janeiro, os imigrantes, ou seja, todos os indivíduos que, no momento do recenseamento, informaram como residência anterior algum município de outro estado brasileiro ou do Distrito Federal. Os resultados encontram-se sumarizados na Tabela 4.

Tabela 4. Municípios selecionados: indicadores das migrações interestaduais (2000-2010)

\begin{tabular}{|l|r|r|r|r|}
\hline \multirow{2}{*}{ Municípios selecionados } & \multicolumn{4}{|c|}{ Migração Interestadual } \\
\cline { 2 - 6 } & \multicolumn{1}{|c|}{$\mathrm{I}$} & \multicolumn{1}{c|}{ E } & \multicolumn{1}{c|}{ SM } & \multicolumn{1}{c|}{ TLM } \\
\hline Armação dos Búzios & 2.319 & 830 & 1.489 & 5,4 \\
Arraial do Cabo & 1.271 & 593 & 678 & 2,4 \\
Cabo Frio & 12.350 & 4.351 & 7.999 & 4,3 \\
Carapebus & 577 & 39 & 538 & 4,0 \\
Campos dos Goytacazes & 10.016 & 6.697 & 3.319 & 0,7 \\
Casimiro de Abreu & 1.967 & 293 & 1.674 & 4,7 \\
Macaé & 25.216 & 6.614 & 18.602 & 9,0 \\
Quissamã & 528 & 74 & 454 & 2,2 \\
Rio das Ostras & 11.887 & 2.073 & 9.814 & 9,3 \\
São João da Barra & 1.378 & 119 & 1.259 & 3,8 \\
Total & 67.509 & 21.683 & 45.826 & 4,1 \\
\hline
\end{tabular}

Fonte: IBGE - Censo Demográfico (2010). 
No contexto das migraçōes interestaduais, esses municípios receberam, no período 2000-2010, um total de 67.509 imigrantes e perderam para outras UFs e o Distrito Federal um total de 21.683 habitantes, portanto o saldo migratório apresentou-se positivo e da ordem de 45.826 pessoas. Entre os municípios que mais atraíram imigrantes, destacam-se: Macaé (37,4\%), Cabo Frio $(18,3 \%)$, Rio das Ostras (17,6\%) e Campos dos Goytacazes (14,6\%), respectivamente. Esses mesmos municípios se destacam também como os maiores expulsores de população na seguinte ordem: Campos dos Goytacazes (30,9\%), Macaé (30,5\%), Cabo Frio (20,1\%) e Rio das Ostras (9,6\%).

Ainda no contexto das migraçôes interestaduais, é importante ressaltar que todos os municípios apresentaram saldos migratórios positivos e que as migraçōes internas exerceram, naquele período, notável influência no crescimento populacional de Rio das Ostras (9,3\%), Macaé (9,0\%), Armação dos Búzios (5,4\%) e Casimiro de Abreu (4,7\%).

Para analisarmos a influência das migraçóes intraestaduais nesse processo, confeccionamos duas matrizes origem-destino, levando em conta: (1) apenas as trocas populacionais entre os municípios selecionados; (2) as trocas populacionais entre eles e os demais municípios fluminenses. Os resultados encontram-se sumarizados na Tabela 5, e estão divididos conforme os tipos - (1) e (2) antes definidos.

Tabela 5. Municípios selecionados: indicadores das migraçôes intraestaduais (2000-2010)

\begin{tabular}{|c|c|c|c|c|c|c|c|c|c|c|c|c|}
\hline \multirow{2}{*}{ Municípios selecionados } & \multicolumn{4}{|c|}{ Migração Intraestadual (1) } & \multicolumn{4}{|c|}{ Migração Intraestadual (2) } & \multicolumn{4}{|c|}{ Migração Intraestadual Total } \\
\hline & $\mathrm{I}$ & $\mathrm{E}$ & SM & TLM & $\mathrm{I}$ & $\mathrm{E}$ & $\mathrm{SM}$ & TLM & $\mathrm{I}$ & $\mathrm{E}$ & $\mathrm{SM}$ & TLM \\
\hline Armação dos Búzios & 1.698 & 1.036 & 662 & 2,4 & 4.412 & 1.358 & 3.054 & 11,1 & 6.110 & 2.394 & 3.716 & 13,5 \\
\hline Arraial do Cabo & 1.277 & 1.259 & 18 & 0,1 & 4.579 & 1.635 & 2.944 & 10,6 & 5.856 & 2.894 & 2.962 & 10,7 \\
\hline Cabo Frio & 6.401 & 4.742 & 1.659 & 0,9 & 36.213 & 14.612 & 21.601 & 11,6 & 42.614 & 19.354 & 23.260 & 12,5 \\
\hline Carapebus & 1.535 & 531 & 1.004 & 7,5 & 1.255 & 177 & 1.078 & 8,1 & 2.790 & 708 & 2.082 & 15,6 \\
\hline Campos dos Goytacazes & 4.531 & 18.141 & -13.610 & $-2,9$ & 13.006 & 14.461 & -1.455 & $-0,3$ & 17.537 & 32.602 & -15.065 & $-3,2$ \\
\hline Casimiro de Abreu & 2.873 & 2.087 & 786 & 2,2 & 7.280 & 1.475 & 8.045 & 22,8 & 10.153 & 1.322 & 8.831 & 25,0 \\
\hline Macaé & 9.137 & 10.544 & -1.407 & $-0,7$ & 23.202 & 8.565 & 14.637 & 7,1 & 32.339 & 19.109 & 13.230 & 6,4 \\
\hline Quissamã & 1.480 & 672 & 808 & 4,0 & 1.820 & 487 & 1.333 & 6,6 & 3.300 & 1.159 & 2.141 & 10,6 \\
\hline Rio das Ostras & 11.868 & 3.551 & 8.317 & 7,9 & 36.566 & 3.781 & 32.785 & 31,0 & 48.434 & 7.332 & 41.102 & 38,9 \\
\hline São João da Barra & 2.976 & 1.213 & 1.763 & 5,4 & 1.191 & 352 & 839 & 2,6 & 4.167 & 1.565 & 2.602 & 7,9 \\
\hline Total & 43.776 & 43.776 & 0 & 0,0 & 129.524 & 46.903 & 84.861 & 7,6 & 173.300 & 88.439 & 84.861 & 7,6 \\
\hline
\end{tabular}

Fonte: IBGE - Censo Demográfico (2010).

Como era de se esperar, as migrações intraestaduais têm uma importância significativamente maior no processo de expansão desses municípios dos respectivos aglomerados urbanos e, consequentemente, sobre o processo de acumulação capitalista na Bacia de Campos. Se, por um lado, as mudanças de residência observadas entre os municípios selecionados, estimadas em 43.776 indivíduos para o período 2000-2010, não implicam ganho populacional líquido para essa extensão urbana como um todo, por outro lado é preciso salientar seu papel na redistribuição espacial da população residente. Isso ocorre como reflexo dos processos internos de seletividade populacional, de seletividade migratória e da dinâmica dos mercados imobiliários e de trabalho, assim como de algum processo, ainda que incipiente, de especialização dos espaços urbanos municipais, no contexto dos aglomerados urbanos. Os fluxos migratórios entre os municípios selecionados podem ser observados na Matriz Origem-Destino 1. 
Matriz Origem-Destino 1. Municípios selecionados: fluxos migratórios de última etapa (2000-2010)

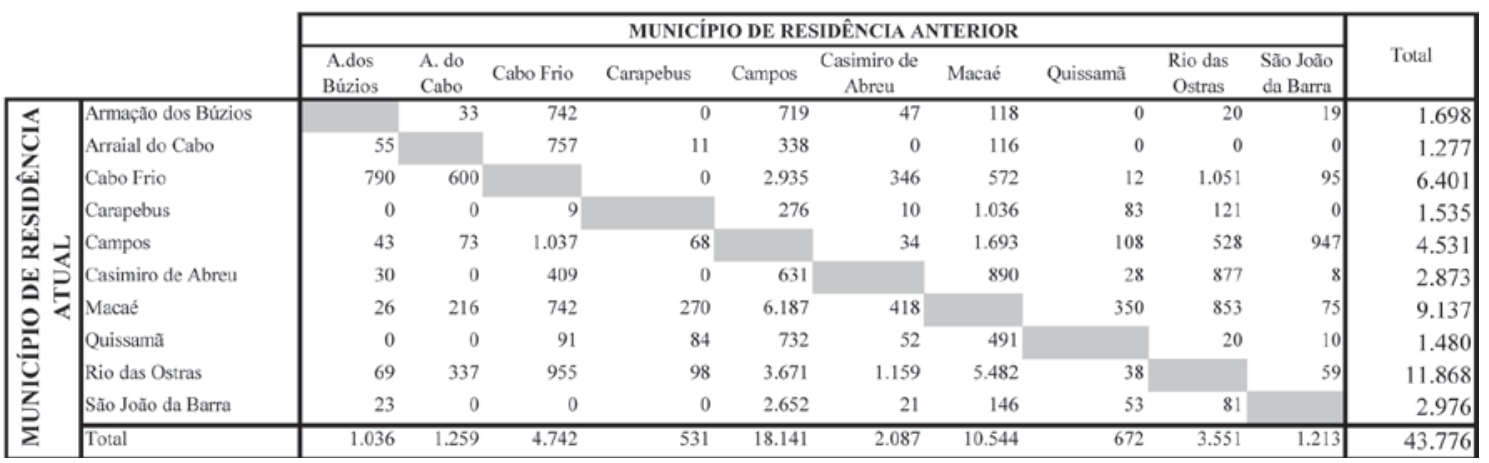

Fonte: IBGE - Censo Demográfico, 2010.

No contexto intrarregional (Matriz Origem-Destino 1), Campos dos Goytacazes e Macaé aparecem como fornecedores líquidos de população, e os demais municípios, notadamente Rio das Ostras, São João da Barra, Cabo Frio e Carapebus, aparecem como receptores líquidos. Ressalte-se que os maiores impactos dessas mudanças de residência sobre os ritmos de crescimento municipais se verificam em Rio das Ostras, Carapebus e Quissamã, nas proximidades de Macaé; e em São João da Barra, limítrofe a Campos.

Considerando-se as mudanças de residência entre os municípios selecionados e os demais municípios fluminenses, o Censo Demográfico de 2010, cujos resultados estão apresentados na Tabela 5, indica um total de 129.524 imigrantes, 46.903 emigrantes e um ganho populacional líquido da ordem de 84.861 indivíduos. Como principais destinos, destacam-se: Rio das Ostras $(28,2 \%)$, Cabo Frio (28,0\%), Macaé (17,0\%) e Campos dos Goytacazes (10,0\%). Esses mesmos municípios destacam-se entre as principais origens emigratórias.

Nas últimas colunas da Tabela 5, é possível analisar as migrações intraestaduais totais. Apenas Campos dos Goytacazes apresenta saldo migratório negativo e, inclusive, bastante elevado (-15.065 habitantes), o que indica que, nesse município, os movimentos migratórios, ao contrário do senso comum, têm contribuído para arrefecer seu ritmo de crescimento. Para os demais municípios, fica evidente, tendo em vista a magnitude das Taxas Líquidas de Migração (TLM), o papel das migraçóes intraestaduais para a aceleração do crescimento populacional, sendo Rio das Ostras e Casimiro de Abreu os casos mais notáveis. A TLM indica que, em 2010, a população de Rio das Ostras encontrava-se em torno de $48 \%$ maior do que aquela que seria verificada na ausência de movimentos migratórios intraestaduais; para Casimiro de Abreu, esse valor ficou em torno de $25 \%$.

Em termos globais, as aglomerações urbanas estudadas receberam, no período de 2000 a 2010, 240.809 imigrantes e registraram um total de 110.122 emigrantes. Em termos líquidos, essa extensão urbana recebeu 130.687 novos habitantes. Os saldos migratórios totais e a influência das migrações sobre os ritmos de crescimento populacional podem ser apreciados nas Figuras 2 e 3 , respectivamente. 
A importância da mobilidade populacional para a acumulação capitalista

Figura 2. Municípios selecionados: saldo migratório de última etapa (2010)

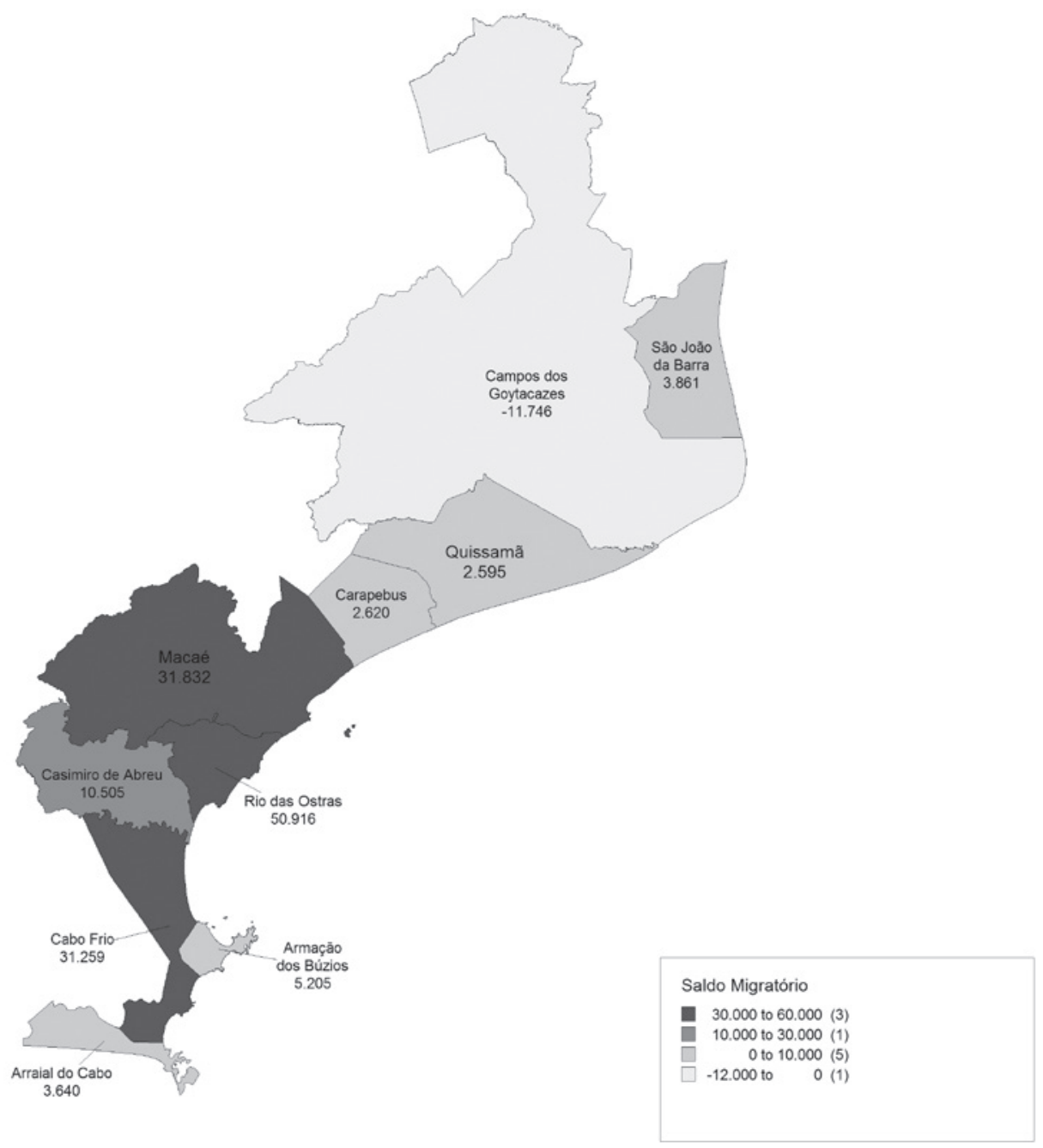

Fonte: IBGE - Censo Demográfico, 2010.

Note-se, na Figura 3, que, à exceção de Campos dos Goytacazes, as migrações são de fundamental importância para a definição do ritmo de crescimento populacional dos municípios e, portanto, para toda a extensão urbana. 
Figura 3. Municípios selecionados: taxa líquida de migração (2010)

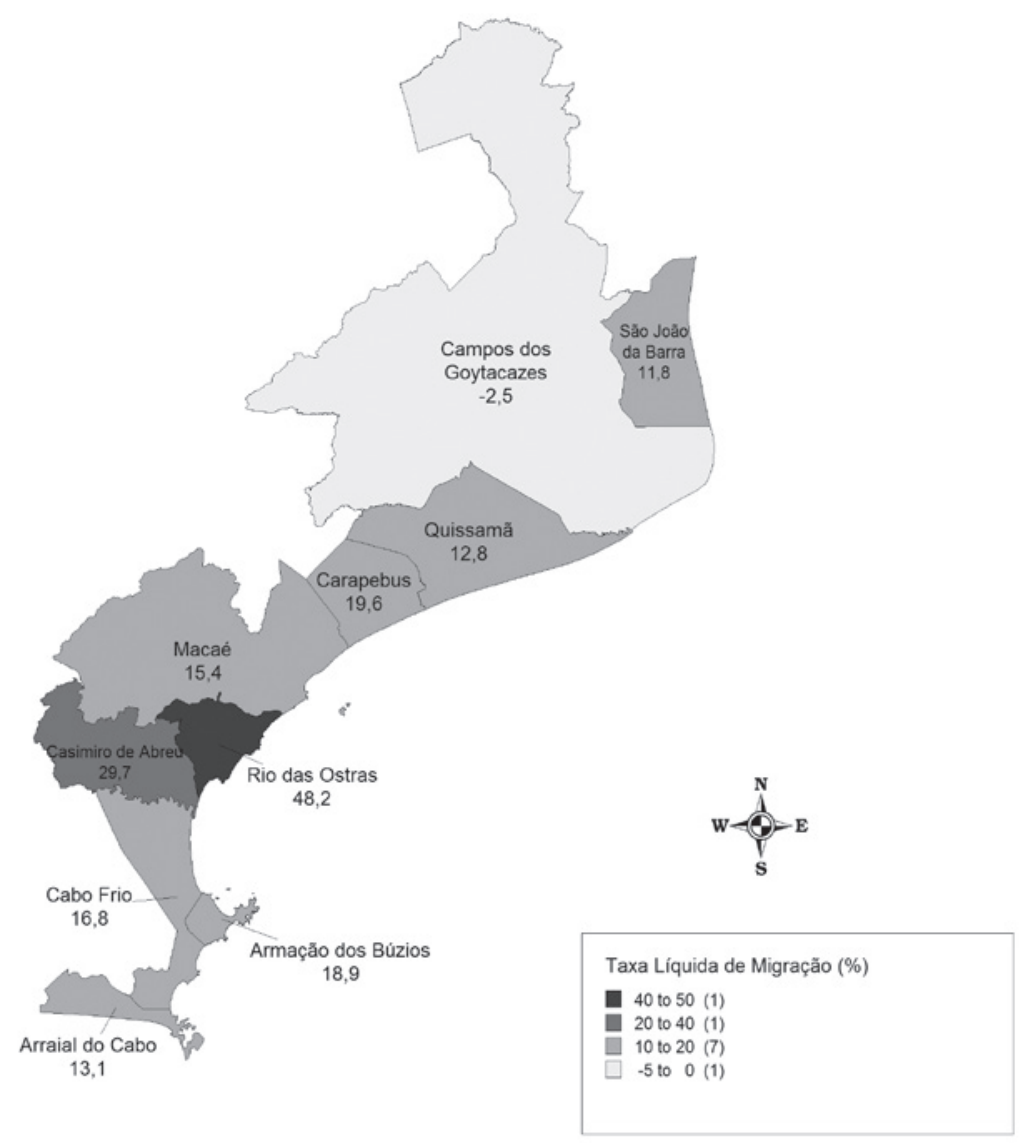

Fonte: IBGE - Censo Demográfico, 2010.

Campos dos Goytacazes, o maior município em extensão territorial do estado do Rio de Janeiro e o maior beneficiário das rendas petrolíferas (royalties e participaçôes especiais), é um caso curioso: apresenta saldo migratório positivo, no contexto das migrações interestaduais, mas, em função das migraçôes intraestaduais, significativamente mais volumosas, o saldo migratório total do município é, diferentemente do que acredita o senso comum, negativo e elevado (da ordem de 11.746 indivíduos).

Outro caso interessante é o de Macaé, base de operaçōes da Petrobras e das demais empresas petrolíferas e parapetrolíferas: apesar de apresentar um saldo migratório total positivo e inclusive bastante elevado, o saldo migratório negativo em relação aos demais municípios selecionados sugere uma seletividade migratória, impulsionada, por um lado, pelo mercado imobiliário do próprio município, caracterizado pelo alto preço da terra, e, por outro, pelos mercados imobiliários de Rio das Ostras, Casimiro de Abreu e Carapebus, que ainda praticam preços relativamente mais baixos. Além disso, a realização de investimentos na estrutura viária que liga esses municípios favorece a emigração nessas 


\section{A importância da mobilidade populacional para a acumulação capitalista}

direções, na medida em que permite a realização do movimento pendular por motivo de trabalho, em espaço de tempo relativamente curto.

Cabo Frio, município turístico na Região dos Lagos, mas na Franja Metropolitana, também apresentou saldo migratório positivo elevado. Nesse caso, o setor de serviços, principalmente as possibilidades de emprego no setor de turismo, atrai muitos imigrantes. Também se aplicam a essa mesma situação os municípios de Armação dos Búzios e Arraial do Cabo.

Finalmente, cabe mencionar o caso do município de Rio das Ostras, que já se encontra conurbado a Macaé. No limite entre esses municípios, mas no território de Rio das Ostras, foi instalada, uma Zona Especial de Negócios (ZEN), no sentido de favorecer economias de escala, inclusive com a promoção de vantagens locacionais. Nesse ponto, é interessante notar que, apesar de estar se desenvolvendo um mercado de trabalho em Rio das Ostras, este reflete mais a dinâmica da indústria do petróleo do que eventuais políticas municipais de diversificação industrial e produtiva. Isso significa dizer que esse mercado de trabalho é altamente dependente do dinamismo econômico da indústria do petróleo. Atente-se para o fato de que esse desenvolvimento é positivo, na medida em que estimula a criação de novos postos de trabalho, mas, por outro lado, a dependência econômica em torno de um único setor expõe esses municípios a uma maior vulnerabilidade, mediante situações adversas como as que estão ocorrendo na atualidade, devido à redução do preço internacional do barril do petróleo e à operação Lava-Jato.

Os preços praticados pelo mercado imobiliário, o desenvolvimento do mercado de trabalho do município e a proximidade espacial com Macaé tornam essa uma importante área de atração para os imigrantes inter e intraestaduais. Seu poder de atração apresenta-se tão elevado que, na década de 2000-2010, recebeu mais imigrantes do que Macaé e Cabo Frio. Como seu poder de retenção populacional também é elevado, o ganho populacional líquido do município, no período considerado, foi de mais de cinquenta mil habitantes e a TLM foi de 48,2\%.

Sob a perspectiva de reprodução e acumulação capitalista, os movimentos migratórios só podem ser considerados funcionais e, portanto, positivos se os imigrantes atraídos pelas possibilidades de emprego no mercado de trabalho forem suficientemente qualificados para nele ingressarem; caso contrário, os acirrados processos de seletividade migratória provocarão volumosos fluxos de (re)emigração. Nos aglomerados urbanos em questão, pode-se afirmar que são elevados os poderes de atração e retenção populacional, bem como a redistribuição espacial da população no território.

Souza, Terra e Campos (2015) verificaram o papel da mão de obra natural e migrante no processo de reestruturação do mercado de trabalho na região da Organização dos Municípios Produtores de Petróleo (Ompetro), que inclui, além de todos os municípios selecionados, o município de Niterói. Nesse estudo, os autores analisaram os movimentos migratórios de data-fixa e partiram do pressuposto de que são significativas as diferenças entre a qualidade da mão de obra dos não migrantes (aqueles que nasceram em um município e nunca residiram em outro) e dos imigrantes (incluindo os naturais que, tendo residido em outro município, retornam ao município de nascimento), estes divididos em três categorias: intraestaduais, interestaduais e internacionais.

Em primeiro lugar, os autores avaliaram os indicadores de escolaridade da população, segundo o estrato populacional e o status migratório, para os períodos 1986-1991; 1995-2000 e 2005-2010, considerando apenas os indivíduos na faixa etária de 20 anos ou mais, à exceção dos adultos matri- 
culados em programas de alfabetização. Assim, inicialmente, observaram a tendência para a elevação do grau de alfabetização da população e que, em todos os períodos, esse era mais elevado entre os migrantes, apesar das diferenças entre os status migratórios.

Tabela 6. Ompetro: grau de alfabetização segundo o estrato populacional e o status migratório (19861991, 1995-2000 e 2005-2010)

\begin{tabular}{|l|r|r|r|r|}
\hline & \multicolumn{3}{|c|}{ Imigrantes } & \multirow{2}{*}{ Período } \\
\cline { 2 - 4 } & Intraestaduais & \multicolumn{1}{|c|}{ Interestaduais } & Internacionais & Nano migrantes \\
\hline $1986-1991$ & 92 & 90,7 & 100 & 85,3 \\
$1995-2000$ & 95,1 & 94 & 99,2 & 91,8 \\
$2005-2010$ & 97,8 & 96,5 & 100 & 94,3 \\
\hline \hline
\end{tabular}

Fonte: Souza, Terra e Campos, 2015.

Através dos Censos Demográficos de 1991 e 2000, os autores analisaram a distribuição da população segundo a variável anos de estudo e estimaram a escolaridade média da população segundo o estrato populacional (não migrante versus migrante) e o status migratório (migrante intraestadual, interestadual e internacional).

Para o período 1986-1991, verificaram que 51\% dos não migrantes eram considerados analfabetos funcionais, estimando em 7,2 anos de estudo a escolaridade média desse estrato populacional. De forma complementar, analisando as mesmas informações para os imigrantes, detectaram um nível menor de analfabetismo funcional (35,6\% entre os imigrantes intraestaduais e 33,4\% entre os interestaduais) e uma escolaridade média mais elevada (8,7 e 9,1 anos, respectivamente).

O Censo de 2000 aponta a redução do analfabetismo funcional para 36,8\% dos não migrantes, $26,2 \%$ dos imigrantes intraestaduais e $25,3 \%$ dos imigrantes interestaduais; e a elevação da escolaridade média dos não migrantes para 7,9 anos de estudo e dos migrantes intraestaduais para 9,1 anos de estudo. E, mesmo diante da impossibilidade imposta pelo Censo Demográfico de 2010, que não permite estimar a escolaridade média, Souza, Terra e Campos (2015) inferiram, a partir da distribuição relativa da variável nivel de instrução segundo o estrato populacional e o status migratório: (i) a elevação da escolaridade média de todos os estratos populacionais e status migratório; (ii) a persistência das diferenças, ainda que em menor magnitude, entre as escolaridades médias dos imigrantes e dos naturais, permanecendo estes últimos com níveis de escolaridade mais baixos; (iii) a convergência da escolaridade do migrante intraestadual para a do migrante interestadual, já apontada pelos sensos anteriores.

Esses resultados revelam, por um lado, o esforço da mão de obra não migrante em sair da margem desse mercado de trabalho, cuja inserção em uma posição relativamente melhor só é possível para os mais qualificados, tendo em vista o uso cada vez mais intenso de tecnologias sofisticadas no processo produtivo. Por outro lado, revelam também a seletividade cada vez mais intensa desse mercado de trabalho, no qual apenas os indivíduos mais qualificados têm sobrevivido à reemigração. Na prática, as diferenças de qualificação profissional se materializam nas condições de inserção e permanência dos indivíduos no mercado de trabalho, assim como em seus rendimentos médios mensais. 


\section{A importância da mobilidade populacional para a acumulação capitalista}

Apesar de a maioria dos trabalhadores ser empregada com carteira assinada, é notória a elevada participação de informais e por conta própria (termo, no contexto brasileiro, muitas vezes associado a trabalho precário) naquele mercado de trabalho: 38,72\% dos não migrantes; 36,24\% dos imigrantes intraestaduais; 32,93\% dos imigrantes interestaduais; e 35,22\% dos imigrantes estrangeiros. Esses resultados comprovam que muitos trabalhadores ficam, de fato, à margem do processo de reprodução do capital. Como abrangem indivíduos de diferentes estratos populacionais e condições socioeconômicas, infere-se que constituem um diversificado reservatório de força de trabalho - nas palavras de Marx, um "exército industrial de reserva" - necessário para manter os salários em baixos patamares, em todos os setores de atividade, comparativamente a uma situação de escassez de oferta de mão de obra.

Souza, Terra e Campos (2015) detectaram que as formas de inserção no mercado de trabalho são significativamente diferenciadas segundo o estrato populacional. Os não migrantes exercem, em sua maioria, ocupaçôes que demandam trabalhadores menos qualificados e, portanto, percebem rendimentos mensais menores, estimados, em média, em $\mathrm{R} \$ 1.456,57$ (a preços de 2010). Segundo os autores, há diferenças significativas entre as ocupaçôes e os rendimentos dos imigrantes, tanto em relação aos não migrantes como em relação ao status migratório. Em linhas gerais, afirmam os autores, predominam imigrantes internacionais e intraestaduais nas ocupações com maior qualificação, e imigrantes interestaduais naquelas com menor qualificação. Os rendimentos médios foram estimados em $\mathrm{R} \$ 3.955,91 ; \mathrm{R} \$ 1.950,48$; e $\mathrm{R} \$ 2.047,26$, respectivamente.

Além da mão de obra imigrante, o trabalhador pendular tem-se tornado cada vez mais imprescindível para a reprodução do capital na Bacia de Campos. Aliás, é interessante salientar que, para um número cada vez maior de indivíduos, verifica-se a dissociação entre o lugar de trabalho e o lugar de residência, e esses movimentos, que antes se restringiam basicamente às regióes metropolitanas, têm sido observados com frequência cada vez maior nas áreas urbanas não metropolitanas. Segundo Marandola Jr. e Ojima (2014, p. 186), a intensificação desses movimentos está "intimamente ligada às transformações na vida urbana e nas instituições, numa regionalização do cotidiano, que acompanha a dispersão de atividades industriais, de lazer, de comércio e de empreendimentos imobiliários".

No Censo Demográfico de 2010, há dois conceitos implícitos de pendularidade: um mais amplo, que considera pendular todo indivíduo que trabalha em um município diferente do município de residência, sem levar em conta a periodicidade do deslocamento, e outro mais estrito, que se refere "àquele realizado por indivíduos que trabalham em municípios diferentes do de residência, e que retornam para casa diariamente, independentemente do tempo habitualmente gasto nesse deslocamento" (Souza et al., 2013, p. 8).

Tendo em vista as características do mercado de trabalho da Bacia de Campos, que tem um regime de contratação por turnos de um número significativo de trabalhadores no segmento usptream da indústria do petróleo, optou-se por se trabalhar com o conceito mais amplo e incluir a pendularidade de longa distância (interestadual).

Considerando-se a pendularidade interestadual, verifica-se a entrada de 12.329 trabalhadores, oriundos principalmente da própria Região Sudeste, mais notadamente do Espírito Santo e de Minas Gerais, mas também das regiões Norte, Nordeste, Centro-Oeste e Sul do país (Tabela 7). A saída de trabalhadores pendulares desses municípios para outros estados brasileiros é pequena, prevalecendo como destinos a própria Região Sudeste. À exceção de Arraial do Cabo, Carapebus, Casimiro de 
Abreu e Quissamã, em todos os outros municípios o saldo pendular é positivo, mas Macaé é o principal receptor dessa mão de obra - absorveu 74,5\% dos trabalhadores pendulares interestaduais - seguido, de longe, por Campos, que absorveu 16,2\%.

Tabela 7. Municípios selecionados: indicadores da mobilidade pendular interestadual, segundo o município selecionado, 2010

\begin{tabular}{|l|r|r|r|}
\hline \multirow{2}{*}{ Municípios selecionados } & \multicolumn{3}{|c|}{ Interestadual } \\
\cline { 2 - 4 } & Entradas & Saídas & Saldo Pendular \\
\hline Armação de Búzios & 128 & 0 & 128 \\
Arraial do Cabo & 2 & 29 & -27 \\
Cabo Frio & 548 & 340 & 208 \\
Carapebus & 6 & 31 & -25 \\
Campos dos Goytacazes & 1.994 & 818 & 1.176 \\
Casimiro de Abreu & 20 & 71 & -51 \\
Macaé & 9.190 & 395 & 8.795 \\
Quissamã & 25 & 32 & -7 \\
Rio das Ostras & 322 & 270 & 52 \\
São João da Barra & 92 & 34 & 58 \\
Total & 12.329 & 2.020 & 10.309 \\
\hline \hline
\end{tabular}

Fonte: IBGE - Censo Demográfico de 2010.

Seguindo o mesmo procedimento adotado para a análise dos movimentos migratórios intraestaduais, a pendularidade entre os municípios selecionados e os demais municípios fluminenses foi subdividida em: (1) intrarregional, que se restringe aos fluxos entre os municípios selecionados, (2) intraestadual parcial, que se refere a toda pendularidade entre os municípios selecionados e os demais municípios fluminenses e (3) intraestadual total.

Os fluxos intraestaduais são significativamente mais densos, sendo a pendularidade intrarregional maior que a pendularidade intraestadual parcial. No contexto intrarregional, apenas Macaé e Búzios apresentaram saldos pendulares positivos (23.364 e 5.061 trabalhadores, respectivamente). Em relação aos demais municípios, juntam-se a Macaé (com um saldo de 17.686 trabalhadores) e Búzios (1.421) os municípios de Cabo Frio (7.533), Campos dos Goytacazes (2.465) e Quissamã (181). 
Tabela 8. Municípios selecionados: indicadores da pendularidade intraestadual

\begin{tabular}{|c|c|c|c|c|c|c|c|c|c|}
\hline \multirow[b]{2}{*}{ Municípios selecionados } & \multicolumn{3}{|c|}{ Inter-regional } & \multicolumn{3}{|c|}{ Intraestadual Parcial } & \multicolumn{3}{|c|}{ Intraestadual Total } \\
\hline & Entradas & Saídas & $\begin{array}{c}\text { Saldo } \\
\text { Pendular }\end{array}$ & Entradas & Saidas & $\begin{array}{c}\text { Saldo } \\
\text { Pendular }\end{array}$ & Entradas & Saidas & $\begin{array}{c}\text { Saldo } \\
\text { Pendular }\end{array}$ \\
\hline Armação de Búzios & 5.370 & 309 & 5.061 & 1.625 & 204 & 1.421 & 6.995 & 513 & 6.482 \\
\hline Arraial do Cabo & 516 & 1.440 & -924 & 455 & 757 & -302 & 971 & 2.197 & -1.226 \\
\hline Cabo Frio & 2.105 & 10.475 & -8.370 & 11.259 & 3.726 & 7.533 & 13.364 & 14.201 & -837 \\
\hline Carapebus & 224 & 2.297 & -2.073 & 51 & 120 & -69 & 275 & 2.417 & -2.142 \\
\hline Campos dos Goytacazes & 2.345 & 8.072 & -5.727 & 5.273 & 2.808 & 2.465 & 7.618 & 10.880 & -3.262 \\
\hline Casimiro de Abreu & 1.462 & 3.752 & -2.290 & 730 & 951 & -221 & 2.192 & 4.703 & -2.511 \\
\hline Macaé & 24.272 & 908 & 23.364 & 18.537 & 851 & 17.686 & 42.809 & 1.759 & 41.050 \\
\hline Quissamã & 323 & 1.129 & -806 & 322 & 141 & 181 & 645 & 1.270 & -625 \\
\hline Rio das Ostras & 3.965 & 12.113 & -8.148 & 2.099 & 2.097 & 2 & 6.064 & 14.210 & -8.146 \\
\hline São João da Barra & 1.321 & 1.408 & -87 & 171 & 172 & -1 & 1.492 & 1.580 & -88 \\
\hline Total & 41.903 & 41.903 & 0 & 40.522 & 11.827 & 28.695 & 82.425 & 53.730 & 28.695 \\
\hline
\end{tabular}

Fonte: IBGE - Censo Demográfico de 2010.

No balanço da pendularidade intraestadual total (Tabela 8), assim como no cômputo da pendularidade total (interestadual + intraestadual total), saldos positivos se verificaram apenas em Macaé e Búzios. O primeiro, por concentrar as atividades da indústria petrolífera e parapetrolífera, e o segundo, pelo desenvolvimento do setor de turismo. Os resultados das tabelas 7 e 8 indicam que, além de atraírem muitos trabalhadores residentes em outros municípios, Macaé e Búzios têm uma grande capacidade de retenção da mão de obra residente. Isso porque, para cada trabalhador que saiu, entraram 24 em Macaé e 14 em Búzios. Segundo Souza e Terra (2015, p. 134),

em Macaé, os números da pendularidade indicam uma polarização regional. Esse município se destaca por atrair significativos fluxos não apenas de seus vizinhos, como também de outras UFs, incluindo aquelas mais distantes com as das regiões Norte e Nordeste. Apesar de Campos dos Goytacazes ser maior e apresentar uma economia mais diversificada, é Macaé que exerce uma importante centralidade: é em torno dele que se (re)organiza o tecido urbano regional.

A literatura nos aponta uma intrínseca relação entre movimentos pendulares e cidades-dormitório, definida por Miglioranza (apud Ojima et al., 2007) como a "cidade cujos habitantes saem, na maioria, para trabalhar em outra cidade, voltando apenas para dormir”. Ojima et al. (2007) consideram razoável supor que "o padrão de cidades-dormitório com baixo dinamismo econômico só passa a existir quando a proporção de movimentos pendulares é mais elevada, em torno de $40 \%$ da população ocupada”. De acordo com essa ótica, os resultados da Tabela 9 indicam uma cidade-dormitório Carapebus - entre os dez municípios selecionados, sugerindo uma possível transformação de Rio das Ostras e Casimiro de Abreu em cidades-dormitório nos próximos anos, caso se mantenham as atuais características econômicas, sociais e demográficas que influenciam tais deslocamentos. 
Tabela 9. Municípios selecionados: população economicamente ativa ocupada, segundo o local de trabalho (2010)

\begin{tabular}{|l|r|r|r|r|r|r|}
\hline \multirow{3}{*}{ Municípios Selecionados } & \multicolumn{6}{|c|}{ PEA ocupada RESIDENTE no município } \\
\cline { 2 - 7 } & \multicolumn{1}{|c|}{ Trabalha no próprio } & \multicolumn{1}{|c|}{ Trabalha em outro } & \multicolumn{2}{c|}{ PEA residente total } \\
\cline { 2 - 7 } & \multicolumn{1}{|c|}{ Absoluto } & \multicolumn{1}{c}{ Absoluto } & \multicolumn{1}{c|}{$\%$} & \multicolumn{1}{c|}{ Absoluto } & \multicolumn{1}{c|}{$\%$} \\
\hline Armação de Búzios & 13.039 & 95,90 & 557 & 4,10 & 13.596 & 100,00 \\
Arraial do Cabo & 10.249 & 81,52 & 2.324 & 18,48 & 12.573 & 100,00 \\
Cabo Frio & 69.346 & 81,78 & 15.445 & 18,22 & 84.791 & 100,00 \\
Carapebus & 3.604 & 59,26 & 2.478 & 40,74 & 6.082 & 100,00 \\
Campos dos Goytacazes & 173.998 & 93,07 & 12.958 & 6,93 & 186.956 & 100,00 \\
Casimiro de Abreu & 12.266 & 71,17 & 4.970 & 28,83 & 17.236 & 100,00 \\
Macaé & 100.154 & 97,41 & 2.658 & 2,59 & 102.812 & 100,00 \\
Quissamã & 7.198 & 83,48 & 1.424 & 16,52 & 8.622 & 100,00 \\
Rio das Ostras & 35.519 & 70,34 & 14.974 & 29,66 & 50.493 & 100,00 \\
São João da Barra & 12.724 & 88,21 & 1.700 & 11,79 & 14.424 & 100,00 \\
Total & 438.097 & 88,04 & 59.488 & 11,96 & 497.585 & 100,00 \\
\hline \hline
\end{tabular}

Fonte: IBGE - Censo Demográfico de 2010.

Utilizando o Censo Demográfico de 2010, Souza e Terra (2015) desenvolveram uma metodologia para estimar o nível de dependência de mão de obra exógena, definida como "toda a mão de obra ocupada não originária do município, conceito que abrange imigrantes e pendulares" (Souza e Terra, 2015, p. 135). Esse indicador é dado pela seguinte fórmula:

$$
N d=\frac{M D O_{\text {exógena }}}{M D O_{\text {ocupada }}} \times 100
$$

Onde:

$\mathrm{Nd}$ = Nível de dependência de mão de obra exógena

MDOexógena (indicador amplo): imigrante não natural entre duas datas fixas que declarou trabalhar no município de residência + indivíduo não residente que declarou trabalhar no município (pendular).

MDOexógena (indicador estrito): indivíduo não residente que declarou trabalhar no município (trabalhador pendular)

MDOocupada: indivíduo natural que reside e trabalha no município + indivíduo não natural residente no município, mas que o declarou como local de trabalho + indivíduo não residente que declarou trabalhar no município 


\section{A importância da mobilidade populacional para a acumulação capitalista}

Atente-se para o fato de que, no denominador, tem-se a população ocupada NO município que inclui todos os indivíduos que trabalham no próprio município de residência e todos aqueles que, apesar de residirem em outra cidade, declaram o município estudado como o local de trabalho -, e não a população ocupada RESIDENTE no município.

Atente-se, ainda, para a diferença entre o indicador ampliado e o estrito. O primeiro inclui, em seu numerador, os imigrantes; no segundo, o numerador se restringe aos pendulares.

Em relação aos imigrantes, as autoras consideraram apenas os mais recentes, captados pelo quesito de data-fixa (imigrantes do período 2005-2010) - admitindo que os mais antigos já se encontram plenamente inseridos na sociedade receptora. Além disso, não consideraram o imigrante natural de retorno como mão de obra exógena, pressupondo-se a migração como um investimento em capital humano para melhor inserção e posicionamento no mercado de trabalho. Em relação aos movimentos pendulares, as autoras trabalharam com seu conceito mais abrangente, tendo em vista as contratações por turnos.

Antes de apresentarem os resultados dos níveis de dependência para os municípios selecionados, Souza e Terra (2015, p. 139) analisaram a relação entre as PEAs ocupada NO e RESIDENTE no município. Como se pode notar na Tabela 10, estima-se um total de 532.851 indivíduos que trabalham em algum dos municípios selecionados, quando sua PEA ocupada residente foi estimada em 497.584 .

Observa-se que, ainda que toda a população ocupada residente em Búzios e em Macaé fosse absorvida pelos respectivos mercados de trabalho, ainda assim haveria postos não preenchidos nesses municípios. Em Armação dos Búzios e Macaé, a população ocupada é cerca de 48\% maior que a ocupada residente. Nos demais municípios, o mercado de trabalho não absorve toda a população ocupada residente, seja por escassez de postos de trabalho, seja pela baixa qualificação profissional da PEA. Nesses casos, a realização da pendularidade surge como importante alternativa para a inserção e a permanência dos indivíduos no mercado de trabalho. É relevante considerar que, além de ser facilitada pelo desenvolvimento dos setores de transporte e comunicação, a pendularidade é, muitas vezes, estrategicamente estimulada pelas diferenças salariais. 
Tabela 10. Municípios selecionados: relação entre a PEA ocupada no município e a PEA ocupada residente no município, por município selecionado (2010)

\begin{tabular}{|l|r|r|r|}
\hline Município Selecionado & $\begin{array}{r}\text { PEA ocupada que } \\
\text { trabalha NO município } \\
(1)\end{array}$ & $\begin{array}{c}\text { PEA ocupada } \\
\text { RESIDENTE no } \\
\text { município (2) }\end{array}$ & $\begin{array}{r}\text { Relação entre as PEA's } \\
(1) /(2)\end{array}$ \\
\hline Armação dos Búzios & 20.164 & 13.596 & 48,31 \\
Arraial do Cabo & 11.224 & 12.573 & $-10,73$ \\
Cabo Frio & 83.256 & 84.792 & $-1,81$ \\
Carapebus & 3.885 & 6.081 & $-36,11$ \\
Campos dos Goytacazes & 183.610 & 186.957 & $-1,79$ \\
Casimiro de Abreu & 14.479 & 17.236 & -16 \\
Macaé & 152.153 & 102.811 & 47,99 \\
Quissamã & 7.868 & 8.621 & $-8,74$ \\
Rio das Ostras & 41.907 & 50.493 & -17 \\
São João da Barra & 14.308 & 14.424 & $-0,8$ \\
Total & 532.851 & 497.584 & 7,09 \\
\hline
\end{tabular}

Fonte: IBGE - Censo Demográfico de 2010.

$\mathrm{Na}$ Tabela 11, encontram-se os resultados das estimativas dos indicadores de dependência de mão de obra exógena. Esse indicador varia entre zero, para mercados de trabalho autossuficientes, e $100 \%$, para os casos de completa dependência. Tais valores são meras referências para a análise dos resultados e, de modo geral, quanto maiores se apresentarem, maior será a dependência do mercado de trabalho em relação à mão de obra exógena.

Tabela 11. Municípios selecionados: nível de dependência de mão de obra exógena (2010)

\begin{tabular}{|c|c|c|c|c|c|c|c|c|c|}
\hline \multirow{3}{*}{$\begin{array}{l}\text { Municipios } \\
\text { Selecionados }\end{array}$} & \multicolumn{6}{|c|}{ Componentes da Mão de Obra exógena } & \multirow{3}{*}{$\begin{array}{c}\text { Mão de obra } \\
\text { ocupada NO } \\
\text { municipio }\end{array}$} & \multirow{3}{*}{$\begin{array}{c}\text { Nível de } \\
\text { Dependência } \\
\text { Ampliado }\end{array}$} & \multirow{3}{*}{$\begin{array}{l}\text { Nível de } \\
\text { Dependência } \\
\text { Estrito }\end{array}$} \\
\hline & \multicolumn{2}{|c|}{ Imigrantes data fixa } & \multicolumn{2}{|c|}{$\begin{array}{l}\text { Pendular intraestadual } \\
\text { total }\end{array}$} & \multicolumn{2}{|c|}{ Pendular interestadual } & & & \\
\hline & Absoluto & $\%$ & Absoluto & $\%$ & Absoluto & $\%$ & & & \\
\hline Armação dos Búzios & 4.041 & 20,0 & 6.997 & 34,7 & 128 & 0,6 & 20.164 & 55,4 & 35,3 \\
\hline Arraial do Cabo & 2.923 & 26,0 & 973 & 8,7 & 2 & 0,0 & 11.224 & 34,7 & 8,7 \\
\hline Cabo Frio & 20.212 & 24,3 & 13.362 & 16,0 & 548 & 0,7 & 83.256 & 41,0 & 16,7 \\
\hline Carapebus & 1.549 & 39,9 & 275 & 7,1 & 6 & 0,2 & 3.885 & 47,1 & 7,2 \\
\hline Campos dos Goytacazes & 45.961 & 25,0 & 7.618 & 4,1 & 1.994 & 1,1 & 183.610 & 30,3 & 5,2 \\
\hline Casimiro de Abreu & 3.340 & 23,1 & 2.193 & 15,1 & 20 & 0,1 & 14.479 & 38,4 & 15,3 \\
\hline Macaé & 38.823 & 25,5 & 42.809 & 28,1 & 9.190 & 6,0 & 152.153 & 59,7 & 34,2 \\
\hline Quissamã & 2.195 & 27,9 & 645 & 8,2 & 25 & 0,3 & 7.868 & 36,4 & 8,5 \\
\hline Rio das Ostras & 12.949 & 30,9 & 6.066 & 14,5 & 322 & 0,8 & 41.907 & 46,1 & 15,2 \\
\hline São João da Barra & 4.482 & 31,3 & 1.492 & 10,4 & 92 & 0,6 & 14.308 & 42,4 & 11,1 \\
\hline Total & 136.475 & 25,6 & 82.430 & 15,5 & 12.324 & 2,3 & 532.851 & 43,4 & 17,8 \\
\hline
\end{tabular}

Fonte: IBGE - Censo Demográfico de 2010.

Como se pode notar na Tabela 11, o nível de dependência ampliado é relativamente alto em todos os municípios. Apenas em Quissamã, Campos dos Goytacazes, Arraial do Cabo e Casimiro de 


\section{A importância da mobilidade populacional para a acumulação capitalista}

Abreu, a dependência ampliada é inferior a 40\%, ou seja, menos de $40 \%$ da mão de obra ocupada no município é exógena. Armação dos Búzios e Macaé apresentaram índices elevadíssimos: 55,4\% e $59,7 \%$, respectivamente.

Em relação ao indicador mais estrito, que considera no numerador apenas a mão de obra pendular, Búzios e Macaé permanecem com os índices mais elevados: 35,3\% e 34,8\%, respectivamente.

Da forma como estão apresentados os resultados, é possível analisar os componentes da pendularidade. Essas informações podem revelar-se muito úteis em contextos nos quais seja necessário adotar medidas para atrair trabalhadores e suprir a carência por mão de obra em determinado mercado de trabalho. Entre os trabalhadores exógenos em Macaé, 57,3\% são pendulares (intra e interestaduais); em Búzios, esse percentual é de 63\%. Em Campos dos Goytacazes, 82,7\% dos trabalhadores exógenos são imigrantes (não naturais e de data fixa).

\section{Considerações finais}

David Harvey (2005) utiliza a teoria marxista para compreender a geografia da acumulação capitalista, considerando que "o capitalismo cria espaços novos para a acumulação" (p. 65) e, para essa criação, necessita "superar as barreiras espaciais e anular o espaço pelo tempo" (idem, ibidem). Nesse sentido, aponta a necessidade de conquistar e levar a indústria para novos espaços, como estratégia para a continuidade do processo de acumulação capitalista.

No caso da indústria do petróleo, essa localização é determinada pela própria localização das jazidas. Isso significa dizer que, se, por um lado, sua instalação gera o desenvolvimento de um setor industrial e de serviços no entorno, por outro lado os demais elementos necessários para a (re)produção capitalista (como mão de obra, transporte e comunicação, entre outros), se estiverem ausentes, devem vir a seu encontro para criar as condições necessárias ao processo de acumulação.

A partir dessa premissa, consideramos que, no contexto do Norte Fluminense, antes produtor de cana-de-açúcar e com uma mão de obra pouco qualificada para as exigências da indústria do petróleo, intensiva em capital, a mobilidade populacional era fator determinante para o processo de acumulação capitalista. Por esse motivo, neste artigo foram pesquisadas as duas formas de mobilidade populacional: migrações internas e pendularidade.

Em relação às migrações, a mais importante sob a ótica da acumulação capitalista nos aglomerados urbanos estudados é a intraestadual, muito embora as migrações interestaduais não devam ser desprezadas. Os municípios que mais atraem imigrantes são: Macaé, Rio das Ostras e Cabo Frio. Em termos relativos, os ritmos de crescimento de todos os municípios na extensão urbana estudada, à exceção de Campos dos Goytacazes, são significativamente influenciados pelas migrações internas.

A pendularidade apresenta-se extremamente elevada, alcançando, inclusive, trabalhadores de outros estados brasileiros, devido à singularidade dos contratos de trabalhadores por turno, do segmento upstream. Mas, assim como ocorre no contexto das migrações internas, os movimentos intraestaduais são os mais significativos. 
Por meio do indicador do nível de dependência, verifica-se elevada dependência por mão de obra exógena nesses municípios, sendo Macaé, onde se situa a base de operações da indústria petrolífera, o que apresenta o maior índice.

Os resultados indicam que, de fato, é por meio das duas formas de mobilidade populacional que esse setor supre sua carência por mão de obra qualificada, indicando que os naturais dos municípios selecionados vêm despendendo esforços no sentido de melhorar sua qualificação profissional e sua posição de inserção e permanência nesses mercados de trabalho. Nesse contexto, tais movimentos são imprescindíveis para a acumulação capitalista e sua ausência implica um ponto de estrangulamento para a atividade da indústria de petróleo, comprometendo o processo de acumulação capitalista na Bacia de Campos.

\section{Referências}

ANP. Anuário Estatístico Brasileiro do Petróleo, Gás Natural e Biocombustiveis. S.1. 2015.

BRITO, Fausto. "Brasil, final do século: a transição para um novo padrão migratório". In CARLEIAL, Adelita (org.). Transições migratórias. Fortaleza: Iplance, 2002.

COSTA, P. "A evolução da indústria petrolífera, uma caracterização geral”. MONIÈ, F. e BINSZTOK, J (orgs.). Geografia e geopolítica do petróleo. Rio de Janeiro: Mauad X, 2012.

EGLER, C. A. G. e MATTOS, M. M. C. L. "Multinacionais no setor petrolífero, geoeconomia e integração regional na América do Sul”. In MONIĖ, F. e BINSZTOK, J. Geografia e geopolítica do petróleo. Rio de Janeiro: Mauad X, 2012.

FARIAS, P. "Nacionalismo e participação popular na campanha 'O petróleo é nosso'”. In PIQUET, R. Petróleo, royalties e regiāo. Rio de Janeiro: Garamond, 2003.

HARVEY, D. "A geografia da acumulação capitalista: uma reconstrução da teoria marxista”. A produção capitalista do espaço. São Paulo: Annablume, 2005.

IBGE. Indicadores sociodemográficos e de saúde no Brasil: estudos e pesquisas. Informação demográfica e socioeconômica. Rio de Janeiro, n. 25, 2009.

- Censo Demográfico de 2010.

- Censo Demográfico de 1991.

- Censo Demográfico de 2000.

OJIMA, R. et al. "A mobilidade pendular na definição das cidades-dormitório: caracterização sociodemográfica e novas territorialidades no contexto da urbanização brasileira”. Cadernos Anpurl UFRJ, v. 21, 2007, pp. 111-32.

PIQUET, R. "Petróleo e desenvolvimento regional no Brasil”. In MONIĖ, F. e BINSZTOK, J. Geografia e geopolítica do petróleo. Rio de Janeiro: Mauad X, 2012.

— e TERRA, D. C. T. "A roda da fortuna: a indústria do petróleo e seus efeitos multiplicadores no Brasil”. In PIQUET, R. (org.). Mar de riqueza, terra de constrastes: o petróleo no Brasil. Rio de Janeiro: Mauad X/Faperj, 2011. 
SOUZA, Joseane e TERRA, Denise C. T. "Indústria petrolífera, mercado de trabalho e nível de dependência da mão de obra exógena nos municípios produtores de petróleo da Bacia de Campos, RJ”, Revista Brasileira de Estudos Urbanos e Regionais, Anpur, v. 17, 2015, p. 123.

_ et al. "O migrante na reestruturação do mercado de trabalho na zona da produção principal da Bacia de Campos”. XVIII Encontro Nacional de Estudos Populacionais, Águas de Lindoia, 2012. _ et al. "A mobilidade pendular entre os municípios da Ompetro-RJ (2000-2010)". Anais... Recife, Encontro Nacional da Anpur, 15, 2013.

— et al. "Mobilidade populacional e as novas espacialidades urbanas: municípios da Ompetro". Eure, Rio de Janeiro (2000-2010), v. 41, 2015, pp. 53-80.

TERRA, Denise C. T et al. "Federalismo no Brasil e o debate sobre o rateio das receitas de petróleo". Revista de Ciências Sociais, Fortaleza, v. 45, n. 2, jul.-dez. 2014, pp. 185-209. 


\section{A cartografia da ação social e a cidade de São Gonçalo, RJ: limites e possiblidades metodológicas para a contribuição do fazer geográfico}

Catia Antonia da Silva ${ }^{l}$

\section{Introdução}

A cartografia da ação social é uma possibilidade metodológica que se inscreve na relação entre geografia e sociologia. Trata-se de reconhecer as trajetórias e as espacialidades escritas pelas práticas cotidianas das bases populares. Diante da aceleração do tempo-mundo, engendradas pela globalização e pelo desenvolvimentismo que o Brasil e a América Latina experimentam, os processos de modernização têm alterado profundamente a produção social do espaço feita pelos grandes agentes econômicos e o Estado. Produzir as cartografias dos homens e mulheres simples significa dar visibilidade e possibilidade de pensar sua própria condição, além de ter na cartografia um instrumento de representação de seu território e de luta social.

Nessa lógica, o objetivo deste trabalho é refletir sobre o sentido do uso da cartografia da ação social no contexto atual, demonstrando conceitos e metodologias utilizados que norteiam a compreensão da cartografia da ação social como um processo que se inicia na pesquisa e nos estágios de vivência com os jovens de São Gonçalo, mas não termina com a confecção de mapas. Ele é concluído quando o grupo social se apropria e, então, analisa as formas fundamentais do uso da cartografia como instrumento formador de sujeitos de direitos e de possiblidade de construção coletiva do olhar, da identidade e das formas de apoderação dos saberes coletivos. A metodologia de apresentação debruça na exposição de quadros analíticos teórico-conceituais, depoimentos dos jovens e exposição de mapas coletivos feitos junto ao projeto Cartografia a ação e a juventude em São Gonçalo (2009-2011), em parceria com Ana Clara Torres Ribeiro.

As principais contribuições deste trabalho são duas: a primeira refere-se à atualização do debate da produção de mapas em um contexto de investimentos tecnológicos sofisticados em programas importados, onde a contraposição da cartografia da ação social, como a expressão do cotidiano vivido

1 Docente Associado da FFP/UERJ. Geografia, Programa de Pós Graduação em História Social, Programa de Pós-Graduação em Geografia da FFP/UERJ. 
e praticado, pode ser mapeada de forma sofisticada ou não. O mais importante é a produção coletiva do mapa a partir de uma problemática vivida e percebida pelo grupo social. A segunda contribuição refere-se ao debate do fazer científico diante da sociedade informacional, na qual o uso da internet permite rapidamente a divulgação da pesquisa. Nesse contexto, cria-se um questionamento: como e quando divulgar a cartografia da ação social dos grupos populares? Como fazer uma ciência geográfica pautada nos princípios éticos que orientam o cuidado com os saberes do outros? Esses são desafios que a ciência geográfica do século XXI precisa enfrentar.

Para identificar os agentes produtores do processo da degradação ambiental, foi apontado o reconhecimento do papel do Estado, os agentes econômicos e as formas de organização, reinvindicação, protestos e lutas sociais dos moradores e pescadores da região. Nesse processo pedagógico, utilizamos a proposta conceitual da cartografia da ação social. Esse conceito, proposto por Ana Clara Torres Ribeiro, norteou a metodologia de criação de mapas produzidos pelas crianças e adolescentes, reconhecendo as ações por meio de elaboração de símbolos: localização dos pescadores e dos problemas, identificação das áreas de protestos, localização do poder público e das barqueatas. $\mathrm{O}$ uso da Cartografia da Ação, principalmente em algumas atividades práticas, possibilitou promover um processo de aprendizagem mais autônomo e livre de discursos pré-estabelecidos e preexistentes nos textos didáticos.

Segundo Ribeiro et al. (2004), a cartografia da ação social é aquela passível de compreensão e de representação do movimento da sociedade, das lutas e de novos anseios, das açóes e desejos das bases populares. É a cartografia da ação que também representa o cotidiano da vida coletiva. Desse modo, a cartografia sugerida aqui é a da denúncia e também a que orienta a ação social, desvendando contextos e antecipando atos (Almeida, 1994). Significa, portanto, a contextualização veloz da ação hegemônica, cada vez mais estrategicamente localista, assim como a valorização imaginativa dos lugares vividos, onde a vida escorre ou ganha força reflexiva e transformadora. Como carta, o mapa não aparece como instrumento isolado ou como bela ilustração de textos, exacerbando critérios estéticos, mas sim como ferramenta analítica e sustento da memória dos outros. Neste sentido, propõe-se uma cartografia incompleta que se faz fazendo. Uma cartografia praticada que não seja apenas dos usos do espaço pelo poder, mas também utilizável, possibilitando a sincronia espaço-temporal, o que apoiaria, inclusive, o trabalho interdisciplinar (Ribeiro, 2012, 2013). Essa seria uma forma de representação da ação que poderia alimentar narrativas e que, em vez do território naturalizado, trataria de território usado, como orienta Milton Santos (1996, p. 18). O território não é uma categoria de análise, mas sim o território usado. Ou seja, para que o território se torne uma categoria de análise dentro das ciências sociais e com vistas à produção de projetos, isto é, com vistas à política, deve-se tomá-lo como território usado (Ribeiro et al., 2001-02, p. 4).

A cartografia da ação social é aquela não oficial, que trata das trajetórias das bases populares, das rotas de lutas e manifestações, trajetórias de trabalho no cotidiano, manifestaçôes culturais, ou das normas sociais ocultas não estatais. Com essa orientação, é possível desvendar um novo mundo, desvelar o invisível, ver beleza no anonimato, enxergar potencial no não considerado, naquilo e naquele visto como pobre de tudo. A proposta articula o pensamento de Milton Santos (1996) sobre os homens lentos, com o de Paulo Freire (1979) sobre a dimensão do compromisso humano, compromisso de reflexão e de consciência frente às contradições e as ambições que criam as fragmentaçōes e as segregações socioespaciais. Assim, a cartografia da ação social pode ser considerada, no contexto 


\section{A cartografia da ação social e a cidade de São Gonçalo, RJ}

de compreensão de um humanismo concreto, como uma categoria analítica e, ao mesmo tempo, metodológica. Isso porque ela permite experimentar por meio de exercícios de construção de novos mapeamentos e símbolos construídos a partir de um contexto do espaço vivido e concebido às novas formas de representação, aos novos projetos e aos novos sentidos das ações dos sujeitos vistos como comuns, banais. É preciso que estejamos abertos para ver novas possibilidades de redesenho do mundo, de escrita de nossa própria história, história das bases populares (Santos, 1996; Certeau, 1998).

O presente artigo tem a intenção de apresentar elementos centrais sobre a cartografia como técnica e processo no contexto da geografia. Busca-se expressar a experiência realizada com o projeto de investigação compartilhado com a professora Ana Clara Torres Ribeiro e seu grupo de pesquisa LASTRO/IPPUR, junto aos pesquisadores do nosso grupo de pesquisa Urbano, Território e mudanças contemporâneas - FFP/UERJ, que contribui muito para o diálogo entre a geografia e a sociologia no debate conceitual e metodológico e para o amadurecimento do sentido de fazer ciência na contemporaneidade (Silva, 2012).

O texto é dividido em duas partes. Uma seção é dedicada à compreensão do debate conceitual e a proposição metodológica da compreensão da cartografia como processo. A segunda seção busca expor algumas experiências realizadas no âmbito do projeto de pesquisa Cartografia da ação e a juventude em São Gonçalo.

\section{Cartografia da ação social e caminhos metodológicos: diálogos entre geografia e sociologia}

Cartografia da ação social é um conceito-instrumento metodológico criado por Ana Clara Torres Ribeiro, desenvolvido ao longo de 16 anos de elaboração do Banco de dados Processos Sociais. Com muitas referências de investigação, destaca-se, entre elas, o projeto "Cartografia da ação e análise de conjuntura: reivindicaçôes e protestos em contextos metropolitanos”, de 2001, e o seu diálogo de longos anos com a Geografia brasileira.

Durante o desenvolvimento desse projeto, a autora consolidou a metodologia que estrutura o banco de dados complexo sobre as formas de lutas e reivindicaçôes dos diferentes grupos sociais na luta pelo direito à cidade em contextos metropolitanos, denominando-o Banco de Processos Sociais. Esse banco, que é alimentado há 16 anos, permite identificar as trajetórias sociais, institucionais e espaciais dos sujeitos e dos movimentos sociais.

Desse modo, Ribeiro trouxe contribuições ao debate, hoje conhecido como o campo das cartografias sociais (Santos, 2011; Acselrad, 2010; Almeida 2009), que problematiza o uso da cartografia como uma das formas de representação social e de demonstração pública das formas de luta por território pelos sujeitos que vêm confrontado os grandes agentes.

No entanto, a diferença entre essas abordagens e a abordagem de Ribeiro refere-se não somente à atenção aos movimentos sociais, mas também aos "movimentos espontâneos" - isto é, as sociabilidades não institucionalizadas a priori, que se conformam nas lutas insurgentes construídas nos limites do suportável na convivência social, obedecendo a normas morais cotidianas do lugar, que vão muito 
além das normas do Estado. Ana Clara Torres Ribeiro conta que, certa vez, ao analisar seu banco de processos sociais, reconheceu a insurgência de um confronto público coletivo a um estuprador na metrópole de Belém. Ela o descreve não como um movimento organizado estrategicamente, mas um movimento espontâneo, demonstrando os limites do suportável coletivo.

Essa construção analítica permite ver as formas de apropriação urbana, a vida metropolitana como vida coletiva, a relação do agir com o sentido das ações, que relaciona razão e emoção, moralidade, espacialidade, sociabilidade, vínculo social e protestos, concretizando-a. Essa leitura, apoiada em Certeau (1998), trata do homem ordinário, ou seja, da construção da vida cotidiana, as trajetórias das práticas do cotidiano. Ela também expressa uma leitura das formas de representação que dá sentido e forma à relação entre sujeito e espaço vivido e espaço concebido. Assim, o diálogo entre a geografia e a sociologia, no entendimento de Ana Clara Torres Ribeiro e corroborado por nós, expõe a relação entre território e ação social na compreensão da relação espaço-tempo do cotidiano. Dos trajetos e arte de viver dos homens lentos (Santos, 1994), dos homens simples (Martins, 2000), dos homens ordinários (Certeau, 1998), os diálogos possíveis na compreensão de duas orientações.

A que vai trabalhar metodologicamente com os estágios de vivência, história oral e grupos focais, permite compreender o cotidiano vivido, o sistema simbólico, os elementos e sentidos que norteiam as ações. Essa possibilidade metodológica, como bem citam as referências de Ana Clara Torres Ribeiro e de Michel de Certeau, que aprofundam o entendimento às referências conceituais da relação entre o cotidiano e a experiência urbana, o que permite ver os interstícios das lutas, reivindicações e insurgências. Como outro lado da mesma moeda, compreendendo numa possibilidade dialética, há os modelos de resistências e de insurgências como enfretamentos às formas de racionalidades dominantes na modernidade. Essas formas concretizam as estruturas do poder e, por isso, da dominação política, econômica, social e cultural. É nesse contexto complexo e ontológico que o sentido do fazer científico se estabelece e é nele que se torna fundamental compreender a cartografia como técnica, como instrumento e como processo. É o que veremos a seguir.

\section{Cartografia como técnica social}

A produção ampliada da sociedade informacional está no centro da problemática da modernidade neste século XXI e teve origem em meados de do século XX (Ianni, 2000). Ribeiro (2012) nos ensina que na sociedade de consumo mediada pelas novas tecnologias de comunicação e informação está o entendimento de que o estudo da técnica é uma exigência da pesquisa, tanto de formas contemporâneas de dominação - apoiadas em ideários de eficácia e monitoramento do tecido social - quanto das resistências e afirmações sociais. Para os projetos dominantes em curso e o advento da globalização, a técnica, que inclui objetos e práticas codificadas, sustenta sistemas e sistematicidades, modelos e paradigmas. Por essa razão, inscreve-se nas formas de apropriação do espaço, criando rotinas ou rupturas planejadas do cotidiano e também gerando sistematicidades que podem impedir conquistas sociais ou se constituir no próprio ápice dessas conquistas (Ribeiro, 2012).

Com essa compreensão da técnica, a experiência urbana é apreendida como um embate contínuo entre sistematicidades efetivadas ou potenciais, movidas por diferentes formas de comunicação, 


\section{A cartografia da ação social e a cidade de São Gonçalo, RJ}

linguagens, táticas e recursos de poder (Ribeiro, 2012; Britto, 2010). É nesse contexto que estão inseridos os programas informacionais modernos de geoprocessamento e mapeamentos. Esses programas sofisticados reduzem o tempo da produção do mapa, mas também reduzem, na mesma velocidade, o domínio cognitivo sobre os processos de produção e confecção cartográficos, tornando os geógrafos consumidores quase perfeitos das tecnologias monopolizadas cada vez mais por grandes empresas. No Século XXI, a leitura cartográfica se torna cada vez mais usual e informacional, com as possibilidades fantásticas produzidas por empresas transnacionais.

Nesse sentido, a cartografia como técnica que agora se encontra em todos os lugares com recursos instantâneos e megaespaciais precisa, pelo menos no campo da geografia e do ensino dela, de uma reflexão epistemológica urgente. Ou seja, uma que remeta à filosofia da ciência, ao significado e sentido de seu uso. O reconhecimento crítico de suas possiblidades e de seus limites feito por Renato Emerson dos Santos (2011) analisa Alfredo Wagner Almeida e reconhece o contexto atual da "guerra de mapas" e das cartografagens como luta e resistência no combate pela visibilidade de suas manifestações e domínio de território, assim como a luta contra as cartografias “oficiais". Também autentica a necessidade dessa reflexão no momento em que seu uso contemporâneo entra em um processo acentuado de racionalização prática e construção de uma rotina do fazer científico, no sentido weberiano em que tudo pode ser mapeado (Weber, 2001). Desse modo, a ação do Estado e das empresas (inclusive com forte presença nos relatórios de impacto ambiental), a exposição de mapas, muitas vezes desenhado sobre o território e induzido a leituras de uma única verdade - tais como fazem parecer no debate sobre "a tradição da leitura dos vazios demográficos" no território brasileiro.

A cartografia como instrumento de representação espacial não pode ser considerada, como única finalidade, o mapa em si. A feitura de concretude da representação deve ser vista como processo de construção social. No capitalismo contemporâneo, onde a ciência torna-se objeto exposto ao consumo, as técnicas de representação como as leis impõem uma leitura de mundo predominante.

É fundamental perder a inocência da leitura cartografia sem uma crítica que inclua as geografias das existências - ou seja, que não deixe de saber que a totalidade do espaço é muito maior do que qualquer forma de representação espacial. O mapa é forma de representação, mas não da totalidade do espaço geográfico. Ele expressa mais a leitura do que a referência à totalidade das verdades.

Mas a verdade é composta de várias objetividades e subjetividades, portanto de muitas leituras e formas de representação, como bem expõe Lefebvre, que identifica o debate sobre a representação social e espacial e analisa a força político-social da construção das formas dominantes de representação. Badiou (1995) nos ajuda a refletir sobre a complexa construção social das verdades contrapondo às opiniōes. No entanto, o autor diz que a verdade como objetividade esconde os ascetismos - "o que é idêntico ao descobrimento do sujeito de verdade como puro desejo de si” (Badiou, 1995, p. 67). Há um sentido, muitas vezes não dito, que constrói um universo cultural de consentimentos que traz a tona alguns elementos e ações, e invisibiliza outros. O mapa como materialidade e representação contribui para esta visibilidade-ocultamento, de acordo com as intencionalidades do sujeito do conhecimento e produtor. 


\section{Cartografia como processo}

Compreender a cartografia como um processo social é uma busca metodológica complexa, mas é necessário aprender a fazê-la. Nesse processo, a confecção do mapa não é o centro nem o sentido das ações. Ele se inicia com as indagações dos sujeitos sociais e/ou institucionais - por que e para que fazer um mapa? Quais as intençôes e intencionalidade? Por que espacializar processos, coisas e açôes? Ao compreender os sentidos, deve-se problematizar o seu uso. Afinal, quem vai ter acesso? Por que e como divulgar? Para a racionalidade dominante - do Estado e das empresas -, espacializar é impor uma dada leitura de mundo como verdade e como norma a ser seguida e, portanto, institucionalizada. Têm-se os mapas políticos, rodoviários, de eventos, dos grandes projetos etc., que acabam por construir ou fortalecer os imaginários urbanos e as fronteiras sociais. $\mathrm{Na}$ maioria das vezes, esses mesmos mapas tornam ocultos processos sociais cotidianos.

O maior exemplo que conheço atualmente são os mapas das grandes empresas que representam os territórios costeiros, onde se destacam as cartas náuticas, que são atualizadas em uma velocidade anual, demarcando os novos empreendimentos, as zonas de contenção à pesca e a navegação. Contemplam áreas como a baía de Guanabara, onde se localizam 42 pontos de pesca artesanal e outros pontos de pesca amadora ou industrial que não aparecem no mapa.

A cartografia como processo é feita problematizando os ocultamentos de desenvolvimentos sociais e ambientais de seres, corpos e ações que se tornam invisibilizados. A contraposição consiste na cartografia da ação social, que busca compreender os conflitos no uso do território e as leituras e subjetividades (identidades, memórias, pertencimento) dos sujeitos em seu cotidiano, que muitas vezes têm visto seu dia a dia romper por causa de ações e próteses que são instaladas de repente. A cartografia da ação social reconstrói a outra leitura que força, no mundo do visível, a ruptura dos ocultamentos.

\section{Cartografia como processo: juventude em São Gonçalo}

De agosto de 2010 a dezembro de 2011, realizamos o projeto Cartografia da ação e a juventude em São Gonçalo, com a contribuição da coordenadora Ana Clara Torres Ribeiro (IPPUR/UFRJ) e de Ivy Shipper, seu bolsista, geógrafo mestre em Planejamento urbano e regional (IPPUR/UFRJ).

O projeto seguiu dois caminhos metodológicos:

1. Realização dos grupos focais com jovens de 17 a 29 anos estudantes ou trabalhadores moradores em São Gonçalo;

2. Crianças de 9 a 14 anos entre o $4^{\circ}$ e $5^{\circ}$ ano do ensino Fundamental no Colégio Carlos Maia, em Porto Velho, bairro de São Gonçalo. O trabalho contou com sete grupos focais de jovens trabalhadores e/ou estudantes, o último deles em agosto de 2012. As atividades nas escolas aconteceram com quatro turmas, com apoio das professoras regentes. 


\section{A cartografia da ação social e a cidade de São Gonçalo, RJ}

Nos dois caminhos metodológicos, partimos do confronto entre a percepção da cidade, das fronteiras invisíveis e dos imaginários urbanos, trabalhando com recorte de notícias sobre São Gonçalo e sua relação com o conhecimento vivido pelos sujeitos participantes das atividades. Ao longo das oficinas, os mapas impressos com seus contornos e ruas eram a base para a reflexão dos problemas e das possibilidades existentes na cidade de São Gonçalo, que experimenta a vida metropolitana.

Dentre os roteiros, orientava-se, sem fazer perguntas diretas aos entrevistados para deixar fluir o pensamento dos jovens. O grupo focal se organizava como uma roda de conversa, com um pesquisador fazendo o papel de estimulador de questóes. Outro pesquisador realizava o registro e outro observava os encaminhamentos. Dentre os grupos, uma entrevista foi realizada um com oito meninas residentes no bairro do Salgueiro, guiada pelo roteiro abaixo:

\section{Roteiro de grupo focal}

- Sobre o trabalho/estudo

- Desde quando estuda/trabalha?

- Onde essas atividades se localizam?

- Como você começou a trabalhar?

- $\quad \mathrm{O}$ que você pensa dessa atividade?

- $\quad \mathrm{O}$ que você aprendeu com essa atividade?

- Os jovens trabalhadores são diferentes dos mais velhos? Como?

- Você pretende continuar nesse trabalho?

- Como está nos estudos?

- Quais dificuldades?

- Quais possibilidades?

- Você pode descrever o seu trabalho/ estudo?

\section{(I) Apropriação do espaço urbano:}

- Onde você mora? É muito difícil chegar ao seu trabalho?

- Quais são os lugares que você mais frequenta em São Gonçalo?

- Quais são os lugares de São Gonçalo que você gostaria de conhecer?

- Porque você não os conhece ainda?

\section{(II) Segregação espacial (Percepção e experiência)}

- Quais são os melhores lugares de São Gonçalo para você? 
- E quais são os piores?

- Onde é o centro de São Gonçalo para você?

- O que você pensa sobre o Alcântara?

- O que o seu trabalho ensinou sobre São Gonçalo? E sobre o Alcântara?

(III) Identidades sociais e conflitos espaciais:

- Você se sente ligado a São Gonçalo?

- Você gostaria de trabalhar em outro lugar? Por quê?

- Como os seus amigos veem o seu trabalho? E a sua família?

- Como os lojistas veem o seu trabalho? E a polícia?

- Você já enfrentou dificuldades no seu trabalho? Quais? Quando?

- Quem ajudou você nesses momentos?

(IV) Sociabilidade: vínculos sociais, redes sociais:

- Quem são os seus melhores amigos?

- Qual é o melhor lugar para fazer amigos?

- O que é diversão para você?

- Como você se diverte?

(V) Desigualdades sociais (percepção e experiência)

- Você vê muitas diferenças sociais em São Gonçalo?

- Quais são essas diferenças?

- Os moradores de São Gonçalo lutam por seus direitos?

- Quem mais luta por seus direitos? Como?

- Quais são as principais necessidades da juventude de São Gonçalo?

- Quais são as necessidades dos jovens que trabalham como vendedores ambulantes?

(VI) Preconceito e exclusão social

- É difícil ser jovem? Por quê?

- Você acha que existe preconceito contra o seu trabalho?

- Você acha que preconceitos podem ser superados? Como? 


\section{A cartografia da ação social e a cidade de São Gonçalo, RJ}

\section{(VII) Imaginário urbano}

- Como são os jovens que você conhece?

- Você gostaria de conhecer outros tipos de jovens?

- Se você pudesse inventar um lugar para reunir os jovens de São Gonçalo, como seria?

- Aonde esse lugar seria?

- Você sente falta de acesso a atividades culturais? Quais?

- Você acha que o acesso a atividades culturais pode ser melhorado? Como?

Fonte: RIBEIRO, Relatório de pesquisa, 2008-12.

\section{Algumas considerações do grupo focal com as meninas do Salgueiro}

A partir da transcrição dos depoimentos apresentados nas rodas dos grupos focais, podemos tecer algumas considerações. Nosso objetivo, nesta seção, é apresentar os temas centrais do debate e que apareceram de forma muito frequente entre os presentes. Dispensamos a apresentação dos nomes das depoentes.

De modo geral, para elas, viver em São Gonçalo, no leste metropolitano fluminense, é relacionar-se ao todo com a região metropolitana do estado do Rio de Janeiro. É fazer parte do espaço social gonçalense convivendo com os limites e possibilidades de uma cidade metropolitana periférica que refletem nas relaçôes sociais e no modo de reconhecimento dos jovens pela cidade de São Gonçalo. A juventude do bairro Salgueiro proporciona uma análise dos desejos e anseios por uma cidade melhor na qualidade de vida, que refletem no modo que sociabilizam com outros indivíduos e com o espaço urbano gonçalense.

Esse panorama abre espaço para o questionamento individual: "o que é viver em São Gonçalo?”. Essa pergunta oferece reflexão que viver em São Gonçalo é fazer parte da história do espaço urbano. Cada jovem criou histórias que marcaram as vidas delas referentes à construção do espaço do município. Lembranças das amizades da época do colégio com conversas e brincadeiras na pracinha. Campeonatos de futebol no campinho do bairro como única atividade de lazer do local sem infraestrutura.

A juventude de São Gonçalo presume no urbano gonçalense a possibilidade de uma vida de qualidade. Para elas, é preciso haver serviços de assistência social no bairro do Salgueiro, por exemplo, assim como programas para prevenção da gravidez e de doenças sexualmente transmissíveis.

A busca por praias em outras cidades para lazer e diversão com amigos e familiares é um paradoxo. Em São Gonçalo, encontram-se as praias das Pedrinhas e da Luz. Mas por que os jovens se deslocam para outras cidades em busca de praias? O conhecimento do município de São Gonçalo pelas jovens gonçalenses é vago. A inviabilidade de deslocamento pela cidade é permanente, acarretando na 
falta de conhecimento de diversos lugares no espaço urbano do município. Dessa maneira, são criados conceitos pré-estabelecidos que determinados lugares não são prazerosos para lazer de uma juventude, que precisa dele para o desenvolvimento sociocultural.

São Gonçalo é a cidade dos encontros dos amigos em boates no Zé Garoto, Porto Velho, Porto da Pedra e Alcântara. Quando não há boates, os jovens se dirigem para Niterói e Rio de Janeiro. Em alguns bairros, não há casas noturnas, mas encontros nas ruas, que são fechadas para entretenimento.

Para a juventude do Salgueiro, em São Gonçalo, a educação oferecida a elas é péssima. Muitos buscam estudar em escolas em bairros distantes ou mesmo em outras cidades, uma vez que partem do princípio que as instituições de ensino de São Gonçalo não são de qualidade. Buscando uma educação melhor, deixam de construir relações com o espaço urbano gonçalense.

Na visão da juventude da cidade, trabalhar em São Gonçalo é algo impossível. Não há oferta de empregos suficiente para acolher essas pessoas que buscam um futuro melhor muitas vezes saindo de São Gonçalo. Embora o município tenha um milhão de habitantes, tem forte participação no PIB do RJ e apresenta forte diversificação dos postos de trabalho. Para os rapazes, sair de São Gonçalo em busca de emprego é fácil. Infelizmente, muitas moças afirmam que é difícil. As jovens mães gonçalenses analisam que não há creches públicas no Salgueiro. Pela falta de creches públicas municipais e estaduais, não há como as mulheres deixarem os seus filhos com pessoas seguras e capacitadas. Isso impossibilita as jovens mães de trabalharem, interrompendo a independência feminina no mercado de trabalho.

Sob a ótica dos entrevistados, a saúde é vista com descaso pelo poder público. Em um bairro como o Salgueiro, onde não há postos de saúde para consultas médicas, os moradores precisam se deslocar para os poucos bairros que têm postos de saúde, como Neves e Jardim Alcântara. A juventude que anseia por uma cidade melhor reivindica melhores condiçóes do sistema de saúde que a cidade tem.

São Gonçalo, cidade do prazer e do desprazer, onde as lembranças afetivas estão intrinsecamente ligadas aos momentos de felicidade. Ao mesmo tempo, cidade rejeitada pela juventude onde há falta de qualidade de vida. Essas duas faces de sentimento se encontram unidas como uma moeda.

São Gonçalo, cidade dos sonhos da juventude gonçalense para um futuro melhor. As jovens do Salgueiro sonham viver em uma cidade que possa proporcionar lazer e se sentirem confortáveis em um espaço urbano que proporcione felicidade e qualidade de vida. Esses sentimentos de carinho pela cidade são limitados pela falta de planejamento urbano social, que afeta todos os jovens que almejam viver um futuro melhor onde os vínculos familiares estão intrínsecos com o espaço urbano.

Viver em São Gonçalo é conviver com os sentimentos de saber que está próximo do convívio afetivo e também se limitar nas carências que todo indivíduo em um espaço urbano necessita. A juventude do bairro do Salgueiro sonha com uma cidade melhor para poderem viver com qualidade no espaço onde estão as memórias marcantes da formação sociocultural. Em síntese, foram estes imaginários sociais expressivos desse grupo de meninas que, de certa forma, apareceram também nos depoimentos dos outros grupos focais realizados com ambulantes, músicos e estudantes universitários da Faculdade de Formação de Professores da Universidade do estado do Rio de Janeiro (FFP-UERJ). 


\section{A cartografia da ação social e a cidade de São Gonçalo, RJ}

\section{Outra experiência do projeto: a cartografia das crianças}

Entre as atividades desenvolvidas no Colégio Carlos Maia no período de 2010 a 2011, apresentaremos resultados de uma oficina que aconteceu em sala de aula. O objetivo da atividade era compreender a leitura das crianças em relação aos problemas ambientais e dos pescadores existentes em São Gonçalo com seu entorno - a baía de Guanabara. O bairro da escola é banhado pelas águas da baía e, próximo a ela, está uma comunidade de pescadores chamada Esso, onde também há uma área de embarque e desembarque. A partir da leitura de notícias de recortes de jornais e de depoimento dos pescadores, foi elaborado um glossário (tipo de vocabulário para entendimento comum) e um quadro analítico que buscasse reconhecer: os agentes, as ações, as reivindicações, os opositores, os tipos de protestos ou manifestaçóes. Com essa base elaborada e discutida, os estudantes da turma do quinto ano elaboraram um mapa baseado nas fronteiras e nos principais bairros.

O resultado do trabalho que reconhece a cartografia da ação social como processo pode ser visto a seguir. O ponto de partida foi um conjunto de problematizações trazidas pelas notícias de jornais e pelo olhar das crianças. Na semana seguinte, os alunos trouxeram para a sala um pescador militante e realizaram entrevista com ele. No trabalho de análise, antes de trabalharem efetivamente no mapa, as crianças conseguiram identificar no espaço representado a localização das barqueatas (formas de manifestações dos pescadores para realizar algum tipo de protesto e reivindicação), as empresas indústria naval, petroquímica, localização dos resíduos sólidos e muitos outros agentes, usos e problemas existentes.

Figura 1. Aplicação da metodologia da cartografia da ação na escola.

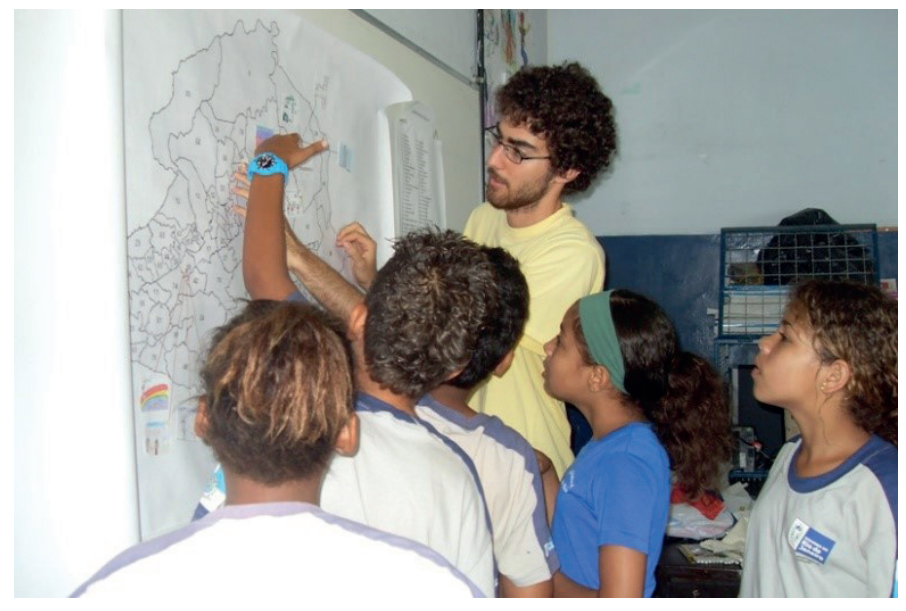

Fonte: Relatório Final. LASTRO-IPPUR-UFRJ\& NUTEMC-FFP-UERJ, 2011.

A produção coletiva do mapa utilizou, em sala de aula, vários recursos discursivos e didáticos, com formatos diversos e a ideia de troca de saberes proporcional a possibilidade de produzir um ensino de geografia fundamentada nas formas de representação da existência no sentido de Sartre - o ser não se constrói pela sua essência. É, antes de qualquer coisa, elaborada na sua reflexão no mundo, portanto no contexto social, cultural, político e espacial no qual se constrói de forma permanente. 
Trata-se da compreensão da pedagogia que se torna livre no exercício da consciência (da ação e sentido dessa ação) como bem ensina Freire (2008). É nesse contexto, confrontando outros mapas, que é possível compreender que o mapa é existencial, sempre um recorte, uma leitura de mundo. Não é a totalidade, mas o que a leitura quer demonstrar.

\section{Algumas conclusões para encaminhamentos do fazer geográfico}

Aproximando-se das conclusões, vale expressar algumas preocupaçōes que estamos atentos no fazer geográfico cotidiano. A primeira delas consiste no entendimento do que é produção da cartografia na contemporaneidade. Limites a serem ultrapassados pelo fazer cartográfico são fundamentais, tendo como referência epistemológica a questão cartografia: "pra quem?”, "cartografia para que?”. $\mathrm{Na}$ superação de limites, superar o fazer cartesiano - ciência das sínteses para a ciência da complexidade (Morin, 1996), em que o mapa deixe de ser o fim para ser o meio do fazer e do saber. Cartografar movimentos da sociedade, das apropriaçôes urbanas, territoriais e o que permite compreender a representação cartográfica como processo social (Ribeiro, Silva, Schipper, 2011). Novas metodologias, incluir sentidos do sujeito, tempo lento da troca de saberes, apreender o cotidiano dos grupos sociais. A cartografia como processo - do sentido, as ações, as problematizações, as formas de representaçōes (mapa, lei etc.) -, valorização da análise processual e não somente do objeto em si. Necessária reaproximação da ciência e arte (linguagens e símbolos) - expressão de movimentos, sentidos, lutas, protestos e reivindicaçôes, medos e desejos (Ribeiro, 2010).

A cartografia dos sujeitos é, na verdade, a cartografia da ação social deles, que incluem ações e intenções - quem elabora o tema e a simbolização, quem elabora os sentidos da ação social.

Estamos diante de uma alteração de paradigma científico necessária - sair das sínteses para a complexidade -, produção de teoria social e geográfica ao alterar a metodologia entender os sentidos, dialogar com o outro - o outro como sujeito por meio de novas maneiras de fazer a pesquisa de campo, o trabalho analítico e as formas de expressão do conhecimento.

\section{Referências}

ACSELRAD, Henri (org.). Cartografia social e dinâmica territorial: marcos para o debate. Rio de Janeiro: IPPUR-UFRJ, 2010.

ALMEIDA, Alfredo W. Nova cartografia social da Amazônia. Manaus: PPGSCA, 2009.

BADIOU, Alain. Ética: um ensaio sobre a consciência do mal. Rio de Janeiro: Relume Dumará, 1995.

BRITTO, Fabiana D. "Co-implicações entre corpo e cidade: da sala de aula à plataforma de açôes". In BRITTO, F. B. e JACQUES, P. B. Corpocidade: debates, açōes e articulaçôes. Salvador: UFBA, 2010, pp. 12-23. 
CERTEAU, Michel de. “A invenção do cotidiano”. Artes do fazer. 3 ed. Petrópolis: Vozes, 1998.

CORDEIRO, Denise. Juventude nas sombras. Rio de Janeiro: Lamparina \& FAPERJ, 2009.

FREIRE, Paulo. Pedagogia da esperança. São Paulo: Paz e Terra, 2008.

IANNI, Octavio. A sociedade global. Rio de Janeiro: Civilização Brasileira, 1992.

LEFEBVRE, Henri. O direito à cidade. São Paulo: Documentos, 1969.

. "La presence et l'absence". Contribution à la theorie das représentation. Paris: Casteman, 1980.

MARTINS, José de Souza. A sociabilidade do homem simples. São Paulo: Contexto, 2008.

MORIN, Edgar. Ciência com consciência. Rio de Janeiro: Bertrand Brasil, 1996.

RIBEIRO, Ana Clara T. "Pequena reflexão sobre categorias da teoria crítica do espaço: território usado, território praticado". In SOUZA, Maria Adélia Aparecida de (org.). Território brasileiro: usos e abusos. São Paulo: Edições Territorial, 2003.

Relatório técnico-científico do projeto: territórios da juventude: experiências em cartografia da ação (São Gonçalo, RJ). Edital Humanidades. Rio de Janeiro: FAPERJ, 2008-12.

. "Dança de sentidos: na busca de alguns gestos". In BRITTO, F. B. e JACQUES, P. B. Corpocidade: debates, ações e articulações. Salvador: UFBA, 2010, pp. 24-40.

. Por uma sociologia do presente: ação, técnica e espaço. Rio de Janeiro: Letra Capital, 2012, v. 1.

. Por uma sociologia do presente: ação, técnica e espaço. Rio de Janeiro: Letra Capital, 2013, v. 5 .

e SILVA, Catia Antonia da. "Faces ativas do urbano: mutaçôes num contexto de imobilismos”. In (org.). Repensando a experiência urbana da América Latina: questões, conceitos e valores. Buenos Aires: CLACSO, 2000, pp. 96-125.

et al. "Por uma cartografia da ação: pequeno ensaio de método". Cadernos IPPUR, ano XV, n. 2 e ano XVI, n. 1, 2001-02.

et al. Relatório técnico-científico do projeto: cartografia da ação e análise de conjuntura: reivindicações e protestos em contextos metropolitanos (quatro volumes). Programa Cientista do Nosso Estado. Rio de Janeiro: FAPERJ, 2005-06.

et al. "Cartografia da ação e a juventude na cidade: trajetórias de método". In et al. (orgs.). Cartografia da ação e movimentos da sociedade: desafios de método e experiências urbanas. Rio de Janeiro: Lamparina, 2011, pp. 31-42.

SANTOS, Boaventura de Souza. "Uma cartografia simbólica das representações sociais: prolegômenos a uma concepção pós-moderna do direito”. Espaço \& Debates, v. 33, ano XI, 1991.

SANTOS, Milton. Técnica, espaço, tempo: globalização e meio técnico-científico informacional, São Paulo: HUCITEC, 1994.

. A natureza do espaço: técnica e tempo, razão e emoção. São Paulo: HUCITEC, 1996.

et al. O papel ativo da Geografia: manifesto. XII Encontro Nacional de Geógrafos, Florianópolis, jul. 2000. 
SANTOS, Renato E. "Cartografias e lutas sociais: notas sobre uma relação que se fortalece. In RIBEIRO, Ana Clara Torres et al. (orgs.). Cartografia da ação e movimentos da sociedade: desafios de método e experiências urbanas. Rio de janeiro: Lamparina, 2011, pp. 43-60.

SILVA, Catia A. da. "O fazer geográfico em busca de sentidos ou a geografia em diálogo com a sociologia do tempo presente”. Boletim Campineiro de Geografia, v.2, p.1, 20-21, 2012.

e SCHIPPER, Ivy. "Cartografia da ação social: reflexão e criatividade no contato da escola com a cidade”. Revista Tamoios [on line], v. 8, p. 20, 2012.

SOUZA, José G. e KATUTA, Ângela M. Geografia e conhecimentos cartográficos. São Paulo: UNESP, 2001.

WEBER, Max. Ciência e política: duas vocações. São Paulo: Martin Claret, 2001. 
Formato 16 × 23

Tipologia: Garamond (texto) Garamond (títulos) Suporte: PDF 